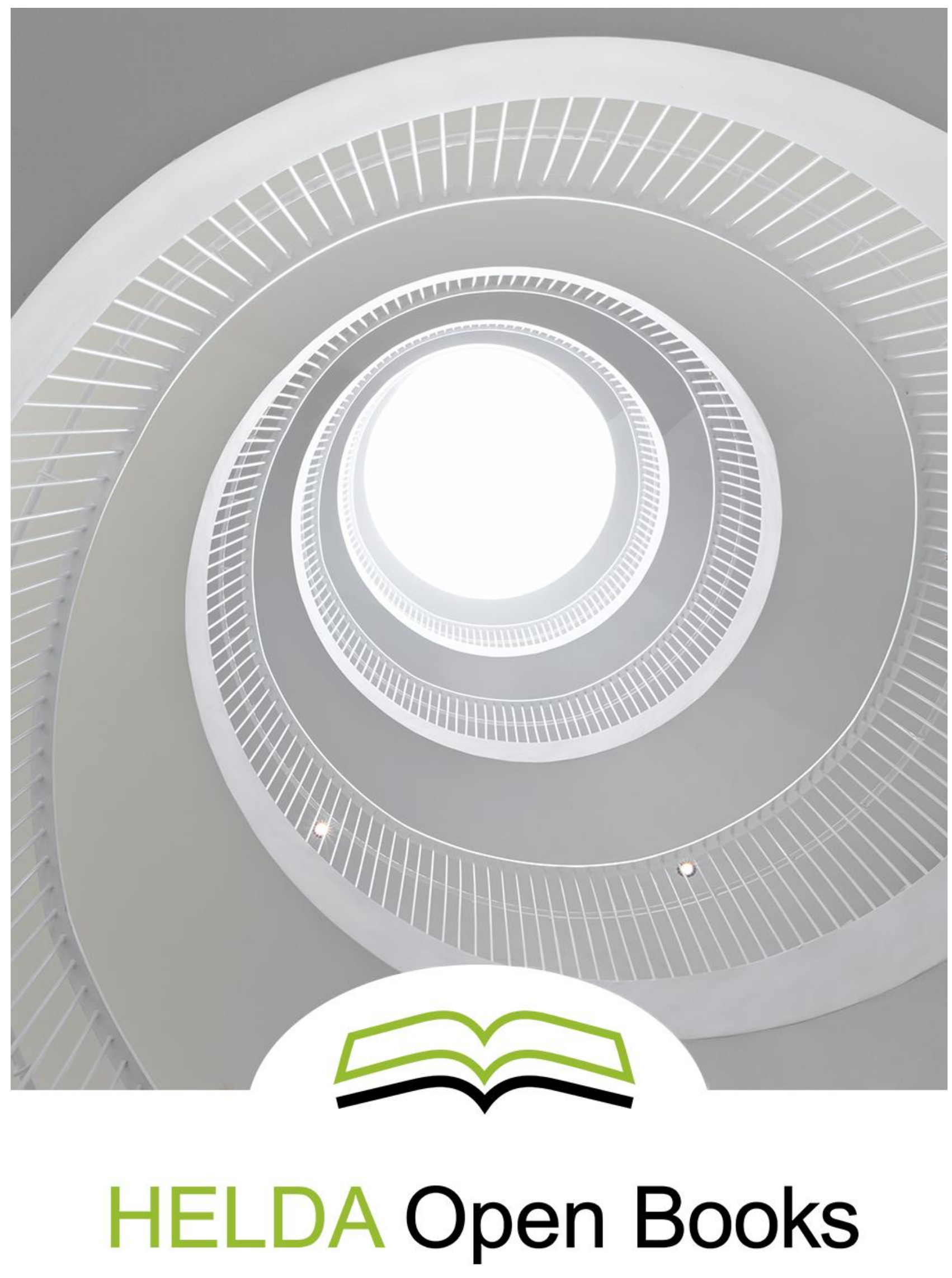




\section{Aku Visala}

\section{Mitä tiede ei voi kertoa sinulle}

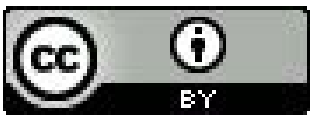

Tämä teos on lisensoitu Creative Commons (4.0) lisenssillä CC BY. Sen on julkaissut Helsingin yliopiston kirjasto tekijän ja Perussanoma Oy:n suostumuksella.

ISBN: 978-951-51-5020-2 (.pdf)

DOI: $10.31885 / 9789515150202$ 


\section{HUMANITAS}

Toimittanut

Tom Holmén \& Olli-Pekka Vainio

\section{Toimituskunta}

Jari Jolkkonen

Anni Maria Laato

Matti Repo

Miikka Ruokanen

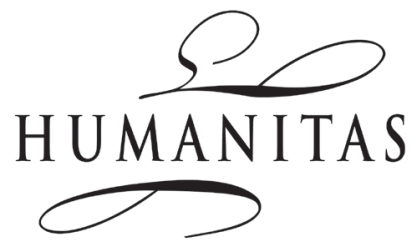




\begin{abstract}
Aku Visala (s. 1979)
Kirjoittaja on teologian tohtori ja uskonnonfilosofi, joka toimii tutkijana Oxfordin yliopistossa (Ian Ramsey Centre for Science and Religion). Hänen väitöskirjansa sai European Society for the Study of Science and Theology -tutkimuspalkinnon. Visalan tutkimukset ovat käsitelleet ajankohtaisia uskonnon evoluutiota koskevia teorioita, niiden teologisia seuraamuksia sekä evoluutiopsykologian ja teologian suhdetta. Visala on kirjoittanut myös laajasti viimeaikaisesta ateismista.
\end{abstract}




\section{MITÄ TIEDE EI VOI KERTOA SINULLE Aku Visala}

底 PeRUSSANOMA OY

PL 15, 02701 Kauniainen www.perussanoma.fi 
Copyright

Pälllys ja taitto

Luokka

ISBN

ISSN

Painettu
Aku Visala ja Perussanoma Oy

Taneli Törölä, Leijonamedia

21

978-951-888-536-1

1798-3053/2

Bookwell Oy,

Porvoo 2010

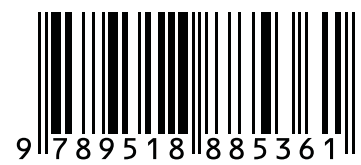




\section{HUMANITAS - SARJA}

Humanitas-kirjasarjan tarkoitus on käsitellä niitä kysymyksiä ja ongelmia, jotka usein liitetään uskonnollisten ja ateististen maailmankatsomusten kohtaamiseen. Erityisesti erilaisten tieteeseen liittyvien uskomusten ja arvojen kohtaaminen haastaa jälkimodernin maailman asukkaat keskusteluun, joka ei aina ole helppoa. Sarjasta vastaavilla on vakaa näkemys siitä, että tämän keskustelun tulee ja se voi tapahtua rakentavasti. Mainittu pyrkimys ei silti merkitse hampaatonta tai väritöntä puhetta.

Miksi Humanitas? Raamatun toteamus "Herran on maa ja kaikki mitä siinä on” (Ps 24:1; 1 Kor 10:26) sisältää hämmästyttävän ajatuksen. Sen mainitsema "Herra" katsoo maailmaa olematta minkään näkökulman vanki, rajoittumatta mihinkään perspektiiviin, itse asiassa halliten ne kaikki. Tästä asemasta käsin ei käydä keskustelua, vaan kerrotaan kuinka asiat ovat, sanellaan. Tässä asemassa olevalla on hallussaan ainoa oikea ja absoluuttinen totuus.

Kuvattu korkea näköala voi kuitenkin kuulua vain "Herralle". Muiden on tyydyttävä keskustelemaan - lopulta riippumatta siitä, onko "Herra" todellinen vai ei. Tälle huomiolle rakentuu inhimillinen sivistys, humanitas.

Tieteen aseman modernissa yhteiskunnassa on toisaalta kiistaton, mutta samalla ongelmallinen. Viisautta on osata nähdä tieteen mahdollisuudet mutta myös tunnustaa sen rajat. Tiede tarjoaa ratkaisuja moniin ongelmiin, mutta samalla se luo uusia. Monet näistä 
ongelmista liittyvät juuri siihen, mitä ihminen on. Toisinaan tiede myös näyttää ottavan "Herran” aseman, joka ei sille välttämättä kuulu. Näin saattaa käydä varsinkin silloin, kun tiede ja jokin tietty poliittinen, aatteellinen tai uskonnollinen ideologia liittoutuvat liian vahvasti. Tällöin jotakin menee sijoiltaan, ja ihminen kärsii. Keskustelu loppuu ja muuttuu yhden ainoan totuuden saneluksi tai sen yritykseksi.

Olennainen oivallus on se, että tietomme maailmasta on rajallista, mutta tästä huolimatta totuutta lähestyvää. Absolutismin ja relativismin väliin sijoittuu aito humanitas.

Se saakoon tässä kirjasarjassa tilaisuuden.

Tom Holmén \& Olli-Pekka Vainio

Jari Jolkkonen

Anni Maria Laato

Matti Repo

Miikka Ruokanen 


\section{SIS ÄLLYSLUETTELO}

ESIPUHE

11

1 JOHDANTO

15

2 KONFLIKTI, ITSENÄISYYS

JA KESKITIEN ETSINTÄ

2.1 PERUSMALLIT

2.2 KONFLIKTI

31

2.3 ITSEN ÏISYYS

40

2.4 KONFLIKTIN JA ITSEN ÄISYYDEN ONGELMIA

49

2.5 P ̈̈̈LLEKKÄISYYS KESKITIEN Ä

56

3 TIETÄMISEN MENETELMÄT:

REALISMI TIETEESSÄ JA TEOLOGIASSA

3.1 ARKIKÄSITYS TIETEEST Ä

JA TIETEEN M ̈̈̈̈ITELMI Ä

3. 2 POSITIVISMI

$3 \cdot 3$ RELATIVISMI

82

3.4 TIEDE JA KRIITTINEN REALISMI

88

3.5 TEOLOGIA JA TEOLOGINEN REALISMI

96

3. 6 KRIITTINEN TEOLOGINEN REALISMI

JA LUONNON TEOLOGIA

101

4 MUUTTUVA LUONTO: FYSIIKKA JA JUMALA

4.1 KESKIAIKAINEN SYNTEESI

4.2 KLASSINEN FYSIIKKA: MEKANISMIT

JA KELLOKONEISTON JUMALA

4.3 UUSI FYSIIKKA: MEKANISMEISTA AVOIMEEN JA KERROKSELLISEEN LUONTOON

5 MUUTTUVA LUONTO: EVOLUUTIO,

IHMINEN JA IHMISMIELI

5.1 DARWIN, DARWINISMI JA LUONNONVALINTA 
5.2 EVOLUUTIO JA IHMISLUONTO

$5 \cdot 3$ IHMISMIELI: SIELUSTA AIVOIHIN

5.4 SELITTÄMINEN JA LUONNON TASOT 168

5.5 YHTEENVETO: MUUTTUVA LUONTO

6.1 LUOMINEN KRISTILLISESSÄ TEOLOGIASSA 180

6.2 JUMALA JA LUOMAKUNTA: KLASSISESTA

TEISMISTÄ PROSESSITEOLOGIAAN

186

6.3 MAAILMANKAIKKEUDEN ALKUPER Ä,

KONTINGENSSI JA J ÄRKVYYS 198

$6.4 \mathrm{HIENOS} \ddot{A} \ddot{T} \mathrm{O}$

209

6.5 JUMALAN TOIMINTA FYSIKAALISESSA MAAILMASSA

215

7 EVOLUUTION TEOLOGIA: LAKI JA SATTUMA 229

7.1 KYSYMYS SUUNNITTELUSTA 230

7.2 KREATIONISMI JA ÄLYKÄS SUUNNITELMA 237

$\begin{array}{ll}7.3 \text { TEISTINEN EVOLUUTIO } & 244\end{array}$

8 TEOLOGINEN IHMISKÄSITYS JA IHMISLUONTO 257

8.1 ELÄIMET, PERSOONAT JA IHMISLUONTO 257

8.2 MORAALI JA IHMISLUONTO 269

8.3 USKONTO JA IHMISLUONTO 279

9 MAAILMANKATSOMUSTEN KONFLIKTI: TEISMI, ATEISMI JA TIETEELLINEN MATERIALISMI 291

9.1 ATEISMI JA NATURALISMI 292

9.2 TIETEEN KAIKKIVOIPAISUUS
JA ARVOVAPAUS

1OLOPPUSANAT: LUONNON TEOLOGIAN

OPETUKSIA JA HAASTEITA

319

SANASTO

325

KIR JALLISUUS

339

VIITTEET

365 




\section{E S I P U HE}

On useita henkilökohtaisia ja filosofisia seikkoja, jotka ovat johtaneet minut kirjoittamaan tämän kirjan. Suurin osa näistä seikoista on lukijan näkökulmasta turhaa tietoa. On kuitenkin muutamia seikkoja, jotka asettavan kirjan sisällön oikeaan perspektiiviin, joten ajattelin olevan lukijan kannalta hyödyllistä, jos otan ne näin aluksi esille.

Tätä kirjaa on kirjoitettu sekä filosofin että teologin hattu päässä (ehkä enimmän filosofin). Tieteen ja uskonnon suhde on kuitenkin ollut pohjoismaisessa uskonnonfilosofiassa kysymys, jota on harvoin pidetty kiinnostavana. Tapana on ollut nimittäin ajatella, että uskonto ja tiede eivät kohtaa. Monien mielestä uskonnon kieli ja tieteen kieli ovat erilaisia ja ne puhuvat erilaisista maailmoista. Filosofien tulisi tämän näkemyksen mukaan keskittyä uskonnollisen kielenkäytön analyysiin eikä esimerkiksi tarkastelemaan uskonnollisia väitteitä ja niiden seurauksia.

Tämä näkemys ei kuitenkaan ole enää kovinkaan suosittu muualla maailmassa. Ilmapiiri on muuttunut ja on muuttumassa luultavasti vielä enemmän. Eräs tähän kehitykseen vaikuttaneista tekijöistä on ollut ateismin voimakas marssi julkisuuteen. Kun ateistit alkoivat puhua äänekkäästi uskonnosta, yhtäkkiä olikin taas muodikasta keskustella siitä, millaisena uskonnolliset näkemykset esittävät maailman ja miten tieteelliset teoriat ohjaavat uskomuksiamme. Uskonnollinen metafysiikka ja tieteen tulokset aina evoluutiopsykologiasta biologiaan nousivat taas ihmisten huulille ja 
kahvipöytäkeskustelujen sisällöksi. Ymmärtävätkö ateistit tieteen ja uskonnon suhteen väärin, kun he esittävät argumentteja uskontoa vastaan tieteellisin perustein? Näin ainakin perinteinen näkemys tieteen ja uskonnon itsenäisyydestä edellyttäisi. Eikö tieteellisten argumenttien esittäminen uskonnollisten kysymysten selvittämiseksi ole pahimman kaltaista sekasotkua? Yhä enenevässä määrin tähän kysymykseen vastataan kieltävästi. Erikoista on se, että tarvittiin nimenomaan ateisteja muistuttamaan siitä, että perinteinen kristillinen teologia todella sisältää suuren määrän luontoa ja luomakuntaa koskevia väitteitä - väitteitä, jotka pitää joko hylätä tai laittaa suhteeseen sen kanssa, mitä tieteen kautta tiedämme luonnosta.

Tämä ajattelutavan muutos uskonnon filosofisessa käsittelyssä ilmeni minulle varsin käsin kosketeltavalla tavalla (jos nyt filosofisista näkemyksistä voi puhua käsin kosketeltavina), kun siirryin 2008 syksyllä Oxfordin yliopistoon vierailevaksi tutkijaksi. Asetuttuani taloksi aloin huomata, että filosofit puhuivat uudessa yliopistossani uskonnosta hyvin erilaisella tavalla kuin olin tottunut pohjoismaisessa ympäristössäni. Suurennuslasi oli uskonnollisen kielen sijasta suunnattu itse maailmaan. Filosofit ja teologit eivät ajatelleet, että tiede ja uskonto ovat toisistaan riippumattomia tapoja puhua toisistaan riippumattomista asioista. Sen sijaan he lähtivät liikkeelle siitä olettamuksesta, että teologia tosiaan puhuu maailmasta siinä missä tiedekin. Huomasin nopeasti, että Oxfordin filosofit ja teologit pohtivat varsin perinteisiä filosofisia ongelmia - esimerkiksi Jumalan olemassaolon puolesta ja vastaan esitettyjä argumentteja ja ihmissielun luonnetta.

Oxfordissa huomasin toisenkin tämän kirjan syntyyn merkittävästi vaikuttaneen seikan: tieteen ja uskonnon suhteesta on ihan oikeaa tutkimusta. On ihmisiä, jotka pohtivat asiaa työkseen. On historioitsijoita, jotka tutkivat tieteen ja uskonnon vuorovaikutusta historian eri vaiheissa. On tieteilijöitä, jotka miettivät teorioidensa uskonnollisia seurauksia. On filosofeja ja teologeja, jotka ovat yrittäneet luoda näistä asioista kokonaisnäkemystä ja saavat siitä palkkansa. Aloin tutustua kirjallisuuteen, käydä seminaareissa, luennoil- 
la ja konferensseissa.

Edellä kuvatut syyt pistivät aivoni liikkeelle. Eräs tämän liikkeen tuloksista on kirja, jota pidät nyt käsissäsi. Tämän kirjan kirjoittaminen on ollut minun tapani selventää ajatuksiani, oppia uutta ja luoda yleiskuva niistä kysymyksistä, jotka liittyvät tieteen ja uskonnon suhteeseen. On kuitenkin tunnustettava, että tässä kirjassa ei ole tarkoitus sanoa yhtään mitään uutta. Jos esitän jonkin uuden näkemyksen, on kysymys lähinnä sattumasta tai siitä, etten ole ymmärtänyt lukemaani. Tarkoitukseni on sen sijaan esitellä lukijalle, millaisia keskusteluja tieteen ja uskonnon suhteesta on käyty ja mitä ne voisivat tarkoittaa.

Kirjan kirjoittaminen on pitkä prosessi, jota ruokkivat niin työ, ystävät kuin vapaa-aikakin. Haluan kiittää inspiraatiosta, varastamistani ideoista ja valaisevista keskustelusta seuraavia henkilöitä: Tom Aechtner, Paul Allen, Justin Barrett, Kelly James Clark, Peter Harrison, Yoaav Isaacs, Heikki Kirjavainen, Simo Knuuttila, Timo Koistinen, David Leech, Tim Mawson, Michael Murray, Antti Mustakallio, Leo Näreaho, Andrew Pinsent, Tapio Puolimatka, Ilkka Pyysiäinen, Panu Raatikainen, Risto Saarinen, Jeffrey Schloss, Nathanael Smith, Mikael Stenmark, Richard Swinburne, Roger Trigg, Wentzel van Huyssteen, Petri Ylikoski. Selvää on, että tästä listasta puuttuu henkilöitä, jotka sinne todellisuudessa kuuluisivat. He tietävät keitä he ovat ja voivat vaatia minulta anteeksipyyntöä, kun seuraavan kerran tapaamme - ja he ansaitsevat sen. Haluan lisäksi kiittää Olli-Pekka Vainiota ja Teemu Sainiota, jotka molemmat lukivat koko käsikirjoituksen ja esittivät monia rakentavia korjausehdotuksia. Dosentti Vainio jakaa kiitokset yhdessä Tom Holménin kanssa siitä, että hyväksyi käsikirjoitukseni Humanitas-sarjaan. Kiitos kuuluu myös sarjan toimituskunnalle siitä, etteivät torjuneet tätä ehdotusta. Lopuksi haluan kiittää vanhempiani Heikkiä ja Eeva-Liisaa, joita ilman en olisi tässä.

Oxfordissa Mikkelinpäivänä, 2010

Aku Visala 



\section{J O H D N T O}

Monet ajattelevat tietävänsä varsin hyvin, mikä tieteen ja uskonnon suhde on ollut ja millainen se on nykyään. Tästä suhteesta vallitsee kulttuurissamme varsin vaikutusvaltainen mielikuva, jota sekä populaarikulttuuri että lehtikirjoittelu pitävät yllä. Tämän näkemyksen mukaan valistuneen ja modernin ihmisen tulee ajatella, että tiede on ainoa mittatikku sille, mikä on totta ja oikeaa. Tiede on vapaata, demokraattista ja etsii peräänantamattomasti totuutta. Se perustuu tosiseikoille, eikä kuvitelmille. Tieteen edistymistä yhteiskunnassa kuitenkin haittaavat jotkut dogmaattiset ihmiset, jotka haluavat käännyttää toiset ja jatkaa muinaisten harhaluulojensa kannattamista, nimittäin uskovaiset. On tietysti myös toisenlainen mielikuva, kolikon kääntöpuoli. Tämän mielikuvan mukaan totuus kaikesta löytyy Jumalan ilmoituksesta, ja tiede puolestaan on ennakkoluuloisten dogmaatikkojen tapa levittää ateismia kattamaan koko yhteiskunta. Tiede rajoittaa keskustelua, sulkee ulkopuolelle muut näkökannat ja rapauttaa perinteiset moraalikäsitykset.

Tällaisessa mielikuvamaailmassa on vaikea keskustella tieteen ja uskonnon suhteesta asiallisesti. Nämä mielikuvat ovat meille tärkeitä, koska ne ovat käytännöllisiä. Se, millainen perimmäinen todellisuus on, ei ole meille ihmisille pelkästään teoreettinen kysymys. Uskonnolliset ja tieteelliset kysymykset eivät ole pelkästään teoreettisia, koska ne liittyvät siihen, miten elämme elämäämme. Näkemyksemme siitä, mitä ihmiset ovat, miten luonto toimii ja miten 
meidän tulisi hankkia tietoa vaikuttavat siihen, mitä pidämme tärkeänä ja mistä etsimme totuutta. Tästä syystä puhe tieteen ja uskonnon luonteesta ja niiden suhteesta herättää usein vahvoja tunteita: niitä koskevat uskomuksemme ovat identiteettimme ja maailmankatsomuksemme ydinkohtia.

Tässä kirjassa tarkastellaan tieteen ja uskonnon suhdetta filosofisesti. Vaikka joillekin aihe saattaa herättää suuria tunteita ja toisille taas lähinnä kyllästymisen ja välinpitämättömyyden tunteita, yritän vakuuttaa lukijani siitä, että tieteen ja uskonnon suhteesta voidaan puhua järkevästi ja siitä kannattaa puhua. Järkevällä keskustelulla en tarkoita sitä, että keskusteluun osallistujien tulisi olla "puolueettomia”. Melkein jokaisella on näistä asioista jonkinlainen näkemys, ja näin ollen "puolueetonta" keskustelijaa ei ole. Olennaista ei kuitenkaan ole sitoutumattomuus, vaan perusteiden esittäminen, toisen osapuolen perusteiden kuunteleminen ja oman lähtökohdan tunnustaminen.

Aivan ensimmäiseksi on rajattava aihetta. Puhe tieteen ja uskonnon suhteesta on ainakin kahdella tavalla harhaanjohtavaa. Usein puhutaan yleisesti tieteen ja uskonnon suhteesta, vaikka itse asiassa puhutaan tieteen ja kristinuskon suhteesta. Tässä kirjassa pitäydytään nimenomaan tieteen ja kristinuskon suhteen tarkasteluun. Joitakin tässä kirjassa esitettyjä näkemyksiä voitaisiin varmaankin soveltaa myös islamilaiseen ja juutalaiseen teologiaan, jotka jakavat osittain kristinuskon jumalakäsityksen. Keskittymistä kristinuskoon voidaan perustella monilla seikoilla. On tunnustettava heti, että uskontoja on monenlaisia ja niissä esiintyy keskenään ristiriitaisia näkemyksiä esimerkiksi perimmäisen todellisuuden luonteesta ja siitä miten siitä saadaan tietoa. "Uskonto" ei siis ole mikään yhtenäinen luokka, jonka suhteesta yleisellä tasolla "tieteeseen" voitaisiin sanoa yhtään mitään. Meidän pitää aina aloittaa kysymällä kenen uskonnosta on kysymys ja millaisia näkemyksiä sen edustajat kannattavat. Jotta keskustelu ei jäisi liian yleiselle ja hämärälle tasolle, on otettava joitakin uskonnollisia näkemyksiä läheiseen tarkasteluun. Tässä kirjassa on valittu tällaisen tarkastelun kohteeksi muutamia kristillisen 
teologian ydinkohtia. Valinta on tehty siksi, että valtaosa siitä keskustelusta, jota tämä kirja yrittää ymmärtää, on käyty kristinuskon vaikutuspiirissä. "Tieteessä ja uskonnossa" kristinusko on aina uskonnon prototyyppi.

Puhe tieteen ja uskonnon suhteesta on harhaanjohtavaa myös toisella tavalla. Usein keskustelijoiden mielessä ei ole koko "tiede", vaan nimenomaan luonnontieteen eri alat kuten esimerkiksi fysiikka ja biologia. Teologian ja yhteiskuntatieteiden tai käyttäytymistieteiden suhteesta puhutaan paljon harvemmin. Tälle luonnontieteen keskeisyydelle on sekä historiallisia ja teoreettisia syitä, johon ei tässä vaiheessa ole syytä mennä tarkemmin. Asiaan vaikuttaa jopa niinkin arkinen seikka kuin kieli. Valtaosa alan kirjoittajista kirjoittaa nimenomaan englanniksi, jonka sana "science" viittaa juuri luonnontieteisiin. Näin ollen voimme sanoa tämän kirjan käsittelevän "tieteen ja uskonnon suhteen" sijaan kristillisen teologian ja joidenkin luonnontieteen tulosten suhdetta. Tämäkin tapa esittää asia on vielä hyvin epätarkka, mutta tässä vaiheessa ei ole syytä vielä mennä asiaan sen syvemmin.

Meillä on monia hyviä syitä etsiä vastauksia kysymyksiin, jotka koskevat luonnontieteiden ja kristillisen teologian suhteesta. Kaikkein tärkein syy on tietenkin kysymys totuudesta. Valtaosa ihmisistä ajattelee, että on olemassa yksi, ihmisistä riippumaton maailma (joka sisältää ihmiset) ja perimmäinen totuus. Näyttää siltä, että meihin ihmisiin on sisäänrakennettu halu ja pyrkimys etsiä totuutta kaikilla elämänalueilla. Sekä kristinusko että tiede näyttävät antavan vastauksia perimmäistä todellisuutta ja totuutta koskeviin kysymyksiimme. Miten ja miksi maailmankaikkeus on tullut olemaan? Millainen on ihmisluonto vai onko sitä ollenkaan? Sekä kristinusko että tiede ainakin näyttävät puhuvan tällaisista asioista. Ovatko niiden vastaukset ristiriidassa vai ovatko ne toisistaan riippumattomia?

Kuten jo edellä tuli ilmi, totuus ei ole pelkästään teoreettinen vaan myös syvästi käytännöllinen seikka. Koko moderni länsimainen elämänmuoto on yhtäältä luonnontieteiden ja tekniikan kehi- 
tyksen ja toisaalta kristillisen perinteen sävyttämä. Nämä kaksi ovat kietoutuneet toisiinsa historiamme kuluessa tavalla, joka vastustaa yksipuolista kuvausta. Sekä kristinuskolla että tieteellä on valtava vaikutus arkielämäämme ja arkiseen elämänmuotoomme. Suuri määrä elämänmuotomme käytäntöjä on tulosta yhä nopeutuvasta teknisestä kehityksestä, jonka väitetään usein perustuvan edistykseen luonnontieteissä. Samalla luonnontieteet ovat länsimaisen maailmankatsomuksen kivijalka: emme enää usko maan pysymiseen paikallaan, koska tieteilijät sanovat, että nämä asiat eivät pidä paikkaansa ja esittävät (vakuuttavia) todisteita tämän näkemyksen virheellisyydestä. Mitä tahansa satummekin uskomaan maailmasta ja ihmisistä ja kosmoksesta (ja Jumalasta) meillä ei ole varaa olla ottamatta huomioon tieteellistä tutkimusta. Kaikesta väitteistä maallistumisen puolesta huolimatta, valtaosa länsimaisista ihmisistä kuitenkin perustelee käyttäytymistapojaan, arvojaan ja politiikkaansa jollakin tavoin kristilliseen arvomaailmaan tai ideoihin perustuvilla väitteillä.

Tämän kirjan tarkoituksena on tarkastella nimenomaan englanninkielistä keskustelua luonnontieteen ja kristillisen teologian suhteesta ja esitellä sitä suomalaiselle lukijakunnalle. Näin ollen monet kirjassa kuvatut näkemykset tuntuvat varmasti suomalaisille lukijoille varsin vierailta ja omituisilta. On kuitenkin tosiasia, että monet meidän näkökulmastamme äärimmäiset kannat - kuten nuoren maan kreationismi - ovat osa keskustelua tieteen ja teologian suhteesta. Äärimmäisyydestään huolimatta ne ansaitsevat järjellistä ja perusteltua kritiikkiä pilkan tai ennakkoluulojen sijaan. Toinen syy englanninkielisen keskustelun erilaisuuteen on se, että etenkin Yhdysvalloissa tilanne poliittisesti erittäin herkkä ja monisyinen. Jotkut katsovat edustavansa tiedettä ja esittävän tämän nojalla yhteiskunnallisia, poliittisia ja moraalisia ohjelmia siinä, missä "kristilliset" näkemykset tavallisesti liitetään edellisille vastakkaisiin poliittisiin ohjelmiin. Suomessa ei onneksi tällaista poliittista tilannetta ole eikä sellaista näytä olevan syntymässä.

Se, mikä tekee tämän kirjan lähestymistavan tieteen ja kristin- 
uskon suhteeseen nimenomaan filosofiseksi, on se, että se keskittyy sekä tieteen että kristinuskon nimissä tehtyihin väitteisiin. Tarkoitus on selvittää, millaisia väitteitä on esitetty ja miten ne voisivat olla keskenään ristiriidassa tai sopia yhteen. Esitän myös perusteita sen puolesta, että sekä tieteen että kristinuskon piirissä todella pyritään esittämään väitteitä, joiden tarkoitus on kertoa meille jotain siitä, millainen maailma on. Vaikka tämä lähtökohta on arkijärjen mukainen, ovat monet kuitenkin asettuneet vastustamaan sitä. Jotkut väittävät, että emme voi puhua maailman perimmäisestä luonteesta yhtään mitään, ja näin ollen on turha väittää tieteen tai kristinuskon jollakin tavalla tavoittavan totuuden. Toiset taas väittävät, että vain toinen osapuoli esittää väitteitä maailmasta, toinen sen sijaan pelkästään ilmaisee tunteita tai merkittäviä kokemuksiaan. On myös niitä, joiden mukaan sekä kristinusko että tiede puhuvat kyllä maailmasta, mutta niiden tavat puhua ovat erilaiset ja ne puhuvat kahdesta eri maailmasta, hengellisestä ja luonnollisesta. Näkemyksiä on monia, ja tulen palaamaan niihin jatkossa laajasti. Tässä vaiheessa lukijalle riittää sen muistaminen, että valitsemani filosofinen näkökulma koskee nimenomaan erilaisia väitteitä ja niiden perusteluja.

Väitteiden ja niiden perusteluihin keskittyvä näkökulma eroaa historiallisesta ja yhteiskunnallisesta näkökulmasta. Voimme esimerkiksi yrittää selvittää historiallisin menetelmin, miten Charles Darwinin aikalaiset suhtautuivat hänen teoriaansa luonnonvalinnasta, miten 1600-luvun fyysikot käyttivät teologisia argumentteja kantojensa puolustamiseen tai miten nykyaikaiset kreationistiset liikkeet käyttävät hyväkseen tietynkaltaisia näkemyksiä tieteellisen toiminnan luonteesta osana kampanjoitansa. Nämä kaikki kysymykset ovat historiallisia tai yhteiskunnallisia ja koskevat sitä, miten asiat ovat. Filosofinen lähestymistapamme puolestaan ei pyri kuvaamaan historiallisia tai yhteiskunnallisia tilanteita, vaan tarkastelemaan väitteitä niiden historian ulkopuolella. On näin ollen perusteltua pitää erillään seuraavat kaksi kysymystä. 
(1) Mikä tieteen ja kristinuskon suhde on ollut (tai on) jossakin tietyssä paikassa tai tilanteessa?

(2) Mitä meidän pitäisi uskoa joidenkin tieteellisten teorioiden ja teologisten näkemysten luonteesta, keskinäisestä yhteensopivuudesta tai ristiriidoista?

Ensimmäiseen kysymykseen voidaan vastata tarkastelemalla jotakin tiettyä yhteiskunnallista ja historiallista tilannetta, jälkimmäiseen taas vastataan arvioimalla erilaisten väitteiden perusteita ja niiden järkevyyttä. Ensimmäinen kysymys on historiallinen ja siihen vastaukseksi riittää tilanteiden kuvaaminen. Jälkimmäinen kysymys on taas filosofinen ja se edellyttää laajempaa näkemystä siitä, miten väitteitä perustellaan ja millaisia järkevyyden kriteerejä sovelletaan. Tämä jälkimmäinen kysymys on se, johon tässä kirjassa keskitytään. Filosofisen näkökulman valitsemalla en halua sanoa, että historiallinen näkökulma olisi epäkiinnostava tai hyödytön - näkemykseni on itse asiassa päinvastainen. Historiallinen näkökulma tieteen ja kristinuskon suhteeseen on erittäin kiinnostava ja tiedollisesti antoisa projekti, johon monet ovat täysin rinnoin heittäytyneet. On ikävä tosiseikka, että inhimilliset kirjoittajat ovat rajallisia, ja kustantaja haluaa pitää kirjojen pituudet tietyissä rajoissa. Sekä historiallisen että filosofisen näkökulman omaksuminen tasapuolisesti olisi jättänyt tämän kirjan niin yleiseksi, että se ei olisi tyydyttänyt lukijaa (eikä kirjoittajaa). Kirja ei ole kuitenkaan kokonaan unohtanut historiallista näkökulmaa: luvut, jotka koskevat näkemyksiämme luonnosta, sisältävät myös jonkin verran historiallista ainesta.

On myös syytä erottaa toisistaan tieteen ja kristinuskon suhteen tutkimus tuosta suhteesta itsestään. Viittaankin jatkossa tämän alan tutkimukseen lyhyesti käyttämällä ilmaisua "tiede ja kristinusko" lainausmerkeissä, koska tämä käytäntö on englanninkielisessä maailmassa varsin yleinen. Erityisesti juuri historialliset ja yhteiskunnalliset kysymykset ovat kuuluneet tämän tutkimuksen alaan. "Tieteen ja kristinuskon" (science and theology/science and religion) tutkimus on joissakin yliopistoissa oma akateeminen oppialansa, 
jolla on usein oma instituutti, professori ja koulutusohjelma. Näin esimerkiksi Oxfordissa ja Cambridgessa Britanniassa (Ian Ramsey Centre Oxfordissa ja Faraday instituutti Cambridgessa), joissa teologian tutkintoa suorittava voi erikoistua johonkin "tieteen ja uskonnon" erityiskysymykseen aina väitöskirjatasolle asti. Lisäksi alalla on nykyisin omat akateemiset julkaisunsa, kuten esimerkiksi Zygon: The Journal for Religion and Science ja Theology and Science, sekä kansainväliset ja mannerkohtaiset kattojärjestönsä kuten esimerkiksi International Society for Science and Religion (ISSR) ja European Society of the Study of Science and Theology (ESSSAT). Usein "tieteen ja kristinuskon" tutkimus on mielletty osana tieteen- ja oppihistorian tutkimusta ja monet alan tutkijoista ovatkin ansioituneet juuri tieteenhistorioitsijoina. Hyvänä esimerkkinä toimii Ronald Numbers, joka on tieteen ja lääketieteen historian professori Wisconsinin yliopistossa ja johtava kreationismin ja antievoluutio liikkeiden historian tutkija. ${ }^{1}$ Toisena esimerkkinä mainittakoon Ian Ramsey Centren nykyinen johtaja Peter Harrison, jonka tutkimukset ovat keskittyneen modernin tieteen syntyyn 1600-luvulla ja sen uskonnolliseen taustaan. Eräs Harrisonin perusväite on, että reformaation seurauksena syntynyt uudenlainen tapa tulkita Raamattua vaikutti merkittävästi luonnontieteiden syntyyn. ${ }^{2}$ Historiallisen tutkimuksen pioneerina on syytä mainita eläkkeelle jäänyt professori John Hedley Brooke, jonka klassikko Science and Religion: Some Historical Perspectives (1991) on toiminut jo kohta 20 vuotta tutkimuksen lähtökohtana. Erityisesti Brooke on keskittynyt tieteen ja kristinuskon suhteeseen 1800-luvun viktoriaanisessa Englannissa.

Historiallisten ja yhteiskunnallisten kysymysten lisäksi "tieteen ja kristinuskon" alalla on hyvin paljon tutkimusta, joka edustaa filosofista näkökulmaa. Keskustelut ovat koskeneet esimerkiksi modernin kosmologian suhdetta oppiin luomisesta, evoluutioteorian teologisia seurauksia ja psykologisen ja yhteiskunnallisen teorioiden suhdetta kristillisiin käsityksiin ihmisluonnosta ja ihmisen paikasta maailmassa. Tutkimuksen poikkitieteellisyyden (tiede, filosofia, teologia) on tavallista, että filosofisen näkökulman edustajilla on 
sekä tieteellinen että teologinen (tai filosofinen koulutus). Keskeisiä kirjoittajia ovat olleet esimerkiksi Ian Barbour, Alister McGrath, John Polkinhorne ja Arthur Peacocke, joista Barbourin, McGrathin ja Peacocken tausta on biotieteissä ja Polkinghornen taas fysiikassa. Myös monet puhtaasti teologisen ja filosofisen koulutuksen saaneet kirjoittajat, kuten Philip Clayton, John Haught ja Keith Ward, ovat olleet paljon esillä.

Historiallisia ja yhteiskunnallisia kysymyksiä ei kuitenkaan voida lopullisesti erottaa filosofisista. Tämä näkyy siinä, että tieteen ja kristinuskon suhteella on sekä paikallinen että universaali ulottuvuutensa. Jokaisella maalla, kielialueella ja traditiolla on omat uskonnolliset erityispiirteensä aivan samoin kuin omat tieteelliset perinteensä. Maassa, jossa johtavat akateemikot ovat kirjallisuudentutkijoita ja jossa valtakirkkona on roomalaiskatolisuus, ovat keskustelut hyvin erilaisia kuin maassa, jossa luonnontieteilijät ovat näkyvästi esillä mediassa ja uskonnollisessa elämässä vaikuttaa löyhä protestanttinen valtionkirkko. Paikallisista erityispiirteistä huolimatta tieteen ja kristinuskon suhteella on universaali, filosofinen ulottuvuutensa. Haluamme uskoa, että asioista on olemassa totuus ja että on olemassa maailma, jota näkemyksemme jäljittävät. Lisäksi haluamme uskoa, että meillä on joitakin varsin yleisesti jaettuja järkevyyden kriteereitä ja järkeviä perusteluita. Näiden oletusten - yhteinen maailma ja jotkut yleiset järkevyyden kriteerit - avulla voidaan ainakin päästä alkuun toiminnassa, jossa kristinuskon ja tieteen suhteesta voidaan esittää perusteltuja näkemyksiä.

Luulen, että harvat lukijat jakavat uskoni filosofian keskeiseen rooliin tieteen ja kristinuskon suhteesta puhuttaessa. Moni saattaa ajatella, että mitään filosofiaa ei tarvita. Olen eri mieltä. Kaikkein olennaisin kysymys nimittäin on se, miten tieteen ja kristinuskon esittämiä väitteitä tulisi tulkita ja miten niihin perustuvia maailmankatsomuksia tulisi arvioida. Tämä arviointi ja tulkinta ovat nimenomaan filosofian tehtäviä. Eräässä mielessä voidaan sanoa, että filosofia pyrkii muodostamaan kaikkein yleisimmän kokonaisnäkemyksen asioista. Se pyrkii ottamaan huomioon kaiken mahdol- 
lisen ja rakentamaan yhtenäisen maailmankatsomuksen. Teologia lähestyy tämän tavoitteen suhteen filosofiaa, sillä teologiakin pyrkii kehittämään maailmankatsomuksen, jonka sisään kaikki saadaan mahtumaan. Käsittelemme siis tässä kirjassa aihetta, joka edellyttää sekä teologista että filosofista työskentelyä ja tieteellisten ja uskonnollisten näkemysten tulkintaa. Tästä syystä filosofian - erityisesti tieteenfilosofian ja uskonnonfilosofian - leikkaaminen pois olisi mielestäni suuri virhe. Ilman filosofista työskentelyä emme edes ymmärrä, mistä tieteen ja kristinuskon suhteessa on kysymys.

En usko, että vakuutan lukijani kovinkaan monesta asiasta. Myöhemmin esitän perusteita sen puolesta, että meidän ei tule edes odottaa saavuttavamme lopullista yksimielisyyttä tieteen ja kristinuskon luonteesta ja suhteesta. Joskus asiat ovat niin monimutkaisia, että ihmiset voivat olla perustellusti eri mieltä. Tämä ei kuitenkaan tarkoita sitä, että pyrkimyksestä totuuteen pitäisi luopua. Se tarkoittaa, että meidän pitää yrittää kovemmin. Sen sijaan, että vakuuttaisin lukijani, toivon, että pystyisin kuitenkin haastamaan lukijani ajattelemaan kristinuskon ja tieteen suhteeseen liittyviä kysymyksiä ja välttämään yksinkertaistuksia. Haluan sanoa ainakin tämän: yksinkertaiset - ja ikävä kyllä varsin yleisesti kannatetut - näkemykset eivät pysty vangitsemaan tämän suhteen monipuolisuutta ja sen mahdollisuuksia.

Sanoisin vielä muutaman sanan tämän kirjan lähtökohdista. Jotta lukijalle ei jäisi epäilystä, mistä kirjan kirjoittaja lähtee liikkeelle, niin sanon mahdollisimman suoraan seuraavat asiat. Tässä kirjassa ei puolusteta mitään kreationismin tai älykkään suunnittelun idean muotoja. Kreationismin eri muotoja pidetään sekä teologisesti että tieteellisesti umpikujina ja älykkään suunnittelun ideaa tieteellisesti epäuskottavana ja teologisesti laihana. Kirjan tarkoituksena ei kuitenkaan ole käsitellä kattavasti näitä näkemyksiä kohtaan suunnattua kritiikkiä, sillä sitä varten on jo olemassa paljon hyvää kirjallisuutta. Tässä kirjassa ei myöskään pyritä kumoamaan kaikkia osapuolia vakuuttavalla tavalla esimerkiksi tieteellistä materialismia tai raamatullista literalismia (tai kreationismia tai älykkään suun- 
nitelman ideaa) eikä pyritä puolustamaan aukottomasti tieteellistä ja teologista realismia. Vaikka kirjassa suositellaan joitakin näkemyksiä, on tarkoitus kuitenkin tehdä tämä hyvin yleisellä tasolla ja johdattaa asiaa tuntematonta lukijaa keskusteluun siinä muodossa, jossa sitä käydään. Yritän esittää kussakin kohdassa jonkinlaisia perusteita sille, miksi suosittelen jotakin näkemystä ja miksi vastustan jotakin toista, mutta tarkemmat perustelut lukija joutuu etsimään oheiskirjallisuudesta.

Koska tämän kirjan kirjoittajalla on näistä asioista omat näkemyksensä ja niitä on käytetty aineiston jäsentämiseen, niin on rehellisyyden nimissä hyvä nostaa niistä tärkeimmät esiin. Tässä kirjassa lähdetään liikkeelle siitä, että

(1) kypsien tieteiden (esimerkiksi evoluutiobiologia ja fysiikka) yleisesti hyväksytyt teoriat (esimerkiksi evoluutio luonnonvalinnan kautta ja nykyaikaiset kosmologian ja fysiikan teoriat) lähestyvät totuutta ja eivätkä edellytä uskonnollisia täydennyksiä,

(2) kristillinen teologia sisältää toisinaan väitteitä todellisuudesta ja näiden väitteiden ymmärtämiseksi ja arvioimiseksi ei tarvitse olla uskonnollinen ihminen,

(3) tieteen ja kristinuskon suhde ei ole lainkaan ongelmaton, ja nykyiset luonnontieteet ja käyttäytymistieteet asettavat rajoja sille, millaisia teologisia näkemyksiä voidaan järkevästi hyväksyä,

(4) näitä asioita koskevien kiistojen eri osapuolet koostuvat järkevistä ja älykkäistä ihmisistä, jotka eivät ansaitse julkista pilkkaa tai nöyryytystä.

Kirjan perusväite on se, että kaksi varsin suosittua tapaa ymmärtää kristinuskon ja tieteen suhde - konflikti ja itsenäisyys - ovat teologisesti, historiallisesti ja filosofisesti huonoja vaihtoehtoja. Niiden sijaan tarkastellaan erilaisia tapoja muotoilla näkemys, joka sijoittuu näiden kahden väliin. Erityisesti tarkastellaan sellaisten "tieteen ja kristinuskon" alan kirjoittajien näkemyksiä, joita voimme kutsua "luonnon teologiaksi". Näitä näkemyksiä ei pidetä lopullisina eikä 
niiden väitetä ratkaisevan kaikkia ongelmia kaikkia osapuolia tyydyttävällä tavalla, mutta niiden kuitenkin ajatellaan antavan suuntaa tulevaisuuden pyrkimykselle.

Kirja rakentuu seuraavalla tavalla. Luvussa 2 tarkastellaan kahta suosittua tapaa ymmärtää kristinuskon ja tieteen suhde - ristiriita ja itsenäisyys - ja kiinnitettään huomioita näiden näkemysten ongelmiin. Näiden kahden mallin sijaan aletaan hahmotella kolmatta mallia, tieteen ja kristinuskon osittaista päällekkäisyyttä. Luku 3 tarkastelee erilaisia tapoja ymmärtää tieteen ja kristinuskon perusluonteet, jotka puolestaan vaikuttavat siihen, miten keskustelua käydään. Luvussa liikutaan siis "tieteen ja kristinuskon" menetelmällisellä tasolla. Luvun keskeisin väite on se, että meillä on hyviä perusteita hyväksyä sekä jonkinlainen kriittinen tieteellinen realismi että teologinen realismi.

Luvut 4 ja 5 luovat yleiskuvan siihen, miten käsityksemme luonnosta on muuttunut luonnontieteiden kehityksen seurauksena sitten keskiajan ja millaisia yleisiä ongelmia nämä muutokset ovat tuottaneet teologisille näkemyksille. Näiden lukujen tarkoituksena on luoda pohja niille teologisille vastauksille, joita esitetään seuraavissa luvuissa. Luku 6 tarkastelee sitä, miten luomisen teologiaa on tulkittu nykyisen tieteellisen tietomme valossa. Siinä esitetään myös useita luonnon teologian edustajien näkemyksiä luomisesta ja Jumalan toiminnasta fysikaalisessa maailmassa. Luvussa 7 tarkastellaan erästä evoluution ja teologian suhteeseen liittyvää kysymystä, kysymystä suunnittelusta. Luku esittelee lyhyesti teologiset perusvaihtoehdot mutta keskittyy erityisesti teistiseen evoluutioon. Luku 8 luo yleiskuvan keskusteluun evoluution, uusien biologisten ja psykologisten tieteiden ja teologian suhteesta. Erityisesti käsitellään kysymyksiä ihmisluonnosta ja kysymystä ihmisen erityisyydestä. Lopuksi luvussa 9 vedetään yhteen keskustelua ja tehdään muutamia filosofisia huomioita tieteestä ammentavien uskontokriitikkojen näkemyksistä. 



\section{JA KESKITIEN ETSINTÄ}

Tieteen ja kristinuskon suhteen tarkastelu on hyvä aloittaa siitä, millaisia mahdollisia suhteita niiden välillä voisi teoriassa olla. Keskustelua hallitsevat usein kaksi mallia - kaksi mallia, joihin tässä kirjassa suhtaudutaan varsin kriittisesti. Ensimmäisen mallin mukaan tiede ja kristinusko ovat pysyvässä ristiriidassa keskenään. Jälkimmäisen mallin mukaan taas tiede ja kristinusko ovat toisistaan riippumattomia. Tässä luvussa luodaan yleiskatsaus siihen, kuinka näiden mallien edustajat tavallisesti perustelevat omaa lähestymistapaansa ja kritisoidaan näitä perusteita. Luvun loppupuolella aloitetaan mahdollisen vaihtoehdon, eräänlaisen keskitien muodostaminen, joka jatkuu kirjan loppuun asti.

\section{1}

PER U S M A L L I T

Ajattele seuraavia tarinoita. Ensimmäinen tarina alkaa siitä, että noin 10000 vuotta sitten on olemassa kaikkivaltias, kaikkitietävä ja täydellisesti hyvä persoonallinen Jumala, joka ei ole aineellinen. Jumala päättää hyvyyttään luoda maailman, koska hän haluaa, että on olemassa olentoja, jotka voivat olla hänen kanssaan yhteydessä. Luotuaan ihmisen ja muun luomakunnan täydellisyyttä hipovaan tilaan ihminen kuitenkin mokaa koko jutun tekemällä kiellettyjä 
asioista, jonka seurauksena kaikki paha, kuolema ja rappio tulee koko luomakunnan osaksi. Ihminen levittäytyy maailmaan ja muodostaa eri kansoja, joiden joukosta Jumala valitsee yhden kansan oman tahtonsa välikappaleeksi. Jumala antaa tälle kansalle ilmaisun omasta tahdostaan lain muodossa ja lupaa vapauttaa kansan alistajien ikeestä. Lisäksi Jumala antaa lupauksen kansansa lopullisesta pelastuksesta kuninkaan muodossa. Lopulta tämä messias ilmestyy ja elämällään, kuolemallaan ja ylösnousemuksellaan asettaa voimaan uudenlaisen suhteen ihmisten ja Jumalan välillä: nyt Jumala haluaa olla kaikkien kansojen Jumala, ei pelkästään tämän yhden. Sanomaa pelastajasta, joka sovittaa syntiinlankeemuksen seuraukset, alkaa julistaa uusi organisaatio, kirkko. Kirkon aika jatkuu siihen asti, kunnes Jumala päättää koota kaikki ihmiset tuomiolle, lähettää osan ikuiseen kadotukseen ja toiset ikuiseen iloon hänen kanssaan.

Toinen tarina alkaa noin 13 miljardia vuotta sitten, jolloin olemaan sinkoaa suuri määrä erilaisia alkeishiukkasia, jotka pyörteen lailla muutaman minuutin aikana järjestäytyvät erilaisiksi alkuaineiden atomeiksi. Kun vuosimiljardit kuluvat, nämä hiukkaset järjestäytyvät auringoiksi, jotka alkavat tuottaa äärettömät määrät energiaa ja alkuaineita. Luonnonlakien mukaan hiukkasista koostuu planeettoja aurinkojen ympärille. Välimatkat aurinkokuntien, planeettojen ja kokonaisten galaksien, tähtien joukkojen, välillä ovat lähes mittaamattoman suuria, täynnä avaruuden tyhjyyttä. Sitten kerran eräällä planeetalla alkuaineet sekoittuvat tietyllä tavalla. Syntyy itseään kopioivia mekanismeja. Näistä muodostuu ensimmäinen solu, ensimmäinen elämä koko maailmankaikkeudessa. Taas kuluu miljoonia ja miljoonia vuosia, kun tästä solusta kehittyy luonnonvalinnan seurauksena yhä monimutkaisempia elämänmuotoja. Lopulta monien sattumien seurauksena kehittyy nisäkkäiden heimosta kädellisten heimo ja kädellisten heimosta lopulta nykyihminen. Ensitöikseen nykyihminen metsästelee kymmeniä tuhansia vuosia, kunnes hän oppii maanviljelyksen ja asettuu aloilleen, rakentaa kaupunkeja, alkaa kirjoittaa ja historia alkaa. Loppu onkin 
kirjaimellisesti historiaa. Tarina ei kuitenkaan lopu tähän. Joskus miljoonien vuosien päässä tulevaisuudessa, kun nykyihminen ei ole edes muisto, elämä lakkaa: ensin tällä pallolla ja sitten muualla. Lopulta maailmankaikkeus joko jatkaa laajenemistaan ikuisesti tai kutistuu kokoon. Tapahtuipa sitten mitä tahansa, niin sillä ei tässä tarinassa ole "lopullista tarkoitusta", ei päämäärää, ei merkitystä missään perustavassa mielessä.

Ensisilmäyksellä näissä tarinoissa on hyvin vähän mitään yhteistä. Ensimmäisessä tarinassa pääosassa ovat persoonat, heidän ajatuksensa ja halunsa: Jumala ja ihmiset. Jumala ohjaa tarinan kulkua ja sen keskuksessa ovat ihmiset ja heidän perimmäinen kohtalonsa. Toisessa tarinassa taas pääosassa ovat persoonattomat maailmankaikkeuden perusosat, hiukkaset, joiden käyttäytymistä ohjaavat rautaiset luonnonlait. Ensimmäinen tarina sijoittuu muutaman tuhannen vuoden sisälle, jälkimmäisessä taas puhutaan arkijärjelle käsittämättömän pitkistä ajanjaksoista, miljardeista ja miljardeista vuosista. Nämä tarinat ovat tällä tavalla esitettynä - kuten jokainen näkee ja sanottakoon se heti suoraan - yhteensopimattomia: niissä on osia, jotka eivät voi olla samaan aikaan tosia. Lukija huomatkoon, että nämä tarinat ovat tahallisia yksinkertaistuksia.

Esittelin nämä tarinat, koska ne pakottavat meidät valitsemaan jonkin seuraavista vaihtoehdoista:

(1) On hyväksyttävä jompikumpi tarina sellaisenaan ja torjuttava toinen.

(2) Jos haluaa hyväksyä molemmat, pitää sanoa, että tarinat puhuvat eri asioista, tai

(3) muokata jompaakumpaa tai molempia niin, että ne eivät ole ristiriidassa, tai

(4) kehittää uusi tarina, johon nämä kaksi tarinaa sulautuvat.

(5) On torjuttava molemmat.

Jätän vaihtoehdon (5) käsittelemättä, koska uskon, että tällainen uskomuksista pidättäytyminen ei ole välttämätöntä, vaikka se on- 
kin yleistä. Neljä ensimmäistä ovat ne vaihtoehdot, jotka tarjoaa Ian Barbourin neljän mahdollisen tieteen ja kristinuskon suhteen luokittelu. Barbourin nimitysten mukaan nämä mallit ovat

(1) ristiriita/konflikti (conflict),

(2) itsenäisyys (independence),

(3) keskustelu (dialogue),

(4) yhdistäminen (integration).

Barbour esitteli luokittelunsa käänteentekevässä kirjassaan Issues in Science and Religion jo vuonna 1966, jonka jälkeen se on sitkeästi elänyt mukana keskusteluissa. ${ }^{3}$

Konfliktimallin perusajatus on se, että tieteen ja kristinuskon välillä vallitsee silottamaton kuilu: ei ole mahdollista hyväksyä osia molemmista, vaan on joko torjuttava tiede tai kristinusko. Tiede ja kristinusko ovat ikään kuin kokonaisia paketteja, jotka eivät voi elää yhdessä samassa päässä eikä samassa elämässä. Konfliktimallista on kaksi muotoa, joista ensimmäinen torjuu kaiken mahdollisen uskonnon ja jälkimmäinen taas tieteen itsenäisyyden. Kutsumme jatkossa edeltävää näkemystä tieteelliseksi materialismiksi ja jälkimmäistä raamatulliseksi literalismiksi. Edeltävän näkemyksen mukaan tiede pystyy tarjoamaan kaiken sen, minkä perinteinen kristinusko tarjoaa, mutta tavalla, joka pitäytyy totuudessa. Jälkimmäisen näkemyksen mukaan taas kristinuskon on annettava perusta tieteelle ja torjuttava kaikki tieteelliset teoriat, jotka johtavat konfliktiin erehtymättömänä ymmärretyn Raamatun ilmoituksen kanssa.

Konfliktimallin vaihtoehdoksi esitetään usein itsenäisyysmallia, jonka mukaan ristiriita tieteen ja kristinuskon välillä on pelkästään kuviteltua. Oikein ymmärrettynä tiede ja uskonto eivät voi olla ristiriidassa: molemmat puhuvat eri asioista ja niiden tarkoitus ihmisten elämässä on erilainen. Tästäkin mallista on monta versiota, mutta niitä kaikkia yhdistää pyrkimys tulkita joko tieteelliset teoriat tai uskonnolliset näkemykset (tai molemmat) niin, että niissä ei puhuta todellisuudesta. Yksi mahdollisuus on ajatella, että todellisuus on 
meille tavoittamaton, josta puolestaan seuraa se, ettemme voi kysyä sen enempää tieteen teorioiden tai teologisten näkemysten totuutta. Toinen mahdollisuus on ajatella, että teologiset näkemykset eivät itse asiassa edes pyri sanomaan maailmasta mitään, vaan kertovat lähinnä ihmisten tunteista ja kokemuksista.

Väite, jota tässä kirjassa pyritään perustelemaan, on se, että sekä konfliktimalli että itsenäisyysmalli ovat ongelmallisia. Niiden tilalle tarvitaan keskitietä, jonka tarjoavat Barbourin kaksi viimeistä mallia, keskustelu ja yhdistäminen. Niputan jatkossa nämä kaksi mallia yhdeksi malliksi, jota kutsun päällekkäisyysmalliksi. Päällekkäisyysmallin perusajatus on se, että tiede ja kristinusko eivät ole toisistaan riippumattomia kokonaisuuksia eivätkä kokonaan päällekkäisiä. Päällekkäisyysmallin parempi nimitys olisikin siis osittainen päällekkäisyys mutta käytännön syistä puhun jatkossa vain päällekkäisyydestä. Yhtäältä kristinuskossa on väitteitä, jotka menevät päällekkäin tieteen teorioiden kanssa ja voivat olla niiden kanssa ristiriidassa tai harmoniassa. Toisaalta taas tieteen monet teoriat ovat kristinuskon näkökulmasta irrelevantteja ja usein tieteen teoriat ja menetelmät ovat niin erilaiset kristinuskoon verrattuna, että niiden ristiriidasta tai harmoniasta on turha puhua. Lyhyesti sanottuna siis päällekkäisyysmallin mukaan kristinusko ja tiede voivat olla osittain ristiriidassa, osittain harmoniassa ja osittain itsenäisiä. Päällekkäisyysmallin sisällä voidaan sitten esittää hyvin erilaisia näkemyksiä siitä, mitkä kohdat menevät päällekkäin, mitkä ovat ristiriidassa ja mitä taas harmoniassa.

\section{2 \\ KO N F L I K T I}

On varsin yleinen ajatus, että tieteen ja kristinuskon välillä vallitsee pysyvä sotatila, tai ainakin eräänlainen kylmä sota, jossa kumpikin osapuoli vetää tarkan rajan ystävän ja vihollisen väliin ja on vakuuttunut siitä, että vain toinen voi voittaa. Rajan toisella puolella 
ovat ne, jotka uskovat horjumatta tieteen olevan ainoa tie tietoon ja siihen, että vastapuoli pyrkii puhumaan samoista asioista. Toisella puolella ovat taas ne, jotka uskovat horjumatta Raamatun ilmoituksen - tai jonkin toisen yliluonnollisen tietolähteen - luotettavuuteen luontoa koskevissa asioissa ja pitävät vastapuolen teorioita oireina puuttuvasta jumalayhteydestä. Nimitämme jatkossa tällaista näkemystä ristiriitamalliksi tai konfliktimalliksi.

Kirjallisuudessa on tapana puhua konfliktiteesistä, joka voidaan esittää sekä historiallisessa että teoreettisessa muodossa:

(Kh) Tieteen ja uskonnon välillä on ollut pysyvä ristiriita siitä lähtien, kun moderni luonnontiede syntyi.

(Kt) Tieteelliset teoriat ja uskonnolliset näkemykset ovat yhteensovittamattomia.

Historiallisen konfliktiteesin mukaan modernin luonnontieteen kehitys on edellyttänyt uskonnollisen auktoriteetin ja ajattelun väistymistä, vanhan ajattelun korvautumista uudella. Tätä kehitystä heijastavat parhaiten tilanteet, joissa uskonnolliset näkemykset ja tieteelliset näkemykset ovat törmänneet tavalla, jossa toinen osapuoli (se, jolla kulloinkin on ollut enemmän yhteiskunnallista valtaa) on päätynyt pakolla sulkemaan toisen ulkopuolelle. Ennen 1900-lukua tietysti kristinuskon auktoriteetti oli se, joka tämän mallin mukaan pakotti tieteelliset teoriat puolustuskannalle ja jonka toimesta tiedemiehiä jopa vainottiin.

Teoreettinen konfliktiteesi sen sijaan väittää, että tieteen ja uskonnon välinen ristiriita on niin suuri, että sitä ei pystytä silottamaan. On siis tehtävä selkeä valinta jommankumman välillä. Nykyään teoreettista konfliktiteesiä perustellaan usein evoluutiobiologian ja luomisen yhteensopimattomuudella tai väitteellä, että Jumalan toiminnalla ei ole paikkaa tieteen kuvaamassa maailmankaikkeudessa. Konfliktimallin molemmat edustajat - tieteelliset materialistit ja raamatulliset literalistit - ajattelevat, että nykyaikainen tiede ja 
perinteinen kristinusko ovat pysyvästi sotajalalla. Molemmat osapuolet ovat siis vakuuttuneet, että tieteelliset teoriat ja uskonnolliset näkemykset puhuvat samoista asioista ja että tiedolla - olkoonkin se havaintotietoa tai ilmoitettua tietoa - on horjumaton perusta.

Aloitamme konfliktimallin käsittelyn tieteellisestä materialismista. Ensimmäisenä täytyy sanoa, että tieteellinen materialismi ei ole kovinkaan hyvä termi mutta parempaa on vaikea löytää. ${ }^{4}$ Vaikka termi on varsin vakiintunut (scientific materialism), se on kuitenkin harhaanjohtava, sillä tieteellinen materialismi ei oikeastaan ole tiedettä eikä välttämättä materialismiakaan. Syyt tähän tulevat ilmi hetken päästä. Termiä "tieteellinen materialismi" on tapana käyttää viittaamaan näkemykseen, jota ovat kannattaneet ainakin muutamat varsin kuuluista tieteilijät ja filosofit. Ehkä kuuluisimpia tästä joukosta ovat biologit Richard Dawkins ja Edward O. Wilson, fyysikot Carl Sagan ja Steven Weinberg sekä filosofi Daniel Dennett. ${ }^{5}$ Näiden kirjoittajien edustama näkemys voidaan karkeasti ottaen tiivistää viiden väitteen muotoon ${ }^{6}$ :

(1) Luonnon, joka sisältää ihmiset ja ihmisen kulttuurin luomukset, lisäksi ei ole mitään. Ei ole olemassa sieluja, ei kuolemanjälkeistä elämää eikä Jumalaa.

(2) Luonto synnyttää itse itsensä, joten se ei ole Jumalan luoma.

(3) Luonnolla ei ole päämäärää eikä tarkoitusta, vaikka yksittäiset ihmiset voivatkin löytää tarkoituksen elämälleen.

(4) Koska Jumalaa ei ole, kaikki selitykset ovat pelkästään luonnollisia ja vain tiede voi löytää ne.

(5) Kaikki elävien olioiden ominaisuudet, mukaan lukien inhimillinen älykkyys ja käyttäytyminen, voidaan selittää kokonaan luonnollisin tavoin. Tällä tarkoitetaan yleensä darwinistisia selityksiä (biologinen reduktionismi).

Tieteellisen materialistin väite (1) on väite siitä, millainen todellisuus pohjimmiltaan on: kaiken olevan - luonnon - perustana on aine (tai energia), eikä esimerkiksi Jumala tai mieli. Luonto ja aine ovat 
itsessään riittäviä selittämään itse itsensä eivätkä ne tarvitse mitään ulkopuolista perustaa. Olennaisia ovat myös väitteet (4) ja (5), jotka koskevat sitä, miten saamme tietoa todellisuuden luonteesta, mitkä ovat luotettavia tietolähteitä. Näiden teesien mukaan tieteellinen menetelmä - erityisesti sellaisena, kuin sitä toteutetaan luonnontieteissä - on ainoa tie totuuteen. Jos siis haluamme saavuttaa tietoa jostakin asiasta, on tieteellinen menetelmä ainoa vaihtoehto.

Yhdistettynä nämä viisi teesiä tuottavat näkemyksen, jonka mukaan ainoastaan tiede voi kertoa meille mitä on olemassa ja miten maailma toimii. Tiede tutkii aineellisia ilmiöitä, ja koska kaikki, mikä on olemassa, on tässä mielessä aineellista, mikään ei jää tieteen ulkopuolelle. Kaikki ilmiöt, vaikutukset ja tieto, jotka ovat ei-tieteellisiä, osoittautuvat illuusioiksi tai luuloiksi. Jos tiede ei voi tutkia joitakin vaikutuksia tai se ei löydä jotakin ilmiötä, ei tätä vaikutusta tai ilmiötä ole olemassa. Näin tieteellinen materialisti esimerkiksi katsoo tietävänsä, että Jumalaa ei ole olemassa: Jumalasta ei hänen mukaansa saada tieteellisen menetelmän avulla tietoa eikä Jumala kelpaa tieteelliseksi selitykseksi millekään aineelliselle.

Koska tieteellinen materialisti uskoo, että tieteen menetelmä on ainoa luotettava tietolähde ja että kaikki on pohjimmiltaan tieteen tavoitettavissa, hän uskoo myös siihen, että kaikki havaittavat ilmiöt voidaan lopulta selittää niiden aineellisten komponenttien käyttäytymisellä. Tätä kantaa on ollut tapana kutsua "fysikalismiksi". Fysikalismin mukaan perimmäisen kuvauksen kaikesta mikä on olemassa antaa fysiikka. Huomaa, kuinka fysikalismi ei varsinaisesti oleta kaiken koostuvan "aineesta" tai "materiasta". Tässä mielessä tieteellinen "materialismi" ei välttämättä ole sidoksissa materialismiin siinä mielessä, että kaiken katsotaan olevan viime kädessä "aineellista". Riittää, että kaikki on viime kädessä sellaista, että fysiikan teoriat voivat antaa siitä kuvauksen. Lisäksi fysikalistilla on tapana uskoa, että kaikki selitykset ovat viime kädessä fysikaalisia selityksiä tai palautettavia fysikaalisiin selityksiin. Fysikalisti kuitenkin tunnustaa, että tällä hetkellä on suuri määrä ilmiöitä, joille ei pystytä antamaan fysikaalista selitystä tai joiden selityksiä ei pystytä 
palauttamaan fysikaalisiin selityksiin. Esimerkiksi ihmisen arkisen käyttäytymisen selitykset, jotka perustuvat haluihin ja uskomuksiin, ja yhteiskunnalliset selitykset, joissa viitataan ryhmien käyttäytymiseen, eivät näytä olevan fysiikan tavoitettavissa juuri nyt. Fysikalisti kuitenkin uskoo, että joskus tulevaisuudessa, kun tiede on saavuttanut täydellisyyden, nämäkään ilmiöt eivät jää fysikaalisten selitysten ulkopuolelle.

Tieteellisen materialismin perusta on vakaa usko tieteelliseen menetelmään tiedon lähteenä. Perusajatus on se, että tieteelliset teoriat perustuvat julkisiin havaintoihin, jotka voidaan tarvittaessa toistaa kokeellisesti. Näiden havaintojen pohjalta voidaan sitten luoda teorioita, joiden ennusteita voidaan jälleen testata kokeellisesti. Sen lisäksi, että teoriat ovat yhteensopivia havaintojen kanssa, niiden tulee olla myös sisäisesti ristiriidattomia. Tämän näkemyksen mukaan uskonnolliset uskomukset ovat oikeastaan tieteellisten uskomusten vastakohtia: ne eivät perustu julkisiin havaintoihin vaan yksilön vahvistamattomiin kokemuksiin, niitä ei voida testata julkisiin havaintoihin perustuvilla kokeilla ja ne ovat sisäisesti ristiriitaisia.

Kuten väitteestä (5) käy ilmi, tieteellistä materialismia motivoi usein evoluutiobiologia. Monet tieteellisen materialismin edustajat ovat juuri biologeja (kuten Dawkins ja Wilson) tai biologiasta vaikutteita saaneita filosofeja (kuten Dennett). Esimerkiksi Wilson on esittänyt, että luonnonvalinnan teorian johdonmukainen soveltaminen ihmisiin tulee paljastamaan, kuinka ihmisen käyttäytyminen ohjautuu geneettisesti ja että vaikutelma siitä, että valitsemme oman käyttäytymisemme, on vain aivojemme tuottama illuusio. Wilson ajattelee myös, että uskonto voidaan selittää samalla tavalla: uskonnollinen käyttäytyminen oli hyödyllinen henkiinjäämisen mekanismi ihmisen menneisyydessä, koska sillä oli kyky lisätä ryhmien sisäistä yhteenkuuluvuutta. Nykyään tällaista yhteenkuuluvaisuuden mekanismia ei kuitenkaan enää tarvita etenkin, kun tiedämme nyt, että uskonnolliset näkemykset ovat räikeästi virheellisiä. Wilson kirjoittaa: 
Jos olemme oppineet historiasta ja tieteestä yhtään mitään, olemme oppineet sen, että into ja halu eivät ole yhtä kuin totuus. Ihmismieli kehittyi uskomaan jumaliin. Se ei kehittynyt uskomaan biologiaan. Usko yliluonnolliseen tuotti ihmisille suurta hyötyä esihistoriallisessa maailmassa, kun aivot vielä kehittyivät. Siten se on ristiriidassa biologian kanssa, joka on modernin maailman tuote, jonka taustalla ei ole geneettisiä algoritmeja. Epämiellyttävä totuus on se, että nämä kaksi uskoa eivät ole faktuaalisesti yhteensopivia. Tästä seuraa se, että ne, jotka janoavat sekä uskonnollista että älyllistä totuutta, eivät koskaan pysty kannattamaan molempia yhdessä.

Tässä paljastuu myös selvästi, kuinka Wilson kannattaa sekä historiallista että teoreettista konfliktiteesiä: tiede ja uskonto ovat ristiriidassa (ja ovat olleet ristiriidassa) ja hitaasti, mutta varmasti, tiede työntää Jumalaa yhä kauemmas ja kauemmas.

Tieteellisen materialistien suosikkivastustajia ja konfliktiteesin kääntöpuolen edustajia nimitämme raamatullisiksi literalisteiksi, tai lyhyesti vain literalisteiksi. Raamatullisella literalismilla viitataan teologiseen näkemykseen, jonka mukaan Raamattu kuvaa luonnon tosiseikat erehtymättömästi. Literalisti voi esimerkiksi korostaa Raamatun luomiskertomuksen tietynlaista kirjaimellista tulkintaa, jonka mukaan Jumala loi maailman tyhjästä noin 10000 vuotta sitten. Näin määriteltynä literalisti vastustaa yleensä ajatusta siitä, että ihminen on kehittynyt muista elämänmuodoista pitkän ajan kuluessa ja että kosmos on kehittynyt valtavien ajanjaksojen kuluessa nykyiseen muotoonsa. Raamatullisen literalismin yhteydessä on usein tapana puhua fundamentalismista, mutta koska tätä termiä käytetään niin sekalaisesti, niin vältän sen käyttöä kokonaan. Fundamentalismin lisäksi puhutaan usein myös kreationismista sen enempää selittämättä mitä tarkoitetaan. On kuitenkin huomattava, että nämä termit viittaavat hyvin erilaisiin joukkoihin monimutkaisia ilmiöitä, fundamentalismi ja kreationismi eivät välttämättä tarkoita samaa asiaa.

Kun siis jatkossa puhun literalismista, viittaan teologisiin näkemyksiin, joiden mukaan 
(L) Raamattu on erehtymätön kaikissa luontoon liittyvissä asioissa.

Toisin sanoen Jumala on ilmoittanut ihmisille joukon väitteitä, jotka koskevat häntä itseään, luontoa ja ihmistä ja nämä väitteet voidaan lukea varsin yksiselitteisesti Raamatusta. Monet ovat sitä mieltä, että väitteestä (1) seuraa se, että jos jokin tieteellinen teoria (tai jokin muu teoria) on ristiriidassa Raamatun ilmoitukseksi ymmärretyn näkemyksen kanssa, tulee tämä Raamatulle kilpaileva näkemys automaattisesti torjua. On helppo nähdä, miten tällainen näkemys johtaa ristiriitamallin kannattamiseen: Raamattu puhuu toisinaan luonnosta, kosmoksen rakenteesta ja luonnonhistoriasta, ja joiltakin osin se on räikeästi ristiriidassa monien hyväksyttyjen tieteellisten tulosten kanssa. Näin on esimerkiksi maailman iän ja ihmisen kehityksen suhteen. Henkilö joutuu siis valinnan eteen: valita joko "tiede" jonkinlaisena kokonaisena maailmankatsomuksen pakettina tai "kristinusko" samanlaisena pakettina.

Raamatun erehtymättömyydellä voidaan myös tarkoittaa muuta kuin Raamatun erehtymättömyyttä luontoa koskevissa asioissa. Lähes kaikki kristityt ovat uskoneet, että Raamattu toimii ohjeena Jumalan, maailman ja ihmisen ymmärtämiseksi, koska se sisältää Jumalan itseilmoituksen. Toisin sanoen Raamattu on teologian päälähde, koska se kertoo Jumalan teoista historiassa ja on kirjoitettu Jumalan tahdosta - se on siis erityisen ilmoituksen dokumentti. Tässä mielessä kaikki kristityt uskovat, että "Raamattu on totta”. Ajatus Raamatun erehtymättömyydestä luontoa koskevissa asioissa on kuitenkin paljon enemmän kuin tämä. Literalisti haluaa sanoa, että sen lisäksi, että Raamattu on totuudellinen puhuessaan Jumalasta ja hänen toiminnastaan, Raamatun jokainen luontoa koskeva lause on totta. Lyhyesti sanottuna siis jokainen Raamatun ilmaus on aina oikea kuvaus kohteestaan.

Erehtymättömyyteen kuuluu lisäksi se, että voimme ymmärtää Raamatun ilmaukset varsin yksiselitteisesti. Raamattu on toisin sanoen selvä ja yksiselitteinen kaikissa asioissa, joista se puhuu, ja me voimme ymmärtää tämän puheen. Näin ollen literalisti halu- 
aa kieltää sen mahdollisuuden, että inhimillisellä tulkinnalla olisi jonkinlainen perustava rooli teologiassa. Literalisti voi joko kieltää tulkinnan tarpeen kokonaan tai sitten todeta, että raamatuntulkinta on erehtymätöntä, koska Jumalan toiminta Raamatun lukijassa (usein Pyhä Henki) takaa tulkinnan oikeellisuuden. Näin ollen literalismille on olennaista, että se antaa tietyllä lailla tulkitulle erityiselle ilmoitukselle kaikkivaltiaan roolin teologian lähteiden joukossa. Järjen ja tradition roolit jäävät tällöin automaattisesti erittäin pieniksi, koska molempien katsotaan yleensä olevan jollakin tavalla perustavanlaatuisesti korruptoituneita. Järki tai traditio eivät tämän näkemyksen mukaan tule mukaan raamatuntulkintaan, koska mitään tulkitsemista ei ole tai sitten Jumala hoitaa tulkitsemisen lukijan puolesta.

Olennaista on ymmärtää, että literalismi on teologinen kanta ja se liittyy laajempaa teologiseen kokonaisnäkemykseen, johon kuuluvat esimerkiksi näkemykset uskonnollisen tiedon lähteistä ja kristillisen kirkon roolista yhteiskunnassa. Nykyaikainen literalismi on pitkälti lähtöisin Yhdysvalloista, jossa 1960-luvulta eteenpäin on nähty uudenlaisen poliittisen ja uskonnollisen tietoisuuden nousu. Se voidaan ymmärtää kuuluvaksi poliittis-yhteiskunnalliseen liikehdintään, jossa halutaan puolustaa perinteisiä yhteiskunnallisia arvoja. Tästä näkökulmasta voidaan väittää, että literalistin motivaatio pitää kiinni Raamatun erehtymättömyydestä on vahvasti moraalinen: Raamatun erehtymättömyys on perusta taistelussa yhä enemmän moraalisesti haaksirikkoutuvaan yhteiskuntaa vastaan. Raamatun on literalistin mielestä oltava yhteisöjen, yksilöiden ja lakien yläpuolella Jumalan selkeänä ilmoituksena. Monet perinteiset kirkkokunnat, kuten roomalaiskatoliset, anglikaanit ja luterilaiset, pitävät Raamattua kyllä teologian lähteenä, mutta ne eivät virallisesti tulkitse Raamatun kuvauksia esimerkiksi maailman synnystä teorioina, jotka voisivat olla ristiriidassa tai kilpailevia tieteellisten teorioiden kanssa.

Literalismi yhdistetään usein kreationismiin tai tieteelliseen kreationismiin (scientific creationism). Palaamme kreationismin eri 
muotoihin ja sisältöön laajasti myöhemmin, mutta voimme tässä kohdin esittää muutamia alustavia määritelmiä. Puhuessani kreationismista tarkoitan kantaa, jonka mukaan

(K) Jumala loi kosmoksen, Maan, eläinlajit ja ihmisen tyhjästä suurin piirtein sellaisena, kun näemme ne, muutamia tuhansia vuosia sitten tavalla, jonka 1. Mooseksen kirja kuvaa.

Näin ollen se, että henkilö uskoo Jumalan luoneen maailman tai että Jumala vaikuttaa maailmassa, ei ole kreationisti. Kreationismi on yksi tapa ymmärtää se, mitä tarkoitetaan sillä teologisella väitteellä, että Jumala on luonut maailman. Näkemystä kutsutaankin usein kirjallisuudessa nuoren maan kreationismiksi (Young Earth Creationism), joka eroaa vanhan maan kreationismista (Old Earth Creationism) tai älykkään suunnittelun (Intelligent Design) ideasta juuri kosmoksen iän suhteen. Vanhan maan kreationistin mukaan maailma on paljon vanhempi kuin nuoren maan kreationisti ajattelee. Hän voi omaksua maailmankaikkeuden iästä vaikka nykyisen tieteellisen näkemyksen, joka on jotakin 13 miljardin vuoden tietämillä. Älykkään suunnittelun edustajat taas eivät ole kiinnostuneita maailman iästä juuri laisinkaan ja hyväksyvät mukisematta, että maailma on paljon vanhempi, kuin Raamattu antaa ymmärtää. Sen sijaan he haastavat sen ajatuksen, että ihminen ja eläinlajit olisivat vain ja ainoastaan sattuman ja luonnonlakien synnyttämiä. $\mathrm{Pa}$ laamme näihinkin näkemyksiin laajasti myöhemmin. Siihen asti on tärkeä pitää mielessä, että varaan termin "kreationismi" ainoastaan kannalle, joka allekirjoittaa teesin (K). 
$2 \cdot 3$

\section{ITSEN ÄISYYS}

Konfliktimallin vaihtoehdoksi on usein esitetty mallia, jossa tiede ja uskonto erotetaan tarkasti toisistaan ja ajatellaan, että ne eivät laisinkaan kohtaa. Jos ristiriitamalli on aikamme tieteellisten materialistien suosikki, niin itsenäisyysmalli on tämän mallin kääntöpuoli ja monien vastaus tieteen edistymiseen. Itsenäisyysmallin etuna ristiriitamalliin nähden on se, että sitä ei voida syyttää tieteen ja kristinuskon erilaisuuden kunnioittamisesta. Malli kunnioittaa tätä erilaisuutta niin paljon, että se eristää tieteen ja kristinuskon toisistaan riippumattomiksi elämänalueiksi. Tavallisesti erottaminen tapahtuu väittämällä, että kristinuskolla ja tieteellä on kummallakin omat toisistaan riippumattomat - kohteensa ja tarkoituksensa ihmisten elämässä. Teologisesta näkökulmasta itsenäisyysmallin edustajia on ollut tapana nimittää fideisteiksi ja itse kantaa fideismiksi (lat. fides = usko).

Itsenäisyysmallia perustellaan usein enemmän tai vähemmän seuraavankaltaisilla väitteillä. ${ }^{8}$

(E1) Tiede pyrkii selittämään julkisesti toistettavia havaintoja siinä, missä teologia pyrkii selittämään kosmoksen järjestystä ja kauneutta sekä yksilöjen sisäisiä kokemuksia (syyllisyys, anteeksianto, jne.)

(E2) Tiede kysyy objektiivia "kuinka" kysymyksiä siinä, missä teologia kysyy yksityisiä "miksi" kysymyksiä arvoista, merkityksestä ja perimmäisestä tarkoituksesta.

(E3) Tietämistä tieteessä ohjaavat looginen yhteensopivuus ja empiirinen testattavuus siinä, missä teologista tietämistä ohjaavat ilmoitus ja Jumala ymmärrettyinä uskonnollisen kokemuksen kautta.

(E4) Tiede esittää ennusteita, joita voidaan testata kokeellisesti siinä, 
missä teologia käyttää symbolista ja analogista kieltä, koska Jumala on transsendentti.

Väitteen (E1) mukaan ne kohteet, joista tiede on kiinnostunut, eivät ole kristinuskon kohteita. Tieteen kohteena ovat luonnon ilmiöt. Luonnosta saadaan tietoa julkisten ja toistettavien kokeiden kautta, joiden pohjalta pyritään luomaan tieteellisiä teorioita. Kristinusko sen sijaan ei ole kiinnostunut luonnon prosesseista, vaan yleisesti luonnossa vallitsevan järjestyksen sekä uskonnollisen kokemuksen lähteestä eli Jumalasta. Väitteen (E2) mukaan uskonnon ja tieteen roolit yksilöiden ja yhteisöjen elämässä ovat hyvin erilaiset. Usein kuulee sanottavan, että uskonto tarjoaa vastauksia kysymyksiin, jotka koskevat arvoja, moraalia ja lopullista tarkoitusta siinä, missä tiede vastaa kysymyksiin erilaisista luonnon mekanismeista. Väite (E3) taas korostaa uskonnon ja tieteen erilaisia tapoja perustella väitteensä. Tieteessä hyvän teorian kriteereinä ovat esimerkiksi kokeellinen tuki, yksinkertaisuus ja yhteensopivuus muiden teorioiden kanssa. Perustellun uskonnollisen näkemyksen kriteerinä sen sijaan on yhteensopivuus Jumalan ilmoituksen sekä sisäisen (uskonnollisen) kokemuksen kanssa. Väite (E4) koskee tieteellisen ja uskonnollisen puhumisen luonnetta: tieteellisten teorioiden avulla voidaan ennustaa luonnon prosesseja. Uskonnolliset näkemykset taas eivät ennusta tällä tavalla, koska niiden kohteena on Jumala, josta ei voida puhua suoraan, vaan ainoastaan käyttäen kuvainnollista tai symbolista kieltä.

Voimme tiivistää erotusmallin seuraavalla tavalla:

(E) Uskonto ja tiede ovat toisistaan riippumattomia ajattelu- ja käyttäytymismuotoja, jotka eivät voi olla ristiriidassa keskenään.

Itsenäisyysmallia voidaan perustella sekä filosofisesti että teologisesti. Filosofiset puolustukset liittyvät usein uskonnollisen kielen ja ajattelun luonteeseen: uskonnollinen tapa puhua asioista näyttää olevan hyvin kaukana "faktakielestä" ja sen motiivina näyttävät ole- 
van pikemminkin yksilöiden ja yhteisöjen kokemukset kuin julkiset ja systematisoidut havainnot. Teologiset perustelut sen sijaan vetoavat Jumalan saavuttamattomuuteen, Raamatun ilmoituksen kuvainnollisuuteen ja ihmisjärjen rajallisuuteen Jumalaa koskevan tiedon lähteenä.

Tieteen ja uskonnon erilaisuutta ovat korostaneet teologiset virtaukset, jotka ovat olleen skeptisiä ihmisjärjen mahdollisuuteen saada tietoa Jumalasta. Usein on korostettu perisynnin vaikutusta ihmisen järkeen ja Jumalan erillisyyttä luomakunnasta. Esimerkiksi Karl Barth ja hänen seuraajansa korostivat, että Jumala voidaan tuntea vain ja ainoastaan tarttumalla uskolla Kristuksessa tapahtuneeseen ilmoitukseen. Kristus on ainoa tapa saada tietoa Jumalasta, koska Jumala on tämän maailman näkökulmasta katsottuna täydellisesti toinen: Jumala ei paljasta itseään maailmassa muuten kuin itseilmoituksensa kautta ja tämä itseilmoitus on Kristus. Uskonnollinen usko on siis Barthin mukaan jotain sellaista, jonka Jumala antaa ihmiselle ja joka riippuu Jumalan toiminnasta. Tällöin usko on myös täysin riippumaton todisteista ja ihmisjärjen yrityksistä ymmärtää luontoa tieteellisesti.

Monet Barthin oppilaat ovat korostaneet Jumalan itseilmoituksen historiallisuutta tavalla, joka tekee siitä immuunin tieteelle. Tämän näkemyksen mukaan Jumalan ilmoituksen paikkana on historia eikä luonto. Israelin kansan historia, sen merkkihenkilöt ja erityisesti Jeesuksen elämä, kuolema ja ylösnousemus ovat historian tapahtumia, joiden kautta Jumala paljastaa itse itsensä. Edes Raamatun tekstit sellaisenaan eivät ole ilmoitusta vaan ainoastaan todistusta historiassa tapahtuneesta ilmoituksesta. Usein puhutaankin ilmoitustapahtumasta erotuksena tämän ilmoitustapahtuman kirjallisesta kuvauksesta. Koska Raamatun kirjoittajat ovat olleet vain ilmoitustapahtuman tulkkeja, meidän ei tarvitse pitää heidän näkemyksiään esimerkiksi eläinlajeista, geologiasta tai maailman luomisen yksityiskohdista ohjeellisina.

Barthin ja hänen oppilaidensa näkemyksillä on merkittäviä seurauksia kristinuskon ja tieteen suhteen kannalta, joista tärkein on 
teologian ja tieteen kohteiden erillisyys ja riippumattomuus. Jos Jumalan itseilmoitus tapahtuu vain ja ainoastaan historiassa eikä sillä ole mitään tekemistä luonnon kanssa, niin ei ole syytä ajatella, että tiede voisi sanoa Jumalasta yhtään mitään. Barthin oletuksena tietenkin on, että tiede tutkii vain luontoa eikä historiaa. Barthin mukaan siis teologia perustuu Jumalan historiallisen ilmoituksen tulkinnalle siinä, missä tiede taas perustuu ihmisjärjen käyttöön luonnon kokeellisessa tutkimuksessa. Koska Jumalasta ei voida saada tietoa Jumalan itseilmoituksen ulkopuolelta, tiede on yksinkertaisesti sokea Jumalan suhteen. Jos ymmärrämme kristillisen uskon Barthin tavoin puhtaasti yliluonnolliseksi Jumalan lahjaksi, ei ole syytä olettaa sille löytyvän perusteita luonnosta, ei edes ihmisluonnosta. Ilman Jumalan lahjoittamaa uskoa luomakunta näyttää olevan vailla Jumalaa. Barth ja hänen seuraajansa ovatkin kritisoineet luonnollista teologiaa eli yrityksiä johtaa Jumalan olemassaolo joistakin luonnon havaittavista piirteistä.

Vaikka Barthin ja hänen seuraajiensa ajatuksia on pidetty teologisesti konservatiivisina, ovat Barthin liberaalit kriitikot samaa mieltä hänen kanssaan tieteen ja uskonnon suhteesta. Teologit, jotka ovat saaneet vaikutteita eksistentialismin nimellä kulkevista filosofisista virtauksista, korostavat myös eroa yksityisen kokemuksen ja luonnon objektien välillä. Ero on niin suuri, että voidaan puhua kahdesta eri maailmasta: persoonallisesta, kokemuksen ja arvojen maailmasta sekä julkisesta esineiden, kappaleiden ja tavaroiden maailmasta. Edeltävä maailma voidaan tuntea vain ja ainoastaan henkilökohtaisen kokemuksen kautta siinä missä jälkimmäinen on lähempänä etäistä ja kylmää tapaa tarkastella maailmaa, joka on tieteilijälle ominainen. Filosofisen eksistentialismin (jota on sekä uskonnollista että ateistista laatua) perusajatus on juuri se, että todellinen oleminen (autenttinen oleminen) on mahdollista vain henkilökohtaisen sitoutumisen ja vapaan valinnan kautta. Eksistentialistille ihmiselämän merkitys on siis löydettävissä ainoastaan henkilökohtaisesta maailmasta ja se edellyttää aina tunteita, persoonallista suhdetta ja valintoja; siihen ei riitä tieteilijän tarkkaileva ja rationalistinen asen- 
ne, joka etsii abstrakteja yleisiä lakeja. ${ }^{9}$

Eräs tapa ymmärtää uskonnollista eksistentialismia on tehdä ero kahden suhteessaolemisen tavan välillä: "minä-sinä" suhteen ja "minä-se" suhteen välillä. "Minä-se" suhde vallitsee yksilön ja elottoman luonnon välillä siinä missä "minä-sinä" suhde taas vallitsee yksilön ja hänen läheistensä välillä. "Minä-sinä" suhde edellyttää henkilökohtaista omistautumista, toisen osapuolen vapauden kunnioittamista ja hänen ymmärtämistään. "Minä-se" suhteessa taas tällaista sitoutumista ymmärtämiseen ei tarvita. Uskonnollinen eksistentialisti katsoo, että yksilön ja Jumalan suhde on puhtaasti "minä-sinä" suhde eikä siinä ole sijaa todisteiden arvioinnille, testaamiselle tai etäiselle tarkastelulle. Jumalaan ei yksinkertaisesti voida suhtautua samalla tavalla kuin tieteelliseen teoriaan tai ongelmaan, jota yritetään ratkaista, vaan suhde Jumalaan on paljon lähempänä suhdetta rakastettuun ihmiseen.

Raamatuntutkimuksessa edellisen suuntaista ajattelutapaa on edustanut esimerkiksi Rudolf Bultmann. Bultmannin mukaan on tavallista, että Raamatussa Jumalan toimintaa kuvataan ikään kuin se olisi julkisessa ja objektiivisessa maailmassa tapahtuvaa, mutta meidän ei tule ymmärtää Jumalan toimintaa tällä tavoin. Ymmärrämme Raamatun sanoman, kun löydämme tällaisen kielen takana olevan itseymmärryksen ja yksityisen ihmisen kokemuksen maailmasta ja itsestään. Bultmannin mukaan siis teologinen kieli ei koske julkisesti tavoitettavia tosiseikkoja, vaan pikemminkin meidän itseymmärrystämme ja suhdettamme maailmaan. Raamatun sanoman ymmärtäminen ei näin ollen tarkoita sitä, että alkaisimme uskoa luonnosta ja maailmasta jotain sellaista, mitä emme uskoneet aiemmin, vaan se tarkoittaa muuttunutta ymmärrystä omasta itsestämme ja suhteestamme maailmaan.

Barthin ja uskonnollisen eksistentialismin lisäksi voidaan ottaa vielä kolmas teologinen tulkinta itsenäisyysmallista, jonka esitti teologi George Lindbeck kuuluisassa kirjassaan The Nature of Doctrine (1984). Lindbeck erottaa kolme erilaista mallia kristillisen opin luonteesta: 
(1) Propositionalistinen malli: opit väitelauseina eli propositioina.

(2) Ekspressivistinen malli: opit uskonnollisen kokemuksen ilmauksina.

(3) Lingvistinen malli: opit kristillisen yhteisön puheen sääntöinä.

Näkemystä, jonka mukaan kristilliset opit perustuvat ilmoituksessa paljastettuihin väitelauseisiin, Lindbeck kutsuu propositionalistiseksi. Propositionalistisen mallin ajatuksena on, että opit ymmärretään julkista maailmaa koskeviksi väitelauseiksi, propositioksi, jotka ovat välttämättä tosia ja Jumalan toimesta ihmisille välitettyjä. Lindbeckin mukaan tällainen ajattelutapa oli tavallista erityisesti keskiajan teologeille kuten esimerkiksi Tuomas Akvinolaiselle. Jos kristinuskon opit ymmärretään yliluonnollisesti välitettyinä väitelauseina, ristiriita tieteellisten teorioiden kanssa on mahdollinen. Propositionalistisen mallin vastapuolena on Lindbeckin mukaan ekspressivistinen malli, jonka mukaan opit ovat sisäisen kokemuksen symbolisia kuvauksia. Tämän mallin mukaan opit eivät laisinkaan koske historiaa tai luontoa, vaan ovat kuvauksia ihmisen kokemuksista, tunteista ja muista mielenliikkeistä. Tämän mallin puitteissa on vaikea nähdä kuinka tiede ja uskonto voisivat olla ristiriidassa ja se tuleekin varsin lähelle uskonnollisten eksistentialistien näkemyksiä.

Lindbeck kuitenkin torjuu propositionalistisen mallin liian teoreettisena ja ekspressivistisen mallin liian subjektiivisena ja ehdottaa kolmatta mallia, jota hän kutsuu lingvistiseksi eli kieliopilliseksi malliksi. Lingvistisen mallin mukaan kristilliset opit eivät ole väitelauseita eivätkä pelkästään kokemuksen kuvauksia vaan sääntöjä, jotka säätelevät miten kristillisessä yhteisössä puhutaan Jumalasta. Lindbeckin mukaan uskonnot ovat yhteisöjen elämäntapoja ja opit ovat näitä elämäntapoja (käyttäytyminen ja puhe) määritteleviä sääntöjä. Näin esimerkiksi kristinusko voidaan oppeineen päivineen ymmärtää traditioksi, jolla on hallussaan omaa käyttäytymistään säätelevät normit. Jos opit ovat tradition sisäisiä sääntöjä, kuten lingvistinen malli esittää, ei ole oikeastaan mitään mieltä kysyä ovatko opit tosia 
jossakin tieteellisessä mielessä. Tällainen kysymys olisi yhtä mieletön, kuin kysymys jalkapallon sääntöjen tieteellisestä totuudesta.

Lindbeckin lingvistisen mallin taustalla on joukko filosofisia oletuksia uskonnollisen toiminnan ja puheen luonteesta. Nämä oletukset ovat peruja filosofisista näkemyksistä, joita ovat esittäneet esimerkiksi filosofi Ludwig Wittgenstein (1889-1951) ja hänen perinteensä jatkajat kuten esimerkiksi D. Z. Phillips ja Vincent Brummer.

Wittgenstein pyrki vastustamaan näkemystä, jonka mukaan tieteen kieli on kaiken kielenkäytön mittari. Loogista positivismia edustaneet olivat vuosisadan alussa esittäneet, että vain ja ainoastaan kieli, joka saa merkityksensä havainnosta on, on merkityksellistä kieltä. Muut tavat käyttää kieltä, kuten moraalinen, taiteellinen, runollinen tai uskonnollinen, eivät ole epätosia vaan mielettömiä. Ne ovat virheellisesti muodostettua kieltä, eikä niissä kirjaimellisesti ole mitään järkeä. Tämä on tietysti erittäin karkea kuvaus loogisesta positivismista mutta riittävä nykyistä tarkoitustani varten. Palaan loogiseen positivismiin laajasti myöhemmin (ks. luku 3.2). Wittgenstein kuitenkin korosti, että eri kielenkäytön tavat tekevät erilaisia asioita, joten niitä ei voida palauttaa toisiinsa. Erilaiset kielenkäytön tavat ovat osia sosiaalisesti rakentuneissa elämänmuodoissa (forms of life) muodostaen erilaisia kielipelejä (language games). Olennaista on, että kukin kielipeli saa merkityksensä siitä käyttäytymisestä, joka kannattelee sitä. Jos siis jotkut ilmaisut repäistään irti alkuperäisestä käyttöyhteydestään ja siitä, mitä niillä siinä yhteydessä tehdään, niin ne muuttuvat merkityksettömiksi.

Tieteen ja uskonnon tapauksessa ajatus kielipeleistä johtaa näiden kahden käyttäytymismuodon ja kielenkäytön tapojen erojen korostamiseen. Tieteellistä kieltä käytetään luonnon prosessien ennustamiseen ja hallintaan. Tieteelliset teoriat ovat kielellisiä rakenteita, jotka ovat hyödyllisiä tuomaan yhteen havaittavien ilmiöiden lainalaisuuksia. Jos tämä on tieteen kielen tarkoitus, meidän ei tulisi olettaa, että se toimii oman tarkoituksensa ja käyttäytymismuotojensa ulkopuolella. Uskonnollinen kieli taas on ankkuroitunut us- 
konnolliseen elämäntapaan: sen tarkoituksena on herättää asenteita ja tunteita, jotka auttavat ihmistä elämään tietyllä tavalla. Uskonnollisen kielen paikka on yhteisössä, joka rukoilee, säätelee toimintaansa rituaalien kautta ja ohjaa jäseniään moraaliseen elämään. Näin uskonnollista tapaa puhua esimerkiksi Jumalasta luomistyöstä ei tulisi pitää samanlaisena kuin tieteen tapaa puhua maailman synnystä. Molemmat tavat puhua ovat päteviä oman käytäntönsä sisällä mutta eivät niiden ulkopuolella. Puhe, jossa uskonnolliset tai tieteelliset ilmaisut irrotetaan käyttöyhteydestään, on mieletöntä puhetta. Jos esimerkiksi jumalapuhe katsotaan tieteellistä teoriaa vastaavaksi puheeksi ja aletaan tieteellisesti tutkia Jumalaa, ei ymmärretä uskonnollista kieltä oikein. Samoin tieteen kieli ymmärretään väärin, jos ajatellaan, että sen avulla voidaan puhua ihmisen elämänongelmista. Wittgenstein itse puhuu uskonnollisista "kuvista": uskonnollinen kuva, kuten esimerkiksi ajatus viimeisestä tuomiosta, ei ole tarkoitettu otettavaksi tieteellisenä teoriana siitä mitä maailman lopussa tapahtuu, vaan kyseessä on kuva, joka ohjaa uskovan ajatuksia ja elämää tässä hetkessä. ${ }^{11}$

Toisiinsa palautumattomien kielipelien ajatus löytyy Lindbeckin mallin taustalta. Koska tämän mallin mukaan kieli saa merkityksensä niistä käytännöistä, joiden yhteydessä sitä käytetään, on mieletöntä kysyä ovatko ilmaisut "tosia" tämän kielenkäytön ulkopuolella. Tämä on mieletöntä, koska ei ole olemassa mitään näkökulmaa, josta kielen ja todellisuuden suhdetta voitaisiin tarkastella käytännöistämme riippumatta - edes tiede ei tarjoa tällaista näkökulmaa. Tällaisesta näkemyksestä seuraa tieteen ja uskonnon radikaali riippumattomuus: erilaisina käytäntöinä ja tapoina käyttää kieltä ne eivät kohtaa. Esimerkiksi Vincent Brümmer on tällä perusteella esittänyt, että koko keskustelu tieteen ja uskonnon suhteesta on pahasti pielessä: ei ole mieltä pitää Jumalaa tieteellistä hypoteesia vastaavana oletuksena, koska se ei uskonnollisessa käyttöyhteydessään ole mikään oletus, vaan koko käytännön perusta. Hän kirjoittaa: 
Väite Jumalan olemassaolosta tulee ymmärtää perustavaksi oletukseksi sen elämänmuodon taustalla, jonka kautta teisti ymmärtää oman elämänsä ja kokemuksensa, ja sen kielipelin taustalla, jossa tämä ymmärrys ilmaistaan. Tämän kielipelin sisällä Jumalan olemassaoloa ei voida kieltää tai epäillä, koska se tarkoittaisi irrottautumista itse elämänmuodosta. Erotettuna kielipelistä ja sen elämänmuodosta väite Jumalan olemassaolosta muuttuu pinnalliseksi ja menettää merkityksensä. ${ }^{12}$

Brümmer siis korostaa, että Jumalasta puhuminen jonkinlaisena tieteellisenä teoriana tyhjentää käsitteen "Jumala" merkityksestä. Tämä johtuu siitä, että usko Jumalaan ei ole mitään muuta kuin sitoutumista uskonnolliseen elämänmuotoon. Jos uskonnon kieli irrotetaan sen normaalista käyttöyhteydestä eli uskonnollisesta elämänmuodosta, niin se muuttuu tyhjäksi. Sama pätee myös toiseen suuntaan: jos otamme tieteelliset teoriat irti niiden käyttöyhteydestänsä, eli luonnon säännönmukaisuuksien kuvauksesta ja selittämisestä, ne muuttumat merkityksettömiksi.

Lopuksi on syytä tarkastella vielä yhtä tapaa ymmärtää tieteen ja kristinuskon itsenäisyys. Paleontologi Stephen Jay Gould pukee sanoiksi kirjassaan Rocks of Ages: Science and Religion in the Fullness of Life (1999) mallin tieteen ja uskonnon riippumattomuudesta, jonka monet näyttävät jakavan. Gould puhuu kahdesta magisteriasta, eli opin auktoriteeteista tai oppialueesta, jotka ovat toisistaan erilliset. Malli kulkeekin yleisesti nimellä NOMA (Non-Overlapping-Magisteria). Gould kirjoittaa:

Tieteen magisterium kattaa havaintojen alueen: mistä universumi on tehty (faktat) ja miksi se toimii niin kuin se toimii (teoria). Uskonnon magisterium taas koskee perimmäistä merkitystä ja moraalisia arvoja. Nämä kaksi magisteriaa eivät kohtaa eikä kumpikaan niistä kata yksin koko todellisuutta. ${ }^{13}$

Gouldin perusidea on, että on erilaisia tapoja hankkia ja arvioida tietoa. Tiede ja uskonto ovat tällaisia toisistaan riippumattomia 
tiedonhankkimisen ja arvioimisen muotoja: ne vastaavat erilaisiin kysymyksiin ja niillä on erilaiset päämäärät. Gouldin pyrkimys on ratkaista ristiriitamallin ongelmat eristämällä tiede ja uskonto toisistaan. Samaan tapaan kuin kielipelien ajatukseen perustuva malli Gould esittää, että emme saa sotkea toisiinsa uskonnollista ja tieteellisiä väitteitä. Tieteilijät eivät saa rakentaa teorioidensa pohjalta näkemyksiä perimmäisistä tarkoituksista tai arvoista (kuten Gould ymmärtää ristiriitamallia kannattavien tieteellisten materialistien tekevän) eivätkä uskonnolliset kirjoittajat saa tehdä perimmäisistä kysymyksistään tieteellisiä teorioita (kuten Gould ymmärtää ristiriitamallia kannattavien raamatullisten literalistien tekevän). Kaikki on siis NOMA periaatteen nojalla hyvin, kun uskonto hoitaa omat asiansa ja tiede omansa.

$2 \cdot 4$

KONFLIKTIN JA ITSENÄISYYDEN ONGELMIA

Ristiriitamallin keskeisin ongelma on se, että sen edustajilla on tapana tehdä kyseenalaisia oletuksia sekä tieteellisten teorioiden että uskonnollisten näkemysten luonteesta sekä historiallisella että teoreettisella tasolla. ${ }^{14}$ Historiallisen konfliktiteesin osalta on sanottava, että mikään järkevä historiantutkimus ei anna tukea näkemykselle, jonka mukaan tieteellinen ja kristillinen ajattelu olisivat toisiaan vastaan lyöviä armeijoita. Mitä tarkemmin katsomme historiaa sitä enemmän näemme kristillisen teologian ja tieteen jatkuvaa vuorovaikutusta ja keskinäistä riippuvuutta (mutta myös paikallisia ristiriitoja ja kahinoita). Näin ollen voidaan sanoa, että historiallinen konfliktiteesi on pohjimmiltaan virheellinen. Kuten jo aiemmin mainitsin, emme voi mennä historiallisen tieteen ja kristinuskon suhteen selvittämisessä tämän pidemmälle tämän kirjan puitteissa. ${ }^{15}$ Teoreettinen konfliktiteesi taas perustuu erittäin ongelmalliseen ajatukseen tiedonhankinnan luonteesta. Teesin taustalla on ajatus, jonka mukaan tiede aloittaa selkeisiin havaintoihin perustuvista fak- 
toista, joista se johtaa teoriansa. Lisäksi teoreettinen konfliktiteesi olettaa, että kristillisen ilmoituksen kautta saatu tieto on erehtymätöntä myös luontoa koskevissa asioissa. Tällä näkemyksellä on taas monia teologisia ongelmia, joihin palaamme hetken päästä.

Ristiriitamallin kaikkein keskeisin ongelma on lyhyesti sanottuna se, että siinä kristinusko ja tiede sekoitetaan tavalla, jossa kummankaan osapuolen näkemysten luonnetta ei ymmärretä tarpeeksi perinpohjaisesti. Tieteellinen materialisti aloittaa tieteen tuloksista ja päätyy rakentamaan niiden varaan kokonaisen maailmankatsomuksen - hän haluaa "tieteellistää maailmankatsomukset". Raamatullinen literalisti taas aloittaa erehtymättömänä pitämästään ilmoituksesta ja päätyy tekemään sen pohjalta tieteellisiä väitteitä - hän taas "ideologisoi tieteen". Molempien virhe on yksipuolisuus: sekä tieteellinen materialisti että raamatullinen literalisti ovat lukinneet taustaoletuksensa ja filosofiansa.

Yksipuolisen tieteenkäsityksen lisäksi tieteellisellä materialismilla on muitakin ongelmia, joista tässä yhteydessä otan esiin lyhyesti kaksi, joihin palaamme myös myöhemmin. Jos otamme tieteellisen materialismin vakavasti, ovat siitä tehtävät ihmisen luonnetta koskevat johtopäätökset varsin synkät - niin synkät, että arkikäsitys omasta itsestämme on vaarassa romuttua kokonaan. Tavallisesti ajattelemme olevamme tietoisia olioita, joilla on kyky käyttää järkeään ja tehdä suhteellisen vapaita valintoja erilaisten ajatusten ja toimintatapojen välillä. Lisäksi ajattelemme omistavamme arvoja ja päämääriä, jotka ajavat meitä käyttäytymiseen, joka ylittää eloonjäämisen ja suvunjatkamisen tarpeet. Jos esimerkiksi Wilsonin edustama tieteellinen materialismi otetaan tosissaan, niin tämä arkikäsitys ei voi pitää paikkaansa. Wilsonin mukaan ihminen nimittäin voidaan ymmärtää puhtaasti fysikaalisena ja biologisena koneena, jonka tahto, tietoisuus, arvot ja moraali ovat ainoastaan illuusioita, joilla geenit ovat varustaneet meidät mahdollisimman tehokasta suvunjatkamista varten.

Toiseksi voidaan huomauttaa, että monet tieteellisen materialismin edustajat esiintyvät julkisuudessa usein nimenomaan tieteen 
edustajina ja puolustajina. Näin he esittävät tieteellisen materialismin tieteen tuloksena, vaikka kyseessä on itse asiassa tulkinta tieteen tuloksista ja tieteellisen menetelmän merkityksestä yhdistettynä erilaisiin filosofisiin näkemyksiin. Palaamme myöhemmin tämän väitteen perusteluihin. Tässä vaiheessa on kuitenkin syytä huomata, että tieteellinen materialismi ei ole tieteen tulos, vaan laaja maailmankatsomus, jonka väitetään perustuvan tieteen tuloksille. Monet kriitikot ovat väittäneet, että tieteellisen materialismin edustajat ovat laajentaneet tieteellisten teorioiden ja käsitteiden alaa niin paljon, että niiden päälle on onnistuttu rakentamaan kokonainen materialistinen filosofia, joka kattaa kaiken aina perimmäisestä todellisuudesta, moraaliin ja arvoihin asti.

Siinä, missä tieteellisen materialismin edustajat ajattelevat, että tieteellisen tutkimuksen tulokset ja niiden tulkinta muodostaa ainoan mahdollisen tiedon perustan, ajattelevat taas raamatulliset literalistit erehtymättömän Raamatun tekstin olevan tällainen perusta. Raamatun tekstien erehtymättömyys on kuitenkin hyvin ongelmallinen ajatus. Kaikkein keskeisin ongelma on se, että vaikka itse Raamatun teksti olisikin erehtymätöntä, niin tulkintamme on aina erehtyväistä. Raamatun tekstin merkitys ei avaudu meille "sellaisena kuin se on kirjoitettu", vaan se edellyttää aina jonkinlaista tulkintaa. Tämä tulkinta puolestaan edellyttää aina enemmän tai vähemmän historiallisesta tilanteesta ja kulttuurista riippuvia periaatteita. Näin ollen vaikka väitettäisiin Raamatun olevan erehtymätön, niin ongelmat eivät mene pois: voidaan aina kysyä kenen tulkinta on erehtymätön ja mitkä periaatteet ovat erehtymättömän tulkinnan kriteereitä. Ajatus Raamatun sanojen erehtymättömyydestä on itse asiassa hyvin outo. On selvää, että tekstien merkitys yleisesti ottaen ei ole mikään sanoihin itseensä piilotettu koodi, joka voidaan yksiselitteisesti avata: tulkinta on välttämätön osa minkä tahansa tekstin ymmärtämistä ja sanat ovat vain osa tätä prosessia.

Toinen literalismin ongelma on se, että Raamattu ei ole väitelauseiden kokoelma, vaan sisältää varsin erilaisia tekstejä täynnä tarinoita, lupauksia, käskyjä, viisauksia, runoja, ylistystä ja muuta 
vastaavaa kirjallista ilmaisua. Erehtymättömyyden ajatus on ymmärrettävä silloin, kun puhutaan väitelauseista, mutta muuttuu hankalammaksi esimerkiksi viisauskirjallisuuden tai tarinoiden suhteen. Toisinaan on hyvin vaikea edes sanoa haluaako tekstin kirjoittaja lukijan ottavan jonkin kertomuksen historiallisena kuvauksena vai opettavaisena tarinana (vai molempina). Tähän liittyvät myös Raamatun tekstien kääntämisen ongelmat: sekä UT että VT on kirjoitettu kielillä, jotka ovat kuolleet. Niiden tulkinnassa on aina sen verran epävarmuutta, ettemme voi ajatella, että meillä olisi jokin yksinkertainen keino tavoittaa erehtymätön alkuperäinen merkitys. Sama pätee myös Raamatun käsikirjoituksiin. Nykyinen tietomme Raamatun tekstien alkuperäisestä muodosta on erittäin hyvä ja luotettava mutta emme voi kuitenkaan olla joka sanan ja sanamuodon alkuperäisyydestä täysin varmoja. Mikä Raamatun käsikirjoitus ja mikä niiden yhdistelmistä on erehtymätön ja mikä taas ei ole?

Kolmanneksi voidaan sanoa, että vaikka erehtymättömyys jossakin muodossa on ollut osa kristillistä teologista traditiota, tämä ei ole ollut ainoa tapa ymmärtää Raamattua. Raamatuntulkinnan historiasta voisi tässä yhteydessä sanoa paljonkin mutta tyydyn vain yhteen lyhyeen huomioon. Esimerkiksi keskiajan teologisissa perinteissä Raamatun tekstien ajateltiin sisältävän monia erilaisia kerroksia aina siitä mitä kirjoittajan ajateltiin sanovan tekstin symboliseen merkitykseen asti. Lisäksi jo useat kirkkoisät, kuten esimerkiksi Augustinus (354-430), korostivat, että Raamattua tulee tulkita ainakin osaksi saatavilla olevan luonnollisen tiedon valossa. Jo näidenkin mainintojen pohjalta voidaan päätellä, että Raamatun "erehtymätön” tulkita ei ole välttämätöntä.

Erotusmalli muodostaa ristiriitamallia paremman lähtökohdan tieteen ja kristinuskon suhteen tarkasteluun, koska se tunnustaa osapuolien erilaisuuden. Tieteellä ja uskonnolla on tosiaan toisistaan poikkeavat käytäntönsä, menetelmänsä hankkia ja arvioida tietoa, erilaiset kysymyksensä ja tavoitteensa. Lisäksi erotusmallia edustavat ratkaisut ovat teologisesti monisyisempiä kuin raamatullinen literalismi. On teologisesti perusteltua korostaa kristinuskon 
ilmoituksen historiallista luonnetta ja Jeesuksen elämän, kuoleman ja ylösnousemuksen keskeistä roolia kristillisessä uskossa. Lisäksi on teologisesti vakuuttavaa ajatella, että kristillinen usko on paljon enemmän kuin uskoa jonkinlaisen väitelauseiden kokoelman totuuteen: kristillinen usko on henkilökohtaista sitoutumista tiettyyn elämänmuotoon ja arvoihin ja sellaisenaan se on aina enemmän kuin teoreettinen asenne.

Vaikka itsenäisyysmalli voikin näyttää päällisin puolin houkuttelevalta, on sillä varsin suuria ongelmia, joiden perusteella monet ovat päätyneet hylkäämään sen. Osa ongelmista on teologisia ja osa taas enemmän filosofisia. Ensinnäkin Barthin ja hänen seuraajiensa tapa luoda vastakkainasetteluja, kuten maailma-Jumala, luonto-historia, ihminen-luonto ja ihminen-Jumala, on syvästi ongelmallinen. Barthin mallissa esimerkiksi ihminen ja hänen pelastuksensa asetetaan irralleen Jumalan luomistyöstä (eli luonnosta). Tästä näkökulmasta tarkasteltuna ei Jumalan toiminta ihmisen pelastamiseksi eikä edes ihminen näytä olevan missään mielessä osa luontoa. Sen lisäksi, että Barth asettaa ihmisen ja luonnon vastakkain, asettaa hän vastakkain Jumalan ja luomakunnan: Jumala on niin erillinen luomakunnasta, että hänen toimintaansa ei voida laisinkaan havaita luonnossa ilman erityistä Jumalan ilmoitusta. Tässä Barth tekee merkittävän irtioton kristillisen teologian perinteestä, jonka mukaan on hyviä perusteita väittää, että Jumalan luova ja ylläpitävä toiminta on ainakin jollakin tavalla näkyvillä luonnossa. Lisäksi Barthin mallissa ihminen ja hänen historiansa on kokonaan luonnon ulkopuolella: tiede on siten kykenemätön sanomaan mitään ihmisen historiasta, ajatuksista ja kokemuksista. Tämäkin väite on hyvin ongelmallinen: voimmehan tutkia ihmisen historiaa, hänen ajatuksiaan ja kokemuksiaan tieteellisesti ilman sen suurempia ongelmia.

Myös teologisessa eksistentialismissa on useita ongelmia. Eksistentialismi korostaa kyllä hyödyllisellä tavalla kristillisen uskon henkilökohtaista ulottuvuutta mutta jos tätä käytetään perustelemaan itsenäisyysmallia, niin se asettaa vastakkain ihmisen "sisäisen kokemusmaailman" ja ihmisen "ulkoisen luonnon maailman" taval- 
la, joka on syvästi harhaanjohtava. Jälleen asetetaan vastakkain ihmisen sisäisyys ja luonto: Jumala toimii vain ja ainoastaan ihmisen sielussa, hänen kokemuksessaan, eikä laisinkaan hänen havaitsemassaan luonnossa. Ja jälleen oletuksena on, että tiede koskee vain ulkoista esineiden maailmaa eikä laisinkaan ihmisen sisäistä kokemusmaailmaa. On monia syitä sille, miksi monet ovat korostaneet hengen ja aineen (sisäisen ja ulkoisen) eroa tällä tavalla ja palaamme niihin myöhemmin.

Samantapainen arvojen ja luonnon tosiseikkojen ongelma vaivaa myös Gouldin NOMA periaatetta: emme voi erottaa yksinkertaisella tavalla "perimmäisiä kysymyksiä" arvoista, merkityksestä ja moraalista havaitusta maailmasta. Tämä pätee myös tieteellisiin teorioihin: tieteelliset kokeet ja teoriat ovat sidoksissa oletuksiin tiedonhankinnan keinoista ja todellisuuden perimmäisestä luonteesta. Nämä oletukset ovat sellaisia, joita on hyvin vaikea tai mahdotonta perustella kokeellisesti. Lisäksi NOMA:n ongelmana teologisesta näkökulmasta on se, että se asettaa teologiset näkemykset tiukkaan pakkopaitaan: teisti ei siis voi tämän mallin nojalla olettaa esimerkiksi, että Jumala puuttuu jollakin tavalla asioiden kulkuun maailmassa tai että Jumalan olemassaolo selittää, miksi kosmokseen on syntynyt rationaalisia ja moraalisia olioita. Jos kristitty haluaa omaksua NOMA:n, on hänen johdonmukaisuuden nimissä myös torjuttava nämä oletukset - oletukset, joiden on ainakin perinteisesti katsottu kuuluvan syvästi kristinuskoon.

Itsenäisyysmallia perustelemaan käytetty kielipeliajattelu on onnistunut kiinnittämään huomiota uskonnollisen kielenkäytön monipuolisuuteen. Jumalapuhe on tosiaan paljon muutakin kuin "teoria Jumalasta" - joukko väitelauseita Jumalan luonteesta ja toiminnasta. Jumalapuheella esimerkiksi pyydetään ja kiitetään Jumalaa ja se ankkuroituu uskonnollisiin käytäntöihin kuten rituaaleihin ja rukoukseen. Ongelmana on kuitenkin se, että jumalapuhe sisältää myös ilmaisuja, jotka ainakin näyttävät väitteiltä todellisuuden luonteesta. On varsin uskottavaa ajatella, että uskonnolliseen käytäntöön osallistuminen edellyttää osallistujalta ainakin sitä, että 
tämä uskoo Jumalan objektiivisen (kielipelin ulkopuoliseen) olemassaolon olevan mahdollista. Näin olisi ainakin alustavia perusteita uskoa, että kristillisen elämän ytimessä on ainakin jonkinlainen "teoria Jumalasta". Kielipeliteorian kannattaja joutuu kuitenkin väittämään, että kristityt, jotka ajattelevat Jumalan olevan olemassa radikaalissa mielessä jumalapuheesta ja uskonnollisista käytännöistä riippumatta, ovat ymmärtäneet jumalapuheen väärin. Tällainen massiivinen virhetulkinta jumalapuheen käyttäjien omalta osalta ei näytä kovinkaan uskottavalta. Jos esimerkiksi Darwinin aikalaiset olisivat ajatelleet, että jumalapuhe on irrallista tieteellisistä teorioista, he tuskin olisivat vaivautuneet kehittelemään erilaisia teologisia malleja Jumalan toiminnasta, jotka olivat yhteensopivia evoluutioteorian kanssa.

Edellisten ongelmien perusteella monet kirjoittajat ovat pyrkineet irrottautumaan sekä ristiriitamallista että itsenäisyysmallista. Historiallinen konfliktiteesin onkin mielestäni pystytty varsin hyvin osoittamaan riittämättömäksi, kuten jo edellä tuli ilmi. Teoreettinen konfliktiteesi sen sijaan onkin hankalampi: joidenkin teologisten näkemysten ja tieteellisten teorioiden välillä näyttää olevan varsin isoja ristiriitoja. Väitän kuitenkin, että näistä paikallisista ristiriidoista ei voida päätellä jonkinlaisen täydellisen ja välttämättömän, globaalin ristiriidan olemassaolo.

Tämän kirjan tehtävänä on hahmotella ristiriitamallille ja erottamismallille keskitie. Tämä kolmas vaihtoehto pyrkii välttämään ainakin osan itsenäisyysmallin ja ristiriitamallin ongelmista. Konfliktiteesiä ei tulla korvaamaan sen vastakohdalla eli teesillä, jonka mukaan kristinusko ja tiede ovat harmoninen kokonaisuus. Haluan vain kiinnittää huomiota siihen, että tieteen ja kristinuskon suhde on ja on ollut paljon monimutkaisempi kuin yksipuolinen konfliktiteesi antaa ymmärtää. Kuten jo edellä tuli ilmi, tämä ei tietenkään sulje pois paikallisten konfliktien mahdollisuutta - itse asiassa tulen väittämään, että toisinaan nämä paikalliset konfliktit ovat varsin suuria ja vaativat monien teologisten mallien revisiointia. 
$2 \cdot 5$

\section{PÄÄLLEKKÄISYYSKESKITIEN Ä}

Jos haluamme vastustaa konfliktiteesiä sen molemmissa muodoissa, on myös vastustettava tieteellistä materialismia ja raamatullista literalismia. Tämä tehtävä on yhtä aikaa sekä teologinen että filosofinen: on pystyttävä kunnioittamaan sekä tieteen että kristinuskon pyrkimystä totuuteen, mutta samaan aikaan tunnustettava kummankin rajat ja sidonnaisuudet.

Päällekkäisyysmallin mukaan meidän tulee ajatella, että tieteen ja kristinuskon "maailmat" ovat osin toisistaan riippumattomat mutta voivat kohdata:

(P) Tiede ja kristinusko eivät ole kokonaan päällekkäisiä mutta eivät myöskään toisistaan riippumattomia ja niillä on monia kohtaamispaikkoja.

Tällä tavoin muotoiltuna päällekkäisyysmalli on erittäin yleinen ja voi sisältää hyvin paljon erilaisia näkemyksiä. Sen sisällä voimme helposti ajatella, että tiede ja kristinusko kohtaavat erittäin harvoin ja merkityksettömissä paikoissa tai että tiede ja kristinusko muodostavat varsin yhtenäisen kokonaisuuden. Toisin sanoen siis osittaisen päällekkäisyyden määrä voi vaihdella varsin suuresti siitä huolimatta, että pysytään mallin rajojen sisällä.

On ainakin kaksi teologista lähestymistapaa tieteeseen, jotka voimme laskea kuuluvaksi päällekkäisyysmallin alaan. Ensimmäinen niistä pyrkii kohti vahvaa tieteen ja kristinuskon synteesiä, kun taas jälkimmäinen korostaa tieteen ja kristinuskon erityispiirteitä. Nämä lähestymistavat ovat

(1) luonnollinen teologia, jossa pyritään osoittamaan Jumalan olemassaolo hyvin perustelluksi väitteeksi sen perusteella, mitä tieteen avulla tiedämme luonnosta,

(2) luonnon teologia, jossa keskitytään tarkastelemaan tieteellisten 
teorioiden ja teologisten teorioiden kosketuspintoja ja ymmärtämään tieteelliset teoriat teologisen viitekehyksen sisällä.

Luonnollisella teologialla tai filosofisella teologialla (natural theology/philosophical theology) viitataan yrityksiin perustella Jumalan olemassaolo ilman viittauksia ilmoitustietoon. ${ }^{16}$ Historiallisesti ottaen luonnollinen teologia on pyrkinyt osoittamaan kristillisten näkemysten järkevyyden kulloinkin saatavilla olevan sekulaarisen tiedon, luonnollisen järjen, nojalla. Eri kirkolliset perinteet ovat antaneet luonnolliselle teologialle hyvin erilaisen roolin. Protestanttisten kirkkojen teologiassa luonnollinen teologia on ollut perinteisesti valtavirran ulkopuolella siinä, missä sen rooli roomalaiskatolisessa perinteessä on ollut suurempi. Kuten aikaisemmin näimme, reformoidun teologian 1900-luvun ykkösnimi Karl Barth suhtautui erittäin kriittisesti ilmoituksen ulkopuolelta saatavaan Jumalaa koskevaan tietoon ja yleensäkin järjen mahdollisuuteen saada Jumalasta tietoa. Roomalaiskatolisessa perinteessä sen sijaan luonnollisella teologialla on Tuomas Akvinolaisen (1225-1274) vaikutuksesta on ollut merkittävämpi rooli. Erittäin lyhyesti ja suuresti yleistäen voidaan sanoa, että katolisessa perinteessä "luonnollisen" tiedon ja "ilmoitustiedon" välillä on haluttu säilyttää suurempi jatkuvuus kuin protestanttisessa teologiassa. Barthin näkemys on Tuomaan näkemykseen nähden toisessa ääripäässä: luonnollisen tiedon ja ilmoitustiedon välillä ei ole minkäänlaista yhteyttä.

Esimerkkinä modernista luonnollisesta teologiasta voimme ottaa filosofi Richard Swinburnen, joka lukuisissa kirjoissaan on pyrkinyt kehittämään kokonaisen luonnollisen teologian järjestelmän. ${ }^{17}$ Swinburnen perusajatus on, että Jumalan olemassaolo voidaan perustella samalla tavalla kuin tieteelliset teoriat perustellaan eli hyväksymällä yksinkertaisin ja selitysvoimaltaan suurin hypoteesi. Swinburne katsoo, että teismi - näkemys jonka mukaan on olemassa kaikkivaltias, kaikkitietävä ja täydellisesti hyvä Jumala, joka on luonut maailman ja ilmoittanut itsensä - on teoria, joka selittää kaikkein parhaiten maailmankaikkeutemme yleiset piirteet. Jumalan olemassaoloa ei voida 
kuitenkaan todistaa johtamalla sitä jostakin yleisestä periaatteesta, vaan sitä tulee pitää enemmän tai vähemmän todennäköisenä. Näin on Swinburnen mukaan kaikkien teorioiden kohdalla: käsillä oleva todistusaineisto, joko tukee oletusta Jumalan olemassaolosta, jolloin Jumalan olemassaolon todennäköisyys kasvaa, tai sitten vastustaa sitä, jolloin sen todennäköisyys laskee.

Swinburnen strategia on periaatteessa yksinkertainen. Koska yksikään Jumalan olemassaolon puolesta esitetty argumentti ei hänen mielestään onnistu yksinään osoittamaan Jumalan olemassaoloa, hän ketjuttaa kaikki argumentit yhteen ja katsoo niiden yhdessä olevan riittäviä nostamaan Jumalan olemassaolon todennäköisyyden niin korkeaksi, että jokaisen järkevän ihmisen kannattaisi hyväksyä se. Tästä strategiasta johtuu nimitys kumulatiivinen (kasautuva) argumentti. Lyhyesti sanottuna Swinburnen argumentti kulkee seuraavalla tavalla. Aluksi hän huomauttaa, että teismin lähtökohtainen todennäköisyys on varsin suuri, koska se on oletuksena yksinkertainen ja erittäin selitysvoimainen. Tämän jälkeen hän lähtee käsittelemään maailmankaikkeutemme yleisiä piirteitä, jotka hänen mukaansa lisäävät teismin todennäköisyyttä. Näitä ovat esimerkiksi

(1) maailmankaikkeudessa havaittu järjestys (teleologinen argumentti eli suunnitteluargumentti),

(2) maailmankaikkeuden olemassaolo (kosmologinen argumentti),

(3) sellaisten olioiden olemassaolo, jotka ovat tietoisia ja moraalisia (argumentit tietoisuudesta ja moraalista),

(4) havaitut ihmeet ja muut Jumalan ilmoitukseen kuuluvat historialliset tapahtumat,

(5) havaitut uskonnolliset kokemukset.

Kun nämä piirteet yhdistetään ja osoitetaan, että teismin alkuperäistä todennäköisyyttä alentavat vastaväitteet eivät onnistu (esimerkiksi pahan ongelma), päädytään Swinburnen mukaan siihen, että teismi on todennäköisesti totta ja hyvä selitys maailmankaikkeuden yleisille piirteille. 
Luonnon teologiaksi (theology of nature) voidaan kutsua lähestymistapaa, joka aloittaa kristinuskon traditiosta ja ilmoituksesta mutta antaa myös merkittävän roolin luonnollisen järjen avulla saatavalle tiedolle luonnosta ja Jumalasta. Luonnon teologia eroaa luonnollisesta teologiasta siinä, että sen edustajat harvemmin katsovat perustelevansa Jumalan olemassaoloa luonnollisen tiedon nojalla. Heidän intressinsä on pikemminkin sen osoittaminen, että Jumalan olemassaolo ja muut kristinuskon näkemykset ovat sopusoinnussa tieteellisten teorioiden kanssa ja täydentävät niitä. Jos synteesi ei ole mahdollinen, on joko muutettava sitä miten tulkitsemme tieteellisiä teorioita tai sitten teologisia näkemyksiä. Sekä luonnollinen teologia että luonnon teologia etsivät yhtymäkohtia tieteen ja kristinuskon välillä. Luonnollinen teologia pyrkii päämääräänsä pitkälti tieteen ja filosofian menetelmien ehdoilla siinä, missä luonnon teologian edustajat taas suosivat päällekkäisyyksien etsimistä teologisten teorioiden ehdoilla. Aiomme jatkossa keskittyä juuri luonnon teologiaan, joten palaamme sen tarkempaan määrittelyyn myöhemmin.

Luonnon teologian edustajat etsivät tieteen ja kristinuskon kohtaamispaikkoja, joihin on tapana viitata rajakysymyksinä (limit questions/boundary questions). Rajakysymykset ovat kysymyksiä, jotka nousevat tieteenharjoittamisesta ja sen tuloksista kokonaisuutena, mutta joihin tieteen on itse vaikea vastata. Jotkut ovat väittäneet, että rajakysymysten tulisi nimenomaan olla sellaisia, että niihin ei ole edes kuviteltavissa mitään tieteellistä vastausta. Tämä näkemys on kuitenkin liian vaativa, koska emme voi (myöhemmin esitettävistä syistä) tarkkaan tietää, mitä tiede voi tutkia ja tietää ja mitä taas ei.

Eräs rajakysymysten joukko koskee tieteellisen tutkimuksen perimmäisiä taustaoletuksia luonnosta. Yksi tapa vastata näihin kysymyksiin on kysyä, miksi moderni luonnontiede syntyi juuri kristinuskon kyllästämässä kulttuurissa eikä jossakin muualla. Tämä kysymys johtaa meidät tarkastelemaan kristillisiä oletuksia maailman perimmäisestä luonteesta. Monet tutkijat ovat esimerkiksi väittäneet, että kristinuskon luontoa koskevat perusoletukset 
olivat ratkaisevan tärkeitä tieteen syntymiselle 1600 -luvulla. ${ }^{18}$ Sekä kristillisen teologian että kreikkalaisen filosofian traditiot olettivat maailman olevan organisoitu ja järkevä kokonaisuus. Ajatus siitä, että on olemassa yksi järkevä Jumala, joka on luonut maailman, johtaa ajatukseen siitä, että maailma on ymmärrettävä ja järjestäytynyt. Kreikkalaisessa filosofisessa perinteessä oli kuitenkin tapana olettaa, että maailman järkevä rakenne on välttämätön ja että tämä rakenne voidaan päätellä järjen avulla yleisistä periaatteista. Jos tieto luonnon rakenteesta voidaan saavuttaa päättelemällä yleisistä periaatteista, ei ole juuri syytä perustaa luonnon tutkimusta testeihin ja kokeisiin. Juutalais-kristillinen luomisajattelu taas eroaa tässä kohdin kreikkalaisesta: koska Jumala loi maailman tyhjästä omasta vapaasta tahdostaan, maailma ei ole välttämätön vaan kontingentti. Maailmankaikkeuden rakenne ei ole tulosta joistakin järjen muuttumattomista ja välttämättömistä ideoista, vaan Jumalan tahdosta. Jumala olisi voinut luoda toisenlaisen maailman, jossa vallitsisivat aivan toiset lait. Näin ollen emme voi saavuttaa totuutta maailmasta pelkästään järkeilemällä, vaan on pyrittävä tutkimaan ilmiöitä mahdollisimman yksityiskohtaisesti. Kristillisen teologian sopiva sekoitus yhtäältä luodun maailman järkevyyttä ja toisaalta sen sattumanvaraisuutta muodosti ponnistuslaudan modernin luonnontieteen syntyyn - ponnahduslaudan, jota kreikkalainen filosofia ei pystynyt tarjoamaan. On kuitenkin huomattava, että luonnontieteen syntyyn liittyvät hyvin monet seikat: ei ole perusteltua ajatella, että kristillinen teologia olisi ollut tämän kehityksen riittävä ehto.

Toinen rajakysymysten joukko koskee tieteen ja kristillisen teologian menetelmiä ja tietämisen luonnetta. Monet kirjoittajat ovat kiinnittäneet huomiota siihen, että jyrkkä ero tieteen objektiiviseksi väitetyn tiedonhankkimismenetelmän ja kristinuskon subjektiiviseksi väitetyn menetelmän välillä ei ole enää perusteltavissa. Ei ole perusteita väittää, että tieteen menetelmä on puhtaasti objektiivinen siinä, missä uskonto perustuu pelkästään subjektiivisille tunteille. Esimerkiksi Barbourin mukaan 
[t]erävä kontrasti [subjektiivisen uskonnon ja objektiivisen tieteen välillä] on 1950-luvulta alkaen asetettu kyseenalaiseksi. Alkoi näyttää siltä, että tiede ei olekaan niin objektiivista eikä uskonto niin subjektiivista kuin oli väitetty. Näillä alueilla on kyllä painotuseroja mutta ero ei ole niin absoluuttinen kuin väitettiin. Tieteellinen aineisto on teoriasidonnaista, ei teoriavapaata. Teoreettiset oletukset vaikuttavat tieteellisen aineiston valintaan, raportointiin ja tulkintaan. Lisäksi teoriat eivät perustu puhtaaseen aineiston loogiseen analyysiin, vaan syntyvät monipuolisessa prosessissa, jossa luova mielikuvitus, analogiat ja mallit ovat keskeisessä osassa. Käsitteelliset mallit auttavat meitä kuvittelemaan asioita, joita emme voi suoraan havaita. Monet näistä piirteistä ovat läsnä myös uskonnossa. Jos uskonnon aineistoon kuuluvat uskonnolliset kokemukset, rituaalit ja pyhät kirjoitukset, on tämä aineisto läpeensä teoriasidonnaista. ... Uskonnolliset uskomukset eivät selvästikään ole kokeellisesti tieteen testattavia, mutta niitä voidaan lähestyä tieteellisen tutkimuksen hengessä. ${ }^{19}$

Barbour hakee tässä ajatusta siitä, että sekä tieteen että teologian tapa tietää perustuu malleihin, joiden avulla monimutkaista todellisuutta yritetään ymmärtää. Molemmat pyrkivät puhumaan perimmäisestä todellisuudesta, johon meillä ei ole suorien havaintojen avulla pääsyä. Molemmat käyttävät hyväkseen erilaisia malleja (teorioita, oppeja, symbolisia kuvauksia, jne.), jotka poimivat tiettyjä piirteitä todellisuudesta ja jättävät toiset huomiotta. Tämän näkemyksen mukaan kaikki tietäminen - niin tieteellinen kuin uskonnollinenkin - on aina sekoitus sekä subjektiivista että objektiivista, teoriaa ja havaintoa. Näin ollen ajatus siitä, että uskonnollinen tietäminen perustuisi vain irrationaaliseen kokemukseen siinä, missä tiede perustuisi puhtaisiin havaintoihin ja niitä johdettuihin teorioihin, ei voi pitää paikkansa. Palaamme tähän väitteeseen seuraavassa luvussa.

Jotta voisimme saada tarkemman kuvan siitä, missä rajakysymykset sijaitsevat ja missä tiede ja kristinusko menevät päällekkäin, meidän tulee tarkentaa käsitteitämme. Toisin sanoen meidän pitää kysyä, mitkä ovat tieteen ja kristinuskon suhteen "yksiköt". Puhutaanko menetelmistä vai väitteistä, uskonnollisista käytännöistä vai 
tieteellisistä tutkimusmenetelmistä?

Voidaan puhua ainakin kolmesta joukosta yksiköitä:

(1) Käytännöt ja instituutiot: kirkot, yliopistot, rituaalit, uskonnollinen elämä, moraali, jne.

(2) Tiedonhankinnan menetelmät: tietämisen yleinen luonne, tieteelliset teoriat ja kokeet, teologiset mallit ja niiden lähteet.

(3) Sisällöt: jollakin hetkellä hyväksyttyjen tieteellisten teorioiden ja teologisten teorioiden sisältö (eli se mitä teoriat väittävät).

Ensiksi voimme puhua tieteestä ja kristinuskosta käytäntöjen joukkoina. Sekä tiede että kristinusko ovat jotain, jota ihmiset tekevät: ne ovat sosiaalisia käytäntöjä. Kristinuskon kohdalla voidaan puhua kristilliseen elämään liittyvistä käytännöistä, kuten rukoilemisesta tai yhteisistä rituaaleista. Lisäksi kristinusko edellyttää jonkinlaisten instituutioiden kuten kirkkojen, seurakuntien tai hallintovirkojen ja muiden vastaavien olemassaoloa ainakin jossakin muodossa. Tieteen kohdalla voimme aivan samalla tavalla puhua tieteellisistä käytännöistä, jotka vaihtelevat tieteenaloittain - siis siitä, mitä tieteilijät tekevät - ja tieteellisistä instituutioista kuten yliopistoista, instituuteista, niiden hallinnosta ja muusta vastaavasta. Yksi tapa lähestyä tieteen ja kristinuskon suhdetta on siis tarkastella niiden käytäntöjen suhdetta. Tämä näkökulma on olennainen juuri historialliselle ja yhteiskunnalliselle "tieteen ja kristinuskon" tutkimukselle, joten emme puutu siihen sen enempää.

Olennaista on kuitenkin huomata, että käytäntöjen näkökulmasta kristinuskolla ja tieteellä on toisistaan riippumattomat tarkoituksensa ihmisten elämässä. Ihmiset eivät mene kirkkoon oppiakseen biologiaa, vaan palvoakseen Jumalaa. Voimme ajatella, että käytäntöjen järkevyys perustuu niiden tarkoituksenmukaisuuteen. Jokin käytäntö on järkevä, jos se saavuttaa tarkoituksensa. Jos kahdella käytännöllä on toisistaan riippumaton tarkoituksensa, ei ole mieltä väittää, että ne olisivat ristiriidassa tai kilpailusuhteessa keskenään. Tämä näyttää pitävän paikkansa nimenomaan kristillisten ja tieteel- 
listen käytäntöjen suhteen: kristillisen käytäntöjen tarkoituksena on löytää ja tukea ihmisen yhteyttä Jumalaa, kun taas tieteellisten käytäntöjen päämääränä on hankkia käyttökelpoista ja totta tietoa todellisuudesta.

Käytäntöjen ja instituution näkökulma on kuitenkin hyvin harvoin sitä mitä ihmiset haluavat, kun he puhuvat "tieteestä ja uskonnosta". Se, mistä ollaan kiinnostuneita tieteen ja kristinuskon suhteessa, on se, miten niiden väitteet maailmasta ovat suhteessa toisiinsa. Keskitymme tässä kirjassa juuri tähän sisältönäkökulmaan (filosofiseen näkökulmaan), mutta väitän kuitenkin, että teemme pahan virheen, jos ohitamme käytäntöjen näkökulman kokonaan. Tähän virheeseen syyllistytään usein olettamalla, että "kristinuskon sisältö” on jotenkin yhtenäinen asia. Näin ei kuitenkaan ole ja huomaamme sen helposti tarkastelemalla kristinuskoa sen käytäntöjen näkökulmasta. "Tavallinen kristitty" on ihminen, jonka uskonnolliset käytännöt koostuvat esimerkiksi rukoilemisesta, Raamatun lukemisesta, kristillisen moraalin soveltamisesta omaan elämään ja osallistumisesta jumalanpalveluksiin ja muuhun toimintaan. Nämä käytännöt muodostavat "tavallisen kristityn" uskomusten perustan. On kuitenkin ryhmä, jonka uskomusten perusta on jossakin määrin erilainen, nimittäin kristinuskon ammattilaiset eli teologit. Siinä missä "tavalliset kristityt" eivät juuri käytä aikaansa uskomustensa tarkasteluun, niin tämä on se, mitä teologit tekevät työkseen. Juuri käytäntöjen näkökulma osoittaa, että "kristillisten käytäntöjen” ja "teologisten käytäntöjen" ero on hyvin suuri ja se antaa meille vahvan syyn erottaa "uskonto" ja "teologia" toisistaan.

Toiseksi voimme puhua tieteestä ja kristinuskosta siitä näkökulmasta miten nämä hankkivat ja arvioivat tietoa. On huomattava, että tämä näkökulma liittyy läheisesti edelliseen: tiedonhankkiminen ja arvioiminen ovat aina joukko erilaisia käytäntöjä. Tieteellinen tiedonhankinta on varsin tarkkaan säädeltyä, vaikka monilla tieteenaloilla onkin toisistaan poikkeavia tiedonhankinnan normeja. Yleisesti ottaen voidaan kuitenkin sanoa, että tieteellinen tiedonhankinta perustuu teoreettisiin oletuksiin, niiden kokeelliseen 
testaamiseen ja teorioiden kehittämiseen tältä pohjalta. Erityisesti luonnontieteissä teoriat pyritään formalisoimaan matemaattisesti. Tieteellisen tiedonhankinnan säätelystä seuraa se, että se on varattu ammattilaisille: teoreettiset ja käytännölliset menetelmät ovat vuosien opettelun takana.

Uskonnollinen tiedonhankinta eroaa varsin suuresti tieteellisestä tavasta hankkia tietoa. Jos tieteellisen tiedon kohteena on luonto, on uskonnollisen tiedon kohteena Jumala. Jumalaa koskevan tiedon lähteinä ovat useimmiten ilmoitus, järki ja uskonnollinen kokemus. "Tavallinen kristitty" ei tarvitse asiantuntijakoulutusta erityisissä "uskonnollisissa menetelmissä", vaan hänen tapansa hankkia tietoa perustuu hänen arkisiin uskonnollisiin käytäntöihinsä. Tämä ei pidä paikkaansa uskonnon ammattilaisten, eli teologien, kohdalla. Heidän käytäntönsä ovat paljon lähempänä tieteellisiä käytäntöjä. Vaikka teologi harvoin tekee kokeita, hän kuitenkin työskentelee menetelmillä, jotka vaativat vuosien koulutuksen. Teologisen työn tuloksena on teorioita, jotka ovat yrityksiä järjestää sekä arkinen uskonnollinen kokemus ja käsitykset että kulloinkin kyseessä oleva teologinen perinne yhtenäiseksi kokonaisuudeksi. Tästä syystä on harhaanjohtavaa puhua "tavallisten kristittyjen" teorioista ja verrata niitä tieteellisiin teorioihin. Vertailu on epäreilu, koska tasot ovat hyvin erilaiset. Jatkossa puhunkin ainoastaan teologisista teorioista enkä arkisista uskonnollisista näkemyksistä. Tämä on myös se syy miksi monet kieltäytyvät puhumasta "tieteen ja uskonnon suhteesta" vaan puhuvat sen sijaan "tieteen ja teologian suhteesta".

Oheisessa taulukossa on tiivistettynä ne erottelut, joita tähän mennessä on tehty tieteen ja kristinuskon suhteesta. Taulukko esittää kolme mahdollista tapaa ymmärtää kristinuskon ja tieteen suhde (ristiriita, päällekkäisyys ja itsenäisyys) kolmella eri tasolla (käytäntöjen taso, tiedonhankinnan menetelmien taso ja sisällön taso). 
Mahdollisia tapoja ymmärtää tieteen ja kristinuskon suhde

\begin{tabular}{|c|c|c|c|}
\hline & Ristiriita & Päällekkäisyys & Itsenäisyys \\
\hline Käytännöt & $\begin{array}{l}\text { Tieteelliset } \\
\text { ja kristilliset } \\
\text { käytännöt ovat } \\
\text { samaa tarkoi- } \\
\text { tusta varten ja } \\
\text { tieteellisten käy- } \\
\text { täntöjen tulee } \\
\text { korvata kristilli- } \\
\text { set käytännöt tai } \\
\text { toisinpäin. }\end{array}$ & $\begin{array}{l}\text { Kristilliset ja tie- } \\
\text { teelliset käytännöt } \\
\text { ovat enemmän } \\
\text { tai vähemmän eri } \\
\text { tarkoituksia varten } \\
\text { mutta ne voivat } \\
\text { kohdata. Tällöin ne } \\
\text { voivat tukea toisiaan } \\
\text { tai olla ristiriidassa } \\
\text { keskenään. }\end{array}$ & $\begin{array}{l}\text { Kristilliset } \\
\text { käytäntöjen } \\
\text { tarkoitus ja tie- } \\
\text { teellisten käytän- } \\
\text { töjen tarkoitus } \\
\text { on erilainen ja } \\
\text { toisistaan riippu- } \\
\text { maton. }\end{array}$ \\
\hline $\begin{array}{l}\text { Tiedon- } \\
\text { hankinnan } \\
\text { menetelmät }\end{array}$ & $\begin{array}{l}\text { Tieteellisen me- } \\
\text { netelmän tulee } \\
\text { korvata kristilli- } \\
\text { nen menetelmä } \\
\text { (materialismi) } \\
\text { tai toisinpäin } \\
\text { (literalismi). }\end{array}$ & $\begin{array}{l}\text { Kristilliset ja tie- } \\
\text { teelliset menetelmät } \\
\text { ovat enemmän tai } \\
\text { vähemmän toistensa } \\
\text { kaltaisia. }\end{array}$ & $\begin{array}{l}\text { Kristilliset } \\
\text { ja tieteelliset } \\
\text { menetelmät ovat } \\
\text { toisistaan riippu- } \\
\text { mattomia. }\end{array}$ \\
\hline Sisältöo & $\begin{array}{l}\text { Tieteelliset } \\
\text { teoriat korvaavat } \\
\text { kristinuskon } \\
\text { näkemykset } \\
\text { (materialismi) } \\
\text { tai toisinpäin } \\
\text { (literalismi) }\end{array}$ & $\begin{array}{l}\text { Jotkut tieteen teoriat } \\
\text { puhuvat samoista } \\
\text { asioista kuin kristin- } \\
\text { uskon näkemykset. } \\
\text { Tällöin toinen voi } \\
\text { korvata toisen tai } \\
\text { sitten jompaakum- } \\
\text { paa tulee muokata. }\end{array}$ & $\begin{array}{l}\text { Tieteen ja kris- } \\
\text { tinuskon teoriat } \\
\text { puhuvat täysin } \\
\text { eri asioista. }\end{array}$ \\
\hline
\end{tabular}

Koska torjuimme sekä ristiriitamallin että itsenäisyysmallin, keskitymme jatkossa päällekkäisyysmallin menetelmällisiin kysymyksiin ja sisältökysymyksiin.

Päällekkäisyysmallin sisällä on syntynyt eräänlainen perusnäkemys tieteen ja kristinuskon suhteesta, jota lähdemme jatkossa jäljittämään. Nimitämme tätä näkemystä jatkossa lyhyesti "standardinäkemykseksi”, jota voimme alustavasti luonnehtia seuraavalla tavalla:

Standardinäkemys tulkitsee sekä tiedettä että teologiaa realisti- 
sesti siltä osin, kun se on sopivaa. Realismilla tarkoitan tässä tietynlaista näkemystä siitä, millaista tiedonhankinta on yleensä luonteeltaan ja mistä tieteessä ja teologiassa pyritään puhumaan. Realismin mukaan sekä tieteelliset teoriat että teologiset näkemykset pyrkivät sanomaan jotain ihmisestä enemmän tai vähemmän riippumattomasta todellisuudesta, ja meidän tulee pyrkiä arvioimaan sitä, miten ne onnistuvat siinä. Todellisuus on meidän ulottuvillamme vain välillisesti, ei "suoraan". Realismi tällä tavoin ymmärrettynä asettuu sekä konfliktimallin että itsenäisyysmallin tiedonkäsityksiä ja todellisuuskäsityksiä vastaan. Toinen olennainen piirre realismissa on se, että sen mukaan ei ole olemassa yhtä ainoata rationaalista tietolähdettä tai perustaa. Meidän on aloitettava siitä pisteestä, jossa olemme, ja teologi aloittaa kristillisen tradition sisältä. Tästä seuraa se, että keskustelun päämääränä ei ole perustella aukottomasti kaikkia tyydyttävällä tavalla oma lähtökohta. Tarkoitus on pikemminkin muokata ja arvioida omaa lähtökohtaa sitä mukaan, kun keskustelu etenee ja uutta tietoa tulee.

Standardinäkemystä luonnehtii se näkökulma, jota olemme luonnehtineet luonnon teologiaksi. Luonnon teologian mukaan tieteellinen tieto on yksi teologian lähde. Jumalaa koskeva tieto saadaan pääosin erityisen ilmoituksen, uskonnollisen kokemuksen ja tradition kautta, mutta tieteellinen tieto on tärkeää ottaa huomioon teologiaa kehitettäessä. Luonnon teologian edustajilla on tapana pyrkiä yhteensopivuuteen teologisten teorioiden ja tieteellisen tiedon välillä. Standardinäkemyksen mukaan meidän ei tule ajatella Jumalan toimintaa radikaalisti irralliseksi luonnon toiminnasta. Meidän tulee sen sijaan etsiä luonnon ja Jumalan toiminnan jatkuvuutta erityisesti siltä pohjalta, mitä nykyaikaiset fysikaaliset ja biologiset tieteet kertovat meille maailmamme monimutkaisuudesta ja kerrostuneisuudesta. Tähän liittyy myös fysiikan, evoluutiobiologian ja biotieteiden tulosten yleinen hyväksyntä, joka kulkee yhdessä literalismin vastustamisen kanssa. Standardinäkemyksen mukaan meillä on siis hyviä syitä olettaa, että tieteiden, erityisesti juuri fysiikan, kemian ja biologian, vakiintuneet teoriat jäljittävät totuutta 
tai lähestyvät totuutta. Se maailma, joka näiden tieteiden kautta paljastuu, ei perusnäkemyksen edustajan mukaan ole teologialle täysin tuhoisa, vaan monet teologiset näkemykset, kuten esimerkiksi ajatus Jumalan jatkuvasta luovasta toiminnasta, on yhteensopiva tämän näkemyksen kanssa. Perusnäkemyksen edustajat painottavat myös teologisen antropologian ja luonnontieteellisten näkemysten yhteyttä: perinteisen teologiset näkemykset löytävät myös paikkansa luonnontieteen paljastaman maailman sisällä, vaikkakin hieman muokatussa muodossa.

\section{Kirjallisuutta}

Tieteellistä materialismia popularisoivat esimerkiksi Dawkins 2006, Dennett 1995, 2006 ja Wilson 1998. Katsaus useiden eri tieteellisten materialistien näkemyksiin uskonnosta ja tieteestä on Giberson \& Artigas 2006. Tieteen ja kristinuskon suhteen yleisesityksiä ovat esimerkiksi seuraavat. Dixon 2008 on lyhyt, ytimekäs ja historiallisesti suuntautunut. Yleisellä tasolla liikkuu McGrath 1999 mutta on kattavuudessaan ja helppolukuisuudessaan erityisen suositeltava alaan perehtyvälle. Saatavilla on myös uusi, laajennettu painos McGrath 2009. McGrathin kanssa kilpaileva perusteos on Sweetman 2010. Katso myös uunituoreet kirjat Barnes 2010 ja Harrison 2010. Alan klassikko on laajasti historiallista, filosofista ja tieteellistä materiaalia sisältävä Barbour 1998, joka on kuitenkin maallikolle toisinaan liian tekninen. Menetelmällisiin ja luokitteluja koskeviin kysymyksiin keskittyy Stenmark 2004 ja sopii näin ollen enemmän filosofisesti suuntautuneille lukijoille. Drees 1996 on pidemmälle ehtineille ja filosofisesti suuntautuneille lukijoille erinomainen ja varsin kriittinen katsaus nykykeskusteluun. Samassa sarjassa on Clayton 1997. Monumentaalinen Clayton \& Simpson 2006 sisältää keskusteluja kaikista tässä kirjassa käsitellyistä teemoista. Lyhyt käsikirja terminologiaan ja kirjallisuuteen on Campbell \& Looy 2009. 



\section{TIETÄMISEN MENETELM ÄT: REALISMI TIETEESSÄ JA TEOLOGIASSA}

Tässä luvussa tarkastellaan varsin yleisellä tasolla sitä, millaisia teologian ja tieteen tiedonhankinnan menetelmät ovat ja miten näitä kumpaakin tulisi tulkita. Luvun perusväite on se, että tieteen ja teologian suhteesta puhuminen on varsin turhaa, jos emme samaan aikaan ole tieteellisiä realisteja ja teologisia realisteja. Aloitan käsittelemällä arkikäsitystä tieteen luonteesta ja tieteellisestä tiedonhankinnasta, jonka jälkeen etenen käsittelemään kolmea erilaista tapaa ymmärtää tieteellinen tiedonhankinta ja tieteellisen tiedon luonne. Nämä tavat ovat positivismi, relativismi ja realismi. Tämän jälkeen tarkastelen myös teologista realismia ja sitä, kuinka sekä tieteellinen realismi että teologinen realismi ovat päällekkäisyysmallin keskeisimmät menetelmälliset edellytykset.

\section{$3 \cdot 1$}

ARKIKÄSITYS TIETEESTÄ JA TIETEEN M ÄÄRITELMIÄ

Voimme lähteä liikkeelle siitä, miten tiede tavallisesti nähdään. Fyysikko ja tieteenfilosofi Alan Chalmers kuvaa kuuluisan tieteenfilosofian oppikirjansa What Is This Thing Called Science? alussa laajalle levinnyttä arkikäsitystä tieteestä seuraavalla tavalla: 
kansanomainen käsitys tieteellisen tiedon luonteesta voidaan vangita sloganilla "tiede johdetaan faktoista". ... Kun väitetään, että tiede on erityistä, koska se perustuu faktoihin, näiden faktojen oletetaan olevan väitteitä maailmasta, jotka voidaan varmentaa suoraan tarkalla ja ennakkoluulottomalla aistien käytöllä. Tieteen tulee perustua siihen mitä voimme nähdä, kuulla ja tuntea sen sijaan, että se perustuisi henkilökohtaisille mielipiteille tai kuvitteellisille spekulaatioille. Jos havainnoimme maailmaa tarkasti ja ennakkoluulottomasti, niin tätä kautta saadut faktat muodostavat varman ja objektiivisen tieteen perustan. Lisäksi jos se päättely, jolla tästä perustasta päätellään tieteelliseen tietoon, eli luonnonlakeihin ja tieteellisiin teorioihin, on pätevää, niin tieteellinen tieto voidaan katsoa varmaksi ja objektiiviseksi. ${ }^{20}$

Arkikäsitys perustuu siis seuraaviin väitteisiin:

(1) Tieteellisen tiedon (teorioiden) tulee perustua objektiivisiin faktoihin, jotka voidaan tavoittaa havainnoilla.

(2) Faktat ovat havainnoitsijasta, teorioista ja käsitteistä riippumattomia.

(3) Tieteellinen tieto voidaan päätellä faktoista ilman erehtymisen mahdollisuutta.

Arkikäsitys kuvaa tieteen ikään kuin rakennukseksi, joka perustuu havainnon avulla tavoitettavaan maailmaan, josta sitten koko talo johdetaan päättelemällä. Olennaista tässä näkemyksessä on se, että perusta on ongelmaton ja periaatteessa erehtymätön. Kaikki tieto voidaan päätellä havainnosta, ja jos tämä päättely on pätevä, on myös tieto varmaa.

Tieteen arkikäsityksellä on merkittäviä seurauksia. Ensinnäkin siitä seuraa, että kaikki tieto kuuluu tieteen piiriin. Jos tiede käsittelee havainnossa annettuja faktoja, ei mitään jää ulkopuolelle, koska ei ole mitään muita keinoja tavoittaa faktoja kuin havainto. Se, mitä kutsumme tiedoksi muilla elämänalueilla, ei siis ole tietoa ollenkaan, jos se ei ole yhtäpitävää tieteellisen tiedon kanssa. Toi- 
seksi tällaisesta näkemyksestä seuraa, että tiede on riippumatonta muista tiedonhankinnan keinoista ja yleisistä oletuksista maailman luonteesta. Tiede ei oleta mitään ennakolta maailmasta, koska se perustaa tietonsa faktoihin, jotka annetaan "puhtaissa" havainnoissa. Kolmanneksi näkemyksestä seuraa, että jokainen, joka on eri mieltä tieteen kanssa siitä mitkä ovat faktoja, ei ole objektiivinen tai puolueeton havainnoitsija. Jos tieteessä faktat ovat objektiivisia ja puolueettomia, niin se, joka ei tunnusta näitä faktoja, on välttämättä ennakkoluuloinen tai subjektiivinen havainnoitsija.

Jos etenemme tieteen arkikäsityksen pohjalta, niin kristinusko asettautuu automaattisesti tiedettä vastaan (mitä tahansa ei-tiedettä vastaan, joka väittää puhuvansa todellisuudesta). Syntyy esimerkiksi seuraavanlaisia vastakkainasetteluja: tiede on julkista - kristinusko yksityistä, tiede perustuu faktoille - kristinusko perustuu jollekin muulle (toiveajattelulle, tunteille, jne.) ja tiede ei erehdy kristinusko erehtyy. Huomaa, että edellisissä esimerkeissä voisimme korvata sanan "kristinusko" millä tahansa muulla, joka esittää vaatimuksia totuudesta, kuten esimerkiksi "taiteella", "kirjallisuudella" tai "filosofialla".

Se, mikä tekee tieteen arkinäkemyksen kiinnostavaksi aiheemme kannalta, on sen laajalle levinnyt luonne ja se, kuinka sitä usein kansanomaisessa kirjoittamisessa käytetään perustelemaan ristiriitamallia. Vielä kiinnostavampaa on se, että arkinäkemys on käytännössä hylätty sekä tieteilijöiden että filosofien joukossa. Chalmers kirjoittaa, että

idea, jonka mukaan tieteellisen tiedon ominaispiirteenä on se, että se voidaan johtaa kokemuksessa ilmenevistä faktoista, voidaan hyväksyä vain varovaisesti ja erittäin jalostetussa muodossa, jos se voidaan hyväksyä ollenkaan. ${ }^{21}$

Tulen palaamaan tieteen arkikäsitykseen myöhemmin tässä luvussa, kun tarkastelen positivismiksi (tai empirismiksi) kutsuttua tapaa ymmärtää tieteen luonne ja käsittelen siinä myös niitä syitä, miksi 
tämä näkemys on lähes universaalisti hylätty. Positivismia voidaan pitää yrityksenä muotoilla arkikäsitys tieteestä mahdollisimman kattavaksi filosofiseksi teoriaksi, joten positivismin tappio voidaan ymmärtää myös tieteen arkikäsityksen tappiona.

Jos alustavasti hylkäämme ajatuksen tieteestä faktoista loogisesti johdettuina tietona, niin edessämme on tieteen luonnetta koskeva yleinen kysymys. Mitä tiede sitten oikein on? On varsin tavallista puhua tieteestä sen enempää tarkentamatta mitä kulloinkin tarkoitetaan. Usein kuulee puhuttavan, että "tiede sanoo X" tai "tutkijat sanovat Y" tai "tiede on todistanut Z" ikään kuin nämä tavat puhua olisivat yksinkertaisia ja ongelmattomia. Ajatus moisen puheen yksinkertaisuudesta ja ongelmattomuudesta kantautuu keskusteluihin tieteen ja kristinuskon suhteesta edellä käsittelemäni tieteen arkikäsityksen kautta.

Tieteestä puhuttaessa voidaan tarkoittaa ainakin tiedettä

(1) tutkimusjärjestelmänä tai instituutiona,

(2) tutkimustoimintana,

(3) jollakin hetkellä hyväksyttynä tieteellisen tiedon kokonaisuutena,

(4) tieteellisenä menetelmänä,

(5) jonakin yksittäisenä tieteenala tai teoriana.

Kun puhutaan tieteestä tutkimusjärjestelmänä tai instituutiona voidaan viitata esimerkiksi yliopistoihin ja niiden laitoksiin instituutioina, tieteelliseen julkaisutoimintaan tai opetukseen ja tieteelliseen koulutukseen. Tiede tutkimustoimintana taas sisältää tutkijoiden käyttäytymisen ja tieteellisen toiminnan kuten kokeiden järjestämisen ja suorittamisen. Näissä molemmissa tapauksissa ollaan lähellä sitä, mitä edellisessä luvussa kutsuin käytännöiksi: tutkimusinstituutiot ja tutkimustoiminta koostuu ihmisten käyttäytymisestä.

Näiden käytännöllisten ulottuvuuksien lisäksi voidaan puhua tieteen teoreettisesta puolesta. On hyvin tavallista viitata tieteeseen jonkinlaisena tiedon kokonaisuutena. Tällöin ajatus näyttää olevan se, että eri tieteenalojen (erityisesti luonnontieteen) jollakin hetkellä 
hyväksytyt teoriat muodostavat yhtenäisen kokonaisuuden. Tiede on tässä mielessä tiedeyhteisön hyväksymän tiedon kokoelma. Tiedon kokonaisuuden lisäksi voidaan puhua tieteestä myös tieteellisenä menetelmänä. Ajatus on tällöin se, että kaikkea tiedettä luonnehtii enemmän tai vähemmän yhtenäinen tapa hankkia ja arvioida tietoa. Tämä ajatus oli juuri tieteen arkiteorian perusta.

Lopuksi voidaan puhua myös jostakin tietystä tieteenalasta ja/ tai jostakin yksittäisestä teoriasta jossakin yksittäisessä tieteessä. Tieteenaloja voidaan luokitella eri tavoin mutta tapana on erottaa toisistaan ainakin luonnontieteet, ihmistieteet ja tekniset tieteet. Luonnontieteiden, kuten fysiikka, kemia ja biologia, ajatellaan keskittyvän niihin osiin maailmasta, jotka ovat ihmisistä riippumattomia. Ihmistieteet ja yhteiskuntatieteet (tai humanistiset tieteet), kuten esimerkiksi sosiologia, psykologia, antropologia ja kielitiede, taas käsittelevät ihmistä jollakin tapaa erityisenä kulttuurisena, kielellisenä, sosiaalisena tai ajattelevana oliona. Teknisiksi tieteiksi voimme kutsua tieteenaloja, joissa ei pyritä suoranaisesti uuden tiedon tuottamiseen, vaan muiden tieteiden tulosten soveltamiseen käytäntöön jollakin tietyllä alalla.

Kuten jo tieteen arkikäsityksen kohdalla huomasimme, tieteen määritteleminen tarkasti on varsin vaikea tehtävä. Jonkinlainen määritelmä on kuitenkin välttämätön, koska monet haluavat erottaa tieteen ei-tieteestä ja valhetieteestä (pseudotieteestä). Kysymystä tieteen ja ei-tieteen erosta kutsutaan filosofisessa kirjallisuudessa "rajanveto-ongelmaksi" (demarkaatio-ongelmaksi). Perinteisesti erilaisten rajanvetokriteerien antaminen on ollut tieteenfilosofien keskeinen tehtävä. Syy rajanvedon tarpeellisuuteen on ollut aidon tieteen (luotettavan tiedon lähteen) ja ei-tieteen ja valhetieteen (harhaanjohtavien tietolähteiden) erottaminen toisistaan. Jos ei ole mahdollista erottaa tarkasti tieteellisen tiedonhankintaa ja tieteellistä tietoa ei-tieteellisestä, niin tieteellisen tiedon erityisasema on uhattuna.

Rajanvetokriteereiksi ja samalla tieteen määritelmiksi on ehdotettu esimerkiksi seuraavia väitteitä: 
(1) Tieteen teoriat voidaan osoittaa todeksi havainnoilla.

(2) Tieteen teoriat voidaan osoittaa vääräksi havainnoilla.

(3) Tieteelliset teoriat tuottavat kokeellisesti testattavia ennusteita.

(4) Tiede pyrkii ratkaisemaan teorioiden tunnistamia ja tarkkaan määritettyjä ongelmia.

(5) Tieteelliset tutkimusohjelmat edistyvät.

(6) Tiede on luonnollisen maailman säännönmukaisuuksien selittämistä.

(7) Tiedettä on se mitä tutkijat tekevät.

(8) Tiedettä on se, mitä tiedeyhteisö kulloinkin tieteeksi hyväksyy

Heti alkuun kannattaa huomata, että nämä kriteerit ovat vetoavat erilaisiin ulottuvuuksiin tieteessä. Kriteerit (1)-(4) vetoavat siihen, miten tieteellinen tiedonhankinta toimii, loput taas tieteen historialliseen kehitykseen sekä tieteen sosiaalisiin ja käytännöllisiin ulottuvuuksiin.

Tieteellisen tiedonhankinnan erityisluonteeseen perustuvat kriteerit kaatuvat lähes aina siihen, että tiedonhankinta eri tieteissä on varsin erilaista eikä niitä yhdistä mikään yksinkertainen tai muuten selkeästi määriteltävä tekijä. Tieteen kohteisiin perustuvat määritelmät, jotka tavallisesti esittävät tieteen tutkivan luonnollisia ja toistettavia ilmiöitä, taas jättävät ulkopuolelle ilmiöitä, jotka eivät ole toistettavissa. Lisäksi tällaista määritelmää vaivaavat ongelmat, jotka koskevat "luonnollisuuden" määrittelemistä. Tieteen historialliseen kehitykseen vetoavat kriteerit taas eivät pysty erottamaan tarpeeksi hyvin tiedettä muista käytännöistä ja lisäksi jotkut asettavat koko ajatuksen tieteen edistyksestä kyseenalaiseksi. Tieteen käytännöllisiin ja sosiaalisiin ulottuvuuksiin perustuvat määritelmät taas jättävät paljon toivomisen varaa, koska ne näyttävät johtavan ikävään relativismiin: jos tiede esimerkiksi on sitä, mitä tieteilijät tekevät tai sanovat, niin mikä tahansa käy tieteestä, jos vain tutkijat niin sanovat.

Monista ehdotuksista huolimatta on varsin yleisesti hyväksytty johtopäätös se, että mikään näistä kriteereistä ei yksin onnistu erot- 
tamaan tiedettä ei-tieteestä. Jokainen kriteeri näyttää jättävän ulkopuolelle jotain sellaista, joka näyttäisi olevan tiedettä, tai laskevan mukaan sellaista, joka ei näyttäisi olevan sitä. Tästä syystä valtaosa kirjoittajista onkin sitä mieltä, että meidän pitää yhdistellä erilaisia kriteereitä ja päättää tapaus kerrallaan mitkä teoriat ja tiedonhankinnan menetelmät kuuluvat tieteen piiriin. Tämä ei tietenkään tarkoita sitä, että mikä tahansa käy tieteestä. Voimme ymmärtää rajanvedon prosessina, jossa meillä on suuri määrä erilaisia prototyyppejä ja kriteereitä, jotka antavat meille tavan erotella hyvä tiede huonosta tieteestä ja ei-tieteestä.

Lopullisen rajanvetokriteerin puutteesta huolimatta voimme lähteä liikkeelle jonkinlaisesta väljästä tieteen määritelmästä, jonka voimme muotoilla seuraavalla tavalla: Tiede on järjestelmällistä tiedon etsintää, joka ei riipu yksilöistä vaan on avoin kaikkien tarkastettavaksi ja toistettavaksi. ${ }^{22}$ Tämä määritelmä sisältää ainakin kolme tärkeää piirrettä:

(1) Tiede tähtää (toteen) tietoon.

(2) Tieteellinen tiedonhankinta on säädeltyä.

(3) Tieteen tulokset ovat avoimia siinä mielessä, että kuka tahansa, jolla on riittävä koulutus, voi tavoittaa ja arvioida ne menetelmät, joilla tuloksiin on päädytty.

Ensinnäkin tiede tähtää tiedon saavuttamiseen. Tiede on siis toimintaa, jonka päämääränä on totuus. Tämä voi kuulostaa latteudelta mutta se ei ole sitä. Totuudelle vaihtoehtoisia päämääriä ovat esimerkiksi parempi elämä, uudet tekniset sovellukset tai poliittinen emansipaatio. Nämä voivat syntyä sivutuotteena totuuden etsimisestä mutta ne eivät ole tieteen päämääriä eivätkä välttämättömiä seurauksia siitä. Aiemmin puhuin käytännöistä ja kiinnitin huomiota siihen, kuinka käytäntöjen järkevyys riippuu siitä mikä niiden päämäärä on. Tällä perusteella voidaan sanoa, että tieteen järkevyys riippuu siitä pidetäänkö sitä hyvänä välineenä totuuden saavuttamiseksi. 
Toiseksi tieteessä hankitaan tietoa tavalla, joka on määritelty etukäteen. Tietoa ei hankita miten sattuu, vaan tutkijoilla on käytössään väljä joukko erilaisia menetelmiä, normeja, taustaoletuksia, kokeita ja päättelyitä tieteenalasta riippuen. Voimme ymmärtää tieteellisen tiedonhankinnan säännöt eräänlaisina raja-arvoina, joita yritetään lähestyä miten parhaiten pystytään kussakin tilanteessa. Huomaa, että määritelmämme ei kuitenkaan oleta yhtä, kaikille tieteenaloilla automaattisesti toteutettavaa "tieteellistä menetelmää".

Kolmanneksi tiede on yhteisöllistä toimintaa. Tutkimustulokset ja se tapa, miten niihin on päädytty, ovat julkisia ja kuka tahansa voi periaatteessa tarkastella niitä. On tietenkin totta, että vain hyvin harva voi käytännössä arvioida ja tarkastella yksittäisiä tieteellisiä tutkimuksia, koska niiden ymmärtäminen edellyttää lähes aina varsin suurta määrää teknistä tietoutta. Olennaista on kuitenkin se, että tämän ymmärryksen voi periaatteessa hankkia kuka tahansa. Ajatus on siinä, että tieteellisen tiedon lähteet, tieteellinen päättely ja sen tulokset eivät saa olla luonteeltaan sellaisia, että ne ovat vain jonkin tietyn joukon tai jonkun yksilön saavutettavissa, koska näillä yksilöillä on jokin erityinen kyky, taipumus tai salattu tietolähde. Lisäksi tieteen avoimuudella ja yhteisöllisyydellä tarkoitetaan tässä sitä, että yksittäisten tutkijoiden tulokset eivät voi saavuttaa tieteellisen tiedon asemaa ilman tiedeyhteisön hyväksyntää.

Tieteen ja teologian suhteen näkökulmasta lopullisen rajanvetokriteerin puute ei ole varsinaisesti ongelma, jos keskitymme tarkastelemaan varsin yleisesti hyväksyttyjä tieteellisten teorioiden joukkoja, kuten evoluutiobiologiaa tai modernia kosmologiaa. Rajanvetokriteerin puuttuminen kuitenkin herättää kysymyksen tieteen objektiivisuudesta tai maailmankatsomuksellisesta neutraalisuudesta. Jotkut kirjoittajat ovat esimerkiksi väittäneet, että tieteen taustalla on oletuksia, jotka ovat luonteeltaan kristinuskon vastaisia tai ainakin vahvasti ateismille puolueellisia. Tästä seuraisi sitten, että emme voisi pitää tiedettä puolueettomana, neutraalina tai objektiivisena tiedonlähteenä. Siihen mitä tällä kritiikillä haetaan ja miten se muotoillaan palaan myöhemmin. Tässä kohdin riittää sen tun- 
nustaminen, että tieteellisiä teorioita muotoiltaessa ja tulkittaessa on aina läsnä käsitteitä, joita ei voida perustella kokeellisesti.

$3 \cdot 2$

POSITIVIS M I

Käsittelin aiemmin näkemystä, jota Chalmers kutsui tieteen arkinäkemykseksi, ja totesin, että positivismi voidaan ymmärtää tämän arkinäkemyksen jalostetuksi versioksi. Tai ehkä olisi perustellumpaa väittää, että arkinäkemyksemme tieteestä periytyy siitä, miten positivistit ymmärsivät tieteen. ${ }^{23}$

Positivistinen teoria tieteestä on muotoiltu 1900-luvun alussa syntyneessä erittäin vaikutusvaltaisessa filosofisessa suuntauksessa, jota kutsutaan loogiseksi positivismiksi. Liikkeen keskeisenä päämääränä oli luoda tiedolle varma perusta, josta etenemällä tiede voisi saavuttaa varmasti totuuden maailmasta. Loogisen positivismin ytimen muodosti Wienin piiri, joka kokoontui maailmansotien välisenä aikana. Piiriin kuuluivat esimerkiksi filosofi Moritz Schlick (1882-1936), yhteiskuntatieteilijä Otto Neurath (1882-1945) ja loogikko Rudolf Carnap (1891-1970). Piirin edustajien ajatuksilla oli kannattajia myös muissa maissa: esimerkiksi suomalaisen filosofian grand old man Eino Kaila haki oppinsa Wienistä, ja Britanniassa loogista positivismia edusti Oxfordin filosofi A. J. Ayer. ${ }^{24}$

Ymmärrämme loogista positivismia, jos käsitämme sen usean eri filosofisen tradition yhteensulautumaksi. Ensimmäinen näistä on filosofinen empirismi, jonka mukaan kaikki aito tieto perustuu havaintoon. Empiristien, kuten esimerkiksi John Locke (1632-1704) ja Francis Bacon (1561-1626), mukaan ainoa mahdollinen tapa saavuttaa tietoa ovat aistihavainnot ja niistä päättelemällä johdetut yleiset väitteet. Toisin kuin empirismiä vastustavat rationalistit, joiden mukaan järjen avulla voidaan tuntea ideat, joista tieto voidaan johtaa, empiristit ajattelijat korostivat sitä, että kaikki ideat tulee johtaa aistihavainnoista. Erityisesti Locken puolustamasta empiris- 
mistä tuli Britanniassa syntymässä olevan modernin luonnontieteen standardifilosofia. Empirismin lisäksi loogisen positivismin taustalla on ranskalainen 1800-luvun klassinen positivismi. Klassisen positivismin edustajia, kuten Auguste Comtea (1798-1854), innoitti Valistuksen edistysusko, jonka mukaan voimme järkeen perustuvan tieteen avulla löytää varman perustan kaikille elämänalueille aina yhteiskunnallisesta elämästä moraaliin ja uskontoon asti. Olennaista on päästä eroon ei-tieteellisestä kuonasta kuten filosofiasta ja perinteisestä teologiasta, jotka olivat vallinneet ennen valistusta. Se, mikä teki loogisesta positivismista "loogisen", oli se tapa, jolla sekä empirismi että positivismi sulautettiin toisiinsa. 1800-luvun loppu ja 1900-luvun alku olivat nähneet logiikan renessanssin, johon osallistuivat esimerkiksi Gottlob Frege (1848-1925) Saksassa ja Bertrand Russell (1872-1970) Britanniassa. Menemättä sen tarkemmin näihin loogisiin innovaatioihin voidaan todeta, että logiikan ajateltiin tarjoavan välineet, joiden avulla empirismille ongelman muodostanut teoreettinen ja matemaattinen tieto saadaan palautettua aistihavaintoihin.

Tuloksena oli joukko näkemyksiä, joita yhdistivät seuraavat väitteet:

(1) Todennettavuusehto eli verifikaatioehto: Mielekäs kieli on pystyttävä todentamaan aistihavainnolla.

(2) Jyrkkä empirismi: Kaikki (tieteellinen) tieto on pystyttävä palauttamaan välittömästi havaittuja tosiasioita koskeviin lauseisiin.

(3) Tieteen yhtenäisyys: Kaikilla tieteillä on sama menetelmä ja samat päämäärät.

Todennettavuusehdon tarkoitus oli erottaa mielekkäät kielenkäytön tavat mielettömistä ja pitää tällä tavoin huoli, että tietoomme ei pääse lipsahtamaan mitään ylimääräistä - jotain havainnon tuolle puolen menevää kuten teologiaa tai filosofiaa. Arkiajattelun näkökulmasta on ehkä aluksi vaikea ymmärtää kuinka radikaali tämä ehto on. Todennettavuusehto ei siis pyri osoittamaan, että aistihavainnoilla 
todentamaton puhe on epätotta, vaan että se on mieletöntä. Esimerkiksi eettiset väitteet, joita ei voida loogisten positivistien mukaan todentamaan aistihavainnoilla, eivät ole epätosia vaan virheellistä puhetta. Jos eettisillä väitteillä katsottiin olevan jokin sisältö, oli tämä sisältö ilmaisu sanojan tunteista. Jos siis sanon, että "tappaminen on väärin" tarkoittaa se, että "hyi, tappaminen on inhottavaa". Etiikkaa ankaramman kohtelun saivat perinteinen metafysiikka ja teologia, joiden katsottiin olevan kirjaimellisesti virheellistä puhetta, hurunkukkua. Tämä näkemyksen mukaan ainoa mielekäs kielenkäytön tapa on eräänlainen välittömiin havaintoihin perustuva faktakieli, joka sisältää lauseita kuten "eduskuntatalo on graniitista" tai "näen nyt valkoista". Faktakielen ulkopuolelle jäävät esimerkiksi moraaliset ilmaisut, puhe toisten ihmisten mielentiloista, menneisyyden tapahtumat, esteettiset arvostelmat, uskonnolliset ilmaisut ja kaikki mahdolliset havaintojen tuolle puolen menevät (metafyysiset) ilmaisut.

Jyrkän empirismin päämäärä oli sama kuin todennettavuusehdon: pitää huoli siitä, että mitään epävarmaa, spekulatiivista tai kuvitteellista "saastetta" ei pääse livahtamaan mukaan tietolähteisiimme. Toisin sanoen siis jyrkän empirismin tarkoitus oli varmistaa, että meillä on varma ja ihmisistä riippumaton tietolähde, josta voimme maailmaa koskevan tietomme johtaa. Ajatuksena jyrkän empirismin taustalla oli tietysti se, että aistihavainnot välittävät meille maailman faktat yksilöistä ja heidän ympäristöstään riippumatta. Voimme tiivistää tämän väitteeseen "havainto kertoo meille miten asiat ovat". Loogisten positivistien kolmas teesi - tieteen yhtenäisyys - johdettiin kahdesta edellisestä. Tieteen yhtenäisyydellä tarkoitettiin sekä tieteellisen menetelmän yhtenäisyyttä että tieteellisen tiedon yhtenäisyyttä. Tieteen yhtenäisyys molemmissa merkityksissä on välttämätön seuraus siitä, että aistihavainto tietolähteenä on ihmisestä riippumaton ja erehtymätön.

Vaikka loogisen positivismin vaikutus oli filosofisessa ja tieteellisessä maailmassa hyvin suuri vielä sotien jälkeenkin, alkoi 1950-luvulta eteenpäin kuulua soraääniä. Lopulta nämä soraäänet kasvoivat kuoroksi, joka johti loogisen positivismin perusoletukset umpiku- 
jaan. Ensimmäinen ongelma oli se, että todennettavuusehtoa ei pystytty muotoilemaan tyydyttävällä tavalla. Ehdon radikaalisuuden ongelmana oli se, että suurin osa ehdon mukaan mielettömistä ilmaisuista näyttävät olevan aivan järkeviä tapoja puhua asioista. Pelkkä arkijärki sanoo, että esimerkiksi eettisillä ja muilla todennettavuusehdon ulkopuolelle rajaamilla puhetavoilla, on jokin merkitys. Me ymmärrämme, mitä tarkoittaa puhe siitä, että tappaminen on väärin tai puhe toisten ihmisten mielentiloista. Tämä puhe voi olla virheellistä siinä mielessä, että tappaminen ei ole väärin, mutta puhe on siitä huolimatta ymmärrettävää eikä mitään hölynpölyä. Tämä todennettavuusehdon ongelma kantautui myös tieteeseen eli sinne mitä todennettavuusehdon tarkoituksena oli puolustaa. Huomattiin nopeasti, että luonnontieteet puhuvat jatkuvasti olioista ja prosesseista, jotka ovat havainnolle näkymättömiä: puhetta esimerkiksi alkuräjähdyksestä, atomeista ja aivotoiminnoista ei pystytä millään palauttamaan kieleen välittömästi havaittavista ilmiöistä. Lisäksi ongelmana oli tieteessä erittäin tavallinen puhe teoreettisista olioista, yleisistä laeista ja säännönmukaisuuksista. Ongelma on siinä, että mikään äärellinen määrä aistihavaintoja ei voi todentaa universaaleja yleistyksiä kuten esimerkiksi painovoimalakia. Sama pätee muihinkin teoreettisiin oletuksiin ja säännönmukaisuuksiin: niitä ei pystytä yksiselitteisesti todentamaan minkäänlaisilla suorilla havainnoilla.

Kaiken tämän lisäksi todennettavuusehto ei näyttänyt sopivan tieteilijöiden käytäntöihin. Sen sijaan, että tutkijat olisivat todentaneet näkemyksiään yksi havaintolause kerrallaan, he pikemminkin esittivät kokonaisia teorioita, jotka sisälsivät useita teoreettisia väitteitä ja olioita, joita ei pystytä arvioimaan muuta kuin välillisesti joidenkin toisten oletusten perusteella. Tätä on usein kutsuttu holistiseksi eli kokonaisvaltaiseksi oikeuttamiseksi: yksittäisen tieteellisen väitteen oikeutus on riippuvainen sitä ympäröivästä kokonaisesta teoriasta. Lopulta kaikkein merkittävin todennettavuusehdon ongelma oli se, että ehtoa itsessään ei pystytä todentamaan aistihavainnolla: ehto ei voi olla omilla kriteereillään arvioituna pätevä - se 
tuhoaa itse itsensä.

Jyrkän empirismin kohtaloksi koitui lopulta teesi havainnon teoriapitoisuudesta. Jos tiivistämme koko valtavan keskustelun yhteen väitteeseen, voimme sanoa, että aistihavainnot eivät anna meille faktoja "sellaisena kuin ne ovat", vaan aistihavainto on vain yksi tekijä, jota muokkaa kokemustamme maailmasta. Muita tekijöitä ovat esimerkiksi omat aiemmat kokemuksemme, hankkimamme tieto, käsitteemme ja ympäristömme. Jo Wittgenstein kiinnitti huomiota tähän ilmiöön: hänen mukaansa me emme pelkästään näe kohdetta vaan näemme kohteen aina jonakin. Tästä seuraa, että loogisen positivismin ajatus siitä, että teoria tulee vasta havainnon jälkeen, on virheellinen: tavoitamme maailman havainnossamme vain osana jotakin laajempaa "teoriaa", kuten kieltä, aikaisempia kokemuksiamme ja käsitteitämme.

Havainnon teoriapitoisuudesta seuraa, että faktojen ja havainnon suhde on radikaalisti erilainen kuin positivistit olettivat. Kun puhumme faktoista, voimme viitata maailmassa vallitseviin tosiseikkoihin, kuten siihen, että eduskuntatalo on graniitista, tai sitten väitteisiin, jotka viittaavat noihin faktoihin, kuten lauseeseen "eduskuntatalo on graniitista". Tietomme koostuu faktoista juuri jälkimmäisessä merkityksessä eli lauseista, jotka viittaavat maailman tosiseikkoihin. Jyrkän empirismin tarkoituksena on johtaa "faktalauseet" suoraan aistihavainnosta, mutta on hyvin epäselvää miten tämä johtaminen oikein tapahtuu. Ymmärtääksemme lauseen "eduskuntatalo on graniittia" tarvitsemme käsitteitä ja kieltä ja aikaisempaa kokemusta emmekä pysty johtamaan näitä siitä, että vain katselemme eduskuntataloa. Havainto siis edellyttää aina jotain käsitteitä, jotka on annettu meille ennen havaintoa itseään.

Loogisen positivismin kritiikki perustui pohjimmiltaan ajatukseen siitä, että tiukka erottelu aistihavainnon ja teorian välillä ei ole mahdollista. Jos kaikki havainto on jossakin mielessä teorian värittämää, loogisen positivismin erehtymätön perusta romahtaa. Puhuessani tieteen arkikäsityksestä aiemmin tässä luvussa kiinnitin jo huomiota siihen mitä positivistisesta tieteenkäsityksestä 
seuraa kristinuskon kannalta, joten varmaan lyhyt muistutus riittää. Jos positivismin näkemys tieteellisestä tiedonhankinnasta ja teorioista hyväksytään, ei jää minkäänlaista tilaa kristinuskon (tai minkään muunkaan ei-tieteen) totuusväitteille. Tämä johtopäätös johtikin monet uskonnolliset ajattelijat positivismin voiman päivinä rakentamaan käsityksiä uskonnosta, joissa uskonnollisia ilmaisuja ei ymmärretty väitelauseina ollenkaan vaan pikemminkin puheena lausujan tunteista tai kokemuksista. Monet filosofit toimivat samaan tapaan myös etiikan kohdalla eli tulkitsivat eettiset väitteet ilmaisuiksi sanojiensa mieltymyksistä ja tunteista. Viittasin näihin malleihin aiemmin, kun tarkastelin Barbourin erottamismallia (luku 2.2) ja palaan niihin myöhemmin tässä luvussa. Sitä ennen on kuitenkin kysyttävä millaista käsitystä tieteellisestä tiedonhankinnasta ja tieteellisistä teorioista positivismin raunioille rakennetaan.

\section{$3 \cdot 3$}

\section{RELATIVIS M I}

Loogisen positivismin kritiikin keskeinen tulos oli se, että aistihavainnot eivät anna meille faktoja sellaisina kuin ne ovat, vaan havaintomme ovat jo etukäteen käsitteidemme ja aiemman kokemuksemme värittämiä. Positivismin romahduksen jälkeen jotkut kirjoittajat veivät havainnon teoriapitoisuuden ajatuksen loppuun asti ja päättelivät, että emme voi tietää todellisuudesta yhtään mitään, koska kaikki yrityksemme tavoittaa todellisuus on ennakolta uskomustemme, kielemme ja kokemuksemme määräämää. Tällaista kantaa kutsutaan jatkossa jyrkäksi relativismiksi tai konstruktivismiksi erotukseksi maltillisista relativismin muodoista.

Voimme erottaa kolme jyrkän relativismin muotoa. ${ }^{26}$

(1) Tiedollinen relativismi: Tietomme todellisuudesta on aina suhteellista kulttuuriin, uskomusjärjestelmiin, kieleen tai muuhun vastaavaan nähden. 
(2) Käsitteellinen relativismi: Erilaiset kulttuurit, uskomusjärjestelmät, kielet tai muut vastaavat ovat yhteismitattomia. Niitä ei voi siis verrata eikä asettaa paremmuusjärjestykseen.

(3) Totuusrelativismi: Erilaisten kulttuurien, uskomusjärjestelmien tai kielien totuudesta ei voida puhua.

Tiedollinen relativismi (1) näyttää seuraavan havainnon teoriapitoisuuden teesistä. Jos tietämisemme perustuu aina havaintoa jäsentäviin teorioihin, kuten havainnon teoriapitoisuuden teesi väittää, on tietämisemme aina riippuvaista näistä teorioista. "Teoriat" voidaan ymmärtää varsin laajasti, jolloin niihin kuuluvat esimerkiksi erilaiset kulttuurit, käsite- ja uskomusjärjestelmät ja luonnolliset kielet. Riippuvaisuussuhde ymmärretään tällöin niin, että teorioista riippuvaiset uskomuksemme ovat oikeutettuja tai tosia joidenkin teorioiden sisällä ja ei-oikeutettuja ja epätosia toisten teorioiden sisällä.

Siinä, missä tiedollisessa relativismissa uskomustemme sisällöt ovat vakiot mutta totuus ja oikeutus suhteellisia, on käsitteellinen relativismi (2) radikaalimpi oletus: sen mukaan tietomme on aina jotakin niin syvästi teorioihin sitoutunutta, että sitä ei voida ymmärtää teorian ulkopuolella. Tästä seuraa, että vertailu eri teoreettisten kehysten (kielten, kulttuurien, ryhmien, jne.) välillä on kokonaan mahdotonta. Tällöin voidaan sanoa, että eri kulttuurit elävät "eri maailmoissa" tai että "kaikkien näkemykset ovat yhtä tosia". Tällaiset ilmaisut ovat tyypillisiä niille, jotka kutsuvat kantaansa "kulttuurirelativismiksi” tai joksikin muuksi vastaavaksi. Käsitteellinen relativismi johtaa lopulta totuusrelativismiin (3), jonka mukaan on mieletöntä kysyä erilaisten havaintojamme ja tietoamme ohjaavien teorioiden totuutta. Tällöin totuus uskomustemme ja todellisuuden vastaavuutena rikkoutuu: totuutta meistä riippumattomasta maailmasta on mahdotonta tietää.

Jyrkkiä relativismin muotoja on tullut tavaksi kutsua konstruktionismiksi. Konstruktionismin mukaan ihmiset ikään kuin luovat omat maailmansa kielensä, kulttuurinsa ja ryhmiensä kautta. Raatikainen tiivistää tämän erinomaisesti toteamalla, että 
[j]yrkkä konstruktionismi joko kiistää, että mitään kielestä, käsitejärjestelmästä tai kulttuurista riippumatonta todellisuutta olisi olemassakaan (idealismi), tai ainakin väittää, että tuo todellisuus on täysin tietomme ja kielemme tavoittamattomissa (kantilainen transsendentaalinen idealismi). Jyrkän konstruktionismin mukaan se todellisuus, josta voidaan saada tietoa, on joka tapauksessa täysin kielen ja käsitteiden soveltamisen konstruoimaa. Ja koska kielet ja käsitejärjestelmät vaihtelevat (kielellisestä, sosiaalisesta, tieteellisestä) ryhmästä toiseen, päätellään, että kullakin ryhmällä on oma todellisuutensa, jotka kaikki ovat olemassa vain käsitteitten soveltamisen kautta. ${ }^{27}$

Esimerkkinä konstruktionismista voidaan ottaa vaikkapa brittifilosofi Peter Winchin (1926-1997) näkemyksen kulttuurien suhteesta. Winch osallistui aikansa kulttuuriantropologiseen keskusteluun, joka käsitteli alkukantaisten kulttuurien maagisia ja taikauskoisia käytäntöjä. Brittiantropologi E. Evans-Pritchard kuvasi Zande kulttuurin maagisia käytäntöjä ja päätyi toteamaan, että kyseiset käytännöt ovat pohjimmiltaan järjettömiä. Winch vastasi tähän väittämällä, että jokainen kulttuuri luo omat järkevyyden kriteerinsä, joten emme voi arvioida Zande heimon maagisia käytäntöjä omien käytäntöjemme näkökulmasta. Kun Zandet puhuvat magiasta, meidän ei tule ymmärtää tätä puhetta samalla tavalla kuin ymmärrämme puheen magiasta omassa kulttuurissamme. Se, että magia on järjetöntä meille, ei tarkoita sitä, että se olisi järjetöntä Zandeille. Emme siis voi arvioida Zande-magian järjellisyyttä, koska emme jaa Zanden elämänmuotoja. Tässä näemme jälleen Wittgensteiniltä (jonka oppilas Winch oli) lainatun ajatuksen siitä, että ilmaisujemme merkitys perustuu niitä ylläpitäviin käytäntöihin (ks. luku 2.3). Jos kullakin kulttuurilla on oma elämänmuotonsa ja heidän käyttämänsä kieli saa merkityksensä tästä elämänmuodosta, niin tätä kieltä ei voi ymmärtää sen elämänmuodon ulkopuolelta.

On tärkeä huomata kuinka jyrkkä konstruktionismi eroaa maltillisesta relativismista, jonka erilaiset muodot ovat lähes kaikkien hyväksymiä. On esimerkiksi täysin järkevää ajatella, että ihmisten 
uskomusten perusteet vaihtelevat suuresti: Martilla voi olla hyviä perusteita olla eri mieltä Minnan kanssa ja Minnalla Martin kanssa. Maltillinen relativisti voi siis hyvinkin ajatella, että uskomusten perusteet ovat suhteellisia ja että näkemyksemme todellisuudesta ovat radikaalistikin taustateorioittemme ohjaamia. Tästä ei kuitenkaan seuraa sitä, että itse todellisuutta ei olisi olemassa tai että meidän tietomme siitä ei voisi parantua. Tärkeää on siis oivaltaa, että positivismin haaksirikosta ei seuraa, että ainoa jäljelle jäävä kanta on jyrkkä relativismi ja konstruktionismi. Meillä on erittäin hyviä kandidaatteja erilaisiksi maltillisiksi kannoiksi positivismin ja jyrkän relativismin väliin kuten tulemme kohta näkemään. Sitä ennen kuitenkin vielä muutama sana jyrkästä konstruktionismista tieteessä.

Jyrkkä konstruktionismi tieteenteoriana johtaa radikaalisti erilaiseen lopputulokseen kuin positivismi. Siinä, missä positivismille oli olennaista tieteen yhtenäisyys ja pyrkimys rakentaa kaikki tieto varmalle perustalle, päätyy konstruktivisti kiistämään kokonaan tieteen yhtenäisyyden ja radikaalisti suhteellistamaan tieteen merkityksen tietolähteenä. Tieteellinen menetelmä ja sen tuottamat teoriat eivät ole minkäänlaisessa erityisasemassa suhteessa muihin tietolähteisiin. Ne ovat vain yksi kulttuurinen, sosiaalinen ja kielellinen käytäntö muiden joukossa. Tästä tietysti seuraa se, että ainoa mahdollinen malli tieteen ja teologian suhteesta on itsenäisyys.

Tällaista näkemystä tieteestä on perusteltu esimerkiksi kuuluisan tieteenhistorioitsijan ja filosofi Thomas Kuhnin (1922-1996) näkemyksillä. Kirjassaan Tieteellisten vallankumousten rakenne (1962, suom. 1994) Kuhn, joka oli tunnettu positivismin kriitikko, käsitteli tieteen (erityisesti fysiikan) kehitystä ja esitti, että meidän ei tule positivistien tavoin olettaa, että tiede kehittyy jatkuvasti kohti parempaa käsitystä maailmasta, vaan että tieteen kehityksessä on valtavia katkoksia. Kuhnin ajatus oli ottaa havainnon teoriapitoisuuden teesi vakavasti ja hän korostikin havaintojen ja tieteellisen tutkimuksen riippuvaisuutta paradigmoista eli laaja-alaisista teorioiden ja uskomusten verkostoista. Kuhn päätyi korostamaan sitä, kuinka tieteen kehityksessä on tapahtunut laaja-alaisia murroksia, 
tieteellisiä vallankumouksia, siirtymiä paradigmoista toiseen. Näin esimerkiksi silloin, kun klassisesta fysiikasta siirryttiin 1900-luvun uuteen fysiikkaan.

Se, miksi Kuhnin ajatusta paradigmanvaihdoksista on tulkittu konstruktivistisella tavalla, johtuu siitä, että Kuhn voidaan ymmärtää tarkoittavan, että vanha ja uusi paradigma ovat yhteismitattomia: koska havainnot ja teoriat ovat kietoutuneet toisiinsa, ei paradigman muutoksen jälkeen ole mahdollista kääntää vanhan paradigman mukaista puhetta uuden paradigman kielelle. ${ }^{28}$ Tällaisesta näkemyksestä näyttäisi seuraavan se, että tiede ei edisty: vanha paradigma ei ole sen lähempänä totuutta kuin vanhakaan; se vain on erilainen. Tämä väite haastaa sekä arkijärjen että yleisesti hyväksytyn näkemyksen tieteestä itseään korjaavana toimintana. Eri paradigmojen sisällä työskentelevät tutkijat asuttaisivat periaatteessa kokonaan eri maailmoja.

Tieteenfilosofi Paul Feyerabend tunnetaan henkilönä, joka ei perääntynyt radikaalista konstruktionismista, vaan vei yhteismitattomuuden ajatuksen loppuun asti. Hänet tunnetaankin yleisesti tieteenfilosofisesta anarkismistaan. Feyerabendin mukaan tieteellisillä tiedonhankinnan tavoilla ei ole minkäänlaista erityisasemaa muihin tiedonhankinnan muotoihin nähden: kaikki yritykset tavoittaa totuus aina maagisista kivistä moderniin fysiikkaan asti ovat samalla viivalla. Tämä kuulostaa jälleen arkijärjen vastaiselta, ja Feyerabend onkin usein esitetty tieteenvastaisena höyrypäänä. Tämä ei kuitenkaan tee oikeutta miehen kirjoituksille. Feyerabend perusti väitteensä tarkkaan tieteenhistorian lukemiseen, joka hänen mukaansa osoittaa esimerkiksi, että eri tieteenaloilla sovelletaan hyvin erilaisia kriteereitä, joilla teorioiden pätevyyttä arvioidaan ja että teorioiden syntyyn ja valintoihin vaikuttavat hyvin monet ei-tieteelliset tekijät.

Jos omaksumme konstruktionistisen näkemyksen tieteellisestä tiedonhankinnasta ja tieteellisistä teorioista, emme voi oikeastaan päätyä mihinkään muuhun kuin hyväksymään itsenäisyysmallin tieteen ja kristinuskon suhteesta ainakin sisältökysymysten suhteen. Emme voi tulla konstruktionismin valossa mihinkään muuhun joh- 
topäätökseen kuin siihen, että sekä kristinusko että tiede "muodostavat omat maailmansa" ja ovat aivan yhtä väärässä (tai oikeassa) puhuessaan "maailmasta sellaisena kuin se on". Voimme ehkä arvottaa tiedettä ja kristinuskoa eri tavoin moraalisilla, yhteiskunnallisilla tai henkilökohtaisilla kriteereillä, mutta totuuden suhteen kummallakaan ei ole etuajo-oikeutta. Tällainen näkemys johtaa vääjäämättä itsenäisyysmalliin ja on itse asiassa itsenäisyysmallin suosion ehkä kaikkein keskeisin syy.

Vaikka konstruktionismin taustalla on monia hyvin tärkeitä ja säilyttämisen arvoisia oivalluksia inhimillisen tietämisen luonteesta ja tieteen rajallisuudesta, niin se on kuitenkin filosofisena teoriana hyvin ongelmallinen. Ohessa esitellään lyhyesti vain muutama keskeinen ongelma. ${ }^{29}$

Ensimmäisenä ongelmana on konstruktionismin itsetuhoisuus. Jos ajattelemme, että kaikki väitteet ovat yhtä tosia tai että ihmiset elävät kokonaan erilaisissa maailmoissa, niin meillä ei ole mitään syytä uskoa konstruktionistien väitteitä. Samaan tapaan kuin positivismi, joka vaati kaikkien väitteiden palauttamista välittömiin aistihavaintoihin mutta joka ei pystynyt perustelemaan tätä vaatimusta, johtaa konstruktionismi radikaalissa muodossaan itsetuhoon. Jos joku väittää minulle, että kaikki väitteet ovat yhtä tosia (tai epätosia), niin minulla ei ole mitään syytä uskoa tähän. Näin ainakin totuusrelativismi on virheellinen kanta sen omilla kriteereillä arvioituna. Muutettavat muuttaen sama pätee myös käsitteelliseen relativismiin: jos uskomme, että maailmamme ovat yhteismitattomia, oletamme niiden välille jonkinlaisen yhteismitallisuuden. Miten voisimme väittää niiden olevan yhteismitattomia, jos emme jollakin tavalla vertailisi niitä? Nämä väitteet johtavat siihen, että jos konstruktionismi pitää paikkansa, emme voi koskaan tietää sitä.

Toinen konstruktionismin ongelma on se, että se ei näytä olevan yhtäpitävä kokemuksemme kanssa. On totta, että arkikokemuksemme osoittaa, että emme voi aina ymmärtää toisia kieliä, kulttuureja tai teorioita. On kuitenkin samaan aikaan kokemuksemme mukaan totta, että voimme ainakin kehittyä ymmärryksessämme, oppia uu- 
sia kieliä ja teorioita. Emme ehkä voi tarkastella maailmaa vapaina omasta "maailmastamme" ja teorioistamme, mutta voimme ajatella, että tietämisen ennakkoehdot voivat kehittyä kohti totuutta.

Nämä (ja monet muut) ongelmat ovat johtaneet monet hylkäämään radikaalit relativismin muodot. Konstruktivismi on epäonnistumisestaan huolimatta hyvä vastalääke positivismin perinnettä vastaan. Konstruktivistit muistuttavat tieteilijöitä ja filosofeja siitä, että tiede ja tietäminen eivät tapahdu missään tyhjiössä: ihmiset ja ihmisyhteisöt ovat hyvin rajallisia tietäjiä ja heidän tietämistään ohjaavat monet biologiset ja sosiaaliset tekijät, joihin he eivät voi suoranaisesti vaikuttaa. Lisäksi konstruktivistit muistuttavat tieteen kehityksen olevan paljon sotkuisempi prosessi kuin monet uskovat. Tiede ei ole edistynyt tasaisesti ja johdonmukaisesti kohti yhä todempia teorioita, vaan pikemminkin eri alat ovat edenneet eri rytmissä ja toisinaan katkokset vanhojen ja uusien teorioiden välillä ovat olleet erittäin suuria. Tavallista on ollut myös se, että teorioita on torjuttu ja hyväksytty perusteilla, jotka eivät ole älyllisiä ollenkaan. Voimme omaksua nämä opetukset konstruktionisteilta mutta torjua heidän edustamansa radikaalin relativismin. On nimittäin parempikin malli - malli, joka sijoittuu konstruktionismin ja positivismin väliin. Tätä näkemystä kutsutaan usein realismiksi.

\section{$3 \cdot 4$}

\section{TIEDE JA KRIITTINEN REALISMI}

Termi "realismi" on niin tavallinen filosofisessa kirjallisuudessa, että toisinaan on hyvin vaikea pysyä selvillä mitä kukin kirjoittaja sillä tarkoittaa. Karkeasti yleistäen voidaan sanoa, että realisti tulkitsee tarkastelemansa tavan puhua asioista aina niin, että siinä pyritään viittaamaan jossakin määrin ihmisestä riippumattomaan todellisuuteen. Toinen yhtä raaka tapa määritellä realismi on sanoa, että realisti ajattelee tarkastelemansa asian olevan "oikeasti olemassa". Keskityn jatkossa realismiin tieteenfilosofisena kantana eli tieteelli- 
seen realismiin. Lyhyesti sanottuna tieteellinen realisti ajattelee, että hyväksyttyjen tieteellisten teorioiden ei-havaittavat voimat, vaikutukset, oliot tai muut vastaavat ovat "oikeasti olemassa" ihmisestä riippumattomassa maailmassa.

Tieteellinen realismi asetetaan yhtäl̈ltä positivismia ja toisaalta konstruktivismia vastaan. Positivismin keskeinen pyrkimys oli palauttaa kaikki havainnon ylittävä tieto havaintoon itseensä. Tähän tieteellinen realisti vastaa yhdessä konstruktionistin kanssa, että havainto ja teoria ovat toisiinsa kietoutuneita eikä niitä voida erottaa niin yksinkertaisesti kuin positivistit olettivat. Konstruktionistit taas väittävät, että tästä yhteenkietoutumisesta seuraa se, ettemme voi väittää tavoittavamme maailmaa ollenkaan. Tämän kuitenkin tieteellinen realisti kieltää, sillä hän uskoo, että vaikka tietomme on aina teorioista riippuvaista, on meillä erilaisia menetelmiä kehittää uusia teorioita ja arvioida vanhoja. Usein ollaankin sitä mieltä, että tieteellisen realismin kaikkein olennaisin piirre on tietomme erehtyväisyys eli fallibilismi, jonka mukaan lopullinen totuus on kyllä olemassa mutta inhimillinen tieto on aina vajavaista. Tästä seuraa, että fallibilistille ehdottoman varmaa tietolähdettä tai tietoa ei ole olemassa: varminkin tieto voi osoittautua vääräksi.

Kuten jo totesimme positivismia käsitellessämme, tieteelliset teoriat ovat täynnä teoreettisia voimia, olioita ja vaikutuksia; teoreettisia siinä mielessä, että niitä ei voida havaita mitenkään suoraan, vaan ne oletetaan selittämään havaittuja ilmiöitä. Positivismin pyrkimyksenä oli palauttaa nämä teoreettiset voimat, oliot ja vaikutukset välittömiin havaintoihin. Konstruktionismi taas väitti, että teoreettiset oliot, voimat ja vaikutukset ovat vain ja ainoastaan ihmisten keksimiä eikä niiden totuudesta voida sanoa mitään. Tieteellinen realismi kuitenkin väittää, että voimme ajatella nykyisin hyväksyttyjen tieteellisten teorioiden ei-havaittavien voimien, vaikutuksien ja olioiden kuvaavan jotain, joka on olemassa itse maailmassa. Ihmisestä riippumaton maailma on siis realistin mukaan olemassa ja teoriamme voivat heijastaa sitä. Tämä heijastaminen on kuitenkin vain välillistä, koska emme voi tavoittaa maailmaa "sellaisena kuin 
se on". Toisin sanoen siis realisti ajattelee, että tietomme voi mennä havaintojemme tuolle puolelle ja että tuo tieto voi "jäljittää totuutta" (track the truth). Realistille maailma ei rajoitu siihen, mitä voimme omien aistiemme kautta saada selville.

Voimme ymmärtää realismin erilaisuuden suhteessa positivismiin ja konstruktivismiin, jos tarkastelemme miten tieteellinen realisti ajattelee tiedonhankinnan toimivan. Positivistin mukaan tieteen perustana ovat havainnot ja havainnoista päättelemällä rakennetut teoriat. Positivisti siis pyrkii johtamaan faktalauseet suoraan havainnoista mutta tämän on jo moneen kertaan todettu olevan lähes mahdotonta. Positivistien menetelmää, jossa päätellään faktalauseet havainnoista, voidaan kutsua induktiiviseksi menetelmäksi. Nimitys "induktiivinen" tulee siitä päättelyn tavasta, jolla yksittäistapauksista päätellään jonkin luokan kattavia yleistyksiä.

Tieteellinen realisti vastustaa induktiivista menetelmää, koska hän ajattelee, että teorioita ja havaintoja ei voida erottaa toisistaan. Sen sijaan realisti kannattaa hypoteettista menetelmää, joka kääntää induktiivisen menetelmän ylösalaisin: hypoteettinen menetelmä ei aloita havainnoista vaan jo olemassa olevista faktalauseista, päättelee niistä seurauksia ja testaa kokeiden avulla. Palataan eduskuntatalon portaille. Positivisti vaatii, että meidän on pystyttävä todentamaan väite "eduskuntatalo on graniitista" välittömällä havainnolla, eli katsomalla tai koskemalla sitä. Hypoteettisen menetelmän kannattaja taas päättelee, että jos eduskuntatalo on graniitista, seuraa siitä se, että se näyttää harmaalta ja on kovaa. Tämän jälkeen on syytä mennä katsomaan eduskuntataloa ja koputtelemaan sitä vasaralla. Jos havaitsen harmaata ja se on kovaa, saa oletus siitä, että se on tehty graniitista tukea.

Huomaa, että väite "eduskuntatalo on graniitista" ymmärretään hypoteettisen menetelmän mukaan hypoteesiksi (eli oletukseksi), joka selittää parhaiten yksittäiset havainnot esimerkiksi eduskuntatalon väristä ja kovuudesta. Väitteen totuuden riippuu viimekädessä maailmassa, jota emme voi havainnossamme kokonaan tavoittaa. Huomaa myös, että hypoteettisen menetelmän erehtyväisyys 
(fallibilismi): voi olla, että eduskuntatalo on tehty jostakin toisesta materiaalista, joka on harmaata ja kovaa. Tällöin pitää keksiä jonkin toinen tapa koputtelun ja värin lisäksi erottaa graniitti toisista kivilajeista ja muista materiaaleista ja järjestää lisää kokeita. Tämä jättää uskomuksemme eduskuntatalon koostumuksesta aina avoimeksi: emme voi koskaan testata kaikkia mahdollisia väitteitä. Voihan olla, että eduskuntatalo koostuu hyvin samankaltaisesta, mutta tähän asti täysin tuntemattomasta materiaalista, joka muistuttaa graniittia.

Hypoteettisessa menetelmässä olennaista on juuri avoimuus uudelleenarvioinnille. Testaamme väitteitä vain suhteessa joihinkin tekijöihin ja suljemme automaattisesti toiset ulkopuolelle. Emme yritä selvittää onko eduskuntatalo graniitista vai kumista. Näin hypoteesien testaaminen ja hyväksyttävyys on aina riippuvaista saatavilla olevasta taustatiedosta, jota ei testata. Onkin tapana sanoa, että väitteiden testaaminen tapahtuu aina jonkin laajemman teorian (tai teorioiden) sisällä. Juuri tätä Kuhn halusi hakea ajatuksellaan tieteellisistä paradigmoista: yksittäisiä teorioita ja väitteitä testataan aina suhteessa johonkin laajempaan teoreettiseen kehykseen. Yksinkertaisen eduskuntataloesimerkkimme kohdalla nämä laajemmat teoreettiset kehykset sisältävät suuren määrän oletuksia esimerkiksi kivilajien luonteesta, siitä miten taloja rakennetaan, siitä millaisia materiaaleja oli saatavilla rakentamisen aikaan ja niin edespäin.

Kuten edellisestä esimerkistä käy hyvin ilmi, realismin mukaan havainnon ja todellisuuden suhde on varsin erilainen kuin positivismissa. Siinä missä positivismin tunnuslauseena oli "tiede perustuu havainnoista johdetuille teorioille" on realismin tunnuslauseena "tiede perustuu teoreettisista oletuksista johdettujen väitteiden kokeelliselle testaamiselle". Tieteen perustana ei siis ole tämän näkemyksen mukaan havainto vaan kokeen ja teorioiden yhteispeli. Havainto on vain yksi tekijä tässä yhteispelissä.

Edellä on kuvattu tietynkaltaista tieteellistä realismia, kriittistä realismia. Voimme erottaa kriittisen realismin naiivista realismista, jonka mukaan maailma on juuri sellainen kuin tieteelliset teoriat 
esittävät sen olevan. Naiivin realismin ja kriittisen realismin ero on se, että naiivin realistin mukaan tieteen teoriat antavat meille maailman sellaisena kuin se on siinä, missä kriittinen realisti korostaa, että vakiintuneetkin tieteelliset teoriat ovat rajallisia kuvauksia todellisuudesta ja voivat erehtyä. Kriittisen realismin mukaan siis

tiede voi erehtyä. Nykyisetkin teoriamme ovat sen mukaan oletettavasti parhaimmillaankin vain likimääräisesti tosia, mutta aina enemmän tai vähemmän epätosia. Kriittinen realismi siis hylkää perinteisen varman tiedon ihanteen ja omaksuu fallibilistisen käsityksen inhimillisen tiedon erehtyväisyydestä. ${ }^{30}$

Sekä kriittisellä realismilla että naiivilla realismilla on kuitenkin sama ydin: molemmat lähtevät liikkeelle siitä, että on olemassa osaksi ihmismielestä ja kielestä riippumaton maailma, joka ylittää sen mitä aisteilla havaitsemme. Voimme esittää nämä realistiset kannat vahvuusjärjestyksessä pehmeämmästä voimakkaampaan:

(1) Minimaalinen realismi: on olemassa ihmismielestä riippumaton todellisuus, joka ei rajoitu aistein havaittavaan todellisuuteen.

(2) Krittinen tieteellinen realismi: on olemassa ihmismielestä riippumaton todellisuus ja kypsien tieteiden vakiintuneet teoriat voivat kuvata tätä todellisuutta niin, että nämä teoriat lähestyvät totuutta.

(3) Naiivi tieteellinen realismi: on olemassa ihmismielestä riippumaton todellisuus, jota tieteen teoriat kuvaavat juuri sellaisena kuin se on.

Edellä sanotun perusteella voidaan väittää, että kriittinen realismi kantana sijoittuu positivismin ja konstruktionismin väliin. Se ottaa tieteen pyrkimyksen totuuteen vakavasti, mutta samaan aikaan hyväksyy havainnon teoriapitoisuuden ajatuksen ja tunnustaa inhimillisen tiedonhankinnan rajallisuuden.

Huomaa, että nämä muodot voidaan laittaa janalle sen mukaan 
miten ne ymmärtävät nykyisen tietomme "etäisyyden" totuuteen. Toinen ääripää on minimaalinen realismi, jonka mukaan ihmisestä riippumaton maailma on kyllä olemassa ja totuus voidaan tietää mutta meidän nykyinen tietomme on hyvin kaukana totuudesta. Toisessa ääripäässä ovat naiivia realismia lähestyvät näkemykset, joiden mukaan nykyinen tietomme on hyvin lähellä tai melkein yhtäpitävä todellisuuden kanssa. Kriittinen realismi sallii erilaisia muotoja, jotka lähestyvät jompaakumpaa ääripäätä. Väliin sijoittuvat kannat ovat yleensä jonkinlaisia maltillisen realismin muotoja, jossa ajatellaan, että nykyinen tietomme jäljittää totuutta jollakin lailla mutta lopullinen totuus on vielä kaukana. Realismi siis voi sallia hyvinkin skeptisiä kantoja, kunhan vain tunnustetaan, että lopullinen totuus on olemassa. Näin se voi tulla erittäin lähelle relativismia tai joitakin pragmatismin muotoja.

Kaikkein keskeisin kriittisen realismin puolesta esitetty argumentti on ns. ihmeargumentti (no miracles argument). Ihmeargumentti käyttää hyväkseen monien realistien kannattamaan edellä kuvattua hypoteettista menetelmää. Ajatus on periaatteessa varsin yksinkertainen ja se perustuu tieteen käytännölliseen ja teoreettiseen menestykseen. Jos tieteen teoriat eivät "jäljittäisi totuutta", elleivät ne rajallisesti kuvaisi maailman joitakin piirteitä, niin olisi ihme, että ne usein toimivat. Toimivuudella tässä tarkoitetaan sekä teoreettista toimivuutta (teoria tuottaa ennusteita ja sopii yhteen muiden teorioiden kanssa) että käytännöllistä toimivuutta (niiden avulla voidaan luoda teknisiä vempaimia ja manipuloida luontoa). Se, että nämä teoriat toimivat, voidaan selittää parhaiten sillä, että niiden ei-havaittavat oliot, voimat ja vaikutukset todella kuvaavat ainakin jollakin tavalla todellisuuden olioita, voimia ja vaikutuksia.

Ihmeargumentti edellyttää siis sen, että tiede edistyy: teorioiden tarkkuus kasvaa, niiden selittämien ilmiöiden määrä kasvaa ja teoriat niveltyvät toisiinsa yhä paremmin. Realistin ei kuitenkaan tarvitse olettaa positivistin tavoin, että tieteen edistys on yksinkertaista tiedon kasautumista. Perinteinen ajatus oli se, että tiede edistyy varsin suoraviivaisesti kohti totuutta. Realisti voi kuitenkin hyväksyä 
valtaosan Kuhnin kritiikistä tällaista edistyksen ajatusta kohtaan ja ajatella, että tieteen edistyksessä on suuriakin vallankumouksia ja katkoksia. Koska realisti ei usko maailman ja tieteellisten teorioiden täydelliseen vastaavuuteen, niin suuretkaan teoreettisten kehyksien muutokset eivät tuota hänelle ongelmia. Realisti kuitenkin torjuu konstruktionistisen tulkinnan tieteellisistä vallankumouksista, jonka mukaan emme voisi laisinkaan vertailla ennen vallankumousta ja vallankumouksen jälkeen vallinneita teorioita.

Kriittistä realismia on kritisoitu monin eri tavoin. Kiinnitän huomiota vain muutamiin näistä kritiikeistä, ettei synny vaikutelmaa siitä, että kriittinen realismi on ongelmaton kanta. En lähde kuitenkaan esittelemään sen tarkemmin vastauksia näihin kritiikkeihin. ${ }^{31}$

Yksi tapa vastustaa kriittistä realismia on pyrkiä osoittamaan, että tieteelliset teoriat eivät jäljitä todellisuutta, koska todellisuus ei vaikuta niiden muodostamiseen. Näin ovat edenneet esimerkiksi konstruktionistiset tieteensosiologit David Bloor ja Barry Barnes ja heidän "Edinburghin koulukuntansa". Tieteensosiologian perusidea on tutkia sitä kuinka yhteiskunnalliset, poliittiset ja sosiaaliset tekijät vaikuttavat tieteen teoriavalintoihin, teorianmuodostukseen ja tuloksiin. Se, että tällaiset tekijät vaikuttavat tieteeseen, ei ole ongelma realistille. Barnes ja Bloor ovat kuitenkin väittäneet, että yhteiskunnalliset olosuhteet eivät pelkästään vaikuta tieteelliseen teorianmuodostukseen, vaan määräävät sen loppuun asti. Siinä, missä realisti aina olettaa, että todellisuus itse on yksi niistä tekijöistä, joka vaikuttaa tieteelliseen teorianmuodostukseen, Barnes ja Bloor korostavat, että kaikki tiedettä muokkaavat tekijät ovat yhteiskunnallisia tekijöitä.

Toinen tapa kritisoida kriittistä realismia on hyökätä suoraan ihmeargumenttia vastaan. Voidaan esimerkiksi väittää, että uudet tieteelliset teoriat eivät anna vanhoja parempia ennusteita tai että tekninen edistys ei itse asiassa ole seurausta tieteellisten teorioiden kehityksestä. Tällöin haastetaan ajatus tieteen edistyksestä kohti yhä paremmin totuutta jäljittäviä teorioita.

Yksi keskeisistä kriittistä realismia vastaan esitetyistä ongelmista 
on teorioiden alimääräytyneisyyden ongelma. Kuten edellä on käynyt ilmi, keskeinen osa kriittistä realismia on se ajatus, että tieteelliset teoriat voivat sisältää oletuksia voimista ja olioista, joita ei voida havaita. Realismin keskeinen väite oli, että kypsien tieteellisten teorioiden oletukset näistä voimista ja olioista lähestyvät totuutta eli kuvaavat maailmassa oikeasti olevia voimia ja olioita. Alimääräytyneisyys haastaa tämän oletuksen väittämällä, että mitä tahansa tieteellisten kokeiden tulosten joukkoa voidaan selittää monilla erilaisilla oletuksilla ei-havaittavista voimista ja vaikutuksista. Koska teorioita ei päätellä suoraan havainnoista, on mahdollista, että meillä voi olla vaikka kuinka monta teoriaa, jotka selittävät samat havainnot, mutta ovat keskenään yhteensopimattomia.

Tieteenfilosofi Larry Laudan on esittänyt ongelman, joka yleensä kulkee hirviömäisellä tittelillä "pessimistinen meta-induktio". Itse ongelma on paljon yksinkertaisempi kuin siitä käytetty ilmaus ja se menee näin. Lyhytkin katsaus tieteenhistoriaan osoittaa, että teoriat, joita joinakin aikoina on pidetty erittäin vakuuttavina, ovat kuitenkin osoittautuneet kokonaan virheellisiksi myöhemmin. Tästä voidaan Laudanin mukaan päätellä, että meidän ei kannata uskoa nykyisiin teorioihin, koska nekin luultavasti osoittautuvat pitkällä aikavälillä aivan yhtä virheellisiksi kuin nykyisiä teorioita edeltäneet teoriat. Tästä johtopäätöksestä juontuu nimitys "pessimistinen".

Edellisistä ongelmista huolimatta erilaiset kriittisen realismin muodot ovat erittäin suosittuja nykypäivänä. Kriittinen tieteellinen realismi näyttää tarjoavan hyvän tasapainon tieteen yhtäältä tieteen rajallisuuden ja inhimillisyyden ja toisaalta tieteen saavutusten ja edistyksen suhteen. Nykykeskustelussa kriittiselle tieteelliselle realismille on kuitenkin vaihtoehtoja, jotka eivät mene positivismin tai relativismin piiriin. En käsittele näitä vaihtoehtoja tässä sen enempää, mutta mainitsen ne lähinnä niitä varten, jotka ovat kiinnostuneet tieteenfilosofisesta keskustelusta laajemmin. Tällaisia vaihtoehtoja ovat esimerkiksi Bas Van Fraassenin edustama konstruktiivinen empirismi, Hilary Putnamin sisäinen realismi ja Nicholas Rescherin pragmatismi. Näitä vaihtoehtoja yhdistää se, että ne tulkitsevat tie- 
teelliset teoriat välineellisesti (instrumentalismi): tieteen teorioita voidaan pitää toimivina, mutta ei varsinaisesti tosina. Esimerkiksi Van Fraassenin konstruktiivisen empirismin pääväite on se, että ihmeargumentti ei riitä perusteeksi uskoa siihen, että tieteellisten teorioiden olettamat oliot ovat todella olemassa. Argumentti osoittaa ainoastaan sen, että jotkut teoriat ovat "empiirisesti päteviä". Tällä ilmaisulla Van Fraassen yrittää sanoa, että teoriat saattavat esimerkiksi tuottaa ennusteita ja toimia teknisten innovaatioiden välineenä, mutta emme voi sanoa mitään niiden olettamista ei-havaittavista olioista, voimista tai vaikutuksista.

\section{$3 \cdot 5$}

\section{TEOLOGIA JA TEOLOGINEN REALISMI}

Kiinnitimme jo aiemmin huomiota siihen, kuinka voimme erottaa sekä tieteessä että kristinuskossa käytäntöjen, menetelmien ja sisältöjen tasot. Termillä "teologia" on tapana viitata juuri kristinuskon sisältöön mutta tämä ei ole suinkaan ainoa tapa ymmärtää se. Teologialla $(\mathrm{kr}$. theos $=$ Jumala, $\operatorname{logos}=$ oppi, tieto) voidaan tarkoittaa ainakin

(1) teologiaa erilaisten oppien kokonaisuutena,

(2) teologiaa akateemisena oppiaineena,

(3) teologiaa kirkon toimintana, jonka tarkoituksena on järjestää

kirkon uskon kokonaisuutta ja ohjata kirkon elämää,

(4) teologiaa menetelmänä hankkia tietoa.

Kun puhuimme tieteestä, kävi ilmi, että "tiedettä" käytetään usein nimenä joko tieteellisen tiedon kokonaisuudelle, tieteelliselle menetelmälle tai sitten tiedeinstituutiolle. Muutettavat muuttaen samaa voidaan sanoa teologiasta. Merkityksessä (1) teologialla viitataan koko kristinuskon, jonkin yksittäisen kirkkokunnan tai jonkin yksittäisen henkilön oppien kokonaisuuteen. Tällöin voidaan puhua 
esimerkiksi "katolisesta teologiasta" ja "luterilaisesta teologiasta" tai "Tuomas Akvinolaisen teologiasta". Viittauksen kohteena ovat näin se, mitä nämä opettavat teologisista kysymyksistä, kuten esimerkiksi Kolminaisuudesta tai pelastuksesta. Voidaan myös puhua jostakin yksittäisestä opinkohdasta, kuten Kolminaisuuden teologiasta, jolloin puhutaan siitä, mitä eri kirjoittajat tai kirkkokunnat ovat sanoneet Kolminaisuudesta.

Merkityksissä (2) ja (3) teologialla viitataan tietynkaltaiseen toimintaan: uskonnollisten näkemysten ja ongelmien järjestelmälliseen tutkimukseen. Järjestelmällisellä tutkimuksella tarkoitan tässä yhteydessä samaa kuin tieteen yhteydessä: on joukko enemmän tai vähemmän yhteisiä sääntöjä ja lähteitä, joiden avulla kehittää näkemyksiä teologisista kysymyksistä ja arvioida niitä kriittisesti. Tällaista tutkimusta voidaan puolestaan harjoittaa kahdessa eri yhteydessä: kirkollisena tutkimuksena tai akateemisena tutkimuksena. Monet teologit korostavat teologian merkitystä juuri kirkon itseymmärrystä rakentavana toimintana. Teologia tällöin pyrkii jäsentämään kirkon uskoa, ratkomaan sekä uskon sisältöön että kirkon käytäntöihin liittyviä ongelmia ja luomaan yhtenäistä käsitystä Jumalasta, ihmisestä ja maailmasta. Teologia akateemisena toimintana taas on tämän kirkollisen teologian ja kirkollisen elämän tutkimusta erilaisilla (empiirisillä ja teoreettisilla) menetelmillä.

Merkityksessä (4) teologialla voidaan tarkoittaa menetelmää hankkia tietoa ja teologisia tietolähteitä. Edellä kommentoinkin jo lyhyesti, että tämä menetelmä on järjestelmällinen siinä mielessä, että sillä on enemmän tai vähemmän jaettuja arvioinnin normeja ja tunnustettu joukko tietolähteitä. Perinteisesti teologian tietolähteiksi on katsottu (a) ilmoitus (erityinen ja yleinen), (b) järki, (c) traditio ja (d) kokemus. Siinä, miten eri kirkkokunnat ovat ymmärtäneet näiden tietolähteiden keskinäiset suhteet, on suuria eroja.

Voimme siis edellisen pohjalta tarjota eräänlaisen työmääritelmän siitä, mitä teologia on. 
(TE) Teologia on järjestelmällistä toimintaa, joka pyrkii totuuteen Jumalasta, ihmisestä ja maailmasta.

Voimme purkaa tämän määritelmän osiin.

(TE1) Teologian kohteena ovat Jumala, ihminen ja maailma.

(TE2) Teologia on järjestelmällistä toimintaa.

(TE3) Teologian päämääränä on totuus.

Väite (TE1) koskee teologian kohdetta eli sitä mistä teologit pyrkivät puhumaan. Kaikkein tärkein kohde on tietenkin Jumala, mutta Jumala ei ole suinkaan ainoa teologian kohde. Teologia puhuu poikkeuksetta myös maailmasta, sen luonteesta, ihmisen luonteesta ja hänen asemastaan maailmassa. Se, että teologia on järjestelmällistä toimintaa (TE2), erottaa sen muusta uskonnollisesta toiminnasta. Teologia toimintana ei ole rukousta tai rituaalia, vaan älyllistä toimintaa, jonka tuloksena on erilaisia käsityksiä, teologisia "teorioita". Kiinnitin aiemmin huomiota siihen, että tieteellisen realismin mukaan tieteellisen toiminnan päämääränä on totuus. Se, miten olen edellä määritellyt teologian (TE3), on yhtäpitävä tämän näkemyksen kanssa. Vaikka teologialla on kristillisissä kirkoissa myös käytännöllinen tehtävä eli jäsentää kirkon ajattelua ja itseymmärrystä, pyrkii teologia kuitenkin totuuteen kohteistaan.

Olemme jo aiemmin maininneet, että luonnon teologian edustajat edustavat sekä tieteellistä kriittistä realismia että teologista realismia. Seuraavaksi käsittelemme mitä tällainen teologinen realismi on ja miten se eroaa literalismista (ks. luku 2.2) ja teologisesta antirealismista sekä fideismistä (ks. luku 2.3). Olemme jo aiemmin käsitelleet näitä teologisen realismin vaihtoehtoja, joten tässä riittää lyhyt muistutus: 
(1) Raamatullinen literalismi: teologiset väitteet ovat tosiasiaväitteitä, ne saadaan erehtymättömästä lähteestä ja ne kuvaavat Jumalaa sellaisena kuin hän on (naiivi teologinen realismi).

(2) Teologinen antirealismi: teologiset väitteet eivät ole tosiasiaväitteitä, vaan ovat esimerkiksi kokemusten tai tunteiden ilmaisuja.

(3) Fideismi: teologiset väitteet ovat tosiasiaväitteitä, mutta emme voi osoittaa, miten ne viittaavat kohteeseensa. Meillä ei siis voi olla mitään uskon ulkopuolista kriteeriä uskonnollisten uskomusten järkevyydelle.

Literalistin mukaan Jumalaa koskeva tietomme koskee Jumalaa yksinkertaisesti sellaisena kuin Jumala todellisuudessa on. Jumalasta ja hänen toiminnastaan saadut kuvaukset ovat periaatteessa erehtymättömiä, koska Jumala on itse ne selkeästi ilmoittanut. Näin myös Jumalaa koskeva tieto on erehtymätöntä eli korjaamatonta. Antirealisti taas väittää, että me voimme kyllä puhua Jumalasta mutta puheemme ei tavoita Jumalaa. Meillä voi olla puhetta Jumalasta mutta tämä puhe ei pyrikään puhumaan mitään varsinaisesta todellisuudesta. Lisäksi jotkut teologiset antirealistit ovat myös konstruktionisteja eli he kiistävät koko "perimmäisen todellisuuden" olemassaolon ihmisen kielestä ja mielestä riippumatta. Tällöin on turha edes puhua Jumalaa koskevasta tiedosta, koska mikään tieto "maailmasta" ei ole mahdollista. Fideisti puolestaan ajattelee, että emme voi uskonnollisen uskon ulkopuolelta käsin arvioida sitä, miten usko tavoittaa Jumalan. Puheemme Jumalasta kyllä viittaa Jumalaan, mutta emme voi esittää tämän puheen totuuden puolesta mitään uskon ulkopuolisia kriteereitä.

Teologinen realismi asettuu kaikkia näitä kolmea käsitystä vastaan. Literalisteja vastaan teologinen realisti väittää, että Jumalaa koskeva tietomme on aina radikaalisti rajallista ja sallii korjauksia. Tämä pätee myös ilmoitettuun tietoon Jumalasta: mitkä sitten ilmoituksen lähteet ovatkaan, niin ilmoituksessa on aina elementti, joka edellyttää inhimillistä tulkintaa. Antirealisteja vastaan taas realisti väittää, että uskonnollisen puheen tarkoituksena on todella 
puhua jostakin sellaisesta, joka "on maailmassa". Lisäksi teologinen realisti puolustaa realistista oletusta yleensä: hänen mukaansa on olemassa maailma, joka tekee puheemme siitä todeksi tai epätodeksi ja jos Jumala on olemassa, on Jumala osa tätä maailmaa. Teologisen realistin mukaan uskonnollinen puhe sisältää siis tosiasiaväitteitä ja ne on tarkoitettu ymmärrettäväksi sellaisena. Fideismiä vastaan teologinen realisti taas puolustaa näkemystä, jonka mukaan meillä on sekä teologisia että ei-teologisia menetelmiä jumalapuheen arvioimiseksi ja nämä menetelmät eivät ole rajoittuneet vain jumalapuheen sisään.

Näin ollen teologisen realismin keskeiset vakaumukset ovat

(1) on olemassa maailma, johon puhe Jumalasta pyrkii viittaamaan (Jumalan olemassaolo koskee tosiasioita),

(2) voimme arvioida sitä, miten puheemme Jumalasta tavoittaa Jumalan.

Lyhyesti sanottuna teologinen realisti vastaa menetelmältään kriittistä tieteellistä realistia: puheemme Jumalasta voi "jäljittää totuutta". Toisin sanoen hän väittää, että voimme saada Jumalan olemassaoloa koskevaa perusteltua tietoa mutta tietomme on aina epätäydellistä.

Teologisen realistin väite (1) johtaa vääjäämättä siihen, että "uskonnollisen" ja "luonnollisen" maailman välillä ei ole periaatteellista eroa. On vain yksi maailma ja jos Jumala on olemassa, on Jumala osa sitä. Jumalaa koskevat väitteet ja muut uskonnolliset väitteet koskevat samaa maailmaa, jota tiede tutkii. Tästä ei välttämättä seuraa, että tieteen ja uskonnon väitteet maailmasta kohtaisivat, mutta siitä seuraa se, että kohtaaminen on periaatteessa mahdollista. Tämä tarkoittaa myös sitä, että jos Jumalaa koskevat väitteet osoittautuvat tosiksi, niin ne kertovat meille jotain ihmisestä riippumattomasta todellisuudesta.

Teologisen realistin väitteen (2) mukaan voimme esittää enemmän tai vähemmän tosia näkemyksiä Jumalasta. Puheemme Jumalasta siis voi sekä viitata Jumalaan jonain itsemme ulkopuolisena 
että esittää enemmän tai vähemmän tosia väitteitä hänestä. Ei siis riitä sen toteaminen, että Jumala joko on tai ei ole maailmassa, vaan ollakseen teologinen realisti pitää myös ajatella, että meidän on mahdollista tietää Jumalasta jotain. Tässä on syytä huomata merkittävä ero teologisen realistin ja fideistin välillä. Realistin mukaan meillä voi olla perusteita ajatella, että Jumala ei ole olemassa tai että näkemyksemme Jumalasta on jotenkin virheellinen. Fideistin mukaan taas tämänkaltaisilla tiedollisilla perusteilla ei ole mitään tekemistä uskonnollisen elämän ja uskomusten kanssa. Fideistille puhe Jumalasta on perusteiden ja erehtymisen ulottumattomissa.

On myös syytä huomata se, että literalismi on myös eräänlaista teologista realismia: literalisti uskoo realistin lailla, että on olemassa ihmisistä riippumaton maailma ja Jumala ja että näistä voidaan saada tietoa. Se, mikä erottaa teologisen realistin literalistista, on se, että literalisti uskoo Jumalaa koskevan tiedon korjaamattomuuteen, mutta teologinen realisti ei. Literalismia voidaan siis pitää teologisena vastineena naiiville realismille sekä positivismille. Se, mikä yhdistää positivismia ja literalismia, on ajatus erehtymättömästä tietolähteestä: positivisti ajattelee, että tieteellinen tieto voidaan päätellä ongelmattomasti havainnoista (ks. luku 3.2). Samaan tapaan literalisti ajattelee, että Jumalaa, maailmaa ja ihmistä koskeva tieto voidaan päätellä ongelmattomasti Raamatun tekstistä. ${ }^{33}$

\section{$3 \cdot 6$}

KRIITTINEN TEOLOGINEN REALISMI

JA LUONNON TEOLOGIA

Nykykeskustelussa teologinen realismi on saanut erilaisia muotoja riippuen siitä, millaista taustaa vasten ne on muotoiltu. Tarkastelen seuraavaksi kahta teologisen realismin ohjelmaa, jotka ovat olleet vaikutusvaltaisia luonnon teologian ja päällekkäisyysmallin edusta- 
jien keskuudessa. Aloitan J. Wentzel Van Huyssteenin postfoundationalistisesta teologiasta, jonka jälkeen tarkastelen brittiteologi ja molekyylibiologin Alister McGrathin tieteellisen teologian ohjelmaa.

Van Huyssteenin tarkoituksena on muotoilla teologian tekemisen yleiset periaatteet löyhän kriittisen realismin pohjalta. ${ }^{34}$ Voimme aloittaa muotoilemalla Van Huyssteenin teologian keskeiset periaatteet: ${ }^{35}$

(1) Kokemukset ja havainnot synnyttävät uskomuksia, joita puolestaan käytetään tulkitsemaan kokemuksia ja havaintoja.

(2) Totuus on objektiivinen ja yksi, mutta ihmisten keinot hankkia tietoa ovat rajallisia ja tieto erehtyväistä.

(3) Ne tavat, joilla hankimme tietoa ja arvioimme sitä, ovat sidonnaisia siihen sosiaaliseen ja kulttuuriseen ympäristöön, josta olemme ne saaneet.

(4) Ympäristöönsä sidonnaisista lähtökohdista on kuitenkin mahdollista edetä keskusteluun toisten lähtökohtien kanssa.

Periaate (1) sanoo saman asian kuin aiemmin käsittelemämme havainnon teoriapitoisuuden teesi. Ajatus on se, että havainnot ja kokemukset eivät toimi tietomme erehtymättöminä perustoina, vaan ne ovat jo aiemman kokemuksemme ja uskomustemme muokkaamia. Havainnot ja teoriamme muodostavat ikään kuin kehän, jossa aiemmin opittu muokkaa kokemustamme, joka taas puolestaan luo uusia uskomuksia.

Periaate (2) vahvistaa sen, mitä olemme aiemmin kutsuneet fallibilismiksi. Fallibilismin mukaan on olemassa ihmisen mielestä ja kielestä riippumaton maailma ja tietomme voi lähestyä totuutta tästä maailmasta. Tietomme on kuitenkin aina rajallista ja enemmän tai vähemmän virheellistä. Tämä ei tarkoita sitä, ettemmekö voisi arkielämässä luottaa siihen, mikä meistä näyttää todelta. Päinvastoin meillä on täysi oikeus luottaa siihen, mikä meistä näyttää todelta. Fallibilismi kuitenkin edellyttää, että emme saa tehdä mistään uskomusten joukosta sellaista, että mikään mahdollinen kritiikki ei 
kosketa sitä.

Periaate (3) korostaa jälleen havainnon, kokemuksen ja käsitteidemme yhteenkietoutuneisuutta. Van Huyssteen liittää tietämisemme vahvasti siihen sosiaaliseen ympäristöön, jossa kasvamme, opimme ja toimimme. Emme hanki tietoa ja arvioi sitä perusteilla, jotka ovat ympäristöstämme riippumattomia, vaan omaksumme tietomme ja arvioinnin kriteerimme pitkälti muilta ympäristömme ihmisiltä. Tämä tarkoittaa sitä, että kokemuksemme, uskomuksemme ja havaintomme ovat ainakin osaksi ankkuroituneet siihen perinteeseen (tai perinteisiin), jonka sisällä me elämme. Tästä seuraa se, että millään perinteellä, teorialla tai uskomuksella ei ole automaattisesti etuajo-oikeutta totuuteen. Näin ollen myös teologilla on oikeus ja mahdollisuus aloittaa oman perinteensä väitteistä ja tietolähteistä ja pitää näitä alustavasti luotettavina.

Edellisestä kolmesta periaatteesta voisi kuvitella, että van $\mathrm{Hu}-$ yssteen vie teologiaa vahvasti relativistiseen suuntaan. Näin ei kuitenkaan ole. Periaatteen (4) tarkoituksena on varmistaa, että teologi pyrkii aina vastaamaan hänen näkemyksiään kohtaan esitettyyn kritiikkiin ja tarpeen mukaan muokkaamaan käsityksiään. Tämä oletus perustuu siihen, että on mahdollista keskustella toisten perinteiden ja näkemysten kanssa, etsiä yhteisiä kohtauspaikkoja ja muokata omia näkemyksiä. Meidän tulee lähteä liikkeelle siitä, mikä meistä näyttää oikealta ja niistä perusteista, jolla olemme tottuneet käyttämään uskomusten arvioinnissa. Emme voi rajata joillakin universaaleilla kriteereillä teologisia tietolähteitä (ilmoitus, kokemus, järki) mahdollisten tietolähteiden ulkopuolelle. Teologialla on siis kaikki oikeus ottaa tietolähteensä aitoina tietolähteinä ja jumalapuheen puheena todellisuudesta. Teologinen realisti ei kuitenkaan voi hyväksyä literalismia, jonka mukaan teologiset tietolähteet tuottavat tietoa, joka on periaatteessa korjaamatonta. Teologinen realisti joutuu tunnustamaan, että kohtaaminen uusien teorioiden, perinteiden ja uskomusten kanssa voi johtaa hänet muokkaamaan ja tulkitsemaan omia teorioitaan, perinnettään ja uskomuksiaan uudella tavalla. Tätä taas literalisti (eikä fideisti) ei voi tehdä: hänelle hänen 
omat teoriansa ja uskomuksensa ovat kaiken ulkoisen kritiikin ulkopuolella.

Tieteen ja kristinuskon suhteen osalta van Huyssteenin teologisesta realismista seuraa se, että teologia ei tarvitse lähtökohtaisesti tieteellistä oikeutusta ollakseen järkevää. Mutta pysyäkseen järkevänä tulee teologian esittää perusteita ja arvioida niitä keskustelussa tieteen kanssa. Näin ollen van Huyssteenin kaltainen teologinen realisti kiistää ne oletukset, jotka ovat sekä konfliktimallin (ks. luku 2.2) että itsenäisyymallin (ks. luku 2.3). Teologia ei ole kokonaan erillinen tieteestä, koska sen tulee ottaa tiede vakavasti ja pyrkiä keskusteluun sen kanssa, mutta ei se ole myöskään tieteen kanssa täysin päällekkäinen, koska molemmilla on osaksi omat tietolähteensä, menetelmänsä ja tuloksensa.

Vaikka van Huyssteenin teologinen realismi perustuu vahvasti teologian omien lähtökohtien tunnustamiseen, siitä ei seuraa, että teologit (ja kristityt) saavat luvan jäädä omaan perinteeseensä ja unohtaa kaiken muun. Nykyisessä maailmassa eri perinteistä ja ajattelutavoista tulevat ihmiset ovat velvollisia keskustelemaan yhdessä näkemystensä totuudesta. Kuten todettua, tällaisessa keskustelussa ei van Huyssteenin mukaan millään perinteellä tai uskomusten järjestelmällä ole etuajo-oikeutta: mikään perinne ei voi vaatia muita automaattisesti omaksumaan oman näkökulmansa. Tähän asti van Huyssteenin malli kuulostaa ilkeällä tavalla fideistiseltä tai konstruktionistiselta: kumpikin nimittäin toteaisi tässä vaiheessa, että mitään perinteistä, ajattelutavoista ja uskomusjärjestelmistä riippumatonta maailmaa ja sitä kautta totuutta ei ole ollenkaan olemassa. Edellä esitetyt van Huyssteenin periaatteet (2) ja (4) kuitenkin sulkevat tällaisen vaihtoehdon pois teologiselta realistilta. Teologinen realisti ajattelee, että koska maailma on yksi, on myös yhteinen keskustelu periaatteessa mahdollista. Tässä yhteydessä van Huyssteen puhuu transversaalisesta rationaalisuudesta, jolla hän tarkoittaa sitä, että tieteen ja teologian välillä voidaan löytää kosketuspintoja ja rajakysymyksiä, vaikka ne eivät menekään kokonaan päällekkäin. Tällaisia kosketuspintoja voivat olla esimerkiksi fysiikan ja teologian käsityk- 
set universumin perimmäisestä syystä (luominen), ihmisluonnosta ja ihmisen uskonnon historiasta ja universumin merkityksellisyydestä ja päämäärästä. Voimme siis pitää van Huyssteeniä oikeastaan päällekkäisyysmallin stereotyyppinä: tiede ja teologia eivät ole täysin päällekkäisiä tai toisistaan riippumattomia, vaan pikemminkin rajallisia, mutta toisiaan täydentäviä tapoja hankkia tietoa maailmasta.

Van Huyssteenin teologiselle menetelmälle on olennaista, että ei ole yhtä, kaikille järkevää alkupistettä (tietolähdettä), joka kaikkien tulee omaksua. Samanlainen lähtökohta on myös brittiläisellä teologilla ja entisellä mikrobiologilla Alister McGrathilla. Siinä missä van Huyssteen pyrkii puolustamaan teologista realismia erityisesti fideismiä ja konstruktionismia vastaan on McGrathin vastustajana tieteellinen materialismi ja naturalismi.

McGrath kutsuu tapaansa ymmärtää teologian luonne tieteelliseksi teologiaksi (scientific theology) tai luonnolliseksi teologiaksi (natural theology). ${ }^{36}$ McGrathin projektin tarkoituksena on rakentaa teologianharjoitus luonnontieteille tyypilliselle menetelmälle ja siihen liittyvälle kriittiselle realismille. Hänen mukaan on uskottavaa ajatella, että luonnontieteen menetelmät ovat hyvin tehokkaita välineitä yhä tarkemman kuvan saamiseksi todellisuudesta. Tästä syystä näiden menetelmien omaksuminen myös teologiassa voisi auttaa ratkaisemaan teologisia ongelmia ja lisäämään keskustelua teologian ja luonnontieteiden välillä.

Tieteellisen teologian ideana on herättää henkiin ajatus luonnollisesta teologiasta. Vaikka McGrath itse puhuu luonnollisesta teologiasta, vastaa hänen luonnollinen teologiansa sitä, mistä olemme aiemmin käyttäneet nimitystä luonnon teologia (ks. luku 2.5). Määrittelimme aiemmin luonnollisen teologian yritykseksi todistaa (eli osoittaa todennäköiseksi) Jumalan olemassaolo ja tai muut uskonnolliset väitteet sekulaarisen tiedon ja tiedonhankinnan periaatteiden pohjalta. Luonnollisen teologian taka-ajatus on tällöin se, että sekulaarinen, erityisesti tieteellinen, tieto ja tiedonhankinnan menetelmät ovat kaiken muun tiedon ja tiedonhankinnan menetel- 
mien mittari. Tämän kuitenkin McGrath ja muut luonnon teologian edustajat kieltävät: teologin ei tarvitse pystyä osoittamaan Jumalan olemassaoloa ja joidenkin muiden uskonnollisen väitteiden totuutta tieteellisesti ennen kuin hän voi ryhtyä puhumaan Jumalasta. Syynä on se, että tiede (eikä mikään muukaan) voi tarjota kaikenkattavaa tietolähdettä ja tietämisen menetelmää, jolla kaikki tieto ja tietäminen pitää oikeuttaa ollakseen uskottavaa.

Luonnon teologia ei siis ole pyrkimystä Jumalan olemassaolon todistamiseen kaikkia vakuuttavalla, universaalilla tavalla, koska tällaista ei voi olla. Tämän sijaan luonnon teologia

tulee ymmärtää sen osoittamisena, että uskonnollisen uskon näkökulmasta tarkasteltuna uskon ja maailman rakenteen välillä on yhtäläisyyksiä. Toisin sanoen luonnollisen teologian tarkoitus ei ole todistaa Jumalan olemassaoloa, vaan se olettaa Jumalan olemassaolon. Se kysyy millainen voimme odottaa maailman olevan, jos se on tällaisen Jumalan luoma. Luonnon järjestyneisyyden etsinnän tarkoituksena ei siis ole osoittaa Jumalan olemassaoloa, vaan vahvistaa jo ennestään olemassa olevaa uskomusta. $^{37}$

McGrathin keskeinen oletus on siis se, että maailma on järjellinen ja säännönmukainen siinä määrin, että voimme saada siitä tietoa. Tämä on juuri se syy miksi luonnontieteet ja teologia ovat mitä parhaimmat keskustelukumppanit: molemmat olettavat maailman järjellisyyden, sen ihmisestä riippumattoman perustavan rakenteen ja ihmisen kyvyn saada tästä maailmasta tietoa (teologinen ja tieteellinen realismi).

Teologisesta näkökulmasta tarkasteltuna luonto ja koko maailma on Jumalan luoma ja se heijastaa luojansa järkevyyttä ja hyvää tahtoa. Nämä seikat luonnosta eivät kuitenkaan paljastu jostakin "objektiivisesta" näkökulmasta, vaan ainoastaan uskon näkökulmasta. Usko näkee luonnon luotuna, erillisenä luojastaan. Luonnosta ei kuitenkaan voi McGrathin mukaan päätellä Jumalan tuntemiseen ilman Jumalan puolelta tulevaa ilmoitusta. Näin ollen Jumalan ole- 
massaolon puolesta esitettyjen perusteiden tarkoitus ei ole osoittaa kaikki vakuuttavalla tavalla Jumalan olemassaolo ja hänen luonteensa, vaan etsiä pisteitä, joissa kristillinen käsitys todellisuudesta kohtaa esimerkiksi tieteen käsityksen todellisuudesta. Luonnollinen teologia on ikään kuin kanava, jonka kautta kristillistä sanomaa välitetään kristillisen yhteisön ulkopuolisille perinteille tekemällä se ymmärrettäväksi esimerkiksi tieteen kielellä. Tällainen luonnon teologia "tarjoaa kaikupohjaa - luottamuksen siihen, että se, mitä julistetaan, tekee asioista ymmärrettäviä siitä huolimatta, että tämä kaikupohja ei tule lähellekään kunnollista 'todistusta."' ${ }^{38}$

McGrath erottaa kolme perinteistä tapaa pyrkiä ymmärtämään Jumalaa luonnon pohjalta: ${ }^{39}$

(1) Vetoaminen järkeen.

(2) Vetoaminen luonnon järjestäytyneisyyteen.

(3) Vetoaminen luonnon kauneuteen.

Järkeen vetoamisella tässä tarkoitetaan ajatusta siitä, että ihmisjärjen olemassaolo ja sen toiminnan periaatteet kertovat meille jotain ihmisjärjen luojasta. Esimerkiksi Augustinus ajatteli, että ihmisjärki on Jumalan kaikkein suurin luomus ja juuri ihmisen rationaalinen sielu on kaikkein lähimpänä Jumalaa. Tästä syystä rationaalisen sielun toiminnassa heijastuu Jumalan luonne ja toiminta. Teologiassaan Augustinus pyrki esimerkiksi soveltamaan tuntemiaan psykologisia lakeja Kolminaisuuden sisäisten suhteiden ymmärtämiseen.

Toinen tapa ymmärtää Jumalaa luonnon pohjalta on ollut tarkastella luonnon järjestäytyneisyyttä ja rakennetta. Juuri se seikka, että luonto on järjestäytynyt, säännönmukainen ja ihmismielelle ymmärrettävä, tekee tieteen mahdolliseksi. Samalla säännönmukaisuus on juuri se, mitä kristitty odottaakin maailmalta, joka on järkevän ja hyvän Jumalan luoma. Kristitty lisäksi odottaa, että jos sekä maailma ja ihminen ovat Jumalan luomia, niin ihmismielen ja luonnon välillä on jonkinlainen harmonia: mielemme on kykenevä ymmärtämään luontoa. Se, että luonnossa on säännönmukaisuutta ja että 
voimme tavoittaa sen mielellämme, ei kuitenkaan ole mikään todiste Jumalan olemassaolon puolesta itsessään. Kristillisen uskon jo omaksunut ihminen kuitenkin näkee tässä säännönmukaisuudessa Jumalan hyvän ja järkevän luonnon toteutumisen. Kristitylle luonto todistaa siitä, millainen Jumala on, ei siitä, että hän on. Luonnon järjestys on kuitenkin kenen tahansa havaittavissa ja on perusteita väittää, että luonto todellakin on tällainen.

Kolmas tapa yrittää ymmärtää Jumalaa luomakunnan kautta on tarkastella luomakunnan kauneutta. Jos ymmärrämme maailman hyvän ja järkevän Jumalan luomana, niin silloin voimme odottaa sen sisältävän myös kauneutta. Kauneuden käsite on tehnyt viime vuosikymmeninä tieteenfilosofisen paluun: muutamat fyysikot ovat esimerkiksi väittäneet, että matemaattisten teorioiden valinnassa kauneus (yksinkertaisuus, eleganssi, symmetria, selitysvoima) on ollut hyvin keskeinen tekijä.

Nämä kaikki kolme lähestymistapaa perustuvat ajatukseen siitä, että Jumalan luonne on joiltakin osin ymmärrettävä luomakunnan perusteella, jos tarkastelemme luomakuntaa luomisen ajatuksen valossa. Näin McGrathille luonto ja ihmisjärki voivat toimia teologian lähteinä mutta ne eivät voi muodostaa sen perustaa: jotta voisimme nähdä luonnossa Jumalan vaikutuksen, on meidän ensin oltava itse Jumalan vaikutuksen (ilmoituksen) kohteena. Luonnon teologia on näin ollen aina alamainen ilmoitetulle teologialle. Mutta ollakseen uskottava, itse ilmoitus vaatii kaikupohjaa muiden perinteiden (ja tieteen) kanssa. Ilman yhteyttä luonnolliseen tietoomme todellisuudesta ilmoitus jäisi meille kokonaan käsittämättömäksi. Ilmoitus siis ei voi olla mitä tahansa ollakseen ilmoitusta. Ilmoituksessa Jumala puhuu itsestään hyvänä luojana ja lunastajana ja jos tämä puhe ei sovi lainkaan yhteen sen kanssa, mitä tiedämme todellisuuden luonteesta, pitää meidän päätellä, että kyseessä ei ole aito ilmoitus. Näin ilmoitettu teologia ja luonnollinen teologia (usko ja järki) ovat jatkuvassa vuorovaikutuksessa keskenään. ${ }^{40}$

Sekä van Huyssteenin postfoundationalismia että McGrathin tieteellistä teologiaa yhdistää se, että molemmat torjuvat positivismin 
ja literalismin vaatimuksen horjumattoman tietolähteen olemassaolosta. Jumalaa koskevaa tietoa (eikä mitään muutakaan tietoa) ei voida johtaa aukottomasti jostakin perustasta, vaan tämä tieto ja sen arviointi perustuu aina useiden tietolähteiden, uskomusten ja kokemuksen yhteispeliin. Yksittäisiä teologisia teorioita testataan aina laajemmassa kehyksessä, johon vaikuttavat ilmoitus, sen tulkinta, uskonnollinen kokemus, järki ja kunkin kristillisen yhteisön ominaispiirteet. Tässä puhutaan samasta perustelujen holismista, josta kriittiset tieteelliset realistit puhuvat. Ilmoitusta tulkitaan järjen ja kokemuksen valossa, joka taas muokkaa kokemusta ja uskomuksiamme, mistä taas seuraa ilmoituksen tulkinta. Uuden tiedon ja vanhan arvioiminen etenee aina kehässä. Näin ollen esimerkiksi tieteen tulokset (uudet uskomukset) tai uudet kokemukset ja yhteiskunnalliset tilanteet voivat kehittää uusia tulkintoja ilmoituksesta tai ilmoituksen tulkinta voi synnyttää uusia tulkintoja tieteen tuloksista. Tieto Jumalasta on kyllä annettu ilmoituksessa, mutta tuon tiedon tulkinta on aina sidoksissa siihen, millainen sosiaalinen ja kulttuurillinen (ja tieteellinen) kehys meillä on ja millaisia kokemuksemme ovat.

McGrath antaa hyvin paljon painoarvoa luonnontieteen teorioille. Hänen mukaansa luonnontiede on osoittautunut luotettavaksi tietolähteeksi ja sen menetelmät olisi syytä omaksua muuallakin, tässä tapauksessa myös teologiassa. Ajatus luonnontieteen menetelmien omaksumisesta teologiassa johtaa siihen, että valinnat teologisten teorioiden välillä pitää tehdä samalla tavalla kuin teorioiden valinta luonnontieteessä. Keskeisiä kriteereitä ovat tällöin yksinkertaisuus, selitysvoima ja yhtäpitävyys muiden hyväksyttyjen teorioiden kanssa. Teologisia teorioita voidaan testata eräänlaisilla kokeilla: teorioita voidaan koetella ilmoituksella, uskonnollisella kokemuksella ja esimerkiksi teoreettisella järjellä. Lopulta se teoria, joka on selitysvoimaisin ja yksinkertaisin, voittaa. Luonnontieteen tulokset tulevat mukaan prosessiin juuri tämän koettelun muodossa.

Edellä esittelemäni teologisen realismin muodot eivät suinkaan ole ongelmattomia. Aiemmin esiteltiin hyvin lyhyesti tieteellisen 
realismin ongelmia (ks. luku 3.4), jotka muutettavat muuttaen sopivat myös teologisen realismin kritiikiksi. Valtaosa teologisen antirealismin ja fideismin puolesta esitetyistä teologisista perusteista vetoaa siihen, että realistinen tulkinta jumalapuheesta on jollakin tavalla Jumalan luonteen vastainen. Tämä on myös kaikkein keskeisin edellä kuvattujen teologisen realismin muotojen kritiikki: jotkut ovat väittäneet, että realistiset ja "tieteelliset" teologiat tuovat uskonnolliseen keskusteluun liikaa filosofisia (erityisesti tieteenfilosofisia) oletuksia maailmasta, tietomme luonteesta ja muusta sellaisesta. ${ }^{41}$

Voidaan sanoa, että sekä kriittinen tieteellinen realismi että teologinen realismi ovat varsin pitkälti muodostaneet sen pohjan, jonka pohjalta päällekkäisyysmallin ja luonnon teologian edustajat ovat lähteneet liikkeelle. Esimerkiksi Peacocke paljastaa realisminsa väittämällä, että

sekä tiede että teologia pyrkivät kuvaamaan todellisuutta ja molemmat tekevät näin metaforisen kielen ja erilaisten mallien avulla, jotka ovat revisioitavissa niiden yhteisöjen sisällä, jossa ne on tuotettu. Sillä onhan teologiankin päämääränä olla niin totuudellinen kuin mahdollista. Näin ollen uskonnollisella kokonaisnäkemyksellä on oltava älyllinen integriteetti ja sen täytyy ottaa huomioon ne todellisuudet, jotka 1900-luvun tiede on paljastanut. ${ }^{43}$

Voidaan myös sanoa, että tieteen ja teologian suhteesta puhumiselle ei oikeastaan ole mitään järkevää syytä, jos sekä tieteellistä realismia että teologista realismia ei ensin oleteta. Tämän voimme nähdä helposti seuraavasta taulukosta, joka vetää yhteen erilaiset tavat tarkastella tiedettä ja teologiaa ja millaisia tieteen ja teologian suhteita ne mahdollistavat. 
Näkemyksiä tieteen ja teologian suhteesta

\begin{tabular}{|c|c|c|c|}
\hline & $\begin{array}{l}\text { Tieteellinen po- } \\
\text { sitivismi }\end{array}$ & $\begin{array}{l}\text { Tieteellinen rela- } \\
\text { tivismi }\end{array}$ & $\begin{array}{l}\text { Tieteellinen rea- } \\
\text { lismi }\end{array}$ \\
\hline $\begin{array}{l}\text { Literalismi } \\
\text { (naiivi teolo- } \\
\text { ginen realismi } \\
\text { ja positivismi) }\end{array}$ & $\begin{array}{l}\text { Ristiriita: } \\
\text { Teologisten } \\
\text { ja tieteellisten } \\
\text { teorioiden tar- } \\
\text { koitus on sama. } \\
\text { Jompikumpi } \\
\text { pitää hylätä. }\end{array}$ & $\begin{array}{l}\text { Harmonia: teolo- } \\
\text { gisten ja tieteel- } \\
\text { listen teorioiden } \\
\text { tarkoitus on sama. } \\
\text { Teologiset näke- } \\
\text { mykset korvaavat } \\
\text { tieteelliset. }\end{array}$ & $\begin{array}{l}\text { Päällekkäisyys: } \\
\text { teologiset ja tie- } \\
\text { teelliset teoriat } \\
\text { ovat päällek- } \\
\text { käisiä. Risti- } \\
\text { riitatilanteessa } \\
\text { teologinen teoria } \\
\text { korvaa tieteelli- } \\
\text { sen. Mahdolli- } \\
\text { nen harmonia. }\end{array}$ \\
\hline $\begin{array}{l}\text { Teologinen } \\
\text { antirealismi } \\
\text { ja fideismi }\end{array}$ & $\begin{array}{l}\text { Itsenäisyys: } \\
\text { teologiset ja tie- } \\
\text { teelliset teoriat } \\
\text { eivät voi olla } \\
\text { ristiriidassa. }\end{array}$ & $\begin{array}{l}\text { Itsenäisyys: teolo- } \\
\text { giset ja tieteelliset } \\
\text { teoriat eivät voi } \\
\text { olla ristiriidassa }\end{array}$ & $\begin{array}{l}\text { Itsenäisyys: } \\
\text { teologiset ja tie- } \\
\text { teelliset teoriat } \\
\text { eivät voi olla } \\
\text { ristiriidassa }\end{array}$ \\
\hline $\begin{array}{l}\text { Te ol og in en } \\
\text { realismi }\end{array}$ & $\begin{array}{l}\text { Päällekkäisyys: } \\
\text { teologiset ja tie- } \\
\text { teelliset teoriat } \\
\text { ovat päällek- } \\
\text { käisiä. Risti- } \\
\text { riitatilanteessa } \\
\text { teologinen } \\
\text { teoria joustaa. }\end{array}$ & $\begin{array}{l}\text { Päällekkäisyys: } \\
\text { teologiset ja } \\
\text { tieteelliset teoriat } \\
\text { ovat päällekkäisiä. } \\
\text { Ristiriitatilanteessa } \\
\text { tieteellinen teoria } \\
\text { joustaa. Mahdolli- } \\
\text { nen harmonia. }\end{array}$ & $\begin{array}{l}\text { Päällekkäisyys: } \\
\text { teologiset ja tie- } \\
\text { teelliset teoriat } \\
\text { ovat päällekkäi- } \\
\text { siä. Ristiriitati- } \\
\text { lanteessa kumpi } \\
\text { tahansa voi jous- } \\
\text { taa. Mahdollinen } \\
\text { harmonia. }\end{array}$ \\
\hline
\end{tabular}

Teologinen realismi ja tieteellinen realismi muodostavat pohjan keskustelulle teologian ja tieteen sisältöjen suhteesta. Teologinen realismi tekee mahdolliseksi sen, että luonnolliseen järkeen ja yleiseen ilmoitukseen perustuva tieto maailmasta (tiede) voi saada roolin teologiassa. Tieteellinen realismi taas avaa päätä tieteen puolelta, koska se torjuu positivistisen vaatimuksen tieteen kaikenkattavuudesta. 


\section{Kirjallisuutta}

Hyviä suomenkielisiä johdatuksia tieteenfilosofiaan ovat vanhahtava Haaparanta \& Niiniluoto 1991 ja uutukainen Raatikainen 2004, joista jälkimmäinen on erityisen suositeltava maallikoille. Pidemmälle ehtineille menee niin ikään vanhempi Niiniluoto 1983. Kannattaa katsoa myös Pihlström 1997. Saarinen \& Niiniluoto 2002 sisältää materiaalia sekä loogisesta positivismista että 1900-luvun relativismista. Niiniluoto 1999 on erinomainen ja kattava johdatus keskusteluun tieteellisestä realismista ja kriittisestä realismista englanniksi. Enemmän luonnontieteisiin ja tieteelliseen menetelmään keskittyy Chalmers 1999. Fideismin historiaan ja sitä koskevaan keskusteluun johdattaa Vainio 2010. Teologista realismia puolustavat pontevasti esimerkiksi Rauser 2009, McGrath 2006a ja useat esseet kirjassa Crisp \& Rea 2009. Teologista realismia ja antirealismia käsitteleviä esseitä sisältää Moore \& Scott 2007. "Tieteen ja kristinuskon” kontekstissa yleiskatsaus kriittiseen realismiin on Allen 2006. Teologian ja tieteen menetelmällisiä yhtäläisyyksiä ja kriittistä realismia puolustaa Barbour 1974. 
Käsitys siitä, millainen luonto on, mistä se koostuu ja miten se toimii, on muuttunut toisinaan hyvinkin radikaalisti länsimaisen ajattelun ja tieteen historian aikana. Edellisessä luvussa käsittelemämme kriittisen realismin mukaan meidän ei tulisi yllättyä suuristakaan muutoksista käsityksissämme: käsityksemme luonnosta kantavat mukanaan aina oletuksia, jotka ovat sidoksissa sekä historialliseen kontekstiin että yksilöihin. Luonto ei sellaisenaan paljastu meille, vaan tavoitamme sen ainoastaan mallien, teorioiden, oletusten ja niitä testaavien kokeiden välityksellä. Tästä seuraa se, että käsityksemme luonnosta riippuu näistä oletuksista ja muuttuu niiden mukana. Käsityksemme luonnosta ja sen toiminnasta ei kuitenkaan ole muuttunut yksin, vaan sen mukana on aina muuttunut myös käsitys Jumalasta, Jumalan toiminnasta ja suhteesta luomakuntaan. Kahden seuraavan luvun tarkoituksena on muodostaa yleiskatsaus siihen, miten käsityksemme luonnosta ja sen tutkimuksesta on kehittynyt viimeisten vuosisatojen aikana. Painopiste on erityisesti fysiikassa ja biologiassa.

Tässä luvussa keskitymme nimenomaan fysiikkaan. Kun puhutaan modernista fysiikasta, tarkoitetaan tavallisesti sitä fysikaalisten tieteiden kehittymistä, joka alkoi 1600-luvulla ja on jatkunut nykypäivään asti. Puhutaan usein tieteellisestä vallankumouksesta ja vallankumous se todella olikin monessa mielessä. Ennen 1600-lukua oli myös fysiikkaa, mutta se harvoin ymmärretään luonnontie- 
teeksi siinä mielessä, miten me tätä ilmaisua käytämme. Kuluneen 300 vuoden ajan, fysiikka on muodostanut luonnontieteen prototyypin - tieteen, jonka kehittyminen on mullistanut käsityksemme maailmankaikkeudesta yhä uudelleen ja uudelleen. Voidaan sanoa, että fysiikka on laajentanut käsitystämme maailmasta kolmella eri tavalla: se on saanut meidät ymmärtämään oman pienuutemme osoittamalla maailmankaikkeuden valtavuuden; se on saanut meidät ymmärtämään oman suuruutemme osoittamalla, kuinka syvälle maailman fysikaaliseen rakenteeseen voimme tunkeutua; ja se on saanut meidät ymmärtämään oman aikamme suhteellisuuden osoittamalla, kuinka nuoria me olemme maailmankaikkeudessa.

Fysiikan kehitys on hyvä esimerkki myös siitä, millaista tieteen ja kristinuskon yhteiselo on ollut. Vaikka uudenlaisten kosmologioiden synty ja kehittyvät tieteelliset menetelmät ovat vaikuttaneet teologiaan valtavasti, niin liikenne on ollut molemminpuolista: myös teologisia ja filosofisia oletuksia on siirtynyt teologiasta fysiikkaan. Jotta ymmärtäisimme näitä valtavia murroksia, niin on ensin tarpeellista tehdä lyhyt katsaus fysiikkaan ja kosmologiaan sellaisena, kun se oli ennen modernin fysiikan ja luonnontieteen läpimurtoa 1600-luvulla. Voimme ymmärtää 1600-luvun valtavan murroksen ainoastaan tarkastelemalla sitä keskiaikaista perinnettä vasten. Tätä murrosta voi olla vaikea ymmärtää, koska 1600-lukua edeltänyt tapa ajatella luontoa, ihmistä ja maailmankaikkeutta on nykyajan ihmisille hyvin vieras. Ennen tätä murrosta länsimaisen ihmisen näkemys maailmankaikkeuden yleisistä piirteistä oli radikaalisti erilainen kuin se oli sen jälkeen. Murros ei ollut siis vain tieteellinen vaan myös maailmankatsomuksellinen. Filosofisesti sanottuna 1600-luvulla ei siis syntynyt pelkästään moderni fysiikka vaan uusi metafysiikka, kokonainen maailmankuva. ${ }^{44}$ 
$4 \cdot 1$

\section{KESKIAIKAINEN SYNTEESI}

Usein on tapana puhua keskiaikaisesta synteesistä, joka sulatti yhtenäiseksi kokonaisuudeksi kaiken sen, mitä nykyisin kutsuisimme fysiikaksi, teologiaksi, filosofiaksi ja tieteeksi. Voitaisiinkin sanoa, että keskiajalla kannatettiin vakaasti edellä esittelemäämme tieteen ja kristinuskon päällekkäisyysmallia. Monien mielestä tärkein tehtävä olikin sulattaa yhdeksi kokonaisnäkemykseksi antiikin filosofia sekä kristillinen teologia. Keskeisessä roolissa tässä synteesissä oli Aristoteleen filosofinen järjestelmä, jonka kirjoitukset alkoivat tulla 1200-luvulta eteenpäin eurooppalaisten ajattelijoiden saataville. Ei ole kuitenkaan perusteltua väittää, että keskiaikainen synteesi olisi ollut jotain sellaista, jonka kaikki keskiaikaiset ajattelijat olisivat jakaneet. Pikemminkin voimme tunnistaa joitakin yleisiä piirteitä, jotka näyttävät toistuvan monien ajattelijoiden kohdalla eri muodoissa. Nämä yleiset piirteet ovat

(1) selittäminen päämääräsyiden avulla,

(2) luonto luotujen olentojen hierarkiana,

(3) tietty käsitys järjen ja ilmoituksen suhteesta,

(4) Jumala luojana ja ylläpitäjänä,

(5) näkemys ihmisestä kosmisen draaman keskipisteenä. ${ }^{45}$

Selittäminen on aina katsottu tieteen (keskiajalla osa filosofiaa) tehtäväksi. Keskiajan ajattelijat perivät Aristoteleelta ajatuksen siitä, että luonnollisten tapahtumien selittäminen perustuu päämääriin, päämääräsyihin. Usein puhutaan myös luonnollisesta teleologiasta tai teleologisesta selittämisestä (kr. Telos = päämäärä). Ajatuksen ymmärtämiseksi tarvitsemme hieman käsitteistöä. Aristoteleen mukaan jokaisella kappaleella on olemus (essenssi), jolla on jokin luonnollinen päämäärä, olotila jota kohti jokainen kappale, jolla on samanlainen olemus, pyrkii. Miksi kappaleilla on tapana pudota maahan? Aristoteelinen vastaus tähän kysymykseen on se, että jo- 
kainen kappale pyrkii kohti luonnollista tilaansa, joka on lepotila. Näin ollen kivien putoaminen maahan selitetään vetoamalla siihen, että kivien luonnollinen paikka on olla maassa, se on niiden päämäärä. Huomio on siis päämäärässä eikä yksittäisissä muutoksissa prosessin kuluessa. Tämä päämäärä sisältyy olion rakenteeseen itseensä, se on osa sitä. On siis osa kiven olemusta pyrkiä kohti lepotilaa maassa. Selittäessään ilmiöitä aristoteelikko ei niinkään katso menneisyyden tapahtumia ja sen prosesseja, vaan siirtää katseensa tulevaisuuteen, muutoksen päämäärään.

Päämäärillä selittämistä motivoi tietynkaltainen näkemys inhimillisen tietämisen luonteesta, jonka keskiaikaiset ajattelijat perivät kreikkalaisesta filosofiasta. Erittäin karkeasti typistettynä ajatus on se, että todellinen tieto koskee ikuisia, aineellisen maailman ylittäviä totuuksia (esimerkiksi Platonin ideat), maailmaa kokonaisuutena. Ymmärrys näistä totuuksista saavutetaan järkeä käyttämällä, ei havainnoilla. Havainnot pikemminkin johtavat harhaan, kuin antavat perustan tiedolle. Sen sijaan järjen avulla ihminen voi tavoittaa kaikkein yleisimmät lainalaisuudet ja johtaa näistä yleisestä periaatteista havaitun maailman olioiden taipumukset käyttäytyä tietyllä tavalla. Järjellä tavoitettavat yleiset totuudet ovat luonteeltaan välttämättömiä, mistä seuraa se, että kaikkien olioiden käyttäytyminen on välttämättä juuri sellaista kuin se sattuu olemaan. Näin ollen esimerkiksi kiven olemuksen ja sen putoamisen välillä ei ole pelkästään säännönmukainen yhteys, vaan käsitteellinen, looginen, yhteys ja voimme tavoittaa tämän yhteyden käyttämällä järkeämme.

Jos käsitys tiedonhankinnasta on tällainen, niin tutkimuksemme on luonteeltaan deduktiivista tai aksiomaattista. Usein puhutaan aksiomaattisesta tieteenihanteesta: tutkimus lähtee oletuksesta, jonka mukaan maailmankaikkeutta ohjaavat järjelliset yleiset periaatteet, joista voimme sitten päätellä loogisesti, miten yksittäiset oliot käyttäytyvät. Tätä aksiomaattista tai deduktiivista ihannetta vastaan asettuu 1600-luvulla induktiivinen tieteenihanne, jonka mukaan meidän tulee aloittaa yleisten periaatteiden sijaan tarkkailemalla yksittäisiä olioita ja niiden käyttäytymistä ja yleistämällä muodostaa 
käsityksiä yleisistä laeista. Tästä kuitenkin myöhemmin lisää.

On helppo nähdä, kuinka selittämisestä päämääräsyillä päästään helposti ajatukseen siitä, jokaisella oliolla on luonnollinen paikkansa maailmassa. Keskiaikaisen kosmologian mukaan maa on liikkumaton keskipiste, jonka ympärillä taivaan eri kehät pyörivät. Tämän Ptolemaioksen Maa-keskeisen näkemyksen mukaan ihmisen fyysinen paikka maailmankaikkeudessa oli yhdenmukainen hänen arvonsa ja "henkisen" paikkansa kanssa. Keskiaikaisessa synteesissä siis oli selvä yhdenmukaisuus maailmankaikkeuden moraalisen rakenteen ja sen fysikaalisen rakenteen välillä. Jokaisella oliolla on paikkansa moraalisessa järjestyksessä niiden arvon ja tarkoituksen mukaan. Ihmisen paikka oli tämän järjestyksen keskivaiheilla. Hänen yläpuolellaan olivat taivaat, enkelit ja henkivallat ja lopulta Jumala, joita koskivat erilaiset säännönmukaisuudet samalla tavalla kuin taivaan fysikaalisia kappaleita, tähtiä ja planeettoja. Ihmisen alapuolella taas olivat eläimet, luontokappaleet ja lopulta luonnon tiedottomat oliot, kivet ja kasvit. Tämä hierarkia katsottiin luonteeltaan ikuiseksi ja välttämättömäksi. Sitä hallitsivat lait - eivät mekaaniset lait, vaan moraaliset.

Teologian osalta keskiaikaista synteesiä luonnehtii tietynkaltainen tapa ymmärtää järjen ja ilmoituksen suhde. Esimerkiksi Tuomas Akvinolainen erotti toisistaan ilmoitetun teologian totuudet ja luonnollisen teologian totuudet. Ihminen pystyy Tuomaan mukaan saavuttamaan tietoa maailmasta, itsestään ja Jumalan olemassaolosta oman järkensä keinon. Ilman ilmoitettuja totuuksia ihmisen tieto Jumalasta jää kuitenkin radikaalisti vajaaksi: Jumala ilmoittaa totuuksia itsestään Jeesuksen elämän, ylösnousemuksen, profeettojen ja muiden historiallisten tapahtumien kautta. Nämä totuudet välittää ihmisille Raamattu, apostolit ja kirkon traditio. Nämä ilmoitetut totuudet ovat välttämättömiä, koska valtaosa Jumalaa koskevasta tiedosta - esimerkiksi Kolminaisuus ja inkarnaatio - eivät ole järjellä tavoitettavia. Luonnollinen teologia ja ilmoitettu teologia eivät kuitenkaan ole ristiriidassa keskenään: järjen ja uskon välillä vallitsee jatkumo. Tällaisen näkemyksen mukaan usko on oikeastaan 
sitä, että henkilö ottaa vastaan kirkon auktoriteetin nojalla esitetyt ilmoitetut totuudet.

Keskiaikaisessa synteesissä yhdistettiin kristillinen ajatus Jumalasta luojana ja Aristoteleen ajatus liikkumattomasta liikuttajasta ja ensimmäisestä syystä. Aristoteleen jumala on fysikaalisesta maailmasta riippumaton, muuttumaton ja ikuinen olio, joka laittaa fysikaalisen maailman muutoksen liikkeelle. Tämä jumala ei kuitenkaan puutu luonnon kulkuun eikä hänellä ole päämääriä eikä tarkoituksia. Monet keskiaikaiset teologit antoivat nämä toiminnot kristilliselle Jumalalle, jonka perinteisesti katsottiin myös ohjaavan luomakuntaa omien päämääriensä mukaan (lat. providentia). Sen lisäksi, että Jumala loi maailman tyhjästä, hän myös jatkuvasti pitää sitä yllä ja toimii siinä. Tuomaan mukaan Jumalan toiminta maailmassa on dynaamista ja tapahtuu monella eri tasolla. Tuomas puhui Jumalan kahdesta tavasta toimia maailmassa: ensisijaisista syistä (lat. causa prima) ja toissijaisista syistä (lat. causa secunda). Jumala on tämän näkemyksen mukaan jokaisen maailman tapahtuman ensisijainen syy, koska hän on luonut maailman ja pitää sitä yllä. Valtaosa Jumalan toiminnasta tapahtuu kuitenkin toissijaisten syiden, eli luonnollisten prosessien välityksellä. Jumala antaa Tuomaan mukaan kaikille maailman olioille niiden olemuksen, mutta niiden olemus ja käyttäytymistä ohjaavat säännönmukaisuudet voidaan löytää puhtaasti luonnollisen järjen avulla.

Siinä missä Jumala oli olemisen ja arvon hierarkian huipulla, oli ihminen kuitenkin kosmisen draaman päätähti. Tässä draamassa luonnon tehtävänä oli toimia lähinnä näyttämönä ihmisen ja Jumalan suhteesta kertovassa tarinassa. Barbour tiivistää tämän tarinan väkevästi:

Maailmanhistorian ajateltiin seuraavan jumalallista suunnitelmaa, jonka vaiheita kuvaavat seuraavat sanat: luominen, liitto, Kristus, kirkko, täyttymys. Ensimmäisten ihmisten lankeemus toi synnin maailmaan. Kosminen draama keskittyy Jumalan pelastavaan toimintaan: Kristuksen inkarnaatioon ja sovittavaan kuolemaan. Meidän tehtävämme on yhdistyä 
Jumalan kanssa, ja pelastus on sitä, että Jumalan yliluonnollinen armo suuntaa omat päämäärämme Jumalan päämäärien mukaisesti. ${ }^{46}$

Voidaan siis sanoa, että keskiaikainen synteesi oli siinä mielessä jumalakeskeinen, että maailmanhistoria alkaa ja päättyy Jumalaan. Synteesi on kuitenkin siinä mielessä ihmiskeskeinen eli antroposentrinen, että ihmisen kohtalo, hänen arvonsa, hänen päämääränsä ja olemuksensa on koko tarinan keskuksessa sekä moraalisessa että fysikaalisessa mielessä.

$4 \cdot 2$

KLASSINEN FYSIIKKA: MEKANISMIT JA KELLOKONEISTON JUMALA

Modernin luonnontieteen kehittyessä 1600-luvulta eteenpäin keskiaikainen synteesi alkaa tehokkaasti murentua. Seuraavat modernissa luonnontieteessä muotonsa saaneet piirteet vaikuttivat synteesin tuhoutumiseen:

(1) Uudet menetelmät: matematiikka, induktio ja kausaalinen selittäminen.

(2) Näkemys luonnosta yhtenäisenä kokonaisuutena, jonka kaikkien osien käyttäytymistä voidaan ennustaa vetoamalla yleisiin lakeihin.

(3) Lisääntynyt tieto maailmasta: kaukoputki ja heliosentrismi.

Uudenlaiselle tiedonihanteelle oli tyypillistä yhdistää havainnot ja näiden havaintojen matemaattinen jäsentäminen. Erityisen tärkeää oli tässä näkemyksessä usko siihen, että matemaattisesti yksinkertaiset mallit ovat monimutkaisempia parempia. Esimerkiksi Johannes Kepler, joka jo 1542 piti heliosentristä mallia keskiaikaista mallia vakuuttavampana, uskoi, että maailmalla on matemaattinen syvärakenne. Hän hyväksyi Nikolaus Kopernikuksen mallin aurin- 
kokunnasta, koska perinteinen näkemys maasta kaiken keskuksena alkoi uusien, yhä lisääntyvien taivaankappaleita koskevien havaintojen nojalla näyttää matemaattisesti yhä monimutkaisemmalta. Oli siis yksinkertaisempaa olettaa, että malli oli väärä, kuin että matematiikka olisi väärässä.

Kuten jo aiemmin on käynyt ilmi, olisi virhe ajatella, että uudet tieteelliset menetelmät olisivat perustuneet pelkästään havaintoihin. Havainnot eivät ilman teorioita ja kokeita johda mihinkään. Mikä oli modernin luonnontieteen kannalta olennaista, oli juuri oikea yhdistelmä havaintoja, niiden matemaattista jäsentämistä ja näiden mallien testaamista kokeellisesti uusilla havainnoilla (ks. luku 3.4). Tapahtui siirtymä aksiomaattisesta tieteenihanteesta induktiiviseen tieteenihanteeseen. Keskiaikaisessa synteesissä edettiin aina yleisistä, järjen avulla tavoitettavista periaatteista (aksioomat) kohti yksittäisten olioiden käyttäytymistä päättelemällä. Induktiivinen tieteenihanne sen sijaan lähtee aina yksittäisistä havainnoista, niiden mittaamisesta ja jatkuu kohti näiden mittausten pohjalta tehtävää yleistämistä. Nämä yleistykset yleensä tiivistetään yhtälön muotoon ja niistä johdetaan seurausväitteitä, joita sitten testataan uusilla havainnoilla. Päättelyn suunta on siis täysin päinvastainen kuin aksiomaattisessa tieteenihanteessa.

Uuteen tieteenihanteeseen kuului myös uudenlainen käsitys selittämisestä. Keskiaikaisen synteesin mukaan päämääräsyyt ovat kaikkein tärkeimpiä olioiden käyttäytymistä selitettäessä. Modernin fysiikan kautta painopiste siirtyi kuitenkin vahvasti päämääräsyistä vaikuttaviin ja materiaalisiin syihin. ${ }^{47}$ Fysikaalisten olioiden käyttäytymisen selittämiseksi alettiin vedota päämäärien sijaan näiden olioiden aiempiin fysikaalisiin tiloihin ja yleisiin lakeihin, joiden avulla niiden tulevaisuuden tilat olisi mahdollista ennustaa. Käsitteet, kuten "massa", "tila" ja "aika", jotka eivät juuri olleet kiinnostaneet keskiaikaisia ajattelijoita, tulivatkin nyt keskeisiksi, koska niille pystyttiin antamaan matemaattinen kuvaus. Tämä siirtymä johtui suureksi osaksi siitä, että modernin fysiikan edustajat katsoivat, että päämääriä ja olemuksia ei pystytä matematisoimaan. 
Uuteen näkemykseen selittämisestä vaikutti vahvasti myös muuttunut näkemys luonnosta. Siinä missä keskiaikainen synteesi ajatteli kullakin olioilla olevan niille kullekin ominainen luontonsa, ajattelivat modernin fysiikan edustajat, että kaikkia fysikaalisia olioita koskevat samankaltaiset lainalaisuudet. Nämä lainalaisuudet eivät koske vain havaittavia olioita, vaan kaikkia mahdollisia fysikaalisia olioita. Tästä Galileo Galilei (1564-1642) päätteli, että kaikki fysikaaliset kappaleet koostuvat samanlaisista rakenneosista ja että näiden osien käyttäytymistä ohjaavat samat lait kuin havaittavien kappaleiden liikkeitä. Syntyi ensimmäinen moderni materialistinen teoria: kaikkien fysikaalisten olioiden katsottiin koostuvan hyvin pienistä, jakamattomista kappaleista, jotka käyttäytyvät samojen sääntöjen mukaan kuin kaikki muutkin kappaleet. Yleensä ei tässä vaiheessa vielä puhuta materialismista, vaan korpuskulaarisesta filosofiasta.

Edellä kuvatun uuden tiedonihanteen ja korpuskulaarisen filosofian kannattajien varhaisin ja tärkein edustaja on Galilei itse. Kun Galilei sai 1610 käsiinsä kaukoputken, niin keskiaikaisen synteesin lopullinen romahdus alkoi. Kaukoputken avulla saatiin ensi kertaa havaintoja, joiden avulla oli periaatteessa mahdollista osoittaa Kopernikuksen heliosentrinen malli aurinkokunnasta paremmaksi kuin perinteinen malli. Galileon kaukoputken kautta romuttui myös se keskiaikaisen synteesin ajatus, että taivaan kehät ja kappaleet ovat täydellisiä eikä niissä tapahdu muutosta. Keskiaikaisen synteesin edustajat ajattelivat, että taivaankappaleiden maailmassa eli kuun yläpuolisessa maailmassa vallitsevat eri lait ja säännönmukaisuudet kuin ihmisten ja eläinten asuttamassa kuun alapuolisessa maailmassa. Kaukoputken kautta romuttui myös ajatus siitä, että ihminen on fyysisesti kosmisen draaman keskuksessa. Koko universumi ei pyöri liikkumattoman maan ympärillä, vaan planeetat kiertävät aurinkoa. Galilein visiot antoivat myös viitteitä siitä, että universumi jatkuu aurinkokuntamme taakse ja että tähdet voisivat olla kaukaisia aurinkoja. Nämä kehityskulut ruokkivat sekä korpuskulaarista filosofiaa, siihen liittynyttä tieteenihannetta sekä uutta heliosentristä maailmankuvaa. 
Ristiriitaan keskiaikaisen synteesin ja uuden fysiikan ja erityisesti niiden menetelmien välillä liittyy myös Galilein kuuluisa riita katolisen kirkon kanssa 1600-luvun ensimmäisinä vuosikymmeninä. Tämä historiallisten episodien sarja annetaan usein esimerkkinä tieteen ja uskonnon jatkuvasta konfliktista ja uskonnon pyrkimyksestä estää tieteen vallankumouksellinen eteneminen. Tällainen väite on kuitenkin liioiteltu ja sitä voidaan hyvin perustein pitää epätotena myyttinä. ${ }^{48}$ En voi tässä käydä käsittelemään "Galileon tapauksen" historiaa seikkaperäisesti, koska olen rajannut historiallisen konfliktiteesin käsittelyn kirjan ulkopuolelle mutta sanon kuitenkin tapauksen kuuluisuuden vuoksi siitä lyhyesti muutaman sanan.

Usein tilanne kuvataan niin, että vastakkain ovat uhmakas tiedemies, jonka puolella ovat havainnot ja teoriat, ja ilkeät dogmaattiset kardinaalit, jotka hylkäävät selkeät havainnot, koska uskovat sokeasti Raamatun auktoriteettiin. Tämä ei laisinkaan pidä paikkaansa. Galileon tapaukseen toki liittyy muitakin ulottuvuuksia, mutta se on parhaiten kuvattavissa oman aikansa tieteellisenä keskusteluna, jota sotkivat tulehtunut yhteiskunnallinen ja kirkollinen tilanne ja huonot ihmissuhteet. Tieteellisesti ottaen kyseessä oli kahden paradigman kohtaaminen, joista Galilein edustama oli vähemmistössä ja jonka puolesta oli hyvin vähän uutta todistusaineistoa. Katolinen kirkko ja valtaosa yliopistoväkeä kannattivat yhä keskiaikaista synteesiä. Meidän on vaikea ymmärtää tilannetta, mutta Galilein aikaan saatavilla oleva todistusaineisto heliosentrisen maailmankuvan puolesta ei ollut kovinkaan hyvää. Näin ollen monet Galilein vastustajat olivat hänen omia työtovereitaan. Vastakkain eivät siis olleet "tiedemiehet" ja "uskonmiehet", vaan teologeja, filosofeja ja yliopistomiehiä oli kaikilla puolilla. Myös yhteiskunnallinen tilanne oli kireä: katolinen kirkko oli hajonnut reformaation seurauksena ja vastauskonpuhdistus oli täydessä käynnissä. Katolisen kirkon viranomaisilla oli annettu paljon valtuuksia kontrolloida "vaarallisten" ajatusten leviämistä. Koska katolinen kirkko oli tässä vaiheessa vielä sitoutunut virallisesti keskiaikaiseen synteesiin ja aristotelismiin, se koki heliosentrisen maailmankuvan edustajat uhkana kirkon yhtenäisyydelle. ${ }^{49}$ 
Korpuskulaarinen filosofia ja siihen liittyvä tieteenihanne saa ensimmäisen muotoilijansa Galileissa mutta se huipentuu Isaac Newtonissa (1642-1727). Newton kehitti Galilein ja muiden edeltäjiensä teorioita eteenpäin kohti suurta synteesiä, jonka hän sementoi uusille matematiikan välineillä, kuten differentiaali- ja integraalilaskennalla. Newtonilla myös kuuluisat luonnonlait, kuten painovoimalaki, saavat tunnistettavan muotonsa. Newtonin mekaniikan teorioiden päälle rakentui kokonaan uudenlainen käsitys maailmasta, joka lopullisesti kumosi keskiaikaisen synteesin. Puhumme tästä näkemyksestä jatkossa mekanistisena maailmankuvana tai pelkkänä mekanismina.

Mekanistisessa maailmankuvassa oli kolme ydinkohtaa:

(1) naiivi realismi,

(2) determinismi,

(3) atomismi..$^{50}$

Mekanistit tulkitsivat klassista fysiikkaa naiivin realistisesti: ajateltiin, että Newtonin teoriat ovat yksi yhteen kuvauksia siitä, miten todellisuus toimii. Tällä oletuksella oli useita kauaskantoisia seurauksia. Ensinnäkin tuli mahdottomaksi uskoa, että se maailma, joka aisteillemme näyttäytyy, on todellinen tai perimmäinen maailma. Meidän maailmamme on keskikokoisten värillisten, maukkaiden tai vähemmän maukkaiden, kauniiden tai rumien kappaleiden maailma. Klassisen fysiikan olioilla on vain massa ja muoto. Kaikki muut ominaisuudet näiden lisäksi katsottiin ihmisen havaintojärjestelmän tuotteeksi. Näin syntyi erottelu ensisijaisten (primary qualities) ja toissijaisten ominaisuuksien (secondary qualities) välillä. Tämä ero on filosofian- ja tieteenhistoriallisesti erittäin tärkeä mutta meidän ei tässä tarvitse mennä siihen syvemmin. Lukijalle riittää huomata, että mekanistinen maailmankuva oli vahvasti reduktionistinen: sen mukaan arkikokemuksemme maailmasta ei paljasta maailman todellista luonnetta, vaan pikemminkin pienten materian kappaleiden säännönmukainen käyttäytyminen selittää sen, miksi meidän 
arkimaailmamme on sellainen kuin se on. Toinen kauaskantoinen seuraus naiivista realismista oli se, että aika ja avaruus katsottiin tarkkailijasta riippumattomiksi ja absoluuttisiksi. Tämän näkemyksen mukaan jokaisella tapahtumalla ja olioilla on oma absoluuttinen paikkansa ajassa - oletus, jonka suhteellisuusteoria myöhemmin asetti kyseenalaiseksi.

Naiivin realismin lisäksi toinen mekanismin tärkeä oletus on determinismi. Lyhyesti sanottuna ajatus on se, että kaikkien järjestelmien, jotka koostuvat fysikaalisten lakien mukaan liikkuvasta aineesta, jokainen tulevaisuuden tila on ennustettavissa niiden nykyisen tilan pohjalta. Kuuluisa tiedemies Pierre Laplace (1749-1827) kuvasi tätä näkemystä näin:

Meidän tulee ymmärtää universumin nykyinen tila sitä edeltäneen tilan tuotteena ja universumin tulevan tilan syynä. Jos olisi olemassa älykkyys, joka voisi edes pienen hetken ymmärtää kaikki luontoa liikuttavat voimat ja kaikkien olioiden sen hetkisen tilan, joka olisi niin suuri, että se pystyisi analysoimaan kaiken tämän tiedon, niin se ymmärtäisi kaikkien kappaleiden liikkeet aina suurimmista planeetoista kevyimpään atomiin asti. Tällaiselle älykkyydelle mikään ei olisi epävarmaa ja sekä tulevaisuus että menneisyys olisi sen silmien edessä. ${ }^{51}$

Ajatus on se, että jos voisimme saada tällä hetkellä täydellisen tiedon universumin hiukkasten liikkeistä ja niitä ohjaavista lainalaisuuksista, niin voimme tämän tiedon perusteella (kunhan on vain tarpeeksi paljon laskentatehoa) ennustaa universumin jokaisen tulevaisuuden tilan. Jokaisen yksittäisen fysikaalisen tilan määrää sen edeltävä fysikaalinen tila rautaisten lainalaisuuksien pohjalta. Universumissa ei ole siis mitään sellaista, jota emme voi ennustaa, jos vain tunnemme alkuehdot riittävän hyvin.

Mekanismin kolmas keskeinen oletus oli atomismi, joka oli ollut jo osa korpuskulaarista filosofiaa. Tämän oletuksen mukaan jokaisen kokonaisuuden käyttäytymisen määrää tämän kokonaisuuden pienimpien osasten käyttäytyminen. Ajatus oli se, että kaikki oliot 
koostuvat pienen pienistä aineen kappaleista, atomeista, ja olioiden käyttäytyminen voidaan selittää tyhjentävästi viittaamalla näiden aineen perusosasten käyttäytymiseen. Sekä Galilein että Newtonin mukaan luonnon oliot (kaikki muut kuin ihminen ja Jumala) eivät ole mitään muuta kuin liikkuvien atomien joukkoja.

Näiden kolmen oletuksen pohjalta syntyi erittäin vaikutusvaltainen kuva maailmasta: maailma erittäin hienosyisenä mekanismina. Mekanistisen maailmankuvan tärkein metafora on kellokoneisto. Kellokoneisto ja universumi koostuvat molemmat materiaalisista perusosista, joiden käyttäytyminen määrää koko koneiston käyttäytymisen. Lisäksi koneen yksittäiset osat noudattavat rautaisia lakeja, joista ei tunneta poikkeuksia. Tällaisessa maailmassa ei ole sattumaa eikä tarkoitusta, ei ihmisen vapaita valintoja tai vastuuta vaan ainoastaan yhdestä fyysisestä tilasta toiseen siirtymistä. Ero keskiaikaiseen synteesiin on valtava. Ihminen ei ole enää maailmankaikkeuden keskuksessa, maailma ei ikään kuin rakennu hänen ympärilleen. Ihmisestä on tullut valtavan kosmisen koneiston tarkkailija - koneiston, jota ohjaa rautainen matematiikka. Lisäksi päämääräsyyt, jotka olivat olleet keskiaikaisen synteesin liima, eivät saaneet enää mitään roolia mekanistisessa maailmankuvassa. Olioilla ei enää katsottu olevan olemuksia, jotka pyrkivät kohti päämääriä: oliot itsessään eivät enää olleet toimijoita, vaan ne ainoastaan tottelivat lakeja, joita voitiin kuvata matemaattisesti.

Mekanistisen maailmankuvan jälkivaikutusta on vaikea liioitella: se oli yli 200 vuotta standardinäkemys, joka vaikutti vahvasti sekä filosofiaan että teologiaan. Aiheemme kannalta olennaista on se, että siirtymä keskiaikaisesta synteesistä mekanistiseen maailmankuvaan aiheutti myös kokonaan uuden tilanteen teologialle. Tilannetta kuvaa hyvin kuuluisa Laplacea koskeva anekdootti. Kun Laplace oli esitellyt uutta teoriaansa aurinkokuntien synnystä, totesi Napoleon hänelle "Olette kirjoittanut valtavan kirjan universumin rakenteesta mutta ette kertaakaan mainitse siinä Luojaa itseään". Tähän Laplace vastasi: "Minulla ei ole tarvetta moiselle hypoteesille". Monet etenkin 1700-luvun ja 1800-luvun kirjoittajat tekivätkin sen johtopäätöksen, 
että mekanistisessa maailmankuvassa ei ole Jumalalle mitään paikkaa. Galilein ja Newtonin kirjoituksissa on kuitenkin hyvin vahvoja teologisia elementtejä (Galilei oli varsin perinteinen kristitty ja Newton vähemmän perinteinen), joiden pohjalta Jumalalle yritettiin löytää paikka mekanistisessa maailmassa. Näitä elementtejä olivat ainakin

(1) Kahden kirjan malli,

(2) Jumala mekanismin suunnittelijana (deismi),

(3) sielu-ruumis dualismi

Jo Galilei puhui kahden kirjan mallista. Ajatus oli se, että Jumala on kirjoittanut kaksi kirjaa, ilmoituksen kirjan ja luonnon kirjan, jotka eivät ole ristiriidassa keskenään. Ihminen etenee kohti Jumalan tuntemista tutkimalla luontoa modernin luonnontieteen keinoin ja tutkimalla Jumalan ilmoitusta Raamatussa. Kun räikeitä ristiriitoja syntyi, ajattelivat kahden kirjan mallin edustajat, että on turvallista tulkita Raamatun teksti kuvainnollisesti. Esimerkiksi kardinaali Baronius, Galilein aikalainen, kirjoitti: "Pyhän Hengen tarkoituksena ei ole opettaa meille kuinka taivaat liikkuvat, vaan kuinka me pääsemme taivaaseen"52. Samaan tapaan ajatteli myös Galilei itse:

Siitä, että Pyhän Hengen tarkoituksena ei ollut opettaa meille liikkuvatko taivaat vai pysyvätkö ne paikallaan, seuraa se, että Pyhä Henki ei meidän puolestamme päätä muitakaan vastaavia kysymyksiä. ... Jos siis Pyhä Henki tahallaan jättäytyi opettamasta meille tämän kaltaisia väitteitä, koska ne ovat korkeimman päämäärämme kannalta sivuseikkoja (nimittäin pelastuksen), niin miksi meillä pitäisi olla velvollisuus valita niissä puolemme. $^{53}$

Galilein ehdotus on siis se, että Raamattua ei tule pitää luonnontieteen oppikirjana, vaan sen todellinen sanoma tulee ymmärtää riippumattomaksi niistä näkemyksistä luonnosta, joita Raamatun kirjoittajilla oli. 
Kahden kirjan mallilla pyrittiin myös antamaan teologinen ja uskonnollinen oikeutus luonnontieteen harjoittamiselle. Luonnon tutkiminen on kahden kirjan mallin valossa uskonnollista toimintaa. Teologin tehtävänä on selvittää Jumalan ilmoitettu tahto Raamatussa, ja fyysikon tehtävä on selvittää maailmankaikkeuden rakenne, joka ilmentää yhtä lailla Jumalan tahtoa. Näin esimerkiksi ajatteli englantilainen tiedemies Robert Boyle (1627-1691), jonka mukaan "koko universumi on Jumalan kadehdittavan käsityötaidon näyte". Myös Newton itse ajatteli samalla tavalla omasta työstään: moderni fysiikka paljastaa täysin uudella tavalla Jumalan suunnitelmallisen toiminnan kauneuden ja Jumalan vallan suuruuden. Mitä hienosyisempi kuva luonnosta tieteen kautta paljastuu sitä suurempi kunnia Jumalalle, luonnon suunnittelijalle.

Jo aiemmin mainittu ajatus universumin matemaattisesta perusrakenteesta oli Jumalan suunnitelman paljastamisessa keskeinen. Ajateltiin, että koska luonto on pohjimmiltaan rationaalinen ja ymmärrettävä, on sen takana oltava kaikkitietävä älykkyys, joka on suunnitellut sen. Näin syntyi ajatus yliluonnollisesta suunnittelijasta, jota voimme tässä kutsua kellokoneiston Jumalaksi. Jo Boyle vertasi Jumalaa kelloseppään: Jumalan kunnia ei riipu hänen tekemistään ihmeistä, vaan pikemminkin hänen universumia koskevasta lainomaisesta suunnitelmastaan. Tämä ajattelutapa johti erilaisten suunnitteluargumenttien määrän kasvuun ja klassisen luonnollisen teologian syntyyn. Klassisen luonnollisen teologian mukaan voimme pelkästään tieteen ja filosofisen päättelyn avulla muodostaa perustellun näkemyksen Jumalan olemassaolosta, sielun kuolemattomuudesta ja ihmisen moraalisesta vastuusta.

Olennaista on huomata, että sekä Newton että Galilei eivät olleet ateistisia mekanisteja, vaan heillä oli varsin kattava käsitys Jumalan toiminnasta luonnossa. Koko universumin koneiston nähtiin heijastavan sen suunnittelijan mittaamatonta voimaa ja älykkyyttä. Vaikka luonnon olioilla itsellään ei katsottu olevan mitään tarkoitusta, niin koko koneistolla kuitenkin oli tarkoitus, koska se oli Jumalan suunnittelema. Vielä 1600-luvulla ja 1700-luvulla mekanistisen maail- 
mankuvan syntyaikoina maailmankaikkeus katsottiin ikuiseksi ja siten myös Jumalan sille asettamat lait olivat ikuisia. Lisäksi sekä Newton että Galilei sallivat Jumalan toisinaan puuttuvan luonnon kulkuun eli tekevän ihmeitä.

Lukuisat 1700-luvun ajattelijat yhdistivät toisiinsa mekanistisen maailmankuvan ja luonnollisen teologian, jolloin syntyi teologinen näkemys, jota tavallisesti kutsutaan deismiksi. Deismin mukaan Jumalan kahdesta kirjasta voidaan tiputtaa toinen, Raamattu, kokonaan pois. Ajatus oli se, että ihminen pystyy saavuttamaan riittävän tiedon Jumalasta pelkästään tieteen kautta. Tähän perustui klassinen luonnollinen teologia, jonka tarkoituksena oli osoittaa, että voimme tieteen ja järjen avulla perustella Jumalan olemassaolon, sielun kuolemattomuuden ja ikuisen moraalilain kaikki järkevät ihmiset vakuuttavalla tavalla. Syntyi ajatus luonnollisesta uskonnosta eli puhtaan järjen uskonnosta, jonka nähtiin olevan kaikkien uskontojen perusta. ${ }^{54}$ Luonnon kirjan lukemiselta ei jäänyt tilaa ilmoituksen kirjalle. Deismillä oli myös oma näkemyksensä Jumalan toiminnasta. Deismin Jumala oli lähinnä enää maailman kellokoneiston virittäjä, joka poistui näyttämöltä, kun tämä viritys oli tehty. Deismin Jumala ei tehnyt "ihmeitä", puuttunut maailman kulkuun tai tehnyt tahtoaan tiettäväksi ihmisille. Näin deistit päätyivät kieltämään ilmoituksen mahdollisuuden ja oikeastaan myös uskonnollisten instituutioiden tarpeen kokonaan.

Filosofian puolella mekanistinen maailmankuva aiheutti suuria ongelmia erityisesti antropologian suhteen. Jos luonto tosiaan koostui vain ja ainoastaan pienistä materian kappaleista ja niiden liikkeitä, niin ei näyttänyt jäävän minkäänlaista tilaa ihmisjärjelle, tahdolle tai moraalille. Jos luonto oli sellainen kuin mekanistit sen ymmärsivät, niin ihmismielen ja luonnon maailman välillä ei näyttänyt olevan minkäänlaista jatkumoa. Näin ollen on helppo ymmärtää miksi niin monet Newtonin jälkeiset (ja aikalaiset) tunsivat vetoa dualismiin, jossa sielu ja ruumis (mieli ja luonto) erotettiin jyrkästi toisistaan tavalla, joka poikkesi keskiaikaisesta synteesistä. Filosofi Rene Descartes muotoili tämän näkemyksen (surullisen) 
kuuluisalla tavalla: ihmisruumiissa on komponentti, joka ei ole aineellinen, vaan jotakin täysin muuta. Ihmispersoona on ruumiissa asuva aineeton sielu - ruumiissa, joka on aineellinen ja osa luontoa (mekanismi tai jonkinlainen kone). Näin ollen ihmisen järki, hänen tahtonsa, persoonansa ja moraalinsa eivät kuulu luonnon mekanismien maailmaan, joka koostuu materiaalisista hiukkasista, vaan hengen maailmaan, joka ei koostu mistään materiaalisista osista.

Mekanistinen maailmankuva muodosti taustan teologiselle keskustelulle aina 1800-luvun lopulle asti, jolloin kaksi uutta tutkimussuuntausta alkoi muuttaa sen oletuksia. Nämä olivat juuri syntynyt evoluutiobiologia ja idullaan oleva uusi fysiikka. Vaikka evoluutiobiologian synty (1860-) sijoittuu ajallisesti ennen uutta fysiikkaa (1900-), pitäydymme vielä fysiikassa ja käsittelemme ensin jälkimmäistä.

\section{$4 \cdot 3$}

UUSI FYSIIKKA: MEKANISMEISTA AVOIMEEN

\section{JA KERROKSELLISEEN LUONTOON}

Vielä 1900-luvun alkuvuosina suurin osa tiedemiehistä uskoi, että fysiikka oli "tullut valmiiksi" ja että kaikki löydöt on jo tehty. Jälkiviisaasti voidaan sanoa, että tämä oli erittäin kaukana todellisuudesta. 1900-luvun alkuvuosikymmenet näkivät ennennäkemättömän mullistuksen, jonka jälkeen mekanistinen maailmankuva menetti uskottavuutensa. Itse asiassa kaikki kolme mekanistisen maailmankuvan oletusta, naiivi realismi, atomismi ja determinismi, joutuivat suuriin vaikeuksiin. Tietomme sekä mikromaailmasta että makromaailmasta laajentui muutamassa vuosikymmenessä räjähdysmäisesti. Viittaan tässä lähinnä kehitykseen, johon vaikuttivat suhteellisuusteorian, kvanttimekaniikan, kaaosteorian ja kosmologian kehitys. Kutsumme jatkossa 1900-luvun fysiikkaa uudeksi fysiikaksi erotukseksi klassisesta fysiikasta. Aloitan lyhyellä katsauksella uusiin teorioihin fysiikassa, jonka jälkeen jatkan tarkastelemaan niitä 
tapoja, joilla nämä uudet teoriat saattoivat mekanistisen maailmankuvan kolme perusoletusta kyseenalaisiksi.

Albert Einsteinin erityinen suhteellisuusteoria asetti Newtonin käsityksen absoluuttisesta tilasta ja ajasta radikaalisti kyseenalaiseksi. Erillisten ajan ja tilan sijaan Einstein oletti yhtenäisen aikaavaruuden, jossa aika on vain yksi ulottuvuus. Tämän näkemyksen mukaan mittaukset jonkin kappaleen nopeudesta ja ajallisesta jatkuvuudesta vaihtelevat sen mukaan, millaisessa suhteessa (ajassa ja nopeudessa) mittauksen tekijä on mitattavaan kappaleeseen. Tästä näkökulmasta tarkasteltuna on vaikea löytää mitään "pysyvää nykyhetkeä”. Vuonna 1915 Einstein kehitti yleisen suhteellisuusteorian, jonka tarkoitus oli ymmärtää gravitaatio erityisen suhteellisuusteorian kehyksessä. Erittäin karkeasti ottaen Einsteinin ajatus oli seuraava. Newton ymmärsi painovoiman voimana, joka vaikuttaa massan omaaviin kappaleisiin, mutta hänellä ei ollut selitystä tälle voimalle. Einsteinin tarjosi tällaisen selityksen. Hänen mukaansa painovoima oli aika-avaruuden kaareutumista. Massa aiheuttaa aika-avaruuden kaareutumisen, joka taas puolestaan ohjaa massan liikettä.

Erityinen suhteellisuusteoria johti kosmologiassa kysymykseen universumin alkupisteen mahdollisuudesta, ja 1960-luvulta eteenpäin vakiintuikin teoria, joka tunnetaan yleisesti nimellä alkuräjähdysteoria (Big Bang teoria). Alkuräjähdysteorian mukaan universumilla oli nähtävästi jonkinlainen alkupiste, singulariteetti, josta kaikki arvioista riippuen noin 13-15 miljardia vuotta sitten lähti liikkeelle. Alkuräjähdysteorian puolesta todisti se, että universumin huomattiin laajenevan koko ajan. Vuonna 1929 Edwin Hubble huomasi, että aurinkokunnat etääntyvät toisistaan jatkuvasti ja käyttäen hyväkseen silloista tietoa tämän etääntymisen nopeudesta, hän laski, että noin 15 miljardia vuotta sitten on ollut hetki, jolloin kaikki aine on ollut samassa pisteessä. Lisää todistusaineistoa alkuräjähdysteorian puolesta esittivät Arno Penzias ja Robert Wilson, jotka vuonna 1965 löysivät taustasäteilyä, jonka lähteenä näytti olevan yleisen suhteellisuusteorian ja Hubblen olettama alkupiste ja siinä tapahtunut jonkinlainen räjähdys. Näin ollen sekä tutkimustulokset 
kosmologiassa että suhteellisuusteoriassa tukevat ajatusta siitä, että universumilla oli alkupiste, mistä puolestaan seuraa sen oletuksen kumoutuminen, että universumi olisi ikuinen. Kysymys universumin ikuisuudesta on kuitenkin visainen ja palaamme siihen tarkemmin myöhemmin. ${ }^{55}$

Suhteellisuusteoria ja uusi kosmologia laajensivat 1900-luvun fysiikassa näkemystämme varsin suurista kappaleista ja fysikaalisten perusvoimien luonteesta. Toisenlainen teoria laajensi näkemystämme mikromaailmasta. Sellaiset fysiikan jättiläiset kuten Max Planck, Niels Bohr, Werner Heisenberg, Erwin Schrödinger ja Paul Dirac olivat osaltaan kehittämässä teorioita, jotka nykyään luetaan kvanttimekaniikan tai kvanttifysiikan alaan. Kvanttifysiikasta on vaikea puhua yleiskielellä, koska se ensi näkemältä vaikuttaa arkijärkemme vastaiselta. ${ }^{56}$ Jotkut fyysikot ovat olleet jopa sitä mieltä, että teoriaa ei voi laisinkaan ymmärtää, vaan meidän pitää ainoastaan hyväksyä teoriaa kannattava matematiikka. Richard Feynmanin tiedetään sanoneen, että "se, joka väittää ymmärtävänsä kvanttifysiikkaa, on aina väärässä”. Yksityiskohdat eivät ole aiheemme kannalta olennaisia. Olennaisia ovat kuitenkin kvanttifysiikan seuraukset perinteisen newtonilaisen fysiikan kannalta. Kvanttifysiikan mukaan atomit eivät ole pienimpiä, jakamattomia materian kappaleita, vaan ne koostuvat pienemmistä hiukkasista, kvarkeista. Erikoista teoriassa on kuitenkin se, että se romuttaa intuitiomme siitä, mitä aine pohjimmiltaan on. Syynä tähän on se, että kvanttifysiikan mukaan kvarkit käyttäytyvät toisinaan kuten hiukkaset ja toisinaan kuten aallot. Näin ollen on hyvin vaikea kuvitella alkeishiukkasten olevan ikään kuin jonkinlaisia kappaleita. Barbourin mukaan "[e]rilaiset 'hiukkaset', jotka koostuvat kvarkeista, näyttävät olevan vain aaltojen hetkellisiä kuvioita, jotka yhdistyvät joissakin paikoissa, hajoavat ja yhdistyvät taas uudelleen toisaalla." ${ }^{57}$ Mikrotasolla tapaamme myös muitakin hyvin omituisia ilmiöitä. Kvanttitasolla esimerkiksi 
olioiden tila näyttää muuttuvan ajan myötä ilman riittävää mekanistista syytä täysin sattumanvaraisesti (indeterminismi), ne näyttävät olevan yhteydessä toisiinsa suurista välimatkoista huolimatta (kietoutuneisuus) ja toisinaan ne käyttäytyvät ikään kuin ne olisivat aaltoja ja toisinaan taas ikään kuin ne olisivat hiukkasia. ${ }^{58}$

Näyttää siis siltä, että mikrotasolla arkikäsitteemme ajasta, paikasta ja kausaliteetista - jotka klassinen fysiikka pystyi vielä säilyttämään - alkavat hajota niin radikaalisti, että meidän on hyvin vaikea kuvitella, millainen mikromaailma oikeastaan on.

Kvanttifysiikka toi mukanaan myös haasteen klassisen fysiikan naiiville realismille ja determinismille. Se nimittäin antaa mahdollisuuden ennustaa hiukkasten joukkojen tulevia tiloja, mutta nämä ennusteet ovat aina todennäköisyyksiä. Yksittäisten hiukkasten käyttäytymistä pystytään siis ennustamaan vain todennäköisyyksillä. Toisin sanoen siis mikrotasolla on jonkin verran sattumanvaraisuutta. Tästä monet ovat päätelleet, että mikrotaso on itse asiassa indeterministinen. Emme yksinkertaisesti pysty ennustamaan jokainen hiukkasen käyttäytymistä aukottomasti. Tästä näyttäisi seuraavan myös makromaailman indeterminismi. Ei ole vaikea kuvitella miksi tämä väite herätti valtavan keskustelun: klassisen fysiikan yksi ydinkohta oli juuri se, että kaikkien fysikaalisten olioiden käyttäytymiselle voidaan antaa tyhjentävä lainomainen selitys. Aihe on kuitenkin hankala ja sen seurauksena kvanttifysiikasta on tavallisesti kaksi tulkintaa:

(1) deterministinen tulkinta, jonka mukaan kvanttiteoria itsessään on vajavainen ja mikromaailman käyttäytymistä ohjaavat mekanistiset periaatteet, joita emme vielä tunne,

(2) indeterministinen tulkinta ("Kööpenhaminan tulkinta"), jonka mukaan kvanttiteoria ei ole vajaa, vaan heijastaa mikromaailmassa itsessään olevaa aitoa indeterminismiä. 
Näistä jälkimmäinen tulkinta ${ }^{59}$, Kööpenhaminan tulkinta, jota esimerkiksi Heisenberg kannatti, on ollut kaikkein suosituin siitäkin huolimatta, että Einstein kannatti edeltävää tulkintaa. Juuri tähän liittyy Einsteinin kuuluisa kommentti siitä, että "Jumala ei heitä noppaa”.

Determinismin ja indeterminismin väliseen ongelmakenttään liittyy myös 1900-luvulla syntynyt kaaosteoria ja muut monimutkaisia järjestelmiä koskevat teoriat. Klassisen fysiikan mukaan täydellinen tieto järjestelmän alkuehdoista ja sen laeista antaa mahdollisuuden ennustaa järjestelmän jokainen tuleva tila. Erilaisia kaoottisia järjestelmiä sen sijaan näyttää luonnehtivan paremmin järjestelmien epävarmuus: äärettömän pieni muutos järjestelmän alkuehdoissa voi tuottaa koko järjestelmän tasolla täysin ennakoimattomia seurauksia. Barbourin mukaan

[d] eterministiset lait ovat tarkkaan ottaen sovellettavissa vain kokonaan suljettuihin järjestelmiin. Nämä lait kuitenkin vain lähestyvät todellisuutta, koska todellisen maailman järjestelmät ovat erittäin herkkiä muutoksille alkuehdoissa, joita ei voida koskaan täydellisesti eristää järjestelmien ulkopuolisista vaikutuksista. ${ }^{60}$

Olennaista on se, että kaoottisten järjestelmien tutkimus näyttäisi viittaavan siihen suuntaan, että emme pysty luomaan teorioita, jotka pystyisivät ottamaan huomioon kaikki monimutkaisiin järjestelmiin vaikuttavat tekijät. Monet ovat tällä perusteella väittäneet, että monimutkaiset järjestelmät ovat luonnostaan indeterminististä. Toisin sanoen puutteellinen kykymme ennustaa tällaisten järjestelmien kehittymistä heijastaisi niiden todellista luonnetta.

Toinen aiheemme kannalta kiinnostava seikka on se, että kaoottisten järjestelmien teoriat eivät ennusta järjestelmien kehitystä järjestelmien komponenttien käyttäytymisen perusteella. Klassisessa fysiikassa fysikaalisen järjestelmän käyttäytyminen on aina johdettavissa sen fysikaalisten komponenttien käyttäytymisestä ja niitä ohjaavista laeista. Kaaosteoriat sen sijaan 
tutkivat järjestelmien laaja-alaisia yleisiä piirteitä, jotka saattavat olla samanlaisia siitä huolimatta, että niiden komponentit ovat hyvin erilaisia. Kaaosteoria tutkii holistisia geometrisia suhteita ja järjestelmän yleisiä ominaisuuksia sen sijaan, että se etsisi järjestelmien käyttäytymisen redusoimista sen [komponenttien] kausaalisiin mekanismeihin. ${ }^{61}$

Olennaista tässä on se, että voimme alkaa puhua todellisuudesta ei pelkästään yhtenä järjestelmänä, kuten mekanistinen maailmankuva oletti, vaan monien järjestelmien kerrostumina, jotka ovat kukin toistensa komponentteja mutta jotka eivät kuitenkaan määritä toistensa lopputiloja. Tässä yhteydessä onkin tapana puhua todellisuuden monikerroksisuudesta tai kerroksellisuudesta. Palaamme tähän hetken päästä.

Nyt kun meillä erittäin rajallinen ja raaka yleiskuva uudesta fysiikasta, voimme kiinnittää huomiota siihen, kuinka se haastaa mekanistisen maailmankuvan kolme keskeisintä oletusta. Lyhyesti sanottuna fysiikka aiheuttaa siirtymät

(1) naiivista realismista kriittiseen realismiin, jossa tunnustetaan, että teoriamme kuvaavat maailmaa vain osittain ja että meillä voi olla keskenään ristiriitaisia malleja samoista ilmiöistä,

(2) atomismista ja reduktiivisesta selittämisestä holismiin ja luonnon monitasoisuuteen, jossa jokaista luonnon tasoa luonnehtivat lait, joita ei voi johtaa niiden perustasta, ja näillä tasoilla on olioita, joiden käyttäytymistä ei voi tyhjentävästi selittää viittaamalla niiden osiin,

(3) determinismistä avoimiin järjestelmiin, joiden käyttäytymistä ei pystytä tyhjentävästi ennustamaan mekanististen lainalaisuuksien pohjalta.

Kiinnitimme jo aiemmin huomiota kriittiseen realismiin ja sen mukaiseen tiedon- ja tieteenihanteeseen (luku 3). Tässä vaiheessa voimme ainoastaan lisätä sen huomion, että tämän luvun kuvauksen perusteella uuden fysiikan teoriat ja niiden näkemys luonnos- 
ta tukevat jossakin määrin kriittistä realismia. On käynyt ilmi, että teoriamme ovat radikaalisti rajallisia ja todellisuus näyttää olevan aina teorioitamme monimutkaisempi. Teoriamme ovat malleja todellisuuden tietyistä piirteistä, joita sitten kokeilemme näiden teorioiden tarkoituksen mukaisesti. Näin ollen meillä on hyviä perusteita hylätä se ajatus, että teoriamme luonnosta kuvaavat luontoa "sellaisena kuin se on" tai antavat meille välittömän pääsyn todellisuuden perimmäiseen luonteeseen. Lyhyesti sanottuna meidän on hylättävä naiivi realismi.

Monet kirjoittajat ovat korostaneet, että siirtymä klassisesta fysiikasta uuteen fysiikkaan muuttaa syvästi näkemyksemme siitä, miten luonnon järjestelmiä tulisi lähestyä. Sen sijaan, että ajattelisimme klassisten mekanistien tapaan, että järjestelmien toiminta voidaan selittää tyhjentävästi viittaamalla niiden fysikaalisten osien käyttäytymiseen, on meidän nyt tunnustettava järjestelmien kerrostuneisuus ja ennakoimattomuus. Nämä tulokset näyttävät kyseenalaistavan klassisen mekanismin yksinkertaisen atomismin, determinismin ja reduktionismin. Näyttää siis siltä, että kokonaisuudet ovat enemmän kuin pelkästään osiensa summia ja niitä ohjaavia lainalaisuuksia ei voida palauttaa jonkinlaiseen yksiselitteiseen joukkoon matemaattisesti muotoiltuja lainalaisuuksia.

Monet puhuvatkin luonnon tasoista ja kerrostuneisuudesta. Tämän näkemyksen mukaan jokaisella luonnon tasolla on sille tyypillisiä rakenteita ja kukin kerros rakentuu sitä yksinkertaisemman kerroksen olioiden osasista. Ylemmillä kerroksilla esiintyy kuitenkin olioita ja säännönmukaisuuksia, joita ei voida palauttaa niiden alempien kerrosten olioihin tai säännönmukaisuuksiin. Tämän tapaisesta tavasta ymmärtää luonnon kerrosten välinen suhde on tapana käyttää nimitystä emergenssi ja se asetetaan tavallisesti reduktionismia vastaan. Emergenssi ei ole yksiselitteinen eikä yleisesti hyväksytty ajatus mutta kiinnostus sitä kohtaan on ollut varsin suuri. Kuten jo edellä sanoimme, emergenssin perusajatus on se, että kullakin luonnon tasolla ilmenee sitä alemmista tasoista suhteellisen riippumattomia säännönmukaisuuksia ja olioita. Näin ollen voidaan väittää, 
että universumi koostuu pelkästään erilaisista fysikaalisista ilmiöistä mutta monet näistä ilmiöistä ovat fysiikan selitysten ulkopuolella eikä niiden selityksiä voida palauttaa fysikaalisiin selityksiin. Voimme kuvata kerrostunutta todellisuutta, jossa kukin kerros "emergoituu" alemmasta kerroksesta seuraavan kuvan avulla.

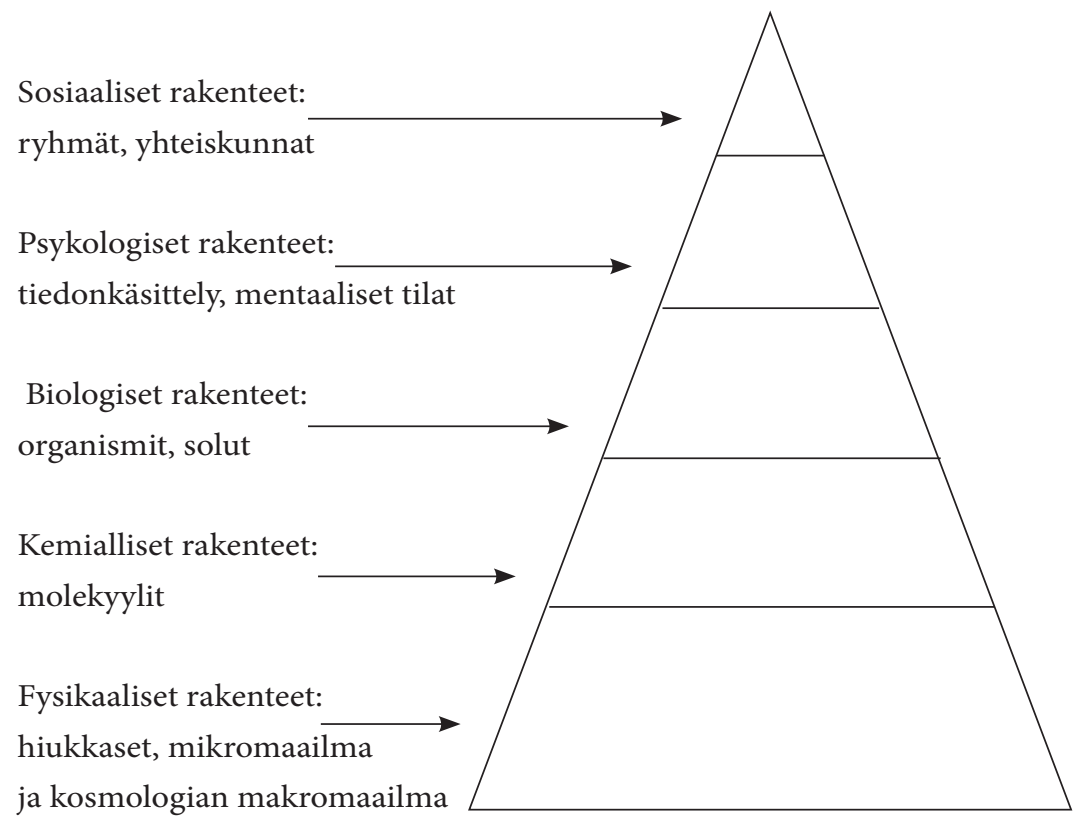

Alhaalta ylöspäin mennessä rakenteiden monimutkaisuus kasvaa ja määrä vähenee. Fysiikan tutkimat rakenteet ovat tämän näkemyksen mukaan kaikkein yleisimpiä rakenteita ja muiden tasojen rakennuspalikoita. Siirtyessämme fysikaalisten rakenteiden tasolta ylöspäin alkaa vastaan tulla rakenteita, olioita ja lakeja, jotka eivät enää hallittavissa fysiikan käsitteistöllä. Aletaan puhua hiukkasten yhdistelmien käyttäytymisestä, näiden hiukkasten muodostamista elävistä organismeista, näiden organismien uskomuksista ja päämääristä sekä näiden organismien muodostamista ryhmistä, jotka 
ihmisen kohdalla tarkoittavat erilaisia sosiaalisia suhteita ja yhteiskunnallisia rakenteita.

Olemme tarkastelleet tässä luvussa fysiikan kehitystä siitä näkökulmasta, millaisia käsityksiä luonnon yleisistä piirteistä se on meille antanut. Aloitimme keskiaikaisesta synteesistä, jonka kokonaisuuden klassinen fysiikka ja sen kannattelema metafysiikka rikkoo. Päädyimme 1900-luvun fysiikkaan ja käsitykseen luonnosta, joka monien mielestä tästä seuraa. Maailma ei ole tämän näkemyksen mukaan kellokoneisto, jolla on alkuehdoissa annettu tulevaisuus, vaan aidosti avoin joukko eritasoisia järjestelmiä, jonka tulevaisuus ei ole määrätty. Luonto ei koostu jakamattomista aineen yksiköistä, kuten mekanistinen maailmankuva oletti, vaan sillä ei näytä olevan arkijärjelle ymmärrettävää "aineellista" pohjaa ollenkaan. Mikromaailma näyttää poikkeavan radikaalisti arki-intuitioistamme. Sekä makromaailma että mikromaailma synnyttävät erilaisia monimutkaisia rakenteita ja järjestelmiä, jotka ovat enemmän kuin osiensa summia: muodostuu olioita ja säännönmukaisuuksia, joita ei voida johtaa niiden osista.

Emergenssin ja kerrostuneisuuden suhteen varoituksen sana on kuitenkin paikallaan. Kyseessä nimittäin on vain yksi tapa tulkita uutta fysiikkaa (ja muitakin tieteitä) ja monet, kuten esimerkiksi tieteelliset materialistit (luku 2.2), pyrkisivät vastustamaan ainakin osia tällaisesta tulkinnasta. Emergenssi ja kerrostuneisuus ovat kuitenkin mahdollisia tapoja ymmärtää luonnon yleisiä piirteitä - tapoja, joita ovat kannattaneet monet uskonnolliset ja ateistiset ajattelijat. Syy, miksi olen tässä päätynyt korostamaan tällaista tulkintaa luonnosta, on se, että nykyistä tieteen ja kristinuskon suhdetta käsittelevää keskustelua on mahdoton ymmärtää ilman tämän näkemyksen tuntemusta. Ennen kuin siirryn tarkastelemaan tätä keskustelua tarkemmin, on meidän käsiteltävä sitä uuden fysiikan ulkopuolista tekijää, joka on vaikuttanut kaikkein eniten siihen, miten nykyisin tarkastelemme luontoa, nimittäin evoluutiobiologian ja mikrobiologian kehitystä. 


\section{Kirjallisuutta}

Erinomainen johdatus teologian ja fysiikan suhteeseen sekä historiassa että nykypäivänä on Hodges 2005, jossa käsitellään kaikkia tämän luvun teemoja. Historiallinen katsaus on Ferngren 2002. Polkinghorne 2002 on lyhyt johdatus kvanttifysiikkaan maallikolle. Jaki 1978 on laaja historiallinen ja filosofinen katsaus. 
MUUTTUVA LUONTO: EVOLUUTIO, IHMINEN JA IHMISMIELI

Melkein kenelle tahansa, joka kuulee puolella korvalla maininnan tieteen ja kristinuskon suhteesta, tulee ensimmäisenä mieleen sana "evoluutio". Puhutaan "luomisen ja evoluution ristiriidasta" tai muusta vastaavasta. Onkin totta, että jollakin tavalla tähän käsitteeseen liittyvillä keskusteluilla on ollut hyvin keskeinen rooli tieteen ja kristinuskon suhteesta puhuttaessa, mutta aidot ongelmat ovat varsin toisenlaisia, kuin arkikeskusteluissa tavallisesti oletetaan. Olemme jo sitä paitsi nähneet, että kysymys evoluutiosta ei ole läheskään ainoa tärkeä asia tai ongelma tieteen ja kristinuskon suhteessa, vaikka se usein sellaisena esitetäänkin. Pikemminkin kysymys evoluutiosta liittyy laajempaan kenttään kysymyksiä, jotka koskevat teologian ja tieteen menetelmiä, tietämisen lähtökohtia ja käsitystämme luonnon ja Jumalan yleisistä piirteistä. Tämä luvun tarkoituksena on luoda yleiskatsaus tieteen ja kristinuskon suhteen kannalta keskeisiin teemoihin evoluutiobiologian kehityksessä. Keskitymme erityisesti siihen, millainen käsitys luonnosta ja ihmisestä osana luontoa nykyisen evoluutiobiologian pohjalta nousee. Varsinaisia teologisia vastauksia evoluutiobiologiaan käsittelemme vasta myöhemmin (luku 7).

Käsite "evoluutio" on arkikeskusteluissa ongelmallinen, koska ihmiset tarkoittavat sillä hyvin monia, keskenään ristiriitaisia asioita. Saatetaan sanoa esimerkiksi, että "ihminen on apina", "maailmaa ei luotu kuudessa päivässä" tai "kaikki on vain olemassaolon taistelua". 
Usein myös ajatellaan evoluution olevan sitä, että kehitys menee eteenpäin ikään kuin vääjäämättä yksinkertaisesta kohti monimutkaisuutta. Olennaista on se, että evoluutioon liitetään usein vaikka minkälaisia näkemyksiä ja tämän seurauksena keskustelu "luomisesta ja evoluutiosta" muodostuu usein täysin käsittämättömäksi. Yritän tässä luvussa tuoda jonkinlaista selkeyttä näihin käsitteisiin. Aion kuitenkin pitää esitykseni varsin lyhyenä, sillä evoluutioteoriasta on saatavilla suomeksi monia hyviä maallikoille kirjoitettuja yleisesityksiä, jotka - toisin kuin tämä kirja - ovat biologian ammattilaisten kirjoittamia. ${ }^{62}$

$5 \cdot 1$

DARWIN, DARWINISMI JA LUONNONVALINTA

Fysiikan kehityksen kannalta sellaisilla hahmoilla kuten Newton ja Einstein on ollut perustava merkitys. Biologian kohdalla samaa voidaan sanoa Charles Darwinista (1809-1882). Darwinin teoriat laskivat sen perustan, jolle nykyaikainen biologia on kehittynyt. Tässä luvussa käsitellään lyhyesti Darwinin perusideoita ja tehdään muutamia erotteluja, jotka ovat aiheemme kannalta tärkeitä. ${ }^{63}$

Aivan aluksi on erotettava darwinismi ja evoluutio toisistaan:

(1) Darwinismi on joukko teorioita, jotka pohjautuvat Darwinin ajatteluun tai kehittävät sitä eteenpäin.

(2) Evoluutio on luonnonilmiö, jota darwinistiset teoriat pyrkivät selittämään.

Näin ollen, kun jatkossa puhumme evoluutiosta, puhumme tietystä ilmiöstä luonnossa eli biologisten eliöiden sukupolvien välillä tapahtuvasta muutoksesta kyseisen populaation käyttäytymisessä ja eliöiden rakenteessa. Darwinismi ja sen nykyinen versio, johon usein viitataan termillä moderni synteesi, pyrkivät selittämään tätä ilmiötä.

Darwin esitteli perusajatuksensa kirjassa Lajien synty vuonna 1859 
ja kehitti niitä eteenpäin useassa myöhäisemmässä kirjassaan. Darwinin argumentti Lajien synnyssä koostuu kahdesta osasta: ensin hän pyrkii osoittamaan, että evoluutio on aito ilmiö, jonka jälkeen hän esittää mekanismin, jonka tarkoituksena on selittää ainakin osa tästä ilmiöstä. Tämä selittävä mekanismi on luonnonvalinnan periaate.

Darwinin aikaan vallitseva teoria eläinlajien luonteesta oli Carl von Linnén (1707-1778) teoria, jonka mukaan eläinlajit ovat siinä mielessä staattisia, että nykyiset lajit ovat olleet nykyisen kaltaisia ennen ja tulevat pysymään sellaisina myös tulevaisuudessa. Tämän näkemyksen mukaan eläinlajit siis pitävät ominaisuutensa huolimatta niiden ympäristöstä. Jokaisella lajilla on ikään kuin oma muuttumaton olemuksensa: riippumatta siitä, missä lajien yksilöt maantieteellisesti ovat kehittyneet, kuuluvat kaksi yksilöä samaan lajiin, jos niillä on samat ominaisuudet. Darwin päätyi kuitenkin pitkän pohdinnan jälkeen hylkäämään ajatuksen lajiominaisuuksista ja niiden pysyvyydestä. Osallistuessaan HMS Beaglen viisivuotisella matkalla Etelä-Amerikkaan ja Tyynellemerelle hän kiinnitti huomiota siihen, että eristyneillä saarilla, kuten esimerkiksi Galapagoksen saarilla, oli eläinlajeja, jotka poikkesivat varsin erikoisilla tavoilla mannermaalla asuvista vastaavista lajeista. Darwinin mukaan ainakin seuraavat neljä seikkaa vaativat selityksen, jota teoria lajien pysyvyydestä ei näyttänyt pystyvän tarjoamaan:

(1) Kunkin eläinlajin muoto ja rakenne ovat erittäin hyvin sopeutuneita sen elinympäristöön.

(2) Monet lajit ovat kuolleet sukupuuttoon eikä mikään yksittäinen katastrofi näytä selittävän kaikkia sukupuuttoja.

(3) Eläinlajit eivät ole levittäytyneet tasaisesti kaikkiin ympäristöihin.

(4) Monilla eläinlajeilla on rakenteita, jotka ovat niiden ympäristöihin ja toimintoihin nähden turhia tai ylimääräisiä.

Ajatus pysyvistä lajeista - joka usein yhdistettiin ajatukseen siitä, että Jumala on luonut eläinlajit yhdellä iskulla - alkoi Darwinista 
näyttää näiden seikkojen valossa yhä epäuskottavammalta. Lyhyesti sanottuna se, mikä kaipasi selitystä, oli se seikka, että

(E) sukupolvien välillä tapahtuu muutosta eliöiden muodossa ja käyttäytymisessä.

Havainnot eläinlajeista erilaisissa ympäristöissä (ja muut syyt, joihin palaamme kohta) viittasivat siihen suuntaan, että ajan kuluessa lajien ominaisuudet ja käyttäytymismallit muuttuvat mutta nämä muutokset eivät ole täysin sattumanvaraisia. Tarvittiin siis mekanismi, joka selittää tätä muutosta.

Tämä selittävä mekanismi oli Darwinin mukaan luonnonvalinnan periaate. Periaate on lyhyesti sanottuna seuraava: jossakin historiallisessa ja paikallisessa joukossa yksilöitä ilmenee vaihtelua yksilöiden ominaisuuksia välillä ja jotkut näistä vaihtelun tuotteista selviävät hengissä paremmin kuin toiset. Vaihtelu on luonteeltaan sellaista, että se voi periytyä. Ajan myötä tämä joukko yksilöitä kehittyy kohti muotoja, jotka ovat ideaaleja henkiinjäämisen kannalta tietyssä ympäristössä. Tässä perusajatuksessa on kolme välttämätöntä elementtiä:

(1) eliöiden välillä esiintyy muuntelua jonkin ominaisuuden suhteen (muuntelu),

(2) eliöiden väliset erot vaikuttavat eliöiden selviytymiseen (kelpoisuuserot),

(3) vanhempien ominaisuudet periytyvät (perinnöllisyys). ${ }^{64}$

Hyvälle tyylilleen ominaisella tavalla Richard Dawkins tiivistää luonnonvalinnan periaatteen - darwinismin ytimen - väitteeksi siitä, että "sattumanvaraisesti määräytyvien piirteiden periytyminen ohjaa evoluutiota henkiinjäämisen kannalta ei-sattumanvaraiseen suuntaan."

On hyvä huomata, kuinka radikaalisti erilainen Darwinin käsitys on verrattuna ajatukseen lajien pysyvyydestä ja lajiolemukses- 
ta. Tapahtuu siirtymä "lajiajattelusta" "populaatioajatteluun". Itse asiassa darwinismi muuttaa koko lajin käsitteen toisenlaiseksi, sillä Darwinin mukaan lajeilla ei ole mitään pysyvää olemusta, vaan laji on historiallinen käsite. Lajit ovat tällöin historiallisten ja paikallisten yksilöiden joukkoja eli populaatioita, eivät kuvauksia jostakin olemuksesta, jotka nämä yksilöt jollakin tavalla jakavat. Lajit voivat näin ollen muuttua ajan kuluessa, niiden yksilöt voivat poiketa suurestikin toisistaan ja ne voivat kuolla sukupuuttoon. Se, mitä luonnonvalinnan mekanismi selittää, ovat muutokset populaatioissa sukupolvien välillä. Se ei siis selitä esimerkiksi yksittäisten eliöiden kasvua tai kehitystä. ${ }^{65}$

Darwinin argumentti sen puolesta, että evoluutio ilmiönä, (E), pitää paikkansa oli sellainen, mitä nykyään kutsuisimme poikkitieteelliseksi. Darwin perusti väitteensä seuraaviin lähteisiin. ${ }^{66}$

(1) Paleontologia: on olemassa jotakuinkin jatkuva fossiilien ketju sukupuuttoon kuolleista lajeista aina meidän tuntemiimme lajeihin asti.

(2) Lajimaantiede: kasvit ja eläimet eivät ole sattumanvaraisesti sijoittuneita, vaan on selviä merkkejä siitä, että yhdestä lajista, joka on tullut jollekin tietylle maantieteelliselle alueelle, on kehittynyt monia erilaisia lajeja.

(3) Anatomia: eri lajeilla on samankaltaisia anatomisia rakenteita, jotka muistuttavat toisiaan, vaikka niiden käyttötarkoitukset ovat erilaiset.

(4) Systematiikka: se, että lajeilla on yhteinen alkuperä, sopii hyvin yhteen lajien historian ja niiden luokittelun kanssa.

(5) Embryologia: eri lajien sikiöillä on selviä rakenteellisia yhtäläisyyksiä.

Nämä seikat eivät ole suinkaan ainoita, jotka tukevat evoluution olemassaoloa, mutta juuri ne olivat käsillä Darwinin aikaan. Myöhemmin 1900-luvulla, kuten kohta näemme, tähän listaan lisättiin myös aineistoa sellaisista uusista tieteistä kuten genetiikka ja mikro- 
biologia. Keräämällä ja yhdistämällä todistusaineistoa kaikista edellä mainituista lähteistä Darwin osoitti tavan, jolla tätä evoluutiota historiallisena kehityksenä tulisi lähteä jäljittämään.

Darwin itse käytti evoluutiosta historiallisena tapahtumasarjana monia metaforia, joista ehkä tunnetuin on ajatus "elämän puusta". Ajatus on se, että kaikki elämä on kehittynyt yhteisestä alkupisteestä kaikkeen nykyisin nähtävään monimutkaisuuteen asti. Nykyiset biologiset lajit ovat tämän puun tuuheaa oksistoa. Jatkossa tulemme näkemään, kuinka ajatusta elämän puusta voidaan käyttää erottamaan erilaisia teologisia vastauksia evoluutioteoriaan.

Darwinin ajatus luonnonvalinnasta evoluution keskeisenä mekanismina on hänen teoriansa kaikkein keskeisin ja radikaalein väite. Ajatus siitä, että eliöt ovat muuttuneet aikojen kuluessa, ei ollut Darwinin aikana enää mikään uutuus, mutta sen merkitystä biologialle ei oltu vielä ymmärretty. Olennaista oli se, että ensi kertaa saatiin ehdotus, joka yhdistää tämä tiedon jonkinlaiseen mekanismiin, joka selittää evoluution suuntaa. Luonnonvalinta selittää sitä, miten eliöiden tarkoituksenmukainen rakenne ja käyttäytyminen on muodostunut juuri tietynlaiseksi. Eliöiden käyttäytyminen ja rakenne eivät siis ole sattumalta sellaisia, kuin ne ovat, vaan ne ovat hyvin tarkoituksenmukaisia kyseisten eliöiden lisääntymisen ja selviytymisen kannalta. Näin ollen tarkoituksenmukainen (lisääntymistä ja selviytymistä tehostava) rakenne ja ominaisuudet olivat aina Darwinille merkki luonnonvalinnan toiminnassa. Lisääntymistä ja selviytymistä parantavia rakenteita, jotka ovat luonnonvalinnan tuottamia, kutsutaan sopeumiksi eli adaptaatioiksi.

Eräs Darwinin argumentti luonnonvalinnan puolesta oli vertaus ihmisen tekemän jalostamisen ja luonnon toiminnan välillä. Ihminen pystyy muuttaman lajien ominaisuuksia valitsemalla lajien sisältämän muuntelun pohjalta syntyneet yksilöt ja käyttää niitä tuottamaan uusia jälkeläisiä, joilla taas on vanhempiensa ominaisuuksia. Luonnossa tällaista ihmisen aikaansaamaa tietoista valintaa ei tietenkään tapahdu. Luonnossa kuitenkin tapahtuu valintaa, jonka toteuttaa se, mitä Darwin kutsui "olemassaolon taisteluksi". Ole- 
massaolon taistelun ajatuksessa näkyy poliittisen filosofin Thomas Malthusin (1766-1834) vaikutus Darwiniin. Malthusin mukaan ihmispopulaation kasvu johtaa vääjäämättä resurssien vähenemiseen ja taisteluun resurssien hallinnasta. Darwin siirsi tämän ajatuksen luontoon väittämällä, että eliöt kamppailevat keskenään rajallisista määristä resursseja (ravintoa, elintilaa, jne.) ja se yksilö, joka saa muuntelun kautta ominaisuuksia, jotka antavat sille edun muihin nähden, päätyy jatkamaan sukuaan. Olemassaolon taistelu johtaa jatkuvasti huonommin sopeutuneiden yksilöiden häviämiseen ja paremmin sopeutuneiden leviämiseen.

Darwinin oletuksilla periytymisen ja muuntelun luonteesta oli myös hyvin kauaskantoisia seurauksia. Koska Darwin vertasi luonnossa tavattua muuntelua ihmisen toimeenpanemaan eläinlajien jalostamiseen, hän ajatteli, että muuntelu on aina hyvin hienovaraista. Tällä perusteella hän uskoi, että evoluutio tapahtuu aina jatkuvana pienten muutosten ketjuna eliöstä toiseen: eliön yhdestä muodosta toiseen siirrytään asteittain monien hyvin pieniä muutoksia sisältävien välimuotojen kautta. Näin ollen evoluutioon ei sisälly hyppäyksiä tai kuoppia, vaan kehitys on jatkuvaa, hidasta muutosta.

Darwinilla oli kuitenkin varsin suuria aukkoja teoriassaan. Eräs näistä aukoista oli fossiiliaineiston vajavaisuus: näytti nimittäin siltä, että monet vaadittavat "välimuodot" eri lajien välillä puuttuivat fossiiliaineistosta kokoaan. Tämä oli Darwinin itsensäkin tunnustama ongelma ja se haastoi hänen oletuksensa hitaasta ja hienovaraisesta eliöiden kehityksestä. Toinen ongelma Darwinin kannalta oli se, että hänellä ei ollut minkäänlaista keinoa selittää muuntelun ilmenemistä. Hän pystyi ainoastaan toteamaan, että lajien sisällä tapahtuu jatkuvasti muuntelua ja jotkut muuntelun seurauksena syntyneet piirteet periytyvät, mutta hänellä ei ollut käsitystä, miten tämä tapahtui. Darwin tunnusti myös itse teoriansa vajavaisuuden, minkä perusteella monet hänen aikalaisensa suhtautuivat hänen teoriaansa skeptisesti. Tämä skeptisyys ei johtunut siitä, että he olisivat torjuneet evoluution ilmiönä, vaan siitä, että he eivät olleet vakuuttuneita, että luonnonvalinnan periaate voisi tehdä kaiken sen selitystyön, 
jonka Darwin sille sälytti.

Vasta 1900-luvun puolenvälin paikkeilla palaset loksahtivat kohdalleen siihen muotoon, jonka nykyisin tunnemme nimellä moderni synteesi. Tähän vaikuttivat munkki Gregor Mendelin (1822-1884) kehittämä teoria perinnöllisyydestä ja sen pohjalle rakentuva populaatiogenetiikka, geenin löytyminen vuonna 1926 Thomas Hunt Morganin toimesta ja lopulta James Watsonin ja Francis Crickin vuonna 1953 löytämä DNA:n rakenne, joka puolestaan selitti miten geneettinen aines tarkkaan ottaen kopioituu. Genetiikan ja darwinismin modernia yhdistelmän kannalta tärkeitä biologeja olivat esimerkiksi Julian Huxley, Theodore Dobzhansky ja Ernst Mayr. ${ }^{67}$

Erityisen tärkeää 1900-luvun kehitykselle oli DNA:n rakenteen löytyminen ja sen toimintamekanismien ymmärtäminen. Olennaista on se, että yhdistymällä erilaisilla tavoilla DNA:n proteiinit koodaavat informaatiota, joka sitten kopioimalla itse itseään toimii geenien perustana. Geenit puolestaan toimivat eliöiden biologisen rakentumisen ohjaajina, ne ovat ikään kuin organismin rakennekaavio. DNA:n toimintamekanismit selittävät myös, miten geneettinen muuntelu tapahtuu: muuntelu on epätäydellistä proteiinisarjojen koodien kopioitumista. Olennaista aiheemme kannalta on se, että standarditulkinnan mukaan geneettinen muuntelu on sattumanvaraista eli sitä ei ohjaa mikään lainalaisuus. Näin ollen suurin osa muuntelusta on joko organismin selviytymisen kannalta merkityksetöntä tai haitallista. Vain hyvin pieni osa muuntelusta vaikuttaa organismin selviämiseen positiivisella tavalla. Geneettisen muuntelun sattumanvaraisuudella on myös tärkeä menetelmällinen merkitys biologian kannalta: evoluution lopputuote on aina tulosta sekä sattumanvaraisesta geneettisestä muuntelusta että luonnonvalinnasta. Tästä käytetään usein ilmaisua "lain ja sattuman yhteispeli". Myös Dawkins itse korostaa tätä näkökulmaa vahvasti: evoluutiobiologia ei väitä, että biologiset organismit olisivat syntyneet sattumalta, vaan kaikkea evoluutiota ohjaa sattuman ja luonnonvalinnan yhteispeli.

Moderni synteesi onnistui yhdistämään siis varsin perustavalla tavalla Darwinin teoriat, uudet molekyylibiologian löydökset ja po- 
pulaatioiden kehityksen matemaattisen mallintamisen. Moderni synteesi kuitenkin päätyi muokkaamaan useita Darwinin näkemyksiä. Yksi näistä oli Darwinin näkemys hienovaraisesta ja asteittaisesta kehityksestä. Esimerkiksi Steven Jay Gould ja Niles Eldredge ovat väittäneet, että fossiiliaineisto ei tue ajatusta asteittaisesta kehityksestä, vaan pikemminkin siinä nähdään pitkiä kausia, jolloin lajit pysyvät staattisina ja lyhyitä ajanjaksoja, jolloin tapahtuu radikaalia kehitystä ja lajeja kuolee nopeasti sukupuuttoon. Tätä tulkintaa on tapana kutsua punktualismiksi (punctuated equilibrium). Punktualismista on ollut paljon keskustelua mutta selvään lopputulokseen ei olla päästy. Toinen merkittävä kehitys Darwinin jälkeen on ollut selkeästi laajentunut näkemys evoluutiota ajavista voimista. On pyritty osoittamaan, että luonnonvalinnan lisäksi evoluutioon vaikuttavat esimerkiksi geneettinen ajautuminen ja muutamat muut luonnonvalinnasta riippumattomat tekijät. Luonnonvalinnan merkityksestä evoluutiovoimana onkin tullut monien darwinistien välinen vedenjakaja. Tavallisesti puhutaan kolmesta erilaisesta käsityksestä, jotka ovat

(1) ultra-darwinismi (esim. Dawkins), jonka mukaan kaikki eliöiden monimutkaiset ja tarkoituksenmukaiset rakenteet ovat aina luonnonvalinnan tulosta,

(2) keskitien malli (esim. John Maynard Smith), jonka mukaan luonnonvalinta on tärkeä mutta ei laisinkaan ainoa evoluutiovoima,

(3) anti-ultra-darwinismi (esim. Gould ja Richard Levontin), jonka mukaan luonnonvalinnan vaikutus pitää aina erikseen osoittaa. ${ }^{68}$

Ultra-darwinistien mukaan ainoa voima, joka tuottaa tarkoituksenmukaisia rakenteita biologisessa maailmassa on luonnonvalinta. Keskitien mallin edustajien mukaan taas luonnonvalinnan tärkeyttä ei pitäisi liioitella: se kyllä selittää suurimman osan tarkoituksenmukaisista rakenteista mutta ei kaikkia. Smith esimerkiksi on korostanut geneettisen ajautumisen (genetic drift) merkitystä. Lopulta esimer- 
kiksi Gould ja Levontin ovat korostaneet luonnonvalinnan sivutuotteiden merkitystä evoluution kannalta. Olennaista heidän mukaansa on se, että luonnonvalinnan sivutuotteena syntyy jatkuvasti rakenteita, jotka voivat myöhemmin taas toimia valinnan kohteena. Näiden eri näkemysten kiistoissa on pitkälti kyse siitä, millainen sattuman ja luonnonvalinnan yhteispeli on evoluutiohistoriassa. Ultra-darwinistien näkökulmasta sattuman rooli on varsin pieni: jos evoluutiohistoria aloitettaisiin alusta uudestaan, olisi sen tuloksena jokseenkin samanlaisia lajeja kuin nykyään. Anti-ultra-darwinistit sen sijaan ovat sitä mieltä, että koska luonnonvalinnan rooli on vähäinen, niin evoluutiohistoria voisi olla radikaalisti toisenlainen.

Edellä esitetyistä vaihteluista huolimatta voidaan sanoa, että darwinistit jakavat suuren määrän yhteisiä oletuksia. Tiivistettynä nämä oletukset ovat

(1) eliöiden luonnollinen alkuperä: ne eivät ole syntyneet nykyisessä muodossaan yhden luomisen aktin tuloksena,

(2) elämän puun ajatus: kaikki elämä on kehittynyt yhteisestä kantamuodosta,

(3) sopeutuminen, selviytyminen ja muuntelu,

(4) luonnonvalinnan rooli. ${ }^{69}$

En nyt käy tässä käsittelemään niitä aiheemme kannalta tärkeitä kysymyksiä, joihin darwinismi liittyy, koska palaan niihin luvussa 5.4. Ennen kuin pääsemme käsittelemään näitä kysymyksiä, on meidän tarkasteltava lyhyesti ihmisen evoluutiota.

$5 \cdot 2$

EVOLUUTIO JA IHMISLUONTO

Jos evoluutio olisi koskenut pelkästään eläinkuntaa, niin se tuskin olisi herättänyt murto-osaakaan siitä keskustelusta, jonka se itse asiassa on herättänyt. Darwinin näkemysten kaikkein haastavin osuus 
oli hänen näkemyksensä ihmisen evoluutiosta ja suhteesta muuhun eläinkuntaan. Lajien synnyssä Darwin ei pukahtanut sanaakaan ihmisistä mutta kirjassaan Ihmisen polveutuminen ja sukupuolivalinta (The Descent of Man and Selection in Relation to Sex, 1871) hän esitti ensimmäisen teorian ihmisen evoluutiosta. Nykyinen näkemys tunnustaa Darwinin puutteet mutta hänen lähestymistapansa ja yleiset linjansa muistuttivat läheisesti nykyistä käsitystä. Verrattuna moniin muihin eläinkunnan jäseniin, ihmislajin "elämän puu" tunnetaan nykyisin erittäin hyvin. En käy tässä kuvaamaan tätä, koska lukija löytää jälleen hyviä suomenkielisiä esityksiä aiheesta helposti ja koska ihmisen evoluutiohistorian yksityiskohdat eivät ole aiheemme kannalta tärkeitä. ${ }^{70}$ Meillä riittää tieto siitä, että ihmisellä on evoluutiohistoria. Nostan sen sijaan esiin muutamia kysymyksiä, jotka ovat aiheemme kannalta tärkeitä. Näitä ovat kysymys ihmisen erityisyydestä ja moraalisesta käyttäytymisestä. Luonnehdin aluksi lyhyesti, millainen evoluutionäkökulma ihmiseen on yleisellä tasolla, jonka jälkeen käsittelen muutamaa nykytieteessä vaikuttavaa tapaa tarkastella ihmistä evoluutionäkökulmasta. Lopetan pohdintoihin evoluutionäkökulman merkittävyydestä.

Jo aiemmin mainittiin se tilanne, johon mekanistinen maailmankuva ajoi ihmisen roolin osana maailmaa (4.2). Jos luonto oli lakien varassa toimiva mekanismi, se ei näyttänyt sallivan rationaalista, tuntevaa ja tahtovaa elämää. Näin ollen mekanistisen maailmankuvan sisällä operoivat ajattelijat usein korostivatkin, että ihminen on koostumukseltaan jollakin tavalla erilainen kuin eläimet tai eloton luonto. Ihmisen "hengen" tai sielun maailman ja luonnon maailman välillä oli katkos. Tällainen katkos alkoi Darwinin jälkeen menettää yhä enenevässä määrin uskottavuuttaan. Jo Darwinille itselleen ja hänen aikalaisilleen oli selvää, että jos evoluutio on oikea tapa ajatella luonnon alkuperää, niin tämän on pädettävä myös ihmiseen. Ihmislajilla on oltava yhteinen alkuperä muiden eläinlajien kanssa ja hänen anatomiset piirteensä ovat perua häntä ajallisesti edeltävistä elämänmuodoista. Darwin itse myöhemmässä tuotannossaan pyrki soveltamaan johdonmukaisesti evoluutionäkökulmaa ihmisen 
muihinkin kuin pelkästään anatomisiin ominaisuuksiin (Tunteiden ilmaisu ihmisillä ja eläimillä, The Expression of Emotions in Humans and Animals, 1872). Ihminen, hänen mielensä rakenne, hänen tunteensa ja käyttäytymisensä (ja joidenkin mielestä myös hänen yhteiskuntansa) voitiin nyt ymmärtää biologian tutkimuskohteena ja sitä kautta luonnollisen maailman osana.

Evoluutionäkökulma ihmiseen perustuu siihen yksinkertaiseen seikkaan, että ne mekanismit, jotka ovat synnyttäneet kaikki muutkin eläinlajit, ovat olleet mukana myös ihmislajin muotoutumisessa. Ihmisen sukupuun jäljittämisen keskeiset menetelmät ovat samat kuin minkä tahansa muunkin lajin: etsitään fossiiliaineistoa, tutkitaan anatomiaa vertaillen muihin lajeihin, tutkitaan yksilönkehitystä ja tutkitaan geenejä. Erityisesti viimeiseksi mainittu on osoittautunut erittäin tärkeäksi ihmisen historian jäljittämisen osalta. On nimittäin käynyt ilmi, että ihmisen genomi kantaa mukanaan suurta määrää informaatiota hänen evoluutionsa eri vaiheista ja on arvioitu, että ihminen jakaa DNA:an noin 99\% lähisukulaistensa, simpanssien ja gorillojen, kanssa.

Aiheemme kannalta kaikkein keskeisin kysymys on se, kuinka pitkälle evoluutionäkökulma ihmiseen vie. Toisin sanoen kysymys on se, kuinka paljon ja mitä tekijöitä evoluutionäkökulma voi ihmislajin osalta selittää. Darwin itse korosti sekä nykyihmisen jatkuvuutta että epäjatkuvuutta hänen lähisukulaistensa kanssa. Monet ihmisen anatomiset piirteet ovat suoralla jatkumolla näiden lähisukulaisten kanssa puhumattakaan 1900-luvulla ilmikäyneistä biologisista ja kemiallisista mekanismeista, joista Darwinilla ei vielä ollut tietoa. Mutta anatomiankin osalta nykyihmisellä on kaksi erityispiirrettä: pystykävely ja suuret aivot. Sen lisäksi, että nykyihmisen aivot ovat suurimmat koko tunnetussa eläinkunnassa (suhteessa ruumiin kokoon), ovat ne myös kaikkein monimutkaisimmat. Juuri aivot näyttäisivät mahdollistavan kaikkein keskeisimmät nykyihmisen muista eläimistä erottavat piirteet, joita ovat erityisesti symbolinen kommunikaatio eli kieli, kehittynyt itsetietoisuus, kyky abstraktiin ajatteluun, erittäin monimutkaiset sosiaaliset verkostot sekä kyky tallettaa 
ja välittää informaatiota. Kysymys siitä, missä määrin näitä piirteitä esiintyy muilla eläimillä, on monessa mielessä vielä auki ja tutkijat ovat erimielisiä. Viime vuosikymmeninä on saatu hyvin paljon uutta tietoa kädellisten käyttäytymisestä ja niiden kyvystä oppia ja ajatella. Tämä tieto on saanut monet ajattelemaan, että edellä mainitut kyvyt eivät ole ihmiselle mitenkään erityisiä, vaan ne ovat idullaan jo hänen lähisukulaisillaan. Toiset taas vastustavat tätä ja korostavat esimerkiksi gorillojen erittäin rajallisia kykyjä oppia symbolisen kommunikaation keinoja. Tämän näkemyksen mukaan ihmisten ja hänen sukulaistensa välillä olisi varsin suuria laadullisia eroja.

Tavallisesti ollaan oltu sitä mieltä, että vaikka monet homo sapiensin anatomiset ja rakenteelliset piirteet ovatkin samalla jatkumolla eläinkunnan kanssa, niin hänen mielensä ja kulttuurinsa tuotokset ylittävät biologisen evoluution rajat. Ihmisen kyky koodata tietoa ja välittää sitä eteenpäin sekä koordinoida sosiaalista käyttäytymistä sanalla sanoen: kulttuuri - on mahdollistanut biologisen evoluution näkökulmasta täysin poikkeuksellisten ilmiöiden syntymisen. Toisin sanoen siis luonnonvalinnan mekanismi on alkanut hellittää otettaan nykyihmisestä, joka esimerkiksi pystyy muokkaamaan omaa käytöstään hankitun ja välitetyn informaation perusteella. Hänen ei tarvitse odottaa, kunnes sopiva geneettinen mutaatio sattuu kohdalle, vaan hän voi käyttämällä hyväkseen aivojaan ja kommunikaatiota muokata käyttäytymistään hyvin nopeasti. Näyttää siis siltä, että biologinen evoluutio tuotti jotakin sellaista, joka pääsi livahtamaan irti luonnonvalinnan otteesta.

Ihmisen erityisyyden osalta varsin tärkeä kysymys on moraalin luonne ja alkuperä. Tämä on ollut Darwinin teorioiden kaikkein vaikeimmin nieltävä kohta jo yli sadan vuoden ajan. Tiedetään myös hyvin, että tämä kysymys oli Darwinille itselleen henkilökohtaisesti erittäin hankala. Kysymys liittyy myös siihen, kuinka paljon evoluutionäkökulma voi todella valottaa nykyihmisen moraalista käyttäytymistä. Darwinin näkemys oli erittäin karkeasti ottaen se, että nykyihmisen moraalinen käyttäytyminen on tulosta hänen evoluutiohistoriastaan. Ihmisen moraaliset tunteet, jotka Darwinin 
mukaan toimivat moraalisen käyttäytymisen motivaattoreina, liittyvät ihmisen evoluutioon sosiaalisena eliönä. Nämä tunteet ovat sopeumia: yksilöt, joilla oli tietynkaltaisia sosiaaliseen käyttäytymiseen liittyviä taipumuksia, kuten esimerkiksi jälkeläisten suojeleminen tai sukulaisten puolesta uhrautuminen, selviytyivät muita paremmin. Se, mikä tekee tästä näkemyksestä hankalan, on se, että moraali näyttää tästä näkökulmasta sattumanvaraiselta. Länsimaisessa perinteessä on ollut vahva taipumus kohti jonkinlaista moraalista realismia eli näkemystä, jonka mukaan oikea ja väärä, hyvä ja paha ovat jollakin tavalla osa maailman rakennetta. Evoluutionäkökulma näyttää kuitenkin johtavan siihen, että jos evoluutiohistoriamme olisi toisenlainen, niin olisivat myöskin moraaliset tunteemme toisenlaiset. Näin ollen syntyy se vaikutelma, että moraaliset tunteemme, kuten esimerkiksi tunne tappamisen tai sukulaisiin suuntautuvan seksuaalisen halun vastenmielisyydestä, voisivat olla toisenlaiset. Tämä tulos näyttää johtavan siihen, ettei ole olemassa mitään objektiivisesti oikeaa ja väärää käyttäytymistä, vaan oikean ja väärän käyttäytymisen normit vaihtelevat evoluutiohistorian mukaan. Tämä kysymys on aiheemme kannalta erittäin tärkeä ja palaamme siihen luvussa 8.2.

Käsittelen seuraavaksi erittäin lyhyesti kolmea erilaista nykytieteen evoluutionäkökulmaa ihmiseen. Kaikki nämä lähestymistavat korostavat sitä, että ihmisen evoluutiohistorialla on selittävää voimaa hänen nykyisen käyttäytymisensä, yhteiskunnallisten rakenteittensa ja kykyjensä osalta. Nämä näkökulmat ovat

(1) kulttuurievoluutio,

(2) sosiobiologia,

(3) evoluutiopsykologia.

Ennen itse asiaa varoituksen sana on kuitenkin paikallaan. Siinä missä evoluutiobiologian moderni synteesi ja sen perusvälineistö on erittäin hyvin vakiintunut tieteellisesti, ovat oheiset ihmiseen omaksutut evoluutionäkökulmat vielä alkutekijöissään. On monia, jotka kieltä- 
vät tällaisten evoluutionäkökulmien mahdollisuuden kokonaan. Haluan kuitenkin käsitellä näitä lähestymistapoja, koska ne ovat erittäin usein esillä keskusteltaessa tieteen ja kristinuskon suhteesta.

Kulttuurievoluutioteorioiksi (tai kulttuuridarwinismiksi) on tapana nimittää tutkimussuuntauksia, jotka soveltavat biologisen evoluution tutkimukseen suunniteltuja käsitteitä ja menetelmiä kulttuurin kehityksen tutkimukseen. Eräs esimerkki kulttuurievoluutioteoriasta Dawkinsin ja Susan Blackmoren memetiikka. Meemi-teorian mukaan voimme ymmärtää kulttuurin koostuvan geeneille analogisista yksiköistä, meemeistä. Meemejä voivat olla esimerkiksi erilaiset ideat, käyttäytymismallit ja kulttuurin fyysiset tuotteet, kuten erilaiset keksinnöt. Näiden erilaisten yksiköiden välillä tapahtuu sitten valintaa, jolloin toiset selviytyvät ja toiset häviävät. Ajan kuluessa ne meemit, jotka kopioituvat hyvin valtaavat valtaosan ihmismielistä ja syrjäyttävät meemit, jotka kopioituvat huonosti. Meemi-teoria on herättänyt runsaasti kritiikkiä ja se on monilta osin torjuttu kokonaan. Teorian keskeinen ongelma on se, että itse meemin käsite on hyvin vaikea muotoilla. Geenien osalta meillä on fysikaalinen perusta ja sen tunnetut mekanismit (DNA) mutta meemien osalta meillä ei ole mitään vastaavaa. Lisäksi meemi-teoria ei anna kuvausta siitä, millaiset mekanismit ohjaavat meemien valikoitumista. ${ }^{71}$

Enemmän positiivista vastakaikua sen sijaan on saanut toinen kulttuurievoluutioteoria, joka kulkee usein nimellä rinnakkaisevoluutioteoria (gene/culture co-evolution theory). Teoria liitetään erityisesti Robert Boydin ja Peter Richersonin teoksiin. ${ }^{72}$ Boydin ja Richersonin lähestymistapa eroaa memetiikasta erityisesti siinä, että he kiinnittävät huomionsa erilaisiin sosiaalisen oppimisen mekanismeihin ja niiden seurauksiin tiedonvälityksen kannalta. Siinä missä memetiikassa kulttuurievoluutio on kokonaan biologisesta evoluutiosta riippumaton prosessinsa, jossa meemien kopioitumisessa ei näytä olevan mitään lainalaisuuksia, rinnakkaisevoluutioteoriassa tarkastellaan ihmisen oppimiskykyjen ja tiedonvälityksen mekanismeja, jotka vaikuttavat informaation välittymiseen kulttuu- 
rissa. Olennaista rinnakkaisevoluutioteoriassa on se, että kulttuuri ja ihminen biologiset ominaisuudet ovat jatkuvassa vuorovaikutuksessa ja ovat oikeastaan kehittyneet rinnakkain. Ajatus on se, että käynnissä on kahdenlaista evoluutiota, kulttuurillista ja biologista, jotka ovat molemmat vuorovaikutuksessa keskenään mutta myös usein toisistaan riippumattomat. Opitut käyttäytymistavat voivat vaikuttaa biologiseen evoluutioon mutta biologinen evoluutio muovaa samanaikaisesti myös kulttuuria.

Darwinin ajatukset ihmisen moraalin evoluutiosta elävät yhä vahvasti tutkimussuuntauksissa, joita nykyisin kutsumme sosiobiologiaksi ja evoluutiopsykologiaksi. Termin "sosiobiologia" otti käyttöön Edward O. Wilson kirjassaan Sociobiology: The New Synthesis (1975). Eräs Darwinin keskeinen ongelma oli se, että luonnonvalinnan periaate näyttäisi johtavan siihen, että eläinmaailman yksilöt ovat jatkuvassa kamppailussa keskenään. Tarkastelemalla luontoa voimme kuitenkin helposti löytää esimerkkejä sosiaalisesta käyttäytymisestä, joka ei näytä tähtäävän yksilön selviämiseen vaan kokonaisten populaatioiden selviämiseen. Sosiobiologian keskeiseksi tehtäväksi katsottiin tämän ongelman ratkaiseminen. Lyhyesti sanottuna sosiobiologia on siis populaatioiden sosiaalisen käyttäytymisen ja selviytymistä edistävien vaikutusten tutkimista evoluutionäkökulmasta. Merkittävimmät läpimurrot tehtiinkin juuri erilaisten hyönteisten käyttäytymisen tutkimuksessa, ja Wilsonin kirjasta suurin osa onkin omistettu juuri tällaiselle tutkimukselle. Kirjan loppuluvussa Wilson kuitenkin laajentaa sosiobiologian näkökulman myös koskemaan ihmisen nykyistä käyttäytymistä ja muotoilee ohjelman, jossa inhimillinen kulttuuri ja erityisesti ihmisen erilaiset moraaliset instituutiot aina avioliitosta yhteiskuntarakenteisiin asti on tarkoitus selittää evoluutionäkökulmasta. Wilsonin ajatus on, että ihmisen nykyiset käyttäytymismallit ovat kaikki enemmän tai vähemmän sopeumia, joilla on vahva geneettinen perusta.

Ajatuksesta "ihmisen sosiobiologiasta" ja Wilsonin vahvasta retoriikasta syntyikin sittemmin 70- ja 80-lukujen kuuluisa sosiobiolo- 
gia-kiista, joka sai vahvasti poliittisia ja ideologisia sävyjä. Menemättä sen enempää itse kiistan poliittisiin ja ideologisiin ulottuvuuksiin voidaan sanoa, että siinä oli pohjimmiltaan kyse siitä, kuinka paljon evoluutionäkökulman katsotaan selittävän ihmisen nykyistä käyttäytymistä. Wilsonin vastustajien mielestä Wilson edusti geneettistä determinismiä kaikkein pahimmillaan, kun Wilson taas ajatteli olevansa vain viemässä loppuun jo Darwinin aloittamaa ohjelmaa ihmistieteiden ja ihmisen käyttäytymisen saattamisesta luonnontieteen piiriin. Kiistan suuruuteen vaikuttivat monet väärinymmärrykset, ylenpalttinen poliittinen retoriikka ja änkyrät persoonallisuudet. Vaikka tilanne on nykyisin paljon rauhallisempi ja monet kiistan osapuolet ovatkin lieventäneet näkemyksiään, niin vastakkainasettelu evoluutionäkökulman omaksuvien tutkijoiden ja sen vastustajien välillä ei ole hävinnyt kokonaan. Näemme yhä esimerkiksi antropologiassa, kulttuurintutkimuksessa ja uskontotieteessä vastakkainasettelua "biologistien" (jotka korostavat ihmisen biologista ja psykologista luontoa) ja "kulturalistien" (jotka puolestaan korostavat inhimillisen kulttuurin ja kielen vaikutusta) välillä. Varsin verisen kiistan seurauksena termi "sosiobiologia" on lähinnä kirosana monille niistä, jotka tutkivat ihmisen kulttuuria ja kehitystä.

Nykyisin on tapana kutsua niitä tutkimussuuntauksia, jotka tutkivat ihmismielen ja käyttäytymisen kehitystä evoluutionäkökulmasta evoluutiopsykologiaksi. Näin ollen myös monet niistä teorioista, jotka vielä 1980-luvulla esiteltiin ihmisen sosiobiologiana, ovat nyt - muutettavat muuttaen - osa evoluutiopsykologiaa. Evoluutiopsykologia ei kuitenkaan ole mikään yksittäinen teoria vaan poikkitieteellinen lähestymistapa ihmiseen, joka pyrkii yhdistämään evoluutionäkökulman muuhun psykologiseen, antropologiseen, sosiologiseen ja neurotieteelliseen tutkimukseen. Syy, miksi tätä pidetään tärkeänä, on se, että ihmismielen rakenteen ja evoluutiohistorian ajatellaan selittävän inhimillisen kulttuurin ja käyttäytymisen perusmuotoja myös nykypäivänä. Tärkein ero sosiobiologiaan on se, että evoluutiopsykologeilla ei ole tapana ajatella, että jotkut käyttäytymismuodot olisivat itsessään luonnonvalinnan tulosta. Luonnonvalinnan tulosta 
ovat ihmismielen mekanismit, jotka taas puolestaan tuottavat käyttäytymistä ja kulttuuria. Lähtökohtana on se, että mieli on kimppu erilaisen informaation käsittelyyn erikoistuneita järjestelmiä, jotka ovat syntyneet luonnonvalinnan seurauksena ratkaisemaan erilaisia ongelmia esi-isiemme keräilijäkulttuureissa. Nykyisissä kulttuureissa elävät ihmiset käyttävät aivojansa kuitenkin varsin eri tavalla kuin heidän esi-isänsä mutta aivojen perusrakenteet ovat kuitenkin samat. Ajatus on se, että nykykulttuurin muodot ovat ihmismielen evoluution sivutuotteita. ${ }^{74}$

Tämän alaluvun keskeinen kysymys on ollut se, kuinka pitkälle evoluutionäkökulma nykyihmiseen voi selittää. Esiin on tullut näkemyksiä, jotka voimme tiivistää seuraavalla tavalla:

(1) biologinen reduktionismi, jonka mukaan valtaosa (tai kaikki) nykyihmisen piirteistä ja käyttäytymisestä voidaan selittää darwinististen mekanismien pohjalta,

(2) antireduktionismi, jonka mukaan evoluutionäkökulma ei kerro meille oikeastaan mitään inhimillisestä käyttäytymisestä, kulttuurista tai yhteiskunnasta,

(3) pluralismi, jonka mukaan evoluutionäkökulma on yksi hyödyllinen tapa tarkastella ihmisen käyttäytymistä ja ominaisuuksia.

Biologista reduktionismia edustavat esimerkiksi Wilson itse sekä Dawkins ja se liittyy läheisesti siihen näkemykseen, jota aiemmin kutsuimme tieteelliseksi materialismiksi (luku 2.2); itse asiassa biologista reduktionismia voidaan pitää tämän näkemyksen yhtenä tärkeimpänä komponenttina. Ajatus on se, että evoluutionäkökulma ja tässä tapauksessa erityisesti ihmisen sosiobiologia pystyy antamaan kaikkein perimmäisimmän selityksen ihmisen käyttäytymiselle. Usein tässä yhteydessä puhutaan "ihmisluonnosta" ja siitä, kuinka tämä luonto on vain ja ainoastaan biologian tavoitettavissa. Näin ollen biologinen reduktionismi osa laajempaa tieteellistä ohjelmaa, jossa ihmistieteet, yhteiskuntatieteet ja psykologia tehdään osaksi biologiaa. ${ }^{75}$

Biologista reduktionismia taas vastustavat antireduktionistit, joi- 
den mukaan ihmisaivojen ja kulttuurin tuotteet ovat luonteeltaan sellaisia, että evoluutionäkökulma ja erityisesti sosiobiologia eivät pysty sanomaan niistä mitään. Ajatus on se, että inhimillinen käyttäytyminen sekä sen tuotteet ovat siinä määrin irrallisia biologisesta evoluutiosta ja niiden fysikaalisesta perustasta, eli aivoista, että psykologian tai yhteiskuntatieteiden "biologisoiminen" ei onnistu. Ihmisen käyttäytymistä määräävät biologian sijaan esimerkiksi erilaiset opitut normit ja jaetut tottumukset, joiden juuret ovat yhteiskunnallisissa rakenteissa ja ihmistenvälisissä sopimuksissa sekä ihmisten tietoisessa ajattelussa. Antireduktionistinen perinne elää yhä vahvasti monien psykologien ja yhteiskuntatieteilijöiden keskuudessa.

Näkemyksen, jota kutsumme tässä pluralismiksi, mukaan evoluutionäkökulma voi olla hyödyllinen tarkasteltaessa inhimillistä kulttuuria ja käyttäytymistä, mutta ei suinkaan ainoa mahdollinen. Tämän näkemyksen mukaan ihminen on biologinen olio mutta myös paljon muuta: on totta, että biologia on ennen psykologiaa ja yhteiskuntaa mutta biologia ei selitä kumpaakaan tyhjentävästi. Tällainen pluralisti siis vastustaa sekä biologista reduktionismia mutta tunnustaa samaan aikaan, että antireduktionismi on liian ankara kanta: evoluutionäkökulman ei tule redusoida muita tieteitä itseensä mutta se voi olla hyödyllinen eri ihmistieteen aloilla.

Palaamme tässä alaluvussa käsiteltyihin teemoihin tarkemmin luvussa 8.2.

\section{$5 \cdot 3$}

\section{IHMISMIELI: SIELUSTA AIVOIHIN}

Kuten jo edellisessä alaluvussa näimme, ihmistieteet, yhteiskuntatieteet ja psykologia eivät ole säästyneet evoluutiobiologian vaikutukselta. Näimme myös, että tällaiselle kehitykselle on suhteellisen hyviä perusteita. Evoluutionäkökulma ihmiseen osana luontoa on poikinut myös uudenlaisia näkökulmia ihmisen psykologiaan ja 
hänen kehitykseensä. Erityisesti sotien jälkeen on avautunut aivan uudenlaisia näkökulmia, jotka ovat tulosta massiivisesta kehityksestä erityisesti aivotutkimuksen ja ihmisen tiedonkäsittelyn tutkimuksen saralla. Käsittelen seuraavaksi kahta tällaista tutkimussuuntausta, jotka ovat aiheemme kannalta tärkeitä. Ne ovat

(1) neurotiede, joka on biologinen tiede ja tutkii ihmisen keskushermoston ja aivojen toimintaa,

(2) kognitiotiede ja erityisesti kognitiivinen psykologia, jotka ovat poikkitieteellisiä aloja ja tutkivat ihmisen tiedonkäsittelyn järjestelmiä (havainto, oppiminen, muisti, päättely)

Tässä luvussa olemme erityisesti kiinnostuneita siitä, mitä näiden tutkimussuuntausten pohjalta voidaan päätellä ihmismielen (perinteisesti "sielun") suhteesta ruumiiseen ja sen toimintaan. Näiden alojen kehitys viittaa vahvasti siihen, että ihmismielen kyvyt, kuten järki, tahto ja tietoisuus, ovat tulosta fysikaalisten järjestelmien, lähinnä aivojen, toiminnasta.

Kuten aiemmin kävi jo ilmi, valtaosa mekanistisen maailmankuvan vaikutuspiirissä eläneistä ajattelijoista korosti ihmismielen ja luonnon maailman erilaisuutta. Ihmisen ajateltiin olevan pohjimmiltaan aineeton sielu, kun taas luonnon katsottiin koostuvan fysikaalisista mekanismeista. Maailma voitiin näin ollen jakaa kahtia: aineellisiin asioihin eli asioihin, joilla on ulottuvuus tilassa ja ajassa (lat. res extensa) ja ajatteleviin asioihin (lat. res cogitans), joilla taas tällaisia ulottuvuuksia ei ole. Edeltävään joukkoon kuuluu koko mekanistinen luonto aina ihmisruumiista eläimiin ja kiviin asti, kun taas jälkimmäiseen joukkoon laskettiin ihmismielet, enkelit ja Jumala. Tällaista näkemystä on tapana kutsua "substanssidualismiksi" ja sen tunnetuin muotoilija oli filosofi ja tiedemies René Descartes (1595-1650). Jonkinlainen dualismi sielun ja ruumiin välillä oli standardinäkemys aina 1600-luvulta eteenpäin, vaikka muutamia materialistejakin esiintyi. Ongelma materialistien kannalta oli se, että heillä ei juuri ollut välineitä selittää, miten ajattelu, havainnot ja päättely 
voisivat olla jonkinlaisen fysikaalisen järjestelmän toimintoja.

On tärkeä huomata, että substanssidualismi siinä muodossa, kun Descartes ja monet muut uuden ajan ajattelijat sen muotoilivat, ei ole mahdollista ennen mekanistista maailmankuvaa. Keskiaikaiset ajattelijat puhuivat kyllä sielusta, mutta tämä näkemys ei välttämättä ollut substanssidualismia siinä mielessä kuin Descartesilla. Tämä johtuu siitä, että sekä antiikin filosofiassa että keskiajalla ei ollut samanlaista käsitystä materiasta kuten 1600-luvulla ja siitä eteenpäin. Kuten jo antiikin filosofiassa, keskiajalla esiintyy kaksi teologista traditiota:

(1) Augustinuksen platonistinen ja dualistinen traditio, jonka mukaan ihminen koostuu kuolemattomasta sielusta, joka on sidottu kuolevaan ruumiiseen.

(2) Tuomas Akvinolaisen aristoteelinen ja hylomorfinen traditio, jonka mukaan ihminen sielu on ihmisruumiin muoto.

Augustinuksen platonismin mukaan ihmissielu koostuu kolmesta osasta, joista korkein on järkisielu. Platonin mukaan ihmisen järkisielulla on oltava yliluonnollinen alkuperä, koska se pystyy saamaan tietoa ikuisista ideoista. Saman ajatuksen omaksuu myös Augustinus siirtämällä sen kristilliseen viitekehykseen: Jumala luo yksittäiset ihmissielut ja valaisee niiden ymmärryksen. Sielun ja ruumiin välillä on tämän käsityksen mukaan selkeä ero ja ruumiin kuollessa sielu, joka on yhtä kuin persoona itse, voi jäädä henkiin. Augustinuksen platonismi edusti hänen jälkeensä teologian ja filosofian valtavirtaa. Tuomaan käsitys sen sijaan perustuu Aristoteleen hylomorfiseen näkemykseen sielun ja ruumiin suhteesta. Ajatus on se, että kaikki aineelliset oliot muodostuvat kahdesta elementistä, muodosta (lat. forma) ja aineesta (lat. materia). Muoto on prinsiippi, joka antaa kullekin aineelliselle kappaleelle sille ominaiset kyvyt ja taipumukset. Ihmissielu ei ole tämän näkemyksen mukaan sen enempää kuin ihmisruumiin muoto, joka antaa sille ne kyvyt, jotka erottavat hänet eläimistä (kieli, ajattelu, järki, jne.). Tuomas käyttää kielikuvaa: jos 
ihmisruumis on silmä, niin sen sielu on näkeminen. Ihmissielu on siis paljon lähempänä jonkinlaista elämän prinsiippiä kuin mitään ruumiista irrallaan olevaa aineetonta olemusta. Mutta jos näin on, muodostuu kuolema Tuomaalle ongelmaksi: sielulla ei varsinaisesti ole persoonallista identiteettiä vaan se on ainoastaan ruumiin ja sielun kokonaisuudella. Nykyisessä filosofisessa keskustelussa on Tuomaan suuntaisia näkemyksiä ollut tapana kutsua kompositionaalisiksi, koska niissä ihminen on kahden toisiinsa kietoutuneiden elementtien (sielu ja ruumis) komposiitti.

Kummankaan keskiaikaisen näkemyksen sisällä ei kuitenkaan esiintynyt substanssidualismille tyypillistä ongelmaa, joka koski sielun ja ruumiin vuorovaikutusta. Jos sielu ymmärretään aineettomaksi ja ruumis taas osaksi mekanistista luontoa, niin miten jokin aineeton olemus voi vaikuttaa mekanistiseen järjestelmään. Kyseessä on yksi kaikkein kuuluisimpia filosofisia ongelmia, "mieli-ruumis" ongelma, joka koskee ruumiin ja sielun vuorovaikutusta. Ratkaisuja oli periaatteessa neljää tyyppiä:

(1) Dualistinen interaktionismi, jonka mukaan sielun ja ruumiin välillä on kaksisuuntainen, vaikkakin mystinen, vaikutus.

(2) Materialismi, jonka mukaan sielu/mieli voi vaikuttaa ruumiiseen, koska sielu/mieli koostuu aineesta samoin kuin ruumis.

(3) Epifenomenalismi, jonka mukaan sielu/mieli ei vaikuta ruumiiseen mutta ruumis sen sijaan vaikuttaa mieleen.

(4) Idealismi, jonka mukaan sielu/mieli pystyy vaikuttamaan ruumiiseen, koska kaikki aine on pohjimmiltaan osa sielua (henkeä).

Descartes itse ei pystynyt kehittämään toimivaa ratkaisua tähän ongelmaan, ja hänen kriitikkonsa eivät unohtaneet huomauttaa tästä. Ne, jotka halusivat pitää kiinni substanssidualismista, kehittivät erilaisia ratkaisuja, joilla puolustaa interaktionismia. Georg Wilhelm Leibniz esimerkiksi ehdotti, että ajattelevien asioiden ja aineen välillä vallitsee Jumalan luomisessa asettama harmonia. Näin ollen sielun ja ruumiin välillä ei tarkkaan ottaen ole minkäänlaista vuoro- 
vaikutusta: sielu aiheuttaa sielullisia asioita ja ruumis fyysisiä asioita. Jumala on kuitenkin virittänyt nämä kaksi toimimaan niin, että niiden välillä ikään kuin olisi interaktiota.

Toinen mahdollinen ratkaisu on hylätä dualismi kokonaan ja väittää, että ihmismieli ei ole mitään muuta kuin aivojen tai jonkin muun fysikaalisen järjestelmän toimintaa. Tätä kantaa on tapana kutsua materialismiksi. Materialismin sisällä ongelma katoaa, koska sielu ja mieli eivät ole ruumiista erillisiä toimijoita. Materialismi synnyttää kuitenkin toisenlaisen ongelman: jos sielu/mieli on pelkkää ainetta ja ainetta ohjaavat fysikaaliset lainalaisuudet, niin mieli ei näytä vaikuttavan yhtään mihinkään. Tästä seuraa kanta, jota on tapana kutsua epifenomenalismiksi (epifenomeeni = sivutuote). Tämän näkemyksen mukaan sielu ja mieli ovat materian sivutuotteita: sielu ja mieli eivät vaikuta ruumiiseen eivätkä mihinkään muuhunkaan aineelliseen mutta ruumis kyllä vaikuttaa mieleen. Mieli on näin ollen ruumiin sivutuote eikä mitään muuta. Viimeinen mahdollisuus on idealismi, jonka mukaan aineella ei ole itsenäistä olemusta ollenkaan, vaan se on viime kädessä osa sielua tai henkeä.

Vaikka sekä idealismilla (esim. George Berkeley 1685-1753) ja materialismilla (esim. Thomas Hobbes 1588-1679) on ollut kannattajansa, on länsimainen valtavirta Descartesin jälkeen puolustanut jonkinlaista dualismia. Tämä tilanne alkoi kuitenkin muuttua 1800-luvun lopussa ja 1900-luvun alussa, jolloin alettiin kiinnittää yhä enemmän huomiota mielen ja aivojen läheiseen yhteyteen esimerkiksi aivovammojen yhteydessä. Lisäksi biologian, ihmisen anatomian ja psykologiatieteen (alkuaan "sielutiede") synty vaikuttivat kehitykseen merkittävästi. Tähän samaan vaakakuppiin myös nykyaikaiset kognitiotieteet ja neurotieteet ovat asettaneet omat painonsa.

Neurotiede on poikkitieteellinen tutkimusala, joka tutkii ihmisen hermojärjestelmän biokemiaa, toimintaa, rakennetta ja syntyä biologian ja lääketieteen keinoin. Välineitä etsitään niin genetiikasta, aivojen sairauksien ja vammojen tutkimuksesta (neurologia), hermosolujen kokeellisesta tutkimuksesta ja biokemiasta. Ihmisen keskushermostoa ohjaavat aivot, joilla on hyvin moninaisia tehtäviä. 
Suurin osan aivojen toiminnasta ja tehtävistä tapahtuu tietoisuuden ulkopuolella: aivot esimerkiksi ohjaavat ruumiin liikkeiden koordinaatiota ja ihmisruumiin elinten toimintaa autonomisen hermoston välityksellä. Yksittäisissä aivoissa on noin 100 miljardia hermosolua, joilla kullakin on yhteys noin 10000 toiseen hermosoluun. Juuri erilaisten mielen toimintojen, kuten kielikyvyn, havaintojärjestelmien ja tunteiden osalta, on neurotieteissä saavutettu merkittävää edistystä viimeisen 30 vuoden aikana. Neurotieteen peruslähteinä olivat pitkään lähinnä kliininen tieto aivovaurioista ja kuolleiden aivojen anatomia. Kun oivallettiin, että aivojen toiminta perustuu sähköimpulsseille, alettiin tätä mittaamaan ihon lävitse (EEG) ja näin saatiin ensimmäinen väylä toimivien aivojen tutkimukseen. Viimeisen 30 vuoden aikana erilaiset aivokuvantamismenetelmät, kuten aivojen magneettikuvaus, ovat avanneet yhä suuremman ikkunan toimivien aivojen maailmaan, mikä on puolestaan johtanut neurotieteiden räjähdysmäiseen kehitykseen.

Jos neurotiede pyrkii hermosolujen tasolta "ylöspäin" kohti mielen toimintoja, pyrkivät kognitiotieteet taas selittämään nimenomaan mielen toimintoja kuten havaintojärjestelmiä, kielen toimintaa, muistia ja ajattelua. Kognitiotieteiden voidaan katsoa olevan löyhä joukko tutkimusaloja, joita ovat esimerkiksi kognitiivinen psykologia, kognitiivinen lingvistiikka (kielitiede), tietojenkäsittelytiede, tekoälytutkimus, filosofia, kognitiivinen antropologia ja kognitiivinen neurotiede. Kognitiotieteen perusajatuksena on se, että ihmisen toimintaa voidaan tarkastella ja selittää tutkimalla ihmisen mielessä tapahtuvia tiedonkäsittelyn prosesseja. Idea on se, että varsin rajatulla määrällä tiedonkäsittelyn toimintoja, voidaan tuottaa suuri määrä erilaisia toimintoja ja käyttäytymistä. Kognitiotieteen historia voidaan jakaa "klassisen kognitiotieteen paradigman" vaiheeseen 1950-1980 -luvuilla ja kognitiotieteen "uuteen aaltoon" 1980-1990 -luvuilla. Klassinen kognitiotiede piti sisällään jäsennellyn teorian ihmismielen luonteesta ja toiminnasta. Uusi aalto taas perustuu klassisen kognitiotieteellisen ajattelun kritiikkiin eikä edusta mitään kovinkaan yhtenäistä ajattelutapaa, vaan on avoin 
monille erilaisille taustanäkemyksille. ${ }^{76}$

Kognitiotieteiden juuret ovat tietojenkäsittelyjärjestelmien kehityksessä 1950-luvulta eteenpäin, jolloin juuri kehittyneistä tietokoneista tuli suosittu analogia sille, miten ihmismieli toimii. Erittäin karkeasti ottaen klassisen kognitiotieteen idea oli se, että ihmismieli on tietokone, jonka fysikaalisena perustana ovat ihmisaivot. Tätä ajatusta kutsutaan usein "tietokonemetaforaksi". Vaikka ihmismieli onkin ankkuroitunut aivoihin, on se kuitenkin pohjimmiltaan tiedonkäsittelyä. Tiedonkäsittely puolestaan on periaatteessa irrallinen aineellisesta perustastaan: ei ole väliä sillä, millaisista materiaaleista tiedonkäsittelyjärjestelmä periaatteessa rakennetaan. Jos siis tietokonemetafora pitää paikkansa, on periaatteessa mahdollista rakentaa täydellinen tekoäly, mieli tietokoneessa. Perinteiseen kognitioajatteluun sisältyvät usein myös "modulaarisuus" ja "nativismi", jotka tulivat jo lyhyesti esille edellisessä luvussa evoluutiopsykologian yhteydessä. Perusajatus on se, että ihmismieli ei ole pelkästään tietokone, vaan hyvin suuri joukko pieniä tietokoneita, joita yleensä kutsutaan moduuleiksi. Jokaisella moduulilla on oma tehtävänsä, kuten esimerkiksi liikkeentunnistus, ja jokainen moduuli käsittelee vain tämän tehtävän kannalta tärkeää informaatiota muista moduuleista riippumatta. Nativismi, joka yleensä liitetään modulaarisuuteen, on puolestaan ajatus, jonka mukaan nämä moduulit ovat jollakin tavalla synnynnäisiä tai ainakin hyvin varhain ja kulttuurista riippumatta kehittyviä. Evoluutiopsykologiassa tämä tietysti yhdistyy ajatukseen siitä, että kukin moduuli on luonnonvalinnan tulosta ihmisen esihistoriallisessa ympäristössä. Perinteisen kognitioajattelun mukaan siis ihmismielen toiminnot ovat samat kulttuurista riippumatta.

Neurotieteellisen tiedon kuitenkin yhä kasvaessa 1980-luvulla tietokonemetafora joutui yhä kovemman kritiikin kohteeksi. Tietokonemetaforan mukaan ihmismielen toimintaperiaate on sama kuin tietokoneen eli symbolien prosessointi sarjassa. Väitettiin kuitenkin, että tämä periaate ei ole aivojen tasolla uskottava ja että aivot toimivat pikemminkin eräänlaisena hermoverkkona, joka kokonai- 
suutena tallentaa ja käsittelee tietoa. Tämän "konnektionismin" mukaan ihmisen mieli koostuu erilaisista hermoverkostoista ja niiden välisistä yhteyksistä. Ajatusprosessit eivät ole symbolijonojen manipulaatiota, vaan ne toteutuvat erilaisissa hajautetuissa verkostoissa. Nykyisin konnektionismi sekä jonkinlainen tietokonemetafora elävät rinnakkain eikä niitä nähdä ainakaan räikeässä ristiriidassa. Koko kognitiotieteen keskeisin kysymys on nyt se, mitä tapahtuu sillä rajapinnalla, kun siirrytään neurofysiologiasta ja aivotiloista kognitiivisiin prosesseihin. Tätä rajapintaa tutkii nykyisin erityisesti kognitiivinen neurotiede.

Neurotieteen ja kognitiotieteen kehitykseen ei ole tämän enempää enää syytä mennä. Halusin lähinnä antaa lukijalle pienen maistiaisen siitä, mitä on tekeillä. Olennaista aiheemme kannalta on se, että neurotieteiden ja kognitiotieteiden kehitys tekee yhä uskottavammaksi ajatella, että ettei ole olemassa aineetonta sielua, joka suorittaa ihmismielen toiminnot. Ihmisen "sielunkyvyt" ovat itse asiassa aivojen toimintojen mahdollistavia ominaisuuksia. Tämä varsin radikaali muutos dualismista erilaisiin materialismin muotoihin on tapahtunut alle sadassa vuodessa ja erityisesti 1900-luvun jälkipuoliskolla. Materialismia löytyy nykyään montaa eri muotoa mutta niitä kaikkia yhdistää ajatus jonkinlaisesta "supervenienssistä" eli "päältävyydestä": mielen tiloissa ei voi tapahtua muutoksia, jos muutosta ei tapahdu samaan aikaan jossakin aivotilassa. Järjestyksessä ankarimmasta kohti kevyempää erilaisia nykyaikaisen materialismin versioita ovat esimerkiksi

(1) Eliminatiivinen materialismi, jonka mukaan mieltä ei ole ollenkaan olemassa, vaan ainoastaan aivojen toimintaa.

(2) Reduktiivinen materialismi (identiteettiteoria), jonka mukaan mielen toiminta on yhtä kuin aivojen toiminta.

(3) Non-reduktivinen materialismi, jonka mukaan mielen toiminta perustuu aivojen toiminnalle mutta mieli ei ole identtinen aivojen kanssa.

(4) Kaksoisaspektiteoria, jonka mukaan mielen toiminta on aivojen 
toimintaa mutta kuvauksia mielen ja aivojen toiminnasta ei voida palauttaa toisiinsa.

Eliminatiivista materialismia on edustanut lähinnä neurotieteilijä/ filosofipariskunta Paul ja Patricia Churchland. Vaikka heidän kantansa on herättänyt paljon keskustelua, se ei ole kuitenkaan saanut montaakaan kannattajaa, koska se vaikuttaa niin äärimmäiseltä. Perusajatus on se, että mieltä ei ole laisinkaan olemassa ja kaiken sen, minkä katsoisimme kuuluvan psykologian alaan, tulee tulevaisuudessa selittämään neurotiede. Tämäkään ei kuitenkaan riitä vielä eliminatiiviselle materialistille vaan hän väittää, että jopa arkiset mentaaliset käsitteemme eli käsitteet, jotka viittaavat mielentiloihin, kuten uskomuksiin, haluihin tai ajatuksiin, tullaan tulevaisuudessa korvaamaan puheella aivotiloista. ${ }^{77}$

Reduktiivisen materialismin edustajat taas eivät kannata mielen eliminoimista vaan redusoimista aivotiloihin. Tässä on jo huomattava ero. Reduktio tässä yhteydessä viittaa siihen, että mielen katsotaan olevan identtinen aivojen kanssa, mitä taas puolestaan kutsutaan identiteettiteoriaksi. Identiteettiteorian mukaan jokainen mielentila on yhtä kuin sitä vastaava aivotila. Tämä ajatus viittaisi siihen, että jokaisella mielentilalla on jokin tietty paikka aivoissa ja jokin juuri sille ominainen aivotila. Nämä oletukset ovat osoittautuneet hyvin ongelmallisiksi useasta syystä. On osoittautunut hyvin hankalaksi "paikallistaa" mielentiloja aivoissa. Voimme kyllä yhdistää jotkut toiminnot joihinkin aivojen osiin mutta yksittäisten mielentilojen ja aivotilojen välistä linkkiä on lähes mahdoton osoittaa. Tämä on johtanut monet hylkäämään reduktiivisen materialismin.

Reduktiivista materialismia suositumpia ovatkin olleet erilaiset non-reduktiivisen materialismin muodot. Non-reduktiiviset materialistit hylkäävät ajatuksen siitä, että jokaista mielentilaa vastaisi aina jokin tietynlainen aivotila. Sen sijaan he väittävät, että jokaista mielentilaa vastaa jokin aivotila mutta ei välttämättä aina sama tai samanlainen aivotila. Erilaiset non-reduktiivisen materialismin muodot saavuttivat filosofiassa standardinäkemyksen aseman 
1980-luvulla. Eräs näistä on Donald Davidsonin kanta, jonka mukaan mielentilat ovat kyllä aivojen tiloja, mutta me emme pysty koskaan linkittämään sitä, mitä tiedämme aivotiloista, mielentiloihin ja puheeseen niistä. Vaikka voisimmekin saada täydellisen fysikaalisen kuvauksen aivotiloista, emme voi kuitenkaan saada vastaavankaltaista lainomaista kuvausta mielentiloista. Mieli on tällöin varsin poikkeuksellinen olio, anomalia. Tästä kannan nimitys anomaalinen monismi (engl. anomalous monism). Toinen mahdollisuus on perinteisten kognitiotieteilijöiden suosima funktionalismi, jonka mukaan mielentilat ovat tiloja, joilla on tietty kausaalinen rooli. Idea on se, että mielentiloilla on sekä vaikutuksia että syitä. Esimerkiksi kivulla polvessa voi olla useita syitä ja sen vaikutuksena voi olla esimerkiksi valittelua ja muuta kipukäyttäytymistä. Mielentilat ovat osia tällaisten syiden ja vaikutusten verkostoa. Olennaista on kuitenkin se, että mielentila on tyhjentävästi kuvattu, kun sen syiden ja seurausten verkosto on kuvattu. Esimerkiksi kiputilalla ei siis ole sen enempää "sisältöä" tai "tunnetta" kuin sen syyt ja vaikutukset. Funktionalismi ja tietokonemetafora ovat kulkeneet yhdessä niin läheisesti, että toisinaan on tapana puhua "tietokonefunktionalismista". Kolmas tapa ymmärtää non-reduktiivinen materialismi on eräänlainen emergenssi (ks. luku 4.3), jonka mukaan mieli on jotain sellaista, joka kyllä koostuu aivojen toiminnoista mutta jota kuitenkaan ei pystytä kuvaamaan aivojen tasolla. Mielellä on omat lakinsa ja lainalaisuutensa, joita voidaan analysoida riippumatta aivojen fysikaalisista tiloista, joista mieli koostuu. Palaamme tähän myöhemmin (ks. luku 8.1), koska tällainen tapa ymmärtää non-reduktiivinen materialismi on ollut varsin suosittu monien teologien keskuudessa.

Lopulta voimme puhua myös kaikkein löyhimmästä materialismin muodosta, kaksoisaspektiteoriasta. Tämän teorian mukaan mielen toiminta perustuu aivojen toimintaan mutta emme voi millään tavalla palauttaa kuvauksia toisesta kuvauksiin toisesta tai selittää jompaakumpaa toisella. Tältä osin kaksoisaspektiteoria on varsin lähellä Davidsonin monismia. Kaksoisaspektiteoriaa voidaan tulkita niin, että mielen ja aivojen suhde jää meille ehkä lopullisesti 
mysteeriksi. Esimerkiksi filosofi Colin McGinnin edustamaa "mysterianismia" voidaan pitää kaksoisaspektiteorian yhtenä muotona. McGinnin mukaan meidän tulee uskoa, että mieli ja erityisesti tietoisuus ovat kyllä jotain sellaista, jotka tapahtuvat aivoissa, mutta me emme voi koskaan tietää, miten tietoisuus on suhteessa aivoihin. Näin ollen tietoisuus jää meille lopullisesti mysteeriksi (tästä nimitys "mysterianismi"). ${ }^{78}$

Olemme tässä luvussa käyneet läpi kehitystä, joka on johtanut kristillisen teologian ja antiikin filosofian inspiroimista sielu-ruumis dualismin muodoista uuden ajan substanssidualismiin ja siitä edelleen kohti 1900-luvun materialismia. Erikoista tässä kehityksessä on ollut sen kehällisyys: perinteisten näkemysten mukaan sielu oli enemmän tai vähemmän osa luontoa ja ihmisruumista, 1600-luvulta eteenpäin dualismi leikkasi sielun irti ruumiista ja luonnosta, mutta viimein 1900-luvulla sielu palasi osaksi ihmisruumista, aivoja ja luontoa. Nykykäsityksen mukaan ihmismieli on siis osa luontoa, vaikkakin hyvin erikoinen osa sitä, ja valtaosa tieteilijöistä ja filosofeista on sitä mieltä, että ihmismielen toimintojen selittämiseksi ei tarvita mitään yliluonnollista. Jatkossa tärkeä seikka tarkastelemassamme kehityksessä on mielen ja maailman sekä mielen ja aivojen dualismin murtuminen 1900-luvulla. Mekanistit jakoivat maailman yksinkertaisesti ajatteleviin aineettomiin asioihin ja fysikaalisiin mekanismeihin. Mieli eristettiin aivoista, ruumiista ja luonnon maailmasta. Tällainen erottelu henkisen mielen ja fysikaalinen maailman välillä on nykyään varsin hankalasti puolustettavissa, koska käsityksemme fysikaalisen maailman luonteesta ja toiminnoista on muuttunut varsin suuresti mekanistien ajoista ja koska meillä on nyt hyvin paljon todistusaineistoa mielen toimintojen ja aivojen toimintojen läheisestä suhteesta. 


\section{$5 \cdot 4$}

\section{SELITTÄMINEN JA LUONNON TASOT}

Ennen kuin siirrymme käsittelemään tarkemmin teologian ja biologian mahdollisia ristiriitoja ja yhtäläisyyksiä sanon vielä muutaman sanan siitä käsityksestä luonnosta, joka meille evoluution ja uusien mielen tieteiden pohjalta nousee. Käsittelimme jo lyhyesti uuden fysiikan käsitystä kerroksellisesta luonnosta ja sen kokonaisvaltaisista prosesseista (ks. luku 4.3). Tässä luvussa jatkan lyhyesti tätä keskustelua.

Biologinen reduktionismi on aiemmin mainittua (ks. luku 4.2) atomismia ja reduktiivista selittämistä vastaava asenne biologiassa. Monet klassisen fysiikan kannattajat ajattelivat, että kaikki luonnon tapahtumat voidaan selittää tyhjentävästi vetoamalla luonnon pienimpien osasten, atomien, käyttäytymistä ohjaaviin yleisiin lakeihin. Toisin sanoen kaikki tieteellinen selittäminen perustuu siihen, että selitettävän kohteen toimintamekanismi puretaan yhä pienempiin ja pienempiin osiin, kunnes päästään kaikkien pohjimmaiselle tasolle, fysiikan tasolle. Biologinen reduktionismi on eräs versio tällaisesta selittämisestä: sen mukaan kaikki eliöiden ominaisuudet, kyvyt, taipumukset ja käyttäytyminen voidaan selittää evoluutiobiologian välineillä ja palauttaa biologian tutkimiin mekanismeihin. Biologiseen reduktionismiin kuuluu myös oletus, että biologiset mekanismit voidaan puolestaan selittää kemiallisilla mekanismeilla ja nämä taas palautuvat fysiikan tutkimiin perusmekanismeihin.

Ennen kuin voimme mennä eteenpäin on selvennettävä joitakin peruskäsitteitä. Termi "reduktio" on erittäin yleinen sekä filosofisissa keskusteluissa että tieteen ja teologian suhteesta keskusteltaessa ja sitä käytetään usein vastustajista ja negatiivisessa merkityksessä sen enempää tarkentamatta. Tämä on virhe ja sotkee keskustelua turhaan, sillä reduktiolla voidaan tarkoittaa useita eri asioita, joista monet ovat täysin perusteltuja ja toiset taas eivät. Reduktiolla voidaan tarkoittaa ainakin 
(1) menetelmällistä reduktiota, jossa tietoisesti rajataan ja yksinkertaistetaan tutkittavaa kohdetta ja siihen vaikuttavia tekijöitä,

(2) tiedollista reduktiota eli teoriareduktiota, jonka mukaan jokin tieteellinen teoria voidaan johtaa jostakin toisesta (yleensä perustavammasta) teoriasta,

(3) ontologista reduktiota, jonka mukaan jokin luonnossa olevien olioiden luokka voidaan osoittaa olevan osa jotain toista (yleensä perustavampaa) olioiden luokkaa.

Menetelmällinen (tai metodologinen) reduktio on hyvin perusteltu ja hyväksytty käytäntö tieteellisessä tutkimuksessa. Tapa on niin yleinen, että siihen hyvin harvoin edes viitataan "reduktiona". Maailma on lähes äärettömän monimutkainen ja ihmismielen kyvyt ovat rajalliset. Kun tutkimme maailmaa, on meidän rajattava yksittäisten tutkimuksemme ulkopuolelle monia erilaisia tekijöitä, joilla voisi olla tai on vaikutusta tutkimuskohteeseemme. Eräs tapa panna toimeen tällainen menetelmällinen reduktio on keskittyä tutkimaan kohteen rakenneosia ja niiden toimintaa tai ajatella kohdetta riippumattomana ympäristötekijöistä. Menetelmällinen reduktio on varsin tavallinen erityisesti fysikaalisissa tieteissä ja voidaan väittää, että se on ollut yksi merkittävä menetelmällinen avain luonnontieteiden edistyksessä. Näin ollen voidaan sanoa, että erityisesti luonnontieteitä (ja myös muita tieteitä) luonnehtii yksinkertaistaminen: käytetään yhä tiiviimpiä ja yleisempiä periaatteita selittämään yhä monimutkaisempien olioiden käyttäytymistä ja prosessien toimintaa.

Siinä, missä erilaiset menetelmällisen reduktion muodot voidaan ymmärtää osaksi tieteellisiä menetelmiä, on teoriareduktio jotain sellaista, jonka osapuolina ovat tieteelliset teoriat. Teoriareduktion mukaan reduktio on suhde kahden teorian välillä: teorian A termit, lait ja yleiset periaatteet voidaan johtaa teorian B termeistä, laeista ja yleisistä periaatteista. Ajatus on tavallisesti se, että "korkeamman tason" teoriat voitaisiin palauttaa tähän tapaan "alemman tason" teorioihin. On esimerkiksi väitetty, että näin toimitaan, kun kaasujen tilavuutta ja painetta koskevat lainalaisuudet johdetaan molekyylien 
käyttäytymistä koskevista mekaanisista laeista. Siitä huolimatta, että teoriareduktio oli 1900-luvun alkupuolella suosittu tieteenfilosofien keskuudessa, on se kuitenkin nykyisin laajasti hylätty. Syy on yksinkertainen: yhtäkään hyvää esimerkkiä kunnolla suoritetusta teoriareduktiosta ei ole pystytty tuottamaan. Teoriareduktion ajatuksen esittivät alun perin jo aiemmin käsittelemämme loogiset positivistit osana tieteen yhtenäisyyden vaatimusta (luku 3.4), ja positivismin haaksirikko johti lopulta myös teoriareduktion hylkäämiseen.

Ontologinen reduktio ei ole suhde tieteellisten teorioiden välillä, vaan maailman olioiden tai prosessien välillä. Ajatus on usein se, että jonkin olion tai olioiden luokan ajatellaan olevan itse asiassa jotakin muuta. Voidaan esimerkiksi väittää, että eliöt ovat itse asiassa vain atomien joukkoja tai että mielentilat ovat vain aivotiloja. Toisinaan ontologisen reduktion yhteydessä puhutaan hieman kieli poskella "vain ja ainoastaan reduktionismista". Usein tämänkaltaiset reduktionistit sanovat esimerkiksi, että "mieli on vain ja ainoastaan aivojen toimintaa", "minuus on vain ja ainoastaan hermosolujen toimintaa" tai "moraali on vain ja ainoastaan moraalisia tunteita, jotka ovat puolestaan vain ja ainoastaan luonnonvalinnan tuotteita". Kysymys siitä, onko onnistuneita ontologisia reduktioita olemassa, on vaikea ja monimutkainen tieteellinen ja filosofinen kysymys. Monet tieteelliset ja filosofiset kiistat ovatkin juuri kiistoja siitä, miten joidenkin olioiden ja niiden luokkien väliset suhteet tulisi ymmärtää. Keskeinen ongelma on kuitenkin se, että monet kirjoittajat liukuvat hyvin nopeasti menetelmällisestä reduktiosta ontologiseen reduktioon. Näin näyttää tapahtuvan erityisesti biologisessa reduktionismissa. Francis Crick kirjoittaa

Voimme toivoa, että lopulta koko biologia pystytään "selittämään" sen alapuolella olevien tieteiden termein ja niin edespäin aina atomien tasolle saakka. ... Nykyisen tietomme mukaan on hyvin epätodennäköistä, että on olemassa mitään sellaista, jota ei voida selittää fysiikalla ja kemialla. ${ }^{79}$

Tästä Crick päättelee, että biologia (myös ihminen ja hänen käyttäy- 
tymisensä) ovat vain ja ainoastaan fysiikkaa ja kemiaa. On kuitenkin hyvin epäselvää, mitä tällaisesta väitteestä pitäisi seurata. Seuraako siitä, että voimme selittää biologiaa, kemialla ja kemiaa fysiikalla, että biologiset eliöt eivät ole jossakin mielessä olemassa? Vai tarkoittaako tämä sitä, että biologialla ei ole mitään omia selityksiä?

Ehkä tunnetuin reduktionismin muoto on kaikkien kolmen edellisen yhdistelmä, "klassinen reduktionismi". Klassisessa reduktionismissa yhdistyvät teoriareduktio, vahva ontologinen reduktio sekä loogiselle positivismille tyypillinen käsitys tieteen yhtenäisyydestä. Vaikka näkemyksen juuret ovatkin loogisessa positivismissa, on sillä myös kannattajansa nykyisin. Kuten edeltävästä Francis Crickin kommentista voimme päätellä, klassisen reduktionismin idea on se, että sekä tieteet että luonto voidaan nähdä kerroksina, jotka voidaan palauttaa niitä alempiin kerroksiin. Tieteiden osalta kyseessä on teoriareduktio ja luonnon tasojen osalta ontologinen reduktio. Tuloksena on yhtenäinen tiede, jossa kaikkien "erityistieteiden" lait, termit ja säännönmukaisuudet voidaan perustaa fysiikkaan. Sama yhtenäisyyden ajatus pätee luontoon: kaikki luonnon monimutkaiset rakenteet voidaan selittää niiden rakenneosille aina fysiikan tutkimiin alkeishiukkasiin ja niihin vaikuttaviin voimiin asti.

\section{Klassinen reduktionismi}

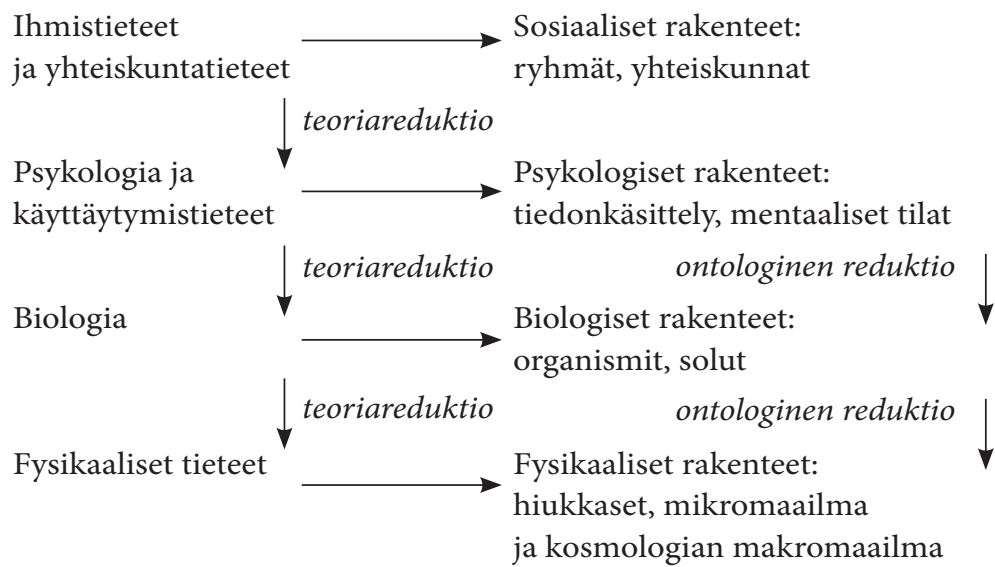


Klassisen reduktion visioilla yhtenäisestä tieteestä, jossa fysiikka viime kädessä selittää kaiken, ja yhtenäisestä luonnosta on yhä kannattajia, vaikka alkuperäisen klassisen reduktionismin ohjelma on käytännössä täysin haaksirikkoutunut tieteenfilosofiassa. Tärkein syy on tietenkin jo aiemmin mainittu teoriareduktion mahdottomuus. Näyttää siltä, että jopa luonnontieteiden sisällä on hyvin erilaisia käsitteitä, joita ei pystytä määrittelemään muiden teorioiden käsitteillä, ja lainalaisuuksia, joita ei pystytä "palauttamaan" jonkin toisen teorian lainalaisuuksiin. Näin ollen on johdonmukaisempaa ajatella, että eri tieteet käyttävät erilaisia käsitteitä ja malleja omien tutkimuskohteidensa kuvaamiseen eikä näitä malleja ja käsitteitä pystytä muuttamaan jäännöksettä jonkin toisen tieteenalan malleiksi tai käsitteiksi. Samoin näyttää perustellulta ajatella tämän seikan heijastavan myös luonnon monimuotoisuutta ja kerroksellisuutta: kuvauksemme ja mallimme luonnosta ovat aina paljon yksinkertaisempia kuin itse luonto ja sen toiminta. Emme pysty yksiselitteisesti "palauttamaan" joitakin luonnonilmiöitä toisiin, perustavampiin ilmiöihin, niiden yhtenäisestä koostumuksesta huolimatta.

Luonnon teologian ja päällekkäisyysmallin edustajat haluavat vastustaa sekä biologista reduktionismia että klassista reduktionismia. Tarkastelimme jo lyhyesti aiemmin emergenssin käsitettä (luku 4.3) ja sitä, kuinka monimutkaisten luonnon rakenteiden katsotaan olevan luonteeltaan sellaisia, että niiden säännönmukaisuudet eivät selity niiden rakenneosien säännönmukaisuuksilla. Viittasimme myös siihen, kuinka monet kannattavat mielen ja aivojen suhteen non-reduktiivista materialismia (luku 5.3), jonka mukaan mieli kyllä perustuu aivojen toiminnalle mutta mielen toimintojen ja aivotapahtumien väliin ei voida vetää yhtäläisyysmerkkejä. Emergenssin ajatus on yksi tapa laajentaa tällainen näkemys mielen ja aivojen suhteesta esimerkiksi elävien olentojen ja niiden elottomien rakenneosien suhteeseen tai mielentilojen ja yhteiskunnallisten rakenteiden välisiin suhteisiin.

Voimme luonnehtia emergenssiä seuraavalla tavalla: ${ }^{80}$ 
(1) Kaikki, mikä sijaitsee ajan ja avaruuden maailmassa, koostuu pohjimmiltaan fysiikan tutkimista alkeishiukkasista. Fysiikka ei kuitenkaan riitä selittämään sitä, miten alkeishiukkasista rakentuu monimutkaisempia rakenteita.

(2) Kun alkeishiukkasten joukot ovat rakenteeltaan tarpeeksi monimutkaisia, syntyy ominaisuuksia, jotka ovat aidosti uusia.

(3) Tällaiset emergentit ominaisuudet eivät palaudu tai niiden syntyä ei voida ennustaa (niitä ei voida redusoida) niiden alemman tason ilmiöiden pohjalta, joista ne kehittyvät.

(4) Korkeamman tason ilmiöt vaikuttavat alemman tason ilmiöiden käyttäytymiseen.

Emergenssin pohjalta avautuva visio luonnon kerroksellisuudesta poikkeaa siis varsin suuresti klassisesta reduktionismista ja biologisesta reduktionismista. Jos emergentit ilmiöt otetaan vakavasti, on biologinen reduktionismi turha yritys: biologian yläpuolella olevia monimutkaisuuden tasoja ei pystytä palauttamaan biologiaan eikä biologisia rakenteita eikä termejä, joilla biologian säännönmukaisuuksia kuvataan, voida palauttaa esimerkiksi kemian tai fysiikan termeiksi. Valtaosa emergentisteistä ajattelee esimerkiksi, että yhteiskunnalliset ja sosiaaliset rakenteet ovat emergenttejä suhteessa yksittäisten ihmisten mielentiloihin ja että mieli on emergentti suhteessa aivoihin.

\section{$5 \cdot 5$}

\section{YHTEENVETO: MUUTTUVA LUONTO}

Olemme nyt nähneet muutamia historiallisia muutoksia käsityksissämme luonnosta ja sen toiminnasta. Aloitimme keskiaikaisesta synteesistä, josta päädyimme mekanistisen maailmankuvan kautta nykyaikaiseen käsitykseen, joka perustuu pitkälti nykyiseen fysiikkaan ja biologiaan. Kiinnitimme myös huomiota siihen, kuinka ihminen, hänen mielensä ja sen tuotteet ovat yhä enenevässä määrin 
tulleet osaksi luontoa. On myös esitetty joitakin syitä ajatella, että luonto on siinä mielessä monikerroksellinen, että se sisältää olioita ja prosesseja, joita ei voida selittää tyhjentävästi niiden rakenneosien toiminnalla. Näin ollen luonto sisältää esimerkiksi organismeja, mieliä ja sosiaalisia rakenteita, joita fysikaaliset tieteet eivät pysty tyhjentävästi kuvaamaan. Oheinen taulukko vetää yhteen tarkastelemaamme kehitystä.

Muuttuvat käsitykset luonnosta (Barbour 1999, 282)

\begin{tabular}{|c|c|c|c|}
\hline & $\begin{array}{l}\text { Keskiaikainen } \\
\text { synteesi }\end{array}$ & Mekanismi & 1900-luku \\
\hline $\begin{array}{l}\text { Miten luonto } \\
\text { muuttuu? }\end{array}$ & $\begin{array}{l}\text { Ei muutosta: } \\
\text { pysyvä järjestys }\end{array}$ & $\begin{array}{l}\text { Muutos perusosien } \\
\text { uudelleenjärjeste- } \\
\text { lynä }\end{array}$ & $\begin{array}{l}\text { Jatkuva muutos: } \\
\text { evolutiivinen, } \\
\text { historiallinen ja } \\
\text { emergentti }\end{array}$ \\
\hline $\begin{array}{l}\text { Voidaanko } \\
\text { muutosta } \\
\text { ennustaa? }\end{array}$ & Teleologia & Determinismi & $\begin{array}{l}\text { Sattuman ja } \\
\text { lain yhteispeli, } \\
\text { rakenne ja avoi- } \\
\text { muus }\end{array}$ \\
\hline $\begin{array}{l}\text { Mistä kaikki } \\
\text { koostuu? }\end{array}$ & $\begin{array}{l}\text { Olioiden luonto/ } \\
\text { olemus }\end{array}$ & Atomismi & $\begin{array}{l}\text { Suhteellisuus, } \\
\text { keskinäinen } \\
\text { riippuvuus }\end{array}$ \\
\hline $\begin{array}{l}\text { Miten luontoa } \\
\text { selitetään? }\end{array}$ & $\begin{array}{l}\text { Hierarkiat, ih- } \\
\text { miskeskeisyys }\end{array}$ & Reduktionismi & $\begin{array}{l}\text { Järjestelmät ja } \\
\text { kokonaisuudet }\end{array}$ \\
\hline Henki ja aine? & $\begin{array}{l}\text { Dualismi (hen- } \\
\text { ki/aine) }\end{array}$ & $\begin{array}{l}\text { Dualismi (sielu/ } \\
\text { ruumis) }\end{array}$ & Monitasoisuus \\
\hline $\begin{array}{l}\text { Hallitseva } \\
\text { kielikuva }\end{array}$ & Kuningaskunta & Kone & Yhteisö \\
\hline
\end{tabular}

Keskiaikaisessa synteesissä luonto ei varsinaisesti muutu, vaan sen järjestys on ikuinen ja pysyvä, koska Jumala on asettanut sen. Mekanistien mukaan taas muutos luonnossa tarkoittaa luonnon jakamat- 
tomien perusosien, atomien, uudelleenjärjestelyä. Nykyaikaisempi käsitys - tai ainakin niin jotkut haluaisivat väittää - on dynaamisempi: luonto on jatkuvassa muutoksen tilassa. Tämän näkemyksen mukaan luonnon järjestelmät, joihin sisältyvät myös biologiset ja psykologiset ja sosiaaliset järjestelmät, ovat jatkuvassa vuorovaikutuksessa eri tasoilla. Tätä muutosta ja vuorovaikusta ei ohjaa täydellisesti mikään laki, vaan se on sattuman ja lainomaisen käyttäytymisen yhteispeliä. Näin ollen kehitys ei etene lukkoon lyödyn ohjelman mukaan vaan on avoin erilaisille mahdollisuuksille. Tämä taas erottaa 1900-luvun käsityksen sekä mekanisteista että keskiaikaisen synteesin edustajista, joista edeltävät uskoivat päämääräsyihin ja jälkimmäiset taas siihen, että kaikelle on olemassa riittävä fysikaalinen syy. Monet myös korostavat, kuinka 1900-luvun kuva luonnosta rikkoo ajatuksen siitä, että kukin luonnon taso voidaan palauttaa sitä alempana olevaan tasoon, kuten mekanistit ajattelivat. Mekanistinen selittäminen lähti aina liikkeelle siitä, että tunnistetaan jonkin prosessin komponentit, joiden toiminta sitten selittää aina kokonaisuuden toiminnan aina pohjalla olevaan perusosiin, atomeihin, asti. Jälleen 1900-luvun kehitys haastaa mekanistisen selittämisen, sillä nykytiedon pohjalta näyttää monien mielestä siltä, että selittäminen ei perustu sille, että ilmiöt ja prosessit palautetaan niiden osasiin.

$\mathrm{Ne}$, jotka haluavat puolustaa osittaista päällekkäisyysmallia ja luonnon teologiaa, joutuvat tekemään sen edellä kuvaamamme luonnon ehdoilla. Tähän maailmaan, jota olen nyt edelliset kaksi lukua kuvannut, on päällekkäisyysmallin edustajan sovitettava teologia, joko muokkaamalla teologiaa tai käsitystä luonnosta. Luonnon teologian kannattajan on saatava aikaan tilanne, jossa ilmoitettujen teologisten näkemysten ja luonnon välillä on ainakin jonkinlaista jatkuvuutta. Tässä sovittamisen tehtävässä on useita haasteita ja avoimia kysymyksiä ja ongelmia eikä voida millään muotoa väittää, että teologiset yritykset olisivat valmiita tai täydellisiä. Epätäydellisyydestä huolimatta niitä kuitenkin on ja niistä keskustellaan. Päällekkäisyysmallin kannalta eräs ongelma on modernin tieteen haaste 
teologian menetelmille. Käsittelimme kuitenkin tätä kysymystä jo laajasti luvussa 3, joten siihen emme tässä yhteydessä enää palaa. Hyväksymme siis päällekkäisyysmallin kannattajien teologisen realismin ja fallibilismin, joka torjuu sekä Raamatun välttämättömän kirjaimellisen tulkinnan että uskonnollisen tiedon riippumattomuuden tieteellisestä tiedosta.

Päällekkäisyysmallin kannalta ainakin seuraavat kysymykset ja ongelmat ovat olennaisia fysiikan kehityksessä:

(1) Jumalan suhde fysikaaliseen todellisuuteen: vaikka 1900-luvun kehityksen seurauksena luonto näyttääkin monikerroksiselta ja dynaamisemmalta kuin mekanistien mukaan, niin se ei siltikään näytä sisältävän mitään selkeästi yliluonnollista. Mitä tulisi ajatella Jumalan ja luomakunnan suhteesta yleisellä tasolla?

(2) Luominen ja fysikaalinen maailma: vallitseva teoria universumin synnystä on alkuräjähdysteoria, jonka mukaan fysikaalisella universumilla on jonkinlainen alkupiste. Miten tämä käsitys sopii yhteen perinteisen näkemyksen luomisesta kanssa? Mitä luomisella ylipäänsä tarkoitetaan?

(3) Jumalan toiminta fysikaalisessa maailmassa: vaikka monikerroksinen ja dynaaminen universumi näyttääkin paljon mekanistien kellokoneistoa paremmalta maailmalta Jumalan toiminnalle, niin silti Jumalan aktiiviselle toiminnalle ei näytä löytyvän paikkaa universumissa. Kristinuskon Jumala on ollut tapana ymmärtää persoonallisena toimijana, joka vaikuttaa maailmassa.

Näitä kysymyksiä käsitellään luvussa 6.

Toinen tärkeä keskustelun osa-alue on evoluutioon ja darwinismiin liittyvät kysymykset. Tällaisia kysymyksiä ovat:

(1) Sattuman ja kaitselmuksen suhde: modernista synteesistä näyttää seuraavan, että sattumalla on varsin suuri osuus evoluutiossa. Miten tämä sopii yhteen sen perinteisen näkemyksen 
kanssa, että Jumala ohjaa luomakuntaa? Sattuman osuudesta näyttää myös seuraavan se, että ihmiset olisivat voineet jäädä syntymättä. Tämä ei näytä olevan yhteensopiva Jumalan luovan tahdon kanssa.

(2) Suunnittelun puute: modernin synteesin valossa huomaamme luonnossa paljon "huonoa suunnittelua", joka ei tue ajatusta, että yksittäiset eliöt ovat Jumalan suunnittelemia. Onko siis teologian välttämättä vedottava yliluonnolliseen suunnitteluun? Lisäksi Darwinin mukaan se suunnittelu, jonka näemme eläinmaailmassa, on tulosta luonnollisista mekanismeista, ei yliluonnollisesta luomisesta. Mitä tästä pitäisi ajatella?

(3) Pahan ongelma: pahan ongelma on aina ollut ongelma teologiassa mutta evoluutio näyttää lisäävän sitä merkittävästi. Lajeja kuolee sukupuuttoon, biologinen maailma on usein julma ja piittaamaton kärsimyksestä. Miten tämä sopii yhteen hyväntahtoisen Jumalan kanssa?

Näitä kysymyksiä käsittelemme luvussa 7.

Kolmas keskustelun osa-alue ovat ne kysymykset ja ongelmat, joita evoluutionäkökulma ja nykyaikaiset mielen tieteet ihmiseen herättävät. Tällaisia kysymyksiä ovat:

(1) Ihmisen erityisyyden ongelma: perinteinen teologinen antropologia pitää ihmistä muuhun luomakuntaan nähden hyvin erityisenä ja tämä erityisyys liitetään usein ihmisen sieluun (järki, tunne, tahto) ja kykyyn olla vuorovaikutuksessa Jumalan kanssa. Evoluutio ja mielen tieteet kuitenkin viittaavat vahvasti ihmisen biologian ja psykologian jatkuvuuteen muun luomakunnan kanssa.

(2) Ihmisen moraalin ja vapaan tahdon ongelma: perinteisen teologisen antropologian mukaan ihmisellä on sekä vapaa tahto että kyky moraalisiin valintoihin. Evoluutio ja mielen tieteet kuitenkin viittaavat siihen, että ihminen on luonnostaan varsin itsekäs ja hänen moraalisia valintojaan ohjaavat hänen tunteensa, 
jotka ovat luonnonvalinnan muokkaamia, eikä hänen järkensä.

Lisäksi mielen tieteiden tulokset näyttävät viittaavan siihen, että mieli on aivotoimintaa ja että aivotoimintaa ohjaavat fysikaaliset lainalaisuudet. Miten käy tällöin vapaan tahdon?

(3) Uskonnon selitysten ongelma: perinteisen teologian mukaan uskonnolliset käyttäytymismallit ja ideat ovat ihmisen vastauksia Jumalan toimintaan tai Jumalan toiminnan ilmaisuja ihmisessä. Evoluutio ja mielen tieteet kuitenkin viittaavat siihen, että uskonnolla on perusta ihmisen biologiassa ja psykologiassa.

Näitä kysymyksiä käsitellään luvussa 8.

\section{Kirjallisuutta}

Darwinismiin ja evoluutioon löytyy monia hyviä johdatuksia suomeksi. Näitä ovat erityisesti Mayr 2003 ja Laihonen \& Salo \& Vuorisalo 1986. Hyvin kirjoitettu katsaus evoluution todistusaineistoon on Dawkins 2009. Hyvä suomenkielinen johdatus ihmisen evoluutiohistoriaan, evoluutiobiologian filosofiaan ja evoluutionäkökulmaan ihmistieteissä (esim. evoluutiopsykologia) on Ylikoski \& Kokkonen 2008. Kognitiotieteiden historiaa ja nykytilaa käsittelee Saariluoma \& Kamppinen \& Hautamäki 2001. Johdatus kognitiotieteiden ja neurotieteiden filosofiaan on Clark 2001. Mielenfilosofian peruskysymyksiä, kuten juuri mielen ja aivojen suhdetta, käsittelee esimerkiksi Crane 2001. Eräs suosittu tapa tulkita emergentismiä tieteen ja teologian kontekstissa on Clayton 2004. Johdatus emergenssin käsitteeseen ja siihen liittyviin teorioihin on Clayton \& Davies 2006. 
Ajatus siitä, että on olemassa Jumala, joka on luonut tyhjästä koko näkyvän maailmankaikkeuden ja kaiken sen, mitä se sisältää, on yksi kristinuskon (ja islamin ja juutalaisuuden) ydinkohtia. Lähes kaikille tulee ensimmäisenä Jumalasta puhuttaessa mieleen juuri se, että Jumala on luoja. Oppi luomisesta on ollut erittäin keskeisessä roolissa tieteen ja kristinuskon suhteesta keskusteltaessa, koska luominen oppina sisältää paljon sellaista, johon tietomme maailmasta vaikuttaa. Teologian historia osoittaa myös sen, että oppia luomisesta on hyvin usein tulkittu kunkin ajan parhaimman luonnollisen tiedon nojalla. Maallikon voi olla aluksi vaikea nähdä, miksi oppi luomisesta on näin keskeinen. Eikö luominen koske lähinnä sitä, mitä kaiken alussa tapahtui? Lyhytkin katsaus teologiseen ja filosofiseen traditioon kuitenkin osoittaa, että tämä on kaukana totuudesta. Kristillinen luomisen teologia sisältää erittäin kattavan käsityksen siitä, millainen maailmankaikkeus on luonteeltaan, millainen sen päämäärä on ja miten Jumala on suhteessa siihen. Käsitys siitä, miten maailmankaikkeus sai alkunsa, on näin ollen vain hyvin pieni osa luomisen teologiaa.

Aloitan lyhyellä teologisella analyysilla siitä, mistä luomisen teologiassa on kyse, jonka jälkeen siirryn käsittelemään Jumalan suhdetta luomakuntaan yleisellä tasolla. Tämän jälkeen käsittelemme viimeaikaista keskustelua kosmologisista argumenteista, luomisesta ja universumin alusta. Lopuksi käsittelemme viimeaikaisia teorioita Jumalan toiminnasta fysikaalisessa maailmassa. 
6.1

LUOMINEN KRISTILLISESSÄ TEOLOGIASSA

Vanhassa testamentissa (VT) ajatus Jahvesta maailman luojana on erittäin tärkeä ja se näkyy lukuisissa yksittäisissä kirjoissa kuten ensimmäisessä Mooseksen kirjassa sekä profeetta- (esim. Jesajan ja Jeremian kirjoissa) että viisauskirjallisuudessa (Jobin kirja, Sananlaskujen kirja). Luominen tulee VT:ssa esiin useassa eri yhteydessä:

(1) Luonnonpalvonnan kielto ja luojan erillisyys luomakunnasta.

(2) Ylläpito ja kaitselmus.

(3) Luomakunnan järjestys ja tarkoitus.

Luomiseen viitataan silloin, kun halutaan vastustaa luonnon palvontaa tai luonnon "jumalallistamista", mikä oli monille kansoille tyypillistä. Luonnonvoimien ja joidenkin luonnollisten kappaleiden, kuten taivaan, kuun, tähtien tai auringon, ajateltiin usein olevan jonkinlaisia perustavia toimijoita. Jahven palvoja ei kuitenkaan saa syyllistyä luonnon palvontaa tällä tavoin, koska luonnonvoimilla ei ole perustavaa, jumalallista luonnetta, vaan ne ovat vielä perustavamman luojajumalan käsialaa. Luomisen ajatuksen tarkoitus on siis tässä korostaa Jumalan ja luomakunnan eroavaisuutta.

VT:ssa luomisella korostetaan myös Jahven suurta ja yhä jatkuvaa, tiettyihin hänelle ominaisiin päämääriin pyrkivää, vaikutusta maailman asioihin, perinteisemmin sanottuna kaitselmusta. Maailman tapahtumat, kansakuntien, sukujen ja yksilöiden kohtalot eivät ole sattumanvaraisia tai tulosta jumalien tai muiden henkivaltojen taistelusta, vaan kaiken takana on Jahven hyvä suunnitelma. Tämän suunnitelman olemassaolosta seuraa, että Jahve ei pelkästään luo maailmaa, vaan hän myös jatkuvasti ylläpitää sitä ja vaikuttaa siinä oman hyvän tahtonsa toteutumiseksi.

Koska maailman on luonut yksi järkevä ja hyvä olento, on se myös järkevä ja arvokas kokonaisuus. Maailma ei ole pohjimmiltaan sattumanvarainen, vaan siltä voidaan odottaa järjestäytynei- 
syyttä, pysyviä lainalaisuuksia ja moraalista luonnetta. Luominen ymmärretään tällöin tapahtumana, jossa Luoja muovaa järjestyksen kaaoksesta samaan tapaan kuin savenvalaja muovaa savesta ruukun (esim. 1. Moos. 2:7, Jer. 18:1-6). Tämä ajatus ei edellytä luomista tyhjästä, ex nihilo, vaan se voidaan yhdistää näkemykseen siitä, että on olemassa jotain ei-järjestynyttä ja ikuista (materia), josta luoja muovaa maailman. Toinen vastaava teema VT:ssa on ajatus luomisesta voittona jostakin persoonallisesta kaaoksen voimasta, kuten erilaisista alkuhirviöistä (esim. Job 3:8, Ps. 74:13-15). Ajatus siitä, että luominen on kaaoksen pakottamista järjestykseen, liittää maailmaan luonnonjärjestyksen lisäksi moraalisen järjestyksen. Tähän liittyvät läheisesti vanhurskauden ja oikeudenmukaisuuden käsitteet: maailmassa vallitsee ihmisistä riippumaton oikeudenmukainen järjestys, jota kohti ihmisten tulee pyrkiä. Tällöin sekä moraalisilla, sosiaalisilla että luonnollisilla asioilla on oma oikea tilansa, ne ovat osa annettua "luonnollista järjestystä".

Kristillisen perinteen alkuvaiheessa luomisen ajatus joutui kohtaamaan erilaisia haasteita, jotka nousivat lähinnä kreikkalaisroomalaisen perinteestä. Esimerkiksi gnostikoiksi kutsutut ryhmät tavallisesti ajattelivat, että luojajumala ja Jumala, joka lunastaa ja sovittaa maailman ovat erillisiä toisistaan. Perusajatus oli se, että aineellisen maailman on luonut jokin "vähemmän pätevä" jumala. Varsinainen Jumala on se, joka pelastaa aineettomat ihmissielut niiden aineellisesta vankilasta. Tehtiin siis ero VT:n Jumalan ja Uuden testamentin (UT) Jumalan välillä. Kirkkoisät kuitenkin torjuivat systemaattisesti tällaisen opetuksen, korostamalla sekä UT:n ja VT:n jatkuvuutta että Jumalan luovan ja lunastavan toiminnan jatkuvuutta. Samalla torjuttiin myös ajatus siitä, että aineellinen maailma olisi itsessään jotenkin pahaa: aineellinen maailma ei ole "varajumalan" tuotantoa ja siten vähempiarvoinen, vaan heijastaa Jumalan luovaa tahtoa.

Toinen haaste opille luomisesta oli sen määrittäminen tapahtuiko luominen tyhjästä vai oliko olemassa jotain, joka toimi luomisen perustana. VT ei ole kristallinkirkas tässä asiassa. Haaste tuli olennai- 
seksi, koska myöhäisantiikin kreikkalais-roomalaisten ajattelijoiden perusnäkemyksen mukaan, maailma on ikuinen. Monet varhaiset kirkkoisät (esim. Justinos Marttyyri) seurasivat tätä ajatusta ja esittivät, että ennen varsinaisen maailman luomista, oli olemassa jotakin ikuista ainetta, josta Jumala muokkasi maailman, antoi sille ikään kuin muodon. Tämä oli yksi tapa välttää pahan ongelma: syy, miksi maailma ei vaikuta parhaalta mahdolliselta, on se, että Jumalan luomisessa muokkaama aine oli viallista. Rajanvedossa gnostikoiden kanssa vakiintui 200-luvun lopulla kuitenkin kanta luomisesta ex nihilo (ei mistään, tyhjästä).

Opilla luomisesta ex nihilo haluttiin rajata ulkopuolelle kaksi muuta näkemystä. Yhtäältä haluttiin korostaa gnostikkoja vastaan, että aineellinen maailma on järjestäytynyt, hyvä ja arvokas, koska se heijastaa Jumalan järkevyyttä ja hyvää tahtoa. Aineellinen maailma ei ole kaoottinen tai sattumanvarainen tai vähempiarvoisempi kuin henkinen maailma. Lisäksi korostettiin sitä, että Jumala ei pelkästään luo kaaokseen järjestystä, vaan luo myös aineen. Jumalan lisäksi ei siis olisi mitään muuta ikuista "ainetta", josta Jumala sitten muokkaisi maailman. Toisaalta haluttiin myös torjua näkemys, jonka mukaan Jumala ja maailma olisivat yhtä (panteismi). Jumalallinen luonto on tämän näkemyksen mukaan riippumaton aineellisesta luonnosta, vaikka Jumalalla onkin luomisen kautta hyvin intiimi yhteys siihen.

Ensimmäisen viiden kristillisen vuosisadan aikana oppi luomisesta vakiintui suurin piirtein sellaiseksi kuin se nykyään tunnetaan. Vaikka edellä kuvatut näkemykset rajattiinkin ulkopuolelle, se, mikä Jumalan ja maailman suhde tarkkaan ottaen oli, jäi varsin avoimeksi. Kristillisen teologian perinteessä on kuitenkin käytetty erilaisia kielikuvia tämän suhteen kuvaamiseksi. Näitä ovat olleet erityisesti:
(1) emanaatio,
(2) rakentaminen
(3) taiteilijan työ. ${ }^{81}$ 
Termille "emanaatio" on vaikea löytää suomennosta; voisi ehkä puhua "erittymisestä" tai "ylitsevuotamisesta". Platonin filosofian kannattajat ja kehittäjät olivat yksi hyvin merkittävä myöhäisantiikin filosofikoulu, ja monet kirkkoisät tunsivat sympatiaa platonistista filosofiaa kohtaan. Emanaation ajatus oli tyypillinen juuri myöhäisantiikin platonismille, jonka mukaan koko todellisuus ikään kuin virtaa tai vuotaa yli kaiken olemisen keskuksesta, Yhdestä. Kristilliseen luomiseen sovellettuna ajatus on jotakuinkin seuraava: luomakunta on tulosta Jumalan ylitsevuotavasta luovasta voimasta. Jumala on ikään kuin lähde, josta maailma pulppuaa. Usein käytetty kielikuva oli auringon valo: Jumala on aurinko, joka valonsäteet virtaavat eteenpäin. Luominen emanaation valossa tulkittuna on kuitenkin ongelmallinen, koska se ei näytä ottavan huomioon Jumalan toiminnan persoonallista luonnetta. Jos maailma ikään kuin pulppuaa tai virtaa ulos Jumalasta, tämä näyttää tapahtuvan itsestään: valonsäteet seuraavat automaattisesti auringon olemassaolosta. Perinteinen näkemys kuitenkin oli, että Jumala ei luo maailmaa automaattisesti vaan omasta vapaasta tahdostaan. Jumalan valinta on jotakin enemmän persoonallista ja tarkoituksenmukaista kuin emanaation kieli näyttäisi sallivan. Jännitteistään huolimatta platonistinen tapa tulkita luomista, tai ainakin siihen liittyvä kuvasto, säilyi yhtenä teologisena virtauksena pitkälle keskiajalle saakka.

Puhe Jumalasta rakentajana tavoittaa paremmin luomisen persoonallisen luonteen: maailma ei ikään kuin itsestään tule ulos Jumalasta, vaan Jumala suunnittelee ja järjestää sen oman tahtonsa mukaisesti. Mallin etu on sen tapa korostaa luomakunnan järjestäytyneisyyttä ja suunnitelmallisuutta: luomakunta on ymmärrettävä, koska se on seurausta Jumalan luovasta tahdosta. Tällaisen puheen ongelma on kuitenkin siinä, että normaalisti rakentaja rakentaa talon jo ennalta olemassa olevista aineksista ja tämän, kuten olemme aiemmin nähneet, halusi kristillisen teologian valtavirta kieltää.

Kolmas mahdollinen puhetapa luomisesta on ymmärtää se ikään kuin taiteilijan itseilmaisuna. Ajatus on siinä, että luomakunta on samanaikaisesti kaunis ja tyylikäs sekä ilmaisee tekijänsä persoo- 
nallisuutta ja tahtoa. Mallissa ei korostu pelkästään Jumalan suunnitelmallisuus vaan myös itseilmaisu: luomakunta ei ole ainoastaan tarkoituksenmukainen vaan se on tarkoitettu nautittavaksi myös esteettisesti. Lisäksi se johtaa ajatukseen siitä, että luomakunnan kauneus voi johtaa katsojansa myös Jumalan tahdon jäljille.

Edellä esitellyt mallit tai puhetavat ovat olleet kristillisessä perinteessä usein päällekkäisiä toistensa kanssa. Kukin malli on korostanut jotakin piirrettä Jumalan ja maailman suhteessa: emanaatio Jumalan ja luomakunnan läheistä yhteyttä, rakentaminen luomakunnan järjestystä ja suunnitelmallisuutta ja taiteilijan itseilmaisu luomakunnan kauneutta ja kykyä viitata tekijäänsä.

Nykykeskustelun kannalta Augustinuksen käsitys luomisesta on erittäin keskeinen. ${ }^{82}$ Genesis-kommentaarissaan Augustinus torjui ajatuksen luomisen kuudesta päivästä ja oli sitä mieltä, että kuvausta ei oltu tarkoitettu kirjaimelliseksi. Hän oli erityisen herkkä kritiikille, jota useat ei-kristityt filosofit esittivät Raamatun alkukertomuksia kohtaan ja suositti, että jos luonnollinen tieto on räikeässä ristiriidassa Raamatun tekstin kanssa, tulee tulkintaa miettiä uudelleen. Sen lisäksi, että Augustinus korosti luomista ex nihilo, oli hän myös vakuuttunut siitä, että ajaton Jumala toteuttaa luomisen yhdessä hetkessä, eikä päivä kerrallaan. Augustinukselle luominen on yksi ainoa hetki ennen koko maailmankaikkeuden alkua ja alkukertomuksen "päivät" eivät ole mitään muuta kuin tämän selittämistä lukijalle.

Augustinus ei kuitenkaan väitä, että maailmankaikkeus olisi luotu nykyisessä muodossaan yhdellä hetkellä: luominen tapahtuu yhdellä hetkellä mutta maailmankaikkeus kehittyy nykyiseen muotoonsa ajan myötä. Augustinuksen tässä yhteydessä käyttämä käsite "rationes seminales" (tai rationis causalis) on hyvin vaikea kääntää. Ajatus on kuitenkin se, että luomisen aktissa Jumala rakentaa luomakuntaan sisään periaatteita (tai voimia), jotka synnyttävät luomakunnan nykyisen muodon ajan myötä. ${ }^{83}$ Kielikuvien tasolla voitaisiin puhua siitä, että Jumala luo luomakunnan "siemenen", joka sisältää kaikki luomakunnan mahdollisuudet, jotka puolestaan muuttuvat todeksi 
vasta ajan myötä muodostaen puun. Augustinus kirjoittaa:

Itse siemenessä oli näin ollen näkymättömänä läsnä kaikki se, joka ajan myötä kehittyi puuksi. Meidän tulee kuvitella maailma juuri tällä tavalla: Jumala teki kaikki asiat yhdessä. ... Tähän sisältyvät kaikki ne maan potentiaalisesti ja kausaalisesti tuottamat oliot, jotka ajan myötä syntyvät. ${ }^{84}$

Lyhyesti sanottuna siis Augustinuksen mukaan maailma ei ole syntynyt nykyisessä muodossaan, vaan se on kehittynyt sellaiseksi niiden periaatteiden ja mahdollisuuksien mukaan, jotka Jumala siihen luomisen hetkellä rakensi sisään.

Edellä on käsitelty lyhyesti joitakin varsin perinteisiä näkemyksiä luomisen teologiasta. On hyvä vetää lopuksi yhteen perinteisen luomisen teologian yleiset piirteet:

(1) Luominen ex nihilo: maailma ja kaikki mikä siinä on syntyy tyhjästä.

(2) Jumalan valinta: luominen ei tapahdu välttämättä, vaan kyse on Jumalan valinnasta. Luomakunta ei näin ollen ole välttämätön (eli se on kontingentti).

(3) Jumalan hyvä tahto ja luomisen suunnitelmallisuus: koska Jumala on järkevä ja hyväntahtoinen, myös maailmankaikkeus heijastaa tätä. Maailmankaikkeudella on päämäärä, sitä ohjaa suunnitelma ja se on ihmisjärjen ymmärrettävissä.

(4) Jatkuva luominen ja luomakunnan riippuvaisuus Jumalasta: luominen ei ole yksittäinen tapahtuma maailmankaikkeuden alussa, vaan jatkuu yhä Jumalan luovan ja ylläpitävän toiminnan muodossa. Luomakunta on myös jatkuvasti riippuvainen Jumalan tahdosta.

(5) Jumalan erillisyys luomakunnasta: vaikka Jumala vaikuttaa luomakunnassa ja pitää sitä jatkuvasti yllä, hän ei kuitenkaan ole osa sitä, vaan luomakunnasta riippumaton. 
6.2

JUMALA JA LUOMAKUNTA: KLASSISESTA TEISMISTÄ PROSESSITEOLOGIAAN

Edellisessä luvussa näimme, kuinka luomisen teologia on kuvausta siitä, millainen maailmankaikkeus on luonteeltaan ja miten Jumala on suhteessa siihen. Karkeasti ottaen meillä on neljä mallia ymmärtää Jumalan ja luomakunnan suhde. Nämä mallit ovat

(1) klassinen teismi,

(2) avoin teismi,

(3) panenteismi,

(4) prosessiteismi.

Kaksi ensimmäistä ovat olleet osa kristillisen teologian traditiota varsin pitkään, vaikka klassinen teismi onkin ollut valtavirta. Kaksi jälkimmäistä vaihtoehtoa sen sijaan ovat olleen teologian historiassa vähemmistössä, mutta muutamat 1900-luvun teologit ja filosofit ovat herättäneet ne jälleen henkiin vastauksina tieteiden ja filosofian kehitykseen. Tulemme näkemään, kuinka sekä klassinen teismi että avoin teismi ovat itse asiassa varsin lähellä toisiaan ja kuinka ne usein asettuvat panenteismiä ja prosessiteismiä vastaan, jotka taas puolestaan ovat läheistä sukua toisilleen.

Polkinghorne kuvaa klassisen teismin ja avoimen teismin eroja seuraavalla tavalla:

tietynkaltaiset teologiset käsitteet näyttävät liittyvän toisiinsa, vaikka ne eivät sisällä loogisesti toisiaan. Yhden ryhmän muodostavat ajattomuus, ensisijainen kausaliteetti, Jumalan muuttumattomuus, taipumus determinismiin ja Jumalan hallinnan korostaminen. Toisessa ryhmässä taas ovat ikuisuus, alaspäinen kausaatio, Jumalan haavoittuvaisuus, taipumus kohti avoimuutta ja luotujen olioiden suhteellinen itsenäisyys. ${ }^{85}$

Polkinghornen luonnehtiman ensimmäisen näkemyksen mukaan 
Jumalan suhde luomakuntaan on varsin samanlainen kuin keskiaikaisessa synteesissä (luku 4.1), jossa Jumala hallitsee luomakuntaa kuninkaan lailla. Jumala on tämän näkemyksen mukaan ajaton, eli luodun maailman ajan "ulkopuolella", kaikkien tapahtumien ensisijainen syy ja muuttumaton siinä mielessä, että maailma ei voi vaikuttaa häneen. Jos Jumala on tällainen, niin Jumala tietää etukäteen kaikki, mitä tapahtuu, ja kaikkivaltiutensa nojalla hallitsee kaikkia tapahtumia maailmassa. Maailma on ikään kuin metsä, jonka polkuja me etenemme, mutta Jumala näkee koko metsän yhdellä kertaa. Hän tietää, mihin kaikki polut vievät ja mitkä polut ihmiset valitsevat. Nimitämme jatkossa tätä näkemystä "klassiseksi käsitykseksi Jumalan ja maailman suhteesta" tai lyhyemmin "klassiseksi teismiksi”.

Klassisen teismin edustajiksi voimme lukea esimerkiksi Augustinuksen ja Tuomas Akvinolaisen. Olennaista tässä näkemyksessä on Jumalan suvereeni hallinta maailmassa: Jumala tietää kaiken, mikä tulee tapahtumaan ja tässä mielessä koko maailma on Jumalan silmien edessä. Näin ollen klassinen teismi on jatkuvasti kallellaan kohti determinismiä ja sillä on ongelmia ihmisen vapaan tahdon kanssa. Vaikka klassisen teismin edustajat korostavat Jumalan jatkuvaa toimintaa ja ylläpitoa, on itse luomisen akti kuitenkin kaikkein tärkein: Jumala ikään kuin luo koko maailmankaikkeuden ja sen tulevaisuuden kertaheitolla. Klassiselle teismille on myös olennaista Jumalan muuttumattomuuden ja yksinkertaisuuden korostaminen. Jumala on ajattomuudessaan koskematon: ajattomassa Jumalassa ei voi olla muutosta eikä osia. Näin ollen mikään maailman tapahtuma ei voi oikeastaan vaikuttaa Jumalaan, vaan vaikutus Jumalan ja maailman välillä on aina yksisuuntaista.

Klassisen teismin ongelmat on tunnettu koko kristillisen teologian historian ajan, mutta valtaosa teologeista on kuitenkin hammasta purren hyväksynyt ongelmat klassisesta teismistä luopumisen sijaan. Tärkeimmät ongelmat ovat ihmisen vapaa tahto, pahan ongelma ja Jumalan ajattomuus. Perinteisesti on katsottu, että ihmisellä on vapaa tahto ainakin maallisissa asioissa. Tämä ei kuitenkaan näytä 
olevan yhteensopiva Jumalan kaikkivaltiuden ja kaikkitietävyyden kanssa: jos Jumala tietää kaiken, mitä tulee tapahtumaan ajattomuudessaan, niin tästä näyttää seuraavan se, että ihmisten valinnat ovat ainoastaan näennäisesti vapaita. Tämä tunnetaan yleisesti "Jumalan kaikkitietävyyden ja vapaan tahdon ongelmana". Klassisen teismin viitekehyksen sisällä ongelman voi ratkaista kahdella tavalla. Voidaan joko luopua Jumalan kaikkitietävyydestä tai ihmisen vapaasta tahdosta, mutta kumpikin näistä ratkaisuista on sellainen, jota klassisen teismin edustaja ei halua tehdä. Toinen keskeinen ongelma klassisessa teismissä on pahan ongelma. Jos jokainen mahdollinen asia maailmassa tapahtuu Jumalan tahdosta, niin silloin myös paha ja kärsimys tapahtuu Jumalan tahdosta. Koska kärsimystä ja pahuutta näyttää tapahtuvan niin paljon, on vaikea nähdä kuinka Jumala voisi olla hyvä ja aiheuttaa kaiken kärsimyksen. Pahan ongelmaan on klassisen teismin sisällä monia erilaisia ratkaisuja mutta ne eivät ole aiheemme kannalta olennaisia. ${ }^{86}$ Kolmas klassisen teismin ongelma on Jumalan ajattomuus ja yksinkertaisuus. Loppuun asti vietynä nämä ajatukset nimittäin johtavat siihen, että Jumala on hyvin kaukana siitä, miten hänet uskonnollisessa arkikielessä esitetään. Klassisen teismin Jumalalla ei esimerkiksi ole tunteita eikä hän ei voi muuttaa mieltään. Hän on täydellisen yksinkertainen eikä hänessä ole minkäänlaista muutosta.

Nämä avoimet kysymykset ovat johtaneet jotkut teologit ja filosofit luopumaan klassisesta teismistä ja hyväksymän jälkimmäisen Polkinghornen kuvaaman näkemyksen, jota usein nimitetään "avoimeksi teismiksi" (open theism). Avoimen teismin mukaan Jumala ei ole ajaton vaan ikuinen. Jumala ei luo koneiston kaltaista järjestelmää, joka toteuttaa hänen tahtoaan vääjäämättä, vaan pikemminkin Jumala aktiivisella toiminnallaan nykyhetkessä pyrkii toteuttamaan tahtoaan maailmassa, jossa on todellista sattumaa ja epävarmuutta. Maailman periaatteellinen avoimuus tekee tämän näkemyksen mukaan tilaa esimerkiksi ihmisen vapaalle tahdolle ja aidolle sattumalle luonnossa. Avoimen teismin mukaan maailma ei ole mikään alusta loppuun valmiiksi luotu kokonaisuus, jota Jumala ajattomuu- 
dessaan katselee, vaan Jumalan ja maailman suhde on paljon intiimimpi: Jumalan näkökulmasta maailma ei ole "valmis", vaan Jumala aktiivisella ohjaavalla työllään osallistuu sen kulkuun. Jumala ikään kuin ottaa riskin ja antaa luomakunnalle suuren määrän itsenäisyyttä ja asettautuu avoimeksi maailman vaikutukselle. Tämä näkemys edellyttää myös sitä, että Jumala rajoittaa kaikkivaltiuttaan: luomakunta ja sen vapaat toimijat ovat aidosti Jumalasta itsenäisiä ja heidän valintansa ovat Jumalan tiedon ulkopuolella.

Avoimen teismin sisällä on helpompi vastata vapaan tahdon ja pahan ongelmiin. Avoimen teismin edustaja ajattelee, että ihmisen vapaa tahto ei ole ristiriidassa Jumalan kaikkitietävyyden kanssa siitäkin huolimatta, että Jumala ei voi tietää, millaisia vapaita valintoja ihmiset tekevät. Ihmisen vapaat valinnat eivät ole määrättyjä ennalta, joten niistä ei voi olla olemassa tietoa Jumalan tiedettäväksi. Avoimen teismin edustajat lisäksi katsovat, että Jumala pystyy tietonsa ja voimansa nojalla ennakoimaan ihmisten vapaiden valintojen tulokset heidän ympäristöissään. Tämä ei tarkoita sitä, että Jumala etukäteen tietää, mitkä nuo valinnat tulevat olemaan, vaan sitä, että Jumala pystyy ennakoimaan noita valintoja erittäin hyvin. Avoin teismi auttaa myös vastaamaan pahan ongelmaan klassista teismiä tehokkaammin. Koska Jumala ei määrää ihmisten vapaita valintoja, voidaan ajatella, että suuri osa kärsimyksestä ja pahasta maailmassa on ihmisten vapaiden valintojen seurausta. Tämä ratkaisu tunnetaan "vapaan tahdon teodikeana" (free will defence). Avoin teismi antaa myös mahdollisuuden ajatella, että osa kärsimyksestä ja pahasta syntyy sen seurauksena, että Jumala rajoittaa omaa kaikkivaltiuttaan luonnon säännönmukaisen toiminnan hyväksi. Luonnon säännönmukainen toiminta on tämän näkemyksen mukaan kaiken elämän edellytys. Jotta Jumala voisi luoda elämää, on hänen sitouduttava luonnon säännönmukaiseen toimintaan. Tämä ratkaisu tunnetaan "vapaiden prosessien teodikeana" (free process defence).

Ajan käsite on erittäin keskeinen klassisen teismin ja avoimen teismin erottamisen kannalta. Käsityksemme ajasta on kuitenkin muuttunut varsin radikaalisti erityisesti fysikaalisten teorioiden 
kehittyessä, mikä puolestaan on heijastunut Jumalan ja maailman suhteen tulkintaan. Karkeasti sanottuna tulkintoja Jumalan ja ajan suhteesta luomisessa on ollut kaksi, jotka perustuvat erilaisille aikakäsityksille:

(1) Jumala on ikuinen.

(2) Jumala on ajaton.

Ensimmäisen näkemyksen mukaan Jumala on ikuinen ja luo maailman tietyllä hetkellä. Jumala ikään kuin on olemassa "ennen" maailmaa ja jollakin hetkellä päättää luoda sen. Ajatus on siinä, että Jumala kokee ajan samalla tavalla kuin mekin eli nykyhetkestä käsin niin, että tulevaisuus on "edessä" ja menneisyys "takana". Aika on tällöin ikään kuin viiva, jota pitkin nykyhetki kulkee eteenpäin. Tällä viivalla on hetkiä, jolloin jotkut maailman tapahtumat ovat historiaa ja toiset tulevaisuutta. Olennaista on, että tulevaisuus ei ole nykyisyyden kannalta "annettu" tai olemassa, vaan muokkautuu nykyhetken edetessä. Jumala on tämän näkemyksen mukaan ikään kuin nykyhetkessä maailman kanssa. Tämä näkemys on juuri se, jota avoimen teismin edustajat kannattavat.

Jälkimmäisen näkemyksen mukaan taas aika on luomakunnan ominaisuus ja tulee olemaan vasta silloin, kun maailma luodaan. Esimerkiksi Augustinus korosti voimakkaasti, että Jumalan näkökulmasta aikaa ei ole olemassa: Jumala ei etene ajassa nykyhetkessä samalla tavalla kuin me, vaan hän on ajaton. Ajaton Jumala ei "etene" ajan viivaa pitkin niin, että tulevaisuus on hänen "edessään" ja menneisyys hänen "takanaan". Tässä mielessä ajattomalle Jumalalle ei ole olemassa menneisyyttä eikä tulevaisuutta vaan ainoastaan yksi pysyvä nykyhetki. Tällaisesta näkemyksestä seuraa se, että luominen ei tapahdu ajassa: ei ole olemassa aikaa, jolloin maailma ei olisi ollut olemassa, koska aika tulee olemaan vasta maailman myötä. Näin ollen on myös järjetöntä kysyä, mitä Jumala teki ennen luomista.

Huomattavaa on, kuinka fysiikan kehitys viime vuosisadan aikana on tehnyt Augustinuksen näkemyksen uudelleen varsin muodik- 
kaaksi. Siirtymä Newtonin absoluuttisesta aikakäsityksestä Einsteinin suhteelliseen käsitykseen ajasta johtaa siihen, että aika katsotaan osaksi avaruutta. Näin ollen ei voi olla olemassa aikaa ilman avaruutta, ei aikaa ilman maailmaa. Fyysikko Paul Davies kirjoittaa:

Ihmiset kysyvät minulta usein koska Big Bang tapahtui. Big Bang ei tapahtunut jossakin tilan pisteessä. Tila tuli olemaan Big Bangin kautta. Samanlainen vaikeus koskee kysymystä siitä mitä tapahtui ennen Big Bangiä. Vastaus on, että ei ole "ennen". Aika tuli olemaan Big Bangin kautta. Kuten olemme nähneet, Augustinus väitti jo kauan sitten, että aika luotiin maailman kanssa eikä maailma jollakin hetkellä, ja tämä on juuri se, johon moderni tiede on päätynyt. ${ }^{87}$

On kuitenkin epäselvää, miten nykyfysiikkaa tulisi tulkita tässä asiassa. Monet ovat päätyneet puolustamaan ajatusta "laatikkouniversumista" (box universe), joka on periaatteessa samanlainen kuin edellä kuvaamamme klassinen käsitys Jumalan ikuisuudesta. Tämän näkemyksen mukaan maailmankaikkeus on menneisyyden ja tulevaisuuden osalta olemassa ja nykyhetki etenee kohti jo olemassa olevaa tulevaisuutta. Toiset ovat puolestaan korostaneet vahvasti sattuman roolia luonnon tapahtumissa ja sitä kautta päätyneet kannattamaan tulevaisuuden avoimuutta. Olennaista on kuitenkin se, että myös avoin teisti voi ajatella, että aika on luodun maailman ominaisuus ja olla yhtä mieltä Augustinuksen kanssa (ja ilmeisesti nykyfysiikan kanssa). Se, minkä avoin teisti kuitenkin torjuu, on se oletus, että kaikki luotu aika olisi Jumalalle ikään kuin yhtäaikaisesti läsnä: avoimen teistin on välttämättä ajateltava, että näin ei voi olla, koska tulevaisuus on aidosti avoin.

Toisistaan eroavista aikakäsityksistään huolimatta avoin teismi ja klassinen teismi ovat varsin lähellä toisiaan verrattuna panenteismiin ja prosessiteismiin. Panenteismi (kr. pan $=$ kaikki, $e n=$ -ssa/-ssä, theos = jumala; "kaikki on Jumalassa") on ollut joidenkin tieteilijöiden, teologien ja filosofien vastaus muuttuneeseen kuvaan maailman luonteesta. Panenteismin nykyaikaiset edustajat, kuten 
esimerkiksi Philip Clayton ja Arthur Peacocke, korostavat todellisuuden kerrostuneisuutta, hyväksyvät ajatuksen emergenssistä ja vastustavat sekä mekanistista maailmankuvaa ja siihen liittyvää reduktionismia ja atomismia. Lyhyesti sanottuna panenteismia luonnehtii ajatus avoimesta ja monikerroksisesta luomakunnasta, joka on osa Jumalaa, joka puolestaan ulottuu luomakunnan ulkopuolelle. Luonnon toiminta ei ole tästä näkökulmasta sen enempää kuin Jumalan säännönmukaista toimintaa.

Peacocke kuvaa luontoa avoimena ja dynaamisena prosessina, joka kehittyessään tuottaa aidosti uusia rakenteita sattuman ja säännönmukaisuuksien yhteispelin kautta. Lisäksi luonnon prosessit ovat toisistaan riippuvaisia ja monitasoisia: meidän ei tule ajatella, että voisimme kuvata luontoa vain yhdellä, esimerkiksi fysiikan, tasolla. Peacocken mukaan tällainen käsitys luonnosta johtaa meidät klassisesta teismistä ja avoimesta teismistä poikkeavaan käsitykseen Jumalan ja maailman suhteesta. Tämän näkemyksen mukaan Jumala on dynaaminen, luova persoonallinen voima, jonka toiminta ei heijastu luonnon säännönmukaisuuksissa ja sattumissa, vaan joka on luonnon säännönmukaisuutta ja sattumaa. Luomakunnan olemassaolo ja dynaaminen luonne viittaa itsensä ulkopuolelle, perustavaan todellisuuteen, jonka sisällä luomakunta on. Tämä todellisuus on luonteeltaan

itseoleva, ... kaiken muun olevaisen perusta, yhtenäinen moninaisuudessaan, olio, joka on pohjattoman monipuolinen ja luova, täydellisen rationaalinen, kaikkitietävä, kaikkivaltias, kaikkialla läsnä oleva ja ikuinen ja persoonallinen tai yli-persoonallinen. ${ }^{89}$

Jumalan olennainen piirre on hänen jatkuva luova tahtonsa: Jumala tuo uusia asioita ja prosesseja olemaan jatkuvasti sattuman ja säännönmukaisuuksien kautta, ei täyttämällä aukkoja tässä prosessissa.

Olennaista panenteismissä on, että Jumala ei ole erillinen luomakunnasta, vaan osa sitä. Panenteisti ei tunnusta eroa luonnollisen ja yliluonnollisen välillä, eikä hänen näkökulmastaan näin ollen ole 
mitään mieltä puhua siitä, että Jumala "puuttuu" luonnon kulkuun ikään kuin Jumala olisi jotain luonnon ulkopuolista. Jumala ei siis toimi luonnon prosessien ulkopuolelta manipuloiden näitä prosesseja vaan niiden sisällä ja niiden kautta. Kosmoksessa ei voi missään tapauksessa tapahtua mitään "yliluonnollista", joka rikkoisi luonnonlakeja, sillä luonnonlakeja ei ole olemassa missään perustavassa mielessä. Ihmeitä voi kyllä panenteistinkin mukaan tapahtua, mutta tällöin kyseessä ei ole luonnollisen järjestyksen rikkoutuminen vaan pikemminkin jonkin yllättävän potentiaalin aktualisoituminen. "Luonnollinen järjestys" ja "luonnonlait" ovat vain luomiamme malleja, jolla ennustamme Jumalan toiminnan säännönmukaisuutta. Jumala on luomisen hetkellä sitonut itsensä säännönmukaiseen toimintaan, koska haluaa kosmoksen olevan rationaalinen.

Jumalan ja maailman välisen eron hajottamisen lisäksi panenteisti haluaa päästä eroon mielen ja ruumiin (sielun ja aineen) erottamisesta. Sen sijaan, että ihmisen katsottaisiin koostuvan sielusta ja ruumiista, meidän tulisi pitää ihmistä fysikaalisista osista ja prosesseista koostuvana kokonaisuutena, jolla on sekä mentaalisia että sosiaalisia ominaisuuksia. Jumalan toiminta ihmisen sielussa tapahtuu aivan samalla tavalla kuin Jumalan toiminta muuallakin luonnossa: Jumala toteuttaa kosmoksen, ihmiskunnan ja yksittäisen ihmisen päämääriä tuntemiemme säännönmukaisuuksien taustalla olevan indeterminismin kautta.

Panenteismi on herättänyt paljon positiivista vastakaikua monien tieteilijöiden ja teologien keskuudessa, koska se näyttää pitävän huolen sekä Jumalan toiminnasta maailmassa että luonnon itsenäisyydestä. Panenteisti torjuu sellaiset tulkinnat Jumalan ja maailman suhteesta, jotka ujuttavat Jumalan erityisiä toimia osaksi kosmosta esimerkiksi sen synnyn yhteydessä: erilaiset kreationismin muodot, jotka olettavat Jumalan yliluonnollisen luomisen tai älykkään suunnitelman ideaan perustuvat teoriat luonnollisiin prosesseihin vaikuttavasta Jumalan yliluonnollisesta voimasta torjutaan. Panenteisti kuitenkin hyväksyy eräänlaisen älykkään suunnittelun idean: kosmoksen prosessit (Jumalan toiminta) ovat päämäärähakuisia. 
Jumalan toiminta tähtää siihen, että kosmokseen syntyy vapaita ja älykkäitä olioita ja että nämä oliot yhdessä koko kosmoksen kanssa lopulta otetaan osaksi jumalallista elämää.

On hyvin vaikea nähdä kuinka panenteismi ja klassinen teismi voisivat olla yhteensopivia. Panenteismin ja avoimen teismin välillä on kuitenkin monia linkkejä. Ensinnäkin panenteistin Jumala on leimallisesti "tämänpuoleisempi" kuin klassisen teismin ja avoimen teismin Jumala: maailma ja sen säännönmukaisuudet ovat Jumalaa, vaikka Jumala ei rajoitu maailmaan. ${ }^{90}$ Toiseksi panenteistin Jumala ei ole kaikkitietävä siinä mielessä, että hän tietäisi varmuudella kaikki kosmoksen tulevat tilat. Jumala voi kyllä ennustaa suhteellisen tarkkaan miten kosmos kehittyy mutta hän ei voi tietää sitä täydelliseksi, koska sellainen tieto olisi loogisesti ristiriitaista. Kolmanneksi panenteistin Jumala muuttuu osana kosmoksen evoluutiota, Jumala siis sekä vaikuttaa kosmokseen että on itse kosmoksen vaikutusten (esimerkiksi rukousten) kohteena. Tästä seuraa esimerkiksi se, että Jumala kärsii luomakunnan kanssa.

Ehkä kuitenkin suurin ero klassisen teismin ja panenteismin välillä on Jumalan rajallisuus: Jumala on sitoutunut säännönmukaiseen toimintaan eikä voi tehdä radikaaleja poikkeamia toimintaansa muuttamatta kosmosta elinkelvottomaksi. Kosmos on nimittäin avoimuudestaan huolimatta järjestelmä, jonka osat ylläpitävät toisiaan. Jos Jumala esimerkiksi alkaisi toimia säännöllisesti eri tavalla painovoimaa koskevissa asioissa tai edes tekisi yhden poikkeuksen, pitäisi hänen muuttaa toimintaansa joka tasolla hiukkasista astrofysiikkaan ja tällöin kosmos ei enää voisi ylläpitää elämää. Näin ollen panenteistin Jumala ei ole kykenevä esimerkiksi poistamaan pahuutta kosmoksesta: pahuus on seurausta siitä miten kosmos toimii ja kosmoksen koko toiminta juuri nykyisen kaltaisena on välttämätöntä älykästä elämää varten.

Panenteismi on puolestaan hyvin läheistä sukua "prosessifilosofialle" ja "prosessiteologialle". Prosessifilosofian juuret ovat 1900-luvun alussa, jossa sen perusajatukset muotoili matemaatikko ja filosofi Albert North Whitehead, joka oli Bertrand Russellin työtoveri 
hänen työstäessään monumentaalista teostaan Principia Mathematica. Whiteheadin työtä teologiseen suuntaan muokkasivat myöhemmin esimerkiksi Charles Hartshorne ja John Cobb. ${ }^{91}$

Lyhyesti sanottuna prosessiajattelun perusidea on se, että luonto on jatkuvassa muutoksen tilassa. Tämä muutos etenee yhteispelinä sattumanvaraisten ja säännönmukaisten prosessien seurauksena ja tuottaa jatkuvasti jotakin uutta, yleensä jotakin monimutkaisempaa kuin sen rakenneosat. Prosessiajattelijoiden vihollinen on sellainen reduktionismi, jossa katsotaan, että luonnon kaikki ilmiöt voidaan palauttaa yhdelle tarkastelun tasolle. Prosessiajattelijat siis asettuvat vahvasti tieteellistä materialismia vastaan, jossa on tapana korostaa fysiikkaa kaikkein "perimmäisenä" selittävänä tekijänä. Reduktionismia vastaan he väittävät, että luonnossa on havaittavissa selkeästi toisistaan poikkeavia monimutkaisuuden tasoja, joita ei voida palauttaa toisiinsa, eikä näin ollen fysikaalinen taso selitysten kannalta perustava. Reduktionismin lisäksi prosessiajattelijat vastustavat vastakkainasetteluja esimerkiksi mielen ja ruumiin sekä ihmisen ja luonnon välillä: kaikki tapahtumat ovat pohjimmiltaan samaa mutta niihin voidaan ottaa kaksi erilaista näkökulmaa, toinen sisältä (mieli) ja toinen ulkoa (aine). Ihminen ei ole tässä tapauksessa mikään poikkeus: vaikka ihmisellä onkin kyky itsetietoisuuteen, on hän jatkumossa muun luomakunnan kanssa.

Prosessiajattelijoilla on taipumus hylätä perinteinen käsitys Jumalasta luomakunnan alkusyynä ja luomakunnasta erillisenä olentona kokonaan. Sen sijaan he korostavat, että Jumala on yksi osa luomakunnan muutoksen prosessia, yksi syy sattuman ja säännönmukaisuuksien yhteispelissä, joka pyrkii jatkuvasti luomaan jotakin uutta. Jumala ei "ohjaa" tai "pistä liikkeelle" vaan hän "houkuttelee" ja "taivuttelee" luomakuntaa tiettyyn suuntaan itsensä uhraavan rakkauden kautta. On selvää, että tällaista Jumalaa ei voida pitää kaikkivaltiaana, kaikkitietävänä tai muuttumattomana: prosessiajattelun mukaan Jumala on jatkuvassa muutoksen tilassa ja maailman vaikutuksien kohteena. Prosessiajattelijoille on myös tyypillistä puhua maailmasta Jumalan ruumiina. Siinä missä panenteistit ajat- 
televat, että maailma on osa Jumalaa, mutta Jumala on maailmaa "suurempi", ajattelevat prosessiteistit, että Jumala yksinkertaisesti on maailma samaan tapaan kuin ihmisellä on ruumis. Tästä tietenkin seuraa se klassisen teismin, avoimen teismin ja panenteismin vastustama tulos, jonka mukaan Jumala ei voi olla olemassa ilman luomakuntaa. Näin ollen luomakunnan on oltava välttämätön ja sen olemassaolo ei voi olla riippuvainen Jumalan luomistyöstä millään perustavalla tavalla.

Jumala ja luomakunta: neljä mallia

\begin{tabular}{|l|l|l|l|l|}
\hline & $\begin{array}{l}\text { Klassinen } \\
\text { teismi }\end{array}$ & Avoin teismi & Panenteismi & Prosessiteismi \\
\hline Luominen & $\begin{array}{l}\text { Luominen } \\
\text { ex nihilo: } \\
\text { Jumala luo } \\
\text { vapaasta } \\
\text { tahdostaan, } \\
\text { joten luo- } \\
\text { makunta on } \\
\text { kontingentti. }\end{array}$ & $\begin{array}{l}\text { Jumala luo } \\
\text { vapaasta } \\
\text { tahdostaan, } \\
\text { joten luo- } \\
\text { makunta on } \\
\text { kontingentti. }\end{array}$ & $\begin{array}{l}\text { Luominen } \\
\text { ex nihilo: } \\
\text { Jumala luo } \\
\text { vapaasta } \\
\text { tahdostaan, } \\
\text { joten luo- } \\
\text { makunta on } \\
\text { kontingentti. }\end{array}$ & $\begin{array}{l}\text { Sekä Jumala } \\
\text { että luoma- } \\
\text { külttämättö- } \\
\text { miä. Luo- } \\
\text { makunnan } \\
\text { olemassaolo ei } \\
\text { riipu Jumalan } \\
\text { toiminnasta. }\end{array}$ \\
\hline Kaikki- \\
valtius
\end{tabular}




\begin{tabular}{|c|c|c|c|c|}
\hline Aika & $\begin{array}{l}\text { Jumala on } \\
\text { ajaton ja } \\
\text { muuttuma- } \\
\text { ton. Ikuinen } \\
\text { nykyhetki. }\end{array}$ & $\begin{array}{l}\text { Jumala on } \\
\text { ikuinen } \\
\text { ja jakaa } \\
\text { nykyhetken } \\
\text { luomakun- } \\
\text { nan kanssa. }\end{array}$ & $\begin{array}{l}\text { Jumala on } \\
\text { osaksi ikui- } \\
\text { nen ja osaksi } \\
\text { ajallinen. }\end{array}$ & $\begin{array}{l}\text { Jumala on } \\
\text { ajallinen ja osa } \\
\text { luomakuntaa. }\end{array}$ \\
\hline $\begin{array}{l}\text { Deter- } \\
\text { minismi/ } \\
\text { indeter- } \\
\text { minismi }\end{array}$ & $\begin{array}{l}\text { Luomakun- } \\
\text { nan men- } \\
\text { neisyys ja } \\
\text { tulevaisuus } \\
\text { ovat Juma- } \\
\text { lalle läsnä } \\
\text { samanaikai- } \\
\text { sesti. Deter- } \\
\text { minismi. }\end{array}$ & $\begin{array}{l}\text { Luoma- } \\
\text { kunnan } \\
\text { tulevaisuus } \\
\text { on aidosti } \\
\text { avoin. Inde- } \\
\text { terminismi. }\end{array}$ & $\begin{array}{l}\text { Luoma- } \\
\text { kunnan } \\
\text { tulevaisuus } \\
\text { on aidosti } \\
\text { avoin. Inde- } \\
\text { terminismi. }\end{array}$ & $\begin{array}{l}\text { Luomakunnan } \\
\text { tulevaisuus on } \\
\text { aidosti avoin. } \\
\text { Indeterminis- } \\
\text { mi. }\end{array}$ \\
\hline $\begin{array}{l}\text { Täydelli- } \\
\text { syys }\end{array}$ & $\begin{array}{l}\text { Jumala on } \\
\text { pysyvästi } \\
\text { täydellisyy- } \\
\text { den tilassa. }\end{array}$ & $\begin{array}{l}\text { Jumala voi } \\
\text { muuttua } \\
\text { mutta hänen } \\
\text { täydellisyy- } \\
\text { tensä pysyy. }\end{array}$ & $\begin{array}{l}\text { Jumala } \\
\text { muuttuu } \\
\text { luomakun- } \\
\text { nan mukana. }\end{array}$ & $\begin{array}{l}\text { Jumala kehit- } \\
\text { tyy luomakun- } \\
\text { nan mukana } \\
\text { kohti täydelli- } \\
\text { syyttä. }\end{array}$ \\
\hline
\end{tabular}

Monet teologisesti suuntautuneet luonnontieteilijät, kuten Peacocke ja Barbour, sekä muutamat teologit (esim. Philip Clayton) ovat olleet taipuvaisia hyväksymään jonkinlaisen panenteismin muodon. Prosessiteologia sen sijaan on harvinaisempaa, koska se edellyttää varsin radikaalia luopumista klassisesta teismistä ja perinteisestä luomisen teologiasta. On kuitenkin sanottava, että toisinaan prosessiteologian ja panenteismin välille on hyvin vaikea tehdä mitään merkittävää eroa. Yleisellä tasolla voidaan sanoa, että prosessiteologian erottaa muista erityisesti käsitys luomisesta (luominen ex nihilo vastaan Jumalan ja maailman välttämättömyys) sekä Jumalan suhde maailmaan (Jumala maailmasta riippumattomana vastaan Jumala 
maailmasta riippuvaisena). Klassinen teismi sen sijaan on yhä varsin suosittu sekä katolisten että protestanttisten teologien keskuudessa. Avoin teismi on taas monien filosofisten teologien ja teististen filosofien suosiossa. ${ }^{92}$

Aiheemme kannalta erityisen tärkeää on se, että valtaosa tutkimamme päällekkäisyysmallin edustajista puolustaa joko avointa teismiä tai panenteismiä. Päällekkäisyysmallin edustajat haluavat korostaa samanaikaisesti sekä luonnon säännönmukaista toimintaa ja sitä kautta tieteen itsenäisyyttä että luonnon tulevaisuuden avoimuutta. On totta, että nykyinen käsitys luonnosta ja sen toiminnasta ei varsinaisesti osoita klassista teismiä virheelliseksi mutta se tuottaa klassiselle teismille lukuisia ongelmia. Suurin näistä ongelmista on klassisen teismin edellyttämä luonnon staattisuus ja muuttumattomuus: tuntemamme luonto on jatkuvassa muutoksessa, johon kuuluvat evoluutio, sattumanvaraisuus ja avoimuus. Avoin teismi ja panenteismi näyttävät tekevän tälle seikalle enemmän oikeutta.

\section{$6 \cdot 3$ \\ MAAILMANKAIKKEUDEN ALKUPERÄ, KONTINGENSSI JA JÄRKEVYYS}

Päällekkäisyysmallin ja luonnon teologian edustajien mukaan Jumalan olemassaolo on yhteensopiva 1900-luvun luonnontieteen kehityksen kanssa. Kuten olemme nähneet, nämä kirjoittajat eivät ajattele johtavansa Jumalan olemassaoloa luonnosta, vaan korostavat kuinka Jumalan olemassaolo tekee monet jotkut tuntemamme maailman piirteet ymmärrettäviksi. Tässä luvussa käsitellään näistä piirteistä erityisesti seuraavia:

(1) maailmankaikkeudella on alku ja näin ollen sen olemassaololla näyttäisi olevan myös syy.

(2) Maailmankaikkeudessa vallitsee järjestys, jonka ihmismieli voi ymmärtää. 
Perinteisen luomisen teologian mukaan maailmankaikkeudella on alku ja sen olemassaololla on syy. Perinteiset kosmologiset argumentit Jumalan olemassaolon puolesta ovat vedonneet näihin seikkoihin. Luonnon teologian edustajat eivät usko näiden argumenttien todistavan Jumalan olemassaoloa, vaan käyttävät niitä osoittamaan, kuinka Jumalan olemassaolo tekee maailmankaikkeuden olemassaolon ymmärrettäväksi. Kosmologisten argumenttien perusidea selittää maailmankaikkeuden olemassaoloa jollakin maailmankaikkeudesta riippumattomalla ja sitä perustavammalla tekijällä. ${ }^{93}$

Voimme erottaa ainakin kaksi erilaista kosmologisten argumenttien perhettä:

(1) Kalam-argumentti ja sen sukulaiset, jotka perustuvat ajatukseen "ensimmäisestä syystä" universumin alussa.

(2) Georg Wilhelm Leibnizin nimeä kantava argumentti (leibnizlainen kosmologinen argumentti) ja sen sukulaiset, joiden mukaan on oltava jokin välttämätön syy sille miksi universumi on olemassa. ${ }^{74}$

Kalam-tyyppinen kosmologinen argumentti perustuu ajatukseen "ensimmäisestä syystä" ja "liikkumattomasta liikuttajasta". Argumentin muotoili ensimmäinen Platon, joka Laeissa väittää, että mikään, mikä on muutoksen alainen (siis itsekin muuttuva), ei voi olla muutoksen perimmäinen syy. Jos oli alku, jossa kaikki oli paikallaan, tarvitaan jokin, joka pystyy aloittamaan liikkeen ilman ulkoista syytä. Tämä olisi liikkumaton liikuttaja. On kuitenkin epäselvää missä määrin Platon tarkoitti keskustelunsa varsinaiseksi argumentiksi. Varsinaiseksi argumentiksi Platonin keskustelun muotoilivat keskiaikaiset muslimiteologit (al-Kindi 801-873 ja al-Ghazali 10581111), joilta se on myös saanut siitä nykykeskustelussa käytetyn nimensä "kalam-kosmologinen argumentti" (arab. kalam = teologi). Nykykeskustelussa argumenttia on puolustanut esimerkiksi William Lane Craig. ${ }^{95}$ Argumentti on jopa hämäävän yksinkertainen ja muodostetaan usein seuraavalla tavalla. 
1. Kaikelle, mikä on tullut olemaan, on olemassa siitä riippumaton syy.

2. Universumi on tullut olemaan.

3. Universumilla on siis siitä riippumaton syy.

Argumentin voima on siinä, että juuri kukaan ei ole valmis kieltämään premissiä (1), koska sen kieltämisestä näyttäisi seuraavan, että ei mistään voi tulla jotain. Tämä vaikuttaa erittäin hankalalta väitteeltä puolustaa. ${ }^{96}$ Keskustelu onkin keskittynyt premissiin (2). Premissi perustuu siihen, että on olemassa jonkinlainen alkupiste ajassa ja paikassa, jota ennen ei ollut mitään muuta kuin tämä ulkoinen syy. Argumentin puolustamiseksi pitää siis osoittaa, että on olemassa kirjaimellinen alkupiste ja että on mielekästä puhua jostakin, joka on universumista "riippumaton" tai "irrallinen". Jos ajatellaan Jumalan olevan tämä universumin ulkoinen syy (ja tämän monet argumentin puolustajat haluavat osoittaa), ajatellaan usein, että Jumala on ikuinen ja on olemassa "ennen aikojen alkua".

Muutamat fyysikot ovat keskustelleet premissistä (2) toisissa yhteyksissä. Kuuluisa matemaattisen fysiikan professori Stephen Hawking on esimerkiksi väittänyt, että

[n]iin kauan kun universumilla on alku, voimme olettaa, että sillä on myös luoja. Mutta jos universumi on todellisuudessa täysin itseriittoinen ja rajaton, niin ei sillä ole loppua eikä alkua: se vain yksinkertaisesti on olemassa. Mihin sitten luoja pannaan? ${ }^{97}$

Hawkingin ajatus on se, että universumilla pitää olla ajalliset tai paikalliset rajat, jotta ajatus luomisesta ja luojajumalasta on mielekäs. Hawking itse sen sijaan on itse heittänyt ilmaan mahdollisuuden, että universumilla ei missään järkevässä mielessä olisi paikallisia tai ajallisia rajoja. Universumi olisi tällöin äärellinen, mutta ajallisesti ja paikallisesti "reunaton". Tämä kuulostaa jälleen arkijärjen vastaiselta. Yksi tapa kuvata tällaista universumia olisi ajatella pisteitä pallon pinnalla: kaikki pisteet ovat samanarvoisia siinä mielessä, että mi- 
kään niistä ei ole alkupiste. Asiasta ei ole yksimielisyyttä eikä Hawkingin "ei rajoja" -oletusta ei ole pystytty testaamaan. Lisäksi malli näyttäisi olevan ristiriidassa hänen omien, varhaisempien näkemyksiensä kanssa. Hawkingin varhaisempi työ erityisesti yhdessä matemaatikko Roger Penrosen kanssa, johti ajatukseen singulariteeteista (mustista aukoista) ja tuki Big Bang teoriaa yhtenäisestä universumin alkupisteestä. "Ei rajoja" -oletus ainakin näyttää olevan ristiriidassa tämän kanssa.

Yhtäältä on sanottava, että jos Hawkingin (ja muut vastaavat) väitteet osoittautuvat paikkansapitäviksi, ne muodostavat ongelman Kalam-argumentille, joka välttämättä edellyttää universumin ajallisen ja paikallisen rajallisuuden. Tästä syystä Kalam-argumentin puolustajat ovatkin pyrkineet osoittamaan ongelmia kaikissa näkemyksissä, jotka perustuvat universumin itseriittoisuudelle tai syntymiselle "ei mistään" itsestään. Toisaalta taas mikään tällainen malli ei ole saanut yleistä hyväksyntää eikä sellaista näytä olevan tulossa. Lopputulokseksi jää varovainen "kyllä" sen puolesta, että maailmankaikkeudella olisi jonkinlainen alkupiste. Jos tämä pitää paikkansa, niin kalam-tyyppisellä kosmologisella argumentilla voidaan ainakin osoittaa, että ajatus luojajumalasta, joka on välttämättä olemassa, on kiinnike tieteen tuntemaan maailmaan.

Monet ovat kuitenkin huomauttaneet, että luomisen teologia ei seiso ja kaadu sen varassa onko universumilla alkupiste ja/tai rajat. Kalam-argumentti olettaa, että sekä universumilla että ajalla on jokin alkupiste. Jotkut ovat kuitenkin väittäneet, että ei ole välttämätöntä uskoa jonkinlaisen alkupisteen olemassaoloon. Esimerkiksi Keith Wardin mukaan luomisessa

tärkeintä on fyysisen riippuvaisuus hengellisestä ja tämä voi pitää paikkansa ilman alkua. Toisin sanoen siis luominen ei koske varsinaisesti universumin alkua, vaan kaiken ajan ja avaruuden ja jokaisen hetken riippuvaisuutta Jumalasta. ${ }^{98}$ 
Kuten olemme jo nähneet, tähän tapaan esimerkiksi monet keskiaikaiset teologit tulkitsivat oppia luomisesta. Aristoteleen, joka oli hyvin vaikutusvaltainen monien keskiaikaisten teologien keskuudessa, mukaan maailma on ikuinen. Tämän näkemyksen mukaan ei ole väliä sillä, onko maailma ikuinen vai ei, sen kannalta loiko Jumala sen vai ei. Olennaista sen sijaan on se, että maailma ei ole välttämätön vaan kontingentti. Maailma olisi voinut olla olematta ja vaatii näin selityksekseen jonkin välttämättömän tekijän eli tekijän, joka ei voi olla olematta olemassa.

Tällainen leibnizlainen kosmologinen argumentti perustuu siihen, että maailmankaikkeutemme olisi voinut olla olematta tai olla kokonaan toisenlainen. Jos maailmankaikkeutemme olisi voinut olla olematta tai olla toisenlainen, pitää meidän selittää miksi se kuitenkin on olemassa ja miksi se on juuri tällainen kuin se on. Selitykseksi maailmankaikkeuden olemassaololle argumentin mukaan kelpaa ainoastaan jokin sellainen, joka on maailmankaikkeutemme "ulkopuolella" - siitä riippumaton olio, joka ei voi olla olematta olemassa. Filosofi Frederick Copleston esitti tämän argumentin nykyaikaisessa muodossa filosofi Bertrand Russellia vastaan seuraavalla tavalla:

Ensimmäiseksi on sanottava, että tiedämme olevan olemassa olioita, jotka eivät ole oman olemassaolonsa syitä. Oma olemassaoloni esimerkiksi riippuu vanhempieni olemassaolosta, ilmasta, ruuasta ja muusta sellaisesta. Toiseksi on sanottava, että maailma on kuviteltu tai todellinen yksilöolioiden kokonaisuus tai aggregaatti, joista yksikään ei kokonaan sisällä oman olemassaolonsa syytä. Ei ole olemassa mitään "maailmaa" erikseen niistä olioista, jotka sen muodostavat yhtään sen enempää kuin on olemassa ihmiskuntaa erikseen ihmisistä, jotka sen muodostavat. Näin ollen, sanoisin, että koska olioita tai tapahtumia on olemassa ja koska yksikään kokemuksessamme ilmenevä olio ei kanna mukanaan oman olemassaolonsa syytä, ... niin olioiden kokonaisuudella on oltava syy, joka on niiden ulkopuolinen. Tämän syyn on oltava jokin olemassa oleva olio. Tämä olio on joko oman olemassaolonsa syy tai sitten ei. Jos se on, 
niin kaikki on hyvin ja kunnossa. Jos se ei ole, meidän pitää jatkaa pidemmälle. Mutta jos jatkamme ikuisesti, niin olemassaololla ei ole laisinkaan selitystä. Joten meidän tulee olemassaolon selittääksemme päätyä lopulta olioon, joka on itse oman olemassaolonsa syy, siis olioon, joka ei voi olla olematta olemassa. ${ }^{99}$

Coplestonin argumentti on korusanaisuudestaan huolimatta varsin tiukka ja sen historia on hyvin pitkä. Jo arabifilosofi Avicenna (IbnSina, 980-1037) esitti vastaavan argumentin Aristoteleen pohjalta. Argumentti menee näin:

1. Jokainen olio on joko kontingentti tai välttämätön.

2. Jos olio on välttämätön, niin välttämätön olio on olemassa.

3. Jos olio on kontingentti, niin on olemassa välttämätön olio, koska

4. kontingentti olio vaatii olemassaololleen syyn (riippumatta siitä edeltääkö tämä syy ajallisesti vaikutusta vai ei).

5. Jos tämä syy on myös kontingentti, niin on olemassa sarja kontingentteja olioita.

6. Ääretön kontingenttien olioiden sarja ei voi olla minkään olion syy.

7. Jokaisen kontingentin olion perimmäinen syy pitää olla olla olio, joka ei vaadi syytä.

8. Näin ollen on olemassa välttämätön olio.

Tämä argumentti ei kalam-argumentin lailla edellytä "aikojen alkupistettä" vaan on yhteensopiva yhtä lailla maailman ikuisuuden kuin Jumalan ikuisuudenkin kanssa. Onnistuessaan argumentti osoittaa, että on olemassa jokin, joka on olemassa välttämättä, siis olio, joka ei voi olla olematta ja joka on kaikkien kontingenttien olioiden syy.

Leibnizlainen kosmologinen argumentti perustuu ajatukseen, jonka mukaan kaikilla kontingenteilla (ei-välttämättömillä) tosiseikoilla tulee olla jokin syy tai selitys (premissi 4). Lisäksi argumentti olettaa, että tällaiseksi syyksi ei kelpaa ääretön syiden sarja, jossa 
edellinen syy selittää jälkimmäisen. Oletus on, että on olemassa jokin välttämätön fakta, johon selittävien syiden sarjan on pysähdyttävä. Tämä oletus tunnetaan yleisesti "riittävän syyn periaatteena" (principle of sufficient reason). Yksi tapa vastustaa leibnizlaista kosmologista argumenttia on kieltää riittävän syyn periaate ja väittää, että maailma kokonaisuutena ei tarvitse selitystä. Maailmankaikkeudelle ei tällöin olisi olemassa riittävää syytä ja riittävän syyn periaate olisi virheellinen. Tämän näkemyksen mukaan, kun olemme selittäneet maailman kaikki oliot, emme enää tarvitse selitystä olioiden kokonaisuudelle. Jos tämä pitää paikkansa, niin kosmologiset argumentit ovat turhia, koska ne yrittävät vastata kysymykseen (miksi maailma on olemassa?), johon ei voida vastata. Tästä vastaväitteestä ei kuitenkaan ole konsensusta. Toinen tapa vastustaa argumenttia on pyrkiä osoittamaan, että ääretön syiden sarja on itse asiassa mahdollinen, mutta tästäkään vastaväitteestä ei ole yksimielisyyttä. ${ }^{100}$

Eri kosmologisen argumentin muotoja koskeva keskustelu on tällä hetkellä vielä avoin. Periaatteessa vaihtoehdot ovat kuitenkin yksinkertaiset. Näyttää siltä, että mikään naturalistinen selitys maailman olemassaololle ei ole saavuttanut yleistä hyväksyntää. Alkuräjähdysteoria kyllä kuvaa miten maailmankaikkeus on tullut olemaan mutta se ei anna maailmankaikkeuden olemassaololle lopullista selitystä. Teoria ei vastaa kysymyksiin siitä, miksi maailmankaikkeus syntyi ja miksi se syntyi juuri sellaiseksi, kun se syntyi. Näin ollen monet naturalistit puolustavatkin ajatusta, että maailman olemassaololle ei ole mitään perimmäistä selitystä: maailma on Bertrand Russelin sanoin "selittämätön fakta". Toinen vaihtoehto, jota monet teistit edustavat, on se, että fysikaalisen maailman synnyn ja olemassaolon perimmäisen selityksen antaa Luoja, joka on välttämätön (ei voi olla olematta) ja johon kaikki selitykset pysähtyvät. Kosmologiset argumentit ovat yksi tapa yrittää osoittaa, kuinka Jumalan olemassaolo tekee maailmankaikkeuden olemassaolosta ymmärrettävän ja antaa sille selityksen. Tämä selitys ei kuitenkaan ole mikään fyysinen tai tieteellinen selitys, vaan perustuu ajatukseen ei-fyysisestä ja persoonallisesta fyysisen todellisuuden perustasta. Huomattavaa 
on, että edes onnistuessaan kosmologiset argumentit tuskin vakuuttavat ateistia. Niitä koskeva keskustelu viittaa kuitenkin vahvasti siihen suuntaan, että maailmankaikkeuden alku ja olemassaolo ovat ymmärrettävissä varsin perinteisen kristillisen luomisen teologian viitekehyksessä.

Sen lisäksi, että päällekkäisyysmallin edustajat ovat olleet kiinnostuneita kosmologisista argumenteista, heitä on myös kiinnostanut toinen maailmankaikkeuden erittäin yleinen piirre: sen ymmärrettävyys. Meillä ei näytä olevan syytä uskoa kaikkien mahdollisten maailmankaikkeuksien olevan ihmiselle ymmärrettäviä: voisihan maailmankaikkeus olla sellainen, ettei ihminen pystyisi ymmärtämään sitä. Samaan aikaan näyttää kuitenkin siltä, että pystymme ymmärtämään maailmankaikkeutta ja maailmankaikkeus on todella ymmärrettävä. Tämä vaatii selitystä. Kun tässä yhteydessä puhutaan maailmankaikkeuden ymmärrettävyydestä, tarkoitetaan jotakuinkin sitä, että

(1) maailmankaikkeudella on rakenne,

(2) jota ihmismieli ja sen välineet (erityisesti matematiikka) pystyvät jäljittämään.

Näin muotoiltuna ymmärrettävyys on itse asiassa ollut klassisesta fysiikasta alkaen koko tieteellisen lähestymistavan perusta. Kuten on jo käynyt ilmi, maailmankaikkeus näyttää paljon monimutkaisemmalta nykyisin kuin mitä klassisen fysiikan (ja klassisen luonnontieteen) edustajat pystyivät kuvittelemaan. Näin ollen myös ymmärrettävyyden ihmeellisyys tai ainakin poikkeuksellisuus kasvaa kasvamistaan, mitä pidemmälle tiede kehittyy. Polkinghorne kirjoittaa:

Se fakta, että voimme ymmärtää maailmaa, on meille niin tuttu, että suurimman osan ajasta pidämme sitä itsestäänselvyytenä. Tämä fakta tekee tieteen mahdolliseksi. Asia olisi kuitenkin voinut olla toisin. Maailmankaikkeus olisi voinut olla kaoottinen epäjärjestys järjestyksen sijaan. On myös mahdollista, että maailmankaikkeuden rakenne olisi sellainen, että 
me emme kykenisi ymmärtämään sitä. ... Mielemme ja maailmankaikkeuden välillä on siis yhtäpitävyys. ${ }^{101}$

Maailman ymmärrettävyys liittyy erityisesti matematiikkaan, joka on monessa mielessä ihmismielen luomus ja järkevyyden mittatikku. Jo klassisen fysiikan edustajat osoittivat, että matematiikkaa voidaan käyttää mallintamaan luonnon ilmiöitä, mutta myös ohjaamaan kokonaan uusien fysikaalista maailmaa koskevien löytöjen jäljille. Monet aiemmat näkemykset mullistavat teoriat on aloitettu pelkällä matematiikalla: näin esimerkiksi suhteellisuusteorian tapauksessa, johon tarvittiin vain liitutaulu. Polkinghornen mukaan

se, että matematiikan avulla voidaan löytää uusia fysikaalisen todellisuuden puolia, viittaa hyvin syvään maailmankaikkeuttamme koskevaan tosiseikkaan: ihmismielen yhdenmukaisuuteen luonnon säännönmukaisuuksien kanssa. Elämme maailmassa, jonka fyysinen syvärakenne on läpinäkyvä, järkevä ja kaunis. ${ }^{102}$

Tämä "matematiikan ällistyttävä tehokkuus" on seikka, joka kaipaa selitystä. Ei näytä olevan välttämätöntä, että ihmismielen tuottamat "kauniit" yhtälöt todella johdattaisivat meidät fyysisen todellisuuden jäljille. Polkinghornen mukaan Jumalan olemassaolo selittää tämän seikan hyvin: Jumala on täydellisen järkevä persoonallinen olio, ja hän on luonut maailmankaikkeuden, joten voimme olettaakin sen heijastavan järkevyyttä. Näin ollen Jumalan täydellinen järkevyys on perusta maailmankaikkeuden järkevyydelle. Lisäksi hän väittää, että koska ihminen on luotu Jumalan kuvaksi, on hänellä kyky ymmärtää maailmankaikkeuden syvärakennetta.

Kuten jo aiemmin on käynyt ilmi, klassisen fysiikan edustajat, erityisesti Galilei ja Newton, perustelivat omaa lähestymistapaansa luontoon, ja erityisesti uskoaan luonnon järkevyyteen ja ihmisen kykyyn ymmärtää sitä matemaattisin välinein, juuri luomisen teologialla. Heidän mukaansa Jumala on luonut maailmaan järjestyksen ja pakottanut sen noudattamaan lakeja, luonnonlakeja. Ihmisen 
tulee tämän näkemyksen mukaan käyttää järkensä kykyjä näiden luonnonlakien löytämiseen ja systematisoimiseen. Olennaista on, että tämä tehtävä katsottiin luonteeltaan hengelliseksi: luonnon perusrakenteiden ymmärtäminen ja paljastaminen on Jumalan luovan tahdon, voiman ja järkevyyden kunnioittamista. Vaikka emme enää jaa Galilein ja Newtonin horjumatonta uskoa deterministisen luonnonlakien järjestelmän olemassaoloon emmekä siihen, että kaikki luonnon ilmiöt voidaan selittää vetoamalla johonkin luonnonlakiin, perusoletus ymmärrettävyydestä ei ole muuttunut.

Itse "luonnonlain" käsite on maailmankaikkeuden ymmärrettävyyttä ja järkevyyttä koskevan keskustelun ytimessä. ${ }^{103}$ Käsitteen historialliset juuret ovat eittämättä teologiset, vaikka nykyään sitä tosin käytetään varsin usein ilman ajatusta luojajumalasta, joka olisi luonnonlakien lähde. Olemme kuitenkin nähneet, että käsite on yhdessä ajatuksen maailmankaikkeuden ymmärrettävyydestä kanssa hyvin hedelmällinen lähtökohta päällekkäisyysmallin edustajille. Olennaista luonnonlaeissa ovat seuraavat piirteet:

(1) universaalisuus,

(2) objektiivisuus,

(3) ajattomuus. ${ }^{104}$

Luonnonlait katsotaan universaaleiksi siinä mielessä, että niiden katsotaan olevan päteviä paikasta ja ajasta riippumatta. Näin ollen fysikaaliset säännönmukaisuudet ovat samanlaiset sekä Tokiossa että Helsingissä ja ne pätevät yhtä lailla niin keskiajalla kuin uudella ajallakin. Luonnonlakien universaalisuudesta seuraa niiden objektiivisuus: luonnonlakien toiminnalle on aivan sama, kuka tarkkailija tai testaaja on tai millaisesta järjestelmästä on kysymys. Olosuhteet ja tutkijat voivat muuttua, mutta ne säännönmukaisuudet järjestelmien toiminnassa, joita monet luonnonlait kuvaavat, ovat pysyviä. Luonnonlait ovat lisäksi ajattomia siinä mielessä, että ne voidaan kuvata matemaattisessa muodossa: luonnonlait ovat mahdollisia ainoastaan, jos "matemaattisen maailman" ja "fysikaalisen maailman" 
välillä on yhtäpitävyyttä.

Tämän perinteisen näkemyksen mukaan luonnonlait muodostavat maailmankaikkeuden syvärakenteen. On kuitenkin kirjoittajia, jotka ovat haastaneet ajatuksen maailmankaikkeuden "perimmäisen" luonteen olemassaolosta ja luonnonlaeista. Esimerkiksi filosofi David Humen mukaan (1711-1776) luonnonlait eivät ole kuvauksia maailman syvärakenteesta, vaan pelkästään ihmisen luomuksia. Humen mukaan voimme tavoittaa maailman ainoastaan aistiemme välityksellä ja luonnonlait eivät ole mitään muuta kuin ihmismielen yrityksiä jäsentää aistihavaintoja. Näin ollen ihmismieli on se, joka tuottaa fysikaalisen maailman ja siinä havaitsemamme järjestyksen, ei itse maailma. Humen näkemys oli suunnattu niitä vastaan, jotka uskoivat järjen mahdollisuuksiin saada tietoa todellisuudesta (rationalistit kuten Descartes ja Newton) ja 1900-luvulla se oli hyvin suosittu aiemmin käsittelemämme loogisen positivismin ja empirismin piirissä. Olemme kuitenkin nähneet kuinka positivismi joutui 1900-luvun puolenvälin jälkeen epäsuosioon (luku 3.2) tehden tilaa tieteelliselle realismille. Tieteellisen realismin valossa Humen näkemys luonnonlakien luonteesta muuttui hankalammaksi puolustaa..

Kriittisen realismin edustajat sijoittuvat tavallisesti luonnonlakien osalta Humen näkemyksen ja Newtonin naiivin realismin väliin. Tämä pätee myös suurimpaan osaan päällekkäisyysmallin kannattajista ja luonnon teologian edustajista. Kriittisen realismin viitekehyksen sisällä on luovuttava sekä Galilein että Newtonin naiivista realismista, jonka mukaan luonnonlait kuvaavat maailmaa juuri sellaisena kuin se on. Tästä ei kuitenkaan seuraa Humen johtopäätös, jonka mukaan luonnonlait ovat vain ja ainoastaan ihmisen tapoja kuvata tavoittamatonta todellisuutta. Kriittisen realismin mukaan luonnonlait tarjoavat toimivia, mutta abstrakteja malleja luonnon säännönmukaisesta toiminnasta ja näin ollen jäljittävät maailmankaikkeuden syvärakennetta.

Lyhyessä katsauksessamme keskusteluun maailmankaikkeuden järkevyydestä ja ymmärrettävyydestä on tullut esiin kolme vaihtoehtoa. 
(1) Maailmankaikkeus on rakenteeltaan järkevä ja ihminen voi ymmärtää sen, koska molemmat ovat järkevän Jumalan luomuksia.

(2) Meillä ei ole selitystä sille, miksi maailmankaikkeus on rakenteeltaan järkevä ja ihminen voi ymmärtää sen.

(3) Maailmankaikkeuden rakenne ja järjestys ovat ihmisen luomuksia.

Kuten kävi ilmi, luonnon teologian edustajat puolustavat vaihtoehtoa (1) mutta väittävät harvoin, että maailmankaikkeuden ymmärrettävyys ja järkevyys osoittaisivat Jumalan olemassaolon kaikkia vakuuttavalla tavalla. He kuitenkin väittävät, että maailmankaikkeuden ymmärrettävyys, josta nykyaikainen luonnontiede merkittävällä tavalla todistaa, on odotettavissa, jos perinteinen luomisen teologia pitää paikkaansa.

\section{4 \\ HIEN O S Ä ÄTÖ}

Viime vuosina valtaosa päällekkäisyysmallin ja luonnon teologian edustajista on kiinnittänyt erityistä huomiota ajatukseen "hienosäädöstä" (fine-tuning), jonka pohjalta on kehitetty erilaisia versioita perinteisistä suunnitteluargumenteista (teleologisista argumenteista) Jumalan olemassaolon puolesta. ${ }^{105}$ Perusväite on ollut samanlainen kuin maailmankaikkeuden olemassaolon ja ymmärrettävyyden osalta (ks. luku 6.3): hienosäädön olemassaolo on ymmärrettävä siitä näkökulmasta, että on olemassa järkevä ja hyväntahtoinen Luoja, joka haluaa maailmankaikkeuden synnyttävän järkeviä ja moraalisiin valintoihin pystyviä olioita.

Keskustelu hienosäädöstä juontaa juurensa keskusteluun "antrooppisesta periaatteesta" ja antrooppisista ilmiöistä. Keskustelun lähtökohtana oli kahden fyysikon, Barry Collinsin ja Stephen Hawkingin, vuonna 1973 tekemä huomio universumimme fysikaalisten vakioiden ja universumin yleisten piirteiden suhteesta. He kiinnittivät huomiota siihen, että tähdet ja galaksit eivät olisi mahdollisia, jos alkuräjähdyksen voimia olisi ollut hiukkasenkin liian pieni tai liian suuri. Sen hetki- 
sissä teorioissa he eivät nähneet selitystä sille, miksi voima oli juuri sellainen kuin se oli. Vuonna 1974 fyysikko Brandon Carter esitti tämän pohjalta "antrooppisen periaatteen", jonka mukaan meidän ei tule odottaa löytävämme universumista mitään sellaista, joka on ristiriidassa sen kanssa, että ihmiset ovat osa sitä. Toisin sanoen siis universumimme on välttämättä oltava sellainen, että se voi synnyttää meidän kaltaistamme elämää. Ennen vuotta 1986 antrooppinen periaate oli kuitenkin vain tiedeyhteisön sisäisen keskustelun sivujuonne, mutta kun John Barrow ja Frank Tipler julkaisivat kuuluisan kirjansa The Anthropic Cosmological Principle, sai keskustelu siivet. Ajatus siitä, että elämän synty on "rakennettu sisään" universumin fysikaalisiin rakenteisiin oli ymmärrettävällä tavalla yleisön mielikuvitusta kutkuttava.

Ajatus hienosäädöstä voidaan esittää hyvin lyhyesti mutta sen perusteleminen vaatii paljon enemmän työtä. Hienosäädön perusajatus voidaan tiivistää seuraaviin väitteisiin:

(1) pienetkin muutokset perustavissa fysikaalisissa vakioissa (perustavissa luonnonlaeissa) johtavat valtaviin seurauksiin maailmankaikkeuden yleisen luonteen suhteen,

(2) meidän fysikaalisen maailmamme vakiot synnyttävät maailmankaikkeuden, joka pystyy synnyttämään meidän kaltaistamme elämää,

(3) luonnonvakiot määräytyvät sattumalta,

(4) pienetkin muutokset fysikaalisen maailmamme vakioihin synnyttäisivät maailmankaikkeuden, joka ei pystyisi ylläpitämään elämää.

Yhdistettynä nämä väitteet johtavat siihen, että maailmankaikkeutemme fysikaaliset vakiot ovat "hienosäädettyjä": kaikista mahdollisista arvoista fysiikaalisilla vakioilla on tässä maailmankaikkeudessa juuri sellaiset arvot, että elämä on mahdollista. Jos siis hienosäätö on todellinen ilmiö, niin voimme päätellä, että maailmankaikkeuttamme pitää yllä hienovarainen luonnonvakioiden tasapaino: pienikin 
muutos jossakin vakiossa muuttaa koko järjestelmän toisenlaiseksi.

Lukija löytää kirjallisuudesta varsin paljon kuvauksia erilaisista fysikaalisista vakioista, joiden arvojen tulee olla sopivia elämän syntyä varten. Seuraavaksi annan muutaman esimerkin tällaisista vakioista. Alkuräjähdysteorian mukaan alkuräjähdys tapahtui noin 13 miljardia vuotta ${ }^{106}$ sitten. Alkuräjähdyksen ensimmäisten sadasosasekuntien aikana tapahtui valtavan nopea universumin laajentuminen. Jos laajentumisen nopeudessa olisi ollut edes $10^{60}$ muutos jompaankumpaan suuntaan, niin universumi olisi joko lakannut laajentumasta ja sortunut takaisin kasaan tai sitten se olisi laajentunut niin nopeasti, että hiukkaset eivät olisi ehtineet liittymään toisiinsa tehden aineen synnyn mahdottomaksi.

Toinen esimerkki koskee atomiytimien rakennetta. Vetyatomia lukuun ottamatta kaikkien atomien ytimessä on kaksi protonia tai useampia. Protoneita pitää yhdessä voima, joka tunnetaan "vahvana vuorovaikutuksena". Jos vahva vuorovaikutus olisi esimerkiksi $10 \%$ pienempi nykyisestä, niin protonit eivät pysyisi yhdessä eivätkä muut atomit vetyatomin lisäksi olisi mahdollisia. Universumissa, jossa olisi vain vetyatomeita, ei voisi syntyä molekyylejä, jotka ovat kaiken hiilipohjaisen elämän perusta. Jos taas vahva vuorovaikutus olisi $4 \%$ prosenttia pienempi nykyisestä, niin atomiytimet voisivat koostua protonien lisäksi neutroneista. Jos näin kävisi, tähtien ytimissä tapahtuvat reaktiot tapahtuisivat hyvin nopeasti, toisin kuten nykyisessä universumissa, jossa ne kestävät miljardeja vuosia. Tästä puolestaan seuraisi se, että universumissa ei voisi olla tähtiä, jotka tuottaisivat hiilipohjaisen elämän edellyttämät alkuaineet.

Kolmas esimerkki koskee niin ikään atomiytimiä. Vahvan vuorovaikutuksen tulee olla juuri sopivassa suhteessa elektromagneettisen voiman kanssa. Elektromagneettinen voima työntää protoneita toisistaan erilleen siinä, missä vahva vuorovaikutus vetää niitä yhteen. Jos jommassakummassa voimassa olisi pienikin muutos, atomiytimet eivät pysyisi yhdessä.

Olennaista näissä esimerkeissä on juuri luonnonvakioiden ja universumimme yleisten piirteiden läheinen yhteys. Hienosäätö viittaa 
siis siihen suuntaan, että ne piirteet, jotka tekevät elämän mahdolliseksi, on kirjattu universumimme perusrakenteeseen. On helppo ymmärtää, kuinka tällaisella tuloksella on varsin suuri teologinen relevanssi. Fyysikko Freeman Dyson kirjoittaa:

näiden fysikaalisten ja astronomisten sattumien [nykyiset fysikaaliset vakiot] perusteella päättelen, että universumi on yllättävällä tavalla vieraanvarainen ympäristö eläville olioille. Koska olen tiedemies ja koulutettu ajattelemaan ja puhumaan 1900-luvun kieltä eikä 1700-luvun kieltä, en väitä että universumin arkkitehtuuri todistaa Jumalan olemassaolon. Väitän vain, että universumin arkkitehtuuri on yhtäpitävä sen oletuksen kanssa, että on olemassa mieli, jolla tärkeä rooli universumin toiminnassa. ${ }^{107}$

Monet ovat käyttäneet edellä kuvattua päättelyä muodostamaan argumentteja Jumalan olemassaolon puolesta. Hienosäätöön perustuva suunnitteluargumentti (argument from fine-tuning tai the new argument from design) voidaan muotoilla seuraavalla tavalla. ${ }^{108}$

1. Universumi on hienosäädetty elämää varten.

2. Hienosäätö on todennäköistä, jos Jumala on olemassa.

3. Hienosäätö on epätodennäköistä, jos Jumalaa ei ole olemassa.

4. Näin ollen hienosäädön olemassaolo on vahva todiste Jumalan olemassaolon puolesta.

Hienosäädön mahdollisuus ja siihen liittyvä hienosäätöön perustuva suunnitteluargumentti on herättänyt erittäin paljon keskustelua. Vastaväitteet ovat koskeneet lähinnä premissiä (3) ja niitä on periaatteessa kaksi. Ensimmäisen vastaväitteen mukaan universumimme fysikaaliset vakiot eivät ole hienosäädettyjä, koska niiden arvot eivät määräydy sattumanvaraisesti, vaan niiden määräytymistä ohjaavat vielä tuntemattomat, perustavammat, fysikaaliset lainalaisuudet. Näin ollen fysikaalisten vakioiden nykyiset arvot ovat niiden ainoat mahdolliset arvot. Tämä vastaväite perustuu ajatukseen siitä, että on olemassa jokin nykyiselle fysiikalle vielä tuntematon teoria, 
joka tarjoaa lait, jotka puolestaan selittävät, miksi universumin vakiot ovat nykyiset. Tämän vastaväitteen ongelmana on se, että tällaisesta teoriasta ei ole vielä tietoa. Jotkut ovat ehdottaneet, että suhteellisuusteorian ja kvanttifysiikan yhdistävä "kaiken teoria" voisi olla tällainen teoria, mutta yksimielisyyttä ei ole.

Toinen, ja ehkä suosituin tapa, vastustaa hienosäädön teologista tulkintaa tunnetaan "multiversumi-vastaväitteenä". Vastaväitteen perusajatus on se, että universumimme fysikaaliset vakiot ovat kyllä sattumanvaraisia, mutta meidän universumimme ei ole hienosäädetty, koska se on osa suurempaa universumien joukkoa (multiversumi). Tässä universumien joukossa kullakin universumilla on omat luonnonvakionsa. Multiversumin ajatus perustuu siihen, että maailmankaikkeuksia syntyy ja häviää jatkuvasti (joko ajallisessa ketjussa tai "samanaikaisesti") ja jokaisen maailmankaikkeuden fysikaaliset vakiot määräytyvät sattumanvaraisesti. Näin ollen hienosäädössä ei ole mitään yllättävää: olemme yhdessä niistä universumeista, jotka kykenevät ylläpitämään elämää. Multiversumi-vastaväitteen mukaan siis ei tarvita selitystä sille, miksi juuri meidän universumimme on hienosäädetty elämää varten.

Multiversumi-vastaväitteen ongelmana on se, että se edellyttäisi jonkinlaista fysiikan kannalta uskottavaa teoriaa toisista universumeista. Tällaisista teorioista on ollut viitteitä, mutta mikään ehdotus ei ole saanut laajaa hyväksyntää. Toinen ongelma on se, että vaikka muita universumeita olisikin olemassa, emme voi saada niistä tietoa. Jo pelkästään määritelmien tasolla voidaan sanoa, että universumit ovat toisistaan kausaalisesti ja ajallisesti riippumattomia. Näin ollen jo puhe siitä, että ne olisivat "samanaikaisia" on tyhjää puhetta: emme voi puhua samanaikaisuudesta tilanteessa, jossa meillä on kaksi toisistaan täysin riippumatonta aikajanaa. Nykyisen tiedon nojalla siis näyttäisi yksinkertaisemmalta olettaa, että on olemassa vain tämä yksi universumi tai sitten jättäytyä ottamasta kantaa koko keskusteluun.

On totta, että hienosäätöön perustuvasta suunnitteluargumentista ei ole yksimielisyyttä, mutta itse vakioiden olemassaolosta ja 
niiden vaikutuksesta tuskin on enää epäselvyyttä: universumin kyky ylläpitää elämää on riippuvainen sen fysikaalisesta perusrakenteesta. Se, miten tätä seikkaa tulee selittää ja voidaanko sitä käyttää evidenssinä Jumalan olemassaolon puolesta, on sen sijaan kiistakysymys. Luonnon teologian kannalta todistaminen on kuitenkin sivuseikka, ja pääasia on jälleen kerran se, että universumimme kyky tuottaa elämää - sen rakenteellinen "hedelmällisyys" - on odotettavissa perinteisen luomisen teologian näkökulmasta. Viittasimme jo aiemmin Augustinuksen luomisen teologiaan (ks. luku 6.1), jonka mukaan luominen tapahtuu luomisen hetkellä maailmankaikkeudelle annettuihin mahdollisuuksiin, jotka realisoituvat ajan kuluessa. Tällainen näkemys olisi yleisellä tasolla yhteensopiva hienosäädön ajatuksen kanssa.

Luonnon teologian edustajalle ajatus hienosäädöstä antaa hedelmällisen lähtökohdan etsiä Jumalaa koskevaa tietoa. Jos kosminen "hienosäätäjä" on persoonallinen toimija, niin voimme ainakin päätellä, että tämä hienosäätäjä haluaa elämän syntyvän (on hyvä) ja haluaa tämän elämän olevan varsin lähellä sellaista elämää, joka nyt on olemassa (arvostaa olentoja, jotka ovat tietoisia, vapaita ja pystyvät moraalisiin valintoihin, arvostamaan kauneutta). Tällainen säätäjä alkaisi jo muistuttaa kristillisen teologian ilmoituksen kautta tuntemaa Jumalaa paljon enemmän kuin välttämätön alkusyy tai jokin muu vastaava kosmologisten argumenttien olettama vaikuttaja.

Edellä esitellyt lyhyet kommentit ovat tällä erää riittävä katsaus hienosäätöä koskevaan keskusteluun. Palaamme aiheeseen kuitenkin myöhemmin teistisen evoluution yhteydessä (luku 7.3). Monet luonnon teologian edustajat, kuten esimerkiksi McGrath ja Peacocke, rakentavat hienosäätönäkökulman pohjalle myös "evoluution teologian", jossa hienosäädettyjen vakioiden ajatellaan ohjaavat monimutkaisempien olioiden ja ilmiöiden kehitystä eri tasoilla aina fysiikasta biologiaan asti. Tästä kuitenkin lisää myöhemmin. 
$6 \cdot 5$

JUMALAN TOIMINTA FYSIKAALISESSA MAAILMASSA

Eräs kaikkein tärkeimmistä kysymyksistä tieteen ja kristinuskon suhteesta puhuttaessa on Jumalan toiminta luomakunnassa. Monien mielestä Jumalan toiminta fysikaalisessa maailmassa on nykyisen tieteellisen tietomme nojalla ongelma. Jumalan toiminnan ongelma syntyy seuraavalla tavalla. Yhtäältä kaikki edellä kuvaamani neljä yleistä mallia, klassisesta teismistä prosessiteismiin edellyttävät Jumalan vaikutusta luonnon prosesseihin ja erityisesti niihin, joilla on tekemistä ihmisten kanssa. Koko luomisen teologian perusajatus on se, että Jumalalla on maailmankaikkeutta koskeva suunnitelma ja hän toimii jollakin tavalla sen toteuttamiseksi. Teologia siis edellyttää Jumalan aktiivista vaikutusta maailmassa. Toisaalta taas meillä on se vaikutelma, että toimiakseen maailmassa Jumalan pitäisi jollakin tavalla puuttua tai rikkoa fysiikan ja muiden tieteiden kuvaamia luonnon lainalaisuuksia. Näin ollen meillä on kaksi perusvaihtoehtoa:

(1) Interventionismi, jonka mukaan maailma on suljettu järjestelmä ja Jumala toimii maailmassa puuttumalla luonnonlakeihin tai rikkomalla niitä.

(2) Immanentismi, jonka mukaan maailma on suljettu järjestelmä ja Jumala toimii maailmassa luonnonlakien kautta tai niiden välityksellä.

Kehityksellä, joka on johtanut näiden kahden perusvaihtoehdon syntyyn, on pitkät juuret. Jumalan toiminta maailmassa ei ollut ongelma keskiaikaisen synteesin sisällä. Ongelma siitä tuli vasta silloin, kun mekanistinen maailmankuva sai valta-aseman. Mekanistisen maailmankuvan viitekehyksessä kaikki Jumalan aktiivinen toiminta maailmassa edellyttää jonkin luonnon säännönmukaisuuden rikkomista. Mekanistien atomismin ja reduktionismin mukaan kaiken luonnon toiminnan aiheuttavat viime kädessä fysikaalisia atomeita ohjaavat luonnonlait. Jos siis Jumala vaikuttaa luonnossa, niin hänen 
tulisi olla yksi tällainen fysikaalinen voima - voima, jota ei fysiikan teorioissa tietenkään ole. Näin ollen Jumalan on toimiakseen muutettava näitä voimia tai jotenkin puututtava niihin. Monet kuitenkin uskoivat, että klassisen fysiikan teoriat ovat lopullisia ja varsin täydellisiä kuvauksia maailmasta, mistä seurasi se, että Jumalasta tuli kellokoneiston Jumala, joka asetti luonnonlait voimaan ja vetäytyi taka-alalle. Syntyi deismi, joka kaikkien immanentismin mukaisten ratkaisujen prototyyppi: koko luomakunta on viritetty luomisen hetkellä toteuttamaan tietty suunnitelma, johon ei Jumala itsekään enää puutu.

Mekanistisen viitekehyksen sisälle sijoittuu myös toinen perusmalli, interventionismi. Interventionismin edustajat hyväksyvät immanentistien kanssa sen ajatuksen, että luonto voidaan ymmärtää itseriittoisena mekanismina. He kuitenkin haluavat pitää kiinni Jumalan aktiivisesta toiminnasta maailmassa, joten heidän on väitettävä, että Jumala todella rikkoo aktiivisella toiminnallaan luonnonlakeja. Perinteisesti sanottaisiin, että vain sellaiset tapahtumat, joille ei ole luonnollista selitystä, ovat Jumalan toimintaa, ihmeitä. Interventionismia ja immanentismia yhdistää ajatus siitä, että maailmankaikkeus on suljettu järjestelmä, johon Jumala joko ulkopuolelta puuttuu tai sitten ei. Ajatus on se, että fysikaaliset teoriat ja niiden yleiset lait (luonnonlait) ovat tosia kuvauksia maailman syvärakenteesta, joka on periaatteessa mekanistinen. Jos maailma on tällainen luonnonlakien ohjaama kone, niin Jumalan aktiiviselle toiminnalle ei jää muuta vaihtoehtoa kuin mekanismin lakien rikkominen. Tämä kuva maailmasta on iskostunut meihin niin syvälle, että arkikielessäkin puhumme usein "Jumalan puuttumisesta asioiden kulkuun" tai "luonnonlakien rikkomisesta". Toinen seikka, joka yhdistää immanentismia ja interventionismia, on se, että ne perustuvat pitkälti klassiseen teismiin. Kuten olemme jo nähneet, klassisella teismillä on taipumus johtaa siihen, että maailman tapahtumat ovat Jumalan määräämiä ennalta. Tältä osin se sopii hyvin yhteen mekanistisen maailmankuvan kanssa, joka korostaa myös maailman ennustettavuutta ja säännönmukaista rakennetta. Klassisen 
teismin ja mekanistisen maailmankuvan sisällä ei yksinkertaisesti näytä olevan mitään muita vaihtoehtoja kuin immanentismi tai interventionismi.

Olemme kuitenkin jo nähneet, kuinka 1900-luvun kehitys on haastanut mekanistisen maailmankuvan atomismin, determinismin ja reduktionismin. Monikerroksellisessa todellisuudessamme kaikki syyt ja selitykset eivät ole "fysikaalisia", vaikka selityksen kohteena ovatkin viime kädessä fysikaaliset rakenteet. Ihmiset, ihmismielet ja yhteiskunnat ovat kyllä fysikaalisia mutta eivät selitettävissä fysiikalla. Maailma ei ole tässä mielessä mikään kone, jonka toiminnalle on riittävät fysikaaliset syyt ja jonka tulevaisuus on täydellisesti määrätty sen alkuehtojen perusteella. Klassisessa fysiikassa luonnonlait nähtiin koko maailman toimintaa ohjaavina periaatteina: kun kaikki lait löydettäisiin, voitaisiin koko maailman toiminta ymmärtää ja selittää tyhjentävästi. Luonnonlait olivat ikään kuin koko maailman selkäranka ja esimerkiksi Newton ja Galilei pitivät juuri tätä maailman piirrettä Jumalan työnä. Jos sen sijaan oletamme realismin viitekehyksen ja tunnustamme maailmamme kerrostuneisuuden ja avoimuuden, niin on luontevampaa ajatella, että luonnonlait ovat meidän kehittämiämme malleja, jotka kuvaavat joitakin luonnon säännönmukaisia osa-alueita. Sattuman rooli aiheuttaa sen, että luonnossa voi olla prosesseja, joihin minkäänlaiset säännönmukaiset kuvauksemme eivät sovi ja joita emme pysty ennustamaan.

Monikerroksellinen ja tulevaisuudelle avoin näkemys luonnosta antaa teoriassa mahdollisuuden ajatella, että Jumala toimii aktiivisesti luonnossa kuitenkaan palauttamatta Jumalaa jonkinlaiseksi fysikaaliseksi syyksi tai tieteessä toimivaksi selitystekijäksi. Monien nykyisten Jumalan toiminnan mallien idea onkin juuri se, että Jumalan toiminta katsotaan samaan aikaan objektiiviseksi eli aidosti maailmaan vaikuttavaksi, mutta myös sellaiseksi, että se ei riko luonnon säännönmukaisuuksia eikä siten tieteen itsenäisyyttä. Tällaisia näkemyksiä on tapana kuvata sanahirviöllä "ei-interventionistinen objektiivinen Jumalan toiminta" (non-interventionist objective divine action), josta käytän jatkossa englanninkielisen ilmaisun mukais- 
ta lyhennettä NIODA.

Nykyisessä keskustelussa NIODA rakennetta noudattavia malleja ovat ainakin seuraavat:

(1) Uustomistinen malli, joka erottaa luomakunnan prosessien ensisijaiset (lat. causa prima) ja toissijaiset syyt (lat. causa secunda).

(2) Kvanttifysiikan inspiroima malli, jonka mukaan Jumalan toiminta perustuu mikromaailman avoimuuksien määrittelemiselle.

(3) Emergentismin inspiroima näkemys, jonka mukaan Jumala toimii "alaspäisen kausaation" tai jonkinlaisen muun vaikutuksen kautta, jossa kokonaisuus vaikuttaa osiin.

Viittasimme jo aiemmin (ks. luku 4.1) lyhyesti Tuomas Akvinolaisen erotteluun ensisijaisten ja toissijaisten syiden välillä. Ajatus elää nykyäänkin vahvasti katolisten tieteilijöiden, teologien ja filosofien keskuudessa. Ehkä vaikutusvaltaisimman nykyaikaisen muotoilun tästä ideasta on antanut tieteenfilosofi Ernan McMullin. McMullinin näkemys maailman säännönmukaisuudesta on varsin perinteinen: maailma on luonnollisten syiden ja säännönmukaisuuksien verkosto, jotka voidaan tavoittaa luonnollisella järjellä. ${ }^{109}$ Jumala ei ole osa tätä verkostoa siinä mielessä kuin maailman prosessit ja oliot ovat osa sitä. Näin ollen tieteellisiin selityksiin ei lopulta tule jäämään aukkoja, vaan kaikelle löytyy riittävä toissijainen syy. Ensisijaiset syyt sen sijaan koskevat maailmaa kokonaisuutena ja erityisesti sen tarkoitusta. Maailman ja sen toimintojen tarkoitus on puolestaan taas toissijaisten syiden kannalta näkymätön ja näin ollen myös tieteelle näkymätön. Ajatus on se, että sekä ensisijaiset että toissijaiset syyt edustavat Jumalan toimintaa maailmassa mutta toissijaiset syyt ovat Jumalan toimintaa erilaisten välineiden välityksellä. Usein käytetty kielikuva on työmiehen ja työkalun suhde. Kirveen osuminen halkoon on riittävä selitys toissijaisten syiden näkökulmasta sille, miksi halko halkesi kahtia. Kirvesmiehen tarkoitus, vaikkapa tässä tapauksessa saunan lämmittäminen, on kuitenkin halkojen ensisijainen syy. Sama pätee luonnon yleisiin säännönmukaisuuksiin: voimme 
kuvata niitä puhumatta Jumalasta, koska ne ovat Jumalan työkaluja oman päämääränsä toteuttamiseksi ja tämä päämäärä on taas tieteellisen kuvauksen ulkopuolella. Samaan aikaan kuitenkin luonnon säännönmukaiset toiminnat ovat Jumalan toimintaa samaan tapaan kuin halkojen halkeaminen on kirvesmiehen toimintaa.

Ensisijaisten ja toissijaisten syiden erottaminen tähän tapaan johtaa siihen, että meille syntyy kaksi toisistaan riippumatonsa selitysten tasoa. Tieteelliset selitykset kuvaavat Jumalan välillistä toimintaa ja ovat omalla alueellaan täydellisiä. Teologiset selitykset puolestaan koskevat maailman tapahtumien tarkoitusta ja päämääriä, jotka voidaan erottaa toissijaisista syistä. Näin ollen Jumalan toiminta on kyllä objektiivista siinä mielessä, että se todella vaikuttaa maailmaan mutta se ei vaikutuksestaan huolimatta "riko" tai "puutu" tieteen tutkimiin luonnon lainalaisuuksiin. Tästä seuraa myös se, että teologialla ei ole mitään sanottavaa toissijaisten syiden yksityiskohdista: teologinen tieto koskee Jumalan tarkoituksia eikä hänen käyttämiään mekanismeja. Näin ollen teologinen tieto ei sano mitään esimerkiksi niistä säännönmukaisuuksista, joita kosmologia tai biologia tutkii. Sama pätee myös toiseen suuntaan: näiden teorioiden pohjalta ei voida sanoa mitään Jumalan päämääristä ja tarkoituksista eikä näin ollen myöskään Jumalan olemassaolosta.

Toinen varsin suosittu tapa ymmärtää Jumalan toiminta maailmassa on kvanttifysiikan ja erityisesti sen indeterministisen tulkinnan inspiroima. Väite on se, kvanttifysiikan teoriat paljastavat maailman, jossa monilla mikromaailman tapahtumilla ei ole mekanistista syytä vaan ainoastaan todennäköisyys. Näin voidaan ajatella, että Jumala on se, joka viime kädessä määrittää mikromaailman tilat. Erään tämän näkemyksen kannattajan, filosofi Robert John Russellin mukaan koko malli perustuu sille ajatukselle, että kvanttimaailmassa on aitoa indeterminismiä: usea erilainen kvanttitila on samaan aikaan mahdollinen emmekä pysty ennustamaan sitä, mikä mahdollinen tila toteutuu. ${ }^{110}$ Mallin mukaan Jumala on se, joka valitsee mikä mahdollinen kvanttitila toteutuu. Russellin mukaan Jumala pystyy tällä tavoin vaikuttamaan maailmaan ilman, että hän 
"puuttuu" mihinkään luonnon säännönmukaisuuksiin.

Keskeinen ongelma tässä näkemyksessä on se, miten Jumalan toiminta kvanttimaailmassa vaikuttaa makroskooppiseen arkimaailmaamme. Kriitikot ovat väittäneet, että vaikka Jumala vaikuttaisikin kvanttitasolla, sillä ei olisi mitään merkitystä arkipäivämme makrotasolla. Russellin vastaväite puolestaan on, että kvanttimaailman tapahtumat voivat helposti kumuloitua esimerkiksi geologian, klassisen fysiikan ja biologian tapahtumiksi aina ihmisten arkeen saakka. Russellin ajatus perustuu jo aiemmin kuvaamallemme ajatukselle maailman kerroksellisesta rakenteesta. Jumala toimisi tämän näkemyksen mukaan ensisijaisesti kaikkein alimmalla tasolla, todellisuuden "pohjalla", joka taas vaikuttaisi ylempien tasojen tapahtumiin rikkomatta kuitenkaan niiden säännönmukaisuuksia. Russell myöskin korostaa, että tämänkaltainen käsitys Jumalan toiminnasta ei sulje pois muita mahdollisia näkemyksiä. Se voi olla osa laajempaa kokonaisnäkemystä Jumalan toiminnasta.

On tavallista, että kvanttifysiikan inspiroima näkemys liitetään osaksi laajempaa NIODAn muotoa, joka perustuu jo aiemmin käsitellylle ajatukselle todellisuuden monikerroksisuudesta ja kerrosten välisistä emergenteistä suhteista. Mainitsimme ohimennen jo aiemmin sen, kuinka emergenssi tekee mahdolliseksi sen, että kokonaisuudet vaikuttavat omiin rakenneosiinsa ja ylemmän tason ilmiöt alemman tason ilmiöihin (ks. luku 5.4). Tähän mahdollisuuteen perustuvat ne NIODAn muodot, joiden mukaan Jumala toimii maailmassa vaikuttamalla järjestelmiin eri tasoilla määrittelemällä niiden ympäristön ja viime kädessä koko todellisuuden kokonaisuuden. Tämän näkemyksen ymmärtämiseksi tarvitsemme muutamia peruskäsitteitä.

Aiemmin kuvaamamme klassisen fysiikan atomismi (ks. luku 4.2) ja klassinen reduktionismi (ks. luku 5.4) perustuvat siihen, että kokonaisuuksien toiminta voidaan aina selittää niiden rakenneosien toiminnalla. Yksittäiset rakenneosat voidaan puolestaan purkaa omiin osiinsa niin pitkälle, kunnes päädytään lopulta fysiikan tutkimiin alkeishiukkasiin. Taustalla on ajatus siitä, että 
kaikki voimat ja vaikutukset luonnossa ovat fysikaalisia voimia ja vaikutuksia eli ne ovat kuvattavissa fysiikan teorioiden kielellä. Toisinaan onkin tapana puhua siitä, että vain fysikaalisilla voimilla ja olioilla on "kausaalista voimaa" (causal power) eli vain ne aiheuttavat vaikutuksia ja näin ollen selittävät tapahtumia. Jos tämä pitää paikkansa, niin syy-seuraus -suhteet tapahtuvat aina "alhaalta ylöspäin" eli osista kokonaisuuteen: rakenneosista itse rakenteeseen. Tällöin puhutaan "ylöspäisestä kausaatiosta" (bottom-up causation). Olemme kuitenkin jo moneen kertaan puhuneet siitä, kuinka monet luonnon teologian edustajat ajattelevat luonnon olevan monikerroksellinen. Olennaista on se, että monikerroksellisessa todellisuudessa syy-seuraus -suhteet kulkevat molempiin suuntiin: osista kokonaisuuteen ja kokonaisuudesta osiin. Näin ollen voidaan myös puhua "alaspäisestä kausaatiosta" (top-down causation tai downward causation). ${ }^{111}$

Alaspäisen kausaation perusidea on se, että ne ympäristöt ja monimutkaiset kokonaisuudet, joiden osia yksittäiset järjestelmät ovat, vaikuttavat näiden yksittäisten järjestelmien osiin, rakenteeseen ja toimintaan. Usein käytetty vertaus on ihmisen suhde omaan ruumiiseensa. Ihmisen ruumiin osien toimintaa ja rakennetta ei pystytä selittämään pelkästään kuvaamalla näiden fysikaalisiin rakenneosiin (atomit, molekyylit, jne.) vaikuttavia voimia. ${ }^{112}$ Esimerkiksi se, miksi minun fysikaaliset osani sattuvat juuri nyt olemaan tietokoneen edessä kirjoittamassa, ei selity fysiikan lakien avulla (alhaalta ylös), vaan käyttäytymiseni kautta (ylhäältä alas). ${ }^{113}$ Jumalan toiminnan ymmärtämiseksi esimerkiksi Peacocke ja McGrath ovat väittäneet, että maailma kokonaisuutena voidaan ymmärtää eräänlaisena "superjärjestelmänä", jolla on hyvin erilaisia rakenneosia (fysikaaliset, psykologiset, sosiaaliset rakenteet ja niiden säännönmukaisuudet), jotka kaikki vaikuttavat toisiinsa. Peacocke kirjoittaa:

Jos Jumala vaikuttaa maailmanjärjestelmän kokonaisuuteen, niin silloin voimme ajatella Jumalan vaikuttavan kaikkiin niihin lukemattomiin maailman alatasoihin, joista tämä järjestelmä koostuu puuttumatta nii- 
hin lakeihin ja säännönmukaisuuksiin, jotka kullakin alatasolla pätevät. ... Yksittäiset maailman tapahtumat voivat näin olla Jumalan tarkoittamia ja tahtomia ilman, että fysiikan, biologian, psykologian tai minkään muukaan asiaankuuluvan tieteen lait rikkoutuisivat. ${ }^{114}$

Tämän näkemyksen mukaan Jumala voi vaikuttaa maailman yksittäisiin osiin puuttumatta niiden luonnolliseen kulkuun vaikuttamalla niiden ympäristöön ja niitä ympäröiviin järjestelmiin ja lopulta maailmaan kokonaisuutena. Tällainen Jumalan toiminta olisi siinä mielessä objektiivista, että se ohjaisi luonnon kulkua, mutta se ei kuitenkaan rikkoisi yksittäisten järjestelmien toimintojen ja rakenteiden säännönmukaisuuksia.

On helppo nähdä, kuinka tällainen käsitys Jumalan toiminnan luonteesta sopii hyvin yhteen panenteismin kanssa. Peacocken mukaan tällainen Jumalan toiminta on

yhteensopiva sen kanssa, että kaikki konkreettiset oliot maailmanjärjestelmässä koostuvat tavallisista fysikaalisista osista ja että maailmanjärjestelmä on kausaalisesti suljettu. Ei ole olemassa mitään dualistisia, vitalistisia tai yliluonnollisia tasoja, joiden kautta Jumala toteuttaisi erityisen tahtonsa. Tämän panenteistisen mallin mukaan Jumalan vaikutus maailmanjärjestelmään ei tapahdu tämän järjestelmän "ulkopuolelta" vaan sen "sisäpuolelta". Maailmanjärjestelmä on Jumalassa. ${ }^{115}$

Panenteismin mukaan maailman ja Jumalan välillä ei ole radikaalia eroa ja luonnon säännönmukainen toiminta ei ole mitään muuta kuin Jumalan säännönmukaista toimintaa. Panenteistille on siis helppoa ajatella, että Jumala vaikuttaa maailmaan kokonaisuutena, koska maailman ja Jumalan välillä ei ole juuri eroa. Klassisen teismin edustaja ei kuitenkaan voi hyväksyä tällaista näkemystä, koska se olettaa maailman olevan osa Jumalaa paljon vahvemmassa mielessä kuin klassisen teismin edustaja haluaa myöntää. Avoin teismi sen sijaan on rajatapaus: jotkut avoimen teismin edustajat (esim. Swinburne) torjuvat Jumalan toiminnasta alaspäisen kausaation kautta, 
kun taas toiset (esim. Polkinghorne) kannattavat sitä.

Polkinghornen teoria Jumalan toiminnasta perustuu alaspäisen kausaation idealle samaan tapaan kuin Peacocken ja hyväksyy siihen liittyvän ajatuksen monikerroksellisuudesta ja yhä lisääntyvästä monimutkaisuudesta luonnosta. Polkinhornen malli kuitenkin eroaa Peacockesta siinä, että se perustuu kaaosteorian soveltamiselle. Tässä mallissa Jumala ymmärretään puhtaaksi hengeksi, joka vaikuttaa monimutkaisiin järjestelmiin syöttämällä niihin uutta informaatiota, joka puolestaan ohjaa niiden alkuehtoja. Kaikkitietävyydellä varustettu Jumala pystyy näin vaikuttamaan maailmaan hyvin pienillä muutoksilla, joiden vaikutukset ovat erittäin mittavat. ${ }^{116}$

Se, että edellä on eroteltu erilaisia NIODAn muotoja, ei tarkoita sitä, että nämä olisivat toiset poissulkevia vaihtoehtoja. Monet käyttävät näitä kaikkia päällekkäin perustellakseen Jumalan erityistä ohjaavaa toimintaa fysikaalisen todellisuuden kaikilla tasoilla. On tosin myönnettävä, että nykyiset NIODA mallit ovat vielä varsin spekulatiivisia: mikään niistä ei ole saanut yleistä hyväksyntää, ja on epätodennäköistä, että nykyiset mallit sitä koskaan saisivatkaan. Halusin kuitenkin esitellä näitä malleja, koska niistä on keskusteltu erittäin paljon ja jonkinlainen malli on mielestäni teologian uskottavuuden kannalta välttämätön. Jos luonnon teologian halutaan tulevaisuudessa olevan edes jollakin tavalla uskottava, on sen pystyttävä vastaamaan kysymykseen Jumalan toiminnan luonteesta. ${ }^{117}$

Se, että tässä luvussa on esitelty NIODAn eri malleja, ei tarkoita sitä, etteikö NIODA rakenteesta poikkeavia malleja ole olemassa nykykeskustelussa. Erilaiset osittaiset interventionistiset mallit ovat suosittuja ja niitä puolustavat usein eri klassisen teismin edustajat, jotka ovat lähes poikkeuksetta myös sielu/ruumis dualisteja. Selvää on, että älykkään suunnitelma idean edustajat kannattavat erilaisia interventionismin muotoja ja kreationistit vielä voimakkaammin. Näiden perinteisten mallien lisäksi on vielä olemassa joukko malleja Jumalan toiminnasta, joka tulee varsin lähelle prosessiteismiä. Voi- 
simme kutsua tällaisia malleja "kenoottisiksi" (kr. kenosis), koska ne sisältävät ajatuksen Jumalan radikaalista itserajoittamisesta.

Eräs esimerkki kenoottisesta tavasta ymmärtää Jumalan toiminta maailmassa on John Haught, jonka mukaan kristinuskon Jumala ei ole mikään yliluonnollinen insinööri tai luonnon näpertelijä. Kristinuskon Jumalan luonne paljastetaan Jeesuksen elämässä, kuolemassa ja ylösnousemuksessa ja tämä Jumala on Jumala, joka luopuu jumaluudestaan, tulee osaksi ihmiselämää kaikkine sen kipuineen ja heikkouksineen. Kristillinen Jumala on nöyrä ja vapautta kunnioittava Jumala. Hän ei ole kuningas, joka käskyttää maailmaa, vaan luo tilan, jossa luomakunta voi kehittyä vapaasti:

Jumalan luovuuden suuruus on siinä, että toisin kuin äärelliset luojat, Jumala kykenee kutsumaan sellaisen maailman olemaan (paikastaan tulevaisuudessa), joka kykenee tekemään itse itsensä. Jumalan nöyryys ja luovuus siis eräässä mielessä "antavat maailman olla". Jumalallinen luova toiminta avaa avaruuden ja ajan, jotta luomakunta voisi tulla omaksi itsekseen, joksikin sellaiseksi, joka on selkeästi erillinen luojastansa ${ }^{118}$

Haughtin ajatus on tässä se, että Jumala ikään kuin vetäytyy pois maailmasta ja vaikuttaa sen kehitykseen hyvin rajallisesti: hän "houkuttelee" ja "kutsuu" mutta ei määrää. Tällaista mallia on varsin vaikea saada mahtumaan klassisen teismin tai avoimen teismin sisään: mallin kannattajat ovat olleetkin usein prosessiteologian tai jonkinlaisen panenteismin kannattajia. ${ }^{119}$ 
Erilaisia malleja Jumalan toiminnasta maailmassa. ${ }^{120}$

\begin{tabular}{|l|l|l|}
\hline Teologia & Metafora & Jumala \\
\hline Klassinen teismi & $\begin{array}{l}\text { Hallitsija-kuningas- } \\
\text { kunta }\end{array}$ & $\begin{array}{l}\text { Kaikkivaltias, kaikkitietävä, } \\
\text { muuttumaton hallitsija }\end{array}$ \\
\hline Deismi & Kelloseppä-kello & $\begin{array}{l}\text { Lainomaisen maailman } \\
\text { suunnittelija ja alkusyy }\end{array}$ \\
\hline Uustomismi & Työmies-työkalu & $\begin{array}{l}\text { Ensisijainen syy, joka toimii } \\
\text { toissijaisten syiden kautta }\end{array}$ \\
\hline Kvanttifysiikka ja & $\begin{array}{l}\text { Sattumanvaraisuuksien } \\
\text { määrääjä }\end{array}$ & Potentiaalien aktualisoija \\
\hline $\begin{array}{l}\text { Panenteismi ja } \\
\text { emergenssi }\end{array}$ & Persoona-ruumis & Kokonaisuuden muokkaaja \\
\hline $\begin{array}{l}\text { Kaaosteorian ja } \\
\text { emergenssi }\end{array}$ & Alkuehtojen asettaja & Kokonaisuuden muokkaaja \\
\hline $\begin{array}{l}\text { Kenosis } \\
\text { Vanhempi-lapsi }\end{array}$ & $\begin{array}{l}\text { Tahdonalainen } \\
\text { rajoittaminen ja heikkouden } \\
\text { omaksuminen }\end{array}$ \\
\hline
\end{tabular}

Tässä yhteydessä on hyvä sanoa muutama sana ihmeistä ja "ihmeen" käsitteestä. Lukija löytää helposti hyvää kirjallisuutta tästä teemasta myös suomeksi, joten pidän käsittelyni erittäin lyhyenä ja kommentoin lähinnä kysymystä siitä, missä määrin tiede on relevantti koko asialle. ${ }^{121}$ Perinteisesti ottaen ihmeitä ja ihmeellisiä tapahtumia on pidetty Jumalan erityiselle toiminnalle tunnusomaisina. Toisinaan niitä on myös käytetty perustelemaan esimerkiksi Raamatun luotettavuutta tai Jumalan olemassaoloa. On tärkeä kuitenkin huomata, että edellä esiteltyjen NIODAn mallien tarkoituksena ei ole käsitellä ihmeitä ollenkaan, vaan ymmärtää kaikkea sellaista Jumalan luovaa toimintaa luonnossa, joka ei rajoitu pelkästään luomisen hetkeen. Perinteisesti tällaista toimintaa on kutsuttu kaitselmukseksi.

Arkikielessä puheeseen ihmeistä liittyy puhe Jumalan "puuttumisesta" arkitapahtumiin, Jumalan "paljastumisesta" tai Jumalasta, joka "rikkoo" arkisten tapahtumien kulun. Tällainen tapa puhua 
liittyy aiemmin kuvaamaamme interventionismiin, jossa ajatellaan, että Jumalan toiminta edellyttää aina jonkin luonnon säännönmukaisuuden rikkoutumista. Olemme jo kuitenkin nähneet, kuinka monet haluavat välttää "luonnollisten" ja "yliluonnollisten" selitysten vastakkainasettelua ja haluavat luopua tällaisesta puheesta kokonaan. Tilannetta sekoittaa se, että termillä "ihme" voidaan viitata moneen eri asiaan. Voidaan puhua ainakin

(1) luonnonlaki-ihmeistä, jolloin Jumalan väitetään toimivan vastoin jotain hyvin tunnettua luonnon säännönmukaisuutta, (2) ihmeistä poikkeuksellisina tapahtumina tai yhteensattumina, (3) ihmeistä tapahtumina, joilla on erityinen uskonnollinen merkitys,

Perinteisesti esimerkiksi Jeesuksen väitetyt ihmeet ovat ihmeitä merkityksissä (1) ja (3): sairaiden parantaminen sisältää säännönmukaisuuden rikkoutumisen ja sillä on erityinen Jumalan tahtoa kommunikoiva merkitys. Arkielämässä on kuitenkin tavallista viitata joko onnellisiin tai onnettomiin sattumiin ihmeinä merkityksessä (2). Tällaiset tapahtumat eivät edellytä yliluonnollista selitystä samaan tapaan kuin ihmeet merkityksessä (1) ja ne voidaan ymmärtää luonnon säännönmukaisuuksien sisällä.

NIODAn eri tulkintojen sisällä voidaan ajatella, että luonnonlakiihmeitä voi tapahtua, vaikka niitä ei siksi kutsutakaan. Esimerkiksi sellaiset panenteistit, kuten Peacocke ja Clayton, kieltävät jyrkästi sen, että Jumala "rikkoisi" luonnonlakeja. Koska luonnon säännönmukaisuudet ovat Jumalan toimintaa, ei Jumala toimimalla yllättävillä tavoilla "riko" mitään tai "puutu" tapahtumien "luonnolliseen" kulkuun. "Ihmeen" kohdalla ei tapahdu rikkomusta, vaan ainoastaan Jumalan yllättävä ratkaisu toimia normaalista poikkeavalla tavalla. Näin ollen panenteistin näkökulmasta puhe ihmeistä "luonnonlakien rikkoutumisena" on jo sellaisenaan tyhjää puhetta. Monet panenteistit ovat kuitenkin esittäneet, että Jumala ei voi mielensä mukaan muutella omaa toimintaansa, koska koko maailmankaikkeus on ko- 
konaisuus, jonka säännönmukaisuudet ovat riippuvaisia toisistaan. Jatkuvat poikkeamiset säännönmukaisesta toiminnasta muuttaisivat koko järjestelmän hyvin epävakaaksi. Tämä antaa kuitenkin mahdollisuuden yksittäisille poikkeuksille Jumalan säännönmukaiseen toimintaan. Tällaiset poikkeukset jäisivät välttämättä vaille luonnon säännönmukaisuuksiin perustuvaa selitystä ja olisivat näin ollen tieteen tavoittamattomissa. Tältä osin siis voitaisiin puhua eräänlaisista luonnonlaki-ihmeistä.

\section{Kirjallisuutta}

Esseitä luomisesta, luonnonlaeista ja Jumalan toiminnasta sisältää Watts 2008. Ikoninen avoimen teismin muotoilu on Swinburne 1993. Panenteismia puolustavia ja kritisoivia esseitä löytyy kokoelmasta Clayton \& Peacocke 2001. Panenteismin ja emergenssin standardiversion esittää Clayton 2004 (ks. myös Clayton 2008) Kriittinen historiallinen ja filosofinen katsaus panenteismiin on Cooper 2007. Erinomainen johdatus keskusteluun vapaasta tahdosta ja Jumalan kaikkitietävyyden ongelmasta on Zagzebski 1991. Hyvä teologinen johdatus sekä luomisen teologiaan että antrooppisiin ilmiöihin eri tasoilla on McGrath 2009. Antrooppisesta periaatteesta kirjoittavat esimerkiksi Barrow \& Tipler 1986 ja hienosäädöstä Davies 2006. Laaja suunnitteluargumentteja koskeva katsaus on Manson 2003. Hieman iäkäs mutta innostava ja laaja katsaus luomisen teologian ja nykyisten fysikaalisten ja biologisten tieteiden suhteeseen on Peacocke 2004 (alkup. painos 1979). Vastaava mutta lyhyempi ja nykyaikaisempi panenteismin, emergenssin ja NIODAn puolustus on Peacocke 2001. Fysiikan ja teologian suhteen historiaa esittelee edistyneemmille Hodgson 2006. Jumalan toimintaa käsittelevän kirjallisuuden joukosta suositeltavia ovat Ward 1990 ja Saunders 2002. 



\section{EVOLUUTION TEOLOGIA: LAKI JA SATTUMA}

Käsittelen tässä luvussa sitä, kuinka luomisen teologian ja päällekkäisyysmallin edustajat käsittelevät evoluutiota ja siihen liittyviä väitettyjä teologisia ongelmia. Tilanteen selventämiseksi olen myös liittänyt mukaan lyhyen katsauksen kreationismiin ja älykkään suunnitelman teorioihin, joita vastaan luonnon teologian edustajat muotoilevat näkemyksensä. Erityisesti tarkastellaan jo aiemmin muotoiltuja ongelmia (ks. luku 5.5), jotka koskevat lähinnä "suunnittelun" ajatusta.

Arkikäsityksen mukaan evoluutio on kaiken tieteen ja teologian yhteensopivuusongelmien ytimessä. Usein ajatellaan, että vastakkain ovat luominen ja evoluutio. Näimme kuitenkin jo edellisessä luvussa, että luomisen ajatuksella on varsin vähän tekemistä evoluution kanssa. Se, mistä evoluution ja kristillisen uskon yhteensopivuusongelmissa on kysymys, on jotain aivan muuta kuin "luominen vastaan evoluutio". Tällainen vastakkainasettelu kuvaa tilanteen täysin väärin ja näiden kahden laittaminen toisiaan vastaan itse asiassa sotkee enemmän kuin selventää. Kyse on paljon laajemmasta joukosta kysymyksiä, jotka koskevat esimerkiksi sitä, miten Jumala vaikuttaa luonnossa (vai vaikuttaako ollenkaan), miten meidän tulisi suhtautua ihmisen alkuperään ja mitä meidän tulisi ajatella luomakunnan tulevaisuudesta. Samoin on kyseenalaista väittää, että tieteen ja teologian suhteen tarkastelussa evoluution ajatuksen tulisi olla keskeisessä roolissa: evoluutio on kyllä tärkeä, mutta ei suinkaan ainoa tärkeä asia. Tämän luvun kuluessa käy ilmi, että valtaosa niistä luonnon teologi- 
an malleista ja teorioista, joita edellisessä luvussa käsiteltiin, soveltuu myös evoluution ymmärtämiseen teologisesta näkökulmasta.

$7 \cdot 1$

KYSYMYS SUUNNITTELUSTA

Jotta voisimme ymmärtää sitä, kuinka suunnitelmallisuuden idea on kytketty Jumalan olemassaoloon ja toimintaan maailmassa, meidän pitää palata hetkeksi Darwinin aikaan. Kiinnitimme jo aiemmin huomiota siihen, kuinka klassinen fysiikka synnytti ajatuksen "kahden kirjan" olemassaolosta ja luonnollisesta jumalatiedosta. Kun päästiin 1800-luvulle, tämä ajatus oli kehittynyt siihen pisteeseen, että teologian keskeisen sisällön ajateltiin olevan tavoitettavissa ja perusteltavissa luonnollisen järjen avulla. Ajateltiin, että tieteen pohjalle voidaan luoda "rationaalinen uskonto" tai luonnollinen uskonto, johon kuuluvat Jumalan olemassaolo, sielun kuolemattomuus ja universaali moraalilaki. Syntyi se, mitä olemme kutsuneet "klassiseksi luonnolliseksi teologiaksi" (ks. luku 4.2). Vaikka lukuisat 1700-luvun suuret filosofit, kuten Kant ja Hume, kritisoivat ankarasti suunnitteluargumentteja, ne olivat vielä voimissaan klassisen luonnollisen teologian piirissä pitkälle 1800-luvulle asti.

Suunnitteluargumenttien lähtökohtana oli se tosiseikka, että eläinlajit ovat erittäin hyvin sopeutuneita ympäristöönsä. Tämän seikan ajateltiin selittyvän Jumalan suunnitelmalla ja suoralla yliluonnollisella toiminnalla. Kaikkein kuuluisin muotoilu tästä ideasta on luonnontutkija ja kirkonmies William Paleyn teoksessaan Natural Theology, or Evidences of the Existence and Attributes of the Deity, Collected from the Appearances of Nature (1802) esittämä argumentti, joka perustuu analogiaan ihmisen suunnittelevan toiminnan ja Jumalan toiminnan välillä. Kirja oli erittäin tunnettu ja suosittu vielä Darwinin aikaan, joka luki sitä oppikirjana osana opintojaan Cambridgessä. Paley oli erityisen vaikuttunut Newtonin mekanistisesta maailmankuvasta ja halusi jalostaa sitä pitämällä 
huolen, että Jumala sopi yhteen sen kanssa. Paley otti Newtonin vision maailmasta kellokoneistona ja käytti sitä Jumalan olemassaolon puolustamiseen. Näin syntyi suunnitteluargumentti, jota on tapana kutsua "analogiseksi suunnitteluargumentiksi" ja se menee näin:

1. Maailmankaikkeus on kuin suuri mekanismi.

2. Tavallisesti suunnittelijat (älykkäät oliot) ovat mekanismien olemassaolon syitä.

3. Näin ollen on olemassa suunnittelija, joka maailmankaikkeuden syy.

Argumentti perustuu vertaukseen (analogia) ja tämä on myös argumentin suuri heikkous: argumentti on hyvin epäselvä. Se ei anna vastausta siihen, missä mielessä maailmankaikkeutta voidaan verrata mekanismiin. Kaikkein tavallisin kielikuva oli - kuten olemme jo nähneet - kellokoneisto ja kelloseppä. Tämä itse asiassa olikin Paleyn argumentin ydin: jos löydämme rantahiekasta kellon ja tarkastelemme sen mekanismeja, niin uskomme hyvin nopeasti siihen, että on olemassa kelloseppä, joka on suunnitellut ja rakentanut kellon. Emme usko, että se olisi syntynyt sattumalta.

Paleyn tarkoituksena on laajentaa tämä argumentti koskemaan nimenomaan biologista luontoa. Paleyn mukaan kaikkialla biologisessa maailmassa tunnistamme jotakin tiettyä tarkoitusta palvelevia rakenteita. Näistä tarkoituksenmukaisista rakenteista voimme sitten johtaa yliluonnollisen suunnittelun olemassaolon. Paley antaa monia esimerkkejä, jotka perustuvat tähän samaan strategiaan: hän puhuu esimerkiksi silmän rakenteesta ja eläinlajien anatomian yksityiskohdista. Tällaisia argumentteja kutsutaan kirjallisuudessa "biologisiksi suunnitteluargumenteiksi". Voimme muotoilla tällaisen argumentin esimerkinomaisesti eläinlaji E:n osalta seuraavalla tavalla:

1. Eläinlaji E on hyvin sopeutunut ympäristöönsä eli on rakenteeltaan tarkoituksenmukainen.

2. Kaikki tarkoituksenmukaisuus on suunnittelun tulosta. 
3. Eläinlaji E on suunnittelun tulos.

4. Suunnittelu edellyttää suunnittelijaa.

5. Näin ollen on olemassa suunnittelija.

On useita syitä sille, miksi Paleyn lähestymistapa ei enää vakuuta nykylukijaa. Ensimmäinen näistä on se, että koko ajatus luonnosta mekanismina, joka on edes jollakin tavalla verrannollinen ihmisen rakentamiin koneisiin, on muuttunut 1900-luvun myötä epäuskottavaksi. Paleyn klassinen luonnollinen teologia on sidoksissa klassiseen fysiikkaan ja mekanistiseen maailmankuvaan. Nykykäsityksen mukaan luonto ei ole lähelläkään sellaista konetta tai mekanismia, jonka ihmiset voisivat rakentaa. Toinen - ja aiheemme kannalta kiinnostavampi - syy on tietysti se, että Darwinin teoria luonnonvalinnasta evoluutiota ohjaavana voimana lyö kiilan molempien edellisten argumenttien premisseihin (2). Biologisen suunnitteluargumentin onnistumisen kannalta olennaista on se, että yliluonnollinen suunnittelija on ainoa tarkoituksenmukaisuuden lähde luonnossa. Jos näin ei ole, niin argumentti hajoaa heti. Olemme jo nähneet, miten Darwin rakensi teoriansa luonnonvalinnasta: luonnonvalinta tuottaa tarkoituksenmukaisia biologisia rakenteita ja käyttäytymismalleja ilman minkäänlaista tietoista suunnittelua. Näin ollen pelkästään se, että evoluutiobiologia toimii, upottaa automaattisesti biologisen suunnitteluargumentin.

Se, että darwinismi kumoaa biologisen suunnitteluargumentin, on johtanut jotkut siihen ajatukseen, että voimme darwinismista päätellä suoraan siihen, että Jumalaa ei ole olemassa. Näin esimerkiksi ajattelee Dawkins, joka hyvän tyylinsä mukaisesti kirjoittaa seuraavaa:

Kreationistien "logiikka" on aina sama. Jokin kaunis luonnonilmiö on liian tilastollisesti epätodennäköinen, liian monimutkainen, liian kaunis, liian kunnioitusta herättävä ollakseen syntynyt sattumalta. Suunnittelu on sattuman ainoa vaihtoehto, jonka kirjoittajat pystyvät kuvittelemaan. Niinpä se on suunnittelijan työtä. Ja luonnontieteen vastaus tähän vir- 
heelliseen logiikkaan on aina myös sama. Suunnittelu ei ole sattuman ainoa vaihtoehto. Luonnonvalinta on parempi vaihtoehto. Itse asiassa suunnittelu ei ole todellinen vaihtoehto lainkaan, koska se synnyttää vielä suuremman ongelman kuin ratkaisee: kuka suunnitteli suunnittelijan? Sattuma ja suunnittelu epäonnistuvat kumpikin tilastollisen epätodennäköisyysongelman ratkaisuina, koska toinen niistä on ongelma ja toinen palautuu siihen. Luonnonvalinta on todellinen ratkaisu. Se on ainoa toimiva ratkaisu, joka on koskaan esitetty. Ja se ei ole vain toimiva ratkaisu, vaan se on hätkähdyttävän elegantti ja vahva ratkaisu. ${ }^{122}$

Dawkinsin väite siis on se, että koska luonnonvalinta selittää biologisten organismien suunnitelmallisuuden, ei ole olemassa yliluonnollista suunnittelijaa. Ehkä kaikkein suosituin tapa tehdä tämä päättely on väittää luonnonvalinnan osoittavan, että biologisessa maailmassa ei ole päämäärähakuista suunnitelmaa eikä näin ollen sillä voi olla tarkoitustakaan. Tästä puolestaan seuraisi, että meillä ei olisi syytä uskoa Jumalan olemassaoloon. Dawkins kirjoittaa:

havaitsemamme universumilla on täsmälleen ne ominaisuudet, jotka voisimme sillä olettaa olevan, jos se on pohjimmiltaan vailla suunnitelmallisuutta, tarkoitusta, pahuutta tai hyvyyttä - se on vain ja ainoastaan sokeaa ja säälimätöntä välinpitämättömyyttä. DNA ei tiedä eikä välitä. DNA vain on. Ja me tanssimme sen tahdissa. ${ }^{123}$

Dawkins näyttää siis ajattelevan niin, että voimme päätellä darwinismista sen, että maailmankaikkeudella ei ole suunnitelmaa eikä tarkoitusta. Tästä taas voimme päätellä, että Jumalan olemassaolo on hyvin epätodennäköinen. Tämäntyyppinen päättely on varsin yleinen mutta on kuitenkin vaikea sanoa, miten se tarkkaan ottaen menee. Filosofi Mikael Stenmark on yrittänyt muotoilla päättelyn yksityiskohtaisemmin ja tarkastelemme sitä lyhyesti. Käytetään esimerkkinä vaikkapa ihmistä, vaikka argumentin voisi toistaa minkä tahansa biologisen organismin suhteen. Voimme aloittaa seuraavasta päättelystä. ${ }^{125}$ 
1. Ihminen syntyi evoluution prosessien kautta.

2. Kaikki lajit, jotka syntyvät evoluution prosessin kautta, syntyvät sattumalta (niillä on alhainen todennäköisyys) siinä mielessä, että evoluutioteoria ei pysty ennustamaan niitä.

3. Näin ollen ihmisen olemassaolo on sattumanvaraisten prosessien tulosta, eikä tulosta Jumalan suunnitelmasta.

Stenmark kuitenkin huomauttaa, että tällaisenaan argumentti on epätäydellinen: emme voi päätellä siitä, että kaikki lajit näyttävät evoluutioteorian näkökulmasta syntyvän sattumalta, sitä, että Jumalalla ei ole suunnitelmaa. Tarvitaan siis jokin oletus lisää, jotta argumentti toimisi. Stenmark ehdottaa tällaiseksi oletukseksi seuraavaa: tiede on ainoa luotettava tietolähde. Täydennetty argumentti menisi siis näin.

1. Ihminen on syntynyt evoluution prosessien tuloksena.

2. Kaikki lajit, jotka syntyvät evoluution prosessien tuloksena, syntyvät sattumalta (niillä on alhainen todennäköisyys) siinä mielessä, että evoluutioteoria ei pysty ennustamaan niitä.

3. Voimme saada tietoa vain niistä asioista, jotka tiede voi löytää.

4. Näin ollen ihmisen olemassaolo on sattumanvaraisten prosessien tulos, eikä tulosta Jumalan suunnitelmasta.

Ongelma tässä argumentissa on kuitenkin se, että oletus 3 ei ole tieteellinen oletus. Mikään tieteellinen koe ei voi osoittaa tällaista. Voimme päätyä uskomaan oletuksen 3, mutta emme tieteellisellä perusteella. Kyseessä on pikemminkin filosofinen valinta. Tästä voimme päätellä, että edelliset argumentit ovat kyllä mahdollisia, mutta toimiakseen ne edellyttävät oletuksia, jotka eivät ole tieteellisiä.

Stenmark ehdottaa vielä kolmatta mahdollisuutta muotoilla argumentti.

1. Ihminen syntyi evoluution prosessien tuloksena.

2. Ihmisen olemassaolo kuuluu Jumalan suunnitelmaan, jos ja 
vain jos (a) Jumala tahtoo ihmislajin olevan olemassa ja (b) on todennäköistä, että ihmisen syntyminen evoluution kautta tapahtuu tästä syystä.

3. Kaikki lajit, jotka syntyvät evoluution prosessien tuloksena, syntyvät sattumalta (niillä on alhainen todennäköisyys) siinä mielessä, että evoluutioteoria ei pysty ennustamaan niitä.

4. Näin ollen ihmisen olemassaolo on sattumanvaraisten prosessien tulos, eikä tulosta Jumalan suunnitelmasta.

Tämäkin tapa päätellä evoluution sattumanvaraisuudesta ihmisen sattumanvaraisuuteen on ongelmallinen. Ongelma on siinä, että teistin ei tarvitse uskoa, että luonnonvalinnalla on jokin tarkoitus itsessään, koska luonnonvalinta ei ole hänen mielestään mikään toimija. Teisti sen sijaan uskoo, että Jumalalla oli mielessään jokin tarkoitus, kun hän käytti luonnonvalintaa välineenä ihmislajin luomiseksi, mikä on puolestaan syy sille, että ihmislajin olemassaololla on tarkoitus eli sen voidaan katsoa kuuluvan Jumalan suunnitelmaan. ${ }^{126}$

Edellisten argumenttien epäonnistuminen viittaa vahvasti siihen, että evoluutiobiologiasta itsestään on vaikea päätellä siihen, että ihmisen olemassaolo on vailla suunnitelmaa tai ihminen ei synnyt tarkoituksenmukaisesti. Tämä johtopäätös pätee myös laajemmin: on hyvin vaikea päätellä evoluutiobiologiasta siihen, että biologinen maailma tai koko maailmankaikkeus on vailla tarkoitusta, josta puolestaan seuraisi, että Jumalaa ei ole olemassa. Pelkästään sattuman roolista evoluution prosessissa ei päästä tähän lopputulokseen ilman lisäoletuksia. Tiivistäen voidaan sanoa, että syy, miksi darwinismista ei voida päätellä Jumalan olemattomuuteen, on se, että

(1) darwinismi käsittelee vain biologisen maailman tarkoituksenmukaisia rakenteita eikä koko maailmankaikkeutta,

(2) darwinismi ei osoita, etteikö biologisella evoluutiolla kokonaisuutena voisi olla jotain päämäärää tai etteikö sitä voisi ohjata jokin sen ulkopuolinen tekijä, 
(3) darwinismiin ei välttämättä kuulu ajatus, että vain tiede antaa meille tietoa todellisuudesta.

Kuten edellä tuli ilmi, meillä on ainakin alustavia syitä epäillä näitä väitteitä. Ainakaan ne eivät ole välttämättömiä ja edellyttävät puolustamista. Näin ollen on vaikea nähdä, miten darwinismi voisi välttämättä johtaa siihen, että Jumalaa ei voi olla olemassa. Se, minkä darwinismi puolestaan osoittaa vääräksi, on tietynlainen tapa ymmärtää suunnittelun ja Jumalan suhde, nimittäin sellainen, jonka mukaan Jumala on synnyttänyt biologisen maailman eliöt nykyisessä muodossaan "yliluonnollisella" tavalla.

Olemme käsitelleet erästä tapaa ymmärtää suunnitteluargumentti ja sitä, kuinka darwinismi antaa meille hyvän syyn torjua tämä argumentti. Annoimme myös joitakin syitä ajatella, että darwinismista on hyvin vaikea päätellä siihen, että Jumalaa ei ole olemassa. Jos suuntaa-antavat perustelumme ovat laisinkaan järkevät, niin voidaan ajatella, että teologisesti tulkittu evoluutio ja evoluutiobiologia ovat mahdollisia. Tämä on itse asiassa johtopäätös, jonka luonnon teologian ja päällekkäisyysmallin edustajat tekevät, mutta ennen kuin voimme siirtyä tarkastelemaan heidän näkemyksiään, on meidän muodostettava yleiskuva kristillisistä vastauksista evoluutioon. Tunnettua on, että teoria luonnonvalinnasta ja evoluutio yleisesti on synnyttänyt varsin suuren spektrin kristillisiä näkemyksiä. Ennen kuin siirrymme käsittelemään näitä näkemyksiä tarkemmin, on ehkä hyvä pistää kaikki näkemyksen yhteen kasaan oheiseen taulukkoon. 
Teologisia vastauksia evoluutioon ${ }^{127}$

\begin{tabular}{|c|c|c|c|c|c|c|}
\hline & 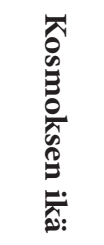 & 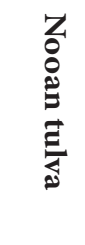 & 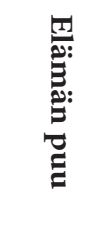 & 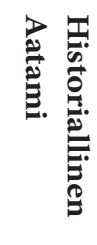 & 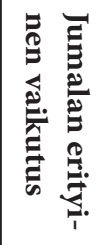 & 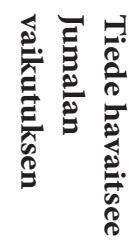 \\
\hline $\begin{array}{l}\text { "Ei-tieteellinen" } \\
\text { kreationismi }\end{array}$ & n. $10 \mathrm{k}$ & kyllä & ei & kyllä & kyllä & ei \\
\hline $\begin{array}{l}\text { Nuoren maan ("tie- } \\
\text { teellinen") kreatio- } \\
\text { nismi }\end{array}$ & n. $10 \mathrm{k}$ & kyllä & ei & kyllä & kyllä & kyllä \\
\hline $\begin{array}{l}\text { Vanhan maan (prog- } \\
\text { ressiivinen) kreatio- } \\
\text { nismi }\end{array}$ & $\begin{array}{l}\text { n. } 13 \\
\text { milj. }\end{array}$ & ei & ei & kyllä & kyllä & kyllä \\
\hline Älykäs suunnitelma & $\begin{array}{l}\text { n. } 13 \\
\text { milj.? }\end{array}$ & ei? & kyllä? & ei? & kyllä & kyllä \\
\hline $\begin{array}{l}\text { Evolutionaarinen } \\
\text { kreationismi }\end{array}$ & $\begin{array}{l}\text { n. } 13 \\
\text { milj. }\end{array}$ & ei & kyllä & kyllä? & kyllä & ei \\
\hline Teistinen evoluutio & $\begin{array}{l}\text { n. } 13 \\
\text { milj. }\end{array}$ & ei & kyllä & ei? & kyllä & ei \\
\hline $\begin{array}{l}\text { Evolutionaarinen } \\
\text { teismi }\end{array}$ & $\begin{array}{l}\text { n. } 13 \\
\text { milj. }\end{array}$ & ei & kyllä & ei? & ei & ei \\
\hline
\end{tabular}

$7 \cdot 2$

KREATIONISMI JA ÄLYKÄS SUUNNITELMA

Määrittelimme aiemmin (ks. luku 2.2) raamatullisen literalismin näkemykseksi, jonka mukaan

(L) Raamattu on erehtymätön kaikissa luontoon liittyvissä asioissa.

Literalisti uskoo, että Raamatun kuvaukset luonnon toiminnasta tulee tulkita historiallisesti ja niitä tulee pitää yhtä auktoritatiivisina 
kuin mitä tahansa muitakin raamatunkohtia. Tässä mielessä literalismi on tärkein kreationismin menetelmällinen komponentti. Määrittelimme myös kreationismin näkemykseksi, jonka mukaan

(K) Jumala loi kosmoksen, Maan, eläinlajit ja ihmisen tyhjästä suurin piirtein sellaisena, kun näemme ne muutamia tuhansia vuosia sitten tavalla, jonka 1. Mooseksen kirja kuvaa.

Nyt on aika tarkentaa tätä näkemystä. Kuten jo edellisestä taulukosta voidaan nähdä, kreationismia on montaa eri muotoa, joista vain osa sopii edellä antamaani kreationismin määritelmään. Taulukko jaottelee sekä kreationistiset että muut näkemykset muutamien hyödyllisten erojen perusteella. Kaikkein merkittävin näistä on tietenkin maailmankaikkeuden ikä: vain nuoren maan kreationistit ja "ei-tieteelliset" kreationistit uskovat, että maailmankaikkeus on noin 10000 vuotta vanha. On yleinen harhaluulo, että Darwin olisi jollakin tavalla osoittanut maapallon vanhemmaksi kuin aiemmin oli luultu. Totuus on kuitenkin se, että jo ennen Darwinia maapallon pitkä ikä oli hyvin tunnettu: lähinnä geologian, arkeologian ja tähtitieteen kautta oli jo 1800-luvun alussa päädytty siihen tulokseen, että maapallo on hyvin vanha, vaikka sen tarkasta iästä ei oltukaan varmoja. Nuoren maan kreationistit sen sijaan uskovat, että 1. Mooseksen kirjan alkuluvun seitsemän päivää ovat kirjaimellisia päiviä ja että Raamatun pohjalta voidaan suoraan laskea universumin ikä, joka on hyvin paljon tieteellistä käsitystä lyhyempi.

Toinen seikka, joka erottaa nuoren maan kreationismin ja ei-tieteellisen kreationismin muista on näiden jakama usko siihen, että 1 . Mooseksen kirjassa kuvattu tulva oli todellakin koko maailman kattava katastrofi. Nuoren maan kreationistit käyttävät tulvan ajatusta selittämään sen geologisen aineiston olemassaolon, jota tavallisesti käytetään perustelemaan maapallon pitkää ikää. Tämän "tulvageologian" rooli on itse asiassa erittäin keskeinen nykyaikaisessa nuoren maan kreationismissa. Koko liikkeen merkittävin lähtölaukaus oli nimittäin John Whitcombin ja Henry Morriksen kirja Genesis Flood: 
The Biblical Record and its Scientific Implications (1961), joka pyrki osoittamaan tieteellisen tiedon ja 1 . Mooseksen kirjan tapahtumien yhteensopivuuden. Morriksen ja Whitcombin argumentti pyrki olemaan nimenomaan tieteellinen: Raamatun kuvaus ei pelkästään ole oikea ja tieteen väärä, vaan Raamatun kuvauksen totuudellisuuden katsottiin olevan pääteltävissä tieteellisistä tuloksista, kunhan ne vain ymmärretään oikein. Tästä tulee nimitys "tieteellinen kreationismi". "Tieteellisen" kreationismin ja "ei-tieteellisen" kreationismin ero on taas puolestaan siinä, että "ei-tieteelliset" kreationistit uskovat Jumalan luoneen maailmankaikkeuden siten, että se vain näyttää vanhalta, mutta ei itse asiassa ole sitä. Siinä missä "tieteellisen" kreationismin edustaja ajattelee oikein ymmärretyn tieteen johtavan ajatukseen 1. Mooseksen kirjan tapahtumien historiallisesta totuudesta, ajattelee "ei-tieteellinen" kreationisti, että tiede $e i$ voi johtaa meitä totuuteen maailmankaikkeuden synnystä, koska Jumala on toiminut tahallaan harhaanjohtavasti.

Kolmas tunnettu kreationismin muoto on vanhan maan kreationismi, jonka edustajat tulkitsevat luomiskertomuksen seitsemän päivää jonkinlaisiksi pitkiksi ajanjaksoiksi ja tunnustavat näin maapallon iän paljon pidemmäksi, kuin nuoren maan kreationistit. Tällaisen "progressiivisen" kreationismin mukaan maailmankaikkeus on kehittynyt pitkän ajan kuluessa, mutta Jumala on puuttunut massiivisesti sen kulkuun luomalla tyhjästä esimerkiksi eläinlajit ja ihmiset. Samaan tapaan kuin muutkin kreationismin muodot vanhan maan kreationistit ymmärtävät paratiisikertomukset historiallisesti (ensimmäisen ihmisen olemassaolo) ja uskovat siihen, että kukin laji syntyi yksittäisen luomisen aktin kautta. Näin ollen kaikki kreationismin muodot evolutionaarista kreationismia lukuun ottamatta torjuvat darwinismin perusajatuksen "elämän puusta" eli eläinten ja ihmisten yhteisestä alkuperästä. Elämän puu on siis varsin merkittävä jakolinja eri kreationismin muotojen ja muiden näkemysten välillä. Progressiivisen kreationismin erityispiirteitä maan pitkäikäisyyden lisäksi on se, että se torjuu tulvageologian ja siihen liittyvän ajatuksen koko maapallon kattaneesta tulvasta. 
Neljäs kreationismin muoto on "evolutionaarinen kreationismi", joka harvoin edes ymmärretään kreationismin muotona. Tämä näkemys hyväksyy maailmankaikkeuden pitkän iän, elämän puun ja torjuu tulvageologian mutta ajattelee samanaikaisesti, että on ollut olemassa ensimmäinen ihminen, jonka ilmaantuminen on edustanut katkosta edeltäviin elämänmuotoihin. Se, miten tämä tarkkaan ottaen on tapahtunut, jää tämän näkemyksen mukaan mysteeriksi. Yksi tapa ymmärtää tämä voisi olla se, että ihmisruumis on kyllä evoluution tulos mutta ihmissielulla on yliluonnollinen alkuperä. Tämä on itse asiassa roomalaiskatolisen kirkon virallinen näkemys. Voidaan kuitenkin kysyä, kannattaako tällaista näkemystä enää edes nimittää kreationismiksi, sillä se edellyttää ainoastaan yhden poikkeuksen biologiseen evoluutioon: ihmissielun.

Usein kreationistit esittävät itsensä aidon ja alkuperäisen kristinuskon edustajina ja syyttävät muita kristillisiä ryhmiä ja kirkkokuntia siitä, että ne ovat luopuneet "selvästä Raamatun sanasta". Tämä väite ei yksinkertaisesti pidä paikkaansa. Näkemykset siitä, milloin ja miten luominen on tapahtunut ja mitä luomisen teologiaan kuuluu, ovat vaihdelleet kristillisen historian aikana ja on suuri yksinkertaistus väittää, että kreationistien tulkinta 1. Mooseksen kirjasta on ainoa oikea ja alkuperäinen. Sama pätee myös siihen väitteeseen, että kreationistien edustama raamatullinen literalismi olisi kuulunut kristinuskon ydinkohtiin. Olemme jo nähneet moneen kertaan, että raamatuntulkinta kristillisessä perinteessä on ollut hyvin monipuolista. Sitä paitsi literalismi nykyisessä muodossaan on varsin uusi ilmiö kristillisessä perinteessä. Näistä syistä valtaosa kristillisten kirkkojen valtavirrasta - esimerkiksi katolinen ja ortodoksinen kirkko sekä anglikaanit, luterilaiset ja valtaosa reformoiduista kirkoista - torjuu kreationismin eri muodot.

Jos kreationismin taustalla ei ole mikään yhtenäinen teologinen perinne, niin mikä sitten motivoi sitä? Mielestäni on hedelmällistä tarkastella kreationismia anti-modernistisena liikkeenä. Tällöin olennaisia seikkoja eivät ole luomisen teologian tai evoluution yksityiskohdat, vaan se, että koko liike asettuu modernia ja liberaalia 
yhteiskuntaa vastaan. Ne asiat, joita kreationisti vastustaa, ovat itse asiassa sekulaarinen moraali, sekulaarinen yhteiskunta ja liberaali arvomaailma. Evoluutio nähdään vain yhtenä, mutta ratkaisevana, osana tätä kokonaisuutta: kreationistien mukaan evoluution hyväksymisestä seuraa automaattisesti moraalin rappio ja yhteiskunnan sekularisoituminen. Jos ihminen on apina, niin hän alkaa käyttäytyä kuin apina. Myös literalismin puolustamisen katsotaan liittyvän tähän: Raamatun kirjaimellisen merkityksen puolustaminen on selkeän Jumalan ilmoittaman moraalin puolustamista ihmiskeksintöä olevan harhaa vastaan. Sekularisaatio on tämän näkemyksen mukaan suora seuraus siitä, että kristityt ovat luopuneet Raamatun kirjaimellisuudesta. ${ }^{129}$

Se, miksi erilaiset kreationismin ja älykkään suunnittelun ideat ovat suosittuja erityisesti Yhdysvalloissa, liittyy paikalliseen poliittiseen ja yhteiskunnalliseen tilanteeseen: tieteen ja uskonnon rajanveto liittyy erityisesti lailla säädeltyyn valtion ja uskonnon erottamiseen ja sitä kautta kouluopetukseen. Yhdysvaltain perustuslain mukaan valtion tulee olla uskonnollisesti neutraali eikä koulussa saa näin ollen opettaa mitään uskonnollista. Tähän liittyvät juuri kuuluisat evoluutio-oikeudenkäynnit kuten Scopesin oikeudenkäynnit (1920) Tennesseessä ${ }^{130}$ ja Arkansasissa käyty oikeudenkäynti (1981) ${ }^{131}$, jotka koskivat nimenomaan kouluopetusta ja evoluution asemaa siinä. Jos kreationismi voidaan ymmärtää tieteenä, voidaan sitä opettaa myös koulussa. Yhdistettynä anti-modernismiin ja epäluuloihin (ja harhaluuloihin) evoluution seurauksista erityisesti moraalin ja yhteiskunnan alueella tästä syntyy tilanne, jossa paine saada kreationismi tieteelliseksi kasvaa hyvin suureksi. Oikeudenkäynneistä ja kreationismin suuntaan kallellaan olevien ryhmien poliittisesta aktiivisuudesta on seurannut valtavat mittasuhteet saanut poliittisten, yhteiskunnallisten ja uskonnollisten näkemysten yhteentörmäys, jolle Euroopassa ei oikeastaan ole vastinetta.

Uusimpaan vaiheeseen tässä kamppailussa liittyy "älykkään suunnitelman" (intelligent design) idea (ID). ID:n edustajien mukaan darwinismi vaatii täydennystä, sillä biologisessa luonnossa on 
rakenteita, joita ei voida selittää vetoamalla luonnonvalintaan tai mihinkään muuhunkaan tunnettuun periaatteeseen. Nämä rakenteet selittää ID:n edustajien mukaan paremmin jonkinlainen älykäs suunnittelu, joka tulee biologisen maailman ulkopuolelta. ID:n kuuluisimmat edustajat ovat biokemisti Michael Behe ja matemaatikko William Dembski. ${ }^{132}$ ID:n perusväitteet ovat seuraavat:

(1) Biologisessa maailmassa on esimerkkejä "palautumattomasta monimutkaisuudesta" (irreducible complexity), joita luonnonvalinnan ja asteittaisen kehityksen ajatuksella on mahdoton selittää.

(2) Palautumaton monimutkaisuus selittyy älykkäällä suunnittelulla.

(3) Naturalismi (anti-älykäs suunnittelu) on tieteen edistymisen kannalta haitallista.

Behen mukaan jotkut biologiset mekanismit ovat luonteeltaan sellaisia, että ne eivät ole voineet syntyä luonnonvalinnan ja asteittaisen kehityksen kautta. Behe suosii erityisesti esimerkkejä solujen kehittyneistä biokemiallisista mekanismeista, kuten esimerkiksi bakteerien käyttämistä "siimamoottoreista". Tällainen mekanismi ei voi kehittyä luonnonvalinnan tuloksena Behe väittää, koska toimiakseen se edellyttää kaikkien osien olevan paikallaan. Se voi ainoastaan syntyä niin, että osat on alun perin suunniteltu sopimaan yhteen ja tuottamaan lopullisen mekanismin. Tästä Behe päättelee, että kyseessä on oltava jonkinlainen älykäs suunnitelma. ${ }^{133}$

Dembski on esittänyt teorian siitä, millaisten tapausten kohdalla voidaan puhua suunnittelusta. Dembskin ajatus on se, että jos sattuma ja säännönmukaisuus epäonnistuvat jonkin seikan selittämisessä, voimme vedota suunnitteluun. Mitä enemmän sattumia jonkin monimutkaisen ilmiön esiintyminen edellyttäisi sitä todennäköisemmältä näyttää se, että se on tulosta joko säännönmukaisuudesta tai suunnittelusta. Pelkkä sattumusten sarja ei kuitenkaan riitä, vaan tarvitaan jokin toistuva kuvio (pattern), jota ilmiö mukailee, jotta suunnittelun olemassaoloon voidaan päätyä. Dembskin mu- 
kaan siis suunnittelu kelpaa selitykseksi vasta silloin, kun sattuma ja säännönmukaisuus (välttämättömyys) epäonnistuvat jonkin ilmiön selittämisessä. Behen kuvaamat solumekanismit ovat luonteeltaan juuri tällaisia ilmiöitä: niitä ei ID:n edustajien mukaan pystytä selittämään sattuman avulla eikä niitä voida johtaa tunnetuista biologisen maailman säännönmukaisuuksista. Näin ollen meidän tulee päätellä, että nämä mekanismit ovat tuotetta biologisen maailman ulkopuolelta tulevasta älykkäästä suunnittelusta.

Kolmas ID:n piirre on eräänlainen tieteenfilosofinen kritiikki nykyisen luonnontieteen menetelmiä ja taustaoletuksia kohtaan. Kritiikin päämääränä on osoittaa, että nykytiede torjuu erilaiset kreationismin ja ID:n muodot filosofisista, ei tieteellisistä syistä johtuen. Koska kyseessä on filosofinen eikä tieteellinen erimielisyys, niin ainakin erimielisyyttä tästä seikasta voisi opettaa kouluissa. Tämän tyyppistä argumentaatiota on edustanut erityisesti oikeustieteilijä Philip Johnson. ${ }^{134}$ Johnsonin mukaan ongelmana on se, että metodologisesta naturalismista (tieteen ei tule vedota Jumalaan tai muuhun vastaavaan selityksissään) päädytään huomaamatta metafyysiseen naturalismiin (ei ole olemassa Jumalaa). Johnson itse asiassa päätyy väittämään, että metafyysinen naturalismi ja metodologinen naturalismi ovat periaatteessa sama asia eikä kristillisen teologian pidä hyväksyä kumpaakaan. Luonnontiede ei näin ollen ole uskonnollisesti neutraalia, vaan on jo lähtökohdissaan sitoutunut siihen, että Jumalaa ei ole olemassa. Toisin sanoen siis tiede on Johnsonin mukaan sitoutunut lähtökohtaisesti siihen, mitä olemme aiemmin kutsuneet tieteelliseksi materialismiksi. Tällainen näkemys on puolestaan ristiriidassa automaattisesti teismin ja kristillisen teologian kanssa. ${ }^{135}$

Siinä missä Scopesin oikeudenkäynti ja Arkansasin oikeudenkäynnit olivat olennaisia kreationismin kannalta, puhutaan ID:n yhteydessä erityisesti oikeudenkäynnistä Doverissa Pennsylvaniassa (2004), joka lähti liikkeelle yrityksestä opettaa ID:ä biologian yhteydessä paikallisessa koulussa. ID:n edustajat hävisivät jutun, mutta itse oikeudenkäynti aiheutti suuren mediamylläkän ja lisäsi suuresti ihmisten tietoisuutta ID:n teorioista. Koska ID:n idean poliittiset 
ja moraaliset tavoitteet ovat pitkälti samansuuntaiset kreationistien kanssa, niin monet ovat ajatelleet, että ID on vain kreationismin kevyt versio tai jonkinlainen "keisarin uusi vaate". ${ }^{136}$ Monessa suhteessa ID kuitenkin eroaa kreationismin eri muodoista: se hylkää ajatuksen nuoresta maasta, ensimmäisestä ihmisestä ja vastustaa literalismia ja tulvageologiaa. Samoin sen edustajat hyväksyvät elämän puun ajatuksen ja luonnonvalinnan evoluutiota ajavana voimana. Yhtäältä on siis monessa mielessä harhaanjohtavaa kutsua ID:ä kreationismiksi. Toisaalta taas ID:ä ajavat samanlaiset intressit kuin kreationismiakin: vaikka ID:n edustajat eivät halua julkisesti korostaa älykkään suunnittelijan "yliluonnollisuutta", on kuitenkin selvää, että kyseessä ei ole mikään luonnollinen suunnittelija ja monet myöntävät tämän suunnittelijan olevan itse asiassa Jumala.

\section{$7 \cdot 3$}

\section{TEISTINEN EVOLUUTIO}

Päällekkäisyysmallin ja luonnon teologian edustajat torjuvat sekä kaikki kreationismin muodot että älykkään suunnitelman idean ja näin ollen päätyvät hyväksymään evoluution olemassaolon ja jonkinlaisen darwinismin. Näin ollen luonnon teologit hyväksyvät darwinismin perusvakaumukset (ks. luku 5.1), joita ovat

(1) eliöiden luonnollinen alkuperä: ne eivät ole syntyneet nykyisessä muodossaan yhden luomisen aktin tuloksena,

(2) elämän puu,

(3) sopeutuminen, selviytyminen ja muuntelu (sattuma),

(4) luonnonvalinnan merkittävä rooli evoluutiota ajavana voimana.

Näiden näkemysten hyväksyminen teologisessa viitekehyksessä ei kuitenkaan ole ongelmatonta. Kuten jo aiemmin huomautimme (ks. tarkemmin luku 5.5), esiin tulevat ainakin seuraavat kysymykset: 
(1) Sattuman ja kaitselmuksen suhde: modernista synteesistä näyttää seuraavan, että sattumalla on varsin suuri osuus evoluutiossa. Miten tämä sopii yhteen sen perinteisen näkemyksen kanssa, että Jumala ohjaa luomakuntaa?

(2) Suunnittelun puute: modernin synteesin valossa huomaamme luonnossa paljon "huonoa suunnittelua", joka ei tue ajatusta, että yksittäiset eliöt ovat Jumalan suunnittelemia. Mitä tästä pitäisi ajatella?

(3) Pahan ongelma: lajeja kuolee sukupuuttoon, biologinen maailma on usein julma ja piittaamaton kärsimyksestä. Miten tämä sopii yhteen hyväntahtoisen Jumalan kanssa?

Käsittelen seuraavaksi useita ratkaisumalleja näihin ongelmiin. Nämä mallit voidaan luokitella laajasti joko teistisen evoluution tai evolutionaarisen teismin alle riippuen siitä, millä tavalla ne ymmärtävät Jumalan vaikutuksen evoluutioon yleensä. Olennaista on kuitenkin se, että kaikki luonnon teologian sisään mahtuvat vaihtoehdot tunnustavat darwinismin itseriittoisuuden biologian alueella.

Teistisen evoluution malleja on monia ja ne ovat keskenään varsin erilaisia. On siis varsin harhaanjohtavaa puhua "teistisestä evoluutiosta" ikään kuin teoriana, joka olisi vaihtoehto kreationismille tai ID:lle. Seuraavassa kuitenkin kolme yleistä piirrettä, jotka valtaosa teistisen evoluution malleista jakaa:

(1) Evoluutio ja jatkuva luominen: evoluutio on Jumalan jatkuvan luovan toiminnan väline.

(2) Konvergentti evoluutio: evoluutiolla näyttää olevan yleinen suunta, mistä puolestaan seuraa, että evoluutiolla voi olla päämäärä (ja tarkoitus).

(3) Evolutionaarinen teodikea (eli prosessiteodikea): Jumala joko vetäytyy maailmasta, koska hän haluaa vapaiden olioiden tekevän vapaita valintoja tai sitten Jumala luo nykyisenkaltaisen todellisuuden, koska se on välttämätöntä vapaiden ja moraalisten olioiden syntymisen takia. 
Käsittelen seuraavaksi muutaman teistisen evoluution ja evolutionaarisen teismin mallin erityisesti näiden kolmen piirteen näkökulmasta.

Katolinen teologi John Haught on kirjoittanut laajasti aiheesta, jota hän kutsuu "evoluution teologiaksi" (Theology of Evolution). ${ }^{137}$ Viittasimme jo aiemmin Haughtin edustamaan "kenoottiseen teologiaan", joka on myös hänen evoluution teologiansa ydinkohta (ks. luku 6.5). Haught on vakuuttunut, että teologinen näkökulma evoluutioon on mahdollisen ja välttämättömän lisäksi sellainen, joka nousee evoluutiosta itsestään. Tämä ei kuitenkaan tarkoita sitä, että Jumala toimisi selittävänä tekijänä biologiassa, koska "meidän tulee sijoittaa jumalallinen todellisuus ja evoluution uskonnollinen tulkinta perimmäiselle selittämisen tasolle, jonne tiede ei periaatteessakaan voi tunkeutua." ${ }^{138}$ Toisaalla hän jatkaa:

se, että ei ole olemassa erityistä luomisen hetkeä eikä Jumala puutu evoluution kulkuun, ei tarkoita sitä, että riittävä ja syvä elämän selitys voisi unohtaa Jumalan. Jumalan luova toiminta tulee ilmi välillisesti niiden luonnollisten syiden kautta, joita evoluutiobiologia tutkii. Kutistamme Jumalan, jos yritämme asettaa hänen toimintansa osaksi luonnollisia ja biologisia syitä. ... Mikä pahinta, tämä on epäjumalanpalvontaa, sillä siinä, missä Jumalan toiminnan tulisi olla kaikkien luonnollisten syiden ketjujen perusta, se tekee Jumalan toiminnasta yhden linkin maailman äärellisten syiden ketjussa. ${ }^{139}$

Tässä kohdassa näemme myös, kuinka Haught viittaa ensisijaisten ja toissijaisten syiden erillisyyteen (ks. luku 6.5): Jumala toimii välillisesti evoluutiobiologian kuvaamien mekanismien ja syiden "kautta”. Näin ollen evoluutiobiologian selityksiin ei jää Jumalan (eikä älykkään suunnittelijan) mentäviä aukkoja, sillä teologiset selitykset ovat yleisemmällä (ja perimmäisemmällä) selitysten tasolla.

Samoin kuin muutkin teistisen evoluution edustajat, Haught sijoittaa Jumalan evoluutiota ohjaavan toiminnan biologisen tason sijaan biologisen evoluution materiaalin tuottavalle fysikaaliselle ta- 
solle. Tämän liikkeen puolestaan mahdollistaa jo edellä esitelty fysikaalisen "hienosäädön" ajatus (ks. luku 6.4): Jumala on fysikaalisen maailman luodessaan säätänyt fysikaaliset perusrakenteet sellaiseksi, että niiden pohjalta voi monimutkaisten rakenteiden kehittyessä syntyä eläviä olentoja ja lopulta ihmisiä, jotka pystyvät vapaisiin valintoihin ja moraaliseen vastuuseen. Näin ollen sattumalla on kyllä merkittävä rooli maailmankaikkeuden kehittymisessä, mutta kehityksen alkuehdot on kuitenkin "rakennettu sisään" jo lähtökohdissa.

Jo aikaisemmin esille tullut ajatus sattuman ja säännönmukaisuuden yhteispelistä pitkien ajanjaksojen kuluessa on saanut monet ajattelemaan, että evoluutiobiologia johtaa ateismiin (ks. 5.1). Haught kuitenkin väittää, että tämä ajatus antaa mahdollisuuden kehittää eteenpäin kristillistä teologiaa. Sattuma (geneettinen mutaatio on sattumanvaraista), säännönmukaisuus (luonnonvalinta) ja "syvä aika" (deep time) ovat itse asiassa tekijöitä, jotka Jumalan olemassaolo ja luova tahto tekee ymmärrettäväksi. Ensinnäkin siinä, missä ateisti näkee sattuman roolin evoluutiossa selkeänä osoituksena siitä, että Jumalaa (kosmisena insinöörinä) ei ole olemassa, pitää Haught taas sattuman olemassaoloa merkkinä siitä, että Jumala antaa maailmalle suuren määrän vapautta. Kenoottisen teologiansa mukaisesti Haught ajattelee, että Jumala "vetäytyy" maailmasta antaakseen sillä mahdollisimman paljon itsenäisyyttä ja vapautta kehittyä arvaamattomiin suuntiin. Sattuma pitää myös huolen siitä, ettei maailma ole kellokoneisto vaan tulevaisuudelle aidosti avoin kokonaisuus, jonka tulevaisuuteen myös ihmiset voivat vapautensa ja valintojensa kautta vaikuttaa. Toiseksi ateisti ottaa säännönmukaisuuden merkkinä siitä, että maailma on viime kädessä persoonaton ja merkityksetön. Haught taas korostaa, että evoluution säännönmukaisuus on merkki Jumalan uskollisuudesta ja johdonmukaisuudesta. Hienosäädettyjen fysikaalisten rakenteiden avulla Jumala antaa kehitykselle rajat, jotka turvaavat maailman kehityksen jatkuvuuden mutta eivät määrää sen tulevaisuutta. Ilman säännönmukaisuutta ei voisi olla mitään eikä ilman sattumaa voisi olla vapautta eikä avointa tulevaisuutta. Kolmanneksi ateisti katsoo, että lähes loputtoman pitkältä tuntuvat 
evoluutiohistorian ajanjaksot eivät näytä suuntautuvan kohti mitään. Haught taas huomauttaa, että Jumala on antanut maailmalle ajan, jotta se voisi lopulta löytää Jumalan aikojen päässä ja yhdistyä ikuisesti hänen kanssaan.

Haught korostaa, että teologian tulee ottaa evoluutio vakavasti, mistä puolestaan seuraa siirtymä klassisen teismin Jumalasta kohti avoimen, kehittyvän ja itsenäisen maailman Jumalaa. On myös siirryttävä staattisesta luontokäsityksestä käsitykseen jatkuvasti kehittyvästä luonnosta ja jatkuvasta luomisesta, mikä johtaa keskiaikaisen synteesin lopulliseen hylkäämiseen (ks. luku 4.1). Haught korostaa moneen otteeseen, että Jumala ei ole lopettanut luomista, vaan se jatkuu yhä. Haughtin lisäksi muut useat muut 1900-luvun katoliset ajattelijat, esimerkiksi Ernan McMullin ja Karl Rahner, ovat korostaneet teologian mahdollisuuksia mukautua kehittyvän universumin ajatukseen. Rahner esimerkiksi esittää, että klassisen kristinuskon näkemykset ihmisluonnosta ja kristologiasta sopivat varsin hyvin yhteen evolutiivisen näkökulman kanssa: evoluutio voidaan ymmärtää Jumalan luovana prosessina, jossa yksinkertaisesta aineesta kehittyy ensin mieli ja sitten henki. Jumalan luova ja pelastava työ alkaa siitä, että hän antaa aineelle pyrkimyksen kohti yhä suurempaa monimutkaisuutta. Koko luomakunta on tällöin jatkuvassa evoluution tilassa, jossa se pyrkii ylittämään itsensä ja lähestymään Jumalaa. Aineeseen sisäänrakennettu pyrkimys kohti henkeä ilmenee ensin monimutkaisten elämänmuotojen syntymisenä ja lopulta ihmisen, ainoan hengellisen olion, saapumisena näyttämölle. Jumalan luova ja pelastava työ tähtää tulevaisuuteen, jossa koko luomakunta tulee osaksi Jumalaa. Inkarnaatio, Jumalan ihmiseksituleminen, on tämän tulevan todellisuuden kuva ja merkki.

Kuten edellä kävi ilmi, monet teistisen evoluution edustajat ajattelevat, että evoluutiolla on jokin päämäärä mutta tämä päämäärä ei käy ilmi biologisen evoluution mekanismeista. Voimme kuitenkin tarkastelemalla kosmista ja biologista evoluutiota yhdessä nähdä, kuinka koko maailmankaikkeuden historia näyttää johtavan tiettyyn suuntaan. Teistisen evoluution mukaan Jumala toteuttaa luovaa 
tahtoaan tämän kosmisen kehityksen välityksellä. Jumalan tahdolla on useita päämääriä, joita ovat esimerkiksi tietoisen elämän, maailmankaikkeuden kauneuden ja arvojen maksimointi. Keith Ward kirjoittaa:

Aineen kehitys kohti yhä monimutkaisempia ja integroidumpia muotoja perustuu aineeseen heti alusta sisäänrakennettujen mahdollisuuksien aktualisoitumiseen. ... Havaitsemme asteittaisen kehityksen aina kvarkeista tietoisuuteen asti. Jokainen askel on ollut edellistä monimutkaisempi ja rakentuneempi ja näemme tässä kosmisessa prosessissa yhä lisääntyvää eriytymistä ja yhä monimutkaisempien kokonaisuuksien rakentumista toimiviksi yksiköiksi. ... On mahdollista ajatella, että maailmankaikkeus ilmentää runsauden periaatetta: asteittainen ja jatkuva kehitys toteuttaa maailmankaikkeuden potentiaalia, joka johtaa yhä lisääntyvään tietoisuuteen, älykkyyteen, luovaan vapauteen ja persoonien väliseen yhteistyöhön. ${ }^{140}$

Wardin ajatus on tässä sama kuin Haugthilla ja muilla luonnon teologian edustajilla: on perusteita väittää, että evoluutiolla on sittenkin päämäärä ja suunta. Tämä suunta puolestaan sopii yhteen Jumalan luovan tahdon kanssa, joka haluaa tuottaa älykästä ja tietoista elämää, joka pystyy moraalisiin valintoihin ja tulemaan tietoiseen suhteeseen Jumalan kanssa.

Se, että biologisen evoluution toiminnassa on sattumaa, ei siis välttämättä johda evoluution päämäärän hylkäämiseen ja sattuman absoluuttiseen valtaan. Teologisesta näkökulmasta tarkasteltuna evoluutiolla on suunta. Vaikka emme voikaan päätellä Jumalan olemassaoloon itse evoluution prosessista, on se yhteensopiva Jumalan luovan toiminnan kanssa. Barbour kirjoittaa:

evoluutio ilmentää sekä sattumaa että päämäärähakuisuutta. Sattumaa esiintyy monella eri tasolla: mutaatio, geneettinen rekombinaatio, geneettinen ajautuminen, ilmastonmuutokset, jne. Evoluutio historiallinen prosessi, joka ei ole toistettavissa eikä sen yksityiskohtainen suunta ole 
ennustettavissa. Sitä voidaan vain kuvata historiallisesti. Tästä huolimatta historia on nähnyt kehityksen kohti monimutkaisempien järjestelmien tasoja ja trendin kohti suurempaa monimutkaisuutta sekä tietoisuutta. Noppaa heitetään, mutta nopat ovat painotettuja, kehitykseen on rakennettu sisään rajoitteita. ${ }^{141}$

Kaikkein tärkein tapa perustella "kehitykseen sisään rakennettuja rajoitteita" on vedota "konvergenttiin evoluutioon" (convergence = läheneminen, kanavoituminen). Konvergentin evoluution ajatus on tapana liittää Cambridgen yliopiston paleontologian professoriin Simon Conway Morrikseen, vaikka hän ei suinkaan ole ainoa tämän kannan edustaja. ${ }^{142}$ Conway Morrisin mukaan geneettinen mutaatio on kyllä sattumanvaraista, mutta ne muodot, jota kohti biologinen evoluutio ajaa biologisia organismeja, ovat varsin vakiot, koska nämä muodot ovat sekä ympäristön että organismien fysikaalisten lainalaisuuksien kannalta parhaita mahdollisia. Monet biologiset rakenteet näyttävät syntyvän toisistaan riippumatta useassa eri elämän puun haarassa: näin on käynyt esimerkiksi kamerasilmien ja yhteyttämisen osalta, joista kumpikin on kehittynyt useita kertoja eri yhteyksissä. Conway Morriksen mukaan tällaisia seikkoja on lukemattomia ja niiden tunnustaminen johtaa lopulta siihen, että jos maailmankaikkeuden fysikaaliset vakiot ovat juuri sellaiset kuin ne ovat omassa maailmankaikkeudessamme, niin nykyisenkaltaista elämää syntyy lähes välttämättä. Ajatus on siis se, että evoluutio on kaikkea muuta kuin sattumanvarainen: se on "hakukone", joka etsii organismien optimaaliset muodot. Optimaalisuuden kehykset tarjoavat fysikaaliset lainalaisuudet, jotka pätevät niin biologisiin organismeihin kuin niiden fyysiseen ympäristöönkin. Nämä lainalaisuudet "kanavoivat" biologista evoluutiota kohti nykyisiä muotoja.

Esimerkiksi McGrath vetoaa konvergentin evoluution ajatukseen perustellessaan sitä mahdollisuutta, että Jumala käyttää hyväkseen evoluution mekanismeja ohjatakseen biologista evoluutiota. Konvergentin evoluution ajatus sopii hyvin yhteen fysikaalisen hieno- 
säädön kanssa ja tuottaa tulokseksi näkemyksen, jossa Jumala sekä antaa luomakunnalle vapautta, mutta myös ohjaa sitä fysikaalisten säännönmukaisuuksien kautta. Augustinuksen luomisen teologia voi toimia yleisenä kehyksenä tällaiselle ajatukselle: Jumala luo koko maailmankaikkeuden yhdellä hetkellä mutta sen mahdollisuudet toteutuvat pitkän kehityksen aikana. Teistisen evoluution ajatus on tapana tiivistää Charles Kingsleyn kuuluisaan lausahdukseen, joka jo vuonna 1871 totesi, että "Vanhastaan tiesimme, että Jumala viisaudessaan pystyy tekemään kaiken. Mutta katso: hän on tätäkin paljon viisaampi, sillä hän pystyy saamaan kaiken tekemään itse itsensä." ${ }^{133}$

Vaikka teistisen evoluution edustajat pystyisivätkin näkemään evoluution yleisissä kehityslinjoissa Jumalan ohjauksen, niin eräs iso ongelma jää vielä jäljelle. Onko uskottavaa väittää, että Jumala käyttää hyväkseen evoluution mekanismeja tahtonsa toteuttamiseksi, koska nämä mekanismit näyttävät tuottavan hyvin paljon kärsimystä sekä eläinkunnassa että ihmiskunnassa? William Paleyn ja klassisen luonnollisen teologian aikana luontoa oli helppo pitää hyvin suunniteltuna, mutta nykyisin - modernin synteesin jälkeen tiedämme, että monet biologisen luonnon piirteet aina solujen mekanismeista moniin eliöiden anatomisiin piirteisiin asti ovat "sotkuisia" ja eivätkä näytä laisinkaan hyvin suunnitelluilta. Teistisen evoluution edustajalla on jo vastaus siihen, miksi näin on: Jumala on luonut biologisen luonnon evoluution välityksellä. Tämä vastaus kuitenkin voidaan asettaa kyseenalaiseksi vetoamalla siihen, että toimiminen evoluution kautta ei ole yhteensopiva Jumalan luonteen (hyvä ja kaikkivaltias) kanssa. Tästä syntyy ongelma, joka tunnetaan kirjallisuudessa "evolutionaarisen pahan ongelmana" (the problem of evolutionary evil). ${ }^{144}$

Pahan ongelma on perinteisesti ehkä suurin kristillisen teismin uskottavuuden ongelma: jos on olemassa kaikkivaltias ja hyväntahtoinen Jumala, niin miksi on niin paljon kärsimystä? ${ }^{145}$ Ongelma voidaan ymmärtää kolmella eri tavalla: 
(1) Looginen pahan ongelma: Jumalan ja pahan olemassaolo ovat keskenään ristiriidassa.

(2) Evidentiaalinen pahan ongelma: pahan olemassaolo tekee Jumalan olemassaolosta epätodennäköisen.

(3) Eksistentiaalinen pahan ongelma: yksittäisen ihmisen on vaikea uskoa Jumalan olemassaoloon ja nähdä kuolemaa, kärsimystä ja muuta pahaa.

Olemme tässä yhteydessä kiinnostuneet nimenomaan evidentiaalisen pahan ongelmasta, jonka purjeisiin biologisen evoluution ajatus lisää tuulta merkittävästi. Biologinen evoluutio näyttää nimittäin perustuvan kärsimykselle, kuolemalle ja kilpailulle. Tunnettua on, että Darwinille itselleen pahan ongelma oli kaikkein keskeisin syy hylätä teismi ja hyväksyä agnostisismi. Erityisen huolestunut Darwin oli siitä, että evoluutio näyttää sisältävän niin paljon eläinten kärsimystä ja kuolemaa, että sitä voisi pitää tuhlaavaisena. Huono suunnittelu, jatkuvat kärsimykset ja koko järjestelmän perustuminen jatkuvaan kilpailuun johtivat Darwinin hylkäämään Jumalan. ${ }^{146}$ Saman ongelman nostavat esiin myös monet nykyiset uskontokriitikot ja tieteellisen materialismin edustajat: biologinen maailma sisältää niin paljon toimintahäiriöitä, huonoa suunnittelua, turhuutta ja julmuutta, että se ei voi pohjimmiltaan olla mitään muuta kuin "sokeaa ja säälimätöntä välinpitämättömyyttä".

Pahan ongelmaan on esitetty useita erilaisia ratkaisuja (eli teodikeoita), joista osa soveltuu myös evolutionaariseen pahan ongelmaan. Eräs perinteinen ratkaisu pahan ongelmaan on se, että kuolema ja kärsimys tulevat maailmaan vasta syntiinlankeemuksen jälkeen eivätkä kuulu luomakunnan täydellisyyden tilaan. Evoluutionäkökulma kuitenkin viittaa vahvasti siihen, että kärsimys ja kuolema ovat aina osa sellaista luomakuntaa, jonka perustana ovat tuntemamme fysikaaliset ja biologiset säännönmukaisuudet. Tästä monet ovat päätelleet, että 
jos kärsimys ja kuolema ovat evoluution välttämättömiä osia, niin ilman niitä ei voisi olla ihmisiä eikä muita tietoisia eläimiä. Ehkä kärsimys ja kuolema ovat valitettavia, mutta välttämättömiä ehtoja tai seurauksia siitä, että planeetallamme voi olla kehittynyttä älyllistä elämää. ${ }^{147}$

Ajatus on se, että tällaisessa maailmankaikkeudessa evoluutio näyttää olevan monimutkaisten ja monimuotoisten biologisten organismien syntymisen kannalta välttämätön. Jos näin on, niin esimerkiksi ihmislajin olemassaolo edellyttää myös evoluution sivutuotteiden, kuten kuoleman ja kärsimyksen, olemassaoloa. Tämäntyyppinen puolustus perustuu jälleen kerran ajatukseen fysikaalisen hienosäädön ja biologisten prosessien yhteydestä. Tämän näkemyksen mukaan maailmankaikkeus on kokonaisuus, jonka perustana ovat tietyt fysikaaliset lainalaisuudet. Jos näitä lainalaisuuksia muutetaan, muuttuu koko maailmankaikkeuden kokonaisuus radikaalisti. Voidaan siis ajatella, että jos Jumala haluaa kaltaistamme elämää, niin hänellä ei ole muuta vaihtoehtoa, kuin valita juuri nykyisen kaltaiset luonnon lainalaisuudet ja hyväksyä niiden sivutuotteet. Tällainen vastaus evolutionaariseen pahan ongelmaan tunnetaan "prosessiteodikeana" (process theodicy tai free-process theodicy).

Prosessiteodikean edustajat ovat kiinnittäneet huomiota siihen, kuinka ateistit liittävät toisinaan varsin arvolatautuneita kielikuvia evoluutioon. Puhe "kylmästä välinpitämättömyydestä" tai "olemassaolon taistelusta" on aina metaforista mutta kantaa sisällään hyvin negatiivisen latauksen ihmiselle ja kaikelle muullekin elämälle vihamielisestä maailmasta. On kuitenkin tendenssimäistä käyttää ainoastaan negatiivisia kielikuvia biologisesta maailmasta, sillä tällaiset kielikuvat ovat aina tulkintakysymyksiä. Kilpailun ja kuoleman kielikuvia ei pitäisi yleistää koskemaan kaikkea evoluution nimellä kulkevaa, sillä ne kuvaavat vain yhtä osaa suuresta kokonaisuudesta. Muunlaisia kielikuvia voidaan helposti käyttää kuvaamaan joitakin evoluution ilmiöitä: voidaan puhua esimerkiksi laajasta yhteistyöstä, harmoniasta, tasapainosta, hämmästyttävästä monimuotoisuudesta tai elämän kyvystä ylittää lähes mahdottomalta vaikuttavia esteitä. 
Prosessiteodikea on siinä mielessä vaativa, että se edellyttää varsin radikaalia visiota maailmankaikkeudesta ja ihmisen roolista siinä: meidän tulee ajatella, että itse asiassa koko maailmankaikkeuden on oltava juuri nykyisen kaltainen, jotta siinä voisi olla ihmisiä. Väite on siis se, että nykyihmisen kaltaiset biologiset ja fysikaaliset olennot edellyttävät maailmankaikkeuden, joka on juuri sen ikäinen, kokoinen ja perimmäiseltä luonteeltaan samanlainen kuin nykyinen maailmankaikkeutemme. Tässä on nähtävillä eräänlainen nykyaikainen paluu ihmiskeskeisyyteen. Keskiaikaisessa synteesissä ihminen oli kaiken keskus mutta mekanistinen universumi yhdistettynä evoluutioon työnsi hänet pois tästä keskuksesta maailmankaikkeuden laitamille sattuman oikuksi. Nyt kuitenkin näyttää siltä, että fysikaalinen todellisuus on syvärakenteeltaan hedelmällinen (hienosäätö) ja että kaikki maailmankaikkeuden tapahtumat (mukaan lukien biologinen elämä) edellyttää tämän syvärakenteen juuri sellaisena kuin se on. Erilleen pirstoutunut maailma alkaa tulla jälleen yhteen, mutta tavalla, joka on hurjempi kuin varhaisempina vuosisatoina osattiin edes kuvitella. Prosessiteodikean kriitikko voi kuitenkin kysyä onko nykyisen kaltainen maailmankaikkeus niin arvokas, sisältääkö se niin paljon itseisarvoa, että se on kaiken sen kuoleman ja kärsimyksen arvoinen, joka siihen on mennyt (ja menee tulevaisuudessa)? Tähän on vastattu väittämällä, että maailmankaikkeus toteuttaa lukuisia Jumalan mielen mukaisia arvoja, joita voivat olla esimerkiksi sen rationaalinen kauneus ja hienovarainen järjestys puhumattakaan elävistä tietoisista ja älykkäistä olioista.

Jätämme prosessiteodikean käsittelyn tällä erää sikseen, mutta haluan kuitenkin korostaa sitä, että teistisen evoluution edustaja tarvitsee jonkinlaisen ratkaisun evolutionaariseen pahan ongelmaan, jotta teistinen evoluutio olisi uskottava. On selvää, että prosessiteodikea on kiistanalainen ja spekulatiivinen tapa käsitellä pahan ongelmaa, mutta monet pitävät sitä mahdollisena ja lupaavana. ${ }^{148}$ Pahan ongelma ei kuitenkaan lopulta ole ominainen juuri teistiselle evoluutiolle, vaan kaikki teismin muodot, jotka hyväksyvät maail- 
mankaikkeuden kehityksen pitkän ajan kuluessa (myös älykkään suunnitelman edustajat ja vanhan maan kreationistit) joutuvat kehittämään siihen vastauksen.

Lopuksi on hyvä vetää yhteen teistisen evoluution edustajien vastaukset tämän alaluvun alussa (sekä luvussa 5.5) esitettyihin ongelmiin. Biologisen evoluution sattumanvaraisuuden suhteen teistisen evoluution edustaja väittää, että Jumalan toteuttaa tahtoaan luomakunnassa käyttämällä hyväkseen biologisen evoluution mekanismeja mutta antaa luomakunnalle suhteellisen paljon vapautta. Sattuma on seuraus tästä vapaudesta. Biologista evoluutiota kuitenkin kanavoivat sen fysikaalisten osasten lainalaisuudet (hienosäätö ja konvergentti evoluutio), jotka pitävät huolen, että Jumalan luova tahto toteutuu pitkässä juoksussa. Näin ollen teistisen evoluution edustajaa ei yllätä, että luonnossa on paljonkin "huonoa suunnittelua": Jumala ei luonut kutakin lajia yhdellä hetkellä täydelliseksi jossakin ympäristössä, vaan antoi luomakunnalle vapautta kehittyä luomiensa rajojen sisällä. Vaikka evoluution mekanismien tasolla nähdään paljon sattumaa, on evoluutiolla yleisellä tasolla suunta kohti monimutkaisuutta, älykkyyttä ja autonomiaa. Biologinen evoluutio on merkki Jumalan jatkuvasta luovasta toiminnasta ja tahdosta synnyttää monimuotoisuutta. Evolutionaarisen pahan ongelmaan teistisen evoluution edustajat ovat vastanneet useilla eri tavoilla, joista ehkä suosituin on prosessiteodikea. Tämän näkemyksen mukaan maailmankaikkeuden biologiset ja fysikaaliset prosessit ovat toisistaan riippuvaisia. Jos Jumala haluaa luoda maailmankaikkeuden, joka sisältää kaltaistamme elämää, niin hänen pitää luoda juuri nykyisen kaltainen fysikaalinen ja biologinen järjestelmä, joka sisältää jonkin verran sattumaa. Sattuma tuo mukanaan myös kärsimyksen mahdollisuuden. Kärsimys ja kuolema ovat tällaisessa maailmankaikkeudessa elämän välttämätön edellytys. Kärsimyksestä huolimatta evoluution prosessi on toisinaan "elegantti ja kaunis" sekä sopiva toteuttamaan Jumalan tahtoa. 


\section{Kirjallisuutta}

Paras ja kattavin johdanto eri kreationismin muotojen historiaan ja nykytilaan on Numbers 1992. Darwinismin ja kristinuskon yhteensopivuutta käsittelee Ruse 2001. Ruse 1988 kuvaa laajasti keskustelun filosofista taustaa ja Ruse 2005 on hyvä johdatus peruskysymyksiin. Älykkään suunnittelun klassikot ovat Behe 1996 ja Dembski 1998. Dembski \& Ruse 2004 ja Pennock 2001 ovat hyviä katsauksia älykkään suunnittelun ympärillä käytyyn keskusteluun ja niistä löytyy sekä kriittisiä että kannattavia puheenvuoroja. Lukuisista älykkään suunnitelman kristillisistä kritiikeistä lähestyttävin on Miller 2002, vaikka Millerin oma teistinen evoluutio jääkin puolitiehen. Älykästä suunnitelmaa kritisoivat ja teistisen evoluution perusajatuksia esittelevät laajasti esimerkiksi Collins 2007, Haught 2007, McGrath 2009, Peacocke 2004, Ward 1996. Konvergentin evoluution klassikko on Conway Morris 2003. "Evolutionaarista pahan ongelmaa" käsittelevät esimerkiksi Murray 2008 ja Southgate 2008. 


\section{TEOLOGINEN IHMISKÄSITYS JA IHMISLUONTO}

Kuten luvussa 5 näimme, ovat sekä evoluutiobiologia että mielen tieteet muuttaneet radikaalisti käsitystämme luonnosta ja ihmisestä osana tätä luontoa. Näimme kuinka evoluutionäkökulmasta tarkasteltuna ihminen voidaan ymmärtää ruumiinsa anatomian ja aivojensa rakenteen osalta (ja monien mielestä myös mielensä ja kulttuurinsa osalta) biologisen evoluution tuotteeksi. Näimme lisäksi kuinka mielen tieteiden, erityisesti neurotieteen ja kognitiotieteiden, edistys on tehnyt erilaisista mieli/ruumis-materialismin muodoista perusnäkemyksiä. Tässä luvussa käsittelemme tarkemmin niitä kysymyksiä ja ongelmia, joita nämä kehityskulut aiheuttavat niille, jotka haluavat puolustaa jonkinlaista päällekkäisyysmallia tieteen ja teologian suhteesta. Nämä kysymykset ja ongelmat koskevat pääasiassa teologisia ihmiskäsityksiä.

8. 1

ELÄIMET, PERSOONAT JA IHMISLUONTO

Nykynäkökulmasta maailmaa tarkastelevan ihmisen on ehkä vaikea ymmärtää, kuinka suuri ihmiskäsityksen muutos on viimeisen 200 vuoden aikana tapahtunut. Traditionaalinen ihmiskäsitys, joka oli ankkuroitu sekä kristilliseen teologiaan että antiikin filosofiaan kumoutui varsin perusteellisesti ensin mekanistisen maailmankuvan 
ja myöhemmin evoluutiobiologian toimesta.

Perinteisen antropologian mukaan ihmispersoonat eivät ole luontokappaleita kuten eläimet, kasvit tai elottoman luonnon kappaleet. Ihmispersoonien käyttäytymistä ei voida näin ollen selittää vetoamalla jonkinlaisiin luonnonlakeihin tai selviämisvaistoihin kuten eläinten kohdalla. Kuten jo aiemmin näimme, tämä perinteistä näkemystä pyrittiin suojelemaan mekanistista maailmankuvaa vastaan kehittämällä erityinen dualismin muoto, substanssidualismi (ks. luku 5.3), josta tuli sekä teologisen että filosofisen antropologian valtavirta. Ihmisen erityiset kyvyt, kuten järki, tietoisuus, vapaa valinta ja moraalinen vastuu, perustuvat tämän näkemyksen mukaan ihmisessä olevaan erityiseen metafyysiseen osaan, sieluun. Sielun alkuperä ei ollut luonnollinen maailma, vaan se perustui Jumalan erityiseen toimintaan. Teologisesti ottaen tämän sielun ajateltiin olevan juuri se, joka tekee ihmisestä Jumalan kuvan (lat. imago Dei). Lisäksi perinteiseen näkemykseen kuului se, että ihmisen moraaliset taipumukset ja kyky moraalisiin valintoihin perustuu Jumalan luomistyöhön: moraalinen järjestys on maailmassa itsessään ja ihmisellä on kyky aistia tuo moraalinen järjestys.

Olemme jo aiemmin jäljittäneet sitä kehitystä, joka haastoi perinteiset antropologiset näkemykset, joten tässä riittää se, että vedämme sen yhteen (ks. luvut 5.2 ja 5.3). Evoluutiobiologian ja mielen tieteiden kehittyessä syntyi yhä suurempi paine revisioida radikaalisti perinteistä antropologiaa:

(1) Ihmisen erityisyydestä jatkuvuuteen muun luonnon kanssa. Perinteisesti ihmisen katsottiin olevan laadullisesti ja määrällisesti erityinen verrattuna muuhun luontoon: ihmisellä on ominaisuuksia, joita luomakunnan muilla olennoilla ei ole ja nämä nostavat ihmisen omaan kategoriaansa. Evoluutiobiologian ja mielen tieteiden valossa on kuitenkin käynyt selväksi, että ihminen ei olekaan niin erityinen: ihmisen ruumis ja hänen mielensä toiminnot (ja enemmän tai vähemmän myös hänen kulttuurinsa, moraalinsa ja yhteiskuntansa) voidaan ymmärtää 
osaksi luontoa ja hänen biologisten ja psykologisten toimintojensa tuotteiksi.

(2) Ihmisen välttämättömyydestä olemassaolon sattumanvaraisuuteen. Perinteisesti ihmisen ajateltiin olevan luomakunnan ydin. Ihmisen olemassaolo on kaikkein keskeisin osa Jumalan luomakuntaa koskevaa suunnitelmaa ja näin ollen ihmisen ajateltiin olevan välttämättä olemassa. Ajatus luomakunnasta ilman ihmistä on tästä näkökulmasta vähintäänkin outo. Biologisen evoluution näkökulmasta ihmisen ei kuitenkaan voida katsoa syntyvän automaattisesti: ihminen sattui syntymään mutta tämä ei näytä ollenkaan välttämättömältä.

(3) Vapaasta tahdosta, vastuusta ja objektivisesta moraalista inhimillisen valintojen ja moraalin ajalliseen ja paikalliseen sidonnaisuuteen. Perinteisesti ihmisellä katsottiin olevan vapaa tahto ja vastuu siitä, että hän elää objektiivisten moraalinormien mukaan. Evoluutiobiologia on kuitenkin tehnyt selväksi sen, kuinka ihmisen moraalinormit ja hänen valintansa ankkuroituvat evoluution synnyttämiin tunteisiin ja taipumuksiin. Tästä seuraa myös ajatus siitä, että moraalinormit eivät ole objektiivisia ja luonnonlakien kaltaisia velvoittavia voimia. Näyttää siltä, että moraalinormit ja valinnat ovat vahvasti sidottuja ihmisen biologiseen kehitykseen ja hänen ympäristöönsä.

(4) Sielusta aivoihin. Perinteisen näkemyksen mukaan ihmisen erityisyyden (vapaa tahto, järki, moraali) perustana on ihmisessä oleva erityinen rakenneosa, jota kutsuttiin usein sieluksi. Mielen tieteet ja evoluutiobiologia tekevät kuitenkin selväksi sen, että ihmismielen ja aivojen välillä on hyvin läheinen yhteys, mistä puolestaan seuraa jonkinlaisen mieli/ruumis-materialismin houkutuksen lisääntyminen.

Vastauksia näihin kysymyksiin on monia riippuen siitä, millainen teologinen antropologia tarkkaan ottaen halutaan kehittää. Haluamme kuitenkin pysytellä yleisellä tasolla menemättä erilaisten teologisten antropologioiden yksityiskohtiin. Kohta (4) on teologisten 
vastausten kannalta kaikkein keskeisin, sillä perinteisesti juuri sielu on ollut se, jonne ihmisen erityisyys, hänen erityiset kykynsä, hänen vapautensa ja moraalinen vastuunsa on asetettu. Aloitan siis siitä.

Kysymys sielun olemassaolosta on pohjimmiltaan kysymys siitä, mikä tekee ihmisestä persoonan: mikä on ihmispersoona? Tavallisesti persoonalla tarkoitetaan ajattelun, tunteiden, tietoisuuden ja tahdon keskusta, joka ankkuroi yksilön identiteetin eli tekee siitä juuri kyseisen yksilön. Perinteisesti vastauksia siihen, mistä ihmisen persoona koostuu, on kolmea eri tyyppiä:

(1) Dualismi: ihmispersoona on sielu, jonka lähde on yliluonnollinen ja joka asuu ruumiissa.

(2) Kompositttimalli: ihmispersoona on sielun ja ruumiin kokonaisuus.

(3) Materialismi: ihmispersoona on ihmisen ruumis ja sen ominaisuudet.

Sekä mallit (1) ja (2) olettavat, että on olemassa jotain ihmisruumiin ja sen ominaisuuksien lisäksi, johon persoonallisuus perustuu. Perinteisen dualismin mukaan persoona on yhtä kuin sielu, kun taas komposiittimallin edustajat ajattelevat, että persoonallisuus edellyttää sekä sielun että ruumiin. Dualismin sisällä on helppo ajatella, että ihmispersoonalla eli sielulla on yliluonnollinen alkuperä. Komposiittimallissa tämä ei ole yhtä selvää: sielu ei siinä ole mikään paikka, jossa ajattelun, tunteen ja tahdon toiminnot tapahtuvat, vaan pikemminkin jotain, joka antaa ruumiille sille ominaisen muodon ja toiminnot. Kutsun jatkossa sekä dualismin että komposiittimallin edustajia "teologisiksi dualisteiksi”, sillä molemmat puolustavat edellä kuvattuja perinteisiä teologisen antropologian näkemyksiä.

On monia erilaisia malleja, jotka voidaan luokitella joko dualistisiksi tai komposiittimalleiksi. Yksi tapa rakentaa dualismin mukainen näkemys on väittää, että evoluutio kyllä tuottaa ihmisen ruumiin ja aivot, mutta korkeammat aivotoiminnot, kuten tietoisuus 
ja järki, tulevat ihmiseen Jumalan erityisen toiminnan välityksellä. Ilman Jumalan erityistä toimintaa jokaisen ihmisen kohdalla syntyisi tämän näkemyksen mukaan pelkästään biologisia koneita. Tämä vaihtoehto toimisi hyvin platonistisen ja augustinolaisen sielukäsityksen kanssa (ks. luku 5.3). Vaihtoehdon (3) mukaan ihmissielu ei synny tämänkaltaisen yliluonnollisen luomisen seurauksena, vaan se jollakin tavalla kehittyy yhdessä biologisen ruumiin kanssa. Tämä näkemys mukailisi paremmin aristoteelista ja Tuomas Akvinolaisen hylomorfista näkemystä sielunsa ruumiin muotona (ks. 5.3). Sielu ei tämän näkemyksen mukaan ole varsinaisesti mikään aineeton olio, vaan jokin, joka antaa ruumille sille ominaiset kyvyt.

Erilaisilla teologisen dualismin muodoilla on nykykeskustelussa monia edustajia erityisesti filosofien keskuudessa, mutta samaan aikaan monet luonnon teologian edustajat ovat kuitenkin hylänneet teologisen dualismin ja hyväksyneet jonkin materialismin muodon. ${ }^{149}$ Heidän mukaansa teologinen antropologia voi aivan hyvin omaksua evoluutiobiologian ja mielen tieteiden suositteleman materialismin tietyin varauksin. Kutsun jatkossa tällaisia näkemyksiä "teologiseksi materialismiksi". Teologisen materialismin mukaan voimme pitää kiinni ihmisen erityisyydestä, mutta emme samassa muodossa kuin aiemmin: ihminen on kyllä erityinen mutta samaan aikaan on tunnustettava hänen jatkuvuutensa muun luomakunnan kanssa. Voimme myös pitää kiinni ihmisen vapaudesta, koska vapaa tahto ei teologisten materialistien mukaan edellytä sielun tai minkään muunkaan ei-luonnollisen komponentin olemassaoloa. Sama sopii muutettavat muuttaen myös moraaliseen vastuuseen: jos vapaa tahto pystytään perustelemaan materialismin sisällä, niin moraalinen vastuu ei ole ongelma. Mikä kaikkein tärkeintä, teologisilla materialisteilla on tapana väittää, että vaikka teologinen dualismi on eri muodoissaan ollut kristillisen perinteen valtavirtaa, niin teologinen materialismi on paremmin yhteensopiva Raamatun tekstien ja varhaiskristillisen perinteen kanssa.

Kuten sanottua, en halua väittää, etteikö teologista dualismia voitaisi puolustaa järkevästi. Keskityn kuitenkin jatkossa teologi- 
siin materialisteihin, koska monet luonnon teologian edustajat ovat taipuvaisia tähän suuntaan. Näkemys, jota teologiset materialistit puolustavat, on tavallisesti jonkinlainen versio non-reduktiivisesta materialismista tai emergentistä materialismista (ks. luku 5.3). Meillä on jo käsitys siitä, miten luonnon teologian edustajat ymmärtävät luonnon monikerroksellisuuden (ks. luvut 4.3 ja 5.4). Heidän mukaan ihmismielen ja aivojen suhde voidaan ymmärtää tässä viitekehyksessä. Ihmismieli on fysikaalinen siinä missä ruumiskin on fysikaalinen, mutta sen toiminnoille ja säännönmukaisuuksille on turha odottaa fysikaalista selitystä. Ihmismieli on oma suhteellinen itsenäinen tasonsa. On selvää, että tämänkaltainen näkemys on irtiotto perinteisestä antropologiasta, mutta teologiset materialistit korostavat, että perinteinen teologinen antropologia voidaan kuitenkin pääosin ymmärtää materialismin viitekehyksessä.

Nancey Murphy on esittänyt, että materialismi on itse asiassa paljon lähempänä raamatullista ihmiskäsitystä, kuin myöhempi kreikkalaisperäinen dualismi. ${ }^{150}$ Raamatullinen käsitys ihmisestä on Murphyn mukaan paljon lähempänä nykyaikaista materialismia kuin mitään tuntemaamme dualismin versiota. VT käyttää usein hepreankielistä ilmaisua "nefesh", joka toisinaan käännetään "hengeksi" tai "sieluksi". On kuitenkin hyvin epätodennäköistä, että tällä viitattaisiin ihmisruumiista mahdollisesti erotettavaan komponenttiin, kuten dualismissa. Raamatullinen "henki" ja "sielu" näyttävät sen sijaan viittaavan koko ihmispersoonaan, elävään ihmiseen. Tässä merkityksessä sielu olisi ihmisen elämän keskus tai jonkinlainen "elämän prinsiippi”. UT on kuitenkin vaikeampi tulkita tässä asiassa. On kuitenkin selvää, että UT:n kirjoittajat eivät ainakaan olleet substanssidualisteja, koska heillä ei ollut vastaavaa mekanistista käsitystä luonnosta ja aineesta. He olettivat merkittävän jatkuvuuden sielun ja ruumiin välillä: olennaista ei ole se, millaisia osia ihmisessä on, vaan miten hän elää. Juuri tähän liittyy esimerkiksi Paavalin puhe "lihasta" ja "hengestä". Paavali ei erota tässä sielua ja ruumista, vaan kaksi erilaista tapaa elää, toinen Jumalan mielen mukainen ja toinen ihmisen mielen mukainen. 
Murphy korostaa myös, että materialismin suuntaan kallellaan oleva raamatullinen ihmiskäsitys on yhteensopiva erityisesti ruumiin ylösnousemuksen ja muiden teologisten ydinkohtien kanssa. Kristityiltä edellytetään uskoa ruumiin ylösnousemukseen, eikä sielujen ikuisuuteen. Lisäksi kristityt uskovat materiaaliseen elämään kuoleman jälkeen: millaista tämä elämä sitten onkin, se on jollakin tavalla aineellista. Vaikka jo Paavali kuvaa elämää ylösnousemuksen jälkeen "mystisin" äänenpainoin, edellyttää hänen kuvauksensa nimenomaan ruumiillista ylösnousemusta ja ruumiillista elämää, vaikka tämä ruumis onkin luonteeltaan "uusi luomus". ${ }^{151}$ Näin ollen on jonkinlaisia perusteita väittää, että teologinen materialismi tuo itse asiassa paremmin esiin raamatullisen ja alkukristillisen ajattelun ominaispiirteitä kuin erilaiset dualismin muodot, joista tuli myöhemmin teologian valtavirtaa.

Vaikka ajattelisimmekin, että teologinen materialismi on yhteensopiva teologisten perusnäkemysten kanssa, on teologisen materialistin silti pystyttävä vastaamaan jollakin tavalla edellä esitettyihin ongelmiin, jotka nousevat materialismista nimenomaan evoluutiobiologian ja mielen tieteiden yhteydessä. Yksi materialistinen vastaus kysymykseen ihmisen erityisyydestä on kieltää koko kysymys ja ajatella, että ihmisen erityisyydellä tai samanlaisuudella muun luomakunnan (lähinnä eläinkunnan kanssa) ei ole mitään merkitystä. Tämän vastauksen ongelmana on se, että se ei millään tavalla selitä sitä, miksi sitten kohtelemme ihmisiä eri tavalla kuin muuta luomakuntaa. Pidämme esimerkiksi ihmisiä moraalisesti vastuullisina toisin kuin eläimiä. Lisäksi teologisen materialistin ongelmana on, että hänen on pystyttävä tunnistamaan ihmisessä jotain kykyjä, joihin hän liittää ajatuksen ihmisestä Jumalan kuvana.

Perinteisesti ihmisen erityisyys ja imago Dei on sijoitettu esimerkiksi

(1) ihmisen tietoisuuteen ja erityisesti itsetietoisuuteen,

(2) kykyyn käyttää symbolista kommunikaatiota eli kieltä,

(3) ihmisen kykyyn käyttää järkeään eli olla rationaalinen, 
(4) ihmisen moraaliseen intuitioon, valintoihin ja käyttäytymiseen,

Käsittelemme seuraavaksi piirteitä (1)-(3) ja jätämme piirteen (4) seuraavaan alalukuun. Yleisesti voidaan sanoa, yksikään näistä piirteitä ei muodosta olemuksellista eroa eläimen ja ihmisen välillä. On toki totta, että nämä ihmisen kyvyt ovat siinä mielessä erityiset, että niille ei löydy vertaa eläinkunnassa. Kuitenkin samaan aikaan näyttää vahvasti siltä, että nämä kyvyt perustuvat puolestaan perustavammille kyvyille ja taipumuksille, jotka ovat nupullaan monilla kehittyneillä ihmisen sukulaisilla. Näin ollen voidaan sanoa, että ihmisen kyvyt sijoittuvat samalle jatkumolle muiden eläinten kanssa, vaikka ne ovatkin pidemmälle kehittyneitä.

Kysymys siitä, missä mielessä tietoisuutta esiintyy ihmisen lisäksi muualla eläinkunnassa, on hankala ja siitä on monia erilaisia näkemyksiä. ${ }^{152}$ Tämä johtuu siitä, että koko tietoisuuden idea yleensäkin on hankalasti lähestyttävä. Se, mitä tarkoitamme käsitteellä "tietoisuus" tai "itsetietoisuus", on jo itsessään merkittävä kiistakysymys emmekä voi tässä yhteydessä mennä sitä koskevaan laajaan keskusteluun. ${ }^{153}$ Kysymys tässä keskustelussa on lähinnä siitä, pystytäänkö tietoisuudelle tyypillisiä laadullisia tiloja redusoimaan tai selittämään aivotiloilla. Väittelyn osapuolina ovat tavallisesti nonreduktiiviset materialistit, joiden mukaan tietoiset tilat ja erityisesti niiden laadulliset ominaisuudet eivät selity aivotiloilla, ja reduktiiviset materialistit, jotka puolestaan väittävät, että tietoiset tilat ja niiden laadulliset ominaisuudet voidaan selittää jäännöksettä aivotiloilla. Non-reduktiivisten materialistien mukaan siis "tietoisuuden tiede" siinä mielessä, että voisimme selittää sen, miten tietoiset tilat syntyvät aivoissa, ei tule onnistumaan. Reduktiiviset materialistit puolestaan puolustavat ajatusta tietoisuuden tieteestä ja uskovat, että kunhan esimerkiksi kognitiivinen neurotiede kehittyy tarpeeksi pitkälle, niin voimme antaa kaikille tietoisille tiloille puhtaasti fysikaalisen selityksen. Tässä törmäämme jälleen mieli/ruumis ongelmaan (ks. luku 5.3) sen polttavimmassa nykymuodossa. Palaamme tähän "mentaalisen kausaation ongelmaan" seuraavassa luvussa va- 
paan tahdon yhteydessä.

Voimme ymmärtää tietoisuuden joukoksi erilaisia toimintoja, joihin kuuluvat kyvyt hankkia informaatiota ympäristöstä ja muokata käyttäytymistä tämän informaation perusteella. Tietoisuus voitaisiin näin ymmärtää organismin kykyinä vastata nopeasti ympäristön haasteisiin. Siitä, miten tietoisuus tarkkaan ottaen syntyy, ei kuitenkaan ole varmuutta. Jos hyväksymme sielu/ruumis-materialismin yleisellä tasolla, kuten teologiset materialistit tekevät, niin on meidän ajateltava, että tietoisuus syntyy vuorovaikutuksessa aivojen biologisten prosessien ja yksilön sosiaalisen ja materiaalisen ympäristön välillä. Näihin voivat vaikuttaa esimerkiksi kieli, sosiaalinen vuorovaikutus ja monet muut tekijät. Yhtäältä inhimillisen tietoisuuden kehityksen mahdollistavat ne lukuisat biologiset rakenteet (aivojen mekanismit ja hermojärjestelmä), jotka ovat läsnä jo monilla eläinlajeilla. Toisaalta taas näyttää siltä, että juuri ihmiselle tyypillinen tietoisuus edellyttää myös jonkinlaista sosiaalista vuorovaikutusta ja ehkä myös kieltä. Kuten sanottua, yksityiskohdat ovat hämärän peitossa ja yksimielisyyttä ole edes siitä, miltä teorian tietoisuudesta tulisi näyttää. Materialismi kuitenkin edellyttää, että tietoisuus on sidottu aivojen toimintaan ja ihmisruumiiseen ja jollakin tavalla "nousee" niiden toiminnasta. Juuri tämä tietoisuuden "mystisyys" on syy, miksi materialismi on jatkuvasti alttiina dualistien kritiikille.

Sielu/ruumis-materialismista seuraa se, että tietoisuutta voidaan pitää asteittaisena ilmiönä. Voidaan ajatella, että kaikki jonkinlaiseen tiedonkäsittelyyn ja itseohjautuvuuteen pystyvät ja ympäristöönsä reagoivat organismit ovat enemmän tai vähemmän tietoisia. Perinteisen dualismin mukaan joko oliolla on sielu tai ei ja näin ollen sillä on joko tietoisuus tai ei. Tässä kohden komposiittimalli on lähempänä materialismia kuin dualismia: komposiittimallin mukaan kaikilla elävillä olioilla on jonkinlainen sielu. Selvää kuitenkin on, että meidän on hyvin vaikea kuvitella, millainen tietoisuus esimerkiksi tiikerin tai linnulla on, millainen niiden "ensimmäisen persoonan näkökulma on”. Jos kuitenkin hyväksymme materialismin missä tahansa muodossa, seuraa siitä se, että eläinten jonkinasteista tietoi- 
suutta on varsin vaikea kieltää. Tietoisuus sellaisenaan ei siis kelpaa ihmisen erityisyyden kriteeriksi. ${ }^{154}$

On myös mahdollista erottaa itsetietoisuuden ja tietoisuuden ilmiöt toisistaan. On ehdotettu, että nimenomaan itsetietoisuus olisi ihmiselle ominainen, ja totta onkin, että itsetietoisuus näyttää eläinkunnassa varsin harvinaiselta. Tavallisesti itsetietoisuudella tarkoitetaan sitä, että organismi pystyy muodostamaan ajatuksia itsestään ja omista ajatuksistaan, taipumuksistaan tai uskomuksistaan. On kuitenkin monia syitä ajatella, että jonkinlaista orastavaa itsetietoisuutta esiintyy ainakin joillakin ihmisen lähisukulaisilla: jotkut apinat esimerkiksi kykenevät tunnistamaan itsensä katsomalla peiliin, mikä ei olisi mahdollista, jos niillä ei olisi jonkinlaista käsitystä omasta itsestään. Ihmisellä on kyky synnyttää useamman kertaluvun mielentiloja aina kolmanteen tai neljänteen kertalukuun asti. Ensimmäisen kertaluvun mielentilat koskevat välittömästi läsnä olevia maailman olioita: näin esimerkiksi silloin, kun haluan syödä silmieni edessä olevaa herkullista kakkua. On helppo ajatella, että eläimillä on ensimmäisen kertaluvun mielentiloja. Toisen kertaluvun mielentilat puolestaan koskevat muiden eliöiden mielentiloja. Ihmiset kykenevät helposti synnyttämään mielentiloja toisten ihmisten mielentiloista ja vieläpä muiden mielentiloista, jotka viittaavat kolmansiin mielentiloihin: "Matti tietää, että Teppo uskoo Sirkan rakastavan häntä." Tämä kyky antaa nähtävästi ihmiselle myös kyvyn muodostaa ajatuksia omista ajatuksistaan, tuntemuksistaan ja haluistaan, mikä puolestaan näyttäisi olevan juuri itsetietoisuuden perusta. Kysymys siitä, perustuuko itsetietoisuus kyvylle ymmärtää toisten ajatuksia vai kyky ymmärtää toisten ajatuksia itsetietoisuudelle, on hankala ja yhä avoin. Aiheemme kannalta olennainen kysymys on kuitenkin se, missä määrin eläimillä, ja erityisesti kädellisillä, on kyky muodostaa näkemyksiä muiden eliöiden mielentiloista. Tutkimus viime vuosikymmeninä on ollut vilkasta. On tutkittu esimerkiksi sitä, kykenevätkö ihmisen lähisukulaiset petokseen (edellyttää ajatuksia toisten uskomuksista ja niiden manipulointia), empatiaan (toisten kärsimyksen tunnistaminen) tai ennustamaan lajikumppa- 
niensa tai ihmisten käyttäytymistä. Konsensusta näiden tutkimusten tulkinnasta ei kuitenkaan ole. Näin ollen itsetietoisuuskaan ei näytä olevan se ehdoton rajalinja, joka tekee ihmisestä ihmisen.

Yksi tapa erottaa ihminen eläimistä on väittää, että ihminen on ainoa organismi, joka kykenee toimimaan järjenmukaisesti ja irrottautumaan vaistonvaraisesta toiminnasta. Ihmisellä on tämän näkemyksen mukaan erityinen "älykkyyden" kyky, jota hän käyttää esimerkiksi päättelyyn, tiedonhankintaan, tulevaisuuden suunnitteluun ja mahdollisten toimintatapojen arviointiin. Eläinten toiminnan katsotaan taas perustuvan aina automaattisiin vaistoihin, joita niiden biologia synnyttää. Edelliset väitteet ovat kuitenkin huonosti perusteltuja. Esimerkiksi monet nisäkäslajit kykenevät monenlaisiin tiedonkäsittelyn toimintoihin, jotka edellyttävät kehittynyttä muistin toimintaa ja päättelyä ja jotka puolestaan mahdollistavat suunnitelmallisen käyttäytymisen. Selvää on, että ihmisen kyky esimerkiksi suunnitella toimintatapoja mahdollisten asiantilojen varalle on kyllä kehittyneempi kuin muilla lajeilla, mutta tämä ei vielä tarkoita sitä, että katkos olisi ehdoton tai edes selkeä.

Älykkyys tai järki on ollut tapana liittää myös luovuuteen ja kykyyn ilmaista itseään symbolisesti eli käyttää kieltä. Samalla tavalla kuin itsetietoisuuden tapauksessa, on selvää, että eläinkunnassa ei ilmene sellaisia kielikykyjä, joilla ihminen on varustettu. Eläimet eivät pysty tuottamaan symbolista kieltä eivätkä kieliopillisia rakenteita. Eläinkunnassa kuitenkin on hyvin paljon kommunikaatiota, jonka tarkoituksena on vaikuttaa toisten käyttäytymiseen ja välittää tietoa. On ollut paljon keskustelua siitä, missä määrin apinat pystyvät oppimaan ja käyttämään kieltä. Jotkut tutkijat ovat olleet hyvin optimistisia ja pystyneet kouluttamaan useita gorilloita ja simpansseja, jotka ovat pystyneet oppimaan useita kymmeniä symboleja ja yhdistelemään niistä pyyntöjä ja tunnetilojen ilmauksia. Toiset tutkijat ovat kuitenkin olleet kriittisiä ja kiinnittäneet huomiota näiden tutkimusten metodologisiin ongelmiin. Keskustelu on vielä kesken eikä lopullista tulosta ole vielä nähtävissä. Muutama seikka on kuitenkin selvä. Ensinnäkin tietomme siitä, mihin läheiset sukulaisemme 
tiedonkäsittelyn ja älykkyyden kyvyt riittävät on lisääntynyt viime vuosikymmenten aikana merkittävästi. Tämä tieto viittaa alustavasti siihen suuntaan, että nämä kyvyt ovat huomattavasti kehittyneempiä kuin vielä 1900-luvun alussa (puhumattakaan Darwinin aikana) oletettiin. Siitä seikasta, että ihmisen lähisukulaiset pystyisivätkin oppimaan jonkinlaisia symbolisen kielen muotoja, ei kuitenkaan seuraa vielä se, että nämä itse kykenisivät tuottamaan symbolisen kielen tai pitämään sitä yllä. Tämäkin seikka viittaa jälleen siihen, kuinka ihmisen ja hänen lähisukulaistensa välillä on tiettyä jatkuvuutta, vaikka erot ovatkin käytännössä varsin suuret. ${ }^{155}$

Ennen kuin siirrymme käsittelemään kysymystä ihmisen moraalista ja moraalisista valinnoista, voidaan tehdä lyhyt välitilinpäätös. Olemme nyt käsitelleet muutamaa seikkaa, jolla ihmisen erityisyyttä on pyritty perustelemaan, ja päätyneet siihen lopputulokseen, että ihmisen ehdotonta erityisyyttä on vaikea perustella. Gregory Petersonin mukaan

on tärkeää huomata keskustelun painopisteen muutos: emme enää keskustele ihmisen ja muiden eläinten absoluuttisesta erosta, vaan nyt olemme kiinnostuneita tekemään mahdollisimman tarkkoja huomioita mahdollisista samankaltaisuuksista ja eroista. ... Väite, että olisi olemassa jonkinlainen absoluuttinen kognitiivinen rajalinja, ei ole enää uskottava. ${ }^{156}$

Ihmismielen kyvyt kuten tietoisuus, älykkyys ja kielikyky, jotka ovat toimineet ihmisen erityisyyden merkkinä, ovat eläimiin verrattuna pitkälle kehittyneitä mutta niiden juuret ovat kuitenkin perustavissa kyvyissä, jotka ovat yhteisiä sekä ihmisille että monille eläimille:

On selvää, että muilla eläimillä ei ole ihmisen vastaavaa itsetietoisuutta. ... Kognitiivinen eläintutkimus viittaa kuitenkin siihen, että rationaalisuus ja itsetietoisuus eivät ole niin selkeästi rajattuja käsitteitä kuten tavallisesti kuvittelemme. Itsetietoisuus sen tavallisessa merkityksessä mitä todennäköisimmin viittaa joukkoon erilaisia kykyjä. Samoin älykkyytemme mahdollistaa useiden aivojen rakenteiden yhteistyö. Osan näistä rakenteista 
ihminen jakaa eläinten kanssa ja osan taas ei. ${ }^{157}$

Voimme siis sanoa, että ihmisen mielen kyvyt ovat yhtäältä hyvin erityisiä mutta toisaalta hyvin samankaltaisia kuin eläimillä. Ihmisen biologisten ja psykologisten kykyjen yhdistyessä kieleen ja kulttuuriin syntyy toimintoja ja korkeampia kykyjä, jotka ovat eläinkunnassa vertaansa vailla. Ihmisen kyky symbolisen kielen käyttöön yhdistettynä hänen itsetietoisuuteensa ja älykkyyteensä antaa ihmiselle mahdollisuuden ilmaista itseään, luoda kulttuuria (tallentaa ja välittää tietoa oppimisen kautta), muodostaa käsityksiä omista ja muiden ajatuksista sekä muokata nopeasti käyttäytymistään uuden tiedon perusteella. Teologiselle materialistille nämä ihmisen kyvyt ovat evoluution tuotteita ja sidoksissa ihmisen biologiseen ja psykologiseen rakenteeseen. Ne ovat osa Jumalan suunnitelmaa mutta niitä ei ole liitetty ihmiseen yliluonnollisen sielun kautta, vaan Jumalan ohjaaman evoluution kautta.

8.2

\section{MORAALI JA IHMISLUONTO}

Vapaan tahdon ongelma liittyy edellä käsittelemäämme kysymykseen tietoisuudesta sekä kysymykseen mielen ja aivojen suhteesta. Kiinnitimme jo huomiota siihen, kuinka dualismin vaikeutena on selittää, miten aineeton sielu ja fyysinen ruumis voivat olla vuorovaikutuksessa (ks. luku 5.3). Ensi katsomalta voisi näyttää siltä, että materialistilla ei tällaista ongelmaa ole, koska hän ajattelee, että mieli koostuu aivojen toiminnasta. Tämä ei kuitenkaan pidä paikkaansa, sillä materialistilla on edessään samankaltainen ongelma: jos mielentilat ovat aivojen tiloja, niin eivätkö silloin aivojen tilat ole riittäviä selityksiä ihmisen käyttäytymiselle? Mihin enää mieltä tarvitaan? Arkijärjen näkökulmasta on ehkä vaikea nähdä, miten tämä ongelma syntyy, joten selvennetäänpä asiaa hieman.

Nykyaikainen mieli/ruumis ongelma voidaan ymmärtää pitkälti 
"mentaalisen kausaation ongelmana": kysymys on siitä, miten mielen tapahtumat, kuten tietoiset valinnat, itse asiassa vaikuttavat fysikaaliseen todellisuuteen. Ongelma on varsin visainen ja nousee materialismin ydinvakaumuksista seuraavan päättelyn seurauksena:

1. Materialismi edellyttää, että mielen toiminta koostuu aivojen toiminnasta.

2. Neurotiede ja biologia puolestaan viittaavat siihen, että aivotoiminta koostuu hermosolujen toiminnasta.

3. Materialismi edellyttää, että kaikkien fysikaalisten olioiden käyttäytymiselle (ja näin ollen myös hermosolujen käyttäytymiselle) on olemassa riittävä fysikaalinen selitys. ${ }^{158}$

4. Näin ollen mielen toiminnalle on riittävä fysikaalinen selitys.

Mutta jos mieltä ohjaavat fysikaaliset säännönmukaisuudet, niin silloin esimerkiksi mielen tilat, kuten tahtomukset ja uskomukset, eivät ohjaa ihmisen käyttäytymistä, vaan käyttäytymistä ohjaavat ainoastaan aivojen toiminnan fysikaaliset säännönmukaisuudet. Toisin sanoen puhe mielentiloista, haluista, uskomuksista ja muista vastaavista ei itse asiassa selitä yhtään mitään ihmisen käyttäytymisessä. Aivojen toiminta selittää sekä ihmisen käyttäytymisen että ihmisen kaikki mielentilat, mukaan lukien halut, uskomukset ja päätökset. Jos materialisti haluaa pitää kiinni ajatuksesta, että mielentilat todella vaikuttavat käyttäytymiseen, on hän puun ja kuoren välissä: hänen pitää kieltää joko (1), (2) tai (3), jos hän haluaa pitää kiinni ajatuksesta, että mielentilat todella selittävät käyttäytymistä. Väitettä (2) materialisti ei halua kieltää, koska se on arkijärjellekin ilmeinen eikä hän voi kieltää väitettä (1) muuttumatta materialistista dualistiksi. Väite (3) onkin sitten vedenjakaja: non-reduktiiviset materialistit tavallisesti torjuvat sen, kun taas reduktiiviset materialistit hyväksyvät sen. Tästä seuraa se, että reduktiivisen materialismin edustajien on hyvin vaikea välttää "epifenomenomenalismia" (ks. luku 5.3) eli sitä, että mieli ei vaikuta yhtään mihinkään, vaan mielentilat ovat itse asiassa vain aivotilojen seurauksia. ${ }^{159}$ 
Non-reduktiivinen materialisti tai emergentti materialisti sen sijaan väittää, että mielentilat kyllä koostuvat hermosolujen toiminnasta, mutta mielentilojen fysikaalinen perusta ei kuitenkaan selitä mielen toimintaa kokonaan. Tämä näkemys perustuu jälleen kerran kuvaamallemme ajatukselle todellisuuden monikerroksellisuudesta ja näiden kerrosten välisistä emergenteistä suhteista. Emergentistin mukaan mielentilat koostuvat kyllä aivojen tiloista samalla tavalla kuin biologiset organismit koostuvat fysikaalisista osista mutta mielentiloja ei kuitenkaan voida selittää fysikaalisilla säännönmukaisuuksilla eikä teorioilla. Tämä näkemys antaa mahdollisuuden ajatella, että ylemmät tasot - tässä tapauksessa mieli - voi vaikuttaa alempaan tasoon - tässä tapauksessa ruumis. Mielen ja aivojen ja käyttäytymisen suhde on emergentistin mukaan oppikirjaesimerkki alaspäisestä kausaatiosta (ks. luku 5.4), jossa monimutkainen fysikaalinen rakenne vaikuttaa monin eri tavoin omiin osiinsa.

Nyt, kun olemme saaneet yleiskuvan materialistisista vaihtoehdoista mentaalisen kausaation ongelmaan, voimme ymmärtää, miksi ratkaisut vapaan tahdon ongelmaan ovat juuri ne, mitkä ne ovat. Ratkaisuja on periaatteessa neljä:

(1) indeterministinen vapaa tahto (libertaristinen vapaa tahto/inkompatibilismi),

(2) deterministinen vapaa tahto (kompatibilismi),

(3) ei vapaata tahtoa,

(4) ongelma on ratkaisematon.

Edelliset ratkaisut ovat itse asiassa analyyseja tahdon käsitteestä eli siitä, mitä tahdolla oikeastaan tarkoitetaan. Kutsumme tässä kannan (1) edustajia indeterministisen vapaan tahdon kannattajiksi, vaikka toisinaan puhutaan myös libertaristisesta vapaasta tahdosta tai inkompatibilismista. Nimitys inkompatibilismi paljastaa, mistä on kysymys: tämän kannan edustajan mukaan vapaa tahto ja determinismi eivät ole yhteensopivia. Hänen mukaansa vapaa tahto edellyttää aitoa indeterminismiä eli sitä, että henkilö olisi voinut ai- 
dosti valita toisin valinnan hetkellä. Jotta vapaa tahto tässä mielessä olisi mahdollista, on henkilön tahdon oltava se syy, joka viime kädessä aiheuttaa hänen valintansa. Jos tämän valinnan aiheuttaa jokin muu, esimerkiksi jokin fysikaalinen syy, niin valinta ei ole enää määritelmän edellyttävällä tavalla vapaa. Ajattele henkilön valintaa bussin tai taksin välillä. Edellä kuvattu näkemys vapaasta tahdosta edellyttää, että valinnan hetkellä kumpi tahansa tila voi toteutua: henkilö voi valita bussin tai taksin, ja vain henkilön valinta tekee eron näiden kahden asiantilan välillä. Jotta tämä olisi mahdollista, on oltava mahdollista, että henkilön valinta bussin tai taksin välillä ei ole minkään muun kuin valinnan määräämä (indetermismi) ja että henkilön valinta todella aiheuttaa jommankumman asiaintilan toteutumisen (mentaalinen kausaatio).

Monet nykyfilosofit ovat kuitenkin puolustaneet kantaa (2), jota tässä nimitämme deterministiseksi vapaaksi tahdoksi (toisinaan myös kompatibilismiksi). Tämän kannan mukaan determinismi ja vapaa tahto ovat yhteensopivia eli vapaa valinta ei edellytä aitoa mahdollisuutta valita toisin. Vapaa tahto tarkoittaa toisin sanoen siis vain sitä, että henkilö on vapaa toimimaan jossakin tilanteessa omien uskomustensa mukaan minkään ulkoisen tekijän estämättä. Tavallista on, että kompatibilismin edustaja muotoilee väitteensä seuraavalla tavalla. "Jos henkilö olisi valinnut taksin sijasta bussin, mikään ulkoinen tekijä ei olisi estänyt häntä ottamasta bussia. Hän kuitenkin valitsi taksin, koska hän halusi päästä nopeasti perille ja uskoi taksin olevan bussia nopeampi. Jos henkilö olisi uskonut bussin olevan nopeampi, niin hän olisi voinut valita sen. Näin ollen taksin valinta oli vapaa." Kompatibilismin mukaan siis henkilön valinnan syynä ovat hänen uskomuksensa: valinta itsessään ei tee eroa bussin ja taksin välillä. Ero inkompatibilismin ja kompatibilismin välillä voi tuntua hienovaraiselta, mutta se on erittäin merkittävä, sillä se antaa mahdollisuuden ajatella, että vapaa tahto sopii yhteen sekä determinismin että puuttuvan mentaalisen kausaation kanssa. On helppo nähdä miksi reduktiivisen materialismin edustajilla on tapana olla kompatibilistisen vapaan tahdon kannattajia: jos usko- 
mukset selittävät valinnat ja uskomukset puolestaan voidaan selittää aivojen toiminnalla ja muilla fysikaalisilla tekijöillä, voidaan ihmisen valintoja pitää vapaina, vaikka ne eivät lisää mitään maailman fysikaalisten syiden järjestelmään. ${ }^{160}$

Kolmas mahdollisuus on hyväksyä determinismi ja päätellä, että vapaata tahtoa ei ole ollenkaan olemassa. Vaikka jotkut klassisen teismin edustajat, jotka puolustavat vahvasti Jumalan kaikkitietävyyttä ja kaikkivaltiutta, näyttävätkin kallistuvan tähän suuntaan, on tällainen kanta filosofisissa keskusteluissa harvinaisuus. Viimeinen mahdollisuus on pitää ongelmaa ratkaisemattomana ja omaksua vapaan tahdon ajatus käytännöllisillä perusteilla, vaikka se vaikuttaakin ristiriitaiselta. Muutamat teistiset (esim. Peter van Inwagen) ja ateistiset (esim. John Searle) filosofit ovat väittäneet, että emme voi elää ilman ajatusta radikaalisti vapaasta tahdosta. ${ }^{161}$ Heidän mukaansa vapaa tahto ei sovi yhteen indetermismin eikä determinismin kanssa: riippumatta siitä, onko fysikaalinen maailma avoin mielentilojen vaikutuksille, emme saa vapaan valinnan ajatusta mahtumaan näkemykseemme maailmasta. Itse ajatus on kuitenkin niin tärkeä identiteettimme kannalta, että emme voi luopua siitä. Ainoa mahdollisuus on tunnustaa vapaan tahdon ristiriitaisuus ja paradoksaalisuus ja jatkaa elämää jännitteessä. Huolimatta edellisistä soraäänistä sekä ateistien että teistien leireistä, valtaosa filosofisista teisteistä, panenteisteistä ja prosessiteologeista puolustaa kantaa (1), kun taas valtaosa ei-teistisistä filosofeista puolestaan kantaa (2).

Useat teismin ja emergentin materialismin edustajat ovat esittäneet indeterministisen vapaan tahdon puolustuksia. ${ }^{162}$ Meidän ei enää tarvitse mennä yksityiskohtiin, koska lukija varmaankin jo ymmärtää, miten tämä puolustus toimii. Ensimmäisenä emergentisti suorittaa mentaalisen kausaation puolustuksen, jonka jo edellä esittelimme. Tämän jälkeen hän esittää mallin siitä, kuinka mieli (korkeampi taso) voi vaikuttaa aivojen toimintaan (alempi taso) ja sitä kautta ihmisen käyttäytymiseen. Tähän voi vielä lisätä aidon indeterminismin puolustuksen, joka valtaosalla luonnon teologian edustajista jo on. Vaikka tällaisten mallien yksityiskohdat ovat kiis- 
teltyjä, näyttäisi kuitenkin olevan mahdollista hyväksyä materialismi ja pitää kiinni indeterministisestä vapaasta tahdosta. Tämä lopputulos tietenkin antaisi tukea teologiselle materialismille.

Tulos edeltävästä keskustelusta on siis se, että jos non-reduktiivinen materialismi ja emergentismi ovat puolustettavissa, on mahdollista ajatella indeterministisen vapaan tahdon olevan mahdollista. Tämä puolestaan takaisi moraalisen vastuun varsin perusteellisella tavalla. Mutta siitä, että moraalinen valinta on periaatteessa mahdollinen, ei voida vielä päätellä, että ihmiset todella tekisivät tällaisia valintoja. Voi olla, että jotkut ihmisluontoon kuuluvat yleiset piirteet tekevät moraalisista valinnoista käytännössä lähes mahdottomia. Palaan seuraavassa moraalin evoluution ongelmiin, jotka on aiemmin jo useita kertoja nostettu esiin (ks. luvut 5.2 ja 8.1).

Voimme ensin vastata lyhyesti moraalinormien sattumanvaraisuutta koskevaan ongelmaan. Ajatus siitä, että ihmisen evoluutio tekee moraalinormit sattumanvaraisiksi, on ongelma silloin, jos moraalinormien perustan katsotaan olevan nimenomaan ihmisluonnossa itsessään. Teisteillä ei kuitenkaan ole tapana ajatella näin, vaan he uskovat, että viimekädessä Jumalan tahto on objektiivisen moraalisen järjestyksen perusta. Näin ollen vaikka teistisen evoluution edustaja ajatteleekin, että Jumala on luonut ihmisen käyttäen evoluutiota välineenä, niin tästä ei seuraa moraalinormien sattumanvaraisuus. Siitä seuraa ainoastaan se, että ihmisen moraaliset tunteet ja intuitiot voivat olla ristiriidassa objektiivisen moraalisen järjestyksen kanssa. Tämän tunnustaminen on tuskin ongelma perinteisen teologisen antropologian edustajille, jotka ajattelevat joka tapauksessa, että ihminen on luonteeltaan varsin itsekäs. Ongelma syntyy, jos väitetään, että ihminen on sidottu hänen biologiansa tuottamiin moraalisiin intuitioihin ja tunteisiin niin vahvasti, että hän ei käytännössä pysty toimimaan koskaan niitä vastaan. Kysymys on siis siitä, onko ihminen luonnostaan itsekäs siinä määrin, ettei hän pysty tekemään mitään muuta.

Moraalin ja sosiaalisen käyttäytymisen evoluutio on ollut viime vuosikymmeninä erittäin kuuma aihe sekä luonnontieteissä että ih- 
mistieteissä. Jo Darwin kiinnitti huomiota siihen, että jos evoluutio luonnonvalinnan kautta pitää paikkansa, niin luonnossa ei tulisi juuri olla altruismia eli käyttäytymistä, joka vähentää yksilön omaa selviytymistä jonkun toisen selviytymisen hyväksi. Viime aikoina on kuitenkin alettu kiinnittää yhä enemmän huomiota laajalle levinneeseen altruistiseen käyttäytymiseen eläinkunnassa. Esimerkiksi ryhmän puolesta uhrautuminen ja ryhmän jäsenten välinen yhteistyö ovat varsin yleisiä biologisessa maailmassa. Näyttää siltä, että Darwinin "olemassaolon taistelun" korostus oli ehkä yksipuolinen. Jos ainoa selviämisen keino olisi itsekkyys, voisi kuvitella, että yhteistyö ja muiden puolesta uhrautuva käytös johtaisi näin toimivien yksilöiden automaattiseen karsiutumiseen, mistä taas puolestaan seuraisi tällaisen käytöksen häviäminen hyvin nopeasti. Olemassaolon taistelun ja epäitsekkyyden (näennäistä) ristiriitaa on tapana kutsua kirjallisuudessa "altruismin ongelmaksi". ${ }^{163}$ Siihen vastaaminen oli itse asiassa Edward Wilsonin sosiobiologian tärkein tehtävä (ks. luku 5.2).

Kuluneiden vuosikymmenien aikana altruismin ongelmaan on esitetty useita erilaisia ratkaisuja. Näitä ovat esimerkiksi:

(1) sukulaisuusvalinta (kin selection),

(2) vastavuoroinen altruismi (reciprocal altruism),

(3) ryhmävalinta (group selection).

Ajatuksen sukulaisuusvalinnasta esitti biologi William Hamilton (1936-2000). Ajatus on se, että luonnonvalinnan kohteena ei ole biologinen organismi, vaan pikemminkin geenit. Jos olennaista onkin geenien selviäminen, eikä organismien, niin silloin organismin uhrautuminen niiden edestä, jotka kantavat samoja geenejä, on ymmärrettävää. Näin ollen voimme olettaa, että biologisilla organismeilla on tapana uhrautua juuri lähisukulaistensa selviämisen edistämiseksi. Yksittäisen organismin kannalta tällainen uhrautuminen ei näytä järkevältä, mutta geenien näkökulmasta tarkasteltuna uhrautuminen ja altruistinen käyttäytyminen kannattavat pit- 
kässä juoksussa. Erittäin kuuluisa muotoilu tästä näkemyksestä on Dawkinsin kielikuva "itsekkäästä geenistä". ${ }^{164}$

Sukulaisuusvalinta selittää kuitenkin varsin kapean osan siitä, mitä kutsuisimme moraaliseksi käyttäytymiseksi ja yhteistoiminnaksi. On helppo ymmärtää, kuinka yksilöiden välinen yhteistoiminta on luonnonvalinnan kannalta hyödyllistä silloin, kun yhteistoiminnan edut ovat välittömiä. On kuitenkin olemassa paljon sellaista yhteistoimintaa ja altruismia, jonka edut eivät ole välittömiä vaan käyvät ilmi vasta pitkällä tähtäimellä. On esitetty, että tällaista käyttäytymistä voisi selittää "vastavuoroinen altruismi" eli ajatus molemminpuolisesta auttamisesta. Idea on se, että kehittyneet eläimet pystyvät yhteistoimintaan ikään kuin se olisi vaihtokauppa: "Jos minä nypin kirput sinun selästäsi, niin sinä nypit kirput minun selästäni." Vastavuoroinen altruismi tuo kuitenkin mukanaan ongelman, jonka kanssa kaikki yhteistoimintaan perustuvat yhteisöt joutuvat elämään: huijarit. Minun kannaltani on nimittäin kaikkein edullisinta antaa toisen nyppiä kirput minun selästäni mutta jättää sitten auttajan kirput nyppimättä. Näin ollen yhteisöjen täytyy kehittää erilaisia rangaistus- ja tarkkailumekanismeja estämään huijarien esiintyminen. Tämä hypoteesi ja koko vastavuoroisen altruismin kysymys laajemminkin on herättänyt suurta kiinnostusta ja johtanut erilaisten evolutionaaristen peliteorioiden ja muiden vastaavien mallien kehitykseen, jotka yrittävät etsiä kaikkein optimaalisimpia yhteistoiminnan muotoja ja jäljittää niitä biologisessa maailmassa.

Kolmas vaihtoehto on "ryhmävalintateoria", jota on kehittänyt erityisesti David Sloan Wilson. Wilsonin tarkoituksena on ollut kehittää vastapaino edellä kuvatulle ajatukselle geeneistä valinnan yksiköinä ja korostaa luonnonvalinnan toimivan monella eri tasolla (geenit, organismit, ryhmät). Erityisesti Wilson korostaa sitä, että ryhmät voivat toimia valinnan yksiköinä: mitä läheisempää yhteistoiminta ryhmässä on, sitä paremmin se selviää kilpailussa muiden ryhmien kanssa. Lopulta geneettistä perimää jatkavat aina ne, jotka sitoutuvat yhteistoimintaan. Palaamme ryhmävalintaan seuraavassa luvussa, joten ei siitä tämän enempää. 
Perinteisen moraalin kannalta ongelma on seuraava. Sekä sukulaisuusvalinta että vastavuoroinen altruismi ovat kyllä uhrautuvaa ja auttavaa käytöstä organismin tasolla mutta pohjimmiltaan ne ovat kuitenkin geenien selviämisen kannalta edullisia. Tässä mielessä "moraalinen" käytös onkin itse asiassa itsekästä käyttäytymistä: kaikki edistää geenien selviämistä seuraavaan sukupolveen. Miten voi olla olemassa "aitoa moraalia" ja moraalista käyttäytymistä, jos tämän käyttäytymisen aiheuttaa vain geenien pyrkimys jatkaa kopioitumistaan? Tähän kysymykseen voidaan vastata väittämällä, että emme saa samaistaa geenien selviytymistä edistävää altruismia koko organismin moraaliseen toimintaan. Ihminen ei ole geneettisten taipumustensa ohjailema nukke, vaan hänen käyttäytymiseensä vaikuttavat geneettisen perimän lisäksi monet muutkin tekijät kuten esimerkiksi opitut käyttäytymismallit ja tietoiset päätökset. Ihmisen toiminnan moraalinen arviointi ottaa huomioon monia tekijöitä: se, että joillakin ihmisen käyttäytymismalleilla on biologinen perusta, koska ne edistävät selviämistä, ei vielä tarkoita sitä, että ihmisen toimintaa kaiken kaikkiaan voisi pitää itsekkäänä.

Tässä kohdassa nousee jälleen esiin jo ennalta tuttu kysymys biologisesta reduktionismista (ks. luvut 5.2 ja 5.4), joka ottaa nyt geneettisen determinismin muodon. Geneettisen determinismin mukaan inhimillinen käyttäytyminen ja kulttuuri ovat kokonaan ihmisen biologisen luonnon eli geneettisen perustan määräämiä. Erityisen ongelman geneettinen determinismi muodostaa juuri moraalin suhteen, sillä perinteisesti ollaan ajateltu, että moraalinen käyttäytyminen edellyttää sekä tietoisuutta moraalisista normeista että kieltäytymistä noudattamasta joitakin impulsseja. Jotkut ovat vieneet ajatuksen geneettisestä determinismistä loppuun asti ja väittäneet, että moraalin evoluutio poistaa meiltä uskon moraaliseen järjestykseen ja paljastaa, kuinka olemme geneettisen perimämme ohjailemia. Esimerkiksi Edward O. Wilsonin ja Michael Rusen mukaan "etiikka siinä muodossa, kun sen tunnemme, on illuusio, jonka geenimme ovat heittäneet silmiemme eteen saadakseen meidät yhteistoimintaan"165 
Olemme jo aiemmin esittäneet syitä torjua biologinen reduktionismi ja sitä kautta myös geneettinen determinismi (ks. luvut 5.2 ja 5.4). Tässä yhteydessä voidaan kuitenkin korostaa, että geneettinen determinismi sisältää erittäin oudon käsityksen geenien ja käyttäytymisen suhteesta. Tämä ajatus on se, että geenit ohjaavat käyttäytymistä varsin välittömällä tavalla luomalla lähes ylitsepääsemättömiä säännönmukaisuuksia. Tämä oletus on kuitenkin hyvin ongelmallinen sen perusteella, mitä tiedämme ihmisen psykologiasta ja monet evoluutiopsykologit ovatkin kritisoineet sitä. Ajatus on se, että geenit eivät ohjaa käyttäytymistämme, vaan geenien pohjalta syntyvät aivot - valtavan monimutkainen tiedonkäsittelyn ja -hankinnan koneisto. Näin ollen kun nousemme geeneistä käyttäytymisen tasolle, mukaan tulee geenien lisäksi valtava määrä monia muita tekijöitä (kulttuuri, psykologia, aivorakenne, jne.). Erityisen tärkeää juuri mielen evoluutiossa on ihmisen itsetietoisuus ja sitä kautta syntyvä kyky muokata omaa käyttäytymistä. On totta, että biologiset impulssit ovat yhä enemmän tai vähemmän vahvoja, mutta ne eivät ole ylitsepääsemättömiä. Ihminen kykenee älykkyytensä avulla synnyttämään toimintasuunnitelmia ja toteuttamaan niitä vastoin hänen biologisia taipumuksiaan. Voidaan siis ajatella, että ihmisen moraalisuus on yksi sivutuote ihmisen älykkyydestä ja kyvystä itsetietoisuuteen. Emme ole moraalisia, koska geeneissämme olisi jonkinlainen "moraalinen ohjelmointi" vaan koska olemme itsetietoisia ja älykkäitä olioita, joiden on välttämätöntä käyttää järkeään ja kehittää moraalisia järjestelmiä, jotta voisimme tulla toimeen keskenämme. Peterson kirjoittaa:

Teologisesti meidän sanotaan olevan Jumalan kuvia mutta samaan aikaan myös epätäydellisiä ja langenneita. Tieteellinen näkökulma viittaa siihen, että luontomme on perintöä evoluutiohistoriastamme ja omasta biologiastamme. Se kuitenkin viittaa myös siihen, että geenit ovat vain osa tätä tarinaa: olemme tiedostavia, ajattelevia olioita, mikä puolestaan tekee meistä hienosyisiä ja monimutkaisia sekä vapaita tavalla, johon muut organismit eivät yllä. Kykenemme ylittämään biologiset impulssimme, jotka muille lajeille olisivat ylitsepääsemättömiä käyttäytymisen moottoreita. ${ }^{166}$ 
Tässä kuvaamamme näkemys on yhtäpitävä sen näkemyksen kanssa, jota aiemmin kutsuimme pluralistiseksi näkemykseksi evoluutionäkökulman hyödyllisyydestä ihmiseen (ks. luku 5.2).

Jos edellä kuvatussa näkemyksessä on järkeä, on ovi jälleen auki teologiselle materialismille. Teistisen evoluution edustaja voi tunnustaa ihmisen evoluution tuotteeksi menettämättä mahdollisuutta puhua aidosta epäitsekkyydestä ja moraalista. Monet ovatkin tällä perusteella väittäneet, että evoluutionäkökulma ihmiseen, joka paljastaa ihmisen sisäänrakennetut yhtäältä itsekkäät ja toisaalta epäitsekkäät biologiset impulssit, on varsin hyvin yhteensopiva perinteisen teologisen antropologian kanssa. Ihminen on samaan aikaan langennut ja itsekäs, mutta kykenee toisinaan (parhaimmillaan) uhrautuvaisuuteen ja epäitsekkyyteen, vaikka se onkin usein vaikeata erityisesti niitä kohtaan, jotka ovat yksilön lähipiirin ulkopuolella.

\section{$8 \cdot 3$}

\section{USKONTO JA IHMISLUONTO}

Teologiseen antropologian ja tieteen suhteeseen liittyy myös kysymys uskonnon alkuperästä. Uskonnon ja ihmisluonnon suhde liittyy myös samaan aikaan ihmisen erityisyyteen: uskonnollinen ajattelu ja käyttäytyminen on nimenomaan ihmislajin erityisominaisuus eikä mitään vastaavaa nähdä eläinkunnassa. Perinteisen antropologian mukaan uskonnon alkuperä on siinä mielessä yliluonnollinen, että uskonnolliset ideat ja käyttäytymismallit ovat ihmisen vastauksia hänen kokemaansa yliluonnolliseen todellisuuteen. Evoluutiobiologia ja mielen tieteet kuitenkin tekevät mahdolliseksi sen, että uskonnolla voidaan katsoa olevan "luonnollinen" alkuperä: se voi perustua ihmisen biologiselle ja psykologiselle rakenteelle, joka puolestaan on biologisen evoluution tuotetta.

Viime vuosikymmeninä on kehittynyt lukuisia teorioita uskonnosta, joiden tarkoituksena on ymmärtää uskonto osana luonnollista maailmaa. Tyypillistä näille teorioille on ollut uskonnollisten 
taipumusten liittäminen yksittäisten kulttuurien tai yhteisöjen sijasta ihmislajin yleisiin psykologisiin tai biologisiin piirteisiin. Lisäksi on korostettu tieteellisen tiedon (erityisesti biologia, kognitiotiede ja neurotiede) merkitystä uskonnon yleisten piirteiden ymmärtämisen kannalta. Voimmekin nimittää tällaisia teorioita biopsykologisiksi uskontoteorioiksi, joita on kolmea eri tyyppiä:

(1) neuroteologia, jossa pyritään selittämään uskonnollisten kokemusten yleisiä piirteitä aivojen toiminnan avulla,

(2) uskonnon evoluutiota koskevat teoriat, joiden mukaan uskonto on sopeutuma, jolla on geneettinen perusta,

(3) kognitivinen uskontotiede, jonka mukaan uskonto ei ole sopeutuma, vaan normaalien ihmismielen tiedonkäsittelyn toimintojen sivutuote.

Neuroteologiaksi nimitetään tutkimussuuntauksia, joissa tutkitaan aivojen toimintaa uskonnollisissa konteksteissa, erityisesti uskonnollisen kokemuksen yhteydessä. Kiinnostuksen kohteena ovat neuroteologiassa olleet uskonnollisten kokemusten ilmeneminen ja vaikutus aivoissa. Tätä on pyritty tutkimaan erilaisten aivokuvantamismenetelmien, kuten aivojen magneettikuvauksen, avulla. Esimerkkinä neuroteologiasta voidaan nostaa esiin Michael Persingerin tutkimukset. Persingerin hypoteesi on, että ihmisaivoissa on uskonnollisesta kokemuksesta vastaava erityinen aivoalue: aluetta stimuloimalla on hänen mukaansa mahdollista tuottaa koehenkilöille uskonnollistyyppinen kokemus "jonkin yliluonnollisen voiman läsnäolosta". ${ }^{167}$ Neuroteologian tuloksista ja teorioista on ollut jonkin verran keskustelua, mutta ne eivät ole saavuttaneet yleistä hyväksyntää lähinnä menetelmällisten heikkouksiensa takia. Yleisesti ottaen voidaankin sanoa, että uskonnollisilla kokemuksilla, uskomuksilla tai käyttäytymisellä ei näytä olevan aivojen tasolla sellaisia erityispiirteitä, jotka eroaisivat merkittävästi ei-uskonnollisista kokemuksista, uskomuksista tai käyttäytymisestä.

Siinä missä neuroteologia pyrkii olemaan uskonnollisen koke- 
muksen neurotiedettä, ottavat erilaiset uskonnon evoluutiota tutkivat teoriat mallia evoluutiobiologiasta. Uskonnon evoluution tutkimuksen lähtökohtana on hyvin yksinkertainen kysymys: miksi uskonnollinen käyttäytyminen on niin yleistä ihmislajin keskuudessa, vaikka se ei näytä edistävän ihmisen henkiinjäämistä? Näyttäisi pikemminkin siltä, että uskonnolliset rituaalit ja uhrit olisivat ihmisen henkiinjäämiselle haitallisia, koska ne vievät aikaa, resursseja eivätkä näytä tuottavan hyötyä. Useat teoriat uskonnon evoluutiosta kuitenkin väittävät, että uskonnolliset käytännöt ja uskomukset ovat itse asiassa henkiinjäämistä edistäviä ja voimme siten ajatella niiden olevan sopeutumia. Ollakseen sopeutuma, on uskonnon perusrakenteiden tai ainakin niiden mekanismien, jotka altistavat ihmiset uskonnolle, oltava koodattuna ihmisen geneettiseen perimään.

Esimerkiksi David Sloan Wilson on esittänyt teorian uskonnosta sopeutumana. Teoriaa on tapana kutsua "uskonnon ryhmävalintateoriaksi”. Wilsonin teoria perustuu paljon kriittisistä keskustelua biologien keskuudessa herättäneeseen ajatukseen ryhmävalinnasta. Ryhmävalinnan mukaan esimerkiksi ihmisryhmien ominaisuudet voivat aiheuttaa geneettisiä valintapaineita, jotka johtavat joidenkin geenien valikoitumiseen. Jos jokin ryhmä on muita ryhmiä parempi selviytymään, tämän ryhmän geneettinen perimä valikoituu ja kasvaa. Wilson käyttää ryhmävalintaa selittämään uskonnollisuutta korostamalla uskonnollisten ryhmien epäitsekästä käyttäytymistä. Uskonnollinen käyttäytyminen lisää ryhmän sisäistä epäitsekästä käyttäytymistä, joka osaltaan lisää ryhmän yhteenkuuluvaisuutta ja parantaa sen toimintaa. Jos tämän lisäksi oletamme ihmisryhmien välisen kilpailun, niin pitkien ajanjaksojen aikana voimme olettaa uskonnollisten ryhmien syrjäyttävän ei-uskonnolliset ryhmät. Näin ollen uskonto olisi rakennettu sisään geneettiseen perimäämme juuri siksi, että se ohjaa ihmisiä epäitsekkääseen käyttäytymiseen. ${ }^{168}$

Kolmatta suosittua tapaa lähestyä uskontoa biopsykologisesti kutsutaan usein kognitiiviseksi uskontotieteeksi (KU). Siinä missä esimerkiksi uskonnon ryhmävalintateorian mukaan uskonto on so- 
peutuma, on KU:n edustajien mukaan uskonto enemmän sivutuote kuin sopeutuma. Näin ollen KU:n tutkimus hakee teoriansa biologian sijaan viimeaikaisesta kognitiivisesta psykologiasta ja evoluutiopsykologiasta. Tutkimuksen lähtökohtana on ajatus uskonnosta ei-uskonnollisten psykologisten järjestelmien sivutuotteena. Voimme nimittää tätä "uskonto sivutuotteena" teesiksi. Teesi perustuu siihen ajatukseen, että ihmismielen perustavat prosessit ovat kaikissa kulttuureissa samoja ja että nämä prosessit vaikuttavat siihen miten ihmiset näkevät maailman ja miten ihmiset ajattelevat. Nämä yleiset prosessit vaikuttavat siihen, millaisia ideoita ihmisten on helppo uskoa ja levittää eteenpäin. KU:n mukaan uskonnolliset ideat ovat ihmisen psykologian kannalta juuri sopivia omaksuttavaksi ja levitettäväksi eteenpäin. ${ }^{169}$

Uskonto sivutuotteena -teesiä tukevat KU:n kirjoittajien mukaan esimerkiksi seuraavat psykologiset ilmiöt. Ensinnäkin uskonnollisia uskomuksia on helppo omaksua, koska ne ovat luonteeltaan rajallisesti intuitionvastaisia. Koska uskonnot ovat yhteisöllisiä, uskonnollisten uskomusten tulee olla luonteeltaan sellaisia, että ihmisryhmien on helppo levittää ja omaksua ne. Toisin sanoen uskonnollisilla uskomuksilla on oltava ominaisuuksia, jotka tekevät niistä muita uskomuksia helpommin omaksuttavia. Rajallinen intuitionvastaisuus -teoria (Minimal Counter-Intuitiveness Theory) väittää, että ideat ja uskomukset, jotka rikkovat ihmismielen luontaisia oletuksia maailman koostumuksesta ja sen olioiden toiminnasta, ovat erityisen tarttuvia. Millainen tahansa intuitionvastaisuus ei kuitenkaan käy, vaan sen pitää olla rajallista: uskomukset ja ideat, jotka sisältävät liian paljon intuitiivisten oletusten rikkomuksia tai ovat luonnollisten oletustemme mukaisia, eivät jää mieleen niin hyvin, kuin ideat, jotka sisältävät yhden tai kaksi rikkomusta. Ajatus on siinä, että kaikkein menestyneimmät uskonnolliset ideat, kuten jumalat ja henget, ovat juuri tällaisia rajallisesti intuitionvastaisia ideoita. Toiseksi uskomukset hengistä ja jumalista leviävät helposti, koska niitä kannattelevat kognitiiviset mekanismit, jotka käsittelevät kaikenlaisia toimijoita (ihmisiä, eläimiä, kuvitteellisia, jne.) eli agentteja. 
Eräs tällainen mekanismi on yliherkkä agentintunnistusjärjestelmä (Hypersensitive Agency Detection Device). Syy, miksi järjestelmää pidetään yliherkkänä, on se, että ihmisille näyttäisi olevan tyypillistä tulkita epäselviä signaaleja ikään kuin toimijoiden tuottamiksi. Tällainen yliherkkyys toimijoiden läsnäololle on varmasti tuottanut esi-isillemme hyötyä tilanteessa, jossa ihmisen elämää ovat uhanneet esimerkiksi saalistavat eläimet. Järjestelmän yliherkkyydestä kuitenkin seuraa se, että epäselvien ympäristön signaalien selittämiseksi kelpaavat myös ideat näkymättömistä ja intuitionvastaisista agenteista, kuten hengistä ja jumalista.

Kaikille biopsykologisille uskontoteorioille on tyypillistä liittää uskonnollinen käyttäytyminen ja ajattelu osaksi ihmisluontoa. Neuroteologian osalta tämä luonto on ihmisaivot ja niiden toiminta, uskontoa sopeutumana selittävien teorioiden kohdalla taas ihmisen synnynnäinen epäitsekkyys ja kognitiivisen uskontotieteen kohdalla ihmisen tiedonkäsittelyn rakenne. Voidaankin sanoa, että näitä teorioita luonnehtii ajatus "uskonnon luonnollisuudesta". Tämä ajatus on kuitenkin moniselitteinen ja voidaan ymmärtää ainakin seuraavilla tavoilla:

(1) Uskonnolliset uskomukset ja käyttäytyminen ovat ihmisille helppoja, koska ihminen on joko geneettisesti viritetty niille sopivaksi (uskonto sopeutumana) tai hänen mielensä mekanismit ovat rakentuneet näin (kognitiivinen uskontotiede).

(2) Uskonnolliset ajattelutavat ja käyttäytyminen ovat siinä määrin luonnollisia ilmiöitä, että niitä voidaan tutkia tieteellisesti (biologia, psykologia, neurotiede).

(3) Uskonnolliset ajattelutavat ja käyttäytyminen eivät ole vain ja ainoastaan kulttuurisidonnaisia, vaan ne liittyvät jollakin tavalla ihmislajin yleisiin ominaisuuksiin.

(4) Uskonnolliset ajattelutavat ja käyttäytyminen ovat vain ja ainoastaan luonnollisia siinä mielessä, että niiden synty ja toimintamekanismit eivät ole millään lailla yliluonnollisia. 
On tärkeää pitää nämä väitteet erillään toisistaan, sillä niitä voidaan perustella toisistaan riippumatta. Aiheemme kannalta olennaisinta on se, että esimerkiksi tieteelliset materialistit kuten Dennett ja Dawkins eivät ole erottaneet väitettä (4) kolmesta edeltävästä väitteestä, vaan ovat esittäneet, että biopsykologiset uskontoteoriat tekevät uskonnolliset väitteet kokonaan epäuskottaviksi tai järjettömiksi. ${ }^{170}$ Ajatus on se, että jos meillä on naturalistinen selitys sille, miksi ihmiset uskovat Jumalaa tai jumaliin, silloin meillä ei ole syytä pitää näitä uskomuksia järkevinä. Tarkastelen seuraavaksi muutamia tapoja puolustaa tätä ajatusta. Voidaan esimerkiksi väittää, että

(1) jonkin aivoalueen aktivoituminen uskonnollisen kokemuksen yhteydessä tekee uskomukset Jumalan olemassaolosta virheellisiksi,

(2) voimme päätellä uskonnon mahdollisesta sopeutumaluonteesta uskonnon perusteettomuuteen tai virheellisyyteen,

(3) voimme päätellä uskonnon sivutuote -teesistä uskonnon perusteettomuuteen tai virheellisyyteen. ${ }^{171}$

Ensimmäisen väitteen mukaan siitä, että olemme pystyneet tunnistamaan uskonnollisen kokemuksen yhteydessä aktivoituvia aivoalueita seuraa se, että voimme uskoa uskonnollisen kokemuksen syyt täysin luonnollisiksi ja uskomukset Jumalasta virheellisiksi. Tällaisessa järkeilyssä on kuitenkin useita ongelmia, joista ensimmäinen on se, että joidenkin aivoalueiden aktivaatio joidenkin kokemusten yhteydessä ei vielä selitä yhtään mitään. Aivojen eri alueet aktivoituvat kaikenlaisten havaintotoimintojen ja ajattelutapojen yhteydessä eikä tästä voida päätellä mitään näiden havaintojen ja ajatusten kohteiden olemassaolosta tai tiedollisesta oikeutuksesta. Emme saa sekoittaa toisiinsa jonkin uskomuksen biologista tilaa ja tiedollista tilaa. Ajattele seuraavaa esimerkkiä. Näen ulkona puun. Vaikka voitaisiinkin antaa täydellinen kuvaus siitä kausaalisesta prosessista, joka liittyy hermosolujeni ja aistielimieni aktivoitumiseen, tästä ei seuraa se, että puu lakkaisi olemasta. Ja vaikka olisi mahdollista 
keinotekoisesti saattaa aikaan tila, jossa näkisin puun, vaikka todellisuudessa ei mitään puuta olisikaan, ei tästä vielä seuraa, ettenkö voisi normaalitilanteessa pitää uskomustani ulkona olevasta puusta oikeutettuna. Sama pätee uskonnollisiin kokemuksiin tulkitaanpa ne millaisiksi tahansa: normaalioloissa ne syntyvät ilman keinotekoista stimulaatiota. Tästä voidaan siis päätellä, että uskonnollisiin uskomuksiin tai kokemuksiin liittyvien luonnollisten biologisten tai psykologisten prosessien olemassaolo ei vielä mitenkään riitä osoittamaan, että ne olisivat virheellisiä tai huonosti perusteltuja.

Toisen väitteen mukaan voimme ajatella, että uskonto on virheellistä, jos voimme osoittaa uskonnon sopeutumaksi, luonnonvalinnan tuotteeksi. Tarkemmin sanottuna siis siitä, että uskonnollisilla uskomuksilla on jokin ei-tiedollinen tehtävä (esimerkiksi epäitsekkään käyttäytymisen edistäminen), voidaan päätellä, että ne eivät ole tosia. Tämä väite on myös hyvin ongelmallinen, koska siinä ajatellaan, että luonnonvalinta yleensäkin suosii joitakin uskomuksia ja hylkii toisia. Luonnonvalinta ei kuitenkaan todellisuudessa suosi uskomuksia vaan käyttäytymismalleja: organismin eloonjääminen on ainoa millä on merkitystä luonnonvalinnan kannalta. Uskonnon ryhmävalintateorian idea on siinä, että uskonnolliset uskomukset edistävät prososiaalista käyttäytymistä ja tällainen käyttäytyminen osaltaan taas antaa joillekin ryhmille edun toisia ryhmiä vastaan. ${ }^{172}$ Toisin sanoen siis uskonnon ryhmävalintateoria ei sano mitään uskonnollisista uskomuksista eikä näin ollen voi sanoa mitään niiden totuusarvosta tai perusteluistakaan. Ja vaikka voisimmekin puhua uskomusten valinnasta evoluution yhteydessä, niin tämäkään ei vielä riittäisi osoittamaan uskonnollisia uskomuksia virheellisiksi. Jotta voisimme päätellä jonkin uskomuksen ei-tiedollisesta evolutiivisesta tehtävästä kyseisen uskomuksen epätotuuteen, meidän tulisi olettaa, että luonnonvalinta toimii joidenkin uskomusten totuutta vastaan. Tämä taas ei voi pitää paikkaansa: luonnonvalinta on, kuten jo sanoimme, neutraali uskomusten totuusarvon suhteen. Näin ollen on hyvin vaikea nähdä, miten uskonnolliset uskomukset voisivat olla vääriä tai perusteettomia pelkästään sillä perusteella, että niillä on 
ei-tiedollisia tarkoituksia.

Kolmannen väitteen mukaan uskonnon sivutuote -teesistä seuraa se, että emme voi pitää uskonnollisia uskomuksia luotettavina tai tosina. Tämä väite on itse asiassa käänteinen versio väitteestä (2), jonka mukaan se, että uskonto on sopeutuma, osoittaa uskonnolliset väitteet virheelliseksi. Väitteen (3) mukaan taas se, että uskonto ei ole sopeutuma, osoittaa uskonnolliset väitteet virheelliseksi. Myös tämän väitteen ongelmat ovat ilmeisiä, sillä käytännöllisesti katsoen kaikki uskomuksemme ovat tässä mielessä evoluution sivutuotteita. Luonnonvalinta ei valinnut uskomuksia, jotka koskevat esimerkiksi kvanttifysiikkaa, mannerlaattojen liikkeitä tai aritmetiikkaa. Meillä on luonnonvalinnan tuottamat välineet näiden uskomusten omaksumiseen ja muodostamiseen, mutta niillä ei ole ollut mitään vaikutusta ihmisen selviytymiseen luonnonvalinnan näkökulmasta.

Väitteisiin (1)-(3) sisältyy sama ongelma: niissä kaikissa sotketaan keskenään uskomuksen tiedollinen tila ja biologinen tai psykologinen tila. Uskomuksen tiedollinen tilan ja sen biologisen tai psykologisen alkuperän suhde on itse asiassa varsin monimutkainen kysymys, johon tässä yhteydessä en lähde perinpohjaisesti vastaamaan. Tässä kohdassa riittää lähinnä sen toteaminen, että emme voi yksiselitteisesti päätellä uskomuksen biologisesta tai psykologisesta alkuperästä sen järjettömyyteen tai epätotuuteen. Näin ollen "uskonnon luonnollisuus" ei alkuunkaan osoita, että uskonnolliset näkemykset olisivat viallisia tai virheellisiä.

Edellä on käsitelty kolmea tapaa päätyä biopsykologisista uskontoteorioista siihen, että uskonto on "vain ja ainoastaan" luonnonilmiö, ja todettu, että mikään näistä ei ole yksistään vakuuttava. Jos biopsykologisia uskontoteorioita halutaan käyttää uskontoa vastaan, on biopsykologiset uskontoteoriat liitettävä osaksi laajempaa ateistista näkemystä. Uskonnollisia näkemyksiä vastaan voidaan esittää monia vastaväitteitä, joista monet ovat varsin hyviä, mutta uskontojen järjettömyyteen tai epätotuuteen ei voida päätyä pelkästään biopsykologisten teorioiden pohjalta. Ateismi ei näin ollen voi olla mikään biopsykologisten uskontoteorioiden välttämätön seuraus. 
Jotkut teologit ovat esittäneet, että uskonnon luonnollisuus on itse asiassa erittäin hyvin yhteensopiva perinteisten teologisten näkemysten kanssa. Uskonnon luonnollisuus on selvästikin yhteensopiva sen kanssa, että ihminen on luotu Jumalan kuvaksi. Tämän näkemyksen mukaan ihmisellä hänellä on tarpeelliset kyvyt ymmärtää Jumalan ilmoitus ja olla vuorovaikutuksessa hänen kanssaan. ${ }^{174}$ Teologisesta näkökulmasta tarkasteltuna olisi hyvin omituista, jos ihminen olisi Jumalan kuva mutta hänellä ei olisi minkäänlaisia psykologisia tai biologisia mekanismeja, joiden avulla lähestyä Jumalaa. Vaikka ajattelisimmekin, että Jumalaa koskevien uskomustemme sisältö on kokonaan "yliluonnollista" perua, niin meidän on silti ajateltava, että ihmisellä on luonnollisia psykologisia ja biologisia mekanismeja (esim. aivot), jotka tekevät tällaisten uskomusten muodostamisesta mahdollisia. ${ }^{175}$

Voimme vetää lopuksi yhteen kolmen edellisen luvun keskustelua perinteisen teologisen antropologian ja nykyisten biologisten ja psykologisten tieteiden suhteesta. Olemme käsitelleet lähinnä kantaa, jota olen kutsunut teologiseksi materialismiksi. Monien luonnon teologien mukaan teologinen materialismi on sekä teologisesti tyydyttävä että yhteensopiva sen kanssa, mitä tieteet kertovat meille ihmisluonnosta. Teologisen materialismin mukaan ihminen kokonaisuutena voidaan ymmärtää Jumalan kuvana, eikä tämän edellytyksenä ole jonkinlaisen ei-luonnollisen komponentin olemassaolo (sielu). Ihmisen erityisyys Jumalan kuvana ei perustu jollekin yhdelle kyvylle, jonka lähde olisi yliluonnollinen, vaan kyseessä on pikemminkin monien eri kykyjen kasautuma - kykyjen, jotka ovat jo nupullaan eläinkunnassa. Barbourin mukaan

ihminen on osa luontoa, vaikkakin hyvin erityinen osa. Me olemme tulosta pitkästä evoluutiohistoriasta ja kannamme vahvaa perintöä tuosta menneisyydestä. Meillä on kuitenkin luovia kykyjä ja mahdollisuuksia, joille ei ole vertaa muiden maailman lajien joukossa. Me olemme biologisia organismeja, mutta myös vastuullisia yksilöitä. Jos viime vuosikymmenien tutkimus on löytänyt suurempaa jatkuvuutta ihmisen ja muiden 
elämänmuotojen välillä kuin mitä ennen uskottiin, näiden löytöjen tulisi johtaa meitä kunnioittamaan enemmän muita elämänmuotoja, eikä kieltämään ihmisen arvoa. Nykyaikainen tiede todistaa meille ihmisen erityisyydestä suhteessa muuhun planeettamme luomakuntaan. ${ }^{176}$

Vaikka ihminen on mieleltään, ruumiiltaan ja kulttuuriltaan evoluution tulos, hän ei ole kokonaan biologisen ja psykologisen luontonsa talutusnuorassa, vaan hänellä on kyky toteuttaa tietoista tahtoaan, muodostaa järjellään hänen impulssiensa vastaisia toimintasuosituksia ja noudattaa niitä. On kuitenkin selvää, että ihminen kantaa itsessään omaa biologista historiaansa eikä hän voi irrottautua siitä kokonaan. Voidaan ajatella, että Jumala on antanut ihmiselle evoluution välityksellä erilaisia kykyjä, jotka mahdollistavat vapaan tahdon, moraalisen vastuun ja välineet ymmärtää Jumalaa. Teologisen materialismin mukaan ihmisen suhde muuhun luomakuntaan on läheisempi kuin perinteisessä antropologiassa, mikä puolestaan sopii hyvin yhteen monien aikamme polttavien kysymysten kanssa.

\section{Kirjallisuutta}

Hyviä johdatuksia teologisten ja tieteellistä ihmiskäsitysten keskusteluun ovat esimerkiksi Brown \& Murphy \& Malony 1998 ja Peterson 2003. Van Huyssteen 2006 on laaja katsaus ihmisen erityisyyteen teologian ja ihmisen esihistorian näkökulmasta. Lähestyttävä ja vasta-alkajalle sopiva esitys teologisesta materialismista on Murphy 2006. Kevyt johdatus teologiseen dualismiin on Ward 1998. Vapaan tahdon ongelmaa käsittelevät esimerkiksi Murphy \& Brown 2007, van Inwagen 1983, 2002 ja Dennett 2003. Joyce 2006 on erinomainen katsaus moraalin evoluutioon liittyviin tieteellisiin ja erityisesti filosofisiin kysymyksiin. Ihmisluonnon määrittelyn ongelmasta ja sen käytöstä tieteissä keskustelee Ylikoski \& Kokkonen 2009. Murray \& Schloss 2009 sisältää uusinta keskustelua biologisista ja psykologisista uskontoteorioista ja niiden teologisista ulottuvuuksista. Laaja keskustelu kognitiivisesta uskontotieteestä ja sen suhteesta teologisiin näkemyksiin on Visala 2009. Suomeksi kognitiivista us- 
kontotiedettä esittelee Ketola \& Pyysiäinen \& Sjöblom 2008. Kevyt mutta informatiivinen suomenkielinen johdanto nykyisen uskontotieteen peruskysymyksiin on Pyysiäinen 2006. 



\section{MAAILMANKATSOMUSTEN KONFLIKTI: TEISMI, ATEISMI JA TIETEELLINEN MATERIALISMI}

Kirjan alkupuolella esiteltiin lyhyesti konfliktimalli, sen kaksi keskeistä teesiä ja tieteelliseksi materialismiksi kutsuttu ajattelutapa, jolla konfliktimallia hyvin usein perustellaan. Tässä vielä tieteellisen materialismin keskeiset väitteet:

(1) Luonnon, joka sisältää ihmiset ja ihmisen kulttuurin luomukset, lisäksi ei ole mitään. Ei ole olemassa sieluja, ei kuolemanjälkeistä elämää eikä Jumalaa.

(2) Luonto synnyttää itse itsensä. Ei ole mitään luonnon ulkopuolista, joten se ei ole Jumalan luoma.

(3) Luonnolla ei ole päämäärää eikä tarkoitusta, vaikka yksittäiset ihmiset voivatkin löytää tarkoituksen elämälleen.

(4) Koska Jumalaa ei ole, kaikki selitykset ovat pelkästään luonnollisia ja vain tiede voi löytää ne kaikki.

(5) Kaikki elävien olioiden ominaisuudet, mukaan lukien inhimillinen älykkyys ja käyttäytyminen, voidaan selittää kokonaan luonnollisin tavoin. Tällä tarkoitetaan yleensä darwinistisia selityksiä (biologinen reduktionismi).

Yksi kirjamme keskeisistä väitteistä on ollut se, että tieteellinen materialismi ei ole ainoa mahdollinen tapa ymmärtää se, miten tiede toimii ja millaisia uskonnollisia seurauksia tieteellisillä tuloksilla on. Samalla on myös esitetty syitä luopua koko ristiriitamallista ja kor- 
vata se mallilla teologian ja tieteen osittaisesta päällekkäisyydestä. Toivon, että lukijalle on tässä vaiheessa tullut selväksi se, että tieteen ja kristinuskon "konfliktissa" on itse asiassa kysymys itse asiassa kahden erilaisen maailmankatsomuksen ristiriidasta, ei tieteen tulosten välttämättömistä seurauksista. Vastakkain ovat erilaiset tulkinnat tieteen ja teologian toiminnasta, tieteen tuloksista ja perimmäisen todellisuuden luonteesta. Toisella puolella on tieteellisellä materialismilla perusteltu ateismi ja toisella puolella taas erilaiset teismin muodot. Tässä luvussa esitän muutamia kommentteja tämän konfliktin luonteesta.

\section{$9 \cdot 1$}

\section{ATEISMIJA NATURALISMI}

Mitä eroa on ateismilla, naturalismilla ja tieteellisellä naturalismilla? Onko niillä mitään eroa?

Arkikielessä ateisteiksi kutsutaan henkilöitä, jotka kieltävät Jumalan tai jumalien olemassaolon ja haluavat asettua uskontojen ulkopuolelle. Terminologisesti ottaen a-teismi tarkoittaa teismin eli jumalauskon kieltämistä. Ateistiksi voidaan luokitella henkilö, joka uskoo, että Jumala ei ole olemassa, sekä henkilö, joka ei usko Jumalan olemassaoloon. Ensimmäistä tapausta kutsumme vahvaksi ateismiksi ja jälkimmäistä taas heikoksi ateismiksi. Toisinaan heikkoon ateismiin viitataan myös uskonnottomuutena, vahvaan ateismiin taas militanttina ateismina tai antiteisminä.

Termiä agnostikko käytetään arkikielessä ihmisestä, joka ei halua syystä tai toisesta ottaa kantaa Jumalan olemassaoloon. Agnostisismi ja ateismi menevät hämmentävästi arkikielessä päällekkäin mutta on tärkeää pitää ne käsitteellisesti erossa toisistaan. Agnostisismia esiintyy ainakin kolmena eri tyyppinä. Ensimmäinen tyyppi, radikaali agnostisismi, pitää kysymystä Jumalan olemassaolosta tai olemattomuudesta mielettömänä. Joko käsite "jumala" katsotaan ristiriitaiseksi tai sitten Jumalan olemassaolo katsotaan ristiriitaiseksi. 
Esimerkiksi radikaalia agnostisismia edustava Kai Nielsen väittää, että Jumala olemassaolosta tai olemattomuudesta puhuminen on mahdotonta, koska se ylittää kielemme rajat. Toinen agnostisismin tyyppi on heikko agnostisismi, jonka mukaan kantaa Jumalan olemassaoloon ei ole syytä muodostaa, koska kummankaan osapuolen perustelut eivät selvästi voita toisia. Tällaiset henkilöt voivat olla sitä mieltä, että ateistinen tai teistinen kanta on voitolla, mutta ei riittävästi henkilön oman kannan pysyvään muotoiluun. Lisäksi heikoksi agnostisismiksi voidaan kutsua kantaa, jonka mukaan emme voi koskaan saada varmaa tietoa Jumalan olemassaolosta tai olemattomuudesta, jonka seurauksena meidän ei tule yrittää muodostaa asiasta näkemystä. Kolmas agnostisismin tyyppi on pragmaattinen agnostisismi, jossa Jumalan olemassaoloon tai olemattomuuteen ei muodosteta kantaa, koska asiaa ei pidetä laisinkaan kiinnostavana tai siihen suhtaudutaan välinpitämättömästi. ${ }^{177}$

Tieteelliseksi ateismiksi kutsutaan näkemystä, jonka mukaan tieteellisen tiedon perusteella voidaan osoittaa, että Jumalaa ei ole olemassa. Kuvaamani tieteellinen materialismi edellyttää juuri tällaisen ateismin mahdollisuuden. Filosofiseksi ateismiksi taas kutsutaan kantaa, jossa omaksutaan ateismi, koska teismin puolesta esitetyt perustelut joko virheellisiä tai riittämättömiä. Filosofinen ateisti voi omaksua ateismin pelkästään sillä perusteella, että teismin puolesta esitetyt perusteet ovat virheellisiä tai sitten hän voi väittää, että ateismin puolesta esitetyt argumentit ovat parempia kuin teistiset argumentit. Filosofisen ateismin etu tieteelliseen ateismiin nähden on se, että se jättää enemmän pelivaraa sen suhteen, mitä tiede voi Jumalasta sanoa.

Nykyisin kaikkein kuuluisin ateismin muoto perustuu nimenomaan tieteelliselle materialismille. Tätä on tapana kutsua uusateismiksi (the new atheism), jonka keskeisiksi edustajiksi lasketaan Richard Dawkins, Daniel Dennett, Sam Harris sekä Christopher Hitchens. ${ }^{178}$ On jo käynyt ilmi, että sekä Dawkins että Dennett ovat tyyppiesimerkkejä tieteellisestä materialismista. Samaa voidaan tässä yhteydessä sanoa myös Harrisista ja Hitchensistä. Vahvoja tie- 
teellisiä ateisteja näistä kirjoittajista tekee se, että heidän mukaansa juuri tieteellinen tutkimus ja sen pohjalta tehtävät johtopäätökset osoittavat, että Jumalaa ei ole olemassa. Uusateistien vaatimus on varsin radikaali: ateismi on niin hyvin perusteltu, että jokaisen järkevän ihmisen tulisi hyväksyä se. Uusateismi on herättänyt varsin laajan keskustelun ja erilaisia vastakirjoja alkaa olla jo useita kymmeniä. ${ }^{179}$

Ateismin puolesta voidaan esittää episteemisiä eli uskomusten totuutta koskevia perusteita sekä ei-episteemisiä eli uskomusten hyödyllisyyttä koskevia perusteita. Uskontokritiikki voidaan samaan tapaan jakaa episteemiseksi, jolloin suhtaudutaan kriittisesti uskonnollisten väitteiden totuuteen, sekä ei-episteemiseksi, jolloin suhtaudutaan kriittisesti uskonnon vaikutukseen yksilössä ja yhteiskunnassa. Uusateistien kritiikki kristinuskoa kohtaan etenee kaikilla näillä rintamilla. Kristinuskon perusväitteiden katsotaan olevan epätosia ja niiden puolesta esitettyjen perusteiden katsotaan olevan järjettömiä. Samoin uusateistien mukaan kristinuskon seuraukset ovat kammottavia: kristinusko on torjuttava nimenomaan moraalilla perusteilla. Ateismi on tapana liittää naturalismiin. Naturalismi terminä on varsin moniselitteinen ja osa sen merkityksistä on päällekkäisiä tieteellisen materialismin kanssa ja osa taas ei. Voimme erottaa ainakin

(1) naturalismin yleisenä tutkimusohjelmana tieteessä,

(2) naturalismin ohjelmana tieteidenvälisessä keskustelussa,

(3) naturalismin maailmankatsomuksena tai filosofisena teoriana.

Naturalismi tutkimusohjelmana voidaan ymmärtää löyhäksi kokoelmaksi tietolähteisiin ja todellisuuden luonteeseen liittyviä oletuksia, jotka valtaosa tieteilijöistä tietäen tai tietämättään jakavat. Tällaisia oletuksia ovat esimerkiksi seuraavat:

(1) Maailma on järjestäytynyt kokonaisuus ja toimii jotakuinkin säännönmukaisesti. 
(2) Olioiden ja prosessien välillä vallitsee suhteellisen pysyviä lainomaisia suhteita, joita voimme jäljittää.

(3) Ihmismieli voi erilaisin välinein (havainnot, päättely, matematiikka) mallintaa luontoa ja testata näitä malleja kokeellisesti.

(4) Metodologinen naturalismi, jonka mukaan luonnon toiminta on siinä määrin säännönmukaista, että tieteellisten selitysten ei tarvitse ottaa huomioon yliluonnollisten toimijoiden (kuten Jumala) erityistä toimintaa.

Näistä oletuksista erityisesti metodologinen naturalismi on aiheemme kannalta tärkeä. Tämän väitteen mukaan tieteen ja teologian välillä vallitsee työnjako: kun tiede selittää luonnollisen maailman olioiden käyttäytymistä, koostumusta tai muuta sellaista, se ei oleta "yliluonnollisia puuttumisia" tapahtumien kulkuun. Toisin sanoen siis metodologisen naturalismin mukaan Jumalaa ei tule käyttää selittävänä periaatteena tieteessä. Kuten on jo aiemmin käynyt ilmi, luonnon teologian edustajat kannattavat naturalismia tutkimusohjelmana tieteessä, sillä heidän mukaansa tieteellinen tutkimus voi edetä ottamatta huomioon Jumalan erityistä toimintaa. Lisäksi he korostavat kuinka kristillisen teologian viitekehystä voidaan käyttää perustelemaan juuri tällaista asennetta tieteessä. Kristillinen teologia antaa hyvät syyt ajatella, että maailma on todellakin järjestäytynyt kokonaisuus, josta ihminen voi saada tietoa ja että Jumalan toiminta on laadullisesti erilaista verrattuna luonnon säännönmukaisuuksien tomintaan.

Sen lisäksi, että ymmärrämme naturalismin yleisenä tutkimusohjelmana, se voidaan myös ymmärtää kantana tieteidenvälisessä keskustelussa. Tällainen naturalismi korostaa taas luonnontieteiden merkitystä kaikkien tieteiden kannalta: erityisesti fysiikan ja biologian katsotaan muodostavan mallin kaikille tieteille juuri menetelmiensä osalta. Tällaista naturalismia luonnehtii ajatus "metodologisesta monismista", jonka mukaan kaikilla tieteillä tulisi olla luonnontieteen kanssa yhtenäiset taustaoletukset ja menetelmät. Tällaisen näkemyksen edustajilla on tapana ajatella, että monet 
tieteenalat, jotka eivät kuulu luonnontieteen piiriin pitää naturalisoida eli tehdä menetelmiensä ja oletustensa puolesta yhteensopiviksi luonnontieteiden kanssa. Olemme edellä käsitelleet jo monia tällaisia pyrkimyksiä naturalisoida esimerkiksi uskonto ja sen tutkimus (luku 8.4), moraali, ihmismieli, ihmisen kulttuuri ja niiden tutkimus (luvut 5.2, 5.3 ja 8.2). Kuvasimme myös biologista reduktionismia, joka on yksi hyvin radikaali esimerkki kaikki ihmis- ja yhteiskuntatieteet naturalisoivasta ohjelmasta (luku 5.4).

Jos taas ymmärrämme naturalismin maailmankatsomuksena, jonkinlaisena laajana filosofisena teoriana todellisuudesta, niin näkökulmamme on varsin erilainen kahteen edelliseen naturalismin muotoon verrattuna. Naturalismi maailmankatsomuksena ja filosofiana on juuri sitä, mitä olemme tarkoittaneet tieteellisellä materialismilla. Mestarillisen kuvauksen tällaisesta maailmankatsomuksesta on antanut filosofi Bertrand Russell:

Yleisesti ottaen tiede paljastaa meille tarkoituksettoman ja merkityksettömän maailman. Tällaisessa maailmassa, jos missään, on ihanteemme löydettävä kotinsa. Ihminen on sellaisten syiden tulosta, joilla ei ollut minkäänlaista päämäärää. Hänen alkuperänsä, kehityksensä, toivonsa, pelkonsa, hänen rakkautensa ja uskonsa eivät ole mitään muuta kuin sattumanvaraisten atomien kokoelma. Mikään into, sankaruus, ajatuksen tai tunteen voima ei voi kannattaa yksilön elämää yli kuoleman rajan. Kaikkien ihmisten aikojen saavutukset, kaikki omistautuminen, inspiraatio ja kirkkaimmankin päivän nerous on tuomittu hävitettäväksi, kun aurinkokunta lopulta kuolee. Ihmisen suurimmatkin saavutukset hautautuvat lopulta universumin raunioihin. Kaikki nämä asiat ovat - vaikka ehkä eivät vailla ongelmia - niin varmoja, että mikään filosofia, joka ne kieltää, ei voi kestää. Vain ja ainoastaan näiden totuuksien pohjalle, vain tämän pohjattoman epätoivon horjumattomalle perustalle, voidaan ihmissielun asumus tästedes rakentaa. ${ }^{180}$

Tieteellinen materialismi ja maailmankatsomuksellinen naturalismi rakentuvat tieteellisten menetelmien ja tieteiden tulosten ympärille, 
mutta samaan aikaan ne sisältävät arvoja, oletuksia ja toimintasuosituksia, jotka eivät nouse tieteestä sellaisenaan.

Omaksumamme teologisen realismin viitekehyksen sisällä on periaatteessa kolme erilaista teologista mahdollisuutta suhtautua edellä esiteltyihin naturalismin muotoihin:

(1) Kova teologinen naturalismi hyväksyy sekä naturalismin tutkimusohjelmana että maailmankatsomuksellisesta naturalismista ne osat, jotka koskevat luonnollisen maailman itseriittoisuutta. Seurauksena on näkemys, joka muistuttaa perinteistä deismiä: Jumala ei tämän näkemyksen mukaan toimi eikä ilmene maailmassa.

(2) Pehmeä teologinen naturalismi hyväksyy naturalismin hyvänä tutkimusohjelmana ja pyrkii luomaan teologisen kokonaisnäkemyksen, joka yhteensopiva tämän tutkimusohjelman ja sen tulosten kanssa. Tämä näkemys torjuu maailmankatsomuksellisen naturalismin.

(3) Supranaturalismi pyrkii osoittamaan, että naturalismi epäonnistuu tutkimusohjelmana ja korvaamaan sen supranaturalistisella tutkimusohjelmalla. Näin ollen supranaturalismi torjuu sekä naturalismin tutkimusohjelmana että maailmankatsomuksena.

Kova teologinen naturalismi on varsin harvinainen kanta mutta silläkin on edustajansa, joista eräs on hollantilainen fyysikko ja filosofi Willem Drees. ${ }^{181}$ Dreesin mukaan meidän tulisi hyväksyä naturalismi tutkimusohjelmana, ohjelmana tieteiden välisissä suhteissa ja myös joiltain osin maailmankatsomuksena, koska se on parhaiten yhteensopiva tieteen edistyksen kanssa. Se, mitä Drees tässä tarkoittaa naturalismilla maailmankatsomuksena, on lähinnä se, mitä olemme aiemmin kuvanneet non-reduktiiviseksi materialismiksi: kaikki koostuu viimekädessä fysikaalisista osista, vaikka niiden avulla ei voida kaikkea selittääkään. Tähän asti Dreesin kanta näyttää samalta, kuin luonnon teologien. Se, mikä erottaa kovan teologisen naturalismin pehmeästä teologisesta naturalismista, on se, että edeltävä 
torjuu kokonaan kaikki teismin muodot lähinnä siksi, että ruumiiton persoona katsotaan mahdottomaksi. Se, mikä jää jäljelle, on antirealistinen ymmärrys uskonnollisesta kielenkäytöstä, jossa "Jumalan" ja muiden uskonnollisten käsitteiden ei katsota viittaavan perimmäiseen todellisuuteen, vaan olevan pelkästään symboleita, joiden avulla ymmärrämme kokemustamme maailmasta. Voidaan siis sanoa, että kova teologinen naturalismi ei ole sen enempää kuin naturalismi yhdistettynä teologiseen antirealismiin.

Luonnon teologian edustajia voidaan puolestaan kutsua pehmeiksi teologisiksi naturalisteiksi, koska he hyväksyvät naturalismin tutkimusohjelmana tieteessä, mutta torjuvat naturalismin kahdessa muussa merkityksessä eli maailmankatsomuksena ja ohjelmana tieteiden välisissä suhteissa. Tämä on juuri se näkemys, jota olemme valtaosan tästä kirjasta jäljittäneet ja muotoilleet, joten tässä yhteydessä siihen ei ole tarvetta mennä syvemmin. Olennaista on nähdä, että luonnon teologiaan kuuluu välttämättömänä osana tieteellisen materialismin ja maailmankatsomuksellisen naturalismin kritiikki. Näin ollen pehmeän teologisen naturalistin on perusteltava, miksi naturalismi tutkimusohjelmana tulisi hyväksyä, mutta samaan aikaan torjua naturalismi maailmankatsomuksena. ${ }^{182}$ Hyvin keskeisessä roolissa on tässä metodologisen naturalismin puolustaminen. Pehmeä teologinen naturalisti pitää metodologista naturalismia perusteltuna, koska sitä seuraamalla ollaan saatu hyviä tuloksia ja paljastettu meille ennestään tuntemattomia mekanismeja, joiden avulla olemme pystyneet manipuloimaan syy- ja seuraussuhteita.

Jotkut ovat kuitenkin väittäneet, että pehmeä teologinen naturalismi epäonnistuu vääjäämättä, koska metodologista naturalismia on mahdoton puolustaa teologisista lähtökohdista. Kutsumme tässä tämän näkemyksen edustajia supranaturalisteiksi. Heidän mukaansa naturalismi epäonnistuu sekä tutkimusohjelmana että maailmankatsomuksena, koska jos Jumala toimii maailmassa (näin supranaturalisti uskoo), niin naturalistinen kuva maailmasta on välttämättä epätäydellinen. Tämä johtaa myös metodologisen naturalismin tuhoon, koska sen ainoa peruste on maailmankatsomuksellinen na- 
turalismi. Tilanteen korjaamiseksi supranaturalisti ehdottaa sellaisen tieteen kehittämistä, joka hylkää metodologisen naturalismin ja hyväksyy tutkimuksen lähtökohdaksi teismin. Olemme jo aiemmin ID:n yhteydessä (ks. luku 7.2) kuvanneet yhtä tämänsuuntaista supranaturalismia. ${ }^{183}$

Monet teistiset filosofit ovat suunnanneet kovaa kritiikkiä naturalismiin maailmankatsomuksena. Tätä kritiikkiä tieteellistä materialismia vastaan ovat esittäneet sekä pehmeät teologiset naturalistit että supranaturalistit. Tämän kirjan tarkoitus ei varsinaisesti ole ollut käsitellä tätä keskustelua mutta koska se toisinaan tulee esiin tieteen ja teologian suhteen yhteydessä, teen tässä siihen lyhyen katsauksen. Viimeaikaisessa filosofisessa keskustelussa teistiset filosofit ovat vastustaneet naturalismia ainakin kahden erilaisen strategian avulla:

(1) Naturalismi kumoaa itse itsensä, koska se ei pysty oikeuttamaan omia tietolähteitään.

(2) Naturalismilla on ongelmia käsitellä inhimillisiä toimijoita ja niiden ominaisuuksia kuten esimerkiksi persoonallista identiteettiä, itsetietoisuutta, moraalisia ominaisuuksia ja järkeä.

Filosofi Alvin Plantinga on esittänyt argumentin, joka tunnetaan tavallisesti nimellä "evoluutioteoreettinen argumentti naturalismia vastaan". Argumentti perustuu vahvasti Plantingan tietoteoriaan, jota emme tässä sen laajuuden ja monimutkaisuuden takia lähde käsittelemään. Voimme kuitenkin esittää lukijalle, miten argumentti toimii ja mihin sillä pyritään. Päättely on lyhykäisesti seuraava: jos naturalismi on totta ja ihmisen tiedonkyvyt (järki, havainnot, muisti) ovat ohjaamattoman evoluution tulosta, meillä ei ole perusteita luottaa niihin. Toisin sanoen siis naturalismin voidaan katsoa olevan itsensä kumoavaa, koska se ei anna meille syytä luottaa tiedonhankinnan mekanismeihimme. Argumentti lähtee siitä liikkeelle, että luonnonvalinta ei välitä biologisten organismien uskomusten totuudesta, vaan ainoastaan siitä, miten nämä käyttäytyvät. Näin ollen meillä ei ole syytä olettaa, että luonnonvalinta tuottaisi sellaisia 
tiedonhankinnan mekanismeja, jotka olisivat luotettavia (= tuottaisivat tosia uskomuksia niille sopivassa ympäristössä). Tässä kohdassa Plantingan tietoteoria tulee mukaan: hänen mukaansa uskomus on oikeutettu vain silloin, kun se on syntynyt luotettavan prosessin kautta. Jos siis on niin, että meillä ei ole syytä uskoa tiedonkykyjemme luotettavuuteen, koska ne ovat evoluution tulosta, niin meillä ei ole myöskään syytä pitää mitään niiden tuotteita oikeutettuina. Näin ollen emme voi oikeutetusti uskoa tieteelliseen materialismiin tai mihinkään muuhunkaan näkemykseen todellisuudesta. Huomaa, että johtopäätös ei ole se, että naturalismi olisi epätosi, vaan että jos se on totta, meidän ei ole rationaalista uskoa siihen. Argumentti on herättänyt paljon keskustelua mutta sen tuloksesta ei ole yksimielisyyttä. Yksi tapa vastustaa sen johtopäätöstä on kieltää Plantingan käsitys oikeuttamisesta ja rationaalisuudesta, mistä puolestaan seuraa ongelman häviäminen. Tällöin ajatellaan, että uskomustemme oikeutus ei ole ainakaan kokonaan riippuvainen uskomuksia tuottavien prosessiemme luotettavuudesta. ${ }^{184}$

Toinen suosittu strategia vastustaa maailmankatsomuksellista naturalismia on väittää, että ihmiset älykkäinä, moraalisesti vastuullisina ja vapaina toimijoina eivät mahdu naturalismin esittämään maailmaan. Näin ollen on joko hylättävä naturalismi tai sitten ajateltava esimerkiksi, että "ihminen on robotti, joka on ohjelmoitu ajattelemaan, että se ei ole robotti". ${ }^{185}$ Argumentin taustalla on ajatus siitä, että teismillä ei ole ongelmia käsitellä persoonallisia toimijoita ja heidän moraalisia ja älyllisiä kykyjään. Lukijan kannattaa kiinnittää huomiota siihen, miten tämä strategia toimii: ajatus on se, että käsitys ihmisistä älykkäinä, vapaina ja moraalisesti vastuullisina olentoina sopii paremmin yhteen teismin kuin naturalismin kanssa. Väite siis ei ole se, että naturalismi päätyisi hävittämään kaikki persoonalliset toimijat (vaikka jotkut ovat myös näin väittäneet). Ajatus on sen sijaan se, että sellaiset persoonallisten toimijoiden ominaisuudet kuten itsetietoisuus ja moraali selittyvät paremmin ja yksinkertaisemmin teismin sisällä. Tämän strategian mukaisia argumentteja on esitetty useita, joista seuraavassa muutamia: 
(1) Naturalismi ei pysty perustelemaan uskoa indeterministiseen vapaaseen tahtoon. Tämä argumentti puree vain niitä naturalisteja vastaan, jotka haluavat pitää kiinni indeterministisestä vapaasta tahdosta. Kuten on jo edellä käynyt ilmi, naturalistit tavallisesti puolustavat erilaisia deterministisen vapaan tahdon versioita (ks. luku 8.2).

(2) Naturalismi ei pysty perustelemaan uskoa mentaaliseen kausaatioon eli siihen, että ihmisen mielentilat todella vaikuttavat maailmaan. Käsittelimme tätäkin väitettä jo aiemmin (ks. luku 8.2) ja totesimme, että ainakin jotkut materialismin muodot ovat yhteensopivia mentaalisen kausaation kanssa. Jotkut ovat kuitenkin jatkaneet hyökkäystä ja väittäneet, että non-reduktiivinen materialismi on epävakaa kanta ja ainoat toimivat vaihtoehdot ovat dualismi ja reduktiivinen materialisti. Jos tämä hyökkäys onnistuu, on naturalistin joko valittava reduktiivinen materialismi ja torjuttava mentaalinen kausaatio tai sitten hyväksyä dualismi. Dualismi kuitenkin sopii vain vaivoin yhteen naturalismin kanssa. Teisti tietenkin väittää, että on valittava dualismi, jonka teismi puolestaan tekee ymmärrettäväksi.

(3) Naturalismi ei pysty perustelemaan ihmisen järjen toimintaa, vaan tekee kaikista ihmisistä robotteja. Tämä vastaväite kuuluu yhteen mentaalisen kausaation ongelman kanssa. Jos jokainen mielentila on pelkkä fysikaalinen tila ja sitä edeltävien fysikaalisten tapahtumien määräämä, niin mielentiloilla ei ole järkiperusteita, vaan ainoastaan syitä. Jos meillä ei ole syytä uskoa, että mielentilamme ainakin joskus ovat tuotetta järkiperusteista, niin meidän tulee ajatella, että mielentilamme eivät jäljitä totuutta. Tätä on tapana kutsua järkiargumentiksi (argument from reason). Järkiargumentin tarkoitus on sama kuin Plantingan argumentilla eli sen osoittaminen, että jos naturalismi pitää paikkansa, niin meillä ei ole perusteita luottaa järkeemme. ${ }^{186}$

(4) Naturalismi ei pysty selittämään tietoisuuden syntyä eikä sen suhdetta aivoihin. Tätä on tapana kutsua argumentiksi tietoisuudesta (argument from consciousness). Jos naturalismi pitää 
paikkansa, niin meillä ei ole syytä olettaa tietoisuuden syntyvän laisinkaan. Tämän argumentin puolustamiseksi on osoitettava, että nykyiset naturalistiset teoriat eivät johda siihen, että tietoisuuden synty on todennäköistä. (ks. luku 8.1). ${ }^{187}$

Tämänkaltaisten argumenttien perusteella teistiset filosofit väittävät, että teismi on naturalismia parempi vaihtoehto, koska se on naturalismia paremmin yhteensopiva arkikäsityksemme inhimillisten persoonien ja niiden moninaisten ulottuvuuksien kanssa. Tämän strategian mukaan naturalismi leikkaa irti liian ison osan maailmaamme - juuri sen osan, jossa asuvat järkevät, vapaat ja moraaliset olennot, joiden rikas kokemus maailmasta ei tyhjene fysiikan tutkimaan maailmaan.

Vaikka kaikki luonnon teologian edustajat eivät olekaan kiinnostuneita naturalismin kritiikistä muuta kuin hyvin pinnallisesti (näin esimerkiksi McGrath), on edellä kuvaamamme maailmankatsomuksellisen naturalismin filosofinen kritiikki luonnon teologian kanssa yhteensopivaa. Luonnon teologian onnistumisen kannalta ei ole välttämätöntä, että maailmankatsomuksellinen naturalismi epäonnistuu, sillä luonnon teologialle riittää ilmoituksen ja tieteen yhteensopivuus. Monet luonnon teologian edustajat (esimerkiksi Ward ja Haught) ovat kuitenkin esittäneet laajasti naturalismin kritiikkiä ja katsovat tämän tuovan lisäperusteita pitää teismiä totena. Esimerkiksi Wardin mukaan

Jumala on parempi selitys tieteen paljastamille tosiseikoille kuin materialismi. Jumala ei silti ole tieteellinen selitys, vaan se on metafyysinen selitys. Jumala on kuitenkin materialismia parempi hypoteesi, koska se tekee tämänkaltaisen maailmankaikkeuden olemassaolon paljon todennäköisemmäksi kuin materialismi. Vaikka uskova ei hyväksykään Jumalan olemassaoloa tämän ylivertaisen selittävän voiman takia, niin silti usko Jumalaan on sekä rationaalinen että luontoa valaiseva asenne. Usko Jumalaan ei ole absurdien väitteiden sokeata hyväksyntää, vaan syvästi tyydyttävä selitys sille, miten ja miksi maailmankaikkeus on olemassa. ${ }^{188}$ 
Samaa mieltä on jopa varsin varovainen luonnon teologian edustaja Polkinghorne. Polkinghorne korostaa juuri edellä kuvaamaamme teismin kykyä ottaa huomioon inhimillinen kokemus ja inhimillinen maailma:

Teistille fysikaalisen maailman järjellinen kauneus ei ole mikään sattumanvarainen tosiseikka, vaan heijastaa Luojan mieltä. Esteettinen kokemus ja eettinen intuitio eivät ole vain psykologisia tai sosiaalisia konstruktioita, vaan merkkejä Jumalan luovasta ja oikeudenmukaisesta tahdosta. Uskonnollinen kokemus ei ole illuusio eikä ihmisen projektio vaan kohtaamista jumalallisen todellisuuden kanssa. Teistinen maailmanselitys on minusta älyllisesti tyydyttävä, koska se yhdistää kokemuksemme maailmasta kokonaisuudeksi siitäkin huolimatta, että joudumme painiskelemaan "ikuisen olion" mysteerin kanssa. Sekä ateisti että teisti havainnoivat samaa inhimillisen kokemuksen maailmaa mutta esittävät siitä erilaiset tulkinnat. Väitän, että teismi tarjoaa perustavamman ja laajemman ymmärryksen kuin ateisteilla on tarjottavanaan. Ateistit eivät ole tyhmiä, mutta he selittävät vähemmän. ${ }^{189}$

Olennaista teististen ja naturalististen filosofien välisessä kiistassa on nimenomaan se, että kiista on luonteeltaan filosofinen: monet tieteen tulokset ovat tämän väittelyn kannalta tärkeitä, mutta ne eivät yksinään ratkaise tätä väittelyä. Kyse on pikemminkin siitä, millaisia filosofisia näkemyksiä näiden tulosten tulkintaan käytetään.

\section{$9 \cdot 2$}

TIETEEN KAIKKIVOIPAISUUS JA ARVOVAPAUS

Kuten olemme nähneet, yksi keskeinen komponentti tieteellisen materialismin kokonaisuudessa on usko tieteen kaikkivoipaisuuteen. ${ }^{190}$ Filosofi Mary Midgleyn mukaan tieteen kaikkivoipaisuus 
on vakaumus, jonka mukaan tulee olla vain yksi ihmisen kyky, joka lopulta ratkaisee kaikki ongelmamme ja sovittelee kaikki ristiriitamme. Ja nykyisin juuri älyn, siinä muodossa kuin sitä tieteessä harjoitetaan, ajatellaan olevan tuo kyky. Tästä näyttää seuraavan, että minkään muun ihmisen kyvyn ja päämäärän ei tule kilpailla sen kanssa eikä meidän itse asiassa edes kannattaisi tuhlata liikaa aikaa niihin. Tiede tulisi yksinkertaisesti tunnustaa absoluuttiseksi mutta hyväntahtoiseksi hallitsijaksi. ${ }^{191}$

Jos uskomme tieteen kaikkivoipaisuuteen, ajattelemme, että tiede (tässä tapauksessa juuri luonnontiede) on kaikkein arvokkain ja tärkein ihmisen pyrinnöistä. Vain ja ainoastaan luonnontiede johtaa meidät totuuden jäljille. Midgley kuitenkin jatkaa:

Mielestäni tällainen itsevaltainen visio ei ole kovinkaan realistinen, ei edes mielikuvituksellisena visiona. Ensimmäiseksi haluan nimittäin väittää, että kyseessä on todellakin visio - hyvin yleinen tapa tarkastella maailmaa, ei mikään tieteellisen järkeilyn tuote. Kyseessä on yksi mahdollinen tapa tarkastella maailmaa monien muiden joukossa. Tämä kyseinen mahdollinen tapa siinä muodossa, kuin se nykyään ilmenee, ei todellakaan ole jotain, joka olisi tullut tieteestä itsestään. ${ }^{192}$

Tämä visio kuitenkin ajaa tieteellisiä materialisteja levittämään näkemyksiään varsin laajasti popularisoimalla tiedettä ja tekemällä siitä vahvoja tulkintoja. Populaaritieteellinen kirjoittelu onkin hyvä lähde, jos haluaa etsiä tämän vision nykyaikaisia ilmaisuja.

Kuuluisa kosmologi Carl Sagan esitti tieteen kaikkivoipaisuuden vision hyvin tyylikkään metaforan avulla. Hänen mukaansa tiede on "kynttilä pimeässä". Kielikuva on voimallinen ja elegantti. Koko maailma on pimeä, harhaluuloja ja taikauskoa täynnä. Ihmiset käyttäytyvät typerästi ja itsekkäästi, koska he eivät tiedä asioiden todellisia syitä, todellista tilaa. On kuitenkin yksi pelastus, ihmisjärki, jonka parhaimpana esimerkkinä on järkeä ja todistusaineistoa seuraava tieteilijä. Perinteestä, filosofiasta ja vastustuksesta huolimatta hän etenee vääjäämättä kohti totuutta - ja totuus vapauttaa koko ihmis- 
kunnan ja ratkaisee sen ongelmat.

Uskoa tieteen kaikkivoipaisuuteen on tapana kutsua tieteisuskoksi eli "skientismiksi". Tieteisuskoa on useaa erilaisesta muotoa, joista voimakkaimmat ovat varsin radikaaleja: näissä tieteisuskon muodoissa inhimillinen toivo paremmasta tulevaisuudesta, totuudesta ja hyvästä elämästä asetetaan tieteen harteille. ${ }^{193}$ Seuraavassa erilaisia tieteisuskon muotoja heikosta voimakkaampaan:

(1) Tiedollinen tieteisusko: ainoastaan tieteellinen tieto on todellista tietoa.

(2) Ontologinen tieteisusko: ainoastaan se, mitä tiede voi tutkia, on olemassa.

(3) Arvoteoreettinen tieteisusko: ainoastaan tiede voi vastata etiikkaa koskeviin kysymyksiimme, selittää perinteisen etiikan olemassaolon ja tarjota meille uuden etiikan.

(4) Eksistentiaalinen tieteisusko: ainoastaan tiede voi vastata perimmäisiin kysymyksiimme, selittää uskonnot ja filosofiat ja tarjota meille uuden, tieteellisen filosofian.

(5) Kaikenkattava tieteisusko: ainoastaan tiede voi ja tulee ratkaisemaan kaikki aidot ongelmamme ja selittämään kaiken, mikä ei ole illuusiota.

Väitteen (1) mukaan vain tieteellisen menetelmän avulla saatua tietoa voidaan pitää totena tai epätotena. Tiedollisen tieteisuskon mukaan voimme kyllä uskoa asioita, joista ei voida saada tieteellistä tietoa mutta näitä uskomuksia ei pystytä osoittamaan oikeiksi tai vääriksi. Toisin sanoen siis vain tieteellinen tieto voi olla totta, mutta meillä voi olla paljonkin oikeutettuja uskomuksia, joiden totuudesta emme voi sanoa mitään lopullista. Astetta vahvempi tiedollisen tieteisuskon versio taas korostaa, että vain tieteellisen tutkimuksen vahvistamia uskomuksia on syytä pitää oikeutettuina. Nämä molemmat tiedollisen tieteisuskon muodot tunnustavat kuitenkin tieteen rajallisuuden: voi olla paljonkin asioita, jotka ovat tieteen ulottumattomissa, mutta emme voi tietää niistä varmasti (heikko 
tiedollinen tieteisusko) mitään tai uskoa niistä oikeutetusti (vahva tiedollinen tieteisusko) mitään.

Tiedollisen tieteisuskon keskeinen ongelma on kuitenkin se, että emme voi näyttää kokeellisesti toteen väitettä, että vain tieteellinen tieto voi osoittautua todeksi tiedoksi. Se, mihin pääsemme omaksumamme realistisen viitekehyksen sisällä, on korkeintaan se johtopäätös, että vakiintuneiden tieteenalojen tulokset ovat historian aikana johdattaneet meitä totuuden jäljille. Tästä on vielä pitkä matka väitteeseen (1), jonka mukaan minkäänlaista muuta tietoa ei voi olla. Toinen tiedollisen tieteisuskon ongelma on se, että meillä on suuri määrä arkitietoa, joka ei periaatteessakaan voi olla tieteellistä, ja tämä arkitieto ohjaa myös tieteellistä toimintaa. Arkiset tiedonhankinnan mekanismit, kuten muisti, päättely ja havainnot, pystytään oikeuttamaan ainoastaan kehällisesti. Meidän on oletettava niiden luotettavuus, jotta tieteellinen toiminta olisi mahdollista.

Tiedollista tieteisuskoa ankarampi kanta on ontologinen tieteisusko (2). Tämän väitteen mukaan vain se, mitä tiede voi tutkia, on olemassa. Väite (1) rajoittaa tietoamme, mutta ontologinen tieteisusko rajoittaa todellisuuttamme. Sen mukaan X on illuusio, jos tiede ei voi saada X:sta tietoa tai tutkia sitä. Ontologisen tieteisuskon kohdalla kysymys on siitä, jääkö mikään ideaalitieteen ulkopuolelle. Jos tulevaisuuden ideaalitiede pystyy selittämään kaiken, on ontologinen tieteisusko tosi kanta. Ontologisen tieteisuskon ongelma puolestaan on se, että siinä tehdään yhden valitun tutkimusnäkökulman pohjalta suuria yleistyksiä. Aiemmin käsittelemämme biologinen reduktionismi on juuri yksi tällainen ontologisen tieteisuskon muoto. Tieteessä menetelmällinen reduktio on hyvin tavallinen. Menetelmällisessä reduktiossa suljemme tarkastelun ulkopuolelle monia tekijöitä. Tämä on täysin perusteltu ja erittäin hyödyllinen tapa tutkia asioita. Todellisuus on liian monimutkainen tutkittavaksi kerralla, joten luonnollisesti suljemme tutkimuksemme ulkopuolelle suuren joukon erilaisia tekijöitä riippuen taustaoletuksistamme. "Vain ja ainoastaan" reduktionisti sen sijaan on sitä mieltä, että jonkin tutkimusnäkökulman tai koko tieteellisen näkökulman 
ulkopuolelle jäävät tekijät ovat illuusiota. Tällöin kuulee esimerkiksi seuraavia lausuntoja: "ihminen on vain ja ainoastaan biologinen organismi", "sinä olet vain ja ainoastaan sähköimpulsseja neuroniverkoissa" ja "uskonto on vain ja ainoastaan evoluution sivutuote". Se, että tutkiessamme ihmisen evoluutiota, tarkastelemme ihmistä biologisena organismina, ei vielä tarkoita sitä, että voisimme tästä päätellä, että ihminen on "vain ja ainoastaan" biologinen organismi (ks. luku 5.4).

Arvoteoreettinen tieteisusko (3) on puolestaan väite, jonka mukaan vain tieteen tulokset voivat vastata eettisiin kysymyksiimme, selittää perinteisen etiikan ja korvata sen. Jälleen ajatuksena on se, että voimme tieteen kautta saavuttaa tietoa moraalimme biologisesta ja fysikaalisesta perustasta ja tämän pitäisi jollakin tavalla ratkaista moraaliset ongelmamme. On kuitenkin hyvin epäselvää, miten voimme johtaa moraalisia ja yhteiskunnallisia arvoja itse tieteellisen tutkimuksen tuloksista. On toki selvää, että monet tieteen tulokset ovat relevantteja pohdinnalle yhteiskunnallisista ja moraalisista kysymyksistä, mutta on liioiteltua väittää, että tällaiset kysymykset voidaan ratkaista pelkällä tieteellisellä tutkimuksella. Voidaan myös ajatella, että ne arvot, jotka luonnehtivat tiedettä, ovat kaikkein parhaita arvojamme. Usein tieteen arvoina pidetään esimerkiksi objektiivisuutta, totuudenetsintää ja tasa-arvoa. Lisäksi voidaan olla sitä mieltä, että tieteen arvo ihmisen toimintana on muita ihmisen toimintoja tärkeämpi, jolloin korostetaan tieteen roolia yhteiskunnassa ja sen tärkeyttä koko ihmiskunnan kannalta. Arvoteoreettinen tieteisusko (3) muodostaa varsin yhtenäisen kokonaisuuden eksistentiaalisen tieteisuskon (4) kanssa. Ajatus on se, että tiede pystyy selittämään, miksi meillä on erilaisia uskontoja ja filosofioita, joiden avulla olemme yrittäneet ymmärtää paikkaamme maailmankaikkeudessa. Koska tiede tarjoaa meille totuuden maailmasta, niin se vastaa myös kysymyksiin, jotka ovat perinteisesti kuuluneet juuri filosofian ja uskontojen alaan.

Kun väitteet (1)-(4) pistetään yhteen, niin saadaan visio tieteen kaikkivoipaisuudesta: tiede kertoo meille, mitä on olemassa, mitä 
voidaan tietää ja mitä me olemme oikeutettuja uskomaan. Lisäksi se kertoo meille mitä tulee pitää oikeana ja vääränä ja mikä paikkamme ja merkityksemme maailmassa on. Ongelmamme tullaan ratkaisemaan, perinteiset filosofiat tullaan korvaamaan. ${ }^{194}$

Arkiset mielikuvat tieteen kaikkivoipaisuudesta pitävät helposti yllä kyseenalaista näkemystä tieteestä ja sen suhteesta ei-tieteeseen, kuten esimerkiksi kristinuskoon. Usein tällaisten mielikuvien tarkoituksena on ylläpitää tieteen ja tieteilijöiden yhteiskunnallista ja tiedollista arvovaltaa. Tiede kynttilänä pimeässä olettaa tietynkaltaisen historiallisen kehityksen olemassaolon: kun tieteen valo alkaa palaa, niin traditiot, uskonnon, harhat ja taikausko häipyvät. Vaikka näiden voimien lopullinen tappio ei ole vielä tapahtunut, niin on se kuitenkin vääjäämätön. Tiede tulee voittamaan ja muokkaamaan koko inhimillisen elon uudelleen, ja tällä kertaa totuuden pohjalle. Tämä ei ole sen enempää eikä vähempää kuin Valistuksen unelma, jota vielä nykyäänkin moni haluaa pitää hengissä. Olemme kuitenkin kiinnittäneet huomiota siihen, että tämän mielikuvan ydin - konfliktiteesi sekä sen historiallisessa että teoreettisessa muodossaan - ei ole hyvin perusteltu (ks. luvut 2.2 ja 2.4). Tieteen kaikkivoipaisuuden visio ei ainakaan tältä osin ole vakuuttava. Lisäksi on selvää, että Valituksen unelma ja projekti tieteen tuottamasta uudesta uljaasta yhteiskunnasta ja sen yhtenäisestä rationaalisesta perustasta on varsin peruuttamattomalla tavalla sortunut omana aikanamme. Tieteen ja tekniikan valtava kehitys 1700-luvulta eteenpäin johti kyllä hyvinvointiin, mutta samalla se johti myös ihmiskunnan historian hirvittävimpiin sotiin ja järjettömään tuhoamiseen. En tietenkään väitä, että nämä olisivat olleet tieteen ja tekniikan syytä, sillä näin ei todellakaan ole. Väitän kuitenkin, että tieteen kaikkivoipaisuuden visio ei voi pestä käsiään näistä hirveyksistä: toimivat ja totuudenmukaiset tieteelliset teoriat eivät vielä yksistään poista tai ratkaise ongelmiamme, ne eivät korvaa uskontojamme tai filosofioitamme, eivät toimi kaiken tietomme lähteenä eivätkä anna meille uusia arvoja. Tiede ei saa dominoida muuta kulttuuria ja vaatia tiedollista kaikkivaltiutta. 
Tieteisusko ja usko tieteen kaikkivoipaisuuteen eivät ole tieteen tuloksia, vaan sekoitus erilaisia filosofisia tulkintoja tieteen tuloksista ja sen menetelmien luonteesta yhdistettynä tieteelliseen materialismiin. Se, että pidämme tässä tieteisuskoa ja tieteellistä materialismia enemmän filosofiana kuin tieteenä, ei tietenkään tarkoita sitä, että ne olisivat automaattisesti virheellisiä. Se, että jotkut väitteet ovat maailmankatsomuksellisia tai filosofisia enemmän kuin tieteellisiä, ei tarkoita sitä, että nämä väitteet olisivat virheellisiä. Päinvastoin monet filosofit ovat vakuuttuneita, että luonnontieteellinen menetelmä on ylivertainen muihin tiedonhankinnan keinoihin nähden ja että erilaiset naturalistiset maailmankatsomukset ovat muita maailmankatsomuksia parempia. Se, mitä haluan tässä sanoa, on se, että kyseessä on nimenomaan filosofinen keskustelu, josta ei selvitä vetoamalla yksistään tieteen tuloksiin. Näin ollen on vastustettava ajatusta, jonka mukaan tieteen kaikkivoipaisuuden puolustajat olisivat nimenomaan tieteen puolustajia ja heidän vastustajansa sen sijaan tieteen vihollisia. Vastakkainasettelu ei missään nimessä saa olla näin yksinkertainen. Meillä on hyviä syitä olla tieteen kaikkivoipaisuuden ja tieteisuskon suhteen hyvin kriittisiä ja näin ovat monet ajattelijat aina uskontojen edustajista moniin ateisteihin asti tehneetkin - ja hyvin perustein. Tieteisuskon ja sen vastustajien kiistassa ei siis ole kyse "tieteen ja uskonnon" tai "tieteen ja tieteenvastaisuuden" vastakkainasettelusta, vaan pikemminkin erilaisista tavoista ymmärtää tieteen luonne ja sen rooli ihmisen elämässä. Meidän siis ei tule niellä pureskelematta väitteitä siitä, että tieteellinen materialismi ja tieteisusko ovat nimenomaan tiedettä, tieteen välttämättömiä ennakko-oletuksia tai sen kiistämättömiä tuloksia. Tieteellinen materialisti usein käärii näkemyksensä tällaiseen pakettiin, markkinoi ne tieteen viimeisinä sanoina ja vaatii niille auktoriteettia nimenomaan siksi, että ne ovat tiedettä.

Tieteen kaikkivoipaisuuden puolustajilla on tapana vedota tällaisissa yhteyksissä tieteen "objektiivisuuteen", "neutraalisuuteen" tai arvovapauteen. Tällöin ajatellaan, että tieteen tekeminen on riippumatonta tekijöidensä arvoista tai maailmankatsomuksesta. Toi- 
sinaan tieteen "neutraalisuuteen" tai "objektiivisuuteen" vedotaan myös yhteyksissä, jossa puhutaan tieteen tulosten suuresta todistusvoimasta: kaikille on rationaalista uskoa tieteen tuloksiin, koska ne on saavutettu menetelmillä, jotka eivät ole sitoutuneet mihinkään maailmankuvaan. Nämäkin väitteet ovat varsin moniselitteisiä. Objektiivisuutta pidetään tavallisesti hyvän tieteen tuntomerkkinä. Ilmaisusta tulee ensimmäisenä mieleen jonkinlainen puolueeton tarkkailija, jolla ei ole minkäänlaisia ennakko-oletuksia kohteestaan. Tämä on se, mihin arkikeskusteluissa koko ajatuksella usein pyritään. Tieteen tulos ratkaisee jonkin kysymyksen lopullisesti, koska se on "puolueetonta" tietoa. Selvää kuitenkin on, että tämä ajatus on hyvin harhaanjohtava ja sekoittaa keskustelua enemmän kuin selventää. Kuten olemme jo aiemmin nähneet (ks. luvut 3.1 ja 3.2), ajatukset tieteestä "puhtaisiin havaintoihin" perustuvana toimintana sekä tietäminen "tarkkailemisena" ovat varsin heikosti perusteltuja. Näin ollen meidän ei tule hyväksyä ykskantaan yleistystä "tiede on puolueetonta ja neutraalia". Tieteen objektiivisuudella ei voida perustellusti tarkoittaa "puolueetonta" tai "ennakko-oletuksetonta" tarkkailua, koska kaikki tietäminen edellyttää ennakko-oletuksia ja ennakkoehtoja.

Luonnollisempaa onkin ymmärtää tieteen objektiivisuus "intersubjektiivisuutena". Vaatimus on se, että tieteen menetelmät ja tulokset ovat avoimia kenen tahansa arvioinnille, joka riittävästi perehtyy asiaan. Tavat, jolla aineisto on kerätty, kokeet on tehty ja niistä on johdettu tulokset, ovat avoimia arvioinnille ja tämä arviointi ei edellytä itse menetelmien tuntemuksen lisäksi mitään erityistä tietolähdettä. Intersubjektiivisuuden vaatimus on näin ollen aiemmin tunnistamamme kolmas tieteen tuntomerkki (ks. 3.1). Lisäksi tieteen intersubjektiivisuuteen kuuluu se, että kukaan yksittäinen tutkija ei voi väittää tutkimustulostaan "tieteelliseksi", jos se ei ole läpäissyt tiedeyhteisön arviointia. Tämä ei tietenkään edellytä täydellistä yksimielisyyttä, mutta se kyllä edellyttää yksittäisen tutkijan tutkimustulosten ja menetelmien arviointia ainakin oman tieteenalan tutkijoiden keskuudessa. 
Se, että ymmärrämme neutraalisuuden ja objektiivisuuden intersubjektiivisuutena, on kuitenkin vain yksi puoli näitä käsitteitä. Vielä on nimittäin vastaamatta kysymys tieteen arvosidonnaisuudesta tai arvovapaudesta, johon neutraalisuus ja objektiivisuus myös liitetään. ${ }^{195}$ Voimme siis kysyä, missä mielessä tiede on vapaa tai sidottu maailmankatsomuksellisiin näkemyksiin. Tähän kysymykseen on kolme perusvastausta ja ne perustuvat eri näkemyksiin tieteellisen toiminnan luonteesta:

(1) Positivismi: tieteen menetelmä ja sen tulokset ovat täysin riippumattomia maailmankatsomuksellisista tai muista perimmäistä todellisuutta koskevista oletuksista.

(2) Relativismi: tieteen menetelmät ja tulokset ovat täysin maailmankatsomuksellisten tai muiden perimmäistä todellisuutta koskevien oletusten sanelemia.

(3) Maltillinen realismi: maailmankatsomukselliset näkemyksemme vaikuttavat toisinaan enemmän ja toisinaan vähemmän tieteen menetelmiin ja tuloksiin mutta myös todellisuus vaikuttaa niihin.

Aiemmin kuvaamamme positivistisen tieteen- ja tiedonkäsityksen mukaan (ks. luku 3.2) maailmankatsomuksellisille oletuksille ei yksinkertaisesti ole osaa tieteessä. Tieteellinen tieto johdetaan havainnosta loogista päättelyä käyttäen. Näin saatu tieto on varmaa ja arvoneutraalia. Positivismin sortuminen tieteenkäsityksenä kuitenkin pakottaa meidät hylkäämään tämän näkemyksen, koska on käynyt selväksi, että tieto - ei edes tieteellinen tieto - ole mahdollista ilman ennakko-oletuksia ja maailmankatsomuksellisia oletuksia. Tämä johtopäätös on johtanut monet ajattelemaan, että tieteen tulokset ovat täysin maailmankatsomusten ja muiden oletusten (minkä tahansa paitsi itse todellisuuden) määräämiä. Näin heistä on tullut relativisteja. Olemme kuitenkin jo aiemmin kiinnittäneet huomiota siihen, että vahvat relativismin ja konstruktivismin muodot ovat erittäin ongelmallisia (ks. luku 3.3). Meillä on siis hyviä syitä hyväk- 
syä jonkinlainen realismi: tiede on inhimillistä toimintaa ja se on näin aina sidoksissa historialliseen aikaan ja paikkaan sekä niiden yksilöiden ja yhteisöjen maailmankatsomuksiin, jotka tiedettä tekevät. Relativisti on siis siinä mielessä oikeassa, että tiede on todella maailmakatsomuksista ja arvoista riippuvaista toimintaa. Relativisti on kuitenkin väärässä siinä, että maailmankatsomukset ja arvot lopulta määräisivät tieteen tulokset. Meillä on realismin nojalla hyviä syitä uskoa siihen, että tiede on tekemisissä todellisuuden kanssa ja ainakin toisinaan itse todellisuus vaikuttaa vahvasti siihen, millaisia tuloksia tiede tuottaa. Tämä prosessi ei kuitenkaan tapahdu maailmankatsomuksistamme ja arvoistamme riippumatta, vaan pikemminkin niistä huolimatta.

Meillä on useita eri tapoja ymmärtää edellä kuvattu maltillinen realismi tieteen arvovapaudesta. ${ }^{196}$ Ensimmäisenä on erotettava tieteen arvovapaus sen tulosten arvoneutraalisuudesta:

(1) Tiede on arvovapaa (vastakohta arvosidonnainen) silloin, kun se ei ehdottomasti sitoudu yhteenkään maailmankatsomukseen.

(2) Tiede on arvoneutraali (vastakohta arvorelevantti) silloin, kun sen tulokset eivät ole relevantteja jonkin maailmankatsomuksen kannalta.

Tämä erottelu erittäin tärkeä pitää mielessä. On hyvinkin mahdollista, että tieteentekijät eivät ole tutkimuksessaan sitoutuneet mihinkään erityiseen maailmankatsomukseen, mutta heidän tuloksensa ovat kuitenkin jonkin maailmankatsomuksellisen näkemyksen kannalta tuhoisia. Näin ollen siis siitä, että jokin tieteen tulos uhkaa vaikkapa perinteistä raamatuntulkintaa ei voida päätellä siihen, että kyseisen tieteenalan edustajat olivat väärällä tavalla sitoutuneita uskonnonvastaiseen tai johonkin muuhun vastaavaan maailmankatsomukseen. Jokin tieteen tulos voi olla samaan aikaan arvovapaa ja arvorelevantti: arvovapaa tutkimuskin voi johtaa tuloksiin, jotka ovat arvorelevantteja jonkin maailmankatsomuksen suhteen. Olennaista on huomata, että arvoneutraalisuus määrittyy aina suhteessa 
johonkin maailmankatsomukseen. Arvovapaus sen sijaan on tieteen sisäinen kysymys. Jos haluamme vastata kysymykseen siitä, onko jokin tietty tieteenala tai tutkimustulos arvovapaa arvosidonnaisuuden sijaan, voimme tehdä sen tarkastelemalla, miten tutkimus on tehty ja millaisia oletuksia siinä on käytetty. Jos taas haluamme tietää onko jokin tieteenala tai tutkimustulos arvoneutraali, meillä pitää olla mielessä jonkin maailmankatsomus, jota vasten kysymme tätä kysymystä.

Edellisen perusteella voidaan sanoa, että tiede ei ole kristillisen teologian suhteen arvoneutraali vaan arvorelevantti, koska monet tieteen tulokset aiheuttavat ongelmia kristilliselle teologialle. Tästä ei kuitenkaan voida päätellä, etteikö tiede olisi arvovapaa. Itse kysymys arvovapaudesta eli siitä, onko tiede lähtökohtaisesti sitoutunut johonkin tiettyyn maailmankuvaan, vaatii lisää selvennystä. Voidaan kysyä, miltä osin (jos miltään osin) tiede on arvovapaata. ${ }^{197}$ Tieteellisessä tutkimuksessa voidaan erottaa neljä vaihetta:

(1) ongelmanasetteluvaihe,

(2) tutkimuksen kehittämisen vaihe

(3) oikeuttamisen vaihe,

(4) soveltamisen vaihe. ${ }^{198}$

Nämä vaiheet eivät välttämättä seuraa toisiaan ajallisesti, mutta ne voidaan erottaa käsitteellisesti toisistaan. Ongelmanasetteluvaiheessa tutkija (ja tutkijat) päättävät, mitkä asiat ovat tutkimisen arvoisia. Ongelmanasettelu ei kuitenkaan ole mikään tutkijoiden yksinoikeus: siihen, mitä pidetään tärkeinä tutkimusongelmina, vaikuttavat esimerkiksi saatavilla olevat resurssit, yhteiskunnallinen tilanne, rahoittajien politiikka, paikalliset tieteelliset traditiot ja meneillään olevat väittelyt. Olennaista on huomata, että näistä tekijöistä on osa tieteen sisäisiä (esimerkiksi tieteelliset väittelyt ja koulukunnat) ja toiset taas tieteen ulkopuolisia (esimerkiksi yhteiskunnallinen tilanne, rahoittajien politiikka). Tutkimuksen kehittämisen vaiheessa tutkija valitsee menetelmänsä, muotoilee oletuksensa ja testaa niitä. 
Tähän vaiheeseen kuuluvat myös taustateorioiden valinta, tutkimuskohteen ja tutkimuksen tulosten käsitteellistäminen. Kolmannessa vaiheessa, oikeuttamisen vaiheessa, tutkija pyrkii perustelemaan tiedeyhteisölle käyttämänsä menetelmät, niiden sopivuuden ja osoittamaan, miksi tutkimustulokset tulisi hyväksyä. Viimeiseksi voidaan puhua myös tutkimustulosten soveltamisen vaiheesta, jossa esimerkiksi pannan täytäntöön tutkimuksen tuloksena syntyneitä toimintasuosituksia tai teknisiä innovaatioita.

Tiukan tieteen arvovapauden puolustajan - esimerkiksi juuri positivistin - mukaan tieteen arvovapaus ilmenee kaikilla neljällä osa-alueella. Tiede on maailmankatsomuksista riippumaton siinä, miten se asettaa ja muotoilee ongelmansa, menetelmissään, tulostensa perusteluissa ja soveltamisessa. Relativistin mukaan taas tiede on arvosidonnainen jokaisessa neljässä vaiheessa. Sen sijaan maltillisen realismin mukaan tieteen tulisi olla arvosidonnaista vaiheissa (1), (2) ja (4) mutta arvovapaata vaiheessa (3). Tämä vaatii hiukan selittämistä.

Kiinnitimme edellä huomiota siihen, kuinka ongelmanasetteluvaihe on sidoksissa vahvasti sekä tieteen sisäisiin että tieteen ulkoisiin tekijöihin. Esimerkiksi pelkkä yhteiskunnallisten tekijöiden vaikutus rahoittajiin voi ohjata varsin merkittävästi tutkimusongelmien ja tutkimuksen suuntaa. Esimerkkinä voisi ottaa vaikkapa terrorismin. Viime vuosikymmenen aikana terrorismin tutkimukseen on suunnattu erittäin paljon rahaa eri ihmis- ja yhteiskuntatieteiden sekä käyttäytymistieteiden aloilla. Yhteiskunnallinen ja poliittinen kiinnostus ilmiötä kohtaan on synnyttänyt paineen saada asiasta lisää tietoa. Tämä puolestaan on kanavoinut rahaa tutkimukseen ja saanut monet tutkijat suuntaamaan tutkimustaan tähän suuntaan. Toinen tapa ajatella asiaa on kiinnittää huomio tieteentekijöihin itseensä. Tieteentekijän oma maailmankatsomus vaikuttaa hänen kiinnostuksensa kohteisiin ja sitä kautta siihen, mitä hän pitää kiinnostavina tutkimusongelmina. Ongelmanasettelu ei siis toimi tyhjiössä ja tämän tosiseikan tunnustaminen onkin synnyttänyt hyvin paljon kiinnostavaa tutkimusta tieteen- ja teknologian tutkimuksessa. ${ }^{199}$ On siis 
syitä ajatella, että ongelmanasetteluvaiheessa emme voi sulkea ulos erilaisia ei-tieteellisiä intressejä tulevat ne sitten yhteiskunnasta, tieteenharjoittajista itsestään tai jostakin muualta. Näin ollen ongelmanasetteluvaihe ei ole arvovapaa vaan arvosidonnainen.

Tutkimuksen kehittämisen vaihetta voidaan pitää myös arvosidonnaisena monesta eri syystä. Yksi näistä on tietysti se, että ei ole mitään yhtä yhtenäistä testattavien hypoteesien keksimisen tapaa (ks. luku 3.5). Tutkimuksen teoriavalinnat, käsitteellistäminen, testaaminen ja tulkitseminen ovat riippuvaisia taustaoletuksista, jotka taas puolestaan riippuvat yksittäisten tutkijoiden oletuksista. On helppo nähdä myös kuinka soveltamisvaihe on arvosidonnainen samalla tavalla kuten ongelmanasetteluvaihe: molempiin vaikuttavat vahvasti yhteiskunnan ja yksittäisten tieteilijöiden intressit. Tässä kohdassa on huomattava, että tutkimus voi tuottaa luotettavia tuloksia siitä huolimatta, että se on jonkin maailmankatsomuksen tai ideologian motivoima. Se, että tutkija suosii jotain maailmankuvaa, ei vielä tarkoita sitä, että hän esittää tosiasiat väärin eli tekee huonoa tiedettä. Se siis, että väitän vaiheita (1), (2) ja (4) arvosidonnaisiksi, ei tarkoita sitä, että voisimme tällä perusteella torjua tieteellisen tutkimuksen tulokset.

Maltillisen realismin ydin on kuitenkin se, että vaiheen (3), eli oikeutusvaiheen, voidaan katsoa olevan arvovapaa. Tutkimustuloksia perusteltaessa on tärkeää pyrkiä vakuuttamaan mahdollisimman moni tiedeyhteisön jäsen ja käyttää yleisesti hyväksyttyjä perustelujen ja menetelmien muotoja. Jos tutkimustulokset ja menetelmät ovat sidoksissa yhteen ainoaan tarkasti rajattuun maailmankatsomukselliseen näkemykseen, se ei tule hyväksytyksi. Voidaan siis väittää, että tieteellisiä tuloksia perusteltaessa olisi syytä olla mahdollisimman arvovapaa. Ajatus on se, että käytetyt perustelujen muodot ovat varsin pitkälle arvovapaita ja niiden perusteena on niiden aiempi toimivuus ja yleisyys.

Edellä piirtämämme tieteen arvovapautta ja arvosidonnaisuutta koskevat kuvan mukaan tieteentekijöillä voi olla erilaisia todellisuus- ja tietokäsityksiä, jotka ohjaavat sitä, millaiselle alalle tutkija 
hakeutuu, mitä hän pitää kiinnostavana tutkimuskohteena ja millaisia välineitä hän käyttää ja miten hän soveltaa tutkimuksensa tuloksia. On kuitenkin olemassa tieteen osa-alue, jossa arvovapaus toteutuu (tai ainakin sen pitäisi toteutua): yhteiset perustelun menetelmät. Näkemyksemme mukaan tiede tuo yhteen erilaisin maailmankatsomuksin varustettuja ihmisiä, jotka pyrkivät tekemään tutkimusta ja perustelemaan niiden tulokset tavoilla, jotka vetoavat mahdollisimman moniin. Tieteeltä siis ei tule vaatia liikaa homogeenisuutta: tieteen sisällä ei ole konsensusta kaikista laaja-alaisista ennakko-oletuksista, jotka ovat sen harjoittajille välttämättömiä, eikä konsensusta sen kaikkien tulosten pätevyydestä.

Jos torjumme ajatukset tieteen kaikkivoipaisuudesta ja täydellisestä arvovapaudesta, ei meidän kuitenkaan tule päätyä relativismiin. Kukaan ei voi kieltää sitä, että tiede toimii: se tuottaa teorioita, jotka ennustavat luonnon käyttäytymistä ja mahdollistavat siihen vaikuttamisen. Tiede on mullistanut maailmankuvamme ja se on pystynyt korjaamaan itseään ja omia virheitään. Olisi siis varsin suuri virhe unohtaa koko tiede vain sillä perusteella, että tieteisusko ei ole perusteltua tai että käytännöllinen tieteenharjoitus osoittautuu toisinaan vähemmän arvovapaaksi. On monia hyviä syitä hylätä tieteisusko ja tieteen kaikkivoipaisuus, mutta samaan aikaan on myös monia hyviä syitä ajatella, että tiede on relevantti monien ihmiskuntaa vaivaavien kysymysten, ongelmien ja haasteiden osalta. Kaikkein suurin syy on tietysti se, että tiede on ollut erittäin tärkeässä roolissa sekä tekniikan että koko länsimaisen kulttuurin kehittyessä ja se on todellakin ratkaissut monia käytännöllisiä ja teoreettisia ongelmiamme. Teologisesta näkökulmasta on myös hyviä syitä kannattaa "korkeaa näkemystä" tieteestä. Luonnon teologian edustajille on tavallista ajatella, että inhimillinen järki ja muut tiedonhankinnan ja tiedonkäsittelyn kyvyt kuuluvat Jumalan suunnitelmaan. Tähän suunnitelmaan kuuluu myös se, että ihminen käyttää näitä kykyjä maailmankaikkeuden järkevän rakenteen ymmärtämiseen ja itsensä, lähimmäistensä ja planeettansa hyvinvoinnin edistämiseen. 


\section{Kirjallisuutta}

Lyhyt suomenkielinen johdanto ateismin luokitteluun ja terminologiaan on Niiniluoto 2003. Filosofisesta ateismista katso esimerkiksi Martin 1990, 2007. Erinomainen filosofinen debatti teistin ja ateistin välillä on Smart \& Haldane 2003. Uusateismiin johdattavat esimerkiksi Dawkins 2006 ja Stenger 2009. Uusateisteja kritisoivat esimerkiksi Fergusson 2009, Hart 2009 ja Williams 2009. Visala 2008 on katsaus uusateistien ja heidän vastustajiensa näkemyksiin tieteen ja uskonnon suhteesta. Monumentaalinen ja ajankohtainen katsaus viimeaikaisiin teismin filosofiin puolustuksiin on Craig \& Moreland 2009. Tieteen kaikkivoipaisuutta kritisoivat esimerkiksi Midgley 1992, 2002, 2006 ja Stenmark 2001. Stenmark 2004 sisältää keskustelua tieteen arvovapaudesta ja objektiivisuudesta. 



\section{LOPPUSANAT: LUONNON TEOLOGIAN OPETUKSIA JA HAASTEITA}

Tämä kirja on käsitellyt tieteen ja teologian suhdetta ja sitä koskevaa keskustelua sellaisena, kun sitä lähinnä englantia puhuvassa maailmassa käydään. Tässä keskustelussa on esitetty monia erilaisia kantoja, joista vain osaa on tässä kirjassa käsitelty. Olen valinnut erityisesti yhden perspektiivin tieteen ja teologian suhteeseen, jota olen sitten käyttänyt keskustelun jäsentämiseen. Tämä perspektiivi on se, mitä olen kutsunut luonnon teologiaksi. Uskon luonnon teologian sopivalla tavalla korostavan sekä tieteen ja teologian erilaisuutta että niiden mahdollisia yhtäläisyyksiä. Tarkoitukseni ei kuitenkaan ole ollut väittää, että luonnon teologia olisi ainoa mahdollinen lähestymistapa.

Luonnon teologia on velkaa erityisesti viime vuosikymmenien kehitykselle analyyttisessä filosofiassa. Filosofinen teologia ja uskonnonfilosofia elävät tällä hetkellä merkittävää renessanssia englanninkielisessä maailmassa ja monet sen keskusteluista ovat tieteen ja teologian suhteen osalta hyvin merkittäviä. Tällaisia ovat esimerkiksi väittelyt suunnitteluargumentista, fysikaalisesta hienosäädöstä, kosmologisesta argumentista sekä teologista realismia koskevat menetelmälliset keskustelut. Analyyttisen filosofian kehitys muodostaa sen taustan, jota vasten nykyistä tieteen ja teologian suhteen tarkastelua tehdään. Filosofinen kehitys pois positivismista kohti realismia ja positivismiin liittyneen tietoteorian romahdus loivat uuden tilan, jota erilaiset mallit (tieteelliset, uskonnolliset, filosofiset) ovat alkamassa täyttää. Tämä kehitys on luonut valtavia mahdollisuuksia 
teologialle - mahdollisuuksia, joista vain kaikuja on tähän mennessä kantautunut Suomeen.

Toivon, että tähän mennessä on tullut selväksi se, että tieteen ja teologian suhde uskomusten järjestelminä on monimutkainen. Yksinkertaistukset, kuten konflikti tai harmonia, ovat ongelmallisia näkemyksiä. Olemme nähneet, kuinka jotkut tieteelliset ja teologiset näkemykset ovat yhtäpitäviä, toiset taas ristiriidassa keskenään ja jotkut taas toisistaan riippumattomia. Näin ollen meidän ei pitäisi purematta niellä yleisiä ja yksinkertaisia toteamuksia "tieteen ja uskonnon suhteesta", vaan pikemminkin meidän tulisi tarkastella yksittäisiä teorioita ja teologisia näkemyksiä. Meidän tulisi olla myös erittäin kriittisiä sellaisia filosofioita kohtaan, jotka jo lähtökohdissaan joko erottavat tieteen ja teologian toisistaan täydellisesti tai sitten pitävät niitä automaattisesti toisensa poissulkevina.

Eräs syy, miksi olen valinnut juuri luonnon teologian perspektiivin, on se, että olen havainnut itsenäisyysmallin olevan monien suomalaisten teologien perusvastaus tässä kirjassa esiteltyihin ongelmiin. Jotkut teologit pakenevat liian helposti "uskon äidinkielen" taakse silloin, kun pitäisi puhua havaittavasta todellisuudesta. Vedotaan mysteeriin heti, kun joku yrittää kritisoida uskonnollisia ja teologisia näkemyksiä "ulkopuolelta". Näin toimiessaan itsenäisyysmallin kannattaja saa sen, mitä hän tilaa: teologia eristetään omaksi elämänalueekseen, jolla ajatellaan olevan omat järkevyyden ja perustelun kriteerinsä. Hinta on kuitenkin erittäin korkea: teologisten näkemysten tiedollinen yhteys muihin tiedon aloihin lakkaa ja samalla lakkaa myös teologian kyky vaikuttaa uskonnollisiin käytäntöihin ja tavalliseen elämään. Kuvaamani luonnon teologian mukaan tällainen näkemys teologian riippumattomuudesta edustaa sekä huonoa filosofiaa että puutteellista teologiaa. Luonnon teologian keskeisenä pyrkimyksenä on saada teologinen ajattelu vuorovaikutukseen tieteellisen tiedon kanssa. Perusajatus on se, että luontoa koskeva tieto on jatkuvasti vuorovaikutuksessa teologian kanssa ja asettaa rajoja sille, millaisia teologisia näkemyksiä meidän tulisi hyväksyä. Emme voi myöskään perustellusti pitää teologisia 
tiedonhankinnan menetelmiä tai järkevyyden kriteereitä täysin tieteen vastaavista riippumattomina. Me ihmiset muodostamme uskomuksia ja koemme maailman suhteellisen samanlaisen biologisen ja psykologisen välineistön avulla, ja nämä samat välineet toimivat niin teologiassa kuin arkisessa uskonnollisessa elämässäkin. Näiden välineiden toimivuus ja menestys, yhteinen ihmisyytemme, asettavat rajoja sille, millaisia järkevyyden kriteereitä voimme totuuden tavoittelussa hyväksyä.

Luonnon teologia korostaa omaa paikkaamme osana traditiota ja jotakin tiettyä ihmisyhteisöä. Meillä ei ole yhtä ainoata ja oikeata tapaa oikeuttaa ja perustella tietolähteitämme. Meillä ei myöskään ole yhtä ainoaa horjumatonta tiedon perustaa, jolle kaikki tieto rakentuu. Tietämisemme on siis aina sidottua tiettyyn kontekstiin. Tästä ei kuitenkaan seuraa se, että tietomme viime kädessä jäisi tämän kontekstin vangiksi. Todellisuus on olemassa ja voimme saada tietoa siitä. Todellisuus vaikuttaa näkemyksiimme, vaikka se ei olekaan ainoa näkemyksiimme vaikuttava tekijä. Ainoa vaihtoehtomme on siis aloittaa siitä tilanteesta, missä kulloinkin olemme, ja kulkea siitä eteenpäin kriittisesti arvioiden omaa näkemystämme keskustelussa toisten kanssa. Järki ei siis vaadi meitä rakentamaan näkemystämme erehtymättömälle perustalle, vaan arvioimaan näkemyksiämme sitä mukaa, kun opimme uutta tietoa. Ward kirjoittaa:

järki voi vain vaatia, että näitä menetelmiä seurataan [päättelyn periaatteita]. Se ei voi sanella yhteisiä tuloksia, sillä nämä tulokset riippuvat siitä, millaista painoarvoa annamme millekin tiedolle, millaista viitekehystä käytämme kokemuksen monimutkaisuutta jäsentämään ja millaisia arvioita meillä on siitä, mikä on elämässä tärkeää. Uskonnolliset maailmankatsomukset eivät ole rationaalisia siksi, että tuottaisivat argumentteja, jotka "todistavat" kaikille pystyville ihmisille niiden totuuden. Uskonnolliset maailmankatsomukset ovat rationaalisia, koska ne on rakennettu ja muodostettu kriittisen reflektion avulla, jossa sovelletaan järkeviä, monipuolisille tulkinnoille avoimia kriteereitä. ${ }^{200}$ 
Jos omaksumme tällaisen käsityksen järkevyydestä, niin emme voi olettaa välttämättä päätyvämme tieteen ja teologian keskustelussa lopputulokseen, josta kaikki järkevät ihmiset olisivat yhtä mieltä. Voi olla niin, että ristiriitatilanteessa molemmat osapuolet voivat pitää kiinni omista näkemyksistään ja olla järkeviä. Voi siis olla, että kaksi järkevää ihmistä uskoo päinvastaisia asioita kykenemättä vakuuttamaan toisiaan. Tästä ei saa kuitenkaan seurata relativismi, konstruktivismi tai mikään muukaan ismi, jonka mukaan totuutta ei ole tai todellisuus on meille luoksepääsemätön. Kokemus ja terve järki osoittavat, että voimme edistyä ymmärryksessämme ja muuttaa näkemyksiämme. Toisinaan todellisuus vastaa kysymyksiimme ja korjaa näkemyksiämme. Toiset voivat tietää minua enemmän ja minä voin erehtyä, joten minun tulee kuunnella heitä.

Maailmankatsomuksia koskeva keskustelu on vaikeudestaan huolimatta kuitenkin mahdollista ja sen päämääränä tulee pitää totuutta. Totuuden tavoittelusta on syytä pitää kiinni siitäkin huolimatta, että maailmankatsomuksia - kehyksiä, joilla jäsennämme kokemustamme maailmasta - ei voida yksiselitteisesti osoittaa tosiksi tai epätosiksi; ne voivat ainoastaan saada tukea tai joutua hankaluuksiin. Voimme arvioida maailmankatsomuksia (ja väitellä niistä) esimerkiksi arvioimalla sitä, miten ne on käsitteellistetty ja millaisia perusteita niiden puolesta on esitetty. Voimme myös arvioida miten jokin maailmankatsomus suhtautuu muihin vastaaviin ja saatavilla olevaan tietoon (josta osa on tietysti tieteellistä ja osa taas ei). Nämä arvioinnin ja väittelyn kriteerit eivät ole lopullisia, mutta niistä voidaan ainakin jossakin määrin olla yhtä mieltä. Meillä on välineitä, joilla arvioida argumentteja, ja menetelmiä, joilla arvioida maailmankatsomusten sisäistä koherenssia. Nämä välineet eivät anna meille kaikki ihmiset vakuuttavia lopputuloksia, vaan enemmän tai vähemmän hyviä perusteita.

Olennaista on ymmärtää se, että maailmankatsomuksellisessa keskustelussa pitää esittää perusteita ja toisten haasteisiin pitää vastata, vaikka samaan aikaan tunnustaisikin, että yksimielisyyttä on vaikea saavuttaa. Juuri tämä piirre luonnehtii filosofista keskustelua 
ylipäänsä. Filosofi Colin McGinnin mukaan

toisinaan voimme sitoutua filosofisiin väitteisiin, mutta usein voimme vain ottaa ne vakavasti. Toivomme löytävämme riittäviä perusteita sen puolesta, että voisimme oikeasti uskoa johonkin filosofiseen väitteeseen, mutta lopulta voimme vain yrittää päästä tilaan, jossa suhtaudumme tähän väitteeseen kunnioituksella. Voimme pitää sitä ehdokkaana totuudeksi. ... Valtaosa filosofisesta keskustelusta koostuu yrityksistä vakuuttaa toiset ottamaan vakavasti oletus, jota itse sattuu pitämään vakuuttavana syistä, joita on hyvin vaikea pukea sanoiksi tai osoittaa yksiselitteisesti. ${ }^{201}$

Monien mielestä McGinnin näkemys filosofisen keskustelun mahdollisuuksista on liian kielteinen. Emmekö todellakaan pysty sen parempaan kuin siihen, että vastapuoli ottaa vakavasti oman näkemyksemme? Toisaalta taas arkikokemus osoittaa, että jo tähänkin tilanteeseen pääseminen vaatii hyvin paljon. On hyvin tavallista, että itse kukin on vakuuttunut vastapuolen järjettömyydestä. On hyvä olla realisti sanan arkikielisessä merkityksessä: ihmisen älylliset kyvyt ovat rajallisia ja rajallinen on myös se aika, jonka voimme käyttää tällaisten asioiden ajattelemiseen. Näkemystemme rajallisuus ei kuitenkaan tarkoita sitä, että maailmankaikkeus olisi jonkinlainen lopullinen mysteeri. Totuus on kyllä olemassa, vaikka kykymme tavoittaa se olisikin rajallinen. 



\section{S A N A STO}

\section{Agnostisismi}

Näkemys, jonka mukaan meidän on pidättäydyttävä ottamasta kantaa Jumalan olemassaoloon. Radikaalin agnostisismin mukaan kannanotoista tulee pidättäytyä, koska Jumalaa koskeva puhe on järjetöntä ja merkityksetöntä. Emme voi ottaa kantaa epäkoherentin näkemyksen puolesta tai sitä vastaan. Tämä näkemys luokitellaan usein jonkinlaiseksi ateismin muodoksi. Heikon agnostisismin mukaan perusteet kumpaankin suuntaan ovat niin heikot, että on perusteltua olla ottamatta kantaa. Toinen heikon agnostisismin muoto väittää, että Jumalan olemassaolo on sellainen, ettemme voi periaatteessakaan tietää siitä mitään. Näin ollen siihen ei tule ottaa kantaa. Käytännöllisen agnostisismin mukaan Jumalan olemassaolo on kysymys, joka ei ole kiinnostava eikä merkityksellinen.

\section{Antirealismi}

Kutsumme antirealistiksi sellaista henkilöä, joka väittää, että jokin tiedon alue ei ole kosketuksissa todellisuuden kanssa, tai uskoo, ettei todellisuutta ylipäänsä ihmisestä riippumattomana ole olemassa. Antirealismia voi esiintyä eri alueilla. Ontologisen antirealistin (konstruktivismi ja relativismi) mukaan ihmisestä riippumatonta todellisuutta ei ole olemassa, vaan ihmisten toiminta "rakentaa" tai synnyttää todellisuuden. Aleettinen antirealisti uskoo, että ihmiset eivät voi koskaan tietää totuutta tai että totuutta ei ole olemassa. Tieteellisen antirealismin mukaan tieteen teoriat eivät tavoita todellisuutta, vaikka ne saattavatkin olla käyttökelpoisia ja toimivia (instrumentalismi). Teologisen antirealistin mukaan teologiset väitteet eivät viittaa ihmisen mielestä riippumattomaan Jumalaan, vaan johonkin muuhun (esim. tunteisiin tai kokemuksiin).

\section{Ateismi}

Näkemys, jonka mukaan Jumalan olemassaoloon ei ole syytä uskoa. Vahva ateisti uskoo, että Jumala ei ole olemassa. Heikko ateisti ei usko Jumalan ole- 
massaoloon. Tieteellinen ateisti uskoo, tieteen osoittavan, että Jumala ei ole olemassa. Filosofinen ateisti voi ajatella, että ateismi on teismiä parempi kanta, koska väitteet teismin puolesta epäonnistuvat.

\section{Atomismi}

Todellisuuden perimmäistä luonnetta koskeva näkemys, jonka mukaan kaikki, mikä on olemassa, koostuu jakamattomista materian kappaleista ja näiden kappaleiden vuorovaikutuksista absoluuttisessa avaruudessa. Näin ollen vain nämä pienimmät kappaleet, "atomit", ovat olemassa ja kaikki muut maailman havaitut ominaisuudet (kuten esimerkiksi värit) ovat ihmisen havaintojärjestelmien tuotetta (korpuskulaarinen filosofia). Synnytti vahvan erottelun aineen (atomit) ja mielen (ajattelu) välillä. Toisinaan puhutaan myös klassisesta materialismista. Lähteenä erityisesti Isaac Newtonin fysiikka ja Rene Descartesin filosofia. Ks. materialismi.

\section{Darwinismi}

Charles Darwinin muotoilema joukko teorioita, joiden tarkoituksena oli selittää biologisen maailman kehitystä ja luonnetta (biologinen evoluutio). Darwinismin perusajatuksia ovat (1) biologisten eliöiden luonnollinen alkuperä, (2) väite kaikkien eliöiden yhteisestä alkuperästä ("elämän puu") ja (3) luonnonvalinnan periaate evoluution selittäjänä (muuntelu, selviytyminen, periytyminen). Moderni synteesi on Darwinin teorioiden ja modernin genetiikan yhdistelmä. Genetiikka täydentää darwinismia selittämällä geenien periytymisen ja muuntelun mekanismeja.

\section{Determinismi}

Filosofinen näkemys, jonka mukaan maailmankaikkeuden jokainen fysikaalinen tila seuraa vääjäämättä sitä edeltävästä tilasta jonkin luonnonlain perusteella. Jos voisimme yhdellä hetkellä tuntea jokaisen fysikaalisen tilan ja tuntisimme luonnonlait täydellisesti, voisimme ennustaa kaikki tulevat tilat. Jos determinismi on totta, niin maailmalla on ainoastaan yksi mahdollinen tulevaisuus, jonka määrää maailman nykyinen tila ja menneisyys. 


\section{Dualismi}

Filosofinen näkemys, jonka mukaan on olemassa kaksi pohjimmiltaan erilaista "perusosaa". Erityisesti dualismi liittyy mielen ja aineen (nykyisin mielen ja aivojen) suhteeseen. Tällöin puhutaan mieli/ruumis dualismista. Substanssidualismin mukaan maailma koostuu kahdesta erilaisesta perusosasta eli substanssista, mielestä eli sielusta sekä aineesta. Substanssidualismin vaihtoehto on ominaisuusdualismi, jonka mukaan mentaaliset ominaisuudet (mielentilat) ovat riippumattomia fysikaalisista (materiaalisista) tiloista. Substanssidualismin kuuluisimman muotoilun esitti Rene Descartes. Ks. atomismi.

\section{Emergenssi}

Filosofinen näkemys osien ja kokonaisuuksien suhteesta. Heikon emergenssin mukaan kokonaisuuksilla on ominaisuuksia, joita niiden osilla ei ole. Vahvan emergenssin mukaan järjestelmän saavutettua suuren monimutkaisuuden asteen siitä tulee jossakin määrin riippumaton sen perusrakenteesta ja ominaisuuksista. Tämä riippumattomuus tulee esiin esimerkiksi niin, että kokonaisuuden toimintaa ei voida selittää tyhjentävästi sen osien toiminnalla ja niin, että kokonaisuuden toiminta alkaa vaikuttaa sen osiin (alaspäinen kausaatio).

\section{Empirismi}

Tietoteoreettinen näkemys, jonka mukaan kaikki tieto perustuu aistihavaintoihin tai on johdettavissa niistä. Vastakohtana rationalismi, jonka mukaan kaikki tieto perustuu järjellä tavoitettaviin ideoihin. Ks. positivismi.

\section{Epifenomenalismi}

Filosofinen näkemys mielen ja aivojen suhteesta, joka vastaa mentaalisen $\mathrm{ka-}$ usaation ongelmaan. Epifenomenalismin mukaan mielenliikkeet ja mielen toiminta ei varsinaisesti aiheuta mitään, vaan mielen toiminta on ainoastaan seurausta aivojen toiminnasta. Mielenliikkeet ja mielen toiminta eivät toisin sanoen selitä ihmisen käyttäytymistä, vaan aivojen toiminta selittää sekä käyttäytymisen että mielen toiminnan. 


\section{Epistemologia}

Filosofian oppiala, joka käsittelee tietoa ja tietämistä. Kutsutaan myös tietoteoriaksi tai tieto-opiksi. Voidaan käyttää myös viittaamaan johonkin tiettyyn epistemologiseen näkemykseen. Jos Matin epistemologia on empiristinen ja Tepon rationalistinen, niin Matti uskoo, että kaikki tieto saadaan aistihavainnoista ja Teppo uskoo, että kaikki tieto saadaan järjen avulla. Epistemologia on hyvin tärkeä erityisesti tieteellisiä menetelmiä koskevien oletusten kannalta.

\section{Evoluutio}

Biologisten eliöiden geneettisen perimän muutos sukupolvien välillä. Toisinaan myös evoluutiolla tarkoitetaan biologisen maailman historiallista kehityskulkua, joka alkaa ensimmäisestä solusta, jatkuu nykyajan eliölajeihin ja siitä eteenpäin. Darwinismi pyrkii selittämään evoluution kulkua. Darwinismin mukaan luonnonvalinta on tärkein evoluutiota selittävä tekijä.

\section{Evoluutiopsykologia}

Poikkitieteellinen tutkimusala, jossa yhdistyvät kognitiivinen psykologia, antropologia, biologia ja neurotiede. Evoluutiopsykologian tehtävänä on yrittää selvittää ihmismielen evoluutiota ja sitä, miten ihmismielen rakenteet ovat kehittyneet vuorovaikutuksessa ihmisen ympäristön ja kulttuurin kanssa. Selittääkseen aivojen ja mielen rakenteita evoluutiopsykologia viittaa ihmisen menneisyydessä vaikuttaneisiin valintapaineisiin. Monien evoluutiopsykologien mukaan ihmismielen rakenteet ovat samat kulttuurista riippumatta ja nämä rakenteet samalla selittävät kulttuurien välisiä yhtäläisyyksiä.

\section{Filosofia}

Tutkimusala, jonka luonne on vaikeasti määriteltävissä ja itsessään merkittävä filosofinen kysymys. Yksi tapa ymmärtää filosofian tehtävä on ajatella, että filosofia pyrkii arvioimaan maailmankatsomuksia ja kehittämään mahdollisimman kattavan ja yleisen näkemyksen siitä, mitkä ovat maailman kaikkein yleisimmät piirteet (metafysiikka), miten tietoa saadaan (epistemologia), miten päättely toimii (logiikka) ja mikä on hyvää (etiikka). On toisinaan päällekkäinen tieteen ja teologian kanssa. Tärkeitä tutkimusalueita ovat edellisten 
lisäksi myös tieteenfilosofia (miten tiede toimii ja mitä se on), mielenfilosofia (mikä mieli on ja miten se se liittyy muuhun maailmaan) ja kielifilosofia (miten kieli toimii).

\section{Funktionalismi}

Näkemys mielen ja aivojen suhteesta erityisesti kognitiotieteessä ja mielenfilosofiassa. Funktionalismin mukaan mielentilat voidaan määritellä niiden vaikutusten mukaan. Ehkä suosituin näkemys on tietokonefunktionalismi, jonka mukaan mielen ja aivojen suhde on karkeasti ottaen samanlainen, kuin tietokoneen ja sen ohjelmien välinen suhde. Mieli on näin ollen tiedonkäsittelyä. Mieli on tietokoneohjelman tapaan erillinen fysikaalisesta perustastaan, vaikka se välttämättä tarvitsee jonkin fysikaalisen perustan. Jos tietokonefunktionalismi pitää paikkansa, on periaatteessa mahdollista, että ihmismieli voidaan siirtää tietokoneeseen tai voidaan kehittää aito tekoäly. Ks. materialismi.

\section{Immanentismi}

Teologinen ja filosofinen näkemys Jumalan toiminnasta maailmassa. Immanentismin mukaan luonnon säännönmukaisuudet (luonnonlait) ovat Jumalasta erillisiä, ja Jumala toimii maailmassa vain näiden säännönmukaisuuksien välityksellä. Näin ollen Jumala ei tee "ihmeitä" siinä mielessä, että hän rikkoisi luonnonlakeja. Maailma on tämän näkemyksen mukaan Jumalasta itsenäinen ja sillä on omat säännönmukaisuutensa, joihin Jumala ei toiminnallaan puutu.

\section{Inkompatibilismi}

Filosofinen näkemys vapaan tahdon ja determinismin suhteesta. Inkompatibilismin mukaan determinismi ja vapaa tahto eivät sovi yhteen. Jotta vapaa tahto olisi mahdollinen, on maailman oltava aidosti indeterministinen ja mentaalisen kausaation tulee olla mahdollista. Jotta vapaa tahto voisi toteutua, on oltava mahdollista, että nimenomaan yksittäinen valinta aiheuttaa eron kahden mahdollisen asiaintilan välillä. Vastakohtana kompatibilismi. 


\section{Indeterminismi}

Filosofinen ja tieteellinen näkemys, jonka mukaan maailman jokainen tila ei seuraa vääjäämättä edellisistä tiloista ja luonnonlaeista. Indeterminismi voidaan ymmärtää näkemykseksi, jonka mukaan kaikkien fysikaalisten järjestelmien tulevia tiloja ei pystytä jäännöksettä ennustamaan niiden alkuehdoista ja tunnetuista luonnonlaeista käsin. Tämä tosiseikka ei puolestaan johdu inhimillisen tietämisen rajallisuudesta, vaan se on fysikaalisen maailman ominaisuus. Näin ollen indeterminismi edellyttää sattuman läsnäoloa maailmassa ja siitä seuraa se, että maailman tulevaisuus on periaatteessa avoin. Vastakohtana determinismi. Ks. inkompatibilismi, kompatibilismi.

\section{Interventionismi}

Teologinen näkemys Jumalan vaikutuksesta maailmassa. Interventionismin mukaan luonnon säännönmukaisuudet (luonnonlait) ovat Jumalasta erillisiä, ja Jumala ainakin toisinaan toimii aktiivisesti maailmassa tavalla, joka puuttuu tai rikkoo näitä säännönmukaisuuksia. Interventionismin mukaan maailma on Jumalasta itsenäinen lakien ja säännönmukaisuuksien kokonaisuus. Jumalan erityinen toiminta edellyttää sitä, että Jumala rikkoo näitä säännönmukaisuuksia.

\section{Kognitiotiede}

Tiedonkäsittelyä eri muodoissa tutkivien tieteiden joukko, johon kuuluvat esimerkiksi kognitiivinen psykologia (ihmisen tiedonkäsittelyn tutkimus), tekoälytutkimus ja kognitiivinen neurotiede. Kognitiotieteen lähtökohtana on ajatus siitä, että esimerkiksi ihmisen tiedonkäsittely (ajattelu) voidaan ymmärtää symbolien prosessointina jossakin fysikaalisessa järjestelmässä. Tämän tietokonefunktionalismin mukaan ihmismieli toimii aivoissa ikään kuin ohjelmisto tietokoneessa. Ks. materialismi, funktionalismi.

\section{Kompatibilismi}

Filosofinen kanta, jonka mukaan vapaa tahto on yhteensopiva determinismin kanssa. Vapaa valinta on kompatibilismin mukaan valinta, jonka syynä ovat henkilön uskomukset ja halut, ei mikään henkilön ulkoinen syy. Näin ollen vapaa valinta ei edellytä sitä, että yksilön valinta tekisi eron kahden 
mahdollisen tulevaisuuden välillä, vaan ainoastaan sitä, että mikään ei estä henkilöä toimimasta hänen uskomustensa ja halujensa mukaan. Näin ollen vapaa tahto on yhteensopiva determinismin kanssa. Vastakohtana inkompatibilismi.

\section{Konstruktivismi}

Radikaali filosofinen kanta, jonka mukaan ihmisestä riippumatonta todellisuutta ei ole olemassa, vaan todellisuus on ihmisen kielen, kulttuurin tai jonkin muun "rakentama" tai synnyttämä. Liittyy kulttuurirelativismiin, jonka mukaan mitään kulttuureista tai kielistä riippumatonta todellisuutta ei ole olemassa. Ks. antirealismi.

\section{Korpuskulaarinen filosofia}

Ks. atomismi

\section{Kreationismi}

Joukko teologisia näkemyksiä, jonka mukaan Jumala loi maailman 1. Mooseksen kirjan kuvaamalla tavalla useita tuhansia vuosia sitten (nuoren maan kreationismi). Menetelmällisenä perustuksena on raamatullinen literalismi, jonka mukaan Raamattu on erehtymätön ja yksiselitteinen luontoa koskevan tiedon lähde. Nuoren maan kreationismi eroaa vanhan maan kreationismista siinä, että jälkimmäinen tunnustaa maapallon pitkäikäisyyden. Jos kreationismi on totta, niin tieteellinen näkemys maailmankaikkeuden iästä ja kehityksestä on radikaalisti virheellinen.

\section{Literalismi}

Teologinen näkemys, jonka mukaan Raamattu on erehtymätön ja yksiselitteinen luontoa koskevan tiedon lähde. Toisinaan puhutaan myös Raamatun erehtymättömyydestä.

\section{Metafysiikka}

Ks. ontologia. 


\section{Materialismi}

Metafyysinen näkemys, jonka mukaan kaikki, mikä on olemassa, koostuu pohjimmiltaan aineesta. Tieteellinen materialismi on joukko sekä menetelmällisiä että metafyysisiä väitteitä, jonka mukaan mitään luonnon ulkopuolista ei ole olemassa, luonnon perustana ovat fysiikan tutkimat oliot ja lainalaisuudet, jotka synnyttävät itse itsensä. Edellisistä seuraa se, että mitään yliluonnollista aineellisen maailman perustaa, kuten Jumalaa, ei voi olla olemassa ja tiede voi saavuttaa periaatteessa totuuden kaikesta. Klassinen materialismi liittyy mekanistiseen maailmankuvaan, jonka mukaan kaikki, mikä on olemassa, koostuu jakamattomista aineen hiukkasista, atomeista. Mieli/ ruumis materialismi on filosofinen kanta, jonka mukaan mielen toiminta perustuu ruumiin toiminnalle. Nykykielellä sanottuna siis mielen toiminta perustuu aivojen toiminnalle. Mieli/ruumis materialismin versioita ovat funktionalismi ja identiteettiteoria. Ks. atomismi, dualismi.

\section{Mentaalinen kausaatio}

Mielen kyky aiheuttaa vaikutuksia mielen ulkopuolisessa maailmassa, erityisesti aivoissa. Mentaalisen kausaation ongelma: jos mieli on aivot ja aivoja ohjaavat fysikaaliset lait, niin miten mielenliikkeet voivat aiheuttaa mitään vaikutuksia avioissa? Vastauksia: (1) dualismi (mieli on aineeton ja aiheuttaa vaikutuksia aivoissa), (2) epifenomenalismi (mieli ei aiheuta mitään vaikutuksia, vaan mielen tilat ovat vain ja ainoastaan aivojen tilojen vaikutuksia), (3) non-reduktiivinen materialismi (mieli on aivot, mutta voi myös vaikuttaa aivoihin).

\section{Naturalismi}

Filosofinen termi, jolla on useita eri merkityksiä. Naturalismi tutkimusohjelmana tieteessä olettaa, että maailma on ihmisjärjelle ymmärrettävä ja toimii enemmän tai vähemmän säännönmukaisesti. Metodologinen naturalismi on periaate, jonka mukaan tiede voi tutkia luonnon säännönmukaisuuksia ottamatta huomioon Jumalan aktiivista toimintaa. Tiede ei tämän näkemyksen mukaan saa selittää luonnollisia ilmiöitä yliluonnollisin keinoin. Naturalismi tieteidenvälisenä ohjelmana puolestaan korostaa luonnontieteellisten menetelmien ja oletusten ylivertaisuutta ja pyrkii tekemään kaikki muutkin tie- 
teet (esimerkiksi yhteiskuntatieteet) luonnontieteen kaltaisiksi. Naturalismi maailmankatsomuksena on yhtä kuin tieteellinen materialismi. Liitetään toisinaan materialismiin.

\section{Neurotiede}

Ihmisen keskushermostoa ja aivoja tutkiva biologinen tiede. Toisinaan puhutaan myös hieman harhaanjohtavasti aivotutkimuksesta. Neurotiede tutkii esimerkiksi hermosolujen toimintaperiaatteita ja sitä, kuinka hermosolujen toiminta rakentaa erilaisia psykologisia kykyjä. Neurotiede, kognitiotiede ja psykologia ovat läheisessä vuorovaikutuksessa keskenään, kun yritämme selvittää miten ihmisen mieli ja aivot toimivat.

\section{Ontologia}

Filosofian oppiala, joka tutkii todellisuuden kaikkein yleisimpiä (tai perinnäisimpiä) piirteitä. Tunnetaan myös nimellä metafysiikka. Voidaan käyttää myös viittaamaan johonkin tiettyyn ontologiseen (tai metafyysiseen) näkemykseen. Jos Matin ontologia on teistinen ja Tepon materialistinen, niin Matti ajattelee, että Jumala on todellisuuden perusta ja Teppo taas, että aine on todellisuuden perusta.

\section{Panenteismi}

Teologinen näkemys, jonka mukaan luonto on osa Jumalaa, mutta Jumala ei rajoitu luontoon. Panenteismin mukaan luonnon toiminta ei ole mitään muuta kuin Jumalan säännönmukaista toimintaa. Näkemys on suosittu joidenkin tieteilijöiden ja teologien keskuudessa (esimerkiksi Philip Clayton ja Arthur Peacocke). Eroaa panteismista, jonka mukaan luonto on identtinen Jumalan kanssa. Panenteismin mukaan maailma on kyllä osa Jumalaa mutta ei identtinen hänen kanssaan.

\section{Panteismi}

Uskonnollinen näkemys, jonka mukaan Jumala ja luonto ovat identtisiä.

\section{Positivismi}

Filosofinen näkemys tieteen ja tiedonhankinnan yleisestä luonteesta. Po- 
sitivismin mukaan kaikki tieto perustuu aistihavaintoihin, joista voidaan loogisesti johtaa tieteellisiä teorioita (empirismi). Kaikki tieto on näin ollen tiedettä, ja aistihavainto muodostaa erehtymättömän tiedon perustan. Tällainen näkemys huipentuu loogisessa positivismissa sotien välisenä aikana Keski-Euroopassa ja vaikuttaa siitä eteenpäin sekä Yhdysvalloissa että IsoBritanniassa ja erityisesti tieteenfilosofiassa.

\section{Prosessiteologia}

Laaja-alainen teologinen näkemys luonnosta ja Jumalasta. Prosessiteologian mukaan maailma on jatkuvassa muutoksessa, joka on avoin erilaisille mahdollisuuksille. Jumala on maailman sisäinen voima, joka on yhtenä tekijänä vaikuttamassa maailman tulevaan kehitykseen. Jumala ei ole luonut maailmaa tyhjästä eikä hallitse täydellisesti sen tulevaa kehitystä. Edustajina esim. David Ray Griffin ja John Cobb. Prosessiteologian juuret ovat Alfred Whiteheadin ja Charles Hartshornen prosessifilosofiassa. Ks. myös panenteismi.

\section{Realismi}

Kutsumme henkilö realistiksi, jos hän uskoo, että jokin tietty tiedonalue on kosketuksissa todellisuuden kanssa ja että voimme jossakin mielessä puhua ihmisestä riippumattomasta todellisuudesta. Tieteellisen realismin mukaan on olemassa ihmisestä riippumaton todellisuus, jotka tieteen teoriat pyrkivät kuvaamaan. Naiivin tieteellisen realistin mukaan todellisuus on juuri sellainen kuin nykyiset tieteelliset teoriat sen kuvaavat. Kriittisen tieteellisen realistin mukaan tieteelliset teoriat ovat malleja, jotka ovat enemmän tai vähemmän tosia. Teologisen realismin mukaan on olemassa ihmisestä riippumaton todellisuus, joka sisältää myös Jumalan ja jota teologiset näkemykset pyrkivät kuvaamaan.

\section{Reduktio}

Tieteenfilosofinen termi, jolla on useita erilaisia merkityksiä. Menetelmällinen reduktio kuuluu tieteelliseen menetelmään. Ajatus on se, että todellisuus on liian monimutkainen tutkittavaksi kerralla, joten jokaisessa tutkimuksessa pyritään määrittelemään tutkittavat tekijät mahdollisimman tarkasti ja rajaamaan muut ulkopuolelle. Tällöin reduktio on menetelmällinen väline. Tie- 
toteoreettisen reduktion mukaan jokin tietty teoria voidaan palauttaa osaksi jotakin toista, yleensä perustavampaa tai laajempaa teoriaa. Tällöin reduktio on suhde kahden teorian välillä. Ontologisen reduktion mukaan jokin itsenäinen olioiden luokka ei olekaan itsenäinen, vaan osa jotakin toista luokkaa. Tällöin reduktio on suhde olioiden ja niiden luokkien välillä. Toisinaan puhutaan myös reduktionismista yleisenä tieteellisenä ohjelmana selittää kokonaisuuksien toiminta aina niiden osien toiminnoilla. Klassisen reduktionismin mukaan voimme selittää kaikki kokonaisuudet viime kädessä näin aina fysiikkaan asti, johon selityksemme pysähtyvät. Biologisen reduktionismin mukaan ihmisen käyttäytyminen ja kulttuuri voidaan selittää jäännöksettä ihmisen geneettisen perimän tuotteena.

\section{Relativismi}

Ks. antirealismi ja konstruktivismi

\section{Skientismi}

Toisinaan myös tieteisusko. Tietoteoreettisen skientismin mukaan tieteellinen menetelmä on ainoa tapa saada tietoa maailmasta. Ontologisen skientismin mukaan vain se, mitä tiede voi tutkia, on olemassa. Arvoteoreettisen skientismin mukaan tiede voi selittää perinteisen etiikan ja antaa meille uudet arvot ja etiikan. Eksistentiaalinen skientismin mukaan tiede voi selittää perinteiset uskonnon ja filosofiat ja tarjota meille uuden filosofian. Skientismin radikaalein versio väittää, että tiede on ainoa tie totuuteen ja tulee ratkaisemaan kaikki ongelmamme, jotka eivät ole illuusioita, ja antamaan meille uuden etiikan, uskonnon ja filosofian.

\section{Sosiobiologia}

Toisinaan kiistanalainen biologian ala, jonka tarkoituksena on tutkia sosiaalisen käyttäytymisen ja moraalin evoluutiota. Keskeisenä vaikuttajana Edward O. Wilson. Wilsonin mukaan myös ihmisen moraali ja ryhmäkäyttäytyminen (yhteiskunta ja kulttuuri) voidaan selittää tyhjentävästi ihmisen biologisella menneisyydellä ja geneettisellä perimällä. Johti kehityttyään 1970-luvulla merkittäviin kiistoihin biologian soveltuvuudesta selittämään ihmisten käyttäytymistä. Nykyisin jotkut sosiobiologian ideat elävät evoluutiopsykologiassa. 


\section{Teismi}

Filosofinen ja teologinen näkemys, jonka mukaan on olemassa persoonallinen, kaikkivaltias, kaikkitietävä, ikuinen (tai ajaton), aineeton ja moraalisesti täydellinen Jumala, joka on luonut maailman, pitää sitä yllä ja ohjaa sitä. Sekä kristinuskon, islamin että juutalaisuuden ydinkohta.

\section{Teistinen evoluutio}

Teologinen näkemys biologisen evoluution luonteesta. Teistisen evoluution mukaan darwinismi selittää kuinka biologinen maailma on kehittynyt nykyiseen muotoonsa. Jumala on kuitenkin käyttänyt biologista evoluutiota välineenä tahtonsa toteuttamiseen puuttumatta sen kulkuun tavalla, joka rikkoisi biologiassa tunnettuja luonnon säännönmukaisuuksia. Näin ollen teistinen evoluutio vastustaa kreationismia, jonka mukaan evoluutiobiologia (ja valtaosa luonnontieteistä) on massiivisesti erehtynyt biologisen maailman alkuperästä, ja älykkään suunnitelman ajatusta, jonka mukaan evoluutiota selittääksemme meidän pitää olettaa yliluonnollisia tekijöitä.

\section{Teologia}

Käsitteellä tarkoitetaan perinteisesti oppia Jumalasta ja jumalallisista asioista. Nykyisin teologia on kristinuskon käytäntöjä, oppeja, ideoita ja perinnettä tutkiva tiede. Sen lähteenä ovat ilmoitus, kokemus, järki ja kirkon traditio. Voidaan myös viitata kristillisten kirkkojen älylliseen toimintaan, jossa ne tulkitsevat ja järjestävät omaa oppiaan, käytäntöjään ja identiteettiään.

\section{Tieteellinen materialismi}

Filosofinen näkemys, jonka mukaan luonnon, joka sisältää ihmiset ja ihmisen kulttuurin luomukset, lisäksi ei ole mitään. Ei ole olemassa sieluja, ei kuolemanjälkeistä elämää eikä Jumalaa. Koska Jumalaa ei ole, kaikki selitykset ovat pelkästään luonnollisia ja vain tiede voi löytää ne kaikki. Kaikki elävien olioiden ominaisuudet, inhimillinen älykkyys ja käyttäytyminen, voidaan selittää kokonaan luonnollisin tavoin. Tällä tarkoitetaan yleensä darwinistisia selityksiä (biologinen reduktionismi). Liittyy usein tieteisuskoon eli skientismiin, jonka mukaan tieteellinen menetelmä on ainoa tapa saavuttaa tietoa maailmasta. 
Älykäs suunnitelma

Teologinen näkemys biologisen evoluution syistä. Älykkään suunnitelman mukaan tuntemaamme evoluutiota ei pystytä täydellisesti selittämään luonnollisilla syillä (luonnonvalinta), vaan se edellyttää yliluonnollisia selityksiä. Ajatus on se, että luonnossa ilmenee toisinaan "palautumatonta monimutkaisuutta". Jokin rakenne on tällä tavalla monimutkainen, kun sen yksittäiset rakenneosat ovat käyttökelvottomia mutta yhdessä muodostavat jotakin tehtävää suorittavan kokonaisuuden. Älykkään suunnitelman mukaan luonnonvalinta ei pysty selittämään tällaisten rakenteiden syntymistä, vaan niiden selittämiseksi tarvitaan yliluonnollinen, älykäs suunnittelija. Kuuluisimpia kannattajia Michael Behe ja William Dembski. 

K I R J A L L I S U U S

\author{
Allen, Paul \\ 2006 Ernan McMullin and Critical Realism in the Science-Theology \\ Dialogue. Aldershot: Ashgate.
}

Atran, Scott

2002 In Gods We Trust: The Evolutionary Landscape of Religion. New York: Oxford University Press.

\title{
Barbour, Ian
}

1974 Myths, Models and Paradigms: The Nature of Scientific and Religious Language. London: SCM Press.

1998 Religion and Science: Historical and Contemporary Issues. London: SCM Press.

Barnes, Michael Horace

2010 Understanding Religion and Science: Introducing the Debate. London: Continuum.

\section{Barrett, Justin}

2004 Why Would Anyone Believe in God? Walnut Creek, CA: AltaMira press.

2007 "Is the Spell Really Broken? Bio-Psychological Explanations of Religion and Theistic Belief”. - Theology and Science 5:1. 57-72.

Barrow, John \& Tipler, Frank

1986 The Antropic Cosmological Principle.

Oxford: Oxford University Press. 
Barrett, Justin \& Leech, David \& Visala, Aku

2010 Can Religious Belief Be Explained Away? Reasons and Causes of Religious Belief. - The Nature of God: Evolution and Religion. Ulrich Frey (toim.). Marburg: Tectum.

Behe, Michael

1996 Darwin's Black Box: The Biochemical Challenge to Evolution. New York: Free Press.

Beilby, James (toim.)

2002 Naturalism Defeated? Essays on Plantinga's Evolutionary Argument against Naturalism. Ithaca: Cornell University Press.

Blackmore, Susan

1999 The Meme Machine. Oxford: Oxford University Press.

\section{Boyer, Pascal}

1994 The Naturalness of Religious Ideas: A Cognitive Theory of Religion. Berkeley: University of California Press.

2001 Religion Explained: The Evolutionary Origins of Religious Thought. New York: Basic Books (Ja ihminen loi jumalat: miten uskonto selitetään, suomentanut Tiina Arppe, Porvoo: WSOY. 2002).

\section{Boyd, Robert \& Richerson, Peter}

1985 Culture and the Evolutionary Process. Chicago: University of Chicago Press.

2005a Not By Genes Alone: How Culture Transformed Human Evolution. Chicago: University of Chicago Press.

2005b The Origin and Evolution of Cultures.

New York: Oxford University Press

\section{Brooke, John Hedley}

1991 Science and Religion: Some Historical Perspectives.

Cambridge: Cambridge University Press. 
Brown, Warren \& Murphy, Nancey \& H. Newton Malony (toim.)

1998 Whatever Happened to the Soul? Scientific and Theological Portraits of Human Nature. Minneapolis: Fortress Press.

\section{Brümmer, Vincent}

1994 Has the Theism-Atheism Debate a Future? - Theology 97.

\section{Buber, Martin}

1993 Minä ja Sinä. Suom. Jukka Pietilä. Porvoo/Helsinki/Juva: WSOY.

Carr, Bernard

2006 Cosmology and Religion. - Oxford Handbook of Religion and Science. Ed. by Philip Clayton \& Zachary Simpson.

New York: Oxford University Press.

Campbell, Heidi \& Looy, Heather (toim.).

2009 A Science and Religion Primer. Grand Rapids: Baker.

Chalmers, Alan

1999 What Is This Thing Called Science? 3. painos.

Buckingham: Open University Press.

Chalmers, David

1996 The Conscious Mind: In Search of a Fundamental Theory. Oxford: Oxford University Press.

Churchland, Paul

1984 Matter and Consciousness: A Contemporary Introduction to the Philosophy of Mind. Cambridge, MA: The MIT Press. 
Clark, Andy

2001 Mindware: Introduction to the Philosophy of Cognitive Science. Oxford: Oxford University Press.

2003 Natural-Born Cyborgs: Minds, Technologies, and the Future of Human Intelligence. Oxford: Oxford University Press.

\section{Clayton, Philip}

1997 God and Contemporary Science.

Edinburgh: Edinburgh University Press.

2004 Mind and Emergence: From Quantum to Consciousness.

Oxford: Oxford University Press.

2008 Adventures in the Spirit: New Forays in Philosophical Theology. Minneapolis: Fortress Press.

Clayton, Philip \& Davies, Paul (toim.)

2006 The Re-Emergence of Emergence: The Emergentist Hypothesis from Science to Religion. Oxford: Oxford University Press.

Clayton, Philip \& Peacocke Arthur (toim.)

2004 In Whom We Live and Move and Have Our Being: Panentheistic Reflections on God's Presence in a Scientific World.

Grand Rapids, MI: Eerdmans.

Clayton, Philip \& Simpson, Zachary (toim.)

2006 Oxford Handbook of Religion and Science.

New York: Oxford University Press.

Cobb, John \& Griffin, David Ray

1976 Process Theology: An Introductory Exposition.

Philadelphia: Westminster Press.

\section{Collins, Francis}

2007 The Language of God: A Scientist Presents Evidence for Belief. London: Pocket Books. 


\section{Collins, Robin}

2009 The Teleological Argument: An Exploration of the Fine-Tuning of the Universe. - The Blackwell Companion to Natural Theology. William Lane Craig \& J. P. Moreland (toim.) Oxford: Blackwell.

\section{Conway Morris, Simon}

2003 Life's Solution: Inevitable Humans in a Lonely Universe. Cambridge: Cambridge University Press.

\section{Cooper, John}

2007 Panentheism, The Other God of the Philosophers: From Plato to Present. Nottingham: Apollos.

\section{Craig, William Lane}

1980 The Cosmological Argument from Plato to Leibniz. London: MacMillan.

2009 The Kalam Cosmological Argument. - The Blackwell Companion to Natural Theology. William Lane Craig \& J. P. Moreland (toim.) Oxford: Blackwell.

Craig, William Lane \& Moreland, J.P (toim.)

2009 The Blackwell Companion to Natural Theology.

Chichester/Malden: Wiley-Blackwell.

Crane, Tim

2001 Elements of Mind: Introduction to the Philosophy of Mind. New York: Oxford University Press.

D’Aquili, Eugene \& Newberg, Andrew

2001 Why God Won't Go Away: Brain Science and Biology of Belief. London: Ballantine Books. 


\section{Davies, Paul}

2006 The Goldilocks Enigma: Why Is the Universe Just Right for Life?.

London: Penguin Books. (Kultakutrin arvoitus: Miksi

maailmankaikkeus on juuri sopiva elämälle? Suom. Hannu

Karttunen. Helsinki: URSA 2007)

\section{Dawkins, Richard}

1978 The Selfish Gene. London: Granada Publishing (Geenien itsekkyys. Suom. Risto Varteva. Helsinki: Arthouse. 1993).

1986 The Blind Watchmaker. Harlow: Longman (Sokea kelloseppä.

Suom. Risto Varteva. Porvoo: WSOY. 1989).

1995 River out of Eden: A Darwinian View of Life.

London: Phoenix (Viesti miljardien vuosien takaa.

Suom. Risto Varteva. Porvoo: WSOY, 1995).

1998 Unweaving the Rainbow: Science, Delusion and the Appetite for Wonder. London: Allen Lane/The Penguin Press.

2004 A Devil's Chaplain: Selected Essays. London: Phoenix.

2006 The God-Delusion. London: Bantam Press (Jumalharha.

Suom. Kimmo Pietiläinen. Helsinki: Terra Cognita. 2007).

2009 The Greatest Show on Earth: The Evidence for Evolution.

London: Bantam Press.

\section{De Waal, Frans}

1998 Hyväluontoinen: Oikean ja väärän alkuperä ihmisessä ja muissa eläimissä. Suom. Kimmo Pietiläinen. Helsinki: Terra Cognita.

2005 Our Inner Ape: The Best and the Worst of Human Nature. London: Granta.

2006 Primates and Philosophers. Stephen Macedo \& Josiah Ober (toim.). Princeton: Princeton University Press. 


\section{Dembski, William}

1998 The Design Inference: Eliminating Chance through Small Probabilities. Cambridge: Cambridge University Press.

2002 No Free Lunch: Why Specified Complexity Cannot Be Purchased without Intelligence. Lanham: Rowman \& Littlefield.

Dembski, William \& Ruse, Michael (toim.)

2004 Debating Design: From Darwin to DNA.

Cambridge: Cambridge University Press.

\section{Dennett, Daniel}

1991 Tietoisuuden selitys. Suom. Tiina Kartano. Helsinki: Arthouse.

1995 Darwin's Dangerous Idea: Evolution and the Meanings of Life. London: Allen Lane/Penguin Books.

2003 Freedom Evolves. London: Allen Lane.

2006 Breaking the Spell: Religion as a Natural Phenomenon.

London: Allen Lane/Penguin Books. (Lumous murtuu: uskonto luonnonilmiönä. Suom. Kimmo Pietiläinen.

Helsinki: Terra Cognita. 2006).

\section{Dixon, Thomas}

2008 Science and Religion: A Very Short Introduction.

Oxford: Oxford University Press.

\section{Drees, Willem}

1996 Religion, Science and Naturalism.

Cambridge: Cambridge University Press.

Dunbar, Robin \& Barrett, Louise (toim.)

2007 Oxford Handbook of Evolutionary Psychology.

Oxford: Oxford University Press. 
Eagleton, Terry

2009 Reason, Faith, and Revolution: Reflections on the God Debate. Yale: Yale University Press.

Evans, John \& Michael Evans

2008 Religion and Science: Beyond the Epistemological Conflict Narrative. - Annual Review of Sociology. Vol.34. 87-105.

Fergusson, David

2009 Faith and Its Critics. Oxford: Oxford University Press.

Ferngren, Gary (toim.)

2002 Science and Religion: A Historical Introduction.

Baltimore/London: The Johns Hopkins University Press.

\section{Flanagan, Owen}

2002 The Problem of the Soul: Two Visions of Mind and How to Reconcile Them. New York: Basic Books.

Flint, Thomas \& Rea, Michael

2009 The Oxford Handbook of Philosophical Theology.

Oxford: Oxford University Press.

Giberson, Karl \& Artigas, Mariano

2006 Oracles of Science: Celebrity Scientists versus God and Religion. New York: Oxford University Press.

\section{Gingerich, Owen}

2006 God's Universe. Cambridge, MA: Harvard University Press.

Goetz, Stewart \& Taliaferro, Charles

2008 Naturalism. Grand Rapids, MI: William B. Eerdmans. 
Gould, Stephen Jay

1999 Rocks of Ages: Science and Religion in the Fullness of Life. New York: Ballantine Publ. Group.

\section{Gregersen, Niels-Henrik}

2006 What Theology Might Learn (and Not Learn) from Evolutionary Psychology: Postfoundationalist Theologian in Conversation with Pascal Boyer. - Evolution of Rationality: Interdisciplinary essays in Honor of J. Wentzel Van Huyssteen. Ed. By Shults, F. LeRon. Grand Rapids, MI: Wm. B. Eerdmans Publishing Co.

\section{Griffin, David Ray}

2001 Re-enchantment without Supernaturalism: A Process Philosophy of Religion. Ithaca: Cornell University Press.

\section{Haaparanta, Leila \& Niinluoto, Ilkka}

1991 Johdatus tieteelliseen ajatteluun. 6. painos.

Helsingin yliopiston filosofian laitoksen julkaisuja 3.

\section{Harris, Sam}

2004 The End of Faith: Religion, Terror and the Future of Reason. London: Simon \& Schuster (Uskon loppu: uskonto, terrori ja järjen tulevaisuus. Suom. Kimmo Pietiläinen. Helsinki: Terra Cognita. 2007).

2006 A Letter to a Christian Nation. London: Bantam Press.

\section{Harrison, Peter}

2007 The Fall of Man and the Foundation of Science. Cambridge: Cambridge University Press.

Harrison, Peter (toim.)

2010 The Cambridge Companion to Science and Religion. Cambridge: Cambridge University Press. 


\section{Hart, David Bentley}

2009 Atheist Delusions: The Christian Revolution and its Fashionable Enemies. Yale: Yale University Press (suomeksi Ateismin harhat. Helsinki: Perussanoma. 2010).

\section{Hasker, William}

1999 The Emergent Self. New York: Cornell University Press.

\section{Haught, John}

2000 God After Darwin: A Theology of Evolution. Boulder, CO: Westview Press.

2001 Responses to 101 Questions on God and Evolution. New York: Paulist Press.

2003 Deeper Than Darwin: The Prospect for Religion in the Age of Evolution. Boulder, CO: Westview Press.

2006a God and Evolution. - The Oxford Handbook of Religion and Science. Philip Clayton \& Zachary Simpson (toim.). Oxford: Oxford University Press.

2006b Is Nature Enough? Meaning and Truth in the Age of Science. Cambridge: Cambridge University Press.

2007 Christianity and Science: Toward a Theology of Nature. Maryknoll, NY: Orbis Books.

2008 God and the New Atheism: A Critical Response to Dawkins, Harris, and Hitchens. Louisville: Westminster John Knox Press.

\section{Hitchens, Christopher}

2007 God is Not Great: How Religion Poisons Everything. London: Atlantic Books (Jumala ei ole suuri: kuinka uskonto myrkyttää kaiken. Suomentanut Matti Kinnunen, Porvoo: WSOY 2008).

\section{Jaki, Stanley}

1978 The Road of Science and the Ways of God. Chicago: Chicago University Press. 


\section{Johnson, Philip}

1991 Darwin on Trial. Washington: Regnery Gateway.

1995 Reason in the Balance: The Case Against Naturalism in Science, Law and Education. Downers Grove: InterVarsity Press.

2002 The Wedge of Truth. Downers Grove: InterVarsity Press.

\section{Jones, Kathleen}

2007 Challenging Richard Dawkins. Norwich: Canterbury Press.

Joyce, Richard

2006 The Evolution of Morality. Cambridge, MA: The MIT Press.

Kenny, Anthony

2005 The Unknown God: Agnostic Essays. London: Continuum.

Ketola, Kimmo \& Pyysiäinen, Ilkka \& Sjöblom, Tommi (toim.)

2008 Uskonto ja ihmismieli: Johdatus kognitiviseen uskontotieteeseen. Helsinki: Gaudeamus.

\section{Knuuttila, Simo}

2001 Time and Creation in Augustine. - Cambridge Companion to Augustine. Eleonore Stump \& Norman Kretzmann (toim.). Cambridge: Cambridge University Press.

\section{Koistinen, Timo}

2000 Philosophy of Religion or Religious Philosophy?: A Critical Study of Contemporary Anglo-American Approaches. Helsinki: Luther-Agricola Seura.

2001 Usko ja tiedollinen oikeutus. Helsinki: STKS.

\section{Kojonen, Rope}

2008 Kertooko luonnon järjestys suunnittelusta? Michael Behe älykkään suunnittelun ajatuksen puolustajana. Pro gradu. Systemaattisen teologian osasto. HY. 
Koskinen, Heikki \& Niiniluoto, Ilkka (toim.)

2002 Wienin piiri. Helsinki: Gaudeamus.

Laihonen, Pasi \& Salo, Jukka \& Vuorisalo, Timo

1986 Evoluutio: Miten elämä kehittyy? Helsinki: Otava.

Leech, David \& Visala, Aku

2010 The Cognitive Science of Religion: A Modified Theist

Response. - Religious Studies (painossa).

Lennox, John

2007 God's Undertaker: Has Science Buried God?

Oxford: Lion Hudson Plc.

\section{Lindbeck, George}

1984 The Nature of Doctrine: Religion and Theology in a Postliberal Age.

Louisville: Westminster John Knox Press.

\section{Mackie, John}

1983 The Miracle of Theism: Arguments For and Against of the Existence of God. Oxford: Clarendon.

Manson, Neil (toim.)

2003 God and Design: The Teleological Argument and Modern Science. London: Routledge.

Martin, Michael

1990 Atheism - A Philosophical Justification.

Philadelphia: Temple University Press.

Martin, Michael (toim.)

2007 Cambridge Companion to Atheism.

Cambridge: Cambridge University Press. 
Mawson, Tim

2005 Belief in God: An Introduction to the Philosophy of Religion. Oxford: Oxford University Press.

\section{Mayr, Ernst}

2003 Evoluutio. Suom. Jani Kaaro. Porvoo: WSOY.

\section{McGinn, Colin}

1993 Problems In Philosophy: The Limits of Inquiry. Oxford: Blackwell.

\section{McGrath, Alister}

1999 Science and Religion: An Introduction. Malden: Blackwell.

2001 A Scientific Theology: Nature. Volume 1. London: T \& T Clark.

2002 A Scientific Theology: Reality. Volume 2. London: T \& T Clark.

2003 A Scientific Theology: Theory. Volume 3. London: T \& T Clark.

2004 Twilight of Atheism: The Rise and Fall of Disbelief in the Modern World. New York: Doubleday. (Ateismin lyhyt historia.

Suomentanut Jukka Raunu. Helsinki: Kirjapaja. 2004)

2005 Dawkins' God: Genes, Memes and the Meaning of Life.

Malden, MA: Blackwell Publishing. (Dawkinsin Jumala:

geenit, meemit ja elämän tarkoitus. Suomentanut Kirsi Nisula.

Helsinki: Kirjapaja. 2006.)

2006a The Order of Things: Explorations in Scientific Theology.

Oxford: Blackwell.

2006b A Scientific Theology. London: T \& T Clark.

2007 Dawkins Delusion: Atheist Fundamentalism and the Denial of the Divine. London: SPCK.

2009 A Fine Tuned Universe: The Quest for God in Science and Theology. Louisville: Westminster John Knox Press.

McMullin, Ernan (toim.)

1985 Evolution and Creation.

Notre Dame: University of Notre Dame Press. 


\section{Midgley, Mary}

1992 Science as Salvation: A Modern Myth and Its Meaning.

London: Routledge.

2002 Evolution as Religion: Strange Hopes and Stranger Fears.

Täydennetty painos. London: Routledge.

2004 The Myths We Live By. Abingdon: Routledge.

2006 Science and Poetry. London: Routledge.

\section{Miller, Kenneth}

2002 Finding Darwin's God: A Scientist's Search for Common Ground between God and Evolution. New York: Harper Perennial.

\section{Moore, Andrew \& Scott, Michael}

2007 Realism and Religion: Philosophical and Theological Perspectives.

Aldershot: Ashgate.

\section{Moreland, J.P}

2008 Consciousness and the Existence of God: A Theistic Argument. New York: Routledge.

2009 The Argument from Consciousness. - The Blackwell Companion to Natural Theology. William Lane Craig and J.P. Moreland (toim.). Oxford: Blackwell.

\section{Murphy, Nancey}

2006 Bodies and Souls, or Spirited Bodies?

Cambridge: Cambridge University Press.

\section{Murphy, Nancey \& Brown, Warren}

2007 Did My Neurons Make Me Do It? Philosophical and Neurobiological Perspectives on Moral Responsibility and Free Will.

Oxford: Oxford University Press. 
Murray, Michael

2008 Nature Red in Tooth and Claw: Theism and the Problem of Animal Suffering. Oxford: Oxford University Press.

Murray, Michael \& Rea, Michael

2008 An Introduction to the Philosophy of Religion.

Cambridge: Cambridge University Press.

Murray, Michael \& Schloss, Jeffrey (toim.)

2009 The Believing Primate: Scientific, Philosophical, and

Theological Reflections on the Origin of Religion.

Oxford: Oxford University Press.

Myers, David G.

2008 A Friendly Letter to Sceptics and Atheists: Musings on Why God Is Good and Faith Isn't Evil. San Francisco: Jossey-Bass.

\section{Nielsen, Kai}

1985 Philosophy \& Atheism: In Defence of Atheism.

Buffalo, NY: Prometheus Books.

Niiniluoto, Ilkka

1999 Critical Scientific Realism. Oxford: Oxford University Press.

2003 Ateismi. - Uskonnonfilosofia. Helenius, Timo et al. (toim.). Helsinki: WSOY.

\section{Numbers, Ronald}

1998 Darwinism Comes to America.

Cambridge/London: Harvard University Press.

2006 The Creationists: From Scientific Creationism to Intelligent Design. Cambridge/London: Harvard University Press.

2007 Science and Christianity in Pulpit and Pew.

New York: Oxford University Press. 
Numbers, Ronald (toim.)

2009 Galileo Goes to Jail and Other Myths about Science and Religion. Cambridge/London: Harvard University Press.

\section{Numbers, Ronald \& Lindberg, David (toim.)}

2003 When Science and Christianity Meet.

Chicago/London: University of Chicago Press.

Näreaho, Leo

2007 Uskonnolliset kokemukset: Mitä aivotutkimus voi kertoa?

- Teologinen aikakauskirja. 3/2007.

Peacocke, Arthur

1993 Theology for a Scientific Age: Being and Becoming

- Natural, Divine and Human. Toinen painos. London: SCM.

2001 Paths from Science Towards God: The End of All Our Exploring.

Oxford: Oneworld.

2004 Creation and the World of Science: The Re-Shaping of Belief. Täydennetty painos. Oxford: Oxford University Press.

Pennock, Robert

2006 The Pre-Modern Sins of Intelligent Design. - The Oxford Handbook of Religion and Science. Philip Clayton \& Zachary Simpson (toim.). Oxford: Oxford University Press.

Pennock, Robert (toim.)

2001 Intelligent Design Creationism and Its Critics: Philosophical, Theological, and Scientific Perspectives. Cambridge: MIT Press.

\section{Peterson, Gregory}

2003 Minding God: Theology and the Cognitive Sciences.

Minneapolis: Fortress Press. 


\section{Pinker, Steven}

1999 How the Mind Works. London: Penguin Books.

\section{Plantinga, Alvin}

2000 Warranted Christian Belief. Oxford: Oxford University Press.

\section{Polkinghorne, John}

1994 Science and Christian Belief: Theological Reflections of a Bottom-Up Thinker. London: SPCK.

1998 Belief in God in an Age of Science.

New Haven/London: Yale University Press.

2002 Quantum Theory: A Very Short Introduction. Oxford: Oxford University Press.

2008 Theology in the Context of Science. London: SPCK.

\section{Pruss, Alexander}

2009 The Leibnizian Cosmological Argument.

- The Blackwell Companion to Natural Theology.

William Lane Craig \& J. P. Moreland (toim.) Oxford: Blackwell.

\section{Puolimatka, Tapio}

2005 Usko, tieto ja myytit. Helsinki: Tammi.

2008 Usko, tiede ja evoluutio. Helsinki: Uusi tie.

Pyysiäinen, Ilkka

2001 How Religion Works: Towards a New Cognitive Science of Religion. Leiden: Brill.

2004 Magic, Miracles and Religion. A Scientist's Perspective. Walnut Creek, CA: AltaMira Press.

2006 Jumalten keinu: Kiertoajelu uskontotieteessä. Helsinki: Gaudeamus. 2009 Supernatural Agents. Why We Believe in Souls, Gods and Buddhas. Oxford: Oxford University Press. 


\section{Raatikainen, Panu}

2004 Ihmistieteet ja filosofia. Helsinki: Gaudeamus.

2007 Reduktionismi, alaspäinen kausaatio ja emergenssi.

- Tiede \& Edistys. 4/2007.

\section{Rea, Michael}

2009 Introduction. - Analytic Theology. Michael Rea \& Oliver

Crisp (toim.) Oxford: Oxford University Press. 1-32.

Rea, Michael \& Crisp, Oliver (toim.)

2009 Analytic Theology. Oxford: Oxford University Press.

\section{Rauser, Randall}

2009 Theology in Search of Foundations.

Oxford: Oxford University Press.

\section{Reppert, Victor}

2003 C. S. Lewis' Dangerous Idea: In Defence of the Argument from Reason. Downers Grove: InterVarsity Press.

2009 The Argument from Reason. - The Blackwell Companion to Natural Theology. William Lane Craig \& J. P. Moreland (toim.)

Oxford: Blackwell.

\section{Ruse, Michael}

2000 The Evolution Wars: A Guide to the Debates. Santa-Barbara/Oxford: ABC-CLIO.

2001 Can a Darwinian be a Christian? The relationship between science and religion. Cambridge: Cambridge University Press.

2005 The Evolution-Creation Struggle.

Cambridge/London: Harvard University Press.

Ruse, Michael (toim.)

1988 But Is It Science: The Philosophical Questions in the Creation/Evolution Controversy. Buffalo: Prometheus Books. 


\section{Russell, Bertrand}

1957 Why I am not a Christian. New York: Simon \& Schuster.

\section{Russell, Robert}

2006 Quantum Physics and the Theology of Non-Interventionist Objective Divine Action. - The Oxford Handbook of Religion and Science. Philip Clayton \& Zachary Simpson (toim.). Oxford: Oxford University Press.

Russell, Robert \& Nancey Murphy \& Chris Isham (toim.)

1993 Quantum Cosmology and the Laws of Nature: Scientific Perspectives on Divine Action. Vatikaani: Vatican Observatory Publications and the Centre for Theology and the Natural Sciences / Notre Dame University Press.

Russell, Robert \& Murphy, Nancey \& Peacocke, Arthur (toim.)

1995 Chaos and Complexity: Scientific Perspectives on Divine Action. Vatikaani: Vatican Observatory Publications and the Centre for Theology and the Natural Sciences / Notre Dame University Press.

Russell, Robert \& Stoeger, William \& Ayala, Francisco (toim.) 1998 Evolutionary and Molecular Biology: Scientific Perspectives on Divine Action. Vatikaani: Vatican Observatory Publications and the Centre for Theology and the Natural Sciences / Notre Dame University Press.

Russell, Robert \& Murphy, Nancey \& Meyering, Theo \& Arbib, Michael (toim.)

1999 Neuroscience and the Person: Scientific Perspectives on Divine Action. Vatikaani: Vatican Observatory Publications and the Centre for Theology and the Natural Sciences / Notre Dame University Press. 
Russell, Robert \& Wegter-McNelly, Kirk \& Polkinghorne, John (toim.)

2001 Quantum Mechanics: Scientific Perspectives on Divine Action. Vatikaani: Vatican Observatory Publications and the Centre for Theology and the Natural Sciences / Notre Dame University Press.

Saariluoma, Pertti \& Kamppinen, Matti \& Hautamäki, Antti (toim.) 2001 Moderni kognitiotiede. Helsinki: Gaudeamus.

Saarinen, Esa \& Niiniluoto, Ilkka

2002 Nykyajan filosofia. Helsinki: WSOY.

Searle, John

2004 Mind: A Brief Introduction. Oxford: Oxford University Press.

Sagan, Carl

1997 The Demon-Haunted World: Science as a Candle in the Dark. New York: Ballantine Books.

\section{Saunders, Nicholas}

2002 Divine Action and Modern Science.

Cambridge: Cambridge University Press.

Savuoja, Ari

2007 Mikä on ihme ja mitä ihmeistä voidaan tietää? Keskustelu ihmeistä uusimmassa englanninkielisessä uskonnonfilosofiassa. Diss. Systemaattisen teologian osasto. HY.

Schloss, Jeffrey

2006 Evolutionary Theory and Religious Belief. - The Oxford Handbook of Religion and Science. Philip Clayton \& Zachary Simpson (toim.). Oxford: Oxford University Press. 
Shermer, Michael

2000 How Do We Believe: The Search of God in the Age Science. New York: W. H. Freeman.

\section{Shults, F. LeRon}

1999 The Postfoundationalist Task of Theology: Wolfhart Pannenberg and the New Theological Rationality. Grand Rapids: Eerdmans.

Shults, F. LeRon (toim.)

2006 The Evolution of Rationality: Interdisciplinary Essays in Honor of J. Wentzel van Huyssteen. Grand Rapids: Eerdmans.

\section{Slingerland, Edward}

2008 What Science Offers to the Humanities.

Cambridge: Cambridge University Press.

\section{Smart, J.J.C \& Haldane, John}

2003 Atheism \& Theism. Toinen painos. Oxford: Blackwell.

\section{Southgate, Christopher}

2008 The Groaning of Creation: God, Evolution and the Problem of Evil. Louisville: Westminster John Knox Press.

\section{Stenger, Victor}

2007 God: The Failed Hypothesis: How Science Shows That God Does Not Exist. Amherst: Prometheus Books.

2009 The New Atheism: Taking a Stand for Science and Reason. New York: Prometheus Books.

\section{Stenmark, Mikael}

2001 Scientism: Science, Ethics and Religion. Aldershot: Ashgate.

2004 How to Relate Science and Religion: A Multidimensional Model. Grand Rapids: William B. Eerdmans. 


\section{Sweetman, Brendan}

2010 Religion and Science: An Introduction. New York: Continuum.

\section{Swinburne, Richard}

1993 The Coherence of Theism. Toinen painos. Oxford: Clarendon Press.

1997 The Evolution of the Soul. Toinen painos. Oxford: Clarendon Press. 2004 The Existence of God. Toinen painos. Oxford: Clarendon Press. 2005 Faith and Reason. Toinen painos. Oxford: Clarendon Press.

\section{Taliaferro, Charles}

1994 Consciousness and the Mind of God.

Cambridge: Cambridge University Press.

2009 The Project of Natural Theology. - The Blackwell Companion to

Natural Theology. William Lane Craig \& J.P. Moreland (toim.).

Oxford: Blackwell.

\section{Taliaferro, Charles \& Stewart Goetz}

2008 Naturalism. Grand Rapids, MI: Eerdmans.

\section{Työrinoja, Reijo}

1986 Uskon kielioppi. Uskonnollisten väitteiden ja käsitteiden luonne Ludwig Wittgensteinin myöhäisfilosofian valossa. Helsinki: STKS.

\section{Vainio, Olli-Pekka}

2004 Ihmiseksi tuleminen: Sören Kierkegaardin teologia.

Helsinki: Kirjapaja.

2006 Luonnontieteen ja teologian liitto? Alister McGrathin A Scientific Theology -projekti. - Teologinen aikakauskirja. 5/2006.

2009 Wentzel van Huyssteenin postfoundationalistinen teologia.

- Teologinen aikakauskirja. 1/2007.

2010 Beyond Fideism: Negotiable Religious Identities.

Aldershot: Ashgate. 


\section{Van Huyssteen, J. Wentzel}

1998 Duet or Duel? Theology and Science in a Postmodern World. London: SCM.

1999 The Shaping of Rationality: Towards Interdisciplinarity in Theology and Science. Grand Rapids, MI: W. B. Eerdmans Publishing Co.

2006 Alone in the World: Human Uniqueness in Science and Theology. Grand Rapids, MI: W. B. Eerdmans Publishing Co.

\section{Van Inwagen, Peter}

1983 An Essay on Free Will. Oxford: Clarendon Press.

2002 Metaphysics. Toinen painos. Boulder: Westview.

2003 The Compatibility of Darwinism and Design. - God and Design: The Teleological Argument and Modern Science. Neil Manson (toim.). London: Routledge.

2006 The Problem of Evil. Oxford: Clarendon Press.

\section{Van Inwagen, Peter \& Zimmerman, Dean (toim.)}

2007 Persons: Human and Divine. Oxford: Oxford University Press.

\section{Ward, Keith}

1996 God, Chance \& Necessity. Oxford: Oneworld Publications.

1998 In Defence of the Soul. Oxford: Oneworld Publications.

1999 God, Faith and the New Millennium: Christian Belief in an Age of Science. Oxford: Oneworld Publications.

2006a Is Religion Dangerous? Oxford: Lion Hudson Plc.

2006b Pascal's Fire: Scientific Faith and Religious Understanding. Oxford: Oneworld Publications.

2008a Big Questions in Science and Religion. West Conshocken, PA : Templeton Foundation Press

2008b Why There Almost Certainly Is a God: Doubting Dawkins. Oxford: Lion Hudson Plc. 
Watts, Fraser (toim.)

2008 Creation: Law and Probability. Minneapolis: Fortress Press.

Wegter-McNelly, Kirk

2006 Fundamental Physics and Religion - Oxford Handbook of Religion and Science. Ed. by Philip Clayton \& Zachary Simpson.

New York: Oxford University Press.

\section{Weinberg, Steven}

1993 The First Three Minutes: A Modern View of the Origin of the Universe. London: Flamingo.

Westhpal, Merold

2009 Whose Community? Which Interpretation?: Philosophical

Hermeneutics for the Church. Grand Rapids: Baker Academic.

\section{Viitala, Jussi}

2003 Inhimillinen eläin, eläimellinen ihminen: Sosiaalisen

käyttäytymisen avaimet. Jyväskylä: Atena.

\section{Wildman, Wesley}

2004 The Divine Action Project, 1988-2003. - Theology and Science 2/1.

\section{Williams, Peter}

2009 A Sceptic's Guide to Atheism: God is Not Dead.

Carlisle: Paternoster Press.

\section{Wilson, David Sloan}

2002 Darwin's Cathedral: Evolution, Religion and the Nature of Society.

Chicago, IL: University of Chicago Press. 
Wilson, Edward O.

1975 Socio-biology: The New Synthesis.

Cambridge, MA: Belknap Press of Harvard University Press.

1998 Consilience: The Unity of Knowledge. London: Little, Brown and Company. (Konsilienssi. Suom. Kimmo Pietiläinen.

Helsinki: Terra Cognita, 2002)

Visala, Aku

2008 Uusateistit ja heidän kriitikkonsa tieteen ja uskonnon rajalla.

- Teologinen aikakauskirja 6/2008.

2009 Religion Explained? A Philosophical Appraisal of the Cognitive Science of Religion. Diss. Systemaattisen teologian osasto. Helsinki.

Religion Explained? Theism, Naturalism and the Cognitive Theories of Religion. Aldershot: Ashgate (tulossa).

Wright, N. T.

2007 Surprised by Hope: Rethinking Heaven, the Resurrection, and the Mission of the Church. London: SPCK.

Ylikoski, Petri \& Kiikeri, Mika

2007 Tiede tutkimuskohteena: Filosofinen johdatus tieteentutkimukseen. Helsinki: Gaudeamus.

Ylikoski, Petri \& Kokkonen, Tomi

2008 Evoluutio ja ihmisluonto. Helsinki: Gaudeamus.

\section{Zagzebski, Linda}

1991 The Dilemma of Freedom and Foreknowledge. New York: Oxford University Press.

2006 Philosophy of Religion: A Historical Introduction. Oxford: Blackwell. 



\section{VIITTEET}

\section{JOHDANTO}

${ }^{1}$ Numbers 1998, 2006, 2007, 2009.

${ }^{2}$ Ks. esim. Harrison 2007.

2 KONFLIKTI, ITSENÄISYYS JA KESKITIEN ETSINTÄ

${ }^{3}$ Barbour 1998 sisältää mallin nykyaikaisen version. Jatkossa seuraan tätä uusinta versiota.

${ }^{4}$ Toisinaan puhutaan samasta näkemyksestä "tieteellisenä naturalismina” (scientific naturalism).

${ }^{5}$ Dawkins on erinomainen kirjoittaja, jonka kirjoista kannattaa katsoa ainakin Dawkins 2009 ja 2006. Wilson 1998 on hyvä yleiskatsaus Wilsonin edustamaan naturalismiin. Dennett on yksi kaikkein sofistikoituneimpia tieteellisen materialismin edustajia. Ks. erityisesti Dennett 1995.

${ }^{6}$ Nämä viisi väitettä tunnistaa esimerkiksi John Haught (2006b, 9). Lisäksi ne löytyvät eriteltynä Victor Stengerin kirjasta The New Atheism (2009). Jotkut tieteelliset materialistit lisäävät vielä kaksi teesiä: (6) usko Jumalaan on vahingollista ihmisille ja pitäisi torjua moraalisilla perusteilla ja (7) moraali ei vaadi jumalauskoa ja ihmiset käyttäytyvät moraalisemmin, jos he eivät usko Jumalaan.

${ }^{7}$ Lainattu Giberson \& Artegas 2006, 216.

${ }^{8}$ Barbour 1998, 86.

9 Teologista eksistentialismia on edustanut esimerkiksi Sören Kierkegaard (1813-1855). Ks. Vainio 2004.

10 Tunnetuin tämän näkemyksen edustaja on Martin Buber (1993) 
${ }^{11}$ Wittgensteinin näkemyksiin johdattaa Työrinoja 1986.

12 Brümmer 1994, 428.

${ }^{13}$ Gould 1999, 7.

${ }^{14}$ Ks. esim Barbourin (1998, 77-84) kritiikki.

${ }^{15}$ Laadukasta konfliktiteesiä (konfliktimyyttiä) käsittelevää kirjallisuutta on olemassa englanniksi runsaasti. Parhaimpia ovat Ferngren 2002, Brooke 1991, Numbers 2009 ja Numbers \& Lindberg 2003.

${ }^{16}$ Kattava ja ajankohtainen katsaus luonnollisen teologian nykytilaan on Craig \& Moreland 2009. Vastaava uunituote filosofisen teologian yleiskatsaus on Flint \& Rea 2009.

${ }^{17}$ Ks. esim. Swinburnen luonnollisen teologian trilogia Swinburne 1993, 2004 ja 2005.

${ }^{18}$ Ks. esim. Jaki 1978.

${ }^{19}$ Barbour 1998, 93.

3 TIETÄMISEN MENETELMÄT: REALISMI TIETEESSÄ JA TEOLOGIASSA

${ }^{20}$ Chalmers 1999, 1.

${ }^{21}$ Chalmers 1999, xxi.

22 Tämänsuuntaista määritelmää tarjoaa esimerkiksi filosofi Ilkka Niiniluoto (1999).

${ }^{23}$ Oheinen katsauksen positivismiin perustana on pitkälti Raatikainen 2004.

${ }^{24}$ Ks. esim. Koskinen \& Niiniluoto 2002.

${ }^{25}$ Raatikainen $(2004,34)$ erottelee hyödyllisesti kolme merkitystä "havainnon teoriapitoisuudelle": (1) taustateoriat ja muut uskomukset vaikuttavat siihen mitä havaitaan ja mitä pidetään havainnossa tärkeänä, (2) taustateoriat ja muut uskomukset vaikuttavat siihen miten havainnon uskottavuutta arvioidaan ja (3) taustateoria antaa havainnolle merkityksen siinä mielessä, että on oltava käsitteitä, joiden kautta havainto kuvataan.

${ }^{26}$ Raatikainen 2004, 43.

${ }^{27}$ Raatikainen 2004, 46. 
${ }^{28}$ Myöhempi keskustelu ja Kuhnin omat kommentit kirjansa jälkeiseen keskusteluun osoittivat, että Kuhn ei ole konstruktivisti. Tämä ei kuitenkaan ole estänyt konstruktionisteja tulkitsemasta Kuhnin näkemyksiä konstruktionismille suosiollisella tavalla.

${ }^{29}$ Niiniluoto 1999 sisältää laajan keskustelun asiasta. Oheisen lyhyen katsauksen perustana on jälleen Raatikainen 2004.

${ }^{30}$ Raatikainen 2004, 72.

${ }^{31}$ Niiniluoto 1999 ja Raatikainen 2004 tarjoavat laajempaa keskustelua.

${ }^{32}$ Tähän tapaan teologisen realismin määrittelee filosofi Michael Rea (2009)

${ }^{33}$ Kiintoisa seuraus teologisesta realismista on se, että puheemme Jumalasta voi olla epätotta ja Jumala voi olla olematta. Fideistille ja antirealistille Jumalan olemattomuus on oikeastaan mahdotonta: Jumalan olemattomuudesta on mahdoton puhua, koska hän ei ole olemassa meistä riippumatta (antirealismi) tai koska epäileminen tarkoittaa uskonnollisesta elämästä luopumista (fideismi). Teologinen realisti sen sijaan voi olla aidosti väärässä puhuessaan Jumalasta. Jumala voi olla joko täysin toisenlainen kuin hän ajattelee tai sitten Jumala voi olla olematta. Tästä syystä suurin osa tieteellisistä ja filosofisista ateisteista on teologisia realisteja. Realistinen ateisti lähtee liikkeelle siitä, että Jumalaa koskevat väitteet ovat tosiaan maailmaa koskevia väitteitä ja että voimme saada Jumalan olemassaolosta tai olemattomuudesta tietoa. Realistinen ateisti kuitenkin päätyy siihen, että puhe Jumalasta on epätotta. On toki mahdollista olla ateisti myös relativistisilla tai konstruktionistisilla oletuksilla varustettuna, mutta tällöin ateismin syynä ei voi olla se, että jumalapuheen katsotaan olevan epätotta, vaan jokin muu, kuten esimerkiksi jumalapuheen moraalittomuus tai epäkäytännöllisyys.

${ }^{34}$ Hyvä suomenkielinen katsaus van Huysteenin ajatteluun on Vainio 2009. Van Huyssteenin ja McGrathin teologian laajempaa kontekstia kuvaa Vainio 2010. Kokoelma van Huyssteenin teologiaa käsitteleviä esseitä on Shults 2006. Van Huyssteenin omia, aiheemme kannalta keskeisiä teoksia, ovat van Huyssteen 1998, 1999, 2006

${ }^{35}$ Nämä periaatteet esittää van Huyssteenin oppilas F. LeRon Shults (1999, 43). 
${ }^{36}$ McGrath on esitellyt tätä perusajatusta monissa kirjoissaan. McGrath 2006a on hyvä tapa aloittaa. McGrath 2006b on lyhyt katsaus mittavaan tieteellisen teologian trilogiaan 2001, 2002, 2003. Suomeksi McGrathin teologista ohjelmaa on esitellyt Vainio $(2006,2010)$.

${ }^{37}$ McGrath 1999, 133-134.

${ }^{38}$ McGrath 1999, 89.

${ }^{39}$ McGrath 1999, 135-137. Toisaalla McGrath $(2009,96)$ erottaa viisi luomakuntaa koskevaa piirrettä, jotka teologia tekee ymmärrettäväksi. Nämä ovat (1) luonnossa havaittava järjestys, jonka ihmismieli voi ymmärtää, (2) maailmankaikkeuden "hedelmällisyys" eli sisäänrakennettu kyky synnyttää elämää, (3) luonto verkostoituneena kokonaisuutena, jota on vaikea palauttaa yksittäisiin rakenneosiin, (4) järjestyksen ja epäjärjestyksen olemassaolo ja yhteispeli luonnossa sekä (5) ihmislajille tyypillinen tietoisuus perimmäisen todellisuuden olemassaolosta.

${ }^{40} \mathrm{McGrathin} \mathrm{luonnon} \mathrm{teologian} \mathrm{voisi} \mathrm{tiivistää} \mathrm{väitteeseen,} \mathrm{jonka} \mathrm{mukaan}$ sekä tiede että teologia puhuvat samasta maailmasta mutta erilaisin välinein ja päämäärin sekä antavat sille erilaisia tulkintoja.

${ }^{41}$ Teologisen realismin kritiikkiä löytyy esimerkiksi Rea \& Crisp 2009 (erityisesti Merold Wesphalin essee). Ks. myös Westphal 2009 ja Moore \& Scott 2007.

${ }^{42}$ Hyvä katsaus kriittiseen realismiin "tieteen ja kristinuskon" alueella on Allen 2006.

${ }^{43}$ Peacocke 2001, 9.

\section{MUUTTUVA LUONTO: FYSIIKKA JA JUMALA}

${ }^{44}$ Esityksemme fysiikan kehityksestä tässä luvussa perustuu seuraaviin lähteisiin: Carr 2006; Hodgson 2005; Barbour 1998; Wegter-McNelly 2006.

${ }^{45}$ Viisi keskiaikaisen synteesin peruspiirrettä esittelee lyhyesti Barbour (1998, 4-9), johon esitykseni perustuu. Laajempaa käsittelyä varten kannattaa katsoa esimerkiksi Ferngren 2002, 31-91.

${ }^{46}$ Barbour 1998, 9.

${ }^{47}$ Aristoteleen mukaan syitä oli neljää eri lajia: päämääräsyyt, muodolliset 
syyt, vaikuttavat syyt ja materiaaliset syyt. Finaaliset syyt eli päämääräsyyt ja formaaliset syy eli muodolliset syyt olivat näistä tärkeimpiä Aristoteleelle itselleen.

${ }^{48}$ Erinomaisia katsauksia Galileon tapaukseen löytyy esimerkiksi teoksista Ferngren 2002, Numbers \& Lindberg 2003, Dixon 2008 sekä Numbers 2009.

${ }^{49}$ Galileon tapausta ei voida hyvin perustein pitää yksittäistapauksena jostakin yleisestä kristillisestä trendistä jarruttaa tieteen edistystä ja vaientaa tiedemiehiä. Kyseessä oli pikemminkin paikallisten historiallisten tapahtumien ja aikansa tieteellisten keskustelujen summa. Näitä ulottuvuuksia olivat ainakin (1) tieteellinen keskustelu, joka koski kahden aurinkokunnan rakennetta koskevan teorian tieteellistä uskottavuutta, (2) teologinen keskustelu, joka koski raamatuntulkinnan kriteerejä (jotka olivat erityisen polttava teologinen ja poliittinen ongelma katolisissa maissa reformaation jälkeen), (3) historiallinen tapahtumaketju, joka johti katolisen kirkon 1616 tuomitsemaan heliosentrisen maailmankuvan ja sen perusteet ja (4) Galilein varsinainen oikeudenkäynti ja tuomio 1633.

${ }^{50}$ Barbour 1998, 165-166.

${ }^{51}$ Lainattu Barbour 1998, 35.

${ }^{52}$ Lainattu Barbour 1998, 14.

${ }^{53}$ Lainattu Barbour 1998, 14.

${ }^{54}$ Tällä kehityksellä oli myös taustansa Euroopan 1600-luvun sodissa ja yhteiskunnallisessa myllerryksessä. Esimerkiksi filosofi John Locke piti ajatusta luonnollisesta uskonnosta tärkeänä juuri sen tähden, että sen avulla voidaan välttää uskonnolliset konfliktit.

${ }_{55}$ Tyylikkään katsauksen universumin alkuun tarjoaa Weinberg 1993.

${ }^{56}$ Arkikielinen johdatus kvanttifysiikkaan on Polkinghorne 2002.

${ }^{57}$ Barbour 1998, 174.

${ }^{58}$ Wegter-McNeilly 2006, 166.

${ }^{59}$ Sai nimensä Niels Bohrilta, joka oli Kööpenhaminassa professorina.

${ }^{60}$ Barbour 1998, 182.

${ }^{61}$ Barbour 1998, 183. 


\section{MUUTTUVA LUONTO: EVOLUUTIO, IHMINEN JA IHMISMIELI}

${ }^{62}$ Ks. esim. Mayr 2003

${ }^{63}$ Tämän luvun keskeiset lähteet ovat Ruse 2001; McGrath 2006; Ylikoski \& Kokkonen 2008.

${ }^{64}$ Ks. esimerkiksi Ylikoski \& Kokkonen 2008, 102.

${ }^{65}$ Dawkins 2003, 81. Lainattu McGrath 2006, 681.

${ }^{66}$ Nämä lähteet esittelee Ruse 2001 ja Ruse 1986.

${ }^{67}$ Huxleyn Evolution: the Modern Synthesis (1942). Dobzhanskyn Systematics and the Origin of Species (1942). Mayrin Tempo and Mode in Evolution (1944).

${ }^{68}$ Ks. esim Ruse 2001, 28-32.

${ }^{69}$ On selvää, että on harhaanjohtavaa puhua "evoluutioteoriasta" ikään kuin se olisi yksi teoria. Pikemminkin meidän tulee ymmärtää "evoluutioteoria" suurena joukkona erilaisia lähestymistapoja biologisiin organismeihin, teorioita eri tieteenaloilla ja välineitä, joita sovelletaan evoluution historiallisen prosessin ymmärtämiseksi. ”Teorian" sijaan on paljon parempi puhua paradigmasta (ks. luku 3.3) tai lähestymistavasta biologisiin organismeihin ja niiden kehitykseen.

${ }^{70}$ Ks. esim. Ylikoski \& Kokkonen 2008.

${ }^{71}$ Meemi-teoriasta ks. Blackmore 1999. Meemiteorian suomenkielistä kritiikkiä löytyy esim. Ylikoski \& Kokkonen 2008.

72 Boyd \& Richerson 1985, 2005a, 2005b. Lyhyen esityksen rinnakkaisevoluutioteoriasta suomeksi tarjoaa Ylikoski \& Kokkonen 2008.

${ }^{73}$ Kiistassa olivat vastakkain yhtäältä Wilson ja monet häntä seuranneet biologit, jotka käyttivät usein melko vahvaa retoriikkaa ja olivat taipuvaisia poliittisesti oikeistolaisiin näkemyksiin ja toisaalta monet antropologit, sosiologit ja muutama biologi (Steven Jay Gould ja Richard Lewontin), jotka käyttivät vähintään yhtä vahvaa retoriikkaa ja olivat kallellaan vasemmalle. Kiista on poliittiset ja yhteiskunnalliset ulottuvuudet saaneena tieteellisenä kiistana erittäin mielenkiintoinen: siihen liittyvät kysymykset biologian poliittisesta relevanssista, ihmistieteiden ja luonnontieteiden suhteesta ("tiedesodat") ja laajemmat kysymykset 
humanistisen sivistyksen ja luonnontieteen suhteesta ("kulttuurisodat").

${ }^{74}$ Evoluutiopsykologian johdatuksia ovat esim. Pinker 1999 ja Dunbar \& Barrett 2007. Suomenkielisen katsauksen ja kritiikin tarjoaa Ylikoski \& Kokkonen 2008.

${ }^{75}$ Wilson kuvaa laajasti näkemyksiään Wilson 1999. Eräs paljon Wilsonia maltillisempi muotoilu tästä kannasta on Slingerland 2009.

${ }^{76}$ Hyvä kognitiotieteen yleisesitys maallikolle on Saariluoma \& Kamppinen \& Hautamäki 2001.

${ }^{77}$ Churchland 1984.

${ }^{78}$ Kaksoisaspektiteoria on varsin lähellä ominaisuusdualismia ja sitä harvoin pidetään varsinaisen materialismin muotona. Mysterianismista McGinn 1993. Ominaisuusdualismista katso Hasker 1999.

${ }^{79}$ Lainattu Barbour 1998, 230.

${ }^{80}$ Oheinen emergenssin luonnehdinnan antaa McGrath 2009, 208. Ehkä kaikkein vaikuttavin vahvan emergenssin puolustus filosofisen teologian piirissä on Clayton 2004, joka on myös hyvä johdatus emergentismin perusajatuksiin.

\section{LUOMISEN TEOLOGIA JA MAAILMANKAIKKEUS}

${ }^{81}$ McGrath 1999, 115-116.

${ }^{82}$ Augustinuksen käsitystä esittelee McGrath 2009, 98-108. Kattavampi katsaus on Knuuttila 2001.

${ }^{83}$ Tämä ajatus perustuu siihen Augustinusta edeltävien kirkkoisien huomioon, että Raamatun alkukertomuksessa ei sanota Jumalan suoranaisesti luoneen esimerkiksi kasveja ja eläimiä, vaan näiden kerrotaan syntyvän Jumalan tahdon mukaisesti Jumalan luomasta maasta. "Maa versoi vihreyttä, siementä tekeviä kasveja ja hedelmäpuita, jotka kantoivat hedelmissään kukin oman lajinsa mukaista siementä" 1. Moos. 1:11. ”Tuottakoon maa kaikenlaisia eläviä olentoja, kaikki karjaeläinten, pikkueläinten ja villieläinten lajit. Ja niin tapahtui” 1. Moos 1:24.

${ }^{84}$ Lainattu McGrath 2009, 103.

${ }^{85}$ Polkinghorne 1998, 74. 
${ }^{86}$ Pahan ongelmasta ks. esim. van Inwagen 2006.

${ }^{87}$ Lainattu McGrath 1999, 118.

${ }^{88}$ Panenteismin yleisesitys on Clayton \& Peacocke 2001. Kriittisen historiallisen ja filosofisen katsauksen panenteismiin tarjoaa Cooper 2007.

${ }^{89}$ Peacocke 2001, 43.

${ }^{90}$ Peacocke käyttää Augustinuksen vertausta: kosmos on kuin sieni, joka kelluu loputtomassa meressä, joka on Jumala. Panenteisti torjuu kuitenkin prosessiteologian ajatuksen, jonka mukaan maailma olisi Jumalan ruumis tai että Jumala rajoittuisi pelkästään tuntemaamme kosmokseen.

${ }^{91}$ Ehkä kuuluisin nykyaikainen prosessiteologian edustaja on David Ray Griffin (2001). Ks. myös Cobb \& Griffin 1976.

${ }^{92}$ Avointa teismiä on kannattanut esim. Richard Swinburne (1993).

${ }^{93}$ Erilaisia kosmologisen argumentin muotoja käsittelee Craig \& Moreland 2009. Suositeltava ja ytimekäs keskustelu kosmologisista argumenteista on Murray \& Rea 2008, 135-146. Erittäin kattavan kuvan kosmologisista argumenteista ja niiden historiasta tarjoaa Craig 1980.

${ }^{94}$ Molemmilla kosmologisen argumentin versiolla on juurensa Tuomas Akvinolaisen kuuluisassa viiden argumentin sarjassa Jumalan olemassaolon puolesta. Tuomaan viisi argumenttia ovat seuraavat. (1) Argumentti liikkumattomasta liikuttajasta, jonka mukaan liikkeen on alettava jostakin sellaisesta, joka ei liiku. Pitää siis olla olemassa jotain joka ei itse liiku mutta liikuttaa jotain muuta. Tämä "liikkumaton liikuttaja" on Jumala. Argumentti perustuu Aristoteleen samankaltaiseen argumenttiin. (2) Argumentti ensimmäisestä vaikuttavasta syystä. Argumentin mukaan jokaisella tapahtumalla on vaikuttava syy mutta tämä syiden ketju ei voi jatkua ikuisesti, vaan on oltava jokin, joka on toisen tapahtuman syy mutta jolla ei ole syytä. Tämä "ensimmäinen syy" on Jumala. (3) Argumentti välttämättömästä oliosta (kosmologinen argumentti). Tämän argumentin mukaan siitä, että maailmankaikkeus ei ole välttämätön voidaan päätellä välttämättömän olion olemassaolo. Tämä välttämätön olio on Jumala. (4) Argumentti täydellisyydestä, joka päättelee täydellisen olion olemassaolon siitä, että maailmassa on epätäydellisyyttä. (5) Argumentti päämääräsyystä, jonka mukaan maailman järjestäytynyt luonne viittaa maailman lopullisen päämäärän olemassaoloon ja sellaisen 
olion olemassaoloon, joka on tämän päämäärän asettanut. Huomattavaa on, että näiden argumenttien tarkoituksena Tuomaalla ei ole todistaa Jumalan olemassaoloa, vaan osoittaa, kuinka ilmoitettu tieto on yhteensopivaa luonnollisella järjellä saatavan tiedon kanssa. Järki vailla ilmoitusta voi saada tietoa Jumalasta mutta pelastavaa uskoa, uskonnollista uskoa kristinuskon Jumalaan, järki ei voi saavuttaa.

${ }^{95}$ Ks. esim. Craig 1980, 2009.

${ }^{96}$ Tämä ei silti tarkoita, etteikö väitteellä olisi puolustajia. Kriitikot ovat kuitenkin esittäneet, että tällaiset puolustukset ovat vain silmänlumetta, koska niissä muutetaan käsitteen "ei mitään" sisältöä.

${ }^{97}$ Lainattu Giberson \& Artegas 2007, 105.

${ }^{98}$ Ward 2008a, 32.

${ }^{99}$ Lainattu Mawson 2005, 153.

${ }^{100}$ Laaja keskustelu leibnizlaisesta argumentista on Pruss 2009.

${ }^{101}$ Lainattu McGrath 1999, 136.

${ }^{102}$ Polkinghorne 1998, 2.

${ }^{103}$ Johdatus keskusteluun luonnonlain käsitteestä ja historiasta on Watts 2008.

${ }^{104}$ Nämä piirteet muotoilee Paul Daviesin pohjalta McGrath $(1999,125)$. ${ }^{105}$ Yleisiä katsauksia hienosäätöön ovat esimerkiksi Davies 2006 ja Barrow \& Tipler 1986. Hyvä johdatus teologiseen keskusteluun hienosäädöstä on McGrath 2009. Itse hienosäätöargumentista keskustelee kattavasti mutta varsin teknisesti Collins 2009. Hyvä kokoelma eri kantojen edustajien kirjoituksia ja mainio johdatus keskusteluun on Manson 2003. ${ }^{106}$ Toiset puhuvat 14.5 miljardista vuodesta. Miljardi sinne tänne. ${ }^{107}$ Lainattu Barbour 1998, 100. Toisaalla Dyson (lainattu Barbour 1998, 205) toteaa: "Mitä enemmän tarkkailen universumia ja tutkin sen rakenteen yksityiskohtia, sitä enemmän löydän todisteita siitä, että jossakin mielessä universumin on täytynyt tietää, että me olemme tulossa”.

${ }^{108}$ Oheisen muotoilun esittää Murray \& Rea 2008, 151.

${ }^{109}$ McMullinin näkemyksestä ks. McMullin 1985.

${ }^{110}$ Russellin näkemyksestä ks. esim. Russell \& Clayton et al. 2000. Hyvä johdatus kvanttifysiikkaan perustuviin NIODA malleihin on Russell 2006.

${ }^{111}$ Harvinaisen selkeä suomenkielinen johdatus emergenssin ja alaspäisen 
kausaation ideoihin on Raatikainen 2007.

${ }^{112}$ Valtaosa luonnon teologian edustajista lähtee liikkeelle siitä, että inhimilliset toimijat saavat aikaan aitoja muutoksia fysikaalisessa maailmassa. Tämä edellyttää heidän mukaansa uskoa vapaaseen tahtoon ihmisen moraalisen vastuun edellytyksenä. Ajatus on se, että lähin analogia Jumalan toiminnalle maailmassa on ihmisen toiminta maailmassa. Perinteisesti ihmisen toiminta fysikaalisessa maailmassa on perusteltu jonkinlaisen sielun olemassaololla (ks. luku 5.3). Valtaosa luonnon teologian edustajista on kuitenkin materialisteja eikä usko aivoista erillisen sielun olemassaoloon, joten heille on välttämätöntä ymmärtää inhimillinen toiminta sekä Jumalan toiminta ilman dualismia. Tämä taas vie monet luonnon teologian edustajat kohti avointa teismiä tai panenteismiä. Klassisen teismin edustajilla on sen sijaan tapana olla dualisteja ja näin ollen perustella eri tavoin Jumalan toimintaa maailmassa. Luonnon teologian edustajista ainakin Peacocke (2001), Polkinghorne (1998), Barbour (1998) ja Ward (1998) puolustavat indeterminististä vapaata tahtoa. Ward on kylläkin ominaisuusdualisti, mutta hän perustelee silti Jumalan toimintaa maailmassa samaan tapaan kuin edeltävät.

${ }^{113}$ Murphy \& Brownin $(2007,63)$ mukaan alaspäistä kausaatiota on käytetty selittämään esimerkiksi aineenvaihduntaa mitokondrioissa ja kokonaisissa soluissa ja työmuistin vaikutuksia ohimolohkon neuronien toimintaan. Murphy \& Brown 2007 on itse asiassa varsin mielenkiintoinen yritys soveltaa alaspäisen kausaation ideaa ratkaisemaan neurotieteen kontekstissa esiintyvä vapaan tahdon ja moraalisen vastuun ongelma. 114 Peacocke 2001, 109.

115 Peacocke 2001, 111.

${ }^{116}$ Ks. esim. Polkinghorne 1994, 1998. Polkinghornen myötä ja hänen kanssaan informaatioteoreettisia lähestymistapoja Jumalan toimintaan maailmassa ovat kehittäneet esimerkiksi Barbour (1998) ja matemaatikko John Lennox (2007). Polkinghorne näyttää kuitenkin uusimmassa kirjassaan (2008) olevan yhä skeptisempi kaikkia nykyisiä Jumalan toiminnan malleja kohtaan, mukaanlukien omansa.

${ }^{117}$ Nykyinen NIODAn ympärillä käyty keskustelu liittyy erityisesti Vatikaanin observatorion pyörittämään varsin mittavaan Divine Action and Mo- 
dern Science (1988-2003) projektiin. Wildman 2004 on erittäin hyvä yhteenveto projektista ja sisältää myös NIODA mallien kritiikkiä. Samoin laadukas yleiskatsaus ja kritiikki on Saunders 2002. Projekti on julkaissut viisi laajaa kokoelmaa artikkeleita, jotka ovat Russell \& Murphy \& Isham 1993, Russell \& Murphy \& Peacocke 1994, Russell \& Stoeger \& Ayala 1996, Russell \& Murphy \& Meyering \& Arbib 1999 ja Russell \& Clayton \& Wegter-McNelly \& Polkinghorne 2001.

${ }^{118}$ Haught 2006a, 704.

${ }^{119}$ Haughtin mallin taustalla on pitkä katolinen kenosisteologian ja prosessiteologian perinne. Erityisen tärkeä tämän perinteen kannalta on ollut geologi ja paleontologi Pierre Teilhard De Chardin (1881-1955) .

120 Taulukko mukailee Barbourin $(1998,305)$ vastaavaa.

${ }^{121}$ Savuoja 2007 on suomenkielinen johdatus nykykeskusteluun.

\section{EVOLUUTION TEOLOGIA: LAKI JA SATTUMA}

${ }^{122}$ Dawkins 2006, 121.

${ }^{123}$ Dawkins 1995, 133.

${ }^{124}$ Dawkins 1986 kehittää ajatusta pidemmälle.

${ }^{125}$ Stenmark 2004, 160.

${ }^{126}$ Samansuuntaisesti Stenmarkin kanssa argumentoi van Inwagen 2003.

127 Taulukko on lainattu Schloss 2006, 192.

${ }^{128}$ Syy sille, miksi "tieteellinen" kreationismi on lainausmerkeissä, on se, että kyseessä ei ole mikään tieteellinen näkemys, vaikka siitä usein käytetäänkin tällaista nimitystä.

129 Tutkimus on vasta alussa mutta kiinnostavia näkökulmia esittelevät Evans \& Evans 2008.

${ }^{130}$ Oikeudenkäynti on hyvin kuuluisa ja siihen liittyy monia harhaluuloja, joita ilmentää esimerkiksi kuuluisa näytelmä Inherit the Wind (1955), josta on myös useita filmatisointeja vuosilta 1960, 1965, 1988 ja 1999. Lyhyt historiallinen katsaus oikeudenkäyntiin löytyy kirjasta Ferngren 2002. Numbers 2006 antaa laajemman katsauksen. Ks. myös Numbers 2008. 
${ }^{131}$ Ruse 1988 sisältää paljon tähän oikeudenkäyntiin liittyvää materiaalia. Ruse oli todistamassa filosofisena asiantuntijana sen puolesta, että kreationismi ei ole tiedettä. Oikeudenkäynteihin ja kreationismin luonteeseen Yhdysvalloissa johdattaa lyhyesti mutta ytimekkäästi Dixon 2006.

${ }^{132}$ Behen Darwin's Black Box: The Biochemical Challenge to Evolution (1996) on yksi ID:n kuuluisimpia teoksia. Samaan sarjaan kuuluvat myös Dembski 1998 ja 2002.

${ }^{133}$ Suomenkielinen katsaus Behen ajatteluun ja suunnittelupäättelyyn on Kojonen 2009.

134 Johnson 1991, 1995, 2002.

${ }^{135}$ Esim. Plantinga (2000) on tämänsuuntaisilla perusteilla väittänyt, että materialistisen tieteen rinnalle pitäisi perustaa kristillinen tiede, joka lähtisi liikkeelle siitä oletuksesta, että Jumala puuttuu maailman tapahtumiin. Samaan tapaan on suomeksi argumentoinut Tapio Puolimatka (2008).

${ }^{136}$ Näin esimerkiksi Robert Pennock (2006).

${ }^{137}$ Keskeisiä teoksia ovat Haught 2000, 2003, 2006b, 2007. Lyhyt johdatus maallikolle on Haught 2001.

${ }^{138}$ Haugth 2001, 76.

${ }^{139}$ Haugth 2001, 18.

${ }^{140}$ Ward 2008a, 46-47.

${ }^{141}$ Barbour 1998, 230.

${ }^{142}$ Uraauurtava teos on Conway Morris 2003. Conway Morriksen ajatus konvergentista evoluutiosta liittyy laajempaan keskusteluun evoluution suunnasta ja sattuman roolista. Conway Morris pyrkii kumoamaan Stephen Jay Gouldin näkemyksen siitä, että sattumalla on erittäin suuri rooli evoluutiossa.

${ }^{143}$ Lainattu McGrath 2009, 196.

144 Toisinaan puhutaan myös "eläinten kärsimyksen ongelmasta" mutta tämä nimitys ei tavoita ongelmaa kokonaisuudessaan. Southgate 2008 ja Murray 2008 ovat tuoreita katsauksia ongelmaan. Edellinen on yleistajuisempi ja helposti lähestyttävä, kun jälkimmäinen on suhteellisen puiseva ja filosofinen mutta kattava ja systemaattinen.

${ }^{145}$ Hyvä johdatus filosofiseen keskusteluun pahan ongelmasta on van 
Inwagen 2006.

146 Tunnettua on myös se, että Darwinin henkilökohtaisen elämän tragediat, erityisesti hänen tyttärensä Annen kuolema, vaikuttivat hänen pohdintaansa hyvän Jumalan olemassaolosta. Voidaan siis sanoa, että evidentiaalisen pahan ongelman ja evolutiivisen pahan ongelman lisäksi häntä vaivasi eksistentiaalinen pahan ongelma. Koko evidentiaalinen/eksistentiaalinen erottelu perustuu siihen, että vaikka meille esitettäisiinkin filosofisia ja abstrakteja perusteluita sille, miksi Jumala sallii pahan, nämä perustelut ei juuri lohduta meitä psykologisesti kohdatessamme pahuutta ja kärsimystä.

${ }^{147}$ Ward 2008a, 64.

${ }^{148}$ Prosessiteodikea on kosminen versio vapaan tahdon teodikeasta, joka on suosittu tapa käsitellä pahan ongelmaa filosofisessa kirjallisuudessa. Vapaa tahto tuottaa sivutuotteena huonoja valintoja ja kärsimystä. Samaan tapaan "vapaat prosessit" eli luonnon säännönmukaisuuksien ja sattuman yhteispeli tuottavat sivutuotteena kärsimystä. Southgate (2008) kehittää varsin toisenlaisen teodikean, joka puolestaan perustuu ajatukselle luomakunnan "jalostamisesta".

149 Teologista dualismia ja erilaisia mieli/ruumis-dualismin muotoja puolustavat esimerkiksi filosofit William Hasker (1999), J.P. Moreland (2008, 2009), Swinburne (1997), Charles Taliaferro (1994) ja Ward (1998). Erilaisia teologisen materialismin muotoja puolustavat esimerkiksi Nancey Murphy (2006), Philip Clayton (2004) ja Gregory Peterson (2003). Ehkä mittavin non-reduktiivisen materialismin, vapaan tahdon ja moraalisen vastuun puolustus nimenomaan aivotutkimuksen kontekstissa on Murphy \& Brown 2007. Laaja katsaus keskusteluihin monista näkökulmista on Van Inwagen \& Zimmerman 2007. Johdatus teologian ja psykologian suhteeseen on Watts 2002. 


\section{TEOLOGINEN IHMISKÄSITYS JA IHMISLUONTO}

${ }^{150}$ Seuraamme jatkossa Murphyn (2006) esitystä asiasta. Kattava katsaus raamatulliseen ihmiskäsitykseen ja sen mukaiseen käsitykseen pelastuksesta, viimeisistä tapahtumista, jne. on Wright 2007. Wright vahvistaa Murphyn keskeisen teesin siitä, että erityisesti VT:n käsitykselle ajatus ruumiin ja sielun erillisyydestä on varsin vieras.

${ }^{151}$ Ks. Wright 2007.

${ }^{152}$ Descartesin mukaan järkeily ja kieli ovat sielun läsnäolon tuntomerkkejä. Tällä perusteella hän päätyi väittämään, että eläimillä ei ole sielua, koska ne eivät käytä kieltä eivätkä anna merkkejä järjenkäytöstä.

${ }^{153}$ Tietoisuudesta on ollut hyvin paljon keskustelua niin psykologiassa kuin filosofiassa ja neurotieteessä. Chalmers 1997 on laaja mutta toisinaan varsin tekninen johdatus filosofiseen keskusteluun. Dennett 1991 on suomenkielinen katsaus Dennettin omaan kiisteltyyn teoriaan tietoisuudesta, joka sijoittuu varsin lähelle reduktiivisen materialismia.

${ }^{154}$ Aiheeseen johdattaa Peterson 2003. De Waal 2005 on alan pioneeri Frans de Waalin populaari katsaus ihmisten ja apinoiden samankaltaisuuksiin. Tunnettua on, että de Waalin käsitys ihmisten lähisukulaisten kyvyistä on varsin positiivinen ja se on saanut osakseen myös kritiikkiä, mutta kirja on silti hyvä katsaus keskusteluun. Ks. myös de Waal 2006. de Waal 1998 on erään de Waalin vanhemman teoksen suomenkielinen käännös. Suomeksi keskustelee asiasta Viitala 2003.

${ }^{155}$ Olen edellä käsitellyt ihmisen erityisyyttä ainoastaan suhteessa eläimiin. On kuitenkin toinen mahdollinen näkökulma, johon en ole puuttunut mutta joka kuitenkin nousee mielen tieteistä, nimittäin ihmisen ja koneiden (erityisesti tietokoneiden) jatkuvuus. Keskustelua aiheesta sisältävät esimerkiksi Peterson 2003 ja Clark 2001 sekä Clark 2003.

156 Peterson 2003, 133.

${ }_{157}$ Peterson 2003, 136.

158 Tätä oletusta on tapana kutsua "kausaalisen sulkeuman periaatteeksi" (the principle of causal closure tai causal closure of the physical) tai ajatukseksi fysikaalisen maailman sulkeutuneisuudesta. Tämä periaate on itse asiassa aivan sama kuin tieteellisten materialistien oletus "kaikkien 
syiden luonnollisuudesta". Ajatus on se, että joskus tulevaisuudessa, kun olemme saavuttaneet tieteellisen täydellisyyden (tai se on periaatteessa mahdollista), niin meillä on kausaalinen ja fysikaalinen selitys kaikelle. Tässä näemme nykyaikaisen version klassisesta reduktionismista, jota kuvasimme luvussa 5.4. Tämän kannan edustaja on siis vakuuttunut siitä, että lopulta kaikkien ilmiöiden selitykset pystytään antamaan fysiikan kielen ja lainalaisuuksien avulla. Jos torjumme klassisen reduktionismin idean, on vaikea nähdä syitä kausaalisen sulkeuman periaatteen kannattamiseksi. Juuri näin non-reduktiiviset ja emergentit materialistit tekevät.

${ }^{159}$ Esimerkiksi Dennettin käsitys mielestä ja sen suhteesta ruumiiseen sisältää juuri tällaisen ongelman. Dennettin mukaan puheemme haluista, uskomuksista, valinnoista ja muista mielentiloista ei itse asiassa viittaa mihinkään aivoissa oleviin "olioihin". Aivoissa ei ole mitään muuta kuin hermosolujen toimintaa ja kun tiede kehittyy tarpeeksi, on periaatteessa mahdollista antaa jokaiselle mielentilalle selitys aivojen toiminnan näkökulmasta. Näin ollen puhe mielestä on ihmisen käyttäytymisen selittämisen kannalta toimivaa ja käytännöllistä mutta viime kädessä varsinaisen selittävän työn tekee ihmisen fysikaalinen aivokoneisto. Ks. Dennett 1991.

${ }^{160}$ Kompatibilismia puolustaa esimerkiksi Dennett 2003.

${ }^{161}$ Ks. esim. van Inwagen 1983 ja Searle 2004.

${ }^{162}$ Näistä merkittävin on Murphy \& Brown 2007.

${ }^{163}$ Hyvä johdatus peruskysymyksiin on Joyce 2006. Ks. myös Kokkonen \& Ylikoski 2008.

${ }^{164}$ Ks. Dawkins 1978 (suomeksi 1993).

${ }^{165}$ Lainattu Peterson 2003, 155.

${ }^{166}$ Peterson 2003, 175.

${ }^{167}$ Lyhyt katsaus neuroteologiaan suomeksi on Näreaho 2007. Yksityiskohtia varten ks. esim. D’Acquili \& Newberg 2001.

${ }^{168}$ Wilson 2002.

${ }^{169}$ Ks. esim. Boyer 2001, josta on myös suomennos Boyer 2007. Ks. lisäksi Barrett 2004 ja Pyysiäinen 2001, 2004, 2009. Suomalaisten kirjoittajien erinomainen yleiskatsaus kognitiiviseen uskontotieteeseen on Ketola \& Pyysiäinen \& Sjöblom 2008. 
${ }^{170}$ Ks. erityisesti Dennett 2006.

${ }^{171}$ Näitä väitteitä käsittelee laajemmin Visala 2009, 2011. Lisäksi ks. Barrett 2007, Barrett \& Leech \& Visala 2010 ja Leech \& Visala 2010.

172 Tämä tietenkin sillä ehdolla, että ryhmävalinnan perusajatus hyväksytään.

173 Tiedollisten tilojen ja niiden psykologisen ja biologisen alkuperän suhdetta käsittelevät tarkemmin esimerkiksi Leech \& Visala 2010 ja Barrett \& Leech \& Visala 2010. Katso myös artikkelit kirjasta Murray \& Schloss 2009.

${ }^{174}$ Ks. esim. Gregersen 2006.

175 Teologisesta näkökulmasta tarkasteltuna meillä on kaksi toisilleen vastakkaista tapaa suhtautua uskonnon luonnollisuuteen: (1) korostaa kristinuskon "epäluonnollisuutta" ja sen eroja muihin uskontoihin nähden tai (2) korostaa ihmisluonnon ja kristinuskon jatkuvuutta. Edellistä vaihtoehtoa suosivat Karl Barthin seuraajat (ks. luku 2.3) ja jälkimmäistä taas luonnollisen teologian edustajat (ks. luku 2.5). Ehkä sopiva malli löytyy jostakin näiden kahden välistä: kristinuskossa on oltava joitakin erityispiirteitä mutta se on myös monessa suhteessa muiden uskontojen kaltainen, koska ihmisen biologia ja psykologia vaikuttavat siihen aivan samalla tavalla, kuten muihinkin uskontoihin.

${ }^{176}$ Barbour 1998, 255.

9 MAAILMANKATSOMUSTEN KONFLIKTI: TEISMI, ATEISMIJA TIETEELLINEN MATERIALISMI

${ }^{177}$ Radikaali agnostikko on sitä mieltä, että Jumalasta ei voi laisinkaan puhua. Vahva ateisti on taas sitä mieltä, että Jumalasta voidaan kyllä puhua mielekkäästä, vaikka sellaista olentoa ei olekaan olemassa. Tarkempaa selvitystä erilaisista filosofisen agnostisismin ja ateismin muodoista, ks. Koistinen 2000, 65-85 ja Niiniluoto 2003. Heikkoa ateismia on edustanut esimerkiksi filosofi Anthony Kenny (2005).

${ }^{178}$ Ks. Harris 2004, 2006 ja Hitchens 2007. Toisinaan mukaan lasketaan myös Victor Stenger (2009) 
${ }^{179}$ Ohessa vain poiminta valtavasta massasta uusateisteja vastaan suunnatuista kirjoista: Eagleton 2009, Hart 2009, Haught 2008, Jones 2007, Lennox 2007, McGrath 2005, 2007, Ward 2006a, 2008b ja Williams 2009.

${ }^{180}$ Russell 1957, 106-107.

${ }^{181}$ Ks. Drees 1996.

${ }^{182}$ Haught 2006b on hyvä keskustelu naturalismista maailmankatsomuksena (tieteellinen materialismi) luonnon teologian näkökulmasta.

${ }^{183}$ Supranaturalismia Suomessa on edustanut Tapio Puolimatka (2008, 2005)

${ }^{184}$ Plantingan argumentin suomennos ja sitä käsittelevää keskustelua löytyy Niin \& Näin lehden numerosta 3/2005. Argumentista keskustelee myös Puolimatka (2005 ja 2008). Beilby 2002 on kokoelma, joka sisältää itse argumentin ja sitä koskevaa keskustelua. Suomenkielinen keskustelu Plantingan epistemologiasta on Koistinen 2001. Plantingan näkemyksestä laajemmin, ks. Plantinga 2000.

${ }^{185}$ Tällaista ihmiskäsitystä kuvaa Slingerland 2008.

${ }^{186}$ Tämänsuuntaisen argumentin esittää esimerkiksi Taliaferro \& Goetz 2008. Järkiargumentin kaikkein kuuluisimman version esittää C. S. Lewis kirjassaan Miracles, a Preliminary Study (alkuperäinen 1947 ja täydennetty painos 1960). Modernin järkiargumentin versioita esittää Reppert 2003 ja 2009.

187 Tämän argumentin ovat esittäneet esimerkiksi Taliaferro \& Goetz 2008, Moreland 2008, 2009.

${ }^{188}$ Ward 1996, 102.

${ }^{189}$ Polkinghorne 1994, 70.

190 Tieteen kaikkivoipaisuuteen liittyvistä ongelmista ja koko ajatuksen motivaatiosta kirjoittaa hyvällä tyylillä Midgley 1992, 2002, 2004, 2006.

${ }^{191}$ Midgley 2006, x.

${ }^{192}$ Midgley 2006, x.

${ }^{193}$ Tieteisuskoa käsittelee seikkaperäisesti Stenmark (2001), jota jatkossa seuraan.

${ }^{194}$ Hyvä katsaus tieteen kaikkivoipaisuuden kannattajien, kuten juuri Wilsonin ja Dawkinsin, näkemyksiin tieteen luonteesta ja suhteesta uskontoon on Giberson \& Artigas 2006. 
${ }^{195}$ Seuraan jatkossa Stenmarkin (2004) näkemystä tieteen maailmankatsomuksellisuudesta.

196 Tätä erottelua koskeva hyödyllinen keskustelu on Stenmark 2004, 171-249.

${ }^{197}$ Meidän tulee erottaa deskriptiivinen kysymys "onko tiede todellisuudessa arvovapaa?" normatiivisesta kysymyksestä "tulisiko sen olla (voiko se periaatteessa olla) arvovapaa?". Keskityn jatkossa normatiiviseen kysymykseen.

198 Nämä vaiheet erottaa Stenmark (2004, 214-216).

${ }^{199}$ Ks. Ylikoski \& Kiikeri 2007.

10 LOPPUSANAT: LUONNON TEOLOGIAN OPETUKSIA JA HAASTEITA

${ }^{200}$ Ward 2006b, 97.

${ }^{201}$ McGinn 1993, 1. 

